\title{
World \\ Bauxite \\ Resources
}

U.S. GEOLOGICAL SURVEY PROFESSIONAL PAPER 1076-B

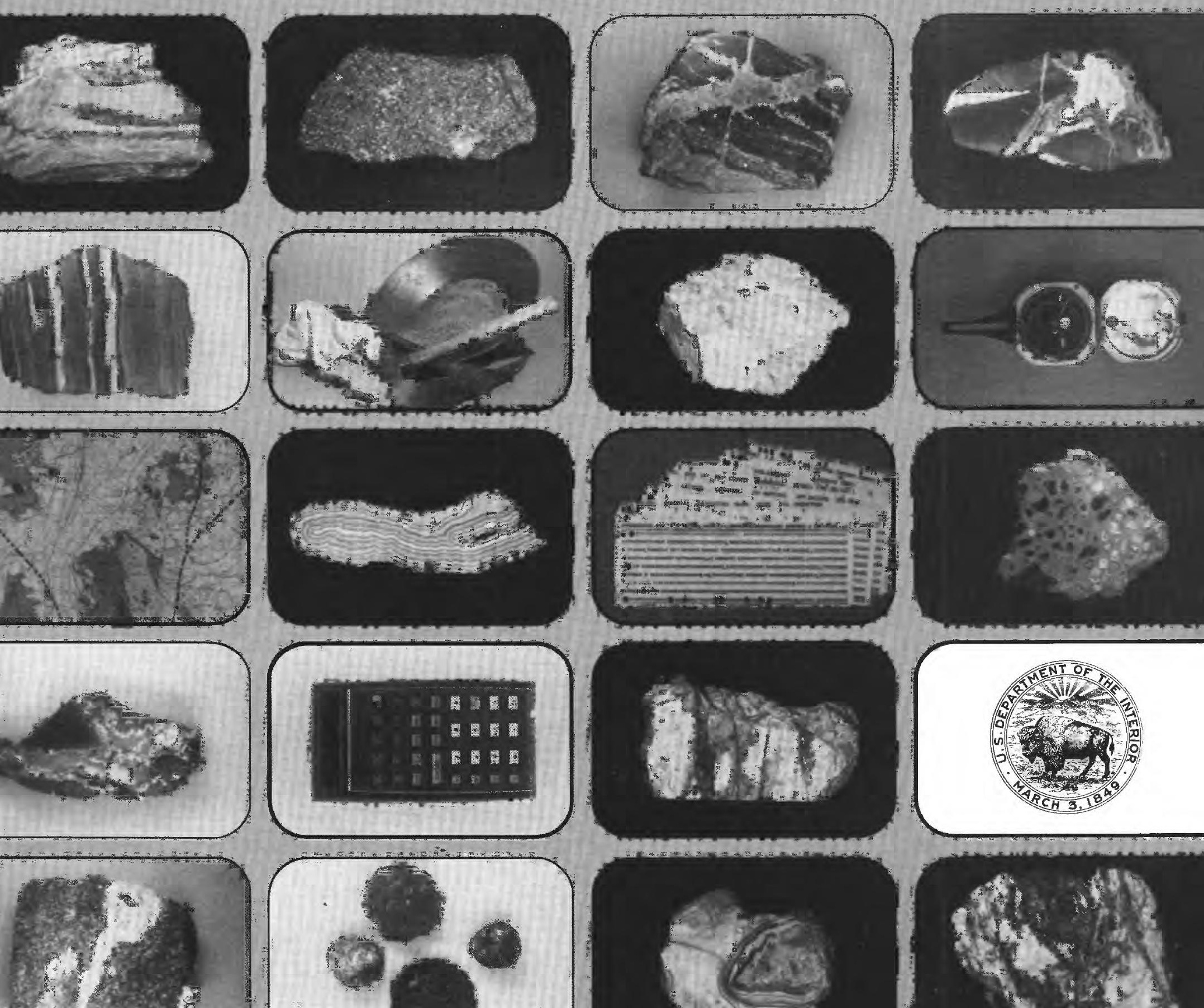




\begin{tabular}{|c|c|c|c|c|}
\hline & & & & 1. Asbestos ore \\
\hline 1 & 2 & 3 & 4 & 2. Lead ore-Balmat Mine, N.Y. \\
\hline \multirow[t]{2}{*}{5} & & 6 & & 3. Chromite-chromium ore, Wash. \\
\hline & 7 & & 8 & 5. Banded iron formation. Palmer, \\
\hline 9 & & 10 & & $\begin{array}{l}\text { Michigan } \\
\text { 6. Ribbon asbestos ore, Quebec, Canada }\end{array}$ \\
\hline 11 & 12 & 13 & 14 & $\begin{array}{l}\text { 7. Manganese ore, banded } \\
\text { rhodochrosite }\end{array}$ \\
\hline
\end{tabular}

8. Aluminum ore, bauxite, Georgia

9. Native copper ore, Keweenawan Peninsula, Mich.

10. Porphyry molybdenum ore, Colo.

11. Zinc ore. Edwards, N. Y.

12. Manganese nodules, ocean floor

13. Botryoidal fluorite ore,

Poncha Springs, Colo.

14. Tungsten ore, North Carolina 


\section{World \\ Bauxite \\ Resources}

By SAM H. PATTERSON, HORACE F. KURTZ,

JANE C. OLSON, and CATHY L. NEELEY

\section{GEOLOGY A N D RESOURCES OF A L U I N UM}

U.S. GEOLOGICAL SURVEY PROFESSIONAL PAPER 1076-B

An updating of information on the geologic and geographic occurrences of world bauxite resources and discussions of uses, exploration and mining, and production

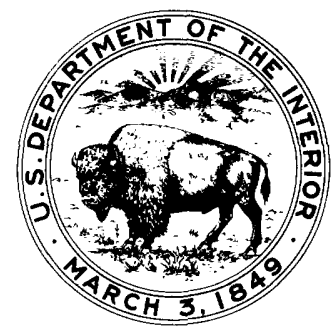




\section{DEPARTMENT OF THE INTERIOR \\ DONALD PAUL HODEL, Secretary}

\section{U.S. GEOLOGICAL SURVEY}

Dallas L. Peck, Director

Library of Congress Cataloging-in-Publication Data

Main entry under title:

World bauxite resources.

(Geology and resources of aluminum) (U.S. Geological Survey professional paper ; 1076-B)

Bibliography: p. 130.

Supt. of Docs. no.: I 19.16:1076-B

1. Bauxite. I. Patterson, Sam H. (Sam Hunting), 1918-. II. Series. III. Series: U.S. Geological Survey professional paper ; 1076-B.

TN490.A5W67 $1986 \quad 553.4 ' 926 \quad 85-600103$

For sale by the Books and Open-File Reports Section, U.S. Geological Survey,

Federal Center, Box 25425, Denver, CO 80225 


\section{CONTENTS}

Abstract

Introduction

Purpose of report, authorship responsibility

Sources of information on bauxite

Acknowledgments

Definitions

Bauxite used for aluminum

Bauxite for uses other than aluminum

Exploration and evaluation of bauxite deposits

Mining methods . . . . . . . . . . . . . . . . . . .

Bauxite processing $\ldots \ldots \ldots \ldots \ldots \ldots \ldots \ldots \ldots$

Alumina production $\ldots \ldots \ldots \ldots \ldots \ldots \ldots \ldots \ldots$

Byproducts

United States and world bauxite production

Geology of bauxite

Classification of deposits

Laterite-karst or silicate-carbonate classification .

Classification based on shapes and occurrences

Other classifications

Mineralogy

Bauxite minerals

Morphology, microtextures, and grain sizes of bauxite minerals

Significance of mineral composition, crystal morphology, and organic matter

Trace elements

Physical characteristics

Origin

Age and mineralogic and geographic distribution of bauxite

World bauxite resources

Definitions of terms

Estimates and distribution of world bauxite resources

North America

United States

History and production $\ldots \ldots \ldots \ldots \ldots \ldots \ldots$

Bauxite districts and regions

Arkansas region

Southeastern United States

Districts in the Coastal Plain

Districts in the Valley and Ridge province

Ferruginous bauxite in Washington, Oregon, and Hawaii

Diaspore in Pennsylvania and Missouri .....

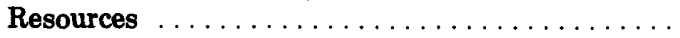

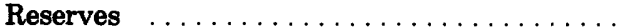

Subeconomic resources

Undiscovered resources .................

Summary of bauxite resources in the United States

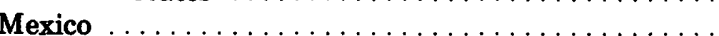

Central America $\ldots \ldots \ldots \ldots \ldots \ldots \ldots \ldots \ldots \ldots \ldots$

Costa Rica

Honduras

Panama

Summary of bauxite resources in Central America ...

\begin{tabular}{|c|c|c|}
\hline \multirow{2}{*}{ Page } & & \\
\hline & aribbean Islands & B50 \\
\hline 1 & Dominican Republic $\ldots \ldots \ldots \ldots \ldots \ldots \ldots$ & \\
\hline 1 & $\ldots \ldots \ldots \ldots \ldots \ldots \ldots \ldots \ldots \ldots$ & \\
\hline 2 & Jamaica & \\
\hline 3 & Other Caribbean occurrences ..... & \\
\hline 3 & Summary of bauxite resources in the Caribbean region & \\
\hline 4 & South America $\ldots \ldots \ldots \ldots \ldots \ldots \ldots \ldots \ldots$ & \\
\hline 4 & Argentina & \\
\hline 4 & $\ldots \ldots \ldots \ldots \ldots \ldots \ldots \ldots \ldots \ldots$ & \\
\hline 8 & $\ldots \ldots \ldots \ldots \ldots \ldots \ldots \ldots \ldots \ldots \ldots$ & \\
\hline 9 & French Guiana $\ldots \ldots \ldots \ldots \ldots \ldots \ldots \ldots \ldots$ & \\
\hline 10 & $\ldots \ldots \ldots \ldots \ldots \ldots \ldots \ldots \ldots \ldots \ldots \ldots$ & \\
\hline 10 & $\ldots \ldots \ldots \ldots \ldots \ldots \ldots \ldots \ldots \ldots \ldots$ & \\
\hline 11 & $\ldots \ldots \ldots \ldots \ldots \ldots \ldots \ldots \ldots \ldots \ldots$ & \\
\hline 13 & $\ldots \ldots \ldots \ldots$ & \\
\hline 14 & Other South American countries & 7 \\
\hline 14 & Summary of bauxite resources in South America ..... & 7 \\
\hline 15 & $\ldots \ldots \ldots \ldots \ldots$ & 7 \\
\hline 16 & $\ldots \ldots \ldots \ldots$ & 7 \\
\hline 17 & $\ldots \ldots \ldots$ & 7 \\
\hline 18 & $\ldots \ldots \ldots \ldots \ldots$ & 7 \\
\hline 18 & $\ldots \ldots \ldots \ldots \ldots$ & 7 \\
\hline & $\ldots \ldots \ldots \ldots \ldots \ldots \ldots \ldots$ & \\
\hline 21 & $\ldots \ldots \ldots \ldots \ldots \ldots \ldots \ldots \ldots \ldots \ldots$ & \\
\hline & $\ldots \ldots \ldots \ldots \ldots \ldots \ldots \ldots$ & \\
\hline 21 & $\ldots \ldots \ldots \ldots \ldots \ldots \ldots \ldots \ldots$ & \\
\hline 23 & $\ldots \ldots \ldots \ldots \ldots \ldots$ & \\
\hline 24 & 2., including Soviet Asia $\ldots \ldots \ldots \ldots \ldots \ldots \ldots$ & \\
\hline 26 & & \\
\hline & $\ldots \ldots \ldots \ldots \ldots \ldots$ & \\
\hline 28 & ropean countries $\ldots \ldots \ldots \ldots \ldots \ldots \ldots \ldots$ & \\
\hline 30 & bauxite resources in Europe $\ldots \ldots \ldots \ldots$ & \\
\hline 30 & $\ldots \ldots \ldots \ldots \ldots \ldots \ldots \ldots \ldots$ & \\
\hline 33 & $\ldots \ldots \ldots \ldots \ldots \ldots \ldots \ldots \ldots$ & \\
\hline 35 & $\ldots \ldots \ldots \ldots \ldots \ldots \ldots \ldots$ & \\
\hline 35 & $\ldots \ldots \ldots \ldots \ldots \ldots \ldots \ldots \ldots$ & \\
\hline 35 & $\ldots \ldots \ldots \ldots \ldots \ldots$ & \\
\hline 35 & $\ldots \ldots \ldots \ldots \ldots \ldots$ & \\
\hline 40 & $\ldots \ldots \ldots \ldots \ldots$ & \\
\hline 42 & $\ldots \ldots$ & \\
\hline 42 & $\ldots \ldots$ & \\
\hline 43 & $\mathbf{M}$ & \\
\hline & & \\
\hline 44 & Mozambique & \\
\hline 46 & $\ldots \ldots \ldots \ldots \ldots \ldots$ & \\
\hline 46 & Africa & \\
\hline 46 & Upper Volta (now Burkina Faso) & \\
\hline 47 & Zaire & 9 \\
\hline 48 & abwe & 10 \\
\hline & $\ldots \ldots \ldots \ldots \ldots$ & 10 \\
\hline 48 & of bauxite resources in Africa & 10 \\
\hline 48 & luding U.S.S.R.) & 10 \\
\hline 49 & & 10 \\
\hline 49 & nesia & 10 \\
\hline 49 & Ir & 11 \\
\hline 49 & & 11 \\
\hline 49 & Pakistan & \\
\hline
\end{tabular}


Asia (excluding U.S.S.R.) -Continued

People's Republic of China

Philippines $\ldots \ldots \ldots \ldots \ldots \ldots \ldots \ldots \ldots \ldots \ldots \ldots, 116$

Saudi Arabia $\ldots \ldots \ldots \ldots \ldots \ldots \ldots \ldots \ldots \ldots \ldots, 116$

Taiwan . . . . . . . . . . . . . . . . . . 117

Turkey $\ldots \ldots \ldots \ldots \ldots \ldots \ldots \ldots \ldots \ldots \ldots \ldots \ldots, 117$

Vietnam .......................... 120

Other Asian countries . . . . . . . . . . . . . 120

Summary of bauxite resources in Asia

\begin{tabular}{r|} 
Page \\
B112 \\
116 \\
116 \\
117 \\
117 \\
120 \\
120 \\
121
\end{tabular}

121

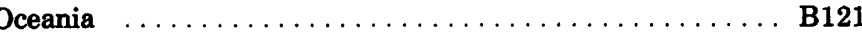

Australia $\ldots \ldots \ldots \ldots \ldots \ldots \ldots \ldots \ldots \ldots \ldots \ldots \ldots, 121$

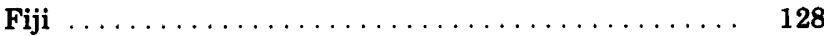

New Zealand $\ldots \ldots \ldots \ldots \ldots \ldots \ldots \ldots \ldots \ldots \ldots \ldots, 128$

Palau ............................ 128

Solomon Islands . . . . . . . . . . . . . . . . . . 129

Other islands . . . . . . . . . . . . . . . . . . 129

Summary of bauxite resources in Oceania ........ 130

References ........................... 130

\section{ILLUSTRATIONS}

FIGURE $\quad$ 1. Diagram of world bauxite production, showing contributions from different regions, $1935-83 \ldots \ldots \ldots \ldots$

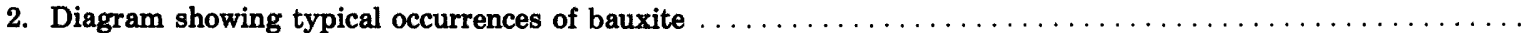

3. Photograph of polished face of pisolitic bauxite from the Andersonville district, Georgia $\ldots \ldots \ldots \ldots \ldots \ldots$

4. Photograph of polished face of transported bauxite from the Arkansas region $\ldots \ldots \ldots \ldots \ldots \ldots \ldots \ldots$

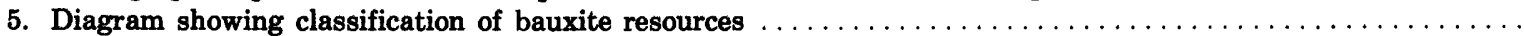

6. Graph showing annual world bauxite production and estimates of reserves and total resources, $1935-83 \ldots \ldots$

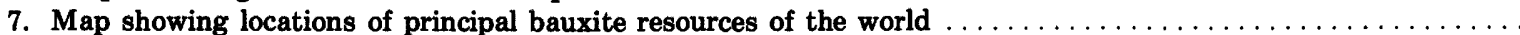

8. Map showing locations of bauxite districts and areas in the Southern United States $\ldots \ldots \ldots \ldots \ldots \ldots$

9. Generalized geologic map of the Arkansas bauxite region

10. Diagrammatic section showing principal types of deposits in the Arkansas bauxite region $\ldots \ldots \ldots \ldots \ldots \ldots$

11-25. Maps showing locations of:

11. Ferruginous bauxite resources in the United States $\ldots \ldots \ldots \ldots \ldots \ldots \ldots \ldots \ldots \ldots \ldots \ldots \ldots$

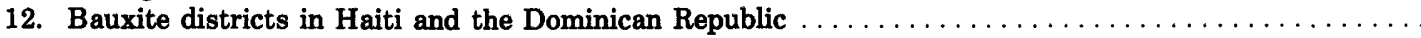

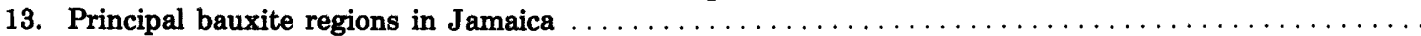

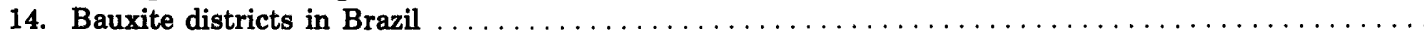

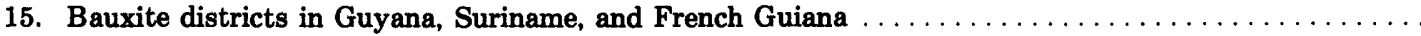

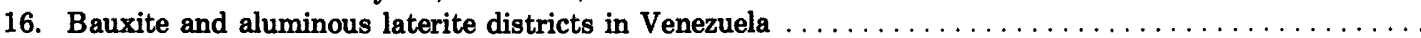

17. Bauxite districts in Europe exclusive of the U.S.S.R. and the United Kingdom $\ldots \ldots \ldots \ldots \ldots \ldots \ldots$

18. Bauxite districts in the U.S.S.R.

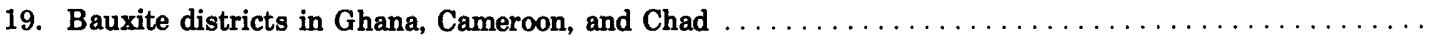

20. Bauxite districts and regions in Guinea-Bissau, Guinea, and Sierra Leone $\ldots \ldots \ldots \ldots \ldots \ldots \ldots$

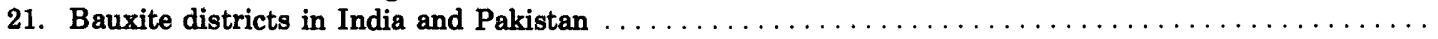

22. Bauxite districts in southeastern Asia and the southwestern Pacific region $\ldots \ldots \ldots \ldots \ldots \ldots \ldots$

23. Principal bauxite districts in the People's Republic of China $\ldots \ldots \ldots \ldots \ldots \ldots \ldots \ldots \ldots \ldots$

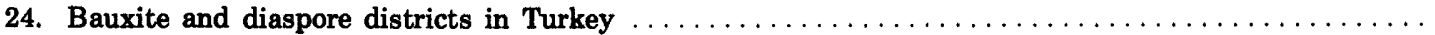

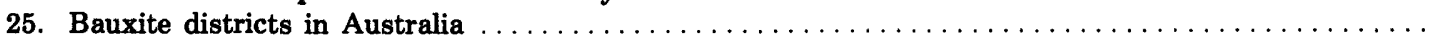

\section{TABLES}

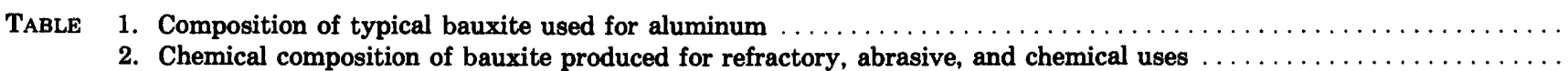

3. Approximate leaching conditions of the European and American Bayer processes $\ldots \ldots \ldots \ldots \ldots \ldots \ldots$

4. Ranges of major-oxide contents in red muds on a dry basis

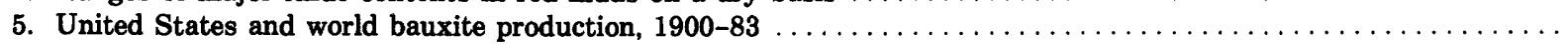

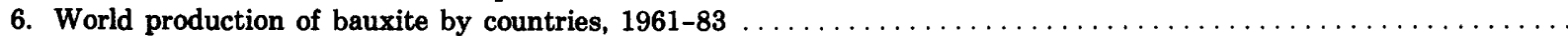

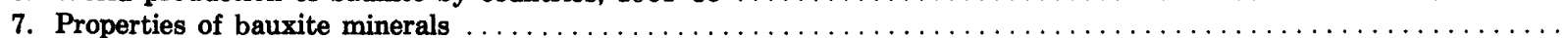

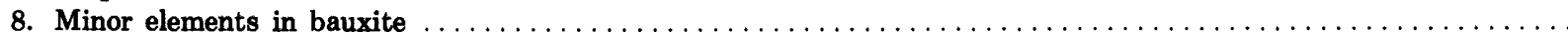

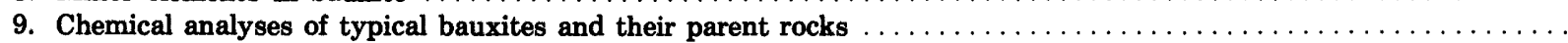

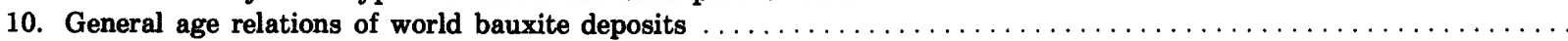

11. Estimates of world bauxite reserves and other resources, 1936-84 
TABLE 12. Estimates of reserves, subeconomic and undiscovered resources, and total resources of bauxite as of $1983 \ldots \ldots \ldots$

13. Chemical analyses of bauxite, bauxitic clay, and kaolin from the Arkansas region $\ldots \ldots \ldots \ldots \ldots$

14. Ranges in grades and average composition of bauxite and bauxitic clay of the Andersonville district ........ 43

15. Average chemical composition of ferruginous bauxite in Washington, Oregon, and Hawaii ............

16. Bauxite reserves and other identified resources in the Arkansas bauxite region as of January $1,1963 \ldots \ldots \ldots$

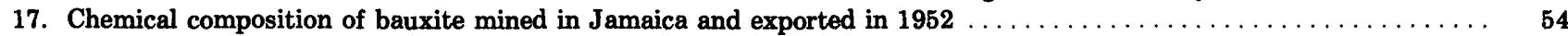

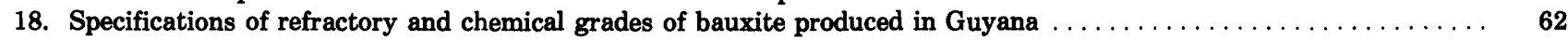

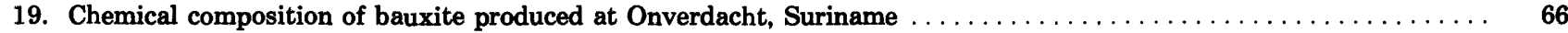

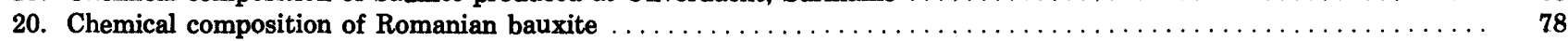

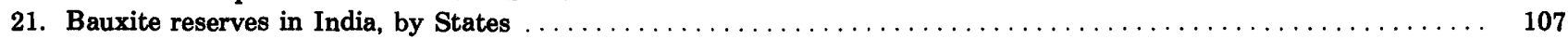

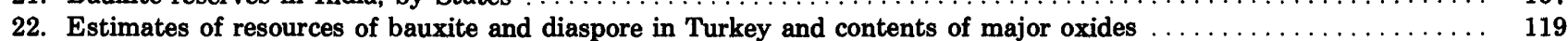

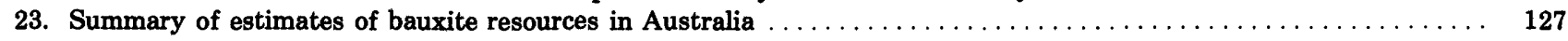





\title{
WORLD BAUXITE RESOURCES
}

\author{
By Sam H. Patterson, Horace F. Kurtz ${ }^{1}$, \\ Jane C. Olson, and Cathy L. NEeley
}

\begin{abstract}
Bauxite, a rock consisting of one or more aluminum hydroxide minerals, is the principal raw material used by the aluminum industry. The types of bauxite are (1) trihydrate, consisting chiefly of gibbsite, $\mathrm{Al}_{2} \mathrm{O}_{3} \cdot 3 \mathrm{H}_{2} \mathrm{O}$; (2) monohydrate, consisting mainly of boehmite, $\mathrm{Al}_{2} \mathrm{O}_{3} \cdot \mathrm{H}_{2} \mathrm{O}$; and (3) mixed bauxite, consisting of both gibbsite and boehmite. A variety of the monohydrate type consisting chiefly of diaspore has the same chemical composition as boehmite but is denser and harder. Diaspore bauxite is used mainly in products resistant to high temperatures, but diaspore is a major mineral in some of the bauxite from which alumina is recovered in Greece and the People's Republic of China. The aluminum industry consumes nearly 90 percent of the bauxite mined; the remainder is used in many different types of refractories, abrasives, chemicals, and miscellaneous products.

Bauxite is mined mainly by open-pit methods. Most bauxite production is from laterite-type deposits at or near the surface that are mined by heavy equipment. The principal underground mines are in Europe, where much of the bauxite occurs at considerable depths. Some bauxite is beneficiated by washing out the fine-grained impurities, but much of it is merely dried before the alumina, $\mathrm{Al}_{2} \mathrm{O}_{3}$, is recovered by the Bayer process, an alkaline leach under moderately high temperatures and pressures. Gallium is the principal byproduct of alumina production, but several other elements and materials either have been recovered in the past or are potentially recoverable.

Bauxite deposits have formed chiefly by weathering of aluminous rock; some have been transported to their present locations, but most are residual accumulations from which most constituents of the parent rock other than alumina have been leached. Bauxite occurs in rocks ranging in age from Precambrian to Holocene, and many deposits in the tropics are probably still forming. Most deposits of gibbsitic bauxite are in the tropics. A few occur in the temperate belts, but the climate was probably tropical or subtropical at the time these formed. Nearly all deposits of this type are of Cenozoic age. Deposits of boehmitic bauxite occur chiefly in southern Europe, the U.S.S.R., Turkey, and the People's Republic of China. Most deposits of this type are associated with carbonate rocks of Jurassic and Cretaceous age, but a few are of Paleozoic age. Though most of these deposits are north of the tropics, they could have formed under tropical conditions. Mixed bauxites are associated with both the gibbsite and boehmite types; however, they tend to be more abundant in deposits of Paleozoic and Mesozoic ages than in younger rocks.

The major world bauxite resources are in Africa, Australia, South America, and the Caribbean region; significant deposits are present in Asia and Europe. Guinea has the world's largest bauxite reserves, estimated to be 5.6 billion tons. Large reserves in Guinea and in other countries are indicated in the following table.
\end{abstract}

\footnotetext{
${ }^{1}$ Horace F. Kurtz, U.S. Bureau of Mines, Washington, DC 20241.
}

\begin{tabular}{|c|c|c|}
\hline & Country & $\begin{array}{l}\text { Bauxite reserves } \\
\text { (millions of } \\
\text { metric tons) }\end{array}$ \\
\hline Guinea & & 5,600 \\
\hline Australia & & 4,440 \\
\hline Brazil & & 2,250 \\
\hline Jamaica & & 2,000 \\
\hline India & & 1,000 \\
\hline Indonesia & & 750 \\
\hline Guyana & & 700 \\
\hline Cameroon & & 680 \\
\hline Greece & & 600 \\
\hline Suriname & & 575 \\
\hline Ghana & & 450 \\
\hline Yugoslavia & & 350 \\
\hline
\end{tabular}

Countries having reserves of 100 million-300 million metric tons include Venezuela, Hungary, the U.S.S.R., Sierra Leone, and the People's Republic of China. The bauxite reserves in the United States are estimated to be only about 38 million metric tons. Several countries in Central American, the Caribbean region, Europe, and Asia have bauxite reserves of less than 100 million metric tons. Very large subeconomic and virtually certain speculative bauxite resources are present in Africa and South America; Asia and Australia may have large subeconomic and speculative resources; other major global regions rank well behind in these categories of resources.

\section{INTRODUCTION}

\section{PURPOSE OF REPORT, AUTHORSHIP RESPONSIBILITY}

This report is an updating of information on the geology, distribution, and quantities of reserves and resources of bauxite, which, except for minor use of nepheline syenite and alunite to produce aluminum in the U.S.S.R., is the only ore of aluminum. It also contains information on the exploration for bauxite, the mining and processing of bauxite, and the uses of bauxite for purposes other than making metal. It is chiefly a revision of parts of earlier reports (U.S. Bureau of Mines, 1953; S.H. Patterson, 1967).

In accordance with the understanding between the Directors of the Geological Survey and the Bureau of Mines (U.S. Bureau of Mines and U.S. Geological Survey, 1976), the Bureau of Mines coauthor, Kurtz, 
was responsible for estimates of the reserves, ${ }^{2}$ and the Geological Survey coauthor, Patterson, was responsible for the overall estimates of resources. Kurtz wrote most of the sections on exploration, mining production, processing, and use, and Patterson wrote the sections on geology. Neeley did much of the library research needed to gather information used in the report, prepared most of the illustrations, and assisted in writing and proofreading the text. Olson reviewed, edited, and computerized the bibliography and is responsible for the referencing in the text.

This report was prepared in response to increasing demands for information on bauxite resulting from wider recognition of the increased dependence on foreign sources for this essential raw material and its importance in the industrial economy of the United States. Domestic reserves of bauxite are less than 5 percent of the estimated minimum demand of the United States to the end of the century. Subeconomic bauxite resources are sufficient to meet less than 25 percent of the minimum demand during this period. Accordingly, the Nation must rely heavily on imports of bauxite, alumina, and aluminum until some of the large nonbauxite resources become viable sources. These potential sources included high-alumina clay (kaolin), anorthosite, alunite (Hall, 1978), dawsonite, aluminum phosphate rock, coal mine waste, coal ash, and copper leach materials.

\section{SOURCES OF INFORMATION ON BAUXITE}

A great deal of published information on bauxite has become available in the last two or three decades. The textbooks and reference volumes that have been published include textbooks by Valeton (1972), Bushinskiy (1971, 1975), Crockett (1978), Banks (1979), and Roskill Information Services (1979). Bárdossy's (1977, 1982) excellent text is on karst bauxite and was first published in Hungarian; an expanded English version was printed 5 years later. Two thorough volumes concerned with bauxite as well as all phases of the aluminum industry were prepared by the Australian Mineral Economics Pty., Ltd. (1981). Another summary was written by Butcher (1982). Chapters on bauxite by Harder and Greig (1960) and Shaffer (1975) are included in AIME's Industrial Minerals and Rocks volumes. Ikonnikov's (1975) report on mineral resources in the People's Republic of China contains considerable information on bauxite in that country. An excellent treatment of the crystal chemistry of the oxides and

\footnotetext{
${ }^{2}$ The metric system is used for all tonnage and other figures throughout this report, except where otherwise noted.
}

hydroxides of aluminum has been released by the Aluminum Company of America (Alcoa) (Wefers and Bell, 1972).

A thorough volume covering several phases of the aluminum industry has been written by Hungarian specialists. Separates of three chapters in this book (Bárdossy, 1975; Bárdossy, Vassel, and Arkossy, 1975; Solymár, Bárdossy, and Jónás, 1975) examined by the senior author are in English, and they are of excellent quality. Books on world resources of bauxite have been written by Bracewell (1962) and Patterson (1967).

Several organizations have held symposia and (or) other meetings concerned with bauxite and related subjects, as discussed below. (1) The International Committee for the Study of Bauxite, Alumina, and Aluminium (ICSOBA) is the most active group. This informal society has held 18 periodic meetings for which the results have been published by l'Académie Yougoslave des Sciences et des Arts at the time this Professional Paper was written. ICSOBA also has held five meetings that are called symposia or congresses. The results of four of these meetings (International Symposium of the International Committee for the Studies of Bauxites, Oxides, and Hydroxides of Aluminium, 1964-1965, 1971, 1973; International Congress for the Study of Bauxites, Alumina, and Aluminium, 1978) were published when this article was prepared. (2) The Jamaica Geological Society held its first symposium on bauxite in 1971 and its fifth in 1982 . Excellent papers on the geology, mineralogy, and mining of bauxite have appeared in the publications (Geological Society of Jamaica, 1971, 1973, 1975, 1980, 1982) resulting from these symposia. (3) An outstanding symposium on bauxite in the United States was held by the Society of Mining Engineers of AIME in 1984 (Jacob, 1984). This symposium volume contains 47 articles written by many of the world's leading authorities on bauxite. Several previous meetings of the Society of Mining Engineers have included sessions on bauxite, and many citations of information resulting from these meetings appear on following pages. The Metallurgical Society of AIME holds annual meetings on light metals, and the yearly Light Metals volumes resulting from these meetings contain information on bauxite. (4) Monograph No. 5 of the Australasian Institute of Mining and Metallurgy published in 1975 contains several bauxite papers presented at a symposium. (5) Several papers on bauxite are included in a report of meetings on lateritization processes held by Project 129 (International Seminar on Lateritisation Processes, 1981, 1983) that is part of International Geologic Correlations Program series sponsored by the International Union of Geological Sciences (IUGS) with small financial assistance by the United Nations Educational, Scientific, 
and Cultural Organization (UNESCO). (6) The centennial volume of the Hungarian Geological Institute edited by Bárdossy (1970) contains many papers that are primarily concerned with the geology of bauxite.

Numerous contributions to the knowledge of bauxite have been published by universities and in professional journals such as Economic Geology, Mineralium Deposita, The American Mineralogist, and Clays and Clay Minerals. Trade journals, including Industrial Minerals, Engineering and Mining Journal, Mining Journal, Mining Magazine, Australian Mining, and Australian Mines Handbook, contain information on bauxite. The journal Aluminium published in Germany, the French Revue de l'Aluminium, a similar one in Italian, and the Aluminum Abstracts in the United States contain information or references on bauxite. Scientific information on bauxite has been contributed in Ph.D. theses printed by French universities. Various theses have been concerned with bauxite deposits in Turkey, Cameroon, Spain and France, Ivory Coast, and probably other countries.

Government agencies and other organizations that publish reports on bauxite include the U.S. Bureau of Mines; U.S. Geological Survey; Australian Bureau of Mineral Resources, Geology and Geophysics; Great Britain Institute of Geological Sciences; Indian Bureau of Mines, Geological Survey of India; West German Bundesanstalt für Bodenforschung HannoverDeutsches Institut für Wirtschaftsforschung Berlin; and Instituti Geologici Publici Hungarici. The International Bauxite Association (IBA) publishes considerable information on bauxite in its quarterly review series. The United Nations organizations have sponsored much work on bauxite. The United Nations Industrial Development Organization (UNIDO) (Balazs, 1984) and the United Nations Conference on Trade and Development (UNCTAD) have held meetings and published reports concerned with bauxite. The United Nations Economic Commission for Asia and the Far East has a report on bauxite in that region.

\section{ACKNOWLEDGMENTS}

Much of the authors' knowledge of bauxite has been gained by conversations and exchanges of information with many authorities on bauxite. Among those to whom we wish to express thanks are James W. Shaffer, Consultant, formerly Kaiser Aluminum Co.; Alan W. Popp, Douglas D. Jinks, Wilson D. Michell, Derek Whitehouse, and Jolin H. Moses, Reynolds Metals Co.; Neil Bliss, E.W. Greig, and I.M. Shvily, Alcan International, Ltd.; J.G. de Weisse, Fritz Schnorf, Robert Unger, and Felix Schmid, Swiss Aluminium, Ltd.;
Andrew Dacko and Leonard Jacob, Jr., Aluminum Company of America; Emile Amade and Alain Gesell, Pechiney Ugine Kuhlman; John Cornish, Miodrag Kaluderovic, and Vincent G. Hill, International Bauxite Association; Parris Lyew-Ayee, The Jamaica Bauxite Institute; Rene A. Cambridge, Suriname Government, Geological and Mining Service; Henry R. Ferrier, Grassalco; E.G. Hopkinson, Guyana Geological Surveys and Mines; George N. Nooten, Guyana Bauxite Co., Ltd.; M.C. Hamilton, Bauxite Industry Development Company, Ltd., Guyana; Patterson A. Thompson and W. Haslyn Parris, Guybau; Paul F. Bustion, J.L. Van Blommestein, and A.A. Meijer, Suralco; A. Brahim and Henk Morroy, N.V. Billiton Mij. Suriname; Carlos Romano Ramos, Departamento Nacional da Produção Mineral, Belem, Brazil; György Bárdossy, Budapest, Hungary; G.I. Bushinskiy, Moscow, U.S.S.R.; Werner Schellmann, Bundesanstalt für Bodenforschung, West Germany; Prof. Emilio Galan, University of Zaragoza, Spain; George Van Buren Day, the Aluminum Association; Betty A. Bryan, World Aluminum Abstracts, Metals Park, Ohio; Harland E. Cofer, Georgia Southwestern College; and the following consultants: Samuel Moment, Portland, Oreg.; Richard C. Roberts, Richmond, Va.; John Hook, Portland, Oreg.; Otis M. Clarke, Jr., Tuscaloosa, Ala. In addition to these authorities, many geologists and engineers assisted the authors in countless ways during visits to mines and plants and searches for information. We are grateful to all of them.

Resource Attachés, Economic Officers, and Chargés in American Embassies and Consulates forwarded considerable information on bauxite referred to in this report. Francis E. Shafer, India; Terry V. McIntyre, Australia; W. Siefken, Cameroon; B.D. Curran, GuineaBissau; D.B. Dlouhy, Republic of Guinea; Robert H. Knickmeyer, Venezuela; and P.T. Hansen, Brazil, were particularly helpful. J. Owen Zurhellen, Jr., Ambassador, and Jap Tjoen San, Assistant Economic Officer, Suriname; and Jolın D. Blanken, Chargé des Affaires, and Dennis Rudy, Economic Specialist, Guyana, provided assistance to the authors during visits to bauxite districts in those countries in 1977 .

\section{DEFINITIONS}

Bauxite is a rock consisting mainly of aluminum hydroxide minerals. It is the principal source of alumina $\left(\mathrm{Al}_{2} \mathrm{O}_{3}\right)$, from which aluminum metal is smelted by an electrolytic process. Both bauxite and alumina are also used for several products other than metal. The name "beauxite" was proposed by Dufrenoy in 1845 (Bracewell, 1962, p. 8) for a material occurring near Les 
Beaux, France, that had been found to consist mainly of a mixture of hydrated aluminum and red iron oxides. The term was later changed to "bauxite" to conform to a change in spelling of the type locality.

Bauxites composed chiefly of the mineral gibbsite are commonly termed "trihydrate bauxites" or "the Suriname type"; those composed of boehmite are called "monohydrate bauxite" or the "European type"; those composed of a mixture of gibbsite and boehmite are called "mixed bauxites." The term "Jamaica type" is applied to very fine grained high-iron gibbsitic bauxite containing minor quantities of boehmite.

\section{USES AND TYPICAL COMPOSITION}

Approximately 90 percent of the world bauxite production is used for making alumina $\left(\mathrm{Al}_{2} \mathrm{O}_{3}\right)$, which is consumed mainly in making aluminum. The other major uses of bauxite are in refractories, abrasives, chemicals, and aluminous cements. Refractory bauxite is used mainly in making firebrick and mixes having $\mathrm{Al}_{2} \mathrm{O}_{3}$ contents in the range 70-90 percent (Industrial Minerals, 1974). Abrasive bauxite is used for fused alumina grinding and polishing materials. The abrasives are made by fusing abrasive-grade bauxite in an arc furnace. Coke is added to reduce iron. The resulting product contains 94-97 percent $\mathrm{Al}_{2} \mathrm{O}_{3}$. Some of the fused alumina prepared this way is also used for special refractory applications. Chemical bauxite is consumed mainly in the production of aluminum sulfate for paper manufacture and water treatment. Other chemicals manufactured include aluminum chloride, aluminum fluoride, sodium aluminate, and aluminum acetate.

Minor quantities of bauxite are used in other applications. Bauxite is a raw material for making electrical insulators and other high-strength porcelain products, and welding rod coatings. It is a flux in steel making. Activated bauxite prepared by heating at various temperatures is used (1) in desulfurization, in decolorization, or as a drying agent in the food- and chemicalprocessing industries (Industrial Minerals, 1974); (2) in petroleum refiming; and (3) as filler in rubber, plastic, and paint. Bauxite is used in highway, mine-road, and railroad construction in countries having abundant supplies of hard varieties. It is used as a building stone and in breakwater construction in India (Kumar and others, 1977, p. 17-18). Calcined bauxite has properties desired in antiskid road aggregate (Hosking and Tubey, 1973).

Alumina also has several applications other than for making aluminum. Alumina hydrate from the Bayer process is used in chemicals requiring a higher degree of purity than can be obtained from bauxite, such as cracking catalysts for the petroleum industry and fire retardant fillers. Calcined alumina is used in abrasives and several types of ceramic fillers, coatings, and refractories requiring its special properties of heat resistance, whiteness, and hardness. Activated alumina that has been calcined to remove all but about 6 percent water is used as a desiccant, as a catalyst carrier, and for other purposes (Carniglia, 1977). Tabular alumina, heated to near the fusion point to form tabular crystals, is used for spark-plug insulators, refractories requiring resistance to thermal shock, and fillers and coatings. Fused alumina is used mainly in synthetic corundum made for abrasives, and minor quantities are used in making synthetic gems.

\section{Bauxite Used for Aluminum}

Though high recoverable alumina $\left(\mathrm{Al}_{2} \mathrm{O}_{3}\right)$ contents are desirable in bauxite used for aluminum, the alumina contents of commercial bauxites range broadly (table 1). The alumina contents of the deposits presently mined range from 55-60 percent $\mathrm{Al}_{2} \mathrm{O}_{3}$ in the highgrade bauxite produced in Guyana, Suriname, and Guinea to low grade (30-35 percent available $\mathrm{Al}_{2} \mathrm{O}_{3}$ ) in the Jarrahdale district, Australia. Generally, reactive silica $\left(\mathrm{SiO}_{2}\right)$ is the most significant impurity in bauxites, while the iron content is mainly a dilutant. In 1941, the specifications for commercial metal-grade bauxites were a minimum of 55 percent $\mathrm{Al}_{2} \mathrm{O}_{3}$ and a maximum of 7 percent $\mathrm{SiO}_{2}, 8$ percent $\mathrm{Fe}_{2} \mathrm{O}_{3}$, and 4 percent $\mathrm{TiO}_{2}$ (Thoenen and Burchard, 1941, p. 35). By 1960, metalgrade bauxite treated in certain plants in the United States could contain a minimum of 48 percent $\mathrm{Al}_{2} \mathrm{O}_{3}$ and as much as 15 percent $\mathrm{SiO}_{2}$ (Harder and Greig, 1960 , p. 80). As early as 1952 , the aluminum industry had learned to use high-iron bauxite; shipments from Jamaica in that year contained 18.9-20.5 percent $\mathrm{Fe}_{2} \mathrm{O}_{3}$ (Bracewell, 1962, p. 115).

\section{Bauxites for Uses Other Than Aluminum}

The bauxite used for making refractories, abrasives, and chemicals must fulfill more rigid compositional requirements than that used for aluminum. Refractory and abrasive grades of bauxite are calcined and chemical grades are dried before being sold or used. Calcined bauxite consists of corundum, $\mathrm{Al}_{2} \mathrm{O}_{3}$, mullite, $\mathrm{Al}_{6} \mathrm{Si}_{2} \mathrm{O}_{13}$, a titanium-aluminum iron-oxide mineral called tiellite in Germany, and glass (Schneider and others, 1982). High-quality low-silica $\left(\mathrm{SiO}_{2}\right)$ bauxite (table 2$)$ is required for all three uses. However, more silica can be tolerated in chemical-grade bauxite than in refractory and abrasive grades. The domestic refractory bauxite 
TABLE 1.-Composition of typical bauxite used for aluminum

[Listed as reported in sources indicated. Most percentages are for total alumina, but several published sources failed to indicate whether available $\mathrm{Al}_{2} \mathrm{O}_{3}$ (recoverable by Bayer process) or total alumina was reported]

\begin{tabular}{|c|c|c|c|c|c|c|}
\hline & \multicolumn{4}{|c|}{ Major oxides, in percent } & \multirow{2}{*}{$\begin{array}{l}\text { Loss on ignition } \\
\text { (LOI) }\end{array}$} & \multirow[b]{2}{*}{ Bauxite minerals } \\
\hline & $\mathrm{Al}_{2} \mathrm{O}_{3}$ & $\mathrm{SiO}_{2}$ & $\mathrm{Fe}_{2} \mathrm{O}_{3}$ & $\mathrm{TiO}_{2}$ & & \\
\hline \multicolumn{7}{|l|}{ Australia } \\
\hline $\begin{array}{l}\text { Weipa } \ldots \ldots \ldots \ldots \\
\text { (Roberts, 1977, p. 5, } \\
\text { table 1). }\end{array}$ & 54.8 & 5.3 & 5.20 & -- & -- & $\begin{array}{l}\text { Mainly gibbsite, minor } \\
\text { boehmite. }\end{array}$ \\
\hline $\begin{array}{l}\text { Gove } \ldots \ldots \ldots \ldots \ldots \ldots \\
\text { (International Bauxite } \\
\quad \text { Association, 1977a, p. 37). }\end{array}$ & 50 & $3.4-4.2$ & 17.1 & 3.4 & 26.4 & $\begin{array}{l}\text { Mainly gibbsite, minor } \\
\text { boehmite. }\end{array}$ \\
\hline $\begin{array}{l}\text { Jarrahdale } \ldots \ldots \ldots \cdots \cdots \\
\text { (A. Murray, written } \\
\text { commun., 1978). }\end{array}$ & $\begin{array}{c}30-35 \\
\text { (Available) }\end{array}$ & $\begin{array}{c}0.3-2.0 \\
\text { (Reactive) }\end{array}$ & 10-25 & -- & -- & Mainly gibbsite, trace boehmite. \\
\hline \multicolumn{7}{|l|}{ Brazil } \\
\hline $\begin{array}{l}\text { Trombetas } \ldots \ldots \ldots \ldots \ldots \\
\text { (Greig, 1977, p. 12, table 3). }\end{array}$ & 55.9 & 4.8 & 9.4 & 1.3 & 28.6 & $\begin{array}{l}\text { Mainly gibbsite, }<1 \text { percent } \\
\text { boehmite. }\end{array}$ \\
\hline $\begin{array}{c}\text { France } \ldots \ldots \ldots \ldots \\
\text { (Mercier and Noble, } \\
\text { 1974, p. 782) }\end{array}$ & 53.0 & 7.8 & 21.4 & 2.6 & 13.3 & Mainly boehmite. \\
\hline $\begin{array}{c}\text { Ghana } \ldots \ldots \\
\text { (Davies, Lloyd, and Macfie, } \\
\text { 1974, p. 76). }\end{array}$ & 51.6 & 1.3 & 17.4 & 1.9 & 27.78 & $\begin{array}{l}\text { Mainly gibbsite, about } 9 \text { percent } \\
\text { of total } \mathrm{Al}_{2} \mathrm{O}_{3} \text { is in boehmite. }\end{array}$ \\
\hline $\begin{array}{l}\text { Greece } \ldots \ldots \ldots \ldots \ldots \\
\quad \text { (Average of } 30 \text { samples; } \\
\text { Aronis, 1955). }\end{array}$ & 57.6 & 3.0 & 22.8 & 2.75 & 12.17 & Mainly boehmite, some diaspore. \\
\hline \multicolumn{7}{|l|}{ Guinea } \\
\hline $\begin{array}{l}\text { Boké-Sangaredi } \ldots \ldots \ldots \ldots \\
\text { (Landi and Casola, 1977, p. 82). }\end{array}$ & $59.1-59.6$ & $0.7-0.9$ & $4.9-5.9$ & $3.3-3.5$ & $30.6-31.0$ & $\begin{array}{l}83-86 \text { percent gibbsite, } 3.5-5.5 \\
\text { percent boehmite. }\end{array}$ \\
\hline $\begin{array}{l}\text { Kindia-Débélé } \ldots \ldots \ldots \ldots \\
\text { (Wyllie, 1976, p. 73). }\end{array}$ & 48 & $1-3$ & -- & - & -- & No data available. \\
\hline $\begin{array}{l}\text { Fria } \ldots \ldots \ldots \ldots \\
\text { (Sparwald, 1978, p. 1). }\end{array}$ & 45.5 & 4.0 & 23.6 & 2.5 & 23.9 & Mainly gibbsite. \\
\hline $\begin{array}{l}\text { Guyana } \\
\text { (Lachmansingh and Nooten, } \\
\text { 1977, p. 2). }\end{array}$ & $55-61$ & $1-10$ & $0.8-5$ & $2-5$ & $30-35$ & Nearly pure gibbsite. \\
\hline $\begin{array}{l}\text { Hungary } \ldots \ldots \ldots \ldots \ldots \ldots \\
\quad \text { (Bárdossy, 1958a). }\end{array}$ & $50-60$ & $1-5$ & -- & - & -- & $\begin{array}{l}\text { Mainly boehmite, minor } \\
\text { gibbsite. }\end{array}$ \\
\hline \multicolumn{7}{|l|}{ India } \\
\hline $\begin{array}{l}\text { Rānchī . . . . . . . . . . } \\
\text { (Roy Chowdhury, 1965, } \\
\quad \text { p. 14-15). }\end{array}$ & $51-60$ & $0.1-5$ & $4-10$ & $0.3-17$ & $22-28$ & $\begin{array}{l}\text { Mainly gibbsite, minor } \\
\text { boehmite. }\end{array}$ \\
\hline $\begin{array}{l}\text { East Coast province } \ldots \ldots \\
\text { (Bharat Aluminium Co., 1977). }\end{array}$ & $43.7-56.5$ & $0.5-4.2$ & $8.6-38.4$ & $2.1-3.5$ & $24.6-30.5$ & $\begin{array}{l}\text { Mainly gibbsite, }<5 \text { percent } \\
\text { boehmite. }\end{array}$ \\
\hline $\begin{array}{l}\text { Indonesia } \ldots \ldots \ldots \ldots \ldots \\
\text { (U.S. Embassy, Jakarta, } \\
\text { Indonesia, State } \\
\text { Department Airgram A-51, } \\
\text { May } 19,1978,1 \text { p.). }\end{array}$ & 53 & 5 & -- & 1.2 & -- & Mainly gibbsite. \\
\hline
\end{tabular}


TABLE 1.-Composition of typical bauxite used for aluminum-Continued

\begin{tabular}{|c|c|c|c|c|c|c|}
\hline & \multicolumn{4}{|c|}{ Major oxides, in percent } & \multirow{2}{*}{$\begin{array}{l}\text { Loss on ignition } \\
\text { (LOI) }\end{array}$} & \multirow[b]{2}{*}{ Bauxite minerals } \\
\hline & $\mathrm{Al}_{2} \mathrm{O}_{3}$ & $\mathrm{SiO}_{2}$ & $\mathrm{Fe}_{2} \mathrm{O}_{3}$ & $\mathrm{TiO}_{2}$ & & \\
\hline $\begin{array}{c}\text { Jamaica } \ldots \ldots \ldots \\
\text { (Bracewell, 1962, p. 115; } \\
\text { Strahl, 1971, p. 66) }\end{array}$ & $49.1-50.6$ & $0.7-6.1$ & $18.9-20.5$ & $2.5-2.7$ & $24.6-27.3$ & $\begin{array}{l}\text { Mainly gibbsite, } 7-10 \text { percent } \\
\text { boehmite. }\end{array}$ \\
\hline \multicolumn{7}{|l|}{ Suriname } \\
\hline $\begin{array}{l}\text { Onverdacht } \ldots \ldots \ldots \\
\text { (Aleva, 1975, p. 259). }\end{array}$ & $58.5-60.0$ & $3.4-4.3$ & $2.7-4.4$ & $2.4-2.7$ & $30.7-31.4$ & Nearly pure gibbsite. \\
\hline \multicolumn{7}{|l|}{ United States } \\
\hline Arkansas $^{1}$ & $45-50$ & 13 & 8 & $2.5-3$ & $25 \pm$ & $\begin{array}{l}\text { Gibbsite, } \mathrm{SiO}_{2} \text { is mainly in } \\
\text { kaolinite. }\end{array}$ \\
\hline $\begin{array}{l}\text { U.S.S.R. } \ldots \ldots \ldots \ldots \ldots \ldots \\
\quad \text { (Sidorenko, 1973). }\end{array}$ & $\begin{array}{l}\text { Ranges broadly, } \\
\text { mainly 45-55. }\end{array}$ & $2-10$ & $5-15$ & -- & -- & $\begin{array}{l}\text { Most deposits are boehmite; } \\
\text { some are mixed with diaspore; } \\
\text { a few are gibbsitic. }\end{array}$ \\
\hline $\begin{array}{l}\text { Yugoslavia } \ldots \ldots \ldots \ldots \ldots \\
\text { Titograd and Mostar } \\
\text { (Mercier and Noble, 1974, } \\
\text { p. 783-784). }\end{array}$ & $56-58$ & $3-5$ & $20-22$ & $2.5-2.7$ & 13.0 & $\begin{array}{l}\text { Mainly boehmite; } \mathrm{SiO}_{2} \text { is in } \\
\text { kaolinite. }\end{array}$ \\
\hline
\end{tabular}

${ }^{1}$ Average composition estimated by U.S. Bureau of Mines (R. B. Stroud, written commun., 1979).

TABLE 2.-Chemical composition of bauxite produced for refractory, abrasive, and chemical uses [All values except bulk specific gravity in percent. LOI, loss on ignition; max, maximum; min, minimum; --, no data]

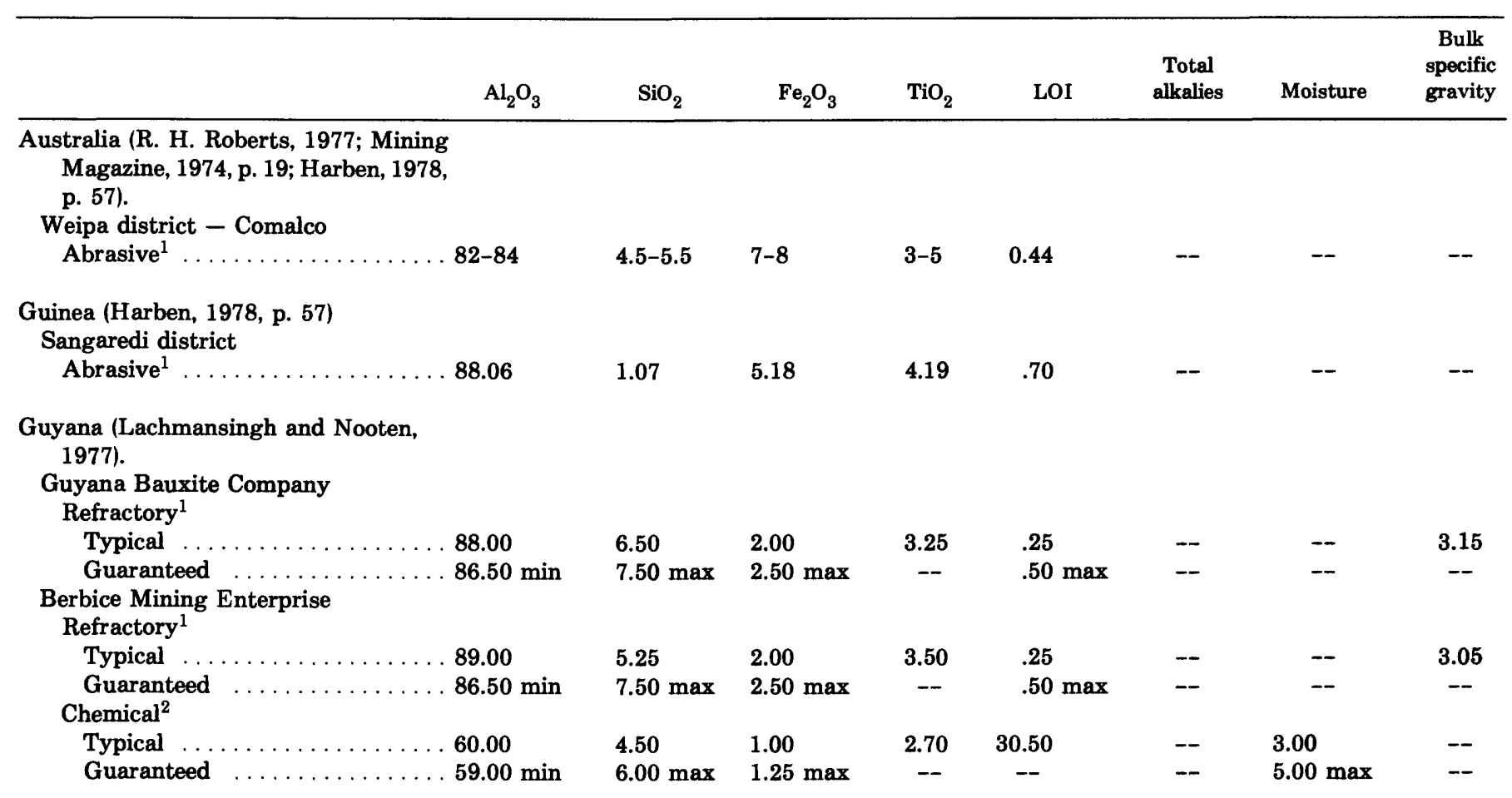


WORLD BAUXITE RESOURCES

TABLE 2.-Chemical composition of bauxite produced for refractory, abrasive, and chemical uses-Continued

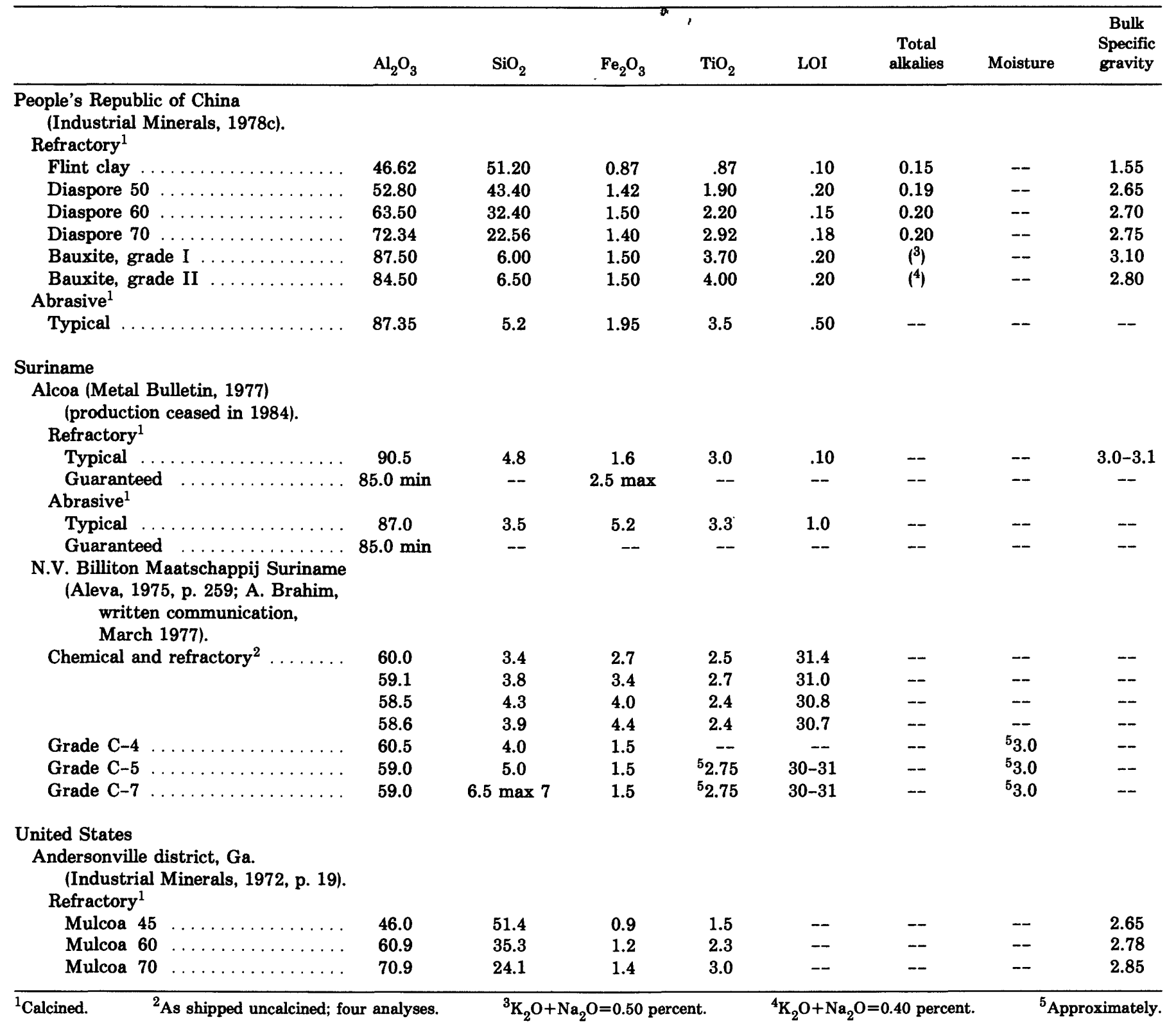

and some of the diaspore bauxite produced in the People's Republic of China also have considerably more silica than refractory bauxite produced elsewhere (table 2). Refractory bauxite from China also contains more alkalies and alkaline earths than most refractory bauxite (Wittmer, 1982). Iron oxide $\left(\mathrm{Fe}_{2} \mathrm{O}_{3}\right)$ contents must be low for chemical and refractory bauxite grades, but considerably higher proportions can be tolerated in abrasive grades (table 2) because iron is removed in processing. A minimum of 3 percent titania $\left(\mathrm{TiO}_{2}\right)$ is required in most bauxite prepared for abrasive use because this oxide influences the toughness of alumina crystals.
Bauxite used in aluminous cements varies considerably in composition. Silica contents must be low for applications requiring rapid hardening properties, whereas as much as $\mathbf{2 5}$ percent iron oxide may be beneficial (Industrial Minerals, 1974, p. 10). Alumina contents must be high in bauxite used for cement requiring resistance to high temperatures and chemical corrosion.

Most bauxite used as a flux in steel making must be high in $\mathrm{Al}_{2} \mathrm{O}_{3}$ content ( $>50$ percent) and low in $\mathrm{SiO}_{2}$ content. The bauxite used for this purpose in India is as much as 10 percent $\mathrm{Fe}_{2} \mathrm{O}_{3}$, and contents of $\mathrm{TiO}_{2}$ are even higher (Kumar and others, 1977, table 9.39). 
Proppants are a nonmetallic use of bauxite that has been developed in the last few years. They are materials used in hydraulic fracturing of deep rocks to increase porosity and thereby improve the recovery of petroleum and gas. Such materials as quartz sand, plastic balls, steel shot, and ground walnut shells are used, but proppants made of fused abrasive-grade bauxite have been found to be more effective in fracturing rocks penetrated in deep wells (Crittenden, 1983). The proppants are spherical particles resembling shotgun pellets. One company advertised three mesh sizes of sintered bauxite proppants: $12 / 30,20 / 40$, and $40 / 70$ mesh, which are approximately equivalent to very coarse to coarse, coarse to medium, and medium sand sizes.

Minor quantities of calcined bauxite are used in welding flux (Andrews, 1984, p. 61). Compositional specifications of the bauxite for this use are proprietary and relate to the residual water after calcination because hydrogen reduced from water in the welding arc may dissolve the molten metal and cause the weld to be brittle.

Activated bauxite has several uses. According to Andrews (1984, p. 62), activated bauxite is produced by low-temperature roasting, which drives off two of the three molecules of the combined water. This dehydration is reversible, and the activated bauxite readily takes up water. The property of recombining with water makes activated bauxite an excellent drying agent for gases and organic liquids. Activated bauxite is also used as an absorbent agent for other elements, as a catalyst, and for filtration.

The major share of the world's abrasive-grade bauxite is produced in the Weipa district, Australia, and the Sangaredi district, Guinea; refractory-grade bauxite is obtained from the People's Republic of China and Guyana (Everts, 1984, p. 89). Suriname formerly ranked with the leading producers of refractory and abrasive grades of bauxite, but Suralco ceased producing calcined bauxite early in 1984 (J.A. Everts, oral commun., 1984) leaving N.V. Billiton Maatschappij Suriname, which ships uncalcined bauxite for nonmetallurgical uses, as the only producer. According to Lebauer (1983, p. 10), refractory bauxite in the People's Republic of China (P.R.C.) occurs in the provinces of Guizhou, Henan, Shanxi, Hebei, Guangxi, and Sichuan. The Chinese refractory bauxite added to the national stockpile in 1982 came from Shanxi and Guizhou provinces (Luke Baumgardner, oral commun., 1984). The reserves of refractory-grade bauxite in the P.R.C. are thought to be as much as 1 billion tons (Lebauer, 1983, p. 9), and Guyana is reported to have 525 million tons of refractory bauxite (Hinds, Ralph, and Pollard, 1983, p. 15).

\section{EXPLORATION AND EVALUATION OF BAUXITE DEPOSITS}

Bauxite exploration programs ordinarily begin with geologic studies to identify areas where conditions have been favorable for the formation of bauxite for laterite. To locate large laterite-type deposits in tropical regions, one must find old plateau areas. As adequate topographic maps were not available, one company found aerial photographs very useful in finding old plateaus in the Amazon basin (Greig, 1977, p. 3). Another company had success in using side-looking radar imagery in this same region (Dennen and Norton, 1977, p. 82). Many of the early bauxite discoveries were made by prospecting outcrops and tracing bauxite stream gravels to their source, and this method is still used in favorable terrain. Some deposits have been discovered by the recognition of the high alumina content of soils analyzed for other purposes. In several tropical countries, stunted or distinctive vegetation has served as a guide to the distribution of bauxite deposits near the surface, because tropical weathering processes that formed the bauxite also removed essential plant nutrients.

Geophysical methods ordinarily are not very successful in locating bauxite because of insufficient differences in the properties of the deposits and the associated rocks; however, the methods have been used in several countries. Surficial karst-type bauxite deposits on Vaghina Island in the South Pacific have a radioactive response and were located by an airborne scintillometer reconnaissance (Chapman and Evans, 1979). Remote sensing of bauxite by satellite has been applied to bauxite exploration with some success (Henderson, Penfield, and Grubbs, 1984). The techniques used include shortwave infrared, visible, very near infrared, and thermal infrared. By use of these methods it has been possible to outline some of the general areas containing bauxite in Australia and West Kalimantan, Indonesia. The topography of the basement rocks underlying coastal plain sediments, which influences the distribution of bauxite in Guyana, was mapped by seismic methods (Greig, 1977). Airborne magnetometer surveys have been used in locating bauxite in Guyana (Bracewell, 1962, p. 20), and magnetometer, seismic, and gravity techniques would be useful in Suriname (Doeve and Groeneveld Meijer, 1963), where the occurrence of bauxite is related to igneous and metamorphic rocks. Geophysical methods have also been applied in bauxite prospecting in Hungary (Ottlik and Szabadvary, 1971), the United States (in Arkansas; Thoenen, Malamphy, and Vallely, 1945), Guyana (E. Anderson, 1969), and other countries. 
After a bauxite deposit has been found, it is sampled by drill holes and test pits or trenches. Many different types of percussion and rotary drills and augers have been used in bauxite exploration (Shaffer, 1975, p. 454). Initial sampling is ordinarily done by widely spaced drill holes to determine the thickness and extent of deposits, and holes are spaced closer in later evaluations. For example, in the exploration of deposits on the Mitchell plateau, Australia, holes were drilled in a grid of $975 \mathrm{~m}$ in the early stages, and later the spacing of holes was reduced to $122 \mathrm{~m}$ where bauxite was found (Joklik, Jackson, and Zani, 1975). The final drilling in the Mount Saddleback district, Australia, was at intersections of a 100-m grid, and selected areas were drilled at 20-m intervals (Owen and Hargreaves, 1975, p. 990). The evaluation of the karst-type deposits requires a much tighter grid of drill holes than does evaluation of the laterite deposits because of the irregular shapes and thicknesses of the karst-type deposits. Test pits or trenches are necessary to study the detailed geology of deposits and to obtain bulk samples required for processing tests under conditions similar to those in a Bayer plant.

Evaluation of bauxite deposits requires many chemical analyses and mineralogical determinations, and several methods are used. Some of these methods are designed for use in the field in reconnaissance work or in preliminary evaluations. Others, requiring sophisticated laboratories, are used for more accurate results and for scientific studies.

Some of the rapid methods that are used in the field or in partly equipped laboratories are based on measurement of weight loss and other changes taking place when bauxite is heated (Schellmann, 1974). Roy Chowdhury and Anandalwar (1964) and Pollard and Barron (1955) have applied loss on ignition as a guide in estimating the quantity of trihydrate bauxite. A thermogravimetric apparatus designed by Van Essen and others (1971) is also reported to be reasonably accurate for determining the quantity of gibbsite in bauxite. Portable differential-thermal-analysis (DTA) equipment is satisfactory for preliminary identification of minerals in bauxite (Hendricks, Goldich, and Nelson, 1946; Park, Hathaway, and Blackmon, 1956). More sensitive laboratory DTA apparatus is used for more refined and scientific studies of bauxite (Mackenzie, 1957; Jónás and Solymár, 1970).

A semimobile laboratory was designed by an aluminum company for use in the Amazon. It has specialized equipment ordinarily found only in well-equipped permanent laboratories including an atomic-absorption spectrophotometer, a photoelectric colorimeter and a rotating heat-pressure digestion system (Mining Engineering, 1971a). A neutron-activation probe developed by Allan B. Tanner, Robert M. Moxham, and Frank E. Senftle of the U.S. Geological Survey and J.A. Baicker of the Princeton Gamma Tech Corporation (Tanner and others, 1972) may prove useful in exploration. This probe, when lowered down a drill hole, will provide semiquantitative determinations of the aluminum in the wallrock. Information on the content of titanium, iron, and other possible constituents in the bauxite might also be obtained by this method.

Standard pressure-temperature wet-chemical analyses are made in most bauxite exploration programs (Shaffer, 1975, p. 454; Greig, 1977), but several other analytical methods are also used. In the chemical method, bauxite samples are commonly analyzed for alumina, silica, iron oxide, titania, and loss on ignition. Available alumina, the alumina that can be recovered by the Bayer process, and reactive silica, the silica that combines with alumina and soda in the Bayer process, are also frequently determined. X-ray emission spectrography (Adler, 1966; Rose, Adler, and Flanagan, 1963; Tertian, Fagot, and Jamey, 1964) and neutronactivation analysis (Dugain and Tatar, 1970; Weisse, Mannweiler, and Rybach, 1978) are efficient methods for determining several elements. X-ray diffraction (Rooksby, 1961; R.H. Black, 1953; Strahl, 1977; Bárdossy and others, 1980) is probably the most reliable method of determining the mineral composition of bauxite, but infrared techniques (Frederickson, 1954; J.L. White, 1974; Solymár and Jónás, 1974), the electron microscope (Remizov, 1966; Bárdossy, Vassel, and Arkossy, 1975; Bárdossy, Csanády, and Csordás, 1978), and the electron probe (Bárdossy and Pantó, 1971) are also used. A computerized method used by one company for organizing the results of mineral identification by $\mathrm{X}$-ray diffraction and analysis by X-ray emission and for tabulating thicknesses for reserve estimates was described by Strahl (1977, 1982). An atomic-absorption spectrometer is used for analysis of samples taken during exploration and for plant processing control at Weipa, Australia (R.H. Roberts, 1977, p. 8).

\section{MINING METHODS}

Open-pit mining accounts for all the bauxite mined in the United States and 80-90 percent of the world bauxite production. In Arkansas, draglines, scrapers, shovels, and trucks are used in stripping operations. Stripping ratios as high as $10 \mathrm{~m}$ of overburden to $1 \mathrm{~m}$ of ore are common, and a ratio of 13 to 1 is the maximum considered feasible. Several pits in Arkansas have been mined to depths of more than $30 \mathrm{~m}$, and about $66 \mathrm{~m}$ is the present economic limit for large ore bodies. The pits stand well for unconsolidated rocks, but slumping does 
take place. Deeper flat-lying ore was recovered by Reynolds Mining Corp. in Arkansas by an underground method of room-and-pillar mining along a retreating cave line, but this company ceased underground operations in 1976.

In Jamaica, the bauxite deposits lie close to the surface, and the overburden of vegetation and topsoil is easily stripped. The ore usually requires no blasting. Shovels, draglines, and end-loaders are used to load the ore. Haulage is by truck, railroad, or aerial tramline to alumina plants or port facilities. In Suriname and Guyana, as much as $60 \mathrm{~m}$ is stripped by draglines, scrapers, or bucket wheel excavators. The ore is loaded into trucks by power shovels, backhoes, and draglines. In some districts the bauxite is trucked to stockpiles near the mines and is reloaded onto trams for haulage to plants.

At Weipa, Australia, bulldozers and scrapers remove the overburden. Front-end loaders, each mining in excess of 500 tons per hour, then load the free-flowing pisolitic ore onto trucks for a short haul to a beneficiating plant for sizing and washing. At the Del Park deposits in the Darling Range of Western Australia, forest clearing and overburden removal is followed by blasting of the hardcap, which comprises the top meter or two of the bauxite deposits. Front-end loaders load dump trucks for haulage to a mobile crushing plant. Bauxite is carried from the crusher to an alumina plant on a belt system $6.5 \mathrm{~km}$ long. The deposits mined for the Boké project in Guinea are under little overburden but require blasting. Loosened ore is loaded by large electric shovels directly onto rail cars for shipment $137 \mathrm{~km}$ to a treatment plant and port at Kamsar. Underground mining accounts for most of the French and Hungarian bauxite production and is widely used in other parts of Europe, including the U.S.S.R. Roomand-pillar and various stoping methods are used.

Kriging and other geostatistical methods, some of which are computerized, are now applied to bauxite reserve calculations and mine planning (see several papers in the symposium volume published by the Geological Society of Jamaica, 1982).

\section{BAUXITE PROCESSING}

Bauxite treatment is usually confined to crushing, washing, and drying operations. Most of the bauxites that are mined do not require the more costly beneficiation techniques used on some other metal ores. Moreover, most impurities, such as the iron, silicon, and titanium, are commonly so finely dispersed in the bauxite that they cannot readily be separated by physical methods. Many bauxites are upgraded, however, by washing or wet screening to remove sand and some of the clay minerals. Heavy-media separation and jigging have been used to separate iron minerals. In Arkansas, siderite has been removed by using spiral concentrators and magnetic separators.

Metallurgical and chemical grades of bauxite that must be transported appreciable distances are dried before shipment. Because crude bauxite may contain 10-30 percent free moisture, drying results in considerable savings in freight. Drying also facilitates the handling of bauxite; the degree to which a specific bauxite is dried depends in part on its handling and dusting characteristics. Bauxite in Suriname is dried to 3-6 percent moisture, whereas Jamaican bauxite is shipped with about 15 percent moisture. Bauxite for use in refractories and abrasives must be calcined to remove both the chemically combined water and free moisture. Bauxite drying to reduce free moisture is done in kilns at about $300^{\circ} \mathrm{C}$. Calcined bauxite is processed by heating at $900-1600^{\circ} \mathrm{C}$ to reduce total volatile matter, including water combined in hydroxyl form in the ore, to less than 1 percent. About 2 tons of crude ore are required to produce 1 ton of calcined bauxite.

\section{ALUMINA PRODUCTION}

Although research on alumina extraction from various mineral raw materials has continued for many years, virtually all the commercially produced alumina is obtained by a process patented by Karl Bayer in 1888 (German Patent 43,977) for use on bauxite. The Bayer process involves a caustic leach of the bauxite, at elevated temperature and pressure, followed by separation of the resulting sodium aluminate solution and selective precipitation of the aluminum as the hydrated aluminum oxide $\left(\mathrm{Al}_{2} \mathrm{O}_{3} \cdot 3 \mathrm{H}_{2} \mathrm{O}\right)$.

Two major variations of the Bayer process are used. Though leaching conditions vary from plant to plant, the European process, which is applied to boehmitic bauxite, operates at higher pressures and temperatures, at stronger caustic concentrations, and for longer periods than the American variation, which is designed to treat gibbsitic ore (table 3). The American process also requires less evaporation and lower temperatures.

In both the European and American processes, the pregnant solution is separated from the insoluble red mud tailings by filtration when very high alumina bauxites are used and by countercurrent decantation and filtration when the bauxite processed contains only moderate or low percentages of alumina. The liquor is cooled until it becomes supersaturated and then is seeded with crystals of aluminum trihydrate. The alumina in solution is precipitated as the trihydrate, 
TABLE 3.-Approximate leaching conditions of the European and American Bayer processes

\begin{tabular}{|c|c|c|}
\hline & European & American \\
\hline $\begin{array}{l}\text { Pressure, in grams per } \\
\text { square centimeter. }\end{array}$ & 15,000 & 4,000 \\
\hline Temperature & $200^{\circ} \mathrm{C}$ & $145^{\circ} \mathrm{C}$ \\
\hline $\begin{array}{l}\text { Caustic concentration, } \\
\text { in grams per liter.. }\end{array}$ & 400 & 170 \\
\hline Digestion time, in hours. & $2-8$ & $0.5-1$ \\
\hline
\end{tabular}

filtered, and washed. Caustic soda is regenerated in the precipitation step and, together with the unprecipitated alumina, is recycled to the digesters. The filtered and washed alumina trihydrate is calcined for use in making metal. A portion of the washed alumina may be left in the trihydrate form for chemical uses or may be further processed under controlled conditions to produce a variety of chemical aluminas, such as activated or tabular alumina for uses other than metal.

The red mud contains $\mathrm{Fe}_{2} \mathrm{O}_{3}, \mathrm{TiO}_{2}, \mathrm{SiO}_{2}$, and a complex sodium aluminum silicate compound which represents a loss of both alumina and soda. For this reason, ore containing more than 8 percent $\mathrm{SiO}_{2}$ is usually uneconomic for treatment by the Bayer process. Approximately 1.1 units (weight unit) of alumma and 1.2 units of soda (expressed as $\mathrm{Na}_{2} \mathrm{CO}_{3}$ ) are lost for each unit of reactive silica in the ore in addition to soda losses in the washed mud. The loss of soda must be made up by addition of caustic soda or soda ash and lime to the spent leach solution to bring it up to the appropriate caustic concentration before it is recycled.

The materials other than bauxite required in the Bayer process are caustic soda or the equivalent soda ash and lime; starch, to aid settling and filtering; and oil, gas, or coal, chiefly for producing steam and calcining alumina. The use of caustic soda has generally replaced the use of soda ash and lime, although some lime is still used to recausticize spent caustic leach solution.

Bauxite containing more than 8 percent silica may be treated by the combination process developed by Alcoa. In this process, bauxite containing 12-15 percent silica is first subjected to a Bayer leach. The resulting red mud, containing the complex sodium aluminum silicate compound, is sintered with limestone and soda ash then leached with water to recover alumina and soda. The insoluble residue (brown mud) resulting from leaching the sintered material has a composition somewhat similar to that of portland cement.
The additional cost required in capital investment, raw materials, and processing by the combination method is partly offset by higher recoveries of alumina and soda. Mining costs are reduced and reserves are increased because high-silica bauxite, regarded as unsuitable for alumina production by the straight Bayer process, can be used. The upper limit of silica in bauxite processed by the combination method is about 15 percent. However, in practice, bauxite containing some clay and as much as 25 percent silica is mined and blended with low-silica ore in proportions that will give a feed material of approximately 12-13 percent silica. The combination process is used in the two plants in Arkansas and in plants in the U.S.S.R.

In 1952, the American Bayer process was modified to treat the high-iron, low-silica bauxite of Jamaica. The major modifications resulted from the need to avoid difficulties in filtration of the red-mud slurry and from the presence of both boehmite and gibbsite in the ore.

The removal of iron and titanium oxides by highintensity magnetic separation has been shown to be workable in beneficiating some bauxites (Murray and Walker, 1979; Iannicelli, 1984). The method is capable of upgrading bauxite from Arkansas and Suriname to meet specifications for refractory-grade bauxite.

\section{BYPRODUCTS}

The world's gallium requirements are now believed to be a little more than $16,000 \mathrm{~kg}$ annually (U.S. Bureau of Mines, 1985). Gallium to meet these needs is recovered as byproducts, and most of the gallium produced is recovered during the extraction of alumina from bauxite. Gallium is recovered from bauxite in West Germany, France, Hungary, People's Republic of China, and Japan. The Alummum Company of America formerly produced gallium from bauxite in Arkansas, but in 1982 supplied this metal only from stocks (Petkof, 1982) and apparently has no plans to reactivate production. The reported consumption of gallium in the United States in 1984 was estimated to be approximately $7,000 \mathrm{~kg}$ (U.S. Bureau of Mines, 1985, p. 52).

The chemistry of gallium is similar to that of aluminum, and apparently gallium substitutes for alumimum in bauxite minerals in variable quantities (table 8). The percentages of gallium in several types of bauxite consumed in the United States (Hudson, 1965, table 1) are as follows: domestic ore-0.0070, Caribbean bauxite-0.0039, and Suriname bauxite-0.0074. In the Bayer process, gallium oxide is dissolved along with the aluminum hydroxide. The gallium is concentrated in the process liquor, from which it can be recovered. Gallium that is not extracted is lost in the alumima and red mud 
residue. Inasmuch as gallium is not recovered in most alumina plants, the potential for much greater recovery exists. Because it is practical to recover gallium only as a byproduct, the quantity available from the very large gallium resources in world bauxite deposits will be limited by the amount of bauxite processed for alumina.

Bauxite at the Boddington mine, Mt. Saddleback district, Western Australia, has been found to contain 3-3.5 g/ton of gold (Engineering and Mining Journal, 1985). Plans to construct a cyanide leach carbon-in-pulp plant to recover 165,000 troy ounces of this gold per year were in an advanced stage when this report was completed. According to the plan, tailings from the gold plant were to be stockpiled and used to supply an alumina plant.

Metals other than gallium and a few nonmetallic compounds are concentrated during the weathering processes that form bauxite. Some of these materials have been recovered during the processing of bauxite, and the recovery of others has been considered. Pig iron was recovered in a plant processing bauxite by the Pedersen process at H申yanger, Norway, from 1928 to 1964 (Miller and Irgens, 1974). Vanadium and gallium are recovered as byproducts of bauxite in Hungary (Miskei, Toth, and Bogardi, 1978). Vanadium and chromium were recovered as byproducts of bauxite processing in Germany during World War II, and vanadium was recovered occasionally from bauxite in France (Bracewell, 1962 , p. 59-60). Studies have been made of the potential for recovering vanadium and a phosphate fertilizer, as well, from bauxite in India containing $0.05-0.10$ percent $\mathrm{V}_{2} \mathrm{O}_{5}$ and $0.10-0.20$ percent $\mathrm{P}_{2} \mathrm{O}_{5}$ (Bhattacharyya, 1977). A sample of sludge precipitated from caustic liquor from a Bayer plant at Muri, India, contained 1.92 percent $\mathrm{V}_{2} \mathrm{O}_{5}$ and 1.75 percent $\mathrm{P}_{2} \mathrm{O}_{5}$.

The high titanium content of bauxite has long attracted attention to that metal as a potential byproduct (Calhoun, 1950). To date, attempts to recover it have been unsuccessful because most titanium in bauxite is in the 325-mesh fraction $(45 \mu \mathrm{m})$ and, therefore, is difficult to concentrate. Moreover, titanium is unaffected by the alkaline digestion process used in alumina extraction, and it is concentrated in the red-mud waste.

A significant untapped potential exists for the recovery of byproducts from the large quantities of redmud wastes generated at Bayer-process alumina plants. This material is ordinarily impounded in red-mud lakes near plants. The average quantity of red mud produced is probably about 1 ton of solids (dry basis) for each ton of alumina extracted. However, the amount varies greatly depending on the type of bauxite and the process used. For example, the extraction of 1 ton of alumina produces about 0.3 ton of red mud when Suriname-type bauxite is the raw material and 2.0 tons when the Arkansas type is processed. The byproduct potentials exist because several metallic and other elements are concentrated as most of the alumina, the major component of bauxite, is removed. The recovery and sale of byproducts would lead to bonus profits and would reduce waste disposal problems. Red-mud disposal is a major environmental concern as well as a significant cost in the production of alumina.

A great deal of research has been done on the utilization of red mud. The U.S. Bureau of Mines (Fursman and others, 1970) has investigated methods of producing alumina, iron, titania, and portland cement from this waste material. A thorough assessment of the technology for possible mud uses was completed by the Battelle Memorial Institute for the U.S. Environmental Protection Agency (Parekh and Goldberger, 1976). Much of the research is either outlined or referred to in reports by Fursman and others (1970) and Parekh and Goldberger (1976), and much of the research in Europe is either described or referenced in the publications of the International Committee for Studies of Bauxites, Oxides, and Hydroxides of Aluminium (ICSOBA). All this research and testing notwithstanding, only minor uses of red mud have been found, and the assessment by Battelle concludes that the technology required for significant use of red mud is yet to be developed.

The composition of red mud ranges broadly (table 4) because of variations in bauxite composition, in additives during processing, and in efficiency of alumina recovery. The alumina unrecovered in processing, as well as the abundant iron in typical red muds, is a tempting potential byproduct. The titania content of mud is appreciably higher than that of beach sand, the principal ore for this metal or oxide in the United States and elsewhere (Hartman, 1959, p 1402). Titania contents of some muds, such as those at one plant in India, are as much as 22.6 percent (Kumar and others, 1977, p. 318), which is considerably higher than titanium contents in mud at U.S. plants.

Calcium contents of mud are high at plants processing bauxite from Arkansas by the combination process because limestone is added at the sintering stage. The

TABLE 4.-Ranges of majoroxide contents in red muds on a dry basis [All values in weight percent]

\begin{tabular}{|c|c|c|c|c|c|c|}
\hline $\begin{array}{c}\text { Source of } \\
\text { bauxite }\end{array}$ & $\mathrm{Al}_{2} \mathrm{O}_{3}$ & $\mathrm{Fe}_{2} \mathrm{O}_{3}$ & $\mathrm{SiO}_{2}$ & $\mathrm{TiO}_{2}$ & $\mathrm{CaO}$ & $\mathrm{Na}_{2} \mathrm{O}$ \\
\hline Jamaica & $.13-22$ & 43-53 & $2-7$ & $6-7$ & $5-8$ & $\overline{1-6}$ \\
\hline Suriname & . $15-20$ & $25-33$ & $8-16$ & $8-12$ & $3-12$ & $4-10$ \\
\hline Arkansas $^{1}$ & $6-9$ & $7-11$ & $12-24$ & $3-5$ & $39-47$ & $2-6$ \\
\hline
\end{tabular}

${ }^{1}$ Red mud from Arkansas is commonly called brown mud. 
limestone and the low iron content cause the mud to be brown rather than red, but it is the same general type of plant waste. The high calcium content of this mud is apparently the principal reason it has been tested as a building and road-construction material and as a soil conditioner.

Some of the possible uses of red mud that have been investigated, in addition to those mentioned above, include the following: (1) construction materials such as lightweight aggregate, building blocks and brick, landfill, and pozzolans for cement; (2) products using the absorptive and neutralizing properties of dry red mud in the abatement of pollutants from both gaseous and liquid effluents from industrial and municipal wastes; (3) fillers for such products as plastics and resins; (4) pigments for concrete, glass, and paint; and (5) flux in steel making, presumably to substitute for fluorspar.

Many minor elements are concentrated in red mud because they tend to occur in minerals that are inert during plant processing, and such elements are therefore potential byproducts. The red mud produced from Arkansas bauxite contains as much as $0.2 \mathrm{~kg}$ of thorium per dry ton and as much as $\mathbf{4 0} \mathrm{ppm}$ uranium (Adams and Richardson, 1960 , p. 1672, table 7), and it is considerably enriched in zirconium. Niobium makes up an average of 0.05 percent of the Arkansas bauxite (Gordon, Tracey, and Ellis, 1958, p. 99; Fleischer and others, 1952) but is difficult to recover (Nieberlein and others, 1954). Logomerac (1969) found concentrations of niobium, zirconium, uranium, and rare-earth elements such as lanthanum and yttrium as well as scandium, germanium, and hafnium in red mud in Suriname, and he suggested that recovery of many of these elements is feasible. In a later report (Logomerac, 1974), he noted that similar concentrations occur in other bauxites.

\section{UNITED STATES AND WORLD BAUXITE PRODUCTION}

Aluminuun was extracted from bauxite in both France and England in the middle of the 19th century, but only small quantities of bauxite were needed for the less than 50 tons of this metal produced by 1885 (Fox, 1932, p. 230). World production increased steadily in the late 1800 's and early 1900 's, but the yearly demand for bauxite did not reach 1 million tons until 1917, when demand was influenced by World War I. World production of bauxite dropped after the war to a low of 318,000 tons in 1921. A yearly production of 2 million tons was first reached in 1928. World production again dropped in the depression years of the early 1930's but recovered as World War II approached and reached a peak of nearly 14 million tons in 1943 (table 5, fig. 1). Production again slumped sharply after the war as the economy adjusted to peacetime conditions and accumulated stocks were consumed. After recovering from this slump, annual world bauxite production exceeded 10 million tons in 1951, 20 million tons in 1958, 50 million tons in 1969, and 80 million tons in 1977. Between 1951 and 1977, world production declined only in 1963 and 1975, and it showed an average annual growth rate of 8.1 percent.

Bauxite production in the United States remained below 1 million tons annually until very intensive mining was started in 1942 to meet World War II requirements; a record production of 6.3 million tons was reached in 1943 (fig. 1). Domestic production has remained between 1.1 million and 2.2 million tons per year from 1946 to 1982 .

France was the world's leading bauxite-producing country during most of the years from the time bauxite was first produced in the 19th century through 1939 , except for the period from 1915 to 1923 , when the United States was the leader. The United States again became the leading producer during World War II and held that position between 1942 and 1945. Bauxite production in both the United States and France dropped below 2 million tons in 1978 and has continued to decline since that date. Suriname was the leading producer for 10 consecutive years, beginning in 1947. Jamaica, which did not produce bauxite until 1952, produced the most bauxite of any country in 1957 and continued to be the leader until 1971, when Australia took the lead (table 6). Australia increased production from less than 100,000 tons in 1962 to 27.583 million tons by 1979 , when it accounted for nearly one-third of the world's output. The two countries producing the next largest amounts of bauxite in recent years have been Guinea and Jamaica, each producing between 8 million and 15 million tons annually. Suriname and the U.S.S.R. have each produced 3 million- 6 million tons per year, and Hungary, Greece, Guyana, Yugoslavia, France, and the United States have all exceeded 2 million tons per year. Countries in which major expansion of bauxite production is expected to take place in the next decade include Australia, Brazil, Guinea, India, and Venezuela, and possibly Cameroon, People's Republic of China, Ghana, Greece, and Indonesia.

Guyana, which has calcining capacity of nearly 1.1 million tons a year (Lachmansingh and Nooten, 1977, p. 7-8), is the leading producer of high-grade bauxite for nonmetallurgical uses. Guyana exports both refractory and chemical grades. Two companies in Suriname produced bauxite used for refractories, abrasives, and chemicals (Industrial Minerals, 1974, p. 13). One producer in the Weipa district, Queensland, Australia, has an annual calcining capacity for abrasive-grade bauxite of 250,000 tons (R.H. Roberts, 1977, p. 11-12). The 
TABLE 5.-United States and world bauxite production, 1900-83

[All values in thousands of metric tons]

\begin{tabular}{|c|c|c|c|c|c|}
\hline Year & United States & World & Year & United States & World \\
\hline 1900 & 23 & 88 & $\overline{1942}$ & $\ldots \ldots \ldots \ldots$ & 8360 \\
\hline 1901 & 19 & 105 & 1943 & $\ldots \ldots \ldots \ldots \ldots \ldots \ldots \ldots \ldots \ldots \ldots \ldots .66333$ & 13970 \\
\hline 1902 & $\ldots$ & 133 & 1944 & $\ldots \ldots \ldots \ldots \ldots \ldots \ldots \ldots \ldots \ldots .2860$ & 6950 \\
\hline 1903 & 49 & 189 & 1945 & $\ldots \ldots \ldots \ldots \ldots \ldots \ldots \ldots \ldots \ldots$ & 3430 \\
\hline 1904 & 49 & 133 & 1946 & $\ldots \ldots \ldots \ldots \ldots \ldots \ldots \ldots \ldots \ldots \ldots \ldots 1122$ & 4350 \\
\hline 1905 & 49 & 159 & 1947 & $\ldots \ldots \ldots \ldots \ldots \ldots \ldots \ldots \ldots \ldots \ldots \ldots 1221$ & 6320 \\
\hline 1906 & 76 & 201 & 1948 & $\ldots \ldots \ldots \ldots \ldots \ldots \ldots \ldots \ldots$ & 8360 \\
\hline 1907 & $\ldots 100$ & 269 & 1949 & $\ldots \ldots \ldots \ldots \ldots \ldots \ldots \ldots \ldots \ldots \ldots \ldots 1167$ & 8230 \\
\hline 1908 & 53 & 243 & 1950 & $\ldots \ldots \ldots \ldots \ldots \ldots \ldots \ldots \ldots \ldots \ldots \ldots 1356$ & 8170 \\
\hline 1909 & 131 & 274 & 1951 & $\ldots \ldots \ldots \ldots \ldots \ldots \ldots \ldots \ldots \ldots \ldots \ldots \ldots 1878$ & 10840 \\
\hline 1910 & $\ldots 151$ & 356 & 1952 & $\ldots \ldots \ldots \ldots \ldots \ldots \ldots \ldots \ldots \ldots \ldots \ldots 1694$ & 12750 \\
\hline 1911 & 159 & 426 & 1953 & $\ldots \ldots \ldots \ldots \ldots \ldots \ldots \ldots \ldots \ldots \ldots \ldots 1605$ & 13780 \\
\hline 1912 & 163 & 436 & 1954 & $\ldots \ldots \ldots \ldots \ldots \ldots \ldots \ldots \ldots \ldots \ldots \ldots .2027$ & 16100 \\
\hline 1913 & 214 & 539 & 1955 & $\ldots \ldots \ldots \ldots \ldots \ldots \ldots \ldots \ldots \ldots \ldots \ldots 1817$ & 17300 \\
\hline 1914 & 223 & 236 & 1956 & $\ldots \ldots \ldots \ldots \ldots \ldots \ldots \ldots \ldots \ldots \ldots \ldots 1772$ & 18400 \\
\hline 1915 & 302 & 322 & 1957 & $\ldots \ldots \ldots \ldots \ldots \ldots \ldots \ldots \ldots \ldots \ldots \ldots .1439$ & 19900 \\
\hline 1916 & 432 & 700 & 1958 & $\ldots \ldots \ldots \ldots \ldots \ldots \ldots \ldots \ldots \ldots \ldots 1332$ & 20700 \\
\hline 1917 & 578 & 1028 & 1959 & $\ldots \ldots \ldots \ldots \ldots \ldots \ldots \ldots \ldots \ldots \ldots \ldots \ldots 1727$ & 22300 \\
\hline 1918 & 615 & 817 & 1960 & $\ldots \ldots \ldots \ldots \ldots \ldots \ldots \ldots \ldots \ldots \ldots .2030$ & 26500 \\
\hline 1919 & 383 & 569 & 1961 & $\ldots \ldots \ldots \ldots \ldots \ldots \ldots \ldots \ldots \ldots \ldots \ldots .1248$ & 27800 \\
\hline 1920 & $\ldots 530$ & 901 & 1962 & $\ldots \ldots \ldots \ldots \ldots \ldots \ldots \ldots \ldots \ldots \ldots \ldots 1391$ & 29500 \\
\hline 1921 & $\ldots 142$ & 318 & 1963 & $\ldots \ldots \ldots \ldots \ldots \ldots \ldots \ldots \ldots \ldots \ldots \ldots \ldots 1549$ & 29000 \\
\hline 1922 & 315 & 702 & 1964 & $\ldots \ldots \ldots \ldots \ldots \ldots \ldots \ldots \ldots \ldots \ldots \ldots 27$ & 32100 \\
\hline 1923 & $\ldots 531$ & 1199 & 1965 & $\ldots \ldots \ldots \ldots \ldots \ldots \ldots \ldots \ldots \ldots \ldots \ldots 1681$ & 36000 \\
\hline 1924 & $\ldots 353$ & 1153 & 1966 & $\ldots \ldots \ldots \ldots \ldots \ldots \ldots \ldots \ldots \ldots \ldots .1825$ & 39200 \\
\hline 1925 & $\ldots 322$ & 1383 & 1967 & $\ldots \ldots \ldots \ldots \ldots \ldots \ldots \ldots \ldots \ldots \ldots 1681$ & 43300 \\
\hline 1926 & $\ldots 399$ & 1375 & 1968 & $\ldots \ldots \ldots \ldots \ldots \ldots \ldots \ldots \ldots \ldots \ldots \ldots 1692$ & 44700 \\
\hline 1927 & $\ldots 326$ & 1878 & 1969 & $\ldots \ldots \ldots \ldots \ldots \ldots \ldots \ldots \ldots \ldots \ldots \ldots 1873$ & 51600 \\
\hline 1928 & $\ldots 381$ & 2031 & 1970 & $\ldots \ldots \ldots \ldots \ldots \ldots \ldots \ldots \ldots \ldots \ldots .2115$ & 57500 \\
\hline 1929 & $\ldots 372$ & 2148 & 1971 & $\ldots \ldots \ldots \ldots \ldots \ldots \ldots \ldots \ldots \ldots \ldots .2020$ & 62800 \\
\hline 1930 & $\ldots 336$ & 1630 & 1972 & $\ldots \ldots \ldots \ldots \ldots \ldots \ldots \ldots \ldots \ldots \ldots \ldots 1841$ & 65600 \\
\hline 1931 & . 199 & 1143 & 1973 & $\ldots \ldots \ldots \ldots \ldots \ldots \ldots \ldots \ldots \ldots \ldots \ldots \ldots 1909$ & 70900 \\
\hline 1932 & 98 & 1000 & 1974 & $\ldots \ldots \ldots \ldots \ldots \ldots \ldots \ldots$ & 79600 \\
\hline 1933 & $\ldots 157$ & 1096 & 1975 & $\ldots \ldots \ldots \ldots \ldots \ldots \ldots \ldots$ & 74800 \\
\hline 1934 & $\ldots 172$ & 1325 & 1976 & $\ldots \ldots \ldots \ldots \ldots \ldots \ldots$ & 77800 \\
\hline 1935 & $\ldots 249$ & 1770 & 1977 & $\ldots \ldots \ldots \ldots$ & 82400 \\
\hline 1936 & $\ldots 386$ & 2830 & 1978 & $\ldots \ldots \ldots \ldots$ & 81000 \\
\hline 1937 & $\ldots 432$ & 3740 & 1979 & $\ldots \ldots \ldots \ldots \ldots \ldots \ldots \ldots \ldots \ldots \ldots \ldots \ldots .1821$ & 85400 \\
\hline 1938 & . 316 & 3870 & 1980 & $\ldots \ldots \ldots \ldots \ldots \ldots$ & 89100 \\
\hline 1939 & $\ldots 381$ & 4340 & $1981^{1}$ & $\ldots \ldots \ldots \ldots \ldots$ & 85500 \\
\hline 1940 & 446 & 4390 & $1982^{2}$ & $\ldots \ldots \ldots \ldots \ldots$ & 77793 \\
\hline 1941 & . . 952 & 6110 & $1983^{2}$ & $\ldots \ldots \ldots \ldots \ldots \ldots \ldots \ldots$ & 76016 \\
\hline
\end{tabular}

${ }^{1}$ Preliminary

${ }^{2}$ Estimated.

People's Republic of China exports 100,000-150,000 tons of refractory-grade and abrasive-grade bauxite a year. Other countries producing bauxite for nonmetallurgical uses include Guinea, France, Greece, Hungary, Turkey, and Yugoslavia. In the United States, bauxite used in refractories is produced in the Eufaula, Ala., Andersonville, Ga., and Arkansas districts, and deposits have been mined for abrasives and chemicals in Arkansas.

\section{GEOLOGY OF BAUXITE}

\section{CLASSIFICATION OF DEPOSITS}

Bauxite deposits occur in a variety of geologic situations and geometric configurations, and many different classifications have been proposed. Several of these classifications are discussed in the following sections. 


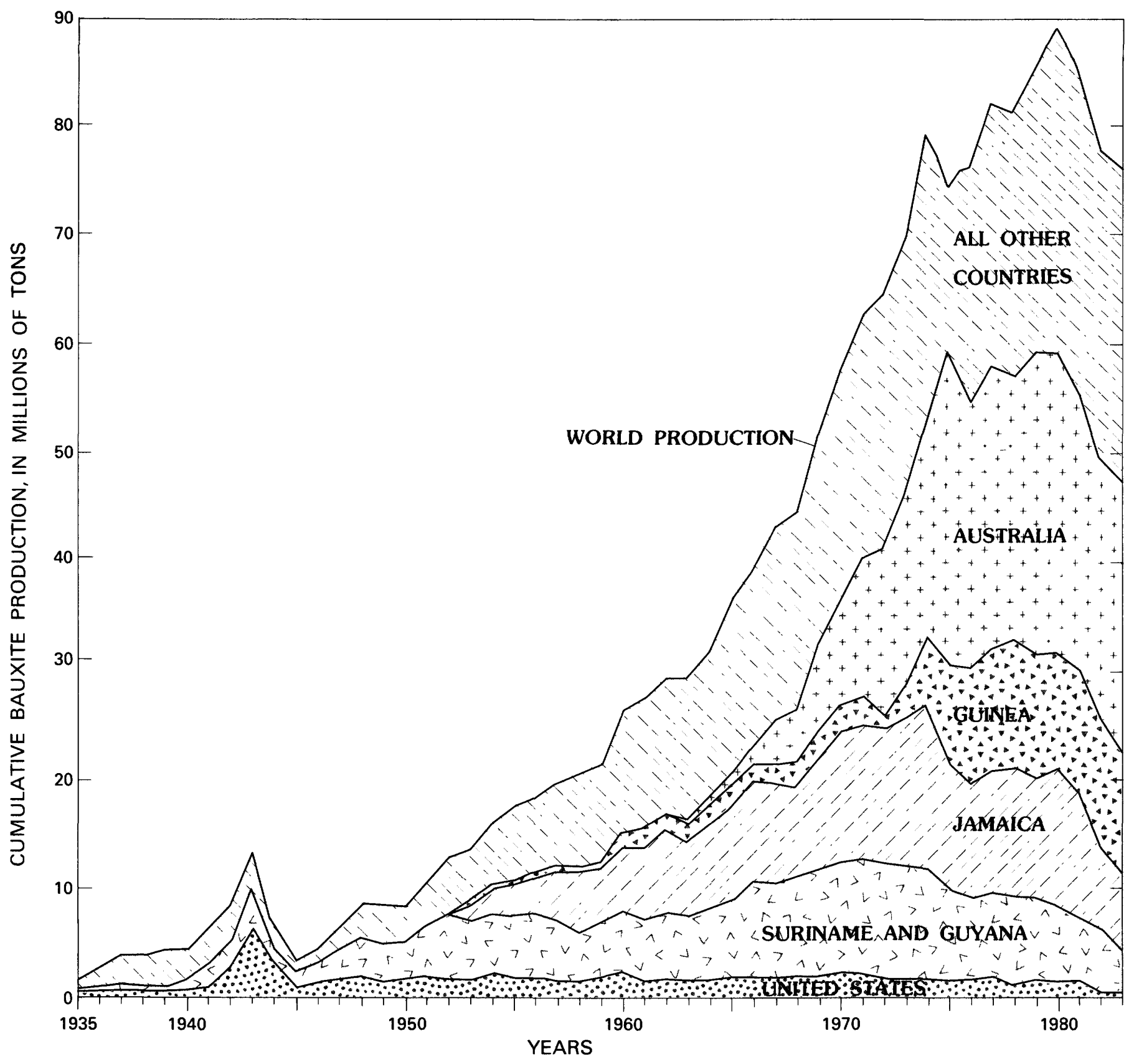

Figure 1.-World bauxite production, 1935-83, showing contributions from different regions.

\section{Laterite-Karst or Silicate-Carbonate Classification}

The most widely used method of classification in Europe and other countries is to assign all bauxites to either karst or laterite types; this classification was used by Valeton (1972) and Bushinskiy (1975) among others. Laterite-type bauxite deposits are the very large blanket deposits formed mainly by surficial weathering in tropical regions. The karst-type deposits are concentrated in solution depressions in carbonate rock.
Because of their geographic distribution and associations with other rocks, karst deposits are also referred to as the terra rossa, limestone, French, or Mediterranean types (Zans, 1961). This two-fold classification was modified by Schellmann (1975), who replaced the terms "laterite" by "silicate" and "karst" by "carbonate." The basis for this usage is his idea that all silicate bauxite formed by lateritic weathering of siliceous rocks and all carbonate bauxite deposits are associated with limestone or dolomite. A problem with this classification 
TABLE 6.-World production of [From U.S. Bureau of Mines records. Minor production in Austria, West Germany,

\begin{tabular}{|c|c|c|c|c|c|c|c|c|c|c|c|}
\hline Year & Australia & Brazil & $\begin{array}{c}\text { Dominican } \\
\text { Republic }\end{array}$ & France & Ghana & Greece & Guinea & Guyana & Haiti & Hungary & India \\
\hline 1961 & 16 & 111 & ${ }^{3} 749$ & 2,225 & 204 & 1,120 & 1,767 & 2,412 & ${ }^{3} 267$ & 1,366 & 476 \\
\hline 1962 & 30 & 191 & ${ }^{34} 717$ & 2,195 & 243 & 1,287 & 1,468 & 2,763 & ${ }^{3} 442$ & 1,473 & 587 \\
\hline$\ldots \ldots$ & 360 & 170 & 34773 & 2,029 & 314 & 1,277 & 1,664 & 2,380 & ${ }^{3} 384$ & 1,363 & 567 \\
\hline 1964 & 796 & 132 & 34760 & 2,433 & 250 & 1,047 & 1,678 & 2,518 & ${ }^{9} 437$ & 1,477 & 593 \\
\hline 1965 & 1,186 & 188 & ${ }^{34} 942$ & 2,664 & 319 & 1,270 & 1,870 & 2,919 & ${ }^{9} 383$ & 1,477 & 707 \\
\hline 1966 & 1,827 & 250 & ${ }^{34} 833$ & 2,811 & 323 & 1,371 & 1,609 & 3,358 & ${ }^{9} 361$ & 1,429 & 750 \\
\hline 1967 & 4,244 & 303 & 34983 & 2,813 & 351 & 1,659 & 1,639 & 3,381 & 359 & 1,650 & 804 \\
\hline 1968 & 4,955 & 285 & 34994 & 2,713 & 285 & 1,836 & 2,117 & ${ }^{3} 3,722$ & ${ }^{5} 446$ & 1,959 & 961 \\
\hline 1969 & 7,921 & 351 & ${ }^{3} 1,093$ & 2,797 & 246 & 1,948 & 2,459 & ${ }^{3} 4,306$ & ${ }^{5} 665$ & 1,934 & 1,085 \\
\hline 1970 & 9,256 & 510 & ${ }^{3} 1,067$ & 2,992 & 342 & 2,292 & 2,490 & ${ }^{3} 4,417$ & ${ }^{5} 632$ & 2,022 & 1,374 \\
\hline 1971 & 12,733 & 566 & ${ }^{34}{ }_{1,088}$ & 3,184 & 329 & 2,861 & 2,630 & ${ }^{3} 3,920$ & ${ }^{5} 643$ & 2,090 & 1,517 \\
\hline 1972 & 14,437 & 765 & ${ }^{34} 1,035$ & 3,402 & 340 & 2,408 & 2,050 & ${ }^{3} 3,344$ & ${ }^{5} 687$ & 2,358 & 1,684 \\
\hline 1973 & 17,596 & 849 & ${ }^{34} 1,145$ & 2,970 & 310 & 2,748 & ${ }^{e} 3,660$ & ${ }^{3} 3,276$ & ${ }^{5} 743$ & 2,600 & 1,297 \\
\hline 1974 & 19,994 & 858 & ${ }^{3} 4_{1,210}$ & 2,855 & 363 & 2,783 & 7,600 & e 33,250 & ${ }^{5} 659$ & 2,751 & 1,114 \\
\hline 1975 & 21,003 & 969 & 34754 & 2,563 & 320 & 3,006 & 8,406 & e 33,250 & ${ }^{5} 522$ & 2,890 & 1,274 \\
\hline 1976 & 24,084 & 827 & 34627 & ${ }^{10} 2,330$ & 272 & 2,551 & 10,848 & е 32,686 & ${ }^{5} 660$ & 2,918 & 1,449 \\
\hline 1977 & 26,086 & 1,120 & ${ }^{34} 576$ & ${ }^{10} 2,059$ & 244 & 2,88 & 10,841 & e 32,731 & ${ }^{5} 588$ & 2,949 & 1,519 \\
\hline 1978 & 24,293 & 1,160 & ${ }^{34} 568$ & ${ }^{10} 1,978$ & 328 & 2,663 & ${ }^{5} 11,627$ & 32,425 & ${ }^{4} 580$ & 2,899 & 1,663 \\
\hline 1979 & 27,583 & 2,388 & 635 & 1,969 & 214 & 2,812 & ${ }^{5} 11,326$ & ${ }^{3} 2,312$ & ${ }^{4} 584$ & 2,976 & 1,952 \\
\hline$\ldots \ldots \ldots \ldots$ & 27,178 & 5,538 & 606 & 1,921 & 225 & 3,286 & ${ }^{5} 11,862$ & ${ }^{3} 1,844$ & ${ }^{4} 312$ & 2,950 & 1,785 \\
\hline $1981^{p}$ & 25,541 & 5,770 & 457 & 1,827 & 181 & 3,216 & ${ }^{5} 11,112$ & ${ }^{3} 1,681$ & ${ }^{4} 427$ & 2,914 & 1,923 \\
\hline $1982^{p}$ & 23,621 & 6,289 & 141 & 1,662 & 64 & 2,853 & $3^{11} 11,827$ & 1,430 & 411377 & ${ }^{11} 2,627$ & ${ }^{11} 1,854$ \\
\hline $1983^{e}$ & 24,500 & 7,000 & - & 1,716 & 63 & 2,900 & 11,080 & ${ }^{11} 1,791$ & -- & ${ }^{11} 2,917$ & ${ }^{11} 1,923$ \\
\hline
\end{tabular}

${ }^{\mathbf{e}}$ Estimate. PPreliminary.

${ }^{1}$ Bone dry equivalent of bauxite shipments and bauxite converted into alumina.

${ }^{2}$ May include 124,300 metric tons of cement-grade bauxite.

${ }^{3}$ Dry bauxite equivalent of crude ore.

${ }^{4}$ Shipments.

${ }^{5}$ Dry bauxite equivalent of ore processed by drying plants.

${ }^{6}$ Bauxite processed for conversion to alumina in Jamaica plus exports of kiln-dried ore.

${ }^{7}$ Data shown include only bauxite (diasporic) for aluminum manufacture; in addition 100,000 to 200,000 tons were produced each year for refractories.

is that, although either the laterite-karst or silicatecarbonate classification can be applied to most of the world's bauxite, a few important deposits cannot be assigned to these classes (Bárdossy, 1979). Transported deposits in Arkansas, Suriname, Guyana, Guinea, and small ones elsewhere are neither laterite nor karst, and the type of parent rock of some of them is unknown. Also, earthy red surficial deposits on carbonate rock, such as the large deposits in Jamaica, are both laterite and karst types of bauxite. A weakness of the silicatecarbonate division is that it is based on composition of the parent rock rather than on composition of the mineral deposit itself, which is the basis for naming most ores.

\section{Classification Based on Shapes and Occurrences}

A classification based on shapes and occurrences of bauxite deposits was used by Harder and Greig (1960).
A modification of this classification organized the varied kinds of bauxite deposits into blanket, interlayer, and pocket types (fig. 2).

Blanket deposits.-Blanket deposits occur at or near the surface and consist of a flat-lying layer of variable thickness and extent. Most blanket deposits are residual, having formed from underlying alumina-silicatebearing rocks of varying types, and only a few contain transported material. Many blanket deposits occur on old plateaus and plains formed during late stages of geomorphic cycles, representing long periods of stable geologic conditions. Typical bauxite in blanket deposits is high in iron and is of the type referred to as aluminous laterite (Fox, 1932). Several of the very large bauxite deposits in the world are of the aluminous-laterite blanket type, including extensive deposits in Australia (fig. $2 F$ ), Africa, South America, and India (fig. $2 E$ ). Low-iron blanket deposits form locally and contain very high grade bauxite. Blanket deposits also overlie nepheline syenite in Arkansas and elsewhere (fig. 2B, C). 
bauxite by countries, 1961-83

Mozambique, Pakistan, Spam, and Zimbabwe not included. Thousands of metric tons]

\begin{tabular}{|c|c|c|c|c|c|c|c|c|c|c|c|c|}
\hline Indonesia & Italy & Jamaica & $\begin{array}{l}\text { Malaya } \\
\text { and } \\
\text { Sarawak }\end{array}$ & $\begin{array}{l}\text { People's } \\
\text { Republic } \\
\text { of China }^{e}\end{array}$ & Romania & $\begin{array}{l}\text { Sierra } \\
\text { Leone }\end{array}$ & Suriname & Turkey & $\begin{array}{l}\text { United } \\
\text { States }\end{array}$ & U.S.S.R. ${ }^{\mathrm{e}}$ & Yugoslavia & $\begin{array}{l}\text { World } \\
\text { total }^{2}\end{array}$ \\
\hline 420 & 327 & ${ }^{3} 6,770$ & 674 & 400 & 69 & --- & 3,453 & -- & 1,248 & 2,500 & 1,232 & 27,800 \\
\hline 461 & 309 & 37,615 & 584 & 400 & 30 & --- & 3,297 & --- & 1,391 & 2,600 & 1,332 & 29,500 \\
\hline 493 & 269 & ${ }^{3} 7,014$ & 609 & 400 & 10 & e30 & 3,438 & --- & 1,549 & 2,600 & 1,285 & 29,000 \\
\hline 648 & 247 & 137,936 & 632 & ${ }^{7} 400$ & e7 & 153 & 3,993 & 4 & 1,627 & 3,000 & 1,293 & 32,100 \\
\hline 688 & 244 & 138,651 & 994 & ${ }^{7} 400$ & ${ }^{e} 12$ & 207 & 4,360 & 10 & 1,681 & 3,200 & 1,574 & 36,000 \\
\hline 701 & 255 & 139,062 & 956 & ${ }^{7} 400$ & ${ }^{e} 15$ & 272 & 5,563 & 32 & 1,825 & 3,300 & 1,887 & 39,200 \\
\hline 920 & 242 & 139,396 & 900 & ${ }^{7} 350$ & ${ }^{e} 15$ & 342 & 5,466 & 21 & 1,681 & 3,600 & 2,131 & 43,300 \\
\hline 879 & 216 & ${ }^{3} 8,526$ & 799 & ${ }^{7} 380$ & $\mathrm{e}_{20}$ & 470 & 5,658 & -- & 1,692 & ${ }^{8} 3,700$ & 2,072 & 44,700 \\
\hline 765 & 216 & 10,499 & 1,073 & ${ }^{7} 450$ & ${ }^{\mathrm{e}} 50$ & 454 & 5,450 & 2 & 1,873 & $8 \mathbf{3 , 8 0 0}$ & 2,128 & 51,600 \\
\hline 1,229 & 225 & ${ }^{6} 12,010$ & 1,139 & ${ }^{7} 500$ & 304 & 440 & 6,022 & 51 & 2,115 & ${ }^{8} 4,000$ & 2,098 & 57,500 \\
\hline 1,238 & 191 & ${ }^{6} 12,440$ & 978 & ${ }^{7} 550$ & e305 & 590 & 6,718 & 153 & 2,020 & ${ }^{8} 4,100$ & 1,958 & 62,800 \\
\hline 1,276 & 97 & ${ }^{6} 12,543$ & 1,076 & ${ }^{7} 550$ & e305 & 694 & 7,777 & 471 & 1,841 & 84,200 & 2,197 & 65,600 \\
\hline 1,229 & 50 & ${ }^{6} 13,600$ & 1,143 & ${ }^{7} 760$ & e 345 & 693 & 7,110 & 352 & 1,909 & ${ }^{8} 4,300$ & 2,167 & 70,900 \\
\hline 1,290 & 32 & ${ }^{3}{ }^{6} 15,328$ & 947 & ${ }^{7} 970$ & 858 & 672 & e 6,706 & 665 & 1,980 & ${ }^{8} 4,300$ & 2,370 & 79,600 \\
\hline 993 & 32 & ${ }^{6} 11,571$ & 704 & 990 & 779 & 716 & 4,928 & 631 & 1,801 & ${ }^{8} 4,400$ & 2,306 & 74,800 \\
\hline 940 & 24 & ${ }^{6} 10,296$ & 660 & 1,300 & 680 & 651 & 4,613 & 461 & 1,989 & 84,500 & 2,033 & 77,400 \\
\hline 1,301 & 35 & ${ }^{6} 11,390$ & 616 & 1,500 & 702 & 745 & 4,805 & 567 & 2,013 & 84,600 & 2,044 & 81,900 \\
\hline 1,008 & 24 & ${ }^{6} 11,739$ & 615 & 1,500 & 708 & 716 & 5,188 & 449 & 1,669 & 84,600 & 2,565 & 81,000 \\
\hline 1,052 & 26 & ${ }^{6} 11,618$ & 387 & 1,500 & 708 & 672 & 5,010 & e350 & 1,821 & 84,600 & 3,012 & 85,400 \\
\hline 1,249 & 23 & ${ }^{6} 12,054$ & 920 & 1,500 & e 710 & 766 & 4,646 & 533 & 1,559 & 84,600 & 3,138 & 89,100 \\
\hline 1,203 & 19 & ${ }^{6} 11,682$ & 701 & 1,500 & e712 & e 610 & 4,100 & 575 & 1,510 & 84,600 & 3,249 & 85,500 \\
\hline${ }^{11} 704$ & ${ }^{11} 24$ & 3118,361 & ${ }^{11} 589$ & 1,500 & 680 & ${ }^{11} 606$ & ${ }^{11} 3,059$ & ${ }^{11} 508$ & ${ }^{11} 732$ & 84,600 & ${ }^{11} 3,668$ & 77,793 \\
\hline 750 & 24 & 7,300 & 460 & 1,500 & 600 & 600 & 1,750 & ${ }^{11} 296$ & ${ }^{11} 697$ & 84,600 & ${ }^{11} 3,500$ & 76,016 \\
\hline
\end{tabular}

${ }^{8}$ Excludes materials other than bauxite used for the production of alumina, estimated as follows in thousand metric tons: nepheline concentrates (25-30\% aluminum), 1968-1,000, 1969-1,000, 1970-400, 1971-1,100, 1972-1,700, 1973-2,200, 1974-3,000, 1975-3,400, 1976-3,500, 1977-3,600; alunite ore (16-18\% aluminum), 1970-200, 1971-400, 1972-500, 1973-600, 1974-600, 1975-600, 1976-600, 1977-600.

${ }^{9}$ Quantities shown include about $14 \%$ moisture.

${ }^{10}$ Includes bauxite identified as "usable for fabrication of alumina" as follows, in metric tons: 1976-2,250; 1977-1,966; 1978-not available.

${ }^{11}$ Reported figure.

Interlayer deposits.-The interlayer type of deposit occurs as discontinuous beds and lenses interstratified in sedimentary or volcanic rocks or along the contact between igneous or metamorphic and younger rocks. Interlayer bauxites are chiefly remnants of old residual blanket deposits that were covered by younger rocks, but they also include transported bauxites that are enclosed by sedimentary rocks. Interlayer bauxites occur (1) enclosed by sedimentary rocks in Arkansas (fig. $2 C$ ), northern South America, the Urals region of the U.S.S.R., the People's Republic of China, and elsewhere; (2) along the contact of igneous or metamorphic rocks with overlying sedimentary rocks in Arkansas and in northern South America; and (3) interbedded in sequences of basaltic lava flows at several places in Australia.

Pocket deposits.-Pocket deposits occur chiefly as fillings of depressions formed in limestone or dolomite (fig. $2 A$ ), but some are associated with other types of rock. Extensive pocket deposits occur at or near the surface in Jamaica (fig. 2D), and smaller ones have been found on several coral islands in the Pacific. Pocket deposits interbedded with carbonate strata are widespread in Europe and occur in a few places in Asia. Deposits of this type vary greatly in shape and size. Some of the larger ones are tabular lenses that essentially form blankets. Others are shaped like saucers, cups, or inverted cones. In plan, they are circular, oval, or irregularly lobate. Many have slump blocks and other evidence of subsidence, as do several of the small deposits in Appalachia (Knechtel, 1963). Nearly all pocket deposits formed on carbonate rocks are partly red or are separated from the underlying strata by zones of red clay or other fine-grained rock that is commonly referred to as terra rossa.

\section{Other Classifications}

Several other classifications have been used by geologists. Davis and Hill (1974) grouped the deposits 


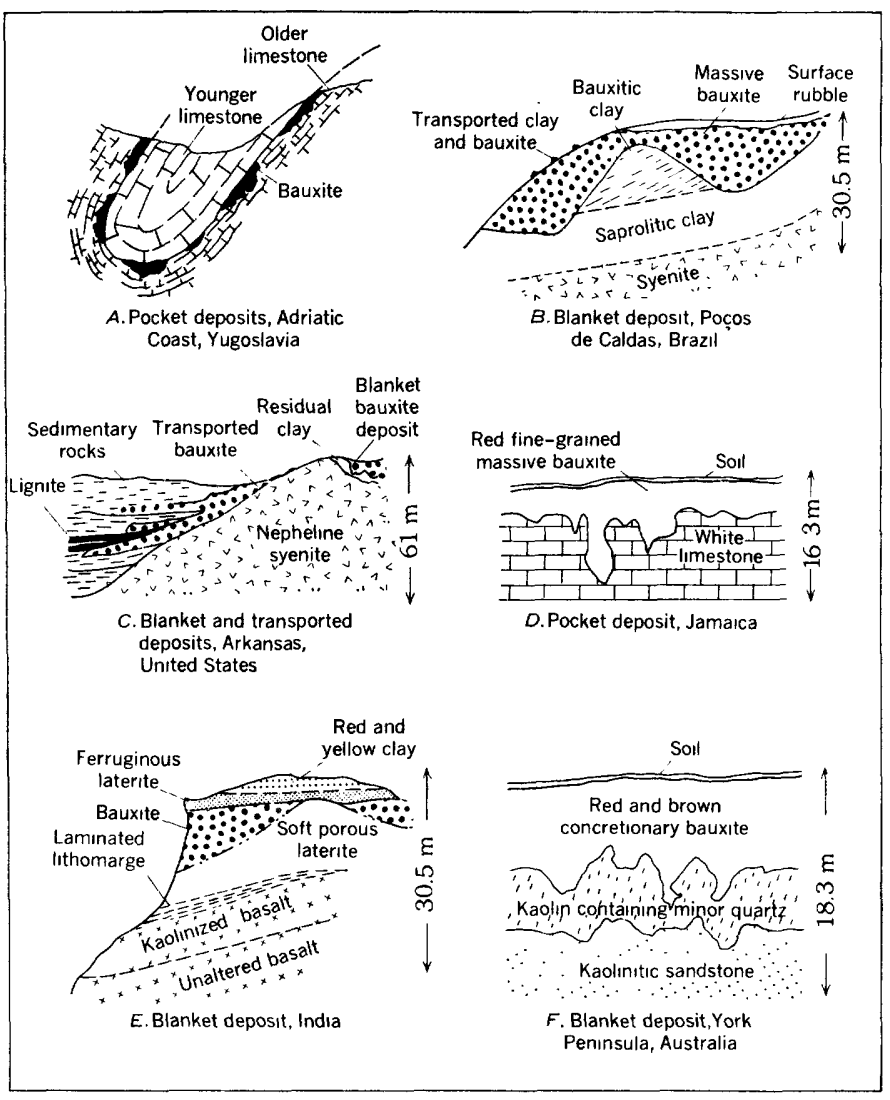

FIGURE 2.-Typical occurrences of bauxite. Modified from Patterson (1967).

in Jamaica into the plateau and graben types, on the basis of geologic occurrence, and into uncontaminated and contaminated deposits, on the basis of their purity. Hose (1960) suggested that bauxites can be assigned to the following four types of deposits: (1) those formed on peneplains, (2) those formed on volcanic domes or plateaus, (3) those formed on limestones or karstic plateaus, and (4) sedimentary or reworked deposits. Grubb (1973) presented the idea of classifying bauxites as low-level and high-level types. He noted that highlevel deposits are typically developed on volcanic or other igneous rocks. Many deposits of this type are porous and friable but show a remarkable retention of parent rock textures. Low-level deposits are commonly associated with low-relief planation. They commonly evolve into a uniform pisolitic horizon that is rich in boehmite. Grubb recognized that the so-called karst bauxites are neither the high-level nor the low-level class. Several other classifications of bauxite deposits are used in the U.S.S.R. (Bushinskiy, 1975); in one system deposits are assigned to the geosynclinal and platform types on the basis of regional geology.

Hill and Ostojic (1984) have proposed a complex classification of bauxite based on contents of gibbsite, boehmite, and iron oxides. The Hill and Ostojic classification divides lateritic bauxite into four types and karstic bauxite into six types.

Many classifications of bauxite and related clay and iron oxides based purely on their chemical and mineral composition have been proposed (Valeton, 1972, fig. 28; Bárdossy and Nicolas, 1973; Gordon, Tracey, and Ellis, 1958, fig. 30; Konta, 1973; and others). In these classification systems, bauxite and associated rocks are divided into such categories as bauxite, clayey bauxite, bauxitic clay, ferruginous bauxite, and ferruginous bauxitic clay, on the basis of definite percentages of composition. Most such classifications have merit, but they can be applied only after mineral or chemical compositions have been accurately determined.

\section{MINERALOGY}

Bauxite Minerals

Gibbsite.-The mineral gibbsite, termed "hydrargillite" in some of the European literature, is an aluminum trihydroxide, $\mathrm{Al}(\mathrm{OH})_{3}$ (Newsome and others, 1960, p. 62). It is commonly referred to as an alumina trihydrate, $\mathrm{Al}_{2} \mathrm{O}_{3} \cdot 3 \mathrm{H}_{2} \mathrm{O}$, because chemical analyses of the mineral indicate a ratio of one molecule of alumina $\left(\mathrm{Al}_{2} \mathrm{O}_{3}\right)$ to three molecules of water. Gibbsite is the major mineral in trihydrate bauxite in the United States, Suriname, Guyana, and many of the large laterite-type bauxite deposits in tropical countries.

Nordstrandite, a polymorph of gibbsite, has been prepared synthetically in the laboratory (Van Nordstrand, Hettinger, and Keith, 1956). It was first found in natural occurrences in soils in western Sarawak (Wall and others, 1962, p. 264) and in Guam (Hathaway and Schlanger, 1965). Nordstrandite was found later in small bauxite deposits in Gippsland, Australia (Grubb, 1973, p. 229), and Davis and Hill (1974) have identified it in several bauxite deposits in Jamaica. It is also reported to be present in bauxite in the southern Urals (Novikov and others, 1975). In Yugoslavia nordstrandite is associated with gibbsite in terra rossa on Jurassic karst limestone in Croatia (Maric, 1967-68) and in Montenegro (Tertian, 1966).

Bayerite, the mineral precipitated in the extraction of alumina by the Bayer process, is also a polymorph of gibbsite. Bayerite has been reported to occur in bauxite in the middle Dnieper region of the U.S.S.R. and has been described by Khorosheva (1969). This bayerite occurs in laterite formed on amphibolite and serpentinite. Most of the bayerite is described as being fine grained, but some is in medium- and coarse-grained crystals associated with gibbsite, boehmite, and diaspore. It 
was also reported to be found in Hungarian bauxites (Gedeon, 1956), but thorough investigation has not verified this occurrence (Bárdossy, 1959, p. 6).

Boehmite.-This mineral is cominonly classed as an alumina monohydrate, $\mathrm{Al}_{2} \mathrm{O}_{3} \cdot \mathrm{H}_{2} \mathrm{O}$, but it is more accurately an aluminum oxide hydroxide, $\mathrm{AlO}(\mathrm{OH})$. Boehmite is the most common bauxite mineral in many deposits in Europe, the U.S.S.R., and the People's Republic of China. It also makes up as much as 20 percent of the bauxite deposits in Jamaica, the Dominican Republic, and Haiti, and it is present in minor amounts in many laterite-type deposits.

Diaspore.-Diaspore has the same chemical composition as boehmite, but its atomic structure is more dense and it is harder (table 7). Diasporic bauxites are most abundant in the People's Republic of China, central Greece, northern Urals (U.S.S.R.), Vietnam, Romania, and Turkey (Bárdossy, 1982, appendix 3; Coumoulos, 1984, table 4).

Corundum.-Corundum, $\mathrm{Al}_{2} \mathrm{O}_{3}$, which is most common in metamorphosed emery deposits, occurs in minor amounts in some bauxites. It is commonly found in pisolites in bauxite in the Soviet Union (Gladkovsky and Ushatinsky, 1964; Kuzemkina, 1960). Corundum has also been identified in Northern Ireland in bauxite deposits that are adjacent to dikes of igneous rock (Eyles and others, 1952, p. 34). It occurs in the Jarrahdale bauxite deposits in the Darling Range, Australia (Grubb, 1971a), and trace amounts of it have been identified by X-ray methods in samples from Arkansas bauxite (Keller, 1964, p. 130).

Other aluminous materials.-In addition to the bauxite minerals, aluminum occurs in several other minerals and in noncrystalline matter in bauxite. Minor quantities of alumina are recovered from some of these materials in Bayer processing. Brief discussions of some of these other forms of aluminum, which are treated as impurities in bauxite in this report, will be given in following sections.

Noncrystalline or very poorly ordered hydrated aluminous solid matter is present in many bauxite deposits. Such material has been called "cliachite" (Palache and others, 1944, p. 667), which presumably has a composition similar to that of gibbsite but may be more hydrated. In addition to "cliachite," the names "sporogelite," “"gibbsitogelite," "diasporogelite," and "alumogel" have been used for noncrystalline aluminous matter in bauxite (Bárdossy, 1959, p. 7). Allophane, a noncrystalline material having a composition generally similar to that of the clay mineral kaolinite but more variable (Ross and Kerr, 1934), has been identified in some bauxites including deposits in Yugoslavia (Bohor and Lahodny-Šarc, 1971). A gel-like material consisting of approximately 4.9 percent
$\mathrm{Al}_{2} \mathrm{O}_{3}, 2.2$ percent $\mathrm{SiO}_{2}, 0.3$ percent $\mathrm{Fe}_{2} \mathrm{O}_{3}$, and about 90 percent water was found in association with lowgrade bauxite in Hawaii (S.H. Patterson, 1971, p. 17-19). This material was later identified as being imogolite (Wada and others, 1972), which is similar to allophane in composition. Imogolite is probably more widely distributed in laterite-type bauxite deposits than presently recognized. In a study of many of the world bauxites of different ages and origins, Bárdossy, Csanády, and Csordás (1978) found that noncrystalline matter was exceptionally abundant in very young deposits in the Iles Loyautés.

True alumina gels no doubt occur in bauxites, but their presence is difficult to establish. Several authorities (Hose, 1960, p. 237; Jurković and Sakač, 1964 , p. 260; Beneslavsky, 1959) believe that many of the banded colloform structures in bauxites are the result of precipitation from hydrogels. Vletter (1963, p. 1005) has observed jellylike masses in the overburden above bauxite at Onverdacht, Suriname, and Mikhailov (1971) found evidence of the influence of gels in the formation of bauxite in Guinea and the U.S.S.R.

Clay minerals.-The kaolin minerals-kaolinite, $(\mathrm{OH})_{8} \mathrm{Si}_{4} \mathrm{Al}_{4} \mathrm{O}_{10}$, halloysite, $(\mathrm{OH})_{8} \mathrm{Si}_{4} \mathrm{Al}_{4} \mathrm{O}_{10}$, and endellite, $(\mathrm{OH})_{8} \mathrm{Si}_{4} \mathrm{Al}_{4} \mathrm{O}_{10} \cdot 4 \mathrm{H}_{2} \mathrm{O}$, the hydrated form of halloysite-are the most common high-alumina clay minerals associated with bauxite deposits. They occur as virtually pure pockets, veins, concretions, and intergrowths with aluminum- and iron-bearing minerals. Kaolinite, the most common mineral in this group, is particularly abundant in deposits of Eocene age or older. Most of the kaolinite associated with bauxite is well ordered. In some deposits, however, the atomic structure of kaolimite is disordered, and the mineral has been incorrectly referred to in many reports as the "fireclay mineral" (Brindley, 1961, p. 65). Halloysite is most common in deposits younger than Eocene, but it also occurs in a few older deposits. Endellite is probably much more common in bauxite than is generally recognized because it converts to halloysite when dried in air at room temperature, and many investigators may have failed to preserve the natural moisture in samples until mineral identifications were made.

Minor amounts of chlorite occur in some bauxite deposits (Caillère, Hénin, and Pobeguin, 1962; Gordon, Tracey, and Ellis, 1958, p. 91), and this mineral is reported to be a major constituent of the weathered rock from which bauxite has formed in Suriname (Kersen, 1956, p. 371) and in Guinea (Lajoinie and Bonifas, 1962, p. 29-30). Probably much of the chlorite associated with bauxite deposits is an aluminous variety similar to that which occurs in high-alumina clays (Keller, 1964, p. 144).

Chamosite.-Chamosite, $\left(\mathrm{Fe}^{2+}, \mathrm{Mg}, \mathrm{Fe}^{3+}\right)_{5} \mathrm{Al}\left(\mathrm{Si}_{3} \mathrm{Al}\right) \mathrm{O}_{10}$ $(\mathrm{OH}, \mathrm{O})_{8}$, is present in some karst bauxites of Paleozoic 
TABLE 7.-Properties of bauxite minerals

\begin{tabular}{|c|c|c|c|c|c|c|c|}
\hline Mineral & $\begin{array}{l}\text { Common } \\
\text { chemical } \\
\text { formula } \\
\text { and name }\end{array}$ & $\begin{array}{c}\text { Alternate } \\
\text { chemical } \\
\text { formula } \\
\text { and name }\end{array}$ & $\begin{array}{l}\text { Crystal } \\
\text { system }\end{array}$ & $\begin{array}{c}\text { Alumina } \\
\text { content } \\
\text { (weight percent) }\end{array}$ & $\begin{array}{c}\text { Combined } \\
\text { water } \\
\text { content } \\
\text { (weight percent) }\end{array}$ & $\begin{array}{l}\text { Specific } \\
\text { gravity }\end{array}$ & $\begin{array}{c}\text { Hardness } \\
\text { (Mohs scale) }\end{array}$ \\
\hline Gibbsite & $\begin{array}{c}\mathrm{Al}_{2} \mathrm{O}_{3} \cdot 3 \mathrm{H}_{2} \mathrm{O} \\
\text { alumina } \\
\text { trihydrate. }\end{array}$ & $\begin{array}{l}\mathrm{Al}(\mathrm{OH})_{3} \text {, aluminum } \\
\text { trihydroxide. }\end{array}$ & Monoclinic & 65.35 & 34.65 & $2.3-2.4$ & $2.2-3.5$ \\
\hline Boehmite & $\begin{array}{l}\mathrm{Al}_{2} \mathrm{O}_{3} \cdot \mathrm{H}_{2} \mathrm{O} \\
\text { alumina } \\
\text { monohydrate. }\end{array}$ & $\begin{array}{l}\text { AlO }(\mathrm{OH}) \text {, aluminum } \\
\text { oxide hydroxide. }\end{array}$ & Orthorhombic & 84.97 & 15.03 & $3.01-3.06$ & $4-5$ \\
\hline Diaspore & . Do. $^{2}$ & Do. $^{2}$ & Do. & 84.98 & 15.02 & $3.3-3.5$ & $6.5-7$ \\
\hline
\end{tabular}

\footnotetext{
${ }^{1}$ Newsome and others, 1960 , p. 9-10.
}

${ }^{2}$ Diaspore differs from boehmite in having a more closely packed and tightly bonded atomic structure.

and Mesozoic age (Bárdossy, 1982, p. 263-264; Coumoulos, 1984, table 2). This mineral is reported to make up as much as 60 percent of some diasporic bauxites.

Iron minerals.-Hematite, $\mathrm{Fe}_{2} \mathrm{O}_{3}$, and goethite, $\mathrm{Fe}_{2} \mathrm{O}_{3} \cdot \mathrm{H}_{2} \mathrm{O}$ or $\mathrm{FeO}(\mathrm{OH})$, are the most abundant impurities in many bauxite deposits. These minerals occur as nodules, as concretions, and as finely disseminated forms intergrown with aluminous minerals. Hematite and goethite are the chief cause of the red and brown colors that are characteristic of many bauxites. Hematite tends to be most abundant in red bauxite, and goethite is the chief pigment in the brown and yellow deposits. Aluminum substitution for iron in goethite in soil was recognized by Norrish and Taylor (1961), and aluminous goethite is now known to occur in many bauxite deposits (Strahl, 1971; Sabiston, 1975; Solymár, 1970). The amount of alumina in bauxite in the form of goethite is as much as 5 percent (Strahl, 1971, p. 6), and possibly as much as 7 percent more $\mathrm{Al}_{2} \mathrm{O}_{3}$ could be recovered from Jamaican bauxite if this oxide were extracted from goethite (Davis, 1973, p. 8). In Suriname, goethite in bauxite in the Paranam district was found to contain about 9-13 percent $\mathrm{AlOOH}$, and about twice that amount (20-25 percent $\mathrm{AlOOH}$ ) is present in goethite in the more weathered deposits in the Moengo district (Grubbs, Rodenburg, and Wefers, 1982).

Several other iron minerals occur in bauxite. Magnetite, $\mathrm{FeFe}_{2} \mathrm{O}_{4}$, and ilmenite, $\mathrm{FeTiO}_{3}$, are common in some bauxites, particularly those that have altered from mafic igneous rocks. Maghemite, $\gamma \mathrm{Fe}_{2} \mathrm{O}_{3}$, occurs in several bauxites (Strahl, 1971; Sabiston, 1975; Bushinskiy, 1975). Siderite $\left(\mathrm{FeCO}_{3}\right)$ is the most abundant iron mineral in Arkansas bauxite (Gordon, Tracey, and Ellis, 1958, p. 88).

Iron also may occur in isomorphous substitution for aluminum in bauxite minerals. Ferruginous boehmite, in which iron is substituted for aluminum at a 1:1 ratio without any appreciable distortion of the crystal lattice, is reported to occur in bauxite deposits in Hérault, France (Caillère and Pobeguin, 1961). Iron substitution in diaspore also has been reported (Bárdossy, 1975).

Titanium minerals. - The titanium minerals in bauxite include the primary minerals ilmenite, $\mathrm{FeTiO}_{3}$ or $\mathrm{FeO} \cdot \mathrm{TiO}_{2}$, rutile, $\mathrm{TiO}_{2}$, and titaniferous magnetite, and the secondary minerals anatase, $\mathrm{TiO}_{2}$, and leucoxene, $\mathrm{TiO}_{2}$, formed during weathering. Titaniferous hematite and sphene, $\mathrm{CaTiSiO}_{5}$ or $\mathrm{CaO} \cdot \mathrm{TiO}_{2} \cdot \mathrm{SiO}_{2}$, are also present in some bauxites. Anatase, ordinarily very fine grained or cryptocrystalline, has been reported in many bauxites and is probably even more common than recognized. In many bauxites, it can be identified most satisfactorily by X-ray examination if the samples are first treated with acid to destroy gibbsite and heated to destroy kaolinite, because the X-ray reflections from these two minerals mask those of anatase (Brindley and Sutton, 1957, p. 395). Another method of overcoming the difficulty is to treat the samples with an organic solvent (Janekovic and Ivekovic, 1973). Leucoxene commonly occurs as a coating on weathered ilmenite and as pseudomorphic replacement of ilmenite or other titanium-bearing minerals. All the X-ray reflections on photographs of nearly 200 samples investigated by Hartman (1959, p. 1401) matched either anatase or rutile and suggests that leucoxene can be either one or a mixture of these two minerals.

Quartz.-Though most of the silicates in bauxite are clay minerals, quartz, $\mathrm{SiO}_{2}$, occurs in minor amounts in many bauxite deposits, and it is abundant in a few. Quartz is particularly abundant in deposits in the Darling Range, Australia, where it is the principal impurity in bauxite containing as little as 30 percent available $\mathrm{Al}_{2} \mathrm{O}_{3}$.

Calcite and dolomite-Calcite, $\mathrm{CaCO}_{3}$, and dolomite, $\mathrm{CaMg}\left(\mathrm{CO}_{3}\right)_{2}$, occur in some bauxite deposits associated 
with carbonate rocks. Most of the natural occurrences have been introduced by moving water after the bauxite formed. Artificial contamination of bauxite by calcite also occurs in mining in some places. The contamination results from the difficulty in separating the bauxite and the underlying limestone where the contact between them is very irregular.

Manganese minerals.-Several manganese minerals occur in minor quantities in bauxite. Those reported in Jamaican bauxite are lithiophorite, $(\mathrm{Al}, \mathrm{Li}) \mathrm{MnO}_{2}(\mathrm{OH})_{2}$, described by Sabiston (1975), and hausmannite, $\mathrm{Mn}_{3} \mathrm{O}_{4}$, manganite, $\mathrm{MnO}(\mathrm{OH})$, and woodruffite, $2(\mathrm{Zn}, \mathrm{Mn}) \cdot 5 \mathrm{MnO}_{2} \cdot 4 \mathrm{H}_{2} \mathrm{O}$, noted by Strahl (1971).

Phosphate minerals.-Minor ainounts of the aluminum phosphate mineral crandallite, $\mathrm{CaAl}_{3}\left(\mathrm{PO}_{4}\right)_{2}(\mathrm{OH})_{5}$ $\cdot \mathrm{H}_{2} \mathrm{O}$, and trace amounts of apatite, $\mathrm{Ca}_{5}\left(\mathrm{PO}_{4}, \mathrm{CO}_{3}\right)_{3}$ $(\mathrm{F}, \mathrm{OH}, \mathrm{Cl})$, occur in bauxite in Janaica (Eyles, 1958; Sabiston, 1975), and two other aluminum phosphate minerals were found in the Mocho Mountain deposits in that country by Grubbs $(1982, p$. 59). Crandallite also has been identified in bauxite from the Rochelois plateau in Haiti (Bárdossy and others, 1977b, table 1). Much of the $\mathrm{P}_{2} \mathrm{O}_{5}$ in bauxite on Rennell Island in the Solomon Islands is probably in the form of crandallite.

Accessory minerals and other minor impurities.-Any resistant accessory mineral that occurs in the parent rock may remain in the bauxite, and a few minor secondary minerals may have formed with or after the bauxite. Accessory minerals in Arkansas bauxite include zircon, tourmaline, kyanite, and garnet; the secondary mineral barite is scarce (Gordon, Tracey, and Ellis, 1958, p. 91-92). Accessory minerals in Guyana bauxites include zircon, tourmaline, rutile, and andalusite (Bleackley, 1961, p. 219). Muscovite partly altered to kaolinite has been noted in bauxite deposits in the Hateg Basin, Romania (Papiu and others, 1971). Nickel occurs in bauxite in Greece (Weisse, 1967), and chromium was found in boehmitic bauxite from the U.S.S.R. (Solymár, Bárdossy, and Jónás, 1975). Many other mineral impurities occur in minor ainounts in bauxite (Bárdossy, 1977; Bushinskiy, 1975).

Organic carbon.-Minor anounts of organic carbon are present in many bauxites. Mercier and Noble (1974) reported the percentages of organic carbon in several commercial bauxites as follows: Weipa, Australia0.2-0.3 percent; Boké, Guinea-0.15 percent; Kimbo (Fria), Guinea-0.3-0.4 percent; typical French bauxite-0.3 percent; Mostar and Titograd, Yugoslavia -0.1 percent; and boehmite and diaspore bauxite processed at the Saint Nicolas plant, Greece-0.05 percent. Bauxite from Rennell Island was found to contain 0.85 percent organic carbon (Matsunaga, Akiyama, and Fujie, 1978, table 2). Organic carbon in bauxite in the Harmons Valley and Mocho Mountains districts,
Janaica, ranges from 0.1 to 0.5 percent, and the average is about 0.2 percent (Grubbs, 1982, p. 59). The radiocarbon age of organic carbon in Janaican red bauxite is $22,415 \pm 1,800$ years B.P., whereas the carbon in a yellow variety of bauxite is only $7,810 \pm 360$ years B.P.

\section{Morphology, Microtextures, and Grain Sizes of Bauxite Minerals}

In scanning-electron-microscope investigations of bauxites from deposits of widely ranging ages and origins, Bárdossy, Csanády, and Csordás (1978) found that mineral morphology, microtextures, and crystal sizes of bauxite minerals vary considerably. Most bauxite minerals occur in grains $0.05-100 \mu \mathrm{m}$ in longest dimension, but secondary crystals tend to be much larger. Generally, gibbsite and diaspore form the larger crystals; most boehmite grains are less than $5 \mu \mathrm{m}$ across. Many grains are equidimensional, others are flakes and rods, and colloform accumulations are common in a few deposits. The grain size and crystallinity of karst-type bauxites increase with increasing age, thickness of overburden, and tectonic stress; porosity varies inversely with these factors. The low-level laterite deposits generally are much finer grained than the older high-level deposits. The largest crystals in laterite bauxite tend to be in secondary growths in cavities. The extremely fine grained gibbsite forming the young bauxite in the Iles Loyautes is in loosely packed stacks. This bauxite has 60-70 percent porosity because of the irregular spacings of the stacks. Triassic bauxites in tectonically deformed areas in Yugoslavia are dense and have porosities in the range 1-5 percent. Sabiston (1975) described two forms of gibbsite in Janaican bauxite. One was in equiaxial crystals about $0.3 \mu \mathrm{m}$ in dianeter, and the other was in much smaller rod-shaped crystals.

\section{Significance of Mineral Composition, Crystal Morphology, and Organic Matter}

The mineral composition of bauxites has played a major role in the design and operation of Bayer-process alumina plants. Most Bayer plants have been designed to use bauxite from a specific deposit and may not function efficiently using bauxite from other districts. The European Bayer-process plants have been designed to recover alumina from boehmite bauxite (monohydrate type), which requires relatively high caustic concentrations and high digestion temperatures and pressures. Plants in the United States using gibbsite bauxite (trihydrate type) require milder digestion conditions. When trihydrate bauxite is the only type used, Bayer 
plant digesters are operated at $140-150^{\circ} \mathrm{C}$, about $4,200 \mathrm{~g} / \mathrm{cm}^{2}$ pressure, and $150-200 \mathrm{~g} / \mathrm{L}$ caustic (as sodium carbonate). In plants that use a mixed gibbsiteboehmite bauxite, such as the bauxite from Jamaica, digesters are operated at $205-250^{\circ} \mathrm{C}$. Higher operating pressures and caustic concentrations are also used for mixed bauxite. Plants using primarily monohydrate bauxite require even more intense digestion conditions than those using mixed bauxite. The more intense digestion systems generally require heavier, more complex, and more expensive plant equipment (Cundiff, 1974, p. 69). The extraction of alumina from diasporic bauxite requires not only high digestion temperatures but also concentrated caustic solutions, long digestion time, and large additions of lime (Ostap, 1984, p. 654; Wargalla and Brandt, 1982).

The type of silicate mineral in bauxite is very important because some silicates cause costly reactions in the Bayer process. Quartz dissolves slowly in the digestive system and reacts little with the caustic solution during the recovery of alumina when the low-temperature process is used. Therefore, trihydrate bauxite containing comparatively high percentages of silica in the form of quartz can be processed profitably. The clay minerals kaolinite and halloysite dissolve in the first few minutes of digestion (Strahl, 1971, p. 67). The dissolved silica is reprecipitated in the digestion vessel in the form of sodium aluminum silicate, which is discharged in the red mud waste. Each ton of silica that is dissolved combines with approximately three-fourths of a ton of caustic soda and 1 ton of alumina. Because the loss of soda and alumina is costly, bauxites averaging more than 5 percent reactive silica generally are considered undesirable for Bayer processing. However, a plant in Arkansas processing bauxite having silica contents greater than 5 percent recovers soda and much of the alumina in the sodium aluminum silicate by the combination Bayer process (Stroud and others, 1969, p. 37). This process includes the addition of lime and a little soda to the residue and sintering. It permits the recovery of much of the alumina that was originally in kaolinite.

According to Ostap (1984, p. 657-658), the extent of dissolution of clay during Bayer processing is a function of the particle size and the degree of crystallinity. Fine-grained, poorly crystallized clay is dissolved completely in Bayer digestion, and the degree of attack on kaolinite decreases with increasing particle size.

In addition to the reactive silicates, other minerals, some of which are present only in minor quantities, cause problems in processing bauxite. For example, crandallite in Jamaican bauxite contributes recoverable alumina in Bayer liquors, but it also releases phosphorus (Sabiston, 1975; Ostap, 1984). Additional lime must be added to precipitate the phosphorus as insoluble phosphates.

Before the existence of aluminous goethite was recognized, all iron minerals were considered undesirable contaminants, but a process for recovering the alumina in this mineral by using an iron hydrogarnet catalyst in the Bayer process has been developed in Hungary (Solymár, Zambó, and Siklosi, 1984). The alumina in goethite is not recoverable in low-temperature Bayer plants, but plants using higher temperatures $\left(240-260^{\circ} \mathrm{C}\right)$ reach the point of goethite dehydration. The dehydrated form of goethite can be dissolved, and the alumina recovered from it is an extraction bonus (Sabiston, 1975, p. 46).

The concentration and properties of the iron minerals in bauxite greatly influence the settling and filtering properties of red mud waste required for the recovery of alumina by the Bayer process (Ostap, 1984). One property causing difficulties is the fineness of grain size. Iron minerals occurring in extremely fine particles, such as those in the Jamaica bauxite that are estimated to be as small as $50 \mathrm{~A}$, require an extensive mud washing circuit and a high proportion of flocculant for acceptable alumina recovery. Bauxites containing iron minerals concentrated in sand-size or larger grains are much simpler to process. Bauxites containing iron in the form of hematite rather than goethite are also much simpler to process, as has been found in Jamaica (Ostap, 1984) and Hungary (Solymár, Zambó, and Siklosi, 1984). Several metallic elements are known to substitute for Fe in goethite, and some of the trace metals in bauxite are likely to occur in this mineral.

Significant variations in Bayer-process digestion and desilication times were noted by Bárdossy, Csanády, and Csordás (1978, p. 261) for bauxites having the same mineralogical composition but different grain sizes, degrees of crystallinity, and textures. Sabiston (1975) also reported that variations in crystal morphology of Jamaican bauxites significantly influence Bayer-process technology. The smaller, rod-shaped crystallites, because of their much greater surface area per unit of weight, had greater caustic solubility than the larger crystals in the low-temperature Bayer system.

The organic matter in bauxite has a strong effect on the caustic leach solutions of the Bayer process and must be controlled to prevent problems in alumina recovery. Meusel (1974) found that as little as 0.21 percent of the bauxite from Weipa, Australia, was organic carbon, and this small amount caused problems in thickening and filtrating leach liquors. Similar problems were caused by the 0.85 percent organic carbon in bauxite from Rennell Island when this material was tested in a pilot plant (Matsunaga, Akiyama, and Fujie, 1978). According to Lever (1983) many organic compounds are 
present in Bayer liquor, and sodium oxalate has one of the most detrimental effects on the alumina trihydrate precipitation process.

\section{TRACE ELEMENTS}

More than 30 different trace elements occur in bauxite, and they range widely in abundance (table 8). Some are present in a few deposits in sufficient quantities to be recovered during bauxite processing (see discussions of byproducts), others may possibly be recovered in the future, but most are of little more than scientific interest.
Trace elements in bauxite occur in several different forms. In the Amazon basin deposits, $\mathrm{Cr}, \mathrm{Ga}, \mathrm{P}$, and $\mathrm{V}$ are mainly in iron oxides, and $\mathrm{Ba}, \mathrm{Pb}$, and $\mathrm{Sr}$ are in kaolin below the bauxite (Dennen and Norton, 1977). No preferential enrichment of trace elements was found in gibbsite, the principal bauxite mineral. Bárdossy and Pantó (1973) found, as would be expected, that many of the trace elements in bauxite in several European countries are concentrated in detrital minerals. For example, $\mathrm{Zr}$ and $\mathrm{Hf}$ were found in zircon, $\mathrm{Ce}, \mathrm{La}, \mathrm{Nd}$ and other elements in monazite, and $\mathrm{Cr}$ in chromite. Identifiable traces of elements also occur in secondary minerals formed in bauxite, such as $\mathrm{Ni}$ in pyrite, $\mathrm{Cu}$ in

TABLE 8.-Minor elements in bauxite

[All values in parts per million. Dash leaders (---), no data]

1. Arkansas, U.S.A., an average of 14 samples (Gordon, Tracey, and Ellis, 1958, table 9, p. 96).

2. Sarawak, Malaysia, an average of 8 samples of bauxite occurring on hills (Wolfenden, 1965, table 2, p. 1054).

3. Weipa, Australia, an average of 21 samples from one drill hole (Jepsen and Schellmann, 1974, table 18, p. 80-81).

4. Istria, Yugoslavia, an average of 18 samples (Sinkovec, 1973, table 2, p. 155).

5. Hercegovina, Yugoslavia, an average of 114 samples (Maksimovic, 1968, table 2, p. 65).

6. Stereá Ellás, an average of 24 samples (Maksimovic and Papastamatiou, 1973, table 1, p. 37).

7. India, range in analyses of 500 samples from 25 deposits (Banerjee, 1975, p. 177, table 2).

8. Iszkaszentgyörgy, Hungary, range of several samples (Dudich, 1973, table 2-AB, p. 50-53).

9. Tikhvin, U.S.S.R., average of 47 samples (Il'in, 1977, table 1, p. 134-135).

10. Var, France, average of 36 samples (Caillère, Maksimovic, and Pobeguin, 1976, table 6).

\begin{tabular}{|c|c|c|c|c|c|c|c|c|c|c|}
\hline & 1 & 2 & 3 & 4 & 5 & 6 & 7 & 8 & 9 & 10 \\
\hline As & $\ldots \ldots \ldots \ldots \ldots \ldots \ldots \ldots$ & $-\cdots$ & 28 & -- & -- & $-\cdots$ & --- & -- & --- & -- \\
\hline B & $\ldots \ldots \ldots \ldots \ldots \ldots \ldots \ldots$ & --- & & -- & -- & --- & --- & $29-87$ & 104 & -- \\
\hline $\mathbf{B a}$ & $\ldots \ldots \ldots \ldots \ldots \ldots \ldots \ldots \ldots \quad 170$ & --- & --- & -- & 28 & 26 & --- & -- & 82 & 4 \\
\hline $\mathbf{B e}$ & $\ldots \ldots \ldots \ldots \ldots \ldots \ldots \ldots$ & --- & --- & -- & --- & --- & --- & $2.2-36$ & --- & 5 \\
\hline $\mathrm{Ca}$ & $\ldots \ldots \ldots \ldots \ldots \ldots \ldots \ldots \ldots 1200$ & --- & 700 & --- & -- & 35 & --- & $71-18000$ & --- & $-\cdots$ \\
\hline $\mathrm{Ce}$ & $\ldots \ldots \ldots \ldots \ldots \ldots \ldots \ldots \ldots,=-$ & --- & 73 & -- & -- & -- & -- & --- & --- & -- \\
\hline Co & $\ldots \ldots \ldots \ldots \ldots \ldots \ldots \ldots$ & 21 & --- & 21 & 27 & 28 & --- & --- & 7 & 21 \\
\hline $\mathrm{Cr}$ & $\ldots \ldots \ldots \ldots \ldots \ldots \ldots \ldots \ldots$ & 260 & 120 & 480 & 737 & 676 & $40-1000$ & $14-626$ & 265 & 440 \\
\hline $\mathrm{Cu}$ & $\ldots \ldots \ldots \ldots \ldots \ldots \ldots \ldots \ldots$ & -- & --- & 53 & 37 & 43 & --- & --- & 10 & $\mathbf{9}$ \\
\hline $\mathbf{F}$ & $\ldots \ldots \ldots \ldots \ldots \ldots \ldots \ldots \ldots \ldots=$ & --- & --- & -- & -- & --- & --- & $600-5700$ & 435 & --- \\
\hline $\mathbf{G a}$ & 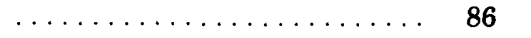 & 27 & 67 & --- & 40 & -- & $<10-70$ & $6.3-82$ & 80 & 59 \\
\hline In & 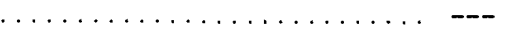 & --- & -- & -- & .5 & --- & --- & --- & --- & --- \\
\hline La & $\ldots \ldots \ldots \ldots \ldots \ldots \ldots \ldots \ldots 100$ & --- & 37 & --- & 138 & 110 & --- & -- & --- & 257 \\
\hline $\mathrm{Li}$ & $\cdots \ldots \ldots \ldots \ldots \ldots \ldots \ldots \ldots \ldots,=$ & --- & -- & -- & 23 & -- & -- & -- & 275 & -- \\
\hline $\mathbf{M g}$ & $\ldots \ldots \ldots \ldots \ldots \ldots \ldots \ldots$ & --- & --- & --- & -- & --- & --- & $60-6000$ & --- & --- \\
\hline Mn & $\ldots \ldots \ldots \ldots \ldots \ldots \ldots \ldots \ldots$ & 310 & -- & --- & -- & 567 & --- & $63-3400$ & --- & 190 \\
\hline Mo & $\ldots \ldots \ldots \ldots \ldots \ldots \ldots \ldots$ & --- & -- & --- & 9 & 5 & -- & $5.3-63$ & --- & 10 \\
\hline $\mathrm{Nb}$ & $\ldots \ldots \ldots \ldots \ldots \ldots \ldots \ldots \ldots \mathbf{5 0 0}$ & --- & --- & --- & --- & -- & --- & $70-100$ & --- & 69 \\
\hline $\mathrm{Ni}$ & $\ldots \ldots \ldots \ldots \ldots \ldots \ldots \ldots$ & 50 & 29 & 210 & 361 & 534 & -- & --- & 30 & 143 \\
\hline $\mathbf{P}$ & $\ldots \ldots \ldots \ldots \ldots \ldots \ldots \ldots \ldots \ldots=-{ }_{--}$ & --- & 198 & --- & -- & --- & --- & $13-3400$ & 1025 & -- \\
\hline $\mathrm{Pb}$ & $\ldots \ldots \ldots \ldots \ldots \ldots \ldots \ldots$ & --- & 37 & --- & 69 & 62 & $<10->200$ & --- & 41 & 108 \\
\hline $\mathbf{R b}$ & $\ldots \ldots \ldots \ldots \ldots \ldots \ldots \ldots \ldots,---$ & --- & -- & --- & 4 & --- & -- & --- & --- & -- \\
\hline $\mathbf{S}$ & $\ldots \ldots \ldots \ldots \ldots \ldots \ldots \ldots \ldots \ldots, \quad=--$ & --- & --- & --- & --- & -- & --- & $80-13000$ & --- & -- \\
\hline $\mathrm{Sc}$ & $\ldots \ldots \ldots \ldots \ldots \ldots \ldots$ & -- & --- & -- & 23 & 19 & -- & -- & 42 & 32 \\
\hline Sn & $\ldots \ldots \ldots \ldots \ldots \ldots \ldots \ldots, \quad=--$ & --- & 17 & -- & --- & --- & --- & --- & --- & -- \\
\hline $\mathrm{Sr}$ & $\ldots \ldots \ldots \ldots \ldots \ldots \ldots \ldots \ldots$ & $\sim 100$ & -- & -- & 42 & 12 & -- & $1300-3500$ & 275 & 76 \\
\hline Th & $\ldots \ldots \ldots \ldots \ldots \ldots \ldots \ldots \ldots$ & --- & 38 & -- & 39.3 & --- & --- & $37-63$ & --- & -- \\
\hline $\mathrm{U}$ & $\ldots \ldots \ldots \ldots \ldots \ldots \ldots \ldots \ldots, \quad---$ & --- & --- & -- & 6.9 & -- & --- & -- & --- & -- \\
\hline V & $\ldots \ldots \ldots \ldots \ldots \ldots \ldots \ldots$ & 240 & 490 & 490 & 363 & 275 & $30->200$ & $56-1200$ & 307 & 400 \\
\hline $\mathbf{Y}$ & $\ldots \ldots \ldots \ldots \ldots \ldots \ldots \ldots \ldots, 150$ & --- & 37 & --- & 77 & 47 & --- & --- & -- & 117 \\
\hline $\mathrm{Zn}$ & $\ldots \ldots \ldots \ldots \ldots \ldots \ldots \ldots, \quad=-$ & --- & 13 & -- & --- & --- & -- & -- & --- & -- \\
\hline $\mathbf{Z r}$ & $\ldots \ldots \ldots \ldots \ldots \ldots \ldots \ldots \ldots \ldots$ & 400 & 966 & 480 & 383 & 303 & $40-400$ & $80-1800$ & 560 & 431 \\
\hline
\end{tabular}


chalcopyrite, $\mathrm{Pb}$ in galena, and $\mathrm{Ce}, \mathrm{La}$, and $\mathrm{Nd}$ in bastnaesite. According to Caillère, Maksimovic, and Pobeguin (1976), Be, Sc, and Y are uniformly distributed through bauxite in Ariège, France; $\mathrm{Ga}, \mathrm{V}, \mathrm{Nb}, \mathrm{Mo}, \mathrm{Cu}$, $\mathrm{Mn}, \mathrm{Zr}$, and $\mathrm{Pb}$ are concentrated in pisolites in some deposits and in the groundmass in others; and $\mathrm{Ni}, \mathrm{Co}$, $\mathrm{La}, \mathrm{Sr}$, and $\mathrm{Ba}$ are more abundant in the groundmass than in pisolites.

Though considerable research has been done on trace elements in bauxite scattered throughout the world, knowledge about them has many shortcomings. The reasons for the limited understanding of trace elements include the following: (1) They have been investigated for different purposes, such as to identify source rocks (Sinclair, 1967), to identify possible byproducts of bauxite (Šargic and Logomerac, 1974), and to increase scientific knowledge (Chowdhury, Chakraborty, and Bose, 1965). (2) Different methods have been used to analyze for trace elements; for this and other reasons the accuracy of determinations by different laboratories may be questionable. (3) Authors have presented their results in different ways and units; therefore, the results of studies are difficult to compare and synthesize. (4) The occurrences of trace elements in bauxite are variable and difficult to understand because their mobilities during weathering are influenced by many contradictory factors, as noted by Lelong and others (1976, p. 162-163). An indication of the random characteristics of trace elements of bauxite was noted by Dudich (1973, table 2A), who recorded the following ranges of concentration in bauxite in four European countries.

Concentration of trace elements in bauxite in four European countries [From Dudich (1973, table 2A); -, no data]

\begin{tabular}{|c|c|c|c|}
\hline & Major & Average & Little \\
\hline $\begin{array}{c}\text { Hungary } . . . \\
\text { Romania } \ldots \\
\text { Bulgaria .... } \\
\text { Hercegovina, } \\
\text { Yugoslavia }\end{array}$ & $\begin{array}{l}. \mathrm{V}, \mathrm{Sr} \\
. \mathrm{Zr}, \mathrm{Pb} \\
. \mathrm{Mn}, \mathrm{Cu} \\
\mathrm{Cr}, \mathrm{Ni}\end{array}$ & $\begin{array}{l}\mathrm{Ni}, \mathrm{Zr}, \mathrm{Ga} \\
\mathrm{V}, \mathrm{Ni}, \mathrm{Cr}, \mathrm{Ga} \\
- \\
\mathrm{V}, \mathrm{Zr}, \mathrm{Ga}\end{array}$ & $\begin{array}{l}\mathrm{Cr} \\
\overline{\mathrm{V}}, \mathrm{Cr}, \mathrm{Zr}, \mathrm{Ga} \\
\text { Mo }\end{array}$ \\
\hline
\end{tabular}

Ga probably has received more attention than other trace elements in bauxite. It was reported to be present in concentrations of 10-82 ppm in bauxites in India (Chowdhury, Chakraborty, and Bose, 1965; Banerjee, 1975 , table 2). Banerjee (1975) also found that Indian deposits are enriched in $\mathrm{Cr}, \mathrm{V}, \mathrm{Zr}$, and $\mathrm{Pb}$. Blackwood and others $(1982$, p. 82) found that $\mathrm{Ga}$ in bauxite in Jamaica ranges from 39 to $92 \mathrm{ppm}$, and the average is approximately $70 \mathrm{ppm}$. Liu (1965) discussed the Ga content in bauxite in the People's Republic of China, and
Gutkin (1971) reported on the $\mathrm{Ga}, \mathrm{Sc}, \mathrm{Nb}$, and $\mathrm{Ta}$ contents in bauxite in the northern Urals. Dennen and Norton (1977) found that bauxite in the Amazon basin is strongly enriched in $\mathrm{Ga}, \mathrm{Fe}, \mathrm{V}, \mathrm{P}$, and $\mathrm{Mn}$ and is depleted in $\mathrm{Pb}, \mathrm{Sr}$, and $\mathrm{Ba}$. In bauxite in Sarawak, Malaysia, only $\mathrm{Cr}$ was concentrated more than $\mathrm{Al}$ during the formation of bauxite (Wolfenden, 1965, table 5). Gordon, Tracey, and Ellis (1958, fig. 31) noted that Cr, $\mathrm{Cu}, \mathrm{Ga}, \mathrm{Nb}$, and $\mathrm{Mo}$ are present in Arkansas bauxite and were concentrated more than $\mathrm{Al}$ during bauxite formation. These authors also noted that the deposits are enriched in $\mathrm{Zr}, \mathrm{Ti}, \mathrm{Sc}, \mathrm{V}, \mathrm{Be}, \mathrm{Mn}, \mathrm{Y}$, and $\mathrm{Pb}$, though they were concentrated less than $\mathrm{Al}$ as the bauxite formed. Other trace elements in Arkansas bauxite include an average of $88.2 \mathrm{ppm}$ Th and $8.1 \mathrm{ppm} U$ found in nine samples investigated by Adams and Richardson (1960, p. 1667). These two authors also found $T h$ and $U$, as well as $\mathrm{Zr}$, in samples of laterite- and karst-type bauxites from several countries.

The halogens $(\mathrm{Cl}, \mathrm{Br}$, and I) that occur in trace amounts in bauxites in several countries are distinctly less concentrated than halogens in marine sediments, according to the findings of Tenyakov and others (1974). These authors concluded that the low halogen contents are sound evidence proving that bauxite formed in fresh rather than marine waters.

\section{PHYSICAL CHARACTERISTICS}

Bauxite occurs in many different forms, and its structure, texture, and physical properties vary appreciably. Some deposits, particularly the karst type, are massive, dense, earthy material containing no recognizable structural features. Many bauxites are pisolitic (fig. 3) or oolitic, and compound pisolites in which several small pisolites are intergrown and are enclosed by larger pisolites are common. Pisolites range in size from 1-2 mm to more than $2 \mathrm{~cm}$. Other features common in bauxites are brecciation, layering, nodules, and platy, cellular, vermicular, tubular, and spongy textures. Concentric banding is common in pisolites and other structures in bauxite, and presumably it indicates cyclic formation. Parts of some deposits retain the structural and textural features of the rocks from which they formed and, therefore, can be referred to as "saprolite." Waterrounded particles (fig. 4) range from sand to cobbles in size and are known to be present in a few deposits consisting of transported bauxite. Slump blocks and other subsidence features occur in some karst bauxites. Fossils are generally rare in bauxite, but marine forms have been identified in several deposits in Europe. The original material of most such fossils has been replaced by bauxite minerals. 


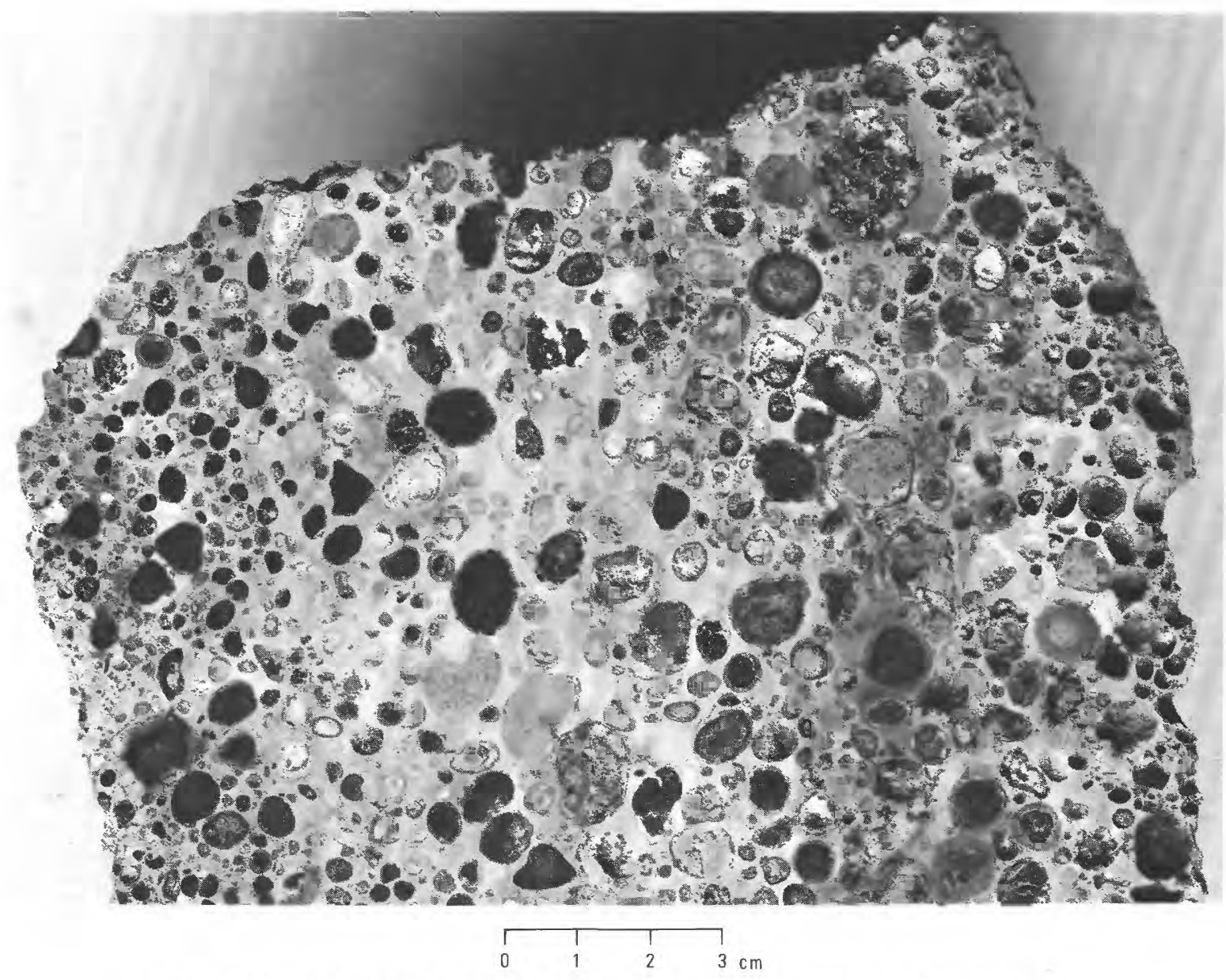

Figure 3.-Polished face of pisolitic bauxite from the Andersonville district, Georgia.

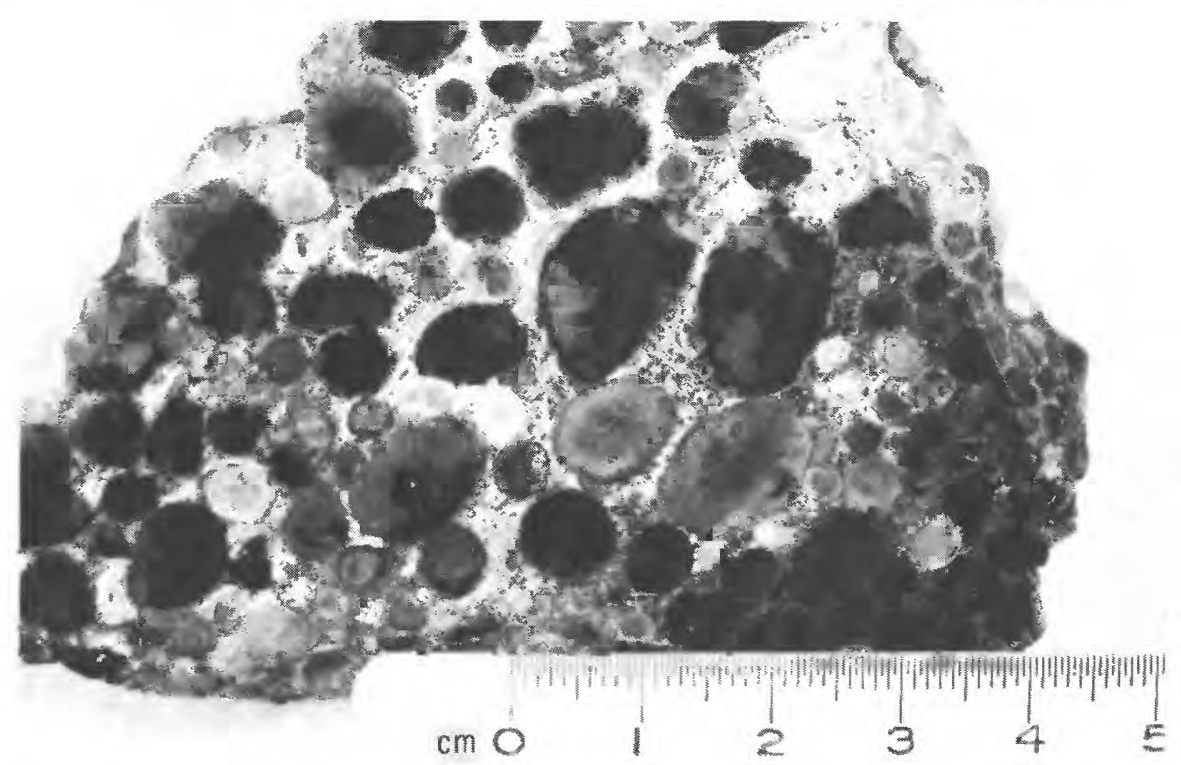

FIGURE 4.-Polished face of transported bauxite from the Arkansas region. Specimen consists of dark pebbles and pisolites in a groundmass of bauxite and kaolin. 
Colors of bauxite range broadly. The most common ones are shades of red or brown. Bauxites are frequently described as brick red, brownish red, reddish brown, or various hues of brown. Some deposits having low iron contents are gray, brownish gray, light gray, or nearly white. Other colors of bauxite include pink, violet, and yellow, and a few bauxite deposits are green. Parts of some deposits rich in organic material are nearly black.

Bauxite ranges from lightweight porous varieties that are less than 1.5 times the weight of water to dense types that are three times as heavy as water. Many deposits are soft and sufficiently unconsolidated to be loosened and loaded by heavy equipment, and others consist of dense, hard bauxite requiring blasting in mining.

\section{ORIGIN}

Geologists have been interested in the origin of bauxite for more than a century, and, although many theories have been proposed, many problems remain unsolved. Older theories include those that bauxite formed by (1) precipitation from hot waters rich in aluminum salts, (2) alteration of aluminous parent materials in seawater, (3) deposition of aluminous materials in lakes, and (4) leaching of aluminous rocks by naturally evolved acid. Most authorities now agree that bauxite forms by weathering under conditions favorable for the retention of alumina and the leaching of other constituents of the parent rock (table 9). The weathering processes that alter rock are active within the zone of influence of the atmosphere, hydrosphere, and biosphere. The processes are classified into chemical and mechanical groups. In chemical weathering, reactions take place with the parent rock that generally remove the more soluble components and add hydroxyl $(\mathrm{OH})$ groups, oxygen, or carbon dioxide to the less soluble ones. Descending surface water is clearly the principal agent of chemical weathering. Living and decaying vegetation and bacteria affect the chemistry of water and elements leached. Mechanical weathering includes the breaking up of deposits, caused by penetrating roots and by alternating expansion and contraction due to solar energy.

TABLE 9.-Chemical analyses of typical bauxites and their parent rocks

[All values in weight percent. From Patterson (1967). LOI, loss on ignition; ---, no data]

1. Nephelene syenite ("gray granite"), Saline County, Ark. (Gordon, Tracey, and Ellis, 1958, table 6, sample 5).

2. "Granitic-textured" bauxite derived from nepheline syenite, Saline County, Ark., average of 3 samples (Gordon, Tracey, and Ellis, 1958, table 10, samples 8-10).

3. Dolerite, Eagle Mountain, Guyana (Harrison, 1934, p. 17).

4. Leached bauxite from 3 (Harrison, 1934, p. 17).

5. Hornblende schist, Yarrikita Hill, Guyana (Harrison, 1934, p. 31).

6. Primary laterite above 5 (Harrison, 1934, p. 31).

7. Surficial bauxite above 6 (Harrison, 1934, p. 31).
8. Solid hornblende basalt, chloritized and saussuritized, Nassau Mountains, Suriname (Kersen, 1956, p. 322, sample I).

9. Residual kaolinitic clay above 8 (Kersen, 1956 , p. 322 , sample IV).

10. Yellowish-white pisolitic bauxite above 9 (Kersen, 1956, p. 322, sample V).

11. Green shale from the Voltaian System, Ghana (Cooper, 1936, p. 11, table I, sample 2047).

12. Average of $\mathbf{1 7}$ samples of lateritic bauxite formed on shale of the Voltaian System, Mount Ejuanema, Ghana (Cooper, 1936, p. 18, table IV).

13. Diabase, Mount Bougourou, Guinea (Lacroix, 1913, p. 290).

14. Porous gibbsitic laterite in contact with 13 (Lacroix, 1913, p. 290).

15. Compact superficial gibbsitic laterite above 14 (Lacroix, 1913, p. 290).

\begin{tabular}{|c|c|c|c|c|c|c|c|c|c|c|c|c|c|c|c|}
\hline & 1 & 2 & 3 & 4 & 5 & 6 & 7 & 8 & 9 & 10 & 11 & 12 & 13 & 14 & 15 \\
\hline $\mathrm{Al}_{2} \mathrm{O}_{3} \ldots$ & 21.11 & 59.8 & 17.29 & 59.00 & 12.18 & 29.15 & 62.44 & 14.01 & 32.92 & 62.96 & 18.20 & 60.53 & 12.36 & 37.03 & 60.19 \\
\hline $\mathrm{SiO}_{2} \ldots$ & 56.51 & 5.3 & 52.00 & 9.80 & 49.75 & 23.39 & 2.79 & 48.75 & 36.20 & .40 & 60.97 & 1.42 & 51.27 & 5.83 & 1.30 \\
\hline $\mathrm{Fe}_{2} \mathrm{O}_{3} \ldots$ & 1.80 & 1.9 & 2.90 & 1.10 & .03 & 23.68 & 2.05 & 3.44 & 13.55 & .63 & 4.69 & 9.75 & 3.29 & 31.73 & 3.91 \\
\hline $\mathrm{FeO} \ldots$ & 1.20 & --- & 8.26 & .97 & 9.88 & 1.32 & --- & 10.80 & .00 & Trace & --- & --- & 6.16 & --- & $-\cdots$ \\
\hline MgO $\ldots$ & .48 & --- & 6.94 & Nil & 9.54 & .05 & .14 & 6.99 & .25 & .19 & 2.75 & \multirow{2}{*}{.73} & 13.26 & .06 & --- \\
\hline $\mathrm{CaO} \ldots$ & .91 & --- & 8.80 & Nil & 11.79 & .01 & -- & 7.90 & Trace & Trace & .63 & & 10.66 & .19 & .17 \\
\hline $\mathrm{Na}_{2} \mathrm{O} \quad \ldots$ & 9.13 & -- & 2.81 & .05 & 1.19 & .08 & -- & 2.52 & .34 & .55 & .61 & -- & 1.60 & --- & --- \\
\hline $\mathrm{K}_{2} \mathrm{O} \ldots$ & 6.34 & -- & .18 & .07 & .11 & .07 & -- & .45 & .00 & Trace & 3.01 & -- & .41 & --- & -- \\
\hline $\mathrm{TiO}_{2} \ldots$ & .50 & 2.0 & .53 & .70 & 4.60 & 4.07 & .45 & 1.10 & 3.41 & 3.89 & .98 & 2.21 & .70 & 1.29 & 1.03 \\
\hline $\mathrm{ZrO}_{2}^{2} \quad \ldots$ & .04 & -- & -- & -- & -- & $\ldots$ & - & -- & -- & -- & --- & -..- & -- & -- & --- \\
\hline $\mathrm{P}_{2} \mathrm{O}_{5}^{2} \ldots$ & .06 & -- & .01 & .38 & .06 & Trace & -- & .14 & .13 & .34 & -- & --- & .11 & -- & --- \\
\hline $\mathrm{SO}_{3}{ }^{\circ} \ldots$ & .15 & --- & -- & $\ldots$ & --- & --- & --- & --- & --- & -- & --- & -- & $-\cdots$ & --- & --- \\
\hline $\mathrm{Cl} \ldots \ldots$ & .39 & --- & $\ldots$ & --- & -- & -- & --- & --- & --- & --- & --- & -- & --- & --- & --- \\
\hline $\mathrm{MnO} \ldots$ & .24 & -- & .05 & Nil & .48 & --- & -- & .20 & .00 & Trace & .42 & -- & -- & --- & $\ldots$ \\
\hline $\mathrm{H}_{2} \mathrm{O}^{-} \quad \ldots$ & .09 & --- & --- & - & --- & --- & $\ldots$ & .10 & .56 & .74 & --- & --- & -- & --- & -- \\
\hline $\mathrm{H}_{2} \mathrm{O}^{+} \ldots$ & 1.50 & --- & .35 & 28.06 & .35 & 18.25 & 31.96 & 3.53 & 12.97 & 30.12 & --- & 25.59 & .40 & 23.02 & 32.00 \\
\hline LÓI . . . & --- & 30.6 & --- & -- & --- & --- & --- & -- & -- & --- & 7.47 & --- & -- & -- & --- \\
\hline Insolubles & --- & --- & -- & -- & -- & -- & -- & --- & --- & -- & --- & --- & -- & .96 & 1.40 \\
\hline Total & 100.45 & 99.6 & 100.13 & 100.13 & 99.96 & 100.07 & 99.83 & 99.93 & 100.33 & 99.82 & - & -- & 100.22 & 100.11 & 100.00 \\
\hline
\end{tabular}


Conditions favorable for weathering and the formation of bauxite, as listed by Harder (1952, p. 35), include "(1) presence of rocks with easily soluble minerals yielding residues rich in alumina; (2) effective rocky porosity, enabling easy access and free circulation of water; (3) normal to abundant rainfall alternating with dry periods; (4) vegetation, including bacteria, advantageously distributed; (5) available sources of appropriate solutions and precipitation agencies; (6) a tropical or at least a warm climate; (7) low to moderate topographic relief, allowing free movement of the water table but a minimum of erosion; and (8) long quiet periods in earth history."

Bauxite deposits have formed from almost every type of rock that contains alumina (Fox, 1932; Harder, 1952). Although bauxite forms more readily from rocks that are high in aluminum and lack resistance to weathering than from resistant rocks that are low in aluminum, parent materials are not as important as the intensity and duration of weathering. Very large deposits of bauxite at Weipa, Australia, have formed on clayey sandstone that apparently contained as little as 4 percent $\mathrm{Al}_{2} \mathrm{O}_{3}$ (Loughnan and Bayliss, 1961, p. 209), and Jamaica bauxite formed on very pure limestone, according to one theory (Hose, 1961, p. 196). Gibbsitic laterite near Energoprojekt's proposed Baniey bauxite mine in Guinea formed on quartzite that is 92 percent silica (Pavlovic and Nikolic, 1973). Nevertheless, a direct relation of the distribution of some bauxite deposits to aluminum-rich parent rocks has been noted in several countries. Nepheline syenite was the principal source rock of bauxite in Arkansas (Gordon, Tracey, and Ellis, 1958) and Iles de Los, Guinea (Bonifas, 1959). Other types of igneous rocks on which bauxite formed include the following: (1) charnockite-Salem district, India (Valeton, 1968); (2) dolerite-Boké district, Guinea (Harder, 1952); (3) rhyolite, tuff, and granite-West Malaysia (Grubb, 1968, p. 60-83); (4) andesite-Sarawak, Malaysia (Wolfenden, 1961); (5) basalt-Ireland (Eyles and others, 1952), Nassau Mountains, Suriname (Kersen, 1956), Minim-Martap and Ngaoundal-Ngaoundourou districts, Cameroon (Belinga, 1968, 1969), and Kimberly region, Australia (Joklik, Jackson, and Zani, 1975); (6) Deccan trap-Madhya Pradesh, India (Roy Chowdhury, Anandalwar, and Tyagi, 1968); and (7) leptynite- and cordierite-bearing granite, Manantenina, Madagascar (Balcet, 1966). Bauxite also formed on several types of sedimentary and metamorphic rocks. Some of the deposits in Madagascar weathered from gneiss (Balcet, 1966), and some in Sierra Leone formed on feldspathic rock and hypersthene gneiss (Bracewell, 1962, p. 98). Deposits in Ghana formed on phyllite, ash, and tuff of Precambrian age and shale of Carboniferous age (Cooper, 1936). Those in the Gove district, Australia, developed on shale, siltstone, and sandstone of Cretaceous age (Grubb, 1970). Some of the bauxite in the very large East Coast province, India, formed on Archean khondalite (Bharat Aluminium Company, 1977; Ramam, 1977). The deposits on Bintan Island, Indonesia, formed on black hornfels (Bemmelen, 1941), and deposits on nearby islands formed on phyllite, sandstone, and shale (Johnson and Marjono, 1963).

Opinions differ among geologists regarding the origin of karst-, Mediterranean-, or pocket-type deposits. This type of bauxite typically occurs above carbonate rocks containing very little alumina. One group of geologists believes that the bauxite formed from residual material remaining after the carbonate rocks were leached, and another group believes that aluminous parent materials of the bauxite were transported to positions above the carbonate rocks. Problems regarding the origin of these types of deposits in the Caribbean Islands are summarized in the first few paragraphs of the section "Caribbean Islands," and European deposits have been discussed by Bushinskiy (1975), Valeton (1972), Weisse (1964), and many others.

Although many field and laboratory investigations have been carried out, the conditions under which the bauxite minerals form are still not fully understood (Keller, 1964, p. 148; Grubb, 1973, p. 228-229). Ample evidence that gibbsite forms at surface temperatures during weathering of many different aluminous materials has been found in the field and laboratory. The laboratory synthesis of boehmite and diaspore, however, commonly requires temperatures and pressures appreciably greater than those present during weathering. The occurrence of these minerals, therefore, has been interpreted as indicative of burial at considerable depths or of active metamorphic processes, but the wide distribution of boehmite in laterite-type bauxite deposits seems to indicate that this mineral has formed under surface conditions. The dehydration of gibbsite by the hot tropical sun to form the boehmite in bauxite in Guinea was suggested by Harder (1952, p. 56). Balkay and Bárdossy (1967) advanced the theory, based on limited data on the lattice energies of the bauxite minerals, that insolation provides enough energy to convert some gibbsite to boehmite and some boehmite to diaspore. The minor corundum in some bauxites is also thought to have developed as the bauxite formed (Beneslavsky, 1959; Gorbachev, 1973).

Field evidence and experimental work support the conclusion that iron is removed by organic complexing during or after the formation of some bauxite deposits. Removal of iron and the formation of bauxite in peat swamps were suggested by Behre (1932) as an explanation for low-iron bauxite in Arkansas. This idea drew criticism from Harder (1933), who pointed out that many bauxite deposits could not have formed this way. 
However, the close association of low-iron bauxite and organic material has since been noted in several places and suggests that Behre's idea has considerable merit. In Ghana, Cooper (1936, p. 24) found low-iron, high-silica bauxite to be restricted to swampy areas rich in decaying organic matter. Similar conditions exist in some deposits in Suriname. Harden and Bateson (1963, p. 1307-1308) outlined the role of humic acids in the formation of bauxite in Guyana. Low-iron bauxite has recently been found in irregular patches of ferruginous deposits that are overlain by organic-matter-rich sandstone in Australia (A.H. White, 1976). Its origin is attributed to leaching of iron by descending water containing humic acids. Gibbsite formed in peaty swamps during Holocene time has been observed in Suriname (Kersen, 1956, p. 298-299, 367) and Hawaii (S.H. Patterson, 1971, p. 45-51). The Hawaii occurrence is significant because the swamp deposits have very low iron contents, whereas iron is very abundant in well-drained areas. The suggestion that iron is leached by water rich in organic material causing unique conditions of acidity (low pH) and low oxidation potential $(\mathrm{Eh})$ is sound on theoretical grounds (Norton, 1973; Petersen, 1971). Artificial weathering experiments in the laboratory (Pickering, 1962; Sapozhnikov, 1968) also indicate that iron can be removed by organic acids.

According to Butty and Chapallaz (1984, p. 121), chelating organic compounds are produced by leaching of vegetable matter or are synthesized by organisms such as fungi, algae, lichens, and bacteria. The acid organic compounds promote protonation of the mineral lattice, thereby extracting metal cations and destroying the mineral framework, or they selectively complex such ions as $\mathrm{Fe}^{++}, \mathrm{Fe}^{+++}, \mathrm{Al}^{+++}$, and $\mathrm{Mn}^{++}$. Carboxylic acids are stronger than silicic acids and may replace adsorbed silica thereby increasing silica solubility.

The common gradation of bauxite downward into kaolinite-rich zones is proof that kaolinite tends to be an intermediate phase between aluminous minerals in fresh rock and bauxite minerals. Apparently quartz impedes the leaching of silica and hydrolysis of kaolinite (Gardner, 1970; Butty and Chapallaz, 1984, p. 130).

Taylor and Hughes $(1975$, p. 545-546) believed that bauxite deposits at low altitudes on Rennell Island formed by biogenic degradation of volcanic ash of andesitic composition in a shallow-water lagoonal environment. This theory is based on the fact that volcanism was widespread in the region in Pliocene to Holocene time, and these two geologists found evidence of hydrogen sulfide and pyrite forming in shallow brackish lagoons. The hydrogen sulfide produced by anaerobic bacteria is thought to have formed a reducing microenvironment of low $\mathrm{Eh}$ and pH in which feldspar and other minerals containing aluminum and iron in the upper layers of sediment were destroyed and alumina-silica gels formed. Gibbsite is believed to have formed from the gels as a result of minor changes in $\mathrm{pH}$ at the sediment-water interface.

Much of the difficulty in understanding the origin of bauxite minerals stems from their occurrence in so many different environments. In addition to the most favorable wet tropical environinent, environunents where gibbsite is known to have formed include such different conditions as those that existed during the development of alpine soils in the Cascade Mountains, Wash. (Reynolds, 1971), and those that existed during the hydrothermal alteration of rocks in Nevada (Hewett, Cornwall, and Erd, 1968). Most diaspore is in deposits showing little evidence of metamorphism, but some in Turkey and Greece is in areas that have been metamorphosed. Corundum is most abundant in metamorphosed emery deposits, but it is also reported to be present in minor quantities in laterite formed by surficial weathering. The alteration of gibbsite to boehmite and boehmite to corundum has taken place in thin contact-metamorphosed zones where bauxite has been intruded by basalt dikes in the Antrim district, Ireland (Eyles and others, 1952), and at Bedarieux, France, and Remeti, Romania (Bárdossy and others, 1972). Gibbsite transported by streams from lateritic deposits was found to be altering to chlorite on the sea floor off Kauai, Hawaii (Swindale and Fan, 1967).

Although most bauxite formed in place, some deposits in sedimentary beds have been transported short distances, and trace amounts of bauxite minerals that occur in ocean sediments have been transported great distances. Transported deposits occur in Arkansas, where bauxite is interbedded with the terrestrial Berger Formation (Gordon, Tracey, and Ellis, 1958). Transported deposits, of which most were deposited in fresh water, also occur in Gujarat, India (Roy Chowdhury and Venkatesh, 1972, p. 88), Sangaredi, Guinea (Akayemov, 1975), and elsewhere. Some of the deposits of Devonian age in the U.S.S.R. are enclosed by marine beds, which is probably the basis for the older theories of marine origin. Very minor quantities of gibbsite of marine origin are widely distributed in Holocene ocean sediments (Biscaye, 1963). In 1971-73, two companies explored seafloor bauxite in the Gulf of Carpentaria, Australia (Ingram, 1973, p. 8). Only minor quantities of bauxite pisolites were found in the exploration program, and they probably were washed in from shore. This gulf is one of the most likely places in the world to find marine bauxite, because the very large Weipa deposits are actively being eroded from sea cliffs on its shores.

\section{AGE AND MINERALOGIC AND GEOGRAPHIC DISTRIBUTION OF BAUXITE}

Bauxite has formed intermittently throughout much of geologic time (table 10) and more intensively during 
TABLE 10.-General age relations of world bauxite deposits

Cenozoic

Quaternary

Holocene and

Pleistocene.

Bauxite deposits in several tropical countries are in belts of heavy rainfall: they formed mainly in Pleistocene time, and several are apparently still forming. Very young laterite-type deposits occur on volcanic rocks in Hawaii; Fiji; Cauca district, Colombia; and elsewhere. Very young karst-type deposits occur on coral rock in the Solomon Islands, Iles Loyautes and on Samar in the Philippines. Many of the very large laterite-type bauxite deposits in Australia, South America, Africa, India, and Indonesia underlying old land surfaces started to form in Late Tertiary time or earlier and continued to be enriched in aluminum throughout the Quaternary.

Tertiary

Many of the very large laterite-type bauxite deposits in tropical countries were forming in late and possibly even early Tertiary time.

Pliocene ........... West Germany (Vogelsberg Mountains)-small deposits of ferruginous bauxite on basalt.

Pliocene and

late Miocene.

Miocene .......... United States (Oregon and Washington)-laterite-type bauxite on Miocene basalt, overlain by Pliocene alluvial deposits.

Jamaica, Haiti, and Dominican Republic-large deposits overlie Eocene to lower Miocene limestone; bauxite formation probably continued throughout post-Miocene time.

Oligocene ......... Yugoslavia (Slovenia and elsewhere)-small reworked deposits of Oligocene age.

Oligocene and Eocene ... Guyana and Suriname (several districts in Coastal Plain region)-high-grade gibbsitic bauxite between sedimentary beds of early Eocene and early Oligocene age. Most of the bauxite probably formed in middle and late Eocene time.

Eocene $\ldots \ldots \ldots \ldots \ldots$ Hungary-in Sümeg, Iszkaszentgyörgy bauxite is underlain by Upper Cretaceous beds and overlain by middle Eocene beds; in Gant bauxite is underlain by Triassic rocks and is overlain by middle Eocene beds.

Greece (Peloponnisos)-small deposits at three localities.

Australia-at Buln Buln, bauxite formed on Eocene basalt and is overlain by lignite, sand, and clay of Oligocene or late Eocene age.

United States (Arkansas, Alabama, Georgia)-gibbsitic bauxite.

Paleocene .......... Hungary (Kislod)-bauxite underlain by Triassic beds and overlain by middle Eocene beds.

Yugoslavia-in Istria bauxite is underlain by Upper Cretaceous (Campanian) beds and is overlain by Paleocene and Eocene strata; in Drnis, Imotski, and Mostar, bauxite is between limestone of Late Cretaceous (Santonian to Campanian) age and upper Paleocene limestone and terrestrial beds.

Mesozoic

Late Cretaceous

Campanian

France (Var, Bedarieux)-boehmitic bauxite underlain by Jurassic rocks and overlain by Cretaceous (Campanian to Maestrichtian) rocks.

Yugoslavia (Jace)-bauxite between Upper Cretaceous (Maestrichtian) formations.

Santonian and Hungary (Halimba)-bauxite underlain by Triassic and Lower Jurassic carbonate beds and overlain by Coniacian. terrestrial beds of Santonian Age.

Turonian ........... Italy (San Giovanni Rotondo)-bauxite between Cenomanian and upper Turonian beds.

Greece (Giona, Parnassós, Elikón)-boehmitic bauxite between Cenomanian and upper Turonian rocks.

Turkey (Akseki, Seydisehir, Sebilkoy)-boehmitic bauxite between older and post-Turonian (Cretaceous) rocks.

Cenomanian ......... France (Brignoles)-boehmitic bauxite between Jurassic and upper Turonian limestones; part of bauxite may have been formed in early Turonian time.

Italy (Abruzzi)-bauxite underlain by carbonate beds of Albian to Cenomanian Age and overlain by younger Cenomanian beds.

Early Cretaceous ........ . France (Revest)-bauxite underlain by Lower Cretaceous and overlain by Cenomanian beds.

Greece (Elevsis, Mégara, Mandra)-boehmitic bauxite between Upper Triassic and Cenomanian beds.

Albian and

Aptian.

France (Ariege)-bauxite in several stratigraphic positions in beds of Aptian and possibly Barremian Ages.

Barremian and

Hauterivian.

Late Jurassic .......... Greece $(\mathrm{G}$

Hungary (Nagyharsany)-bauxite underlain by Jurassic beds and overlain by Barremian beds.

Yugoslavia (Niksic)-boehmitic bauxite between Upper Triassic and Lower Cretaceous rocks.

Late Triassic

U.S.S.R. (Southern Urals)-bauxite underlain by Upper Devonian beds and overlain by Lower Jurassic rocks.

Late and Middle

Triassic.

Yugoslavia (Lika, Bjelaj-Lipa)-large low-grade deposits between Middle Triassic (Ladinian) and Upper Triassic (Carnian) rocks; minor deposits of approximately this age occur in several other districts. 


\begin{abstract}
Paleozoic
Permian . . . . . . . . . . People's Republic of China (P.R.C.) (Guizhou, Sichuan)-diaspore and boehmite. Vietnam (Cao Bang)-diaspore.

Pennsylvanian ......... P.R.C. (Yunnan, Shandong, Henan, Manchuria)-principal bauxite deposits are mixed boehmite and (Late Carboniferous). diaspore in bed $\mathrm{G}$ in middle or Upper Carboniferous coal-bearing rocks. Smaller bauxite resources occur in bed $A$ and other beds in Upper Carboniferous rocks in Henan, Shandong, and Manchuria. U.S.S.R. (Central Asia)-bauxite found in Middle* Carboniferous rocks.

United States (Pennsylvania, Missouri)-diaspore deposits in coal-bearing rocks of Pottsville age.

Mississippian (Early Carboniferous).

Devonian U.S.S.R. (Russian platform, Urals, Taymer Range)-bauxite in Lower* Carboniferous rocks.

U.S.S.R. (Salar, Urals, Timanskiy)-Timan deposits are Middle Devonian; 3 bauxite zones in East Urals are Eifelian (Middle Devonian); 2 zones in West Urals are Eifelian and 1 is Frasnian (Upper Devonian).
\end{abstract}

Late Proterozoic . . . . . . . . . U.S.S.R. (Bokson, Siberia)-diaspore and boehmite. certain periods than others. The oldest known bauxite deposits-in the East Sayan Mountains of Asiatic U.S.S.R.-are of Late Proterozoic age (Goretskiy, 1958). More than three-fourths of the world's bauxite resources is in young laterite-type deposits. Most of these are no older than late Tertiary in age, and some are still forming. The principal ages of karst-type bauxite are Devonian (U.S.S.R.), Carboniferous (U.S.S.R., People's Republic of China), Permian (People's Republic of China), Jurassic (Mediterranean countries), Early Cretaceous (Mediterranean countries), Late Cretaceous (Mediterranean countries, U.S.S.R.) and Paleocene and Eocene (Mediterranean countries and Kazakhstan, U.S.S.R.). The large deposits in Jamaica, Haiti, and the Dominican Republic are Miocene and Pliocene in age. The youngest karst deposits are still forming on elevated coral reefs on Pacific islands.

The general relationship of monohydrate bauxite being more abundant in old deposits and the dominance of trihydrate type in young deposits was first pointed out by Tucan (1934). Though there are exceptions to this trend, diaspore is certainly far more abundant in Paleozoic deposits than in younger ones, boehmite is the dominant mineral in Mesozoic bauxite, and gibbsite is the major mineral in deposits of Cenozoic age. Moreover, many of the exceptions to the trend, such as diaspore in Tertiary bauxite deposits in Yugoslavia, are in tectonic zones (Grubic, 1975, p. 172), where crustal disturbances may have brought about dehydroxylization of gibbsite.

In a general way, bauxite deposits of similar geologic ages and mineralogical characteristics are distributed in global belts that may have been shifted by plate tectonics. Nearly all the large upper Tertiary and younger laterite-type deposits are located in or near the tropical belts (between lat $30^{\circ} \mathrm{S}$. and $30^{\circ} \mathrm{N}$.). Most Mesozoic and lower Tertiary bauxites are in a global belt between lat $35^{\circ}$ and $50^{\circ}$ N., but a few in Siberia are between lat $50^{\circ}$ and $60^{\circ}$ N. Paleozoic bauxites in the U.S.S.R. are mostly between lat $50^{\circ}$ and $68^{\circ} \mathrm{N}$., but some have been found between $74^{\circ}$ and $77^{\circ} \mathrm{N}$. The occurrence of bauxites where the present climate is temperate or colder has long been puzzling to geologists. An interesting explanation has been advanced by Bárdossy $(1973,1977)$, who noted that the Devonian bauxite deposits in the northern Urals extend along the zone between the Russian and Siberian plates. On the basis of this and other observations, he applied modern concepts of plate tectonics and advanced the theory that many deposits are on plates having global positions quite different from their positions at the time the bauxite formed. Accordingly, deposits now located in cold regions may have formed in equatorial belts.

\section{WORLD BAUXITE RESOURCES}

\section{DEFINITIONS OF TERMS}

In this report, the term "resources" and related terms (fig. 5) are used as outlined by the U.S. Bureau of Mines and the U.S. Geological Survey (1980, p. 1-3). The definitions are applied to bauxite as follows:

Resource-A concentration of [bauxite in] the Earth's crust in such form and amount that economic extraction of the commodity from the concentration is currently or potentially feasible.

Identified Resources.-Resources whose location, grade, quality, and quantity are known or estimated from specific geologic evidence. Identified resources include economic, marginally economic, and subeconomic components. To reflect varying degrees of geologic certainty, these economic divisions can be subdivided into measured, indicated, and inferred. ${ }^{3}$

Demonstrated-A term for the sum of measured plus indicated. Measured.Quantity is computed from dimensions revealed in

\footnotetext{
${ }^{3}$ The terms "proved," "probable," and "possible," which are commonly used by industry in economic evaluations of ore or mineral fuels in specific deposits or districts, have been loosely interchanged with the terms measured, indicated, and inferred. The former terms are not a part of this classification system.
} 


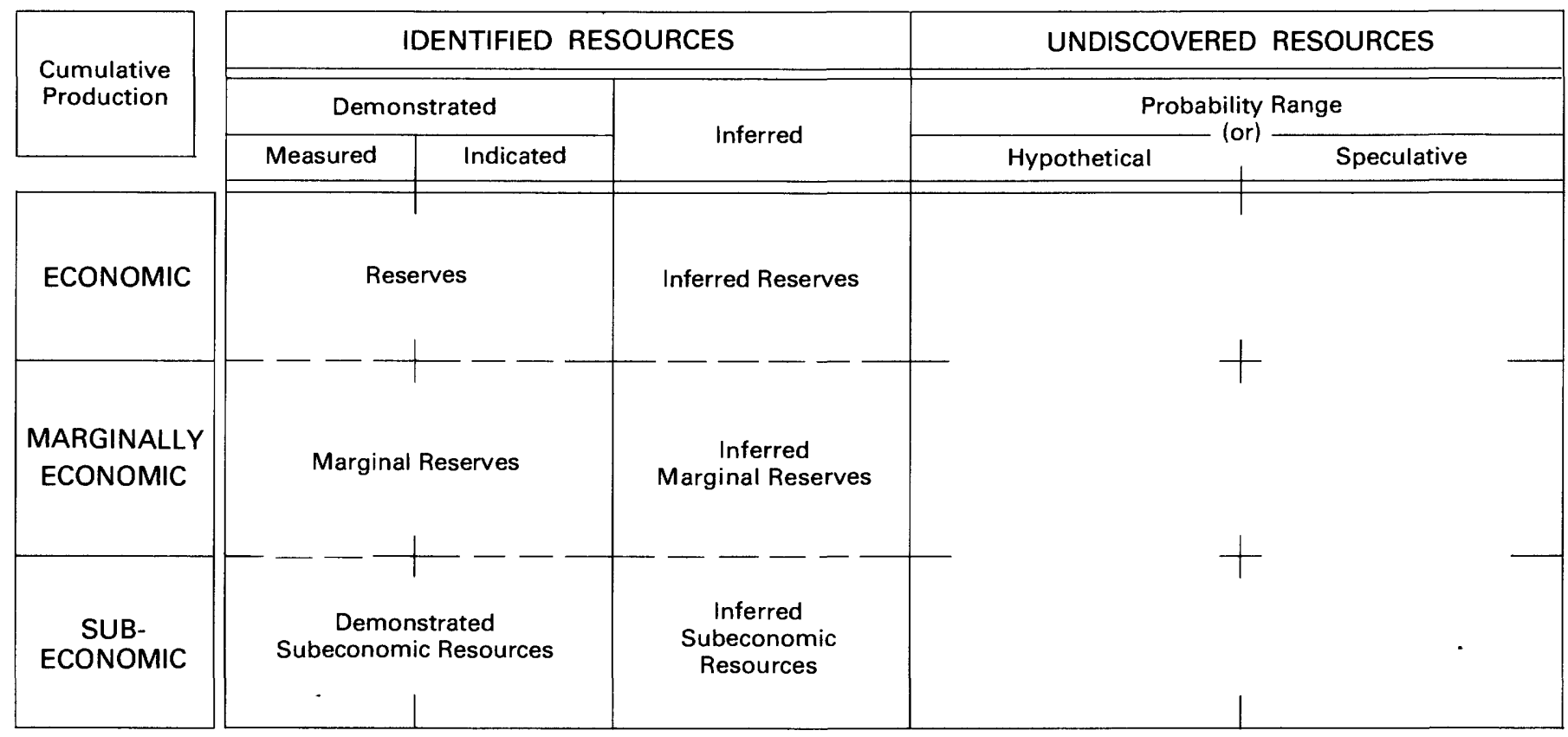

Other

Occurrences

Includes nonconventional and low-grade materials

FIGURE 5.-Classification of bauxite resources. From U.S. Bureau of Mines and U.S. Geological Survey (1980, fig. 1).

outcrops, trenches, workings, or drill holes; grade and (or) quality are computed from the results of detailed sampling. The sites for inspection, sampling, and measurement are spaced so closely and the geologic character is so well defined that size, shape, depth, and mineral content of the resource are well established. Indicated.-Quantity and grade and (or) quality are computed from information similar to that used for measured resources, but the sites for inspection, sampling, and measurement are farther apart or are otherwise less adequately spaced. The degree of assurance, although lower than that for measured resources, is high enough to assume continuity between points of observation.

Inferred.-Estimates are based on an assumed continuity beyond measured and (or) indicated resources, for which there is geologic evidence. Inferred resources may or may not be supported by samples or measurements.

Reserves.-[Reserves consist of bauxite that] could be economically extracted or produced at the time of determination. The term reserves need not signify that extraction facilities are in place and operative. Reserves include only recoverable materials; thus, terms such as "extractable reserves" and "recoverable reserves" are redundant and are not a part of this classification system.

Marginal Reserves.-That part of the [bauxite resources] which, at the time of determination, borders on being economically producible. Its essential characteristic is economic uncertainty. Included are resources that would be producible, given postulated changes in economic or technologic factors.

Economic. - This term implies that profitable extraction or production under defined investment assumptions has been established, analytically demonstrated, or assumed with reasonable certainty. Subeconomic Resources.-The part of identified resources that does not meet the economic criteria of reserves and marginal reserves.

Undiscovered Resources.-Resources, the existence of which are only postulated, comprising deposits that are separate from identified resources. Undiscovered resources may be postulated in deposits of such grade and physical location as to render them economic, marginally economic, or subeconomic. To reflect varying degrees of geologic certainty, undiscovered resources may be divided into two parts:

Hypothetical Resources. - Undiscovered resources that are similar to known mineral bodies and that may be reasonably expected to exist in the same producing district or region under analogous geologic conditions. If exploration confirms their existence and reveals enough information about their quality, grade, and quantity, they will be reclassified as identified resources.

Speculative Resources.-Undiscovered resources that may occur either in known types of deposits in favorable geologic settings where mineral discoveries have not been made or in types of deposits as yet unrecognized for their economic potential. If exploration confirms their existence and reveals enough information about their quantity, grade, and quality, they will be reclassified as identified resources.

The accuracy of an estimate of world bauxite reserves is limited because of the many problems involved. The problems include wide differences in thoroughness of geologic investigation and in methods of appraising deposits and reporting data, errors and incompleteness of chemical analyses and mineralogical determinations, and uncertainties in the technology and economics of recovering alumina from new deposits. These problems 
TABLE 11.-Estimates of world bauxite reserves and other resources, 1936-1984

[All estimates in millions of tons; (M) metric tons, (L) long tons, (U) undesignated tons. --, no data]

\begin{tabular}{|c|c|c|c|c|}
\hline Yea & Reserves & $\begin{array}{c}\text { Subeconomic } \\
\text { and undiscovered } \\
\text { resources (rounded) }\end{array}$ & $\begin{array}{c}\text { Total } \\
\text { resources (rounded) }\end{array}$ & References \\
\hline 1936 & $964(\mathbf{U})$ & - & - & R. J. Anderson, 1936. \\
\hline 1945 & $1,056 \quad(\mathrm{~L})$ & - & - & U.S. Surplus Property Board, 1945. \\
\hline 1950 & $1,605(\mathrm{M})$ & - & - & U.S. Bureau of Mines, 1953. \\
\hline 1953 & $2,414(\mathrm{M})$ & - & - & Lipkowitz, 1953, p. 127. \\
\hline 1958 & 3,224 (L) & - & - & Wilmot, Sullivan, and Trought, 1959, table 20. \\
\hline 1959 & $7,500 \quad$ (L) & - & $10,000 \quad(\mathrm{~L})$ & Daniels and Derbyshire, 1959, p. 10. \\
\hline 1960 & 5,220 (U) & - & - & Vidal, 1963, table 6. \\
\hline 1962 & $>6,000(\mathrm{U})$ & - & - & Ginsberg, 1962, table 8. \\
\hline 1963 & 5,760 (U) & 8,740 (U) & $15,000(\mathrm{U})$ & S. H. Patterson, 1963. \\
\hline 1964 & $9,399(\mathrm{M})$ & - & - & Bárdossy, 1964, table 2. \\
\hline 1965 & $5,800(\mathrm{U})$ & $9,600(\mathrm{U})$ & 15,400 (U) & S. H. Patterson, 1967. \\
\hline 1968 & $3,993-6,310(\mathrm{M})$ & - & - & Weisse, 1968, table 2. \\
\hline 1969 & 9,437 (U) & - & - & Kauter, 1968, p. 603. \\
\hline 1970 & 10,695 (U) & - & - & Beneslavskiy, 1970 , p. 35 . \\
\hline 1972 & $8,000(\mathbf{M})$ & - & - & Weisse, 1972, table 3 . \\
\hline 1974 & 15,000 (U) & - & - & World Miming, 1975, p. $15 .^{1}$ \\
\hline 1974 & $15,500 \quad(\mathrm{~L})$ & $10,000-15,300(\mathrm{~L})$ & $25,000-39,000(\mathrm{~L})$ & U.S. Bureau of Mines, 1975a, p. 15. \\
\hline 1975 & $9,400(\mathrm{M})$ & $8,600(\mathrm{M})$ & $18,000(\mathrm{M})$ & Societé Aluminium Pechiney, 1975, table 1. \\
\hline 1975 & $17,748(\mathrm{M})^{2}$ & - & - & International Bauxite Association, $1976 \mathrm{~b}$, table 1. \\
\hline 1975 & - & - & $21,400(\mathrm{M})$ & Shaffer, 1975 , table 5 . \\
\hline 1976 & $20,210(\mathrm{M})$ & - & - & Industrial Minerals, 1978a. \\
\hline 1976 & 24,000 (L) & $11,000-16,000(\mathrm{~L})$ & $35,000-40,000(\mathrm{~L})$ & U.S. Bureau of Mines, 1977. \\
\hline 1978 & - & - & $37,481 \quad(\mathrm{M})$ & Bielfeldt, Lotze, and Winkhaus, 1978, p. 106. \\
\hline 1978 & $27,000(\mathrm{M})$ & $13,000-23,000(\mathrm{M})$ & $40,000-50,000(\mathrm{M})$ & U.S. Bureau of Mines, 1979. \\
\hline 1978 & $14,075(\mathrm{M})^{3}$ & - & $38,225(\mathrm{M})$ & Lotze, 1978, table 2. \\
\hline 1978 & $28,515(\mathrm{M})^{4}$ & - & $28,515(\mathrm{M})$ & Zambó, 1978, table 1. \\
\hline 1978 & $32,700(\mathrm{M})$ & - & - & Cornish, 1978, p. 30. \\
\hline 1979 & $22,000-23,000(\mathrm{M})$ & $18,000-27,000(\mathrm{M})$ & $40,000-50,000(M)^{5}$ & S. H. Patterson and others, unpub. data. \\
\hline 1980 & $16,267(\mathrm{M})$ & $17,244(\mathrm{M})^{6}$ & $33,611(\mathrm{M})^{7}$ & Souare, 1981, table 4. \\
\hline 1980 & $30,780(\mathrm{M})^{8}$ & $108,946(\mathrm{M})^{9}$ & $138,845(\mathrm{M})$ & Hill, 1980, table 2; Ostojic, 1980, table 1. \\
\hline 1981 & $34,000(\mathrm{M})$ & - & - & Bárdossy, 1981, p. 287. \\
\hline 1981 & $28,700(\mathrm{M})$ & - & - & Australian Mineral Economics Pty., 1981, table 2.2. \\
\hline 1981 & $18,861(\mathrm{M})^{10}$ & $121,492(\mathrm{M})^{11}$ & $140,353(\mathrm{M})$ & Hill and Ostojic, 1981, table 4. \\
\hline 1982 & $22,400(\mathrm{M})^{12}$ & $18,000-28,000(\mathrm{M})$ & $40,000-50,000(\mathrm{M})$ & U.S. Bureau of Mines, 1982, p. 17. \\
\hline 1983 & - & - & $31,500(\mathrm{M})$ & Shaffer, 1983, table 5. \\
\hline 1983 & 20,236 & - & $31,913(\mathbf{M})^{13}$ & Peterson and Arbelbide, 1983, table 6. \\
\hline 1983 & $21,000(\mathrm{M})^{14}$ & - & - & Baumgardner and McCawley, 1983, table 3. \\
\hline 1984 & $18,858(\mathrm{M})$ & - & - & Balazs, 1984, table 1. \\
\hline 1984 & $15,030(\mathrm{M})^{15}$ & $85,660(\mathrm{M})^{16}$ & $100,000(\mathrm{M})$ & Lotze, 1984, table 4. \\
\hline 1984 & $21,000(\mathrm{M})$ & $33,000-55,000(\mathrm{M})$ & $55,000-75,000(\mathrm{M})$ & This report. \\
\hline
\end{tabular}

\footnotetext{
${ }^{1}$ Summary of paper presented by B. Balkay.

${ }^{2}$ Estimate is for total reserves in International Bauxite Association member countries (Australia, Dominican Republic, Ghana, Guinea, Guyana, Haiti, Indonesia, Jamaica, Sierra Leone, Suriname, and Yugoslavia) only.

${ }^{3}$ Reserves in East European countries not included.

${ }^{4}$ Includes some subeconomic bauxite as the term is used in this report.

${ }^{5}$ Estimates are based on information available in December 1979, and they include broad assumptions for the sizes of subeconomic and undiscovered resources.

${ }^{6}$ Total possible reserves.

${ }^{7}$ World reserves.

${ }^{8}$ Measured, indicated, and inferred reserves.

${ }^{9}$ Identified subeconomic and undiscovered resources.

${ }^{10}$ Demonstrated and inferred economic resources.

${ }^{11}$ Undeveloped and subeconomic and undiscovered resources.

${ }^{12}$ Estimate is for reserve base.

${ }^{13}$ Identified in situ material plus indicated and inferred bauxite.

${ }^{14}$ Demonstrated in situ material associated with 91 mines in market-economy countries, excludes Yugoslavia.

${ }^{15}$ Developed and undeveloped reserves.

${ }^{16}$ Potential ores and undiscovered resources.
} 
are so great that two authorities concerned with world bauxite reserves have stated (Harder and Greig, 1960, p. 81):

The estimation of world reserves of aluminum ores presents a variety of problems that are not encountered in most other ore calculations, and therefore most estimates reflect individual opinions. One of the problems in any such estimate is the variety of raw materials which contain appreciable amounts of alumina ranging from ${ }^{* * *} 30$ to 50 percent in aluminous laterite and low-grade bauxite, from 50 to 62 percent in medium and high-grade bauxite and from 55 to 75 percent in diaspore rocks.

Additional errors may be introduced in any world bauxite estimate by variations in reporting tonnages in the extensive literature on this subject. Whether reserves are expressed in terms of tonnage in the ground, wet tons recoverable by mining, or the recoverable dry weight and in short, long, or metric tons may cause considerable discrepancies in estimates (Dreyer, 1977). The type or condition of the tons included is not indicated in many published reserve estimates.

The reserve estimates for most countries include measured, indicated, and inferred bauxite, and the last two categories account for the large totals. The estimates for the subeconomic and undiscovered resources are based on piecemeal information and geologic inferences concerning bauxite in the following locations. (1) Deposits in large regions of lateritic soils in tropical countries; many of these deposits are remotely located. (2) Bauxite deposits that are known to be present at depths too great to be mined profitably and that, therefore, have been inadequately explored. Deposits of this type occur mainly in Europe. (3) Large deposits in active districts and other identified bauxite deposits that contain too much reactive silica or are otherwise too low in grade to be classed as reserves. Because of the assumptions on which the estimates for the subeconomic and undiscovered resources are based, these estimates are at best little more than orders of magnitude.

One of the greatest problems in accurately estimating resources is due, in large measure, to different usages of terms in the official reserve estimates of foreign governments. The United Nations Economic and Social Council, Expert Group on Definitions and Terminology for Mineral Resources $(1979$, p. 9) has outlined the problem as follows:

The terms "resources" and "reserves" give rise to confusion because in a number of languages, among them English, French, and Spanish, they have general as well as technical meanings. In some languages only one term is available, while in Russian both terms have virtually the same meaning. Furthermore, it is not uncommon for the terms to be used interchangeably, as synonyms, by non-specialists. For example, the Economic and Social Council refers in its resolution to "reserves" where, in line with the established technical definitions in many English-speaking countries, "resources" would have been more appropriate. The Expert Group therefore recommends that the term "resources" be used exclusively for general classification purposes.

The limitations on the accuracy of reserve estimates outlined in foregoing paragraphs are minimal compared with those that apply to subeconomic and undiscovered resources. In several tropical countries the known minable deposits are so large that very little attention has been given to the subeconomic, low-grade, and remote deposits, and, therefore, no estimates of their size have been made. Furthermore, some of these few estimates of subeconomic and undiscovered resources that have been made are so large that they have little value: for example, the estimate that 7 billion tons of speculative bauxite resources exists in remote parts of Guyana (Singh, 1972, p. 625).

\section{ESTIMATES AND DISTRIBUTION OF WORLD BAUXITE RESOURCES}

Estimates of world bauxite resources have increased markedly in the last half century (table 11, fig. 6). When the first estimate was published, in 1936, the total known bauxite reserves were a little less than 1 billion tons; less than 100 million additional tons had been found by the end of World War II. Major increases in estimates of world bauxite reserves began in 1959, and the largest estimate currently published is the one for 32.7 billion tons in an International Bauxite Association article (Cornish, 1978, p. 30). The estimate for world bauxite reserves in this report (table 11,12 ) is 22 billion-23 billion tons. It is smaller than the estimate in the International Bauxite Association article because that estimate includes considerable bauxite classified as subeconomic in this report. Estimates of subeconomic and undiscovered bauxite resources also have increased significantly in recent years. In this report, the bauxite in these two categories is estimated to be 18 billion-33 billion tons; thus total resources are estimated to be 40 billion-55 billion tons. Because of the many assumptions on which the estimates for the subeconomic and undiscovered resources are based, these figures are at best little more than order-ofmagnitude estimates.

The major world bauxite resources are in Africa, Australia, South America, and the Caribbean region; significant deposits are present in Asia and Europe (fig. 7). Guinea has the world's largest bauxite reserves, estimated to be 5.6 billion tons. Large reserves in Guinea and in other countries are indicated in the following table. 

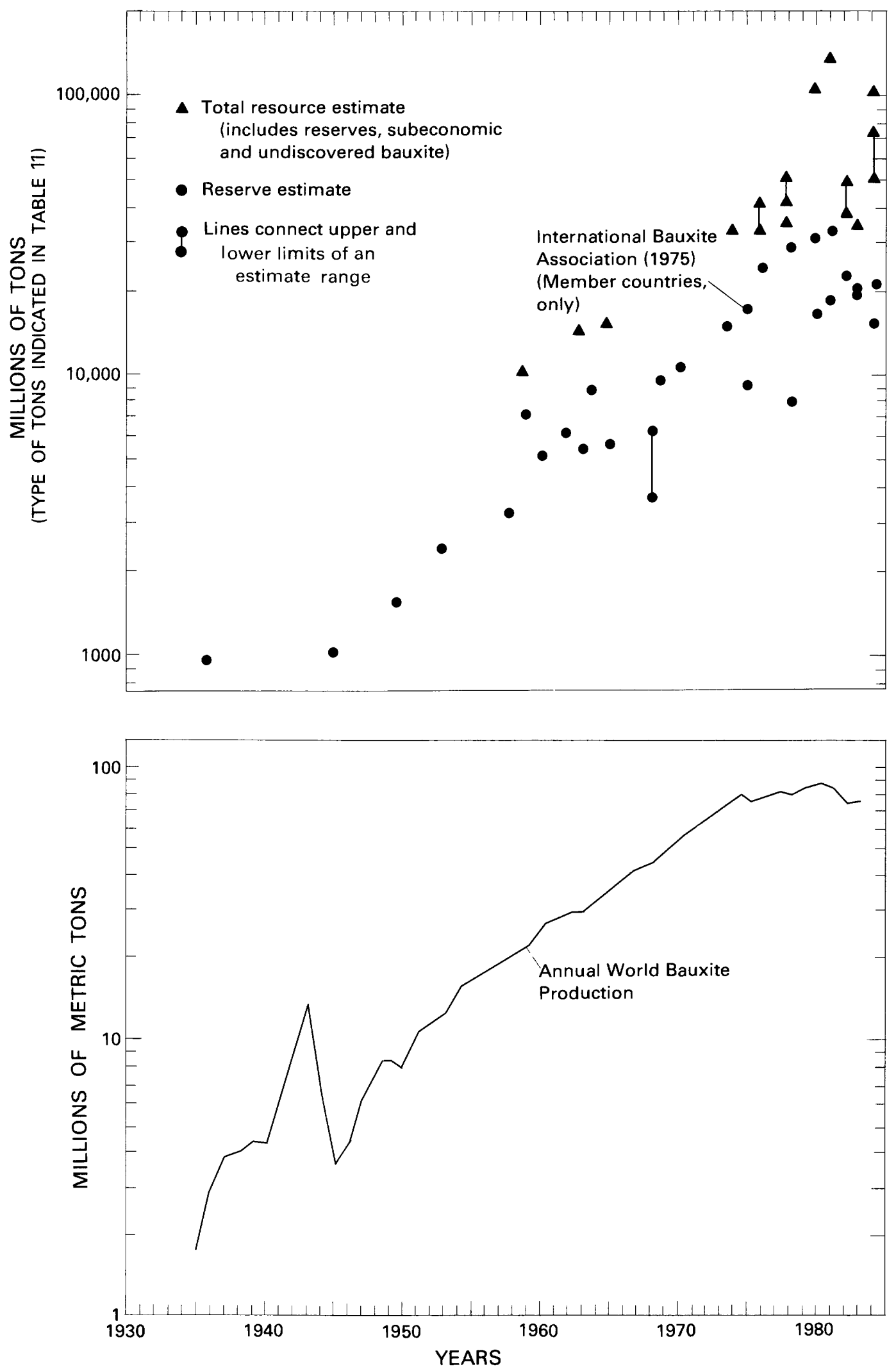

Figure 6.-Annual world bauxite production and estimates of reserves and total resources, 1935-83. 


\begin{tabular}{|c|c|}
\hline Country & $\begin{array}{l}\text { Bauxite reserves } \\
\text { (millions of } \\
\text { metric tons) }\end{array}$ \\
\hline Guinea & $\ldots \ldots 5,600$ \\
\hline Australia . & $\ldots \ldots 4,440$ \\
\hline Brazil ... & $\ldots \ldots 2,250$ \\
\hline Jamaica . . & $\ldots 2,000$ \\
\hline India & $\ldots 1,000$ \\
\hline Indonesia & $\ldots 750$ \\
\hline Guyana .. & $\ldots 700$ \\
\hline Cameroon & $\ldots 680$ \\
\hline Greece ... & $\ldots \quad 600$ \\
\hline Suriname . & $\ldots \ldots \quad 575$ \\
\hline Ghana ... & $\ldots \quad 450$ \\
\hline Yugoslavia & . 350 \\
\hline
\end{tabular}

Countries having reserves of 100 million-300 million metric tons include Venezuela, Hungary, the U.S.S.R., Sierra Leone, and the People's Republic of China. The bauxite reserves in the United States are estimated to be only about 38 million metric tons. Several countries in Central America, the Caribbean region, Europe, and Asia have bauxite reserves of less than 100 million metric tons.

Very large subeconomic and virtually certain speculative bauxite resources are present in Africa and South America; Asia and Australia may have large subeconomic and speculative resources; other major global regions rank well behind in these categories of resources.

\section{NORTH AMERICA}

\section{UNITED STATES}

\section{History and Production}

The following brief history of the discovery of bauxite in the United States is summarized from a discussion by Gordon, Tracey, and Ellis (1958, p. 71-73) and from reports listed in their bibliography.

Pisolitic structures in bauxite attracted attention long before identifications were made and the value recognized. Rocks later found to be bauxite were described as early as 1842 , under the names "amygdaloid" and "pudding stone." Bauxite was first identified in occurrences along the road from Little Rock to Sweet Home, Ark., by J.C. Branner, State Geologist of Arkansas, in 1887. His report, however, was not published for 4 years. In the meantime, a note was published by Nichols $(1888$, p. 905) describing bauxite in Floyd County, Ga. This is usually considered to be the first documented discovery in the United States. The actual identification of bauxite in Georgia may have taken place as early as 1881 .
Production of bauxite began in Georgia in 1888 and was followed by production in Arkansas in late 1894 or early 1895 . Domestic production, including the World War I peak, remained below 1 million tons annually until very intensive mining was started in 1942 to meet World War II requirements; a record production of 6.3 million tons was reached in 1943 (fig. 1). This provided such large stocks that only 2.9 million tons was mined in the following year and only 997,000 tons in 1945 , the final year of the war (table 5). Since 1945, U.S. production has remained between 1.1 and 2.2 million tons per year, and imports have risen sharply.

Bauxite was mined in three areas in the United States in 1984, and several other districts were actively mined in the past. The Arkansas region has produced more bauxite than all other districts in the United States combined. About 71 million tons were produced in this State from 1899 through 1976. Production in other States from 1889 through 1976 amounted to only 4.9 million tons. Alabama produced about 61 percent of this total, Georgia, about 36 percent, and Tennessee, Virginia, Oregon, and Washington, the remainder. The bauxite mined in Oregon and Washington was for plant tests only. The Arkansas region was not only the leading producer but also the source of all domestic bauxite used for aluminum. Bauxite for use in refractories is produced in the Andersonville district, Georgia, and the Eufaula district, Alabama. Chemical-grade bauxite is mined on a small scale in Arkansas and has in the past been mined in the Andersonville district, Georgia, and in the Northwest Georgia district. Other areas in the Southeastern States where bauxite was produced before or during World War II include the following: (1) eastern Tennessee (Dunlap and others, 1965); (2) Warm Springs district, Georgia (W.S. White, 1965); (3) Irwinton district, Georgia (Lang and others, 1965); (4) Rock Run and Goshen Valley areas, Alabama (Cloud, 1967); and (5) Anniston, Fort Payne, and Ashville areas, Alabama (Cloud, 1966). About 30,000 tons of bauxite were mined in Virginia during World War I and World War II (Warren, Bridge, and Overstreet, 1965), and small tonnages were dug in the Tippah-Benton district in northeastern Mississippi (Tourtelot, 1964) and the Indian Mound district in western Tennessee (Dunlap and others, 1965).

\section{Bauxite Districts and Regions}

Bauxite deposits occur in several parts of the United States. The major deposits in the Arkansas region are near the boundary between the Mississippi embayment of the Gulf Coastal Plain and the Interior Highlands (fig. 8). The Eufaula district, Alabama, and the Andersonville district, Georgia, are in the eastern part of the Gulf 


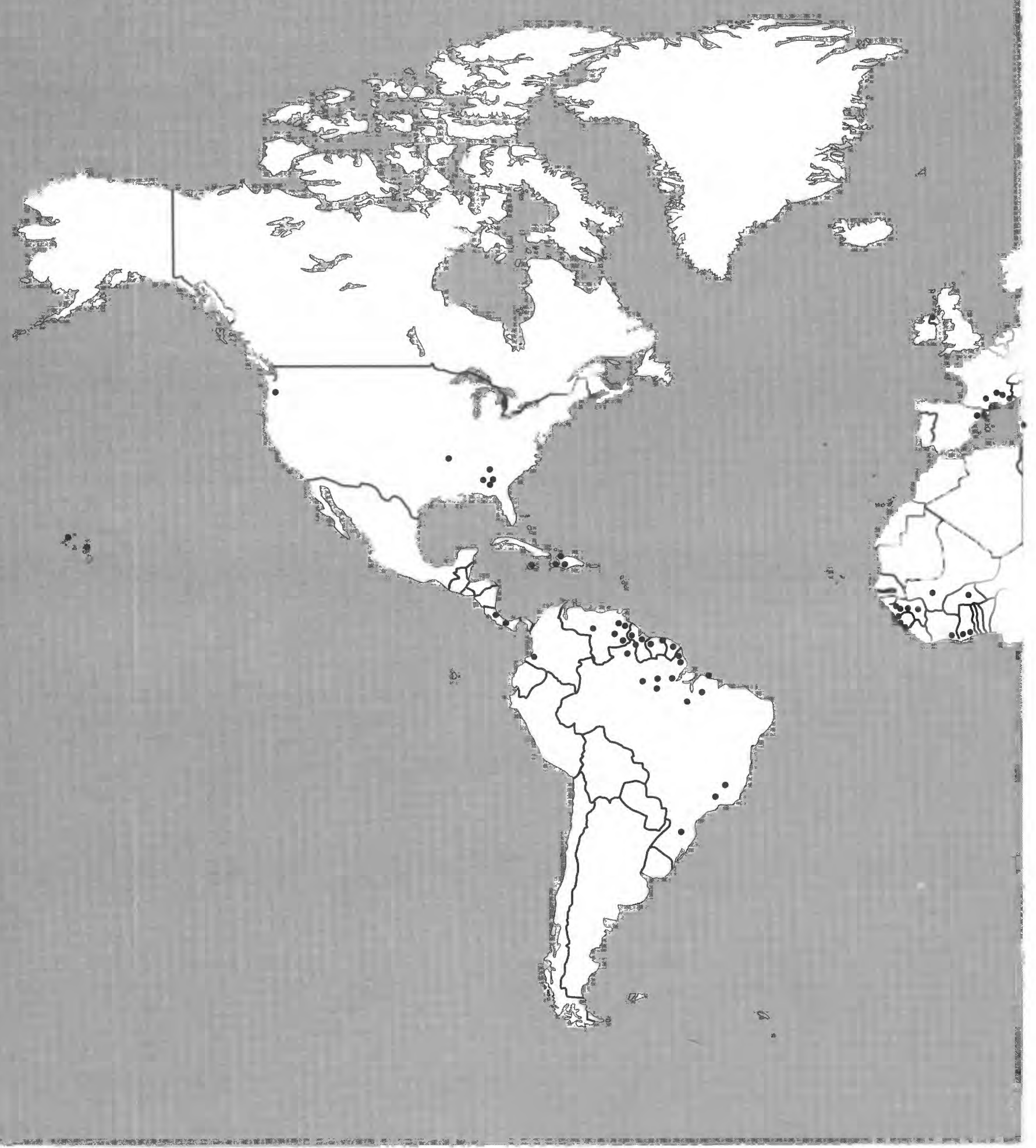




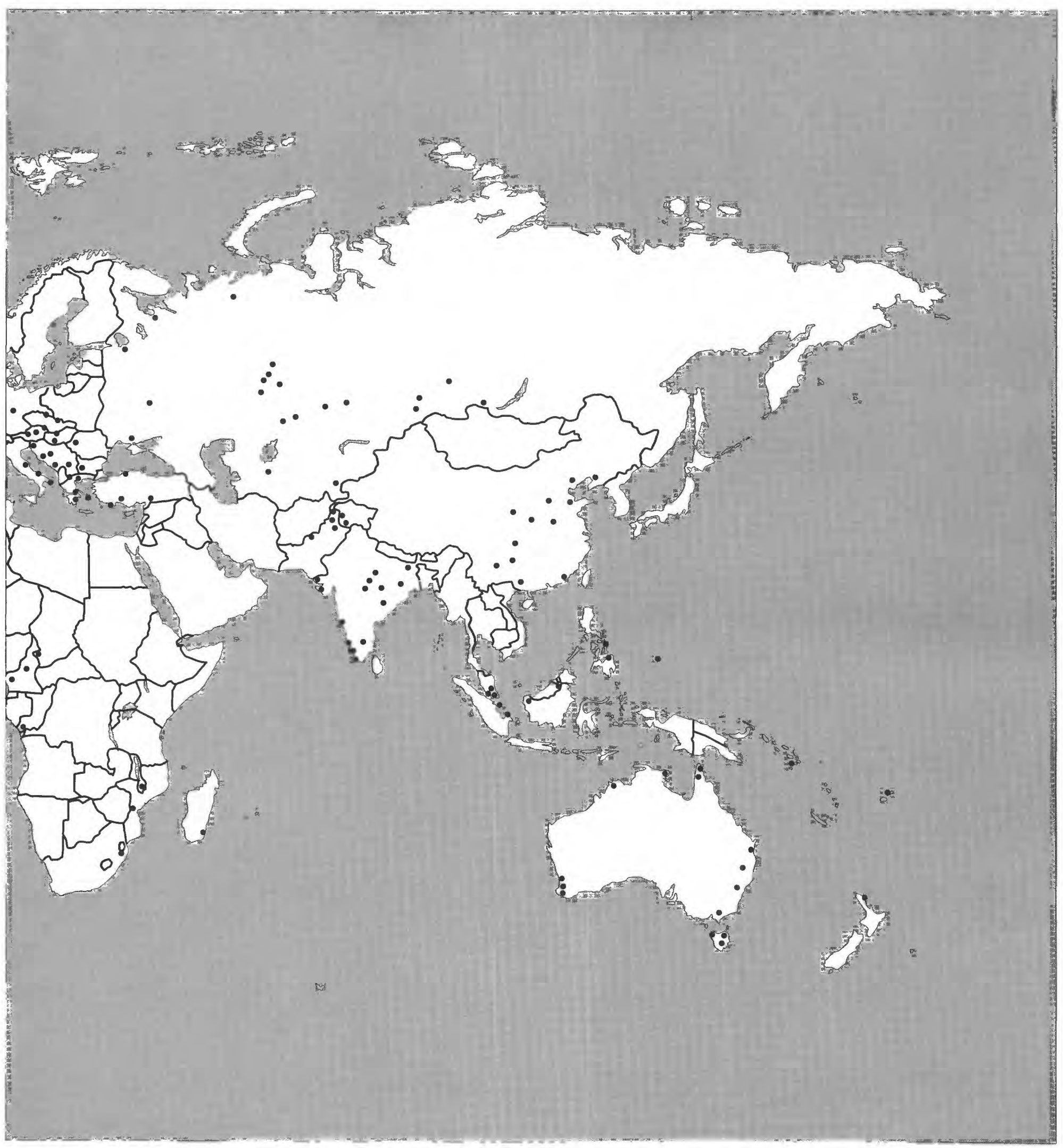

bauxite resources of the world. 
TABLE 12.-Estimates of reserves, subeconomic and undiscovered resources, and total resources of bauxite as of 1983

Most figures for reserves are on a recoverable-bauxite, dry basis and include measured, indicated, and inferred categories; however, some estimates used in compilation failed to designate types of tons used and whether converted to a dry basis. Few of the published estimates of subeconomic and undiscovered bauxite indicated the specifications of bauxite included, and most figures are believed to be on an in-the-ground basis. Differences between metric and long tons were ignored in most estimates because the resulting error is well within the limits of accuracy. Estimates for continents and regions are rounded to the nearest 500 million tons except for North and Central America. The limits for the range in world total reserves are rounded to the nearest 1 billion tons and the total resources (reserves and subeconomic and undiscovered resources) to the nearest 5 billion tons.

All estimates in millions of metric tons. VS, very small; S, small, M, moderate. Subeconomic bauxite includes demonstrated and inferred bauxite, and undiscovered bauxite includes hypothetical and speculative deposits. Most estimates for subeconomic and undiscovered resources are rounded.

\begin{tabular}{|c|c|c|c|}
\hline & Reserves & $\begin{array}{l}\text { Subeconomic and } \\
\text { undiscovered } \\
\text { resources }\end{array}$ & $\begin{array}{l}\text { Total } \\
\text { resources }\end{array}$ \\
\hline \multicolumn{4}{|l|}{ North America } \\
\hline United States .... & 38 & $275-300$ & $300-325$ \\
\hline Mexico $\ldots \ldots \ldots$ & 0 & S & $\mathrm{S}$ \\
\hline Subtotal & 38 & $275-300$ & $300-325$ \\
\hline \multicolumn{4}{|l|}{$\begin{array}{l}\text { Probable additional } \\
\text { subeconomic and } \\
\text { undiscovered deposits }\end{array}$} \\
\hline Total (rounded) & 40 & $275-300$ & $300-325$ \\
\hline \multicolumn{4}{|l|}{ Central America } \\
\hline Costa Rica & 78 & 120 & 200 \\
\hline Honduras $\ldots \ldots \ldots$ & 0 & 10 ? & $10 ?$ \\
\hline Panama ......... & 0 & $70+$ & $70+$ \\
\hline Subtotal & 78 & 200 & 280 \\
\hline \multicolumn{4}{|l|}{$\begin{array}{l}\text { Probable additional } \\
\text { subeconomic and } \\
\text { undiscovered deposits }\end{array}$} \\
\hline Total (rounded) & 80 & 200 & 300 \\
\hline \multicolumn{4}{|l|}{ Caribbean region } \\
\hline Dominican Republic & 30 & 15 & 45 \\
\hline Haiti $\ldots \ldots \ldots \ldots$. & 10 & 40 & 50 \\
\hline Jamaica $\ldots \ldots \ldots$ & 2,000 & $0-500$ & $2,000-2,500$ \\
\hline Subtotal & 2,000 & $0-500$ & $2,000-2,500$ \\
\hline \multicolumn{4}{|l|}{$\begin{array}{l}\text { Probable additional } \\
\text { subeconomic and } \\
\text { undiscovered deposits }\end{array}$} \\
\hline Total (rounded) & 2,000 & $0-1,000$ & $2,000-3,000$ \\
\hline \multicolumn{4}{|l|}{ South America } \\
\hline Brazil $\ldots \ldots$ & 2,250 & 2,750 & 5,000 \\
\hline Colombia & 0 & 100 & 100 \\
\hline French Guiana .... & 42 & 130 & 170 \\
\hline Guyana .......... & 700 & 300 & 1,000 \\
\hline Suriname & 575 & 225 & 800 \\
\hline Venezuela & 235 & $6,000-8,000$ & $6,000-8,000$ \\
\hline Subtotal ...... & 4,000 & $9,000-11,000$ & $13,000-15,000$ \\
\hline \multicolumn{4}{|l|}{$\begin{array}{l}\text { Probable additional } \\
\text { subeconomic and } \\
\text { undiscovered deposits }\end{array}$} \\
\hline Total (rounded) & 4,000 & $15,000-21,000$ & $19,000-25,000$ \\
\hline \multicolumn{4}{|l|}{ Europe } \\
\hline Austria & $\mathbf{0}$ & 2 & 2 \\
\hline France $\ldots \ldots \ldots$ & 30 & 500 & 500 \\
\hline Greece $\ldots \ldots \ldots \ldots$ & 600 & 400 & 1,000 \\
\hline Hungary ........ & 300 & $50-100$ & $350-400$ \\
\hline
\end{tabular}

Italy Romania Spain $\ldots \ldots \ldots$ United Kingdom ... U.S.S.R. . . . . . .

West Germany ....

Yugoslavia ........ Subtotal ......

Probable additional

subeconomic and

undiscovered deposits ..... $\quad \mathbf{M}$

Total (rounded)

\begin{tabular}{rcc}
5 & 45 & 50 \\
50 & $S$ & $50+$ \\
5 & $100-150$ & $100-150$ \\
0 & 3 & 3 \\
300 & $300-400$ & $600-700$ \\
2 & $S$ & 2 \\
350 & $450-550$ & $800-900$ \\
\hline 1,500 & $2,000-3,000$ & $3,000-3,500$ \\
\hline
\end{tabular}

Africa

\begin{tabular}{|c|c|c|c|}
\hline Angola & 0 & $10+$ & $10+$ \\
\hline Cameroon $\ldots \ldots \ldots$ & 680 & $800+$ & $1,500+$ \\
\hline Chad $\ldots \ldots \ldots \ldots$ & 0 & 30 & 30 \\
\hline Ghana $\ldots \ldots \ldots \ldots$ & 450 & 100 & 550 \\
\hline Guinea & 5,600 & $2,400-4,400$ & $8,000-10,000$ \\
\hline Guinea-Bissau $\ldots \ldots$ & 0 & $500 ?$ & $500 ?$ \\
\hline Ivory Coast $\ldots \ldots \ldots$ & 0 & 10 & 10 \\
\hline Madagascar $\ldots \ldots$. & 0 & $200+$ & $200+$ \\
\hline$\ldots \ldots \ldots \ldots$ & 0 & 60 & 60 \\
\hline$\ldots \ldots \ldots \ldots$ & 0 & $880+$ & $880+$ \\
\hline Mozambique $\ldots \ldots$ & 2 & ? & 2 \\
\hline Sierra Leone . . . . . . & 140 & $\mathbf{M}$ & $140+$ \\
\hline South Africa ..... & 0 & 70 & 70 \\
\hline $\begin{array}{l}\text { Upper Volta ........ } \\
\text { (now Burkina Faso) }\end{array}$ & $\mathbf{0}$ & $20 ?$ & $20 ?$ \\
\hline aire $\ldots \ldots \ldots \ldots$. & 0 & $200+$ & $200+$ \\
\hline limbabwe .. & 2 & 3 & 5 \\
\hline
\end{tabular}

Zimbabwe ............

Subtotal ......

Probable additional

subeconomic and

undiscovered deposits

\begin{tabular}{lll}
7,000 & $5,000-7,000$ & $12,000-14,000$ \\
\hline
\end{tabular}

Total (rounded)

Asia

India $\ldots \ldots \ldots \ldots \ldots \quad 1,000 \quad 2,000-4,000 \quad 3,000-5,000$

Indonesia $\ldots .750$

$\begin{array}{lrrr}\text { Iran } \ldots \ldots \ldots \ldots \ldots & 0 & 70 & 70\end{array}$

$\begin{array}{lrrr}\text { Malaysia } \ldots \ldots \ldots \ldots & 15 & 5 & 20\end{array}$

Pakistan ....... $20 \quad 80-130 \quad 100-150$

People's Republic

of China ...... $150 \quad 350-1,350 \quad 500-1,500$

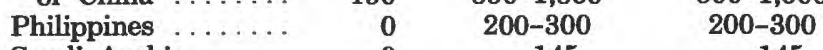

$\begin{array}{llll}\text { Saudi Arabia } \ldots \ldots & 0 & 145 & 145\end{array}$

Taiwan $\ldots \ldots \ldots \ldots, \quad 0 \quad 50-100 \quad 50-100$

$\begin{array}{lrr}\text { Turkey } \ldots \ldots \ldots \ldots & 25 & 435\end{array}$

Vietnam ....... 000

Subtotal ..... $2,000 \quad 3,000-8,500 \quad 7,000-10,500$

Probable additional

subeconomic and

undiscovered deposits ..... 1,000-2,500 1,000-2,500

Total (rounded) \begin{tabular}{rrr}
2,000 & $6,000-11,000$ & $8,000-13,000$ \\
\hline
\end{tabular}

Oceania

Australia $\ldots \ldots \ldots \quad 4,440 \quad 1,500-3,500 \quad 6,000-8,000$

$\begin{array}{crrr}\text { Fiji } \ldots \ldots \ldots \ldots \ldots & 0 & 1,400-3,500 & 10\end{array}$

New Zealand ..... $\quad 0 \quad 20 \quad 20$

Palau ........ 00 40-50

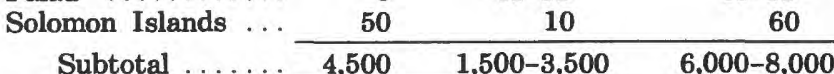

Probable additional

subeconomic and

undiscovered deposits ..... 1,000-2,000 1,000-2,000

Total (rounded) . $4,500 \quad 2,500-5,500 \quad 7,000-10,000$

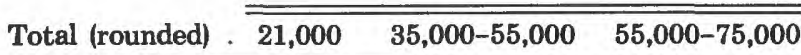




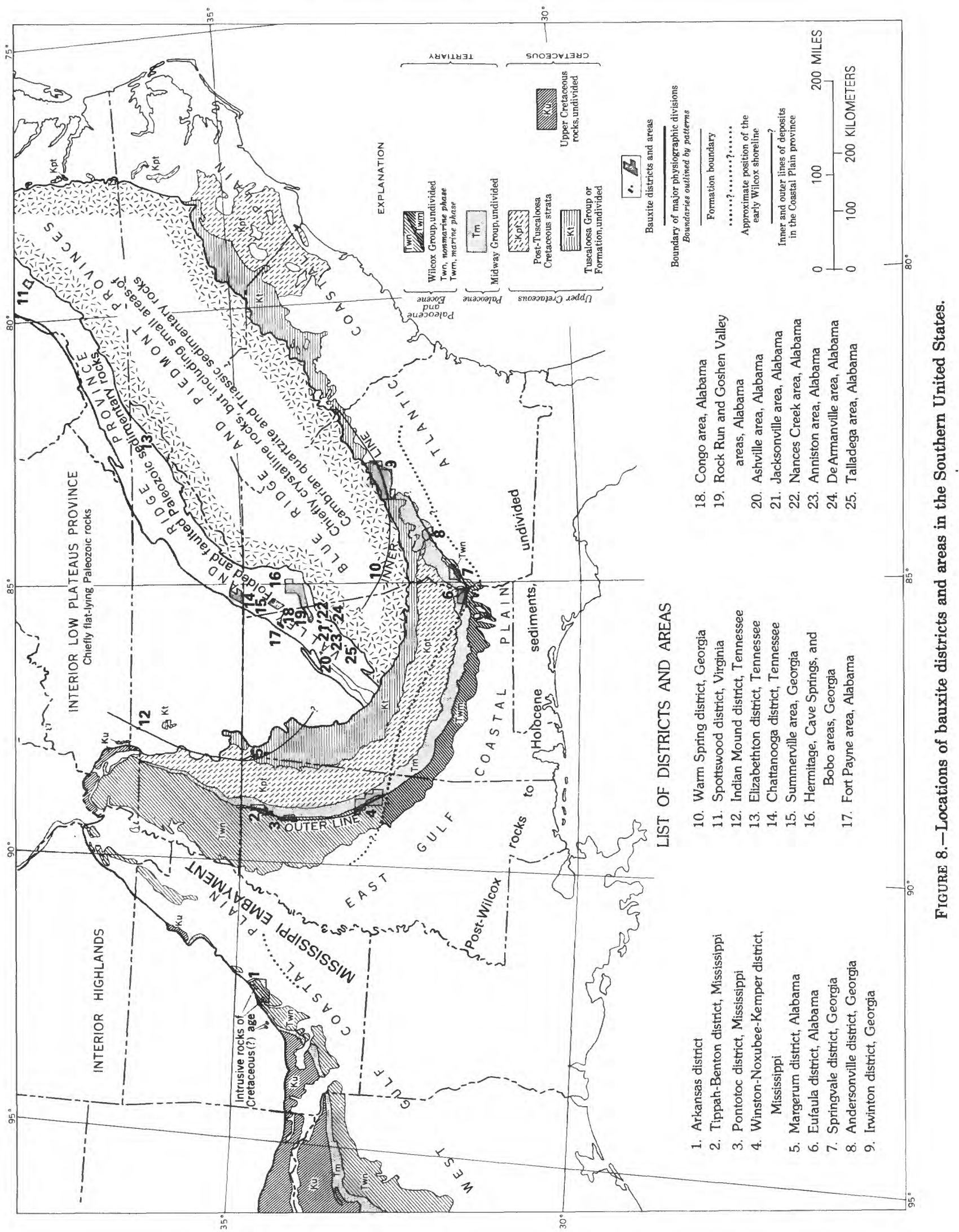


Coastal Plain. Small deposits that are no longer mined are scattered through the Valley and Ridge province in Alabama, Georgia, Tennessee, and Virginia, and small occurrences of bauxite are known in the Coastal Plain province of Mississippi and in the western part of Tennessee (fig. 8). Lateritic bauxite that occurs in Oregon, Washington, and Hawaii has been evaluated and mined for alumina recovery tests. Diaspore deposits in Missouri and Pennsylvania have been mined for many years for use in refractories but have little promise as sources of aluminum.

\section{ARKANSAS REGION}

The largest deposits of commercial bauxite in the United States occur within an area of about $700 \mathrm{~km}^{2}$ in Saline and Pulaski Counties, Ark. (fig. 9). Arkansas bauxite is associated with a nepheline syenite intrusion (fig. 10), which, during early Tertiary time, stood as low hills above a plain sloping gently southeastward. Thick bauxite deposits formed on the hills by weathering processes, erosion, slumping, and subsequent weathering of heterogeneous material. Bauxite also accumulated as sedimentary deposits near the edge of the plain. After a change in physiographic conditions, most of the area was covered by a series of flat-lying sand and clay beds; only the tops of the syenite-cored hills remained exposed. Consequently, the largest deposits, and those with the least overburden, are near the present nepheline syenite exposures. No commercial deposits are known more than a few miles south and east of the syenite outcrops.

The bauxite in Arkansas formed almost entirely from nepheline syenite in place or from detritus derived from these rocks (Gordon, Tracey, and Ellis, 1958, p. 101-137). Detrital deposits in sedimentary rocks are

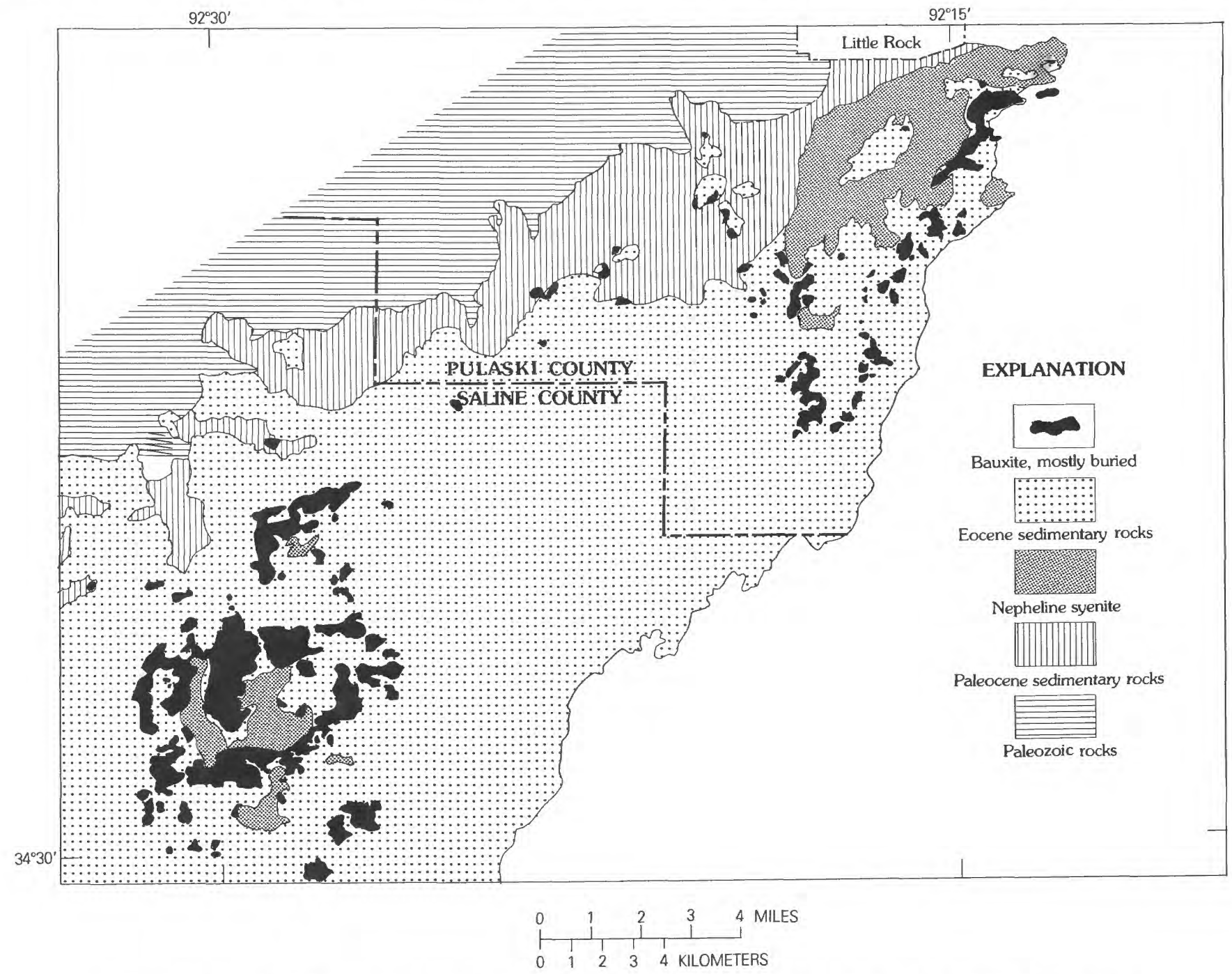

FIGURE 9.-Generalized geology of the Arkansas bauxite region. Adapted from Gordon, Tracey, and Ellis (1958). 


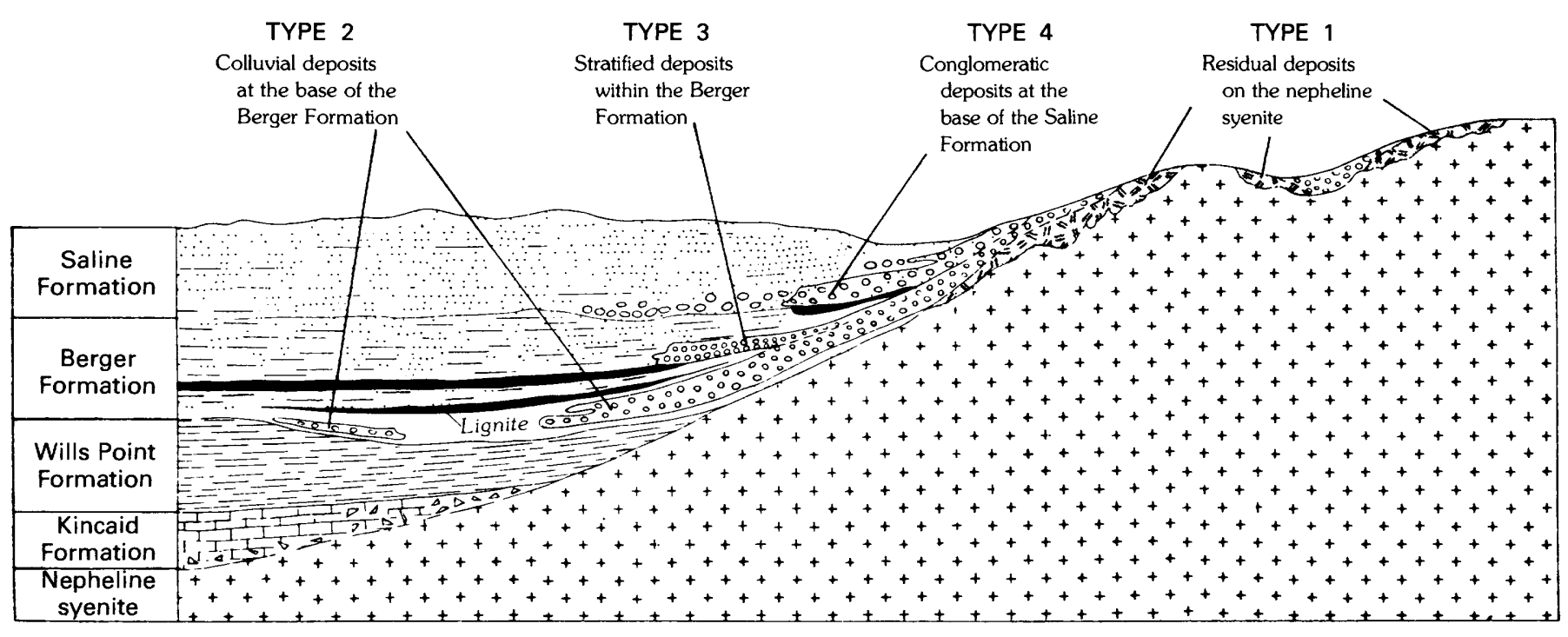

FIGURE 10.-Principal types of deposits in the Arkansas bauxite region. Adapted from Gordon, Tracey, and Ellis (1958, fig. 33).

confined to the Saline and Berger Formations of Wilcox age (middle and early Eocene) and are above an erosional surface cutting the Paleocene Wills Point and Kincaid Formations. Therefore, the principal period of bauxite formation is established as late Paleocene and early Eocene. Gordon, Tracey, and Ellis (1958) recognized the following types of deposits: (1) residual on nepheline syenite (fig. 10), (2) colluvial at the base of the Berger Formation, (3) stratified within the Berger Formation, and (4) conglomeratic at the base of the Saline Formation. The residual type formed in place by lateritic weathering. The three other types have all been transported from the residual deposits. Their classification as to type is based on stratigraphic position, particle size, and other sedimentary features.

Typical bauxite deposits in Arkansas are lenticular and range greatly in size. Some cover less than 0.4 hectare, but other tabular lenses extend over areas of more than one hundred times this size. The average thickness of type 1 (residual) deposits is approximately $5 \mathrm{~m}$, and the maximum is more than $15 \mathrm{~m}$. Most type 2 (transported) deposits have thicknesses similar to those of type 1 . Type 3 deposits are commonly about $3 \mathrm{~m}$ thick, and the maximum thickness on record is about twice this. Most type 4 deposits are about $5 \mathrm{~m}$ thick, but some down dip are considerably thicker.

Most of the metal-grade bauxite is associated with lower grade bauxite, bauxitic clay, and kaolin. In type 1 deposits, the best grade bauxite is ordinarily pisolitic material in the upper part. The pisolitic bauxite grades downward into granite-textured bauxite, which in turn grades, as silica content increases, into massive kaolin and into kaolinitic saprolite. Type 2 deposits are typically pisolitic in the upper part; the lower part consists of fragmental gibbsitic material mixed with kaolin. Most type 2 deposits are both overlain and underlain by kaolinitic clay. Type 3 deposits consist of stratified beds and crossbedded detrital bauxite composed of pebbles and cobbles ranging from about $2 \mathrm{~mm}$ to $10 \mathrm{~cm}$ in diameter. Type 3 deposits interfinger with shale of the Berger Formation. Type 4 deposits consist of a transported rubble of irregular and angular blocks of bauxite having the lithologic characteristics of the residual type 1 deposits. The largest blocks are more than $1 \mathrm{~m}$ in longest dimension. In places, the type 4 deposits overlie granite-textured bauxite; elsewhere they interfinger with silty clay of the Wilcox beds.

Gibbsite is the major bauxite mineral in the Arkansas deposits; it occurs in crystalline, microcrystalline, and cryptocrystalline forms. The crystalline and microcrystalline forms commonly line cavities and are the principal components of pseudomorphs after feldspar in parts of residual deposits. Cryptocrystalline gibbsite, the most common form, occurs in pisolites and in the enclosing matrix in most of the bauxite. Boehmite is present in minor quantities in a few deposits (Gordon, Tracey, and Ellis, 1958 , p. 85-86), and trace amounts of corundum have been reported to be present in Arkansas bauxite (Keller, 1964, p. 130). Kaolinite is the principal clay mineral in the bauxite, and halloysite is present primarily in residual deposits. As the alumina in this clay is recovered in the combination process, the clay is in a sense part of the ore.

Numerous mineral impurities are present in Arkansas bauxite. Siderite $\left(\mathrm{FeCO}_{3}\right)$ is the principal iron mineral in most deposits. Hematite $\left(\mathrm{Fe}_{2} \mathrm{O}_{3}\right)$, goethite $\left(\mathrm{FeO}(\mathrm{OH})\right.$ ), magnetite $\left(\mathrm{FeFe}_{2} \mathrm{O}_{4}\right)$, and pyrite $\left(\mathrm{FeS}_{2}\right)$ are present, and maghemite $\left(\gamma-\mathrm{Fe}_{2} \mathrm{O}_{3}\right)$ may also occur. 
Most titanium is in anatase $\left(\mathrm{TiO}_{2}\right)$, and minor amounts occur in unaltered ilmenite $\left(\mathrm{FeTiO}_{3}\right)$, sphene $\left(\mathrm{CaTiSiO}_{5}\right)$, and rutile $\left(\mathrm{TiO}_{2}\right)$. Minor accessory minerals include chlorite, chamosite, zircon, and barite.

In addition to the major oxides mentioned in the foregoing discussion, the Arkansas bauxite contains several minor elements. Most of these are discussed in the section on minor elements, and one is mentioned in the section on byproducts.

Because of wide variations in the mineralogy and abundance of impurities, the contents of $\mathrm{Al}_{2} \mathrm{O}_{3}$ and other oxides in Arkansas bauxite range broadly (table 13). Some of the high-grade bauxite contains as much as 62.0 percent $\mathrm{Al}_{2} \mathrm{O}_{3}$, only 4.6 percent $\mathrm{SiO}_{2}$, and very little $\mathrm{Fe}_{2} \mathrm{O}_{3}$. The bauxitic clay deposits commonly contain at least 50 percent $\mathrm{Al}_{2} \mathrm{O}_{3}$ and 19-22 percent $\mathrm{SiO}_{2}$. Most of the gibbsitic Arkansas bauxite mined contains 45-50 percent $\mathrm{Al}_{2} \mathrm{O}_{3}$, about 13 percent $\mathrm{SiO}_{2}, 8$ percent $\mathrm{Fe}_{2} \mathrm{O}_{3}, 2.5-3$ percent $\mathrm{TiO}_{2}$, and about 25 percent $\mathrm{H}_{2} \mathrm{O}$ (table 1).

TABLE 13.-Chemical analyses of bauxite, bauxitic clay, and kaolin from the Arkansas region

[All values in weight percent. --, not determined; LOI, loss on ignition. All data from Gordon, Tracey, and Ellis (1958, table 10, p. 109)]

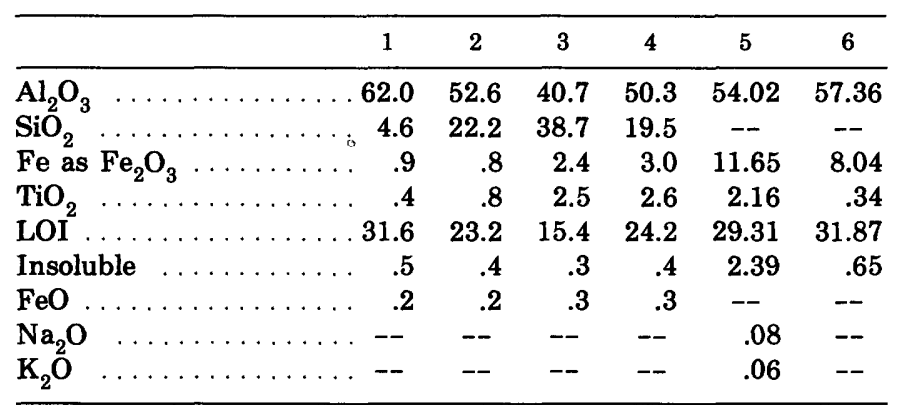

1. Tan granular-textured bauxite.

2. Grayish-tan, soft, granitic-textured bauxitic clay.

3. Gray fragmental-appearing clay.

4. White granitic-textured bauxitic clay.

5. Pisohitic bauxite.

6. Granite-textured bauxite.

\section{SOUTHEASTERN UNITED STATES}

The bauxite deposits of the Southeastern United States occur in the Coastal Plain and the Valley and Ridge physiographic provinces (fig. 8). Most deposits in the Coastal Plain province lie along an arc, referred to as the "outer line" (Bridge, 1950, pl. 1), that extends from central Georgia into southern Alabama and eastern and northeastern Mississippi (fig. 8). A few deposits similar to those in the Coastal Plain extend as far inland as the "inner line" (fig. 8) in western Tennessee, northwestern Alabama, and central Georgia.
The "inner line" is the approximate inland boundary of the coastal plain that existed in Paleocene and Eocene time when the bauxite formed (Overstreet, 1964, p. 7). Deposits of the Valley and Ridge province extend discontinuously from northeastern Alabama northnortheastward through adjacent parts of Georgia and Tennessee into northeastern Tennessee and west-central Virginia (Bridge, 1950).

Districts in the Coastal Plain

The two active bauxite districts in the Southern States, the Andersonville in west-central Georgia (Zapp, 1965; Beck, 1949) and the Eufaula in eastern Alabama (S.A. Allen, 1949; Warren and Clark, 1965; Clarke, 1972), are both in the Coastal Plain. Deposits in both districts are in the Nanafalia Formation of Wilcox age (Paleocene). Most of the bauxite bodies are within large, flat-lying, lenticular kaolin deposits. Bauxite bodies in the Eufaula district extend over areas ranging from about 0.2 hectare to nearly 1.6 hectares and are 1$15 \mathrm{~m}$ thick. Most deposits contain less than 10,000 tons, and the average size is about 3,000 tons. Those in the Andersonville district, Georgia, are larger and thinner; they may be as much as 4 hectares in areal extent and may have an average thickness of nearly $2 \mathrm{~m}$.

In addition to the two active districts in the Coastal Plain, small bauxite deposits occur in the Irwinton district, Georgia (Lang and others, 1965); in the Warm Springs district, Georgia (W.S. White, 1965), where the deposits apparently are in outliers of Coastal Plain sediments on Piedmont crystalline rocks; and in northeastern Mississippi (Conant, 1965; Tourtelot, 1964). Although small tonnages of bauxite have been mined in some of these districts, they are not thought to have significant potential for future bauxite production.

In physical appearance and mineral content, the bauxite in the Coastal Plain deposits is similar to the transported bauxite deposits in the Arkansas region. The higher grade bauxite is pisolitic, and the lower grade tends to be more earthy or clayey. In many deposits, the higher grade bauxite occurs as pods in the centers of large bodies, in which the center core is enclosed by concentric envelopes of clayey bauxite, bauxitic clay, and kaolin. Because of the occurrence and variations of the deposits, several grades of bauxite and bauxitic clay are present (table 14).

By thorough work on the mineralogy of the deposits in the Andersonville district, Flock (1966) confirmed earlier conclusions that kaolinite is the most abundant mineral in the deposits, and gibbsite is the second most abundant. Titanium-bearing ilmenite, rutile, and brookite were identified by microscopic methods, and anatase was found by X-ray diffraction. Flock also 
TABLE 14.-Ranges in grades and average composition of bauxite and bauxitic clay of the Andersonville district [Average analyses computed from a large number of analyses of each grade of samples; range of constituents given in parentheses. Definition and composition in percent. Modified from Zapp (1965, table 1)]

\begin{tabular}{|c|c|c|c|c|c|c|c|c|c|}
\hline \multirow{2}{*}{$\begin{array}{l}\text { Mineralogic } \\
\text { composition }\end{array}$} & \multirow[b]{2}{*}{ Material } & \multirow[b]{2}{*}{ Grade } & \multicolumn{2}{|c|}{$\begin{array}{c}\text { Chemical and } \\
\text { physical } \\
\text { definition }\end{array}$} & \multicolumn{5}{|c|}{ Average chemical composition } \\
\hline & & & $\mathrm{Al}_{2} \mathrm{O}_{3}$ & $\mathrm{SiO}_{2}$ & $\mathrm{Al}_{2} \mathrm{O}_{3}$ & $\mathrm{SiO}_{2}$ & $\mathrm{Fe}_{2} \mathrm{O}_{3}$ & $\mathrm{TiO}_{2}$ & $\mathrm{H}_{2} \mathrm{O}+$ \\
\hline \multirow{3}{*}{$\begin{array}{l}\text { Gibbsite } \\
\text { exceeds } \\
\text { kaolinite }\end{array}$} & Bauxite & A & $>51$ & $<7$ & $\begin{array}{c}59.6 \\
(56-61)\end{array}$ & $\begin{array}{c}5.6 \\
(3-7)\end{array}$ & $\begin{array}{c}1.4 \\
(0.5-3.0)\end{array}$ & $\begin{array}{c}2.8 \\
(2.5-3.5)\end{array}$ & $\begin{array}{c}30.6 \\
(30-32)\end{array}$ \\
\hline & Bauxite & B & $>51$ & $7-15$ & $\begin{array}{c}56.8 \\
(52.5-59.5)\end{array}$ & $\begin{array}{c}11.9 \\
(7-15)\end{array}$ & $\begin{array}{c}1.0 \\
(0.3-3.0)\end{array}$ & $\begin{array}{c}2.4 \\
(1.8-3.0)\end{array}$ & $\begin{array}{c}27.9 \\
(26.5-30)\end{array}$ \\
\hline & Bauxite & Chemical & $>51$ & $>15$ & $\begin{array}{c}52.9 \\
(51-54)\end{array}$ & $\begin{array}{c}18.9 \\
(15-22.5)\end{array}$ & $\begin{array}{c}1.0 \\
(0.3-3.0)\end{array}$ & $\begin{array}{c}2.2 \\
(1.6-2.9)\end{array}$ & $\begin{array}{c}25.0 \\
(22-27)\end{array}$ \\
\hline $\begin{array}{r}\text { Kaolinite } \\
\text { exceeds }\end{array}$ & Bauxitic clay & $45-51 \% \mathrm{Al}_{2} \mathrm{O}_{3}$ & $45-51$ & -- & $\begin{array}{c}48.2 \\
(45-51)\end{array}$ & $\begin{array}{c}27.1 \\
(22.5-53)\end{array}$ & $\begin{array}{c}1.1 \\
(0.5-3.0)\end{array}$ & $\begin{array}{c}2.0 \\
(1.4-2.6)\end{array}$ & $\begin{array}{c}21.6 \\
(18-23)\end{array}$ \\
\hline gibbsite & Bauxitic clay & $40-45 \% \mathrm{Al}_{2} \mathrm{O}_{3}$ & $40-45$ & $<43$ & $\begin{array}{c}42.7 \\
(40-45)\end{array}$ & $\begin{array}{c}37.4 \\
(32-43)\end{array}$ & $\begin{array}{c}1.1 \\
(0.5-3.0)\end{array}$ & $\begin{array}{c}1.8 \\
(1.2-2.5)\end{array}$ & $\begin{array}{c}17.0 \\
(14.5-19)\end{array}$ \\
\hline
\end{tabular}

found montmorillonite, which is ordinarily absent in bauxite deposits, to be present in amounts ranging from 0.5 to 8.0 percent. This mineral was most abundant in the upper parts of kaolin deposits above the bauxite.

The origin of the bauxite in the Coastal Plain has long been puzzling to geologists. Clarke (1966, p. 913-914) theorized that the original source of the aluminum was "feldspars in granite, granite gneiss, and pegmatites" in the Appalachian Piedmont. He noted that carbonate beds in the Clayton Formation underlie the bauxitebearing Nanafalia Formation and thought that the clay and bauxite were deposited in ponds on a karst topography. Jones (1972) generally agreed with Clarke but thought the parent material was residuum in the Piedmont formed from several aluminous minerals. According to his idea, the iron content of the parent material was reduced during transportation. Burst (1974) pointed out the marked similarities between the deposits in the Andersonville and the Eufaula districts. He thought that the local depositional basins of the aluminous materials were cutoff meanders because of the "giant banana" shape of the deposits. His reason for not accepting the karst topography ideas was the absence of carbonate beds below the bauxite in the Andersonville district. Burst concluded that gibbsite formed by "desilicification" of degraded aluminosilicate lattices under proper pH conditions. Gibbsite was thought to have formed first in isolated nuclei, and silica moving outward from groups of nuclei formed halos around gibbsite concentrations. The envelopes of progressively lower grade bauxitic materials enclosing bauxite were believed to have formed in this way.

Several features of the bauxite deposits in the Coastal Plain remain unexplained. No adequate explanation for the low iron content of the bauxite has been advanced.
Burst's theory on the origin of envelopes of lower grade material seems to ignore the probable influence of moving subsurface water. The parent clays were probably higher in iron at the time of deposition, and iron was removed by chemical processes active in the presence of decaying organic matter and low $\mathrm{pH}$ conditions. The association of scattered impure lignite deposits with the bauxite suggests that conditions favorable for such a chemical environment existed at the time of bauxite formation.

\section{Districts in the Valley and Ridge province}

Several small bauxite districts are scattered through the Valley and Ridge physiographic province (fig. 8). The most productive districts were in eastern Tennessee (Dunlap and others, 1965; McIntosh, 1949) and northwestern Georgia (W.S. White and Denson, 1966; Lewiecki, 1949). The largest deposits in these districts contained 150,000 to 200,000 tons; the largest may have contained as much as 300,000 tons. Small tonnages were also mined in districts in northeastern Alabama (Cloud, 1966,1967 ) and west-central Virginia (Warren, Bridge, and Overstreet, 1965). Most known deposits in this province are either exhausted or depleted to the point that mining is no longer profitable.

Most of the bauxite in the Valley and Ridge province is in deposits occurring as subconical sinkhole fillings in Paleozoic carbonate rock. The deposits are commonly elliptical or subcircular in shape and less than $100 \mathrm{~m}$ in maximum horizontal dimension; the greatest depth from the surface to the bottom of deposits is a little less than $60 \mathrm{~m}$. A few deposits are elongate, and they probably are in solution chambers along joints. The higher grades of bauxite are ordinarily enclosed by concentric 
envelopes of clayey bauxite, bauxitic kaolin, and kaolin. The outer kaolin envelope is commonly separated from the carbonate wallrock by an envelope of cherty red clay. Collapse structures occur in some deposits; apparently they were formed by the slumping of bauxite as the carbonate rock was dissolved. The outer red clay zone in some deposits has been referred to as terra rossa (Knechtel, 1963) and is similar in composition to the typical residuum on limestone and dolomite in the region.

Though geologists generally agree that most of the bauxite in the Valley and Ridge province formed in sinkholes, opinions differ as to the parent rock and explanations for the enveloping lower grade aluminous rocks and cherty materials. Bridge $(1950$, p. 193 , fig. 7) postulated that the kaolin and bauxite were derived from crystalline rock debris transported from igneous and metamorphic rocks in the Blue Ridge and Piedmont provinces. Knechtel (1963) pointed out similarities between the terra rossa associated with sinkhole deposits and the cherty residuum on carbonate rock and suggested that the bauxite formed in filled sinkholes by leaching of introduced residuum. Leaching of residuum in sinkholes by acid water moving downward followed by collapse of deposits would also account for the present concentric envelopment of deposits and their low iron contents. The acidity of the water is suggested by scattered organic-matter-rich layers in the upper parts of some deposits and by the fact that typical sinkholes on the present surface are swampy and rich in decaying organic matter. Knechtel (1963, p. 155) thought that the bauxite in the Valley and Ridge province formed at many different times since the close of the Paleozoic Era.

FERRUGINOUS BAUXITE IN WASHINGTON, OREGON, AND HAWAII

Low-grade ferruginous laterite-type bauxite (table 15) occurs in the following districts (fig. 11): (1) Cowlitz and Wahkiakum Counties, Wash. (Livingston, 1966; V.T. Allen, 1948); (2) Columbia County, Oreg.; (3) Washington and Multnomah Counties, Oreg. (Libbey, Lowry, and Mason, 1945; Jackson, 1971); (4) Salem Hills, Marion County, Oreg. (Corcoran and Libbey, 1956); and (5) on Kauai and East and West Maui, Hawaii (S.H. Patterson, 1971). Small deposits having little value are also present in the Chehlam Hills, Estacada, Mehama, and other areas in Oregon, and very low grade aluminous material is present on the island of Hawaii. The lateritic bauxite in all three States occurs in irregular blanketlike layers. The deposits underlie the flat or gently sloping upland surfaces on thoroughly weathered basaltic lava flows and pyroclastic deposits. Most of the bauxite in

\begin{tabular}{|c|c|c|c|c|c|}
\hline District & $\mathrm{Al}_{2} \mathrm{O}_{3}$ & $\mathrm{SiO}_{2}$ & $\mathrm{Fe}_{2} \mathrm{O}_{3}$ & $\mathrm{TiO}_{2}$ & $\begin{array}{l}\text { Loss on } \\
\text { ignition }\end{array}$ \\
\hline Cathlamet, Washington ${ }^{1}$ & 38.8 & 6.6 & 28.7 & 4.2 & 21.7 \\
\hline $\begin{array}{l}\text { Portland Hills, Oregon, } \\
\text { Hutchinson-Nexon } \\
\text { property, } 14 \text { samples }^{2}\end{array}$ & 34.3 & 8.6 & 24.5 & n.d. & n.d. \\
\hline $\begin{array}{l}2 \text { test pits, Reynolds } \\
\text { Metals Co., Oregon, } \\
56 \text { samples }^{3} \ldots \ldots \ldots\end{array}$ & 35 & 5 & 33 & 6 & 20 \\
\hline Salem Hills, Oregon ${ }^{4}$ & 35 & 6.7 & 31.5 & 6.5 & 20.2 \\
\hline Kauai, Hawaï ${ }^{5}$ & 25.9 & 4.7 & 39.4 & 6.7 & n.d. \\
\hline West Maui, Hawaï ${ }^{5}$ & 38 & 7 & 22 & 4 & n.d. \\
\hline East Maui, Hawaï ${ }^{5}$ & 31.8 & 7.8 & 32 & 6.9 & n.d. \\
\hline
\end{tabular}

Washington and Oregon is overlain by a younger silt overburden. This overburden generally is thin, but in places it is as much as $10 \mathrm{~m}$ thick. The bauxite in Hawaii and in most of the Salem district, Oregon, is overlain only by a thin layer of soil. However, some of the deposits in the Salem district extend downward from the uplands onto the surrounding slopes. Deposits on the slopes commonly are under red clayey material as much as $3 \mathrm{~m}$ thick.

The very low grade aluminous material on the island of Hawaii consists of ferruginous allophane clays containing minor quantities of gibbsite (Allen and Sherman, 1965 , p. 95). This material formed on a thin layer of volcanic ash overlying basalt. The area in which these deposits occur is now under cultivation and has far more value as cropland than as a potential source of aluminum.

The ferruginous bauxite deposits are the trihydrate type, and the gibbsite occurs mainly as fine disseminated clay-sized particles, pseudomorphic replacements of feldspar, irregular corallike nodules, and fillings of vesicles and veins. In Washington and Oregon, the bauxite is in dense clayey masses, nodules, and pisolites. The deposits in Hawaii are thought to contain appreciable quantities of noncrystalline alumina (S.H. Patterson, 1971, p. 17-19), and probably such material is present in the deposits in Oregon and Washington. Halloysite is the principal aluminous mineral other than 


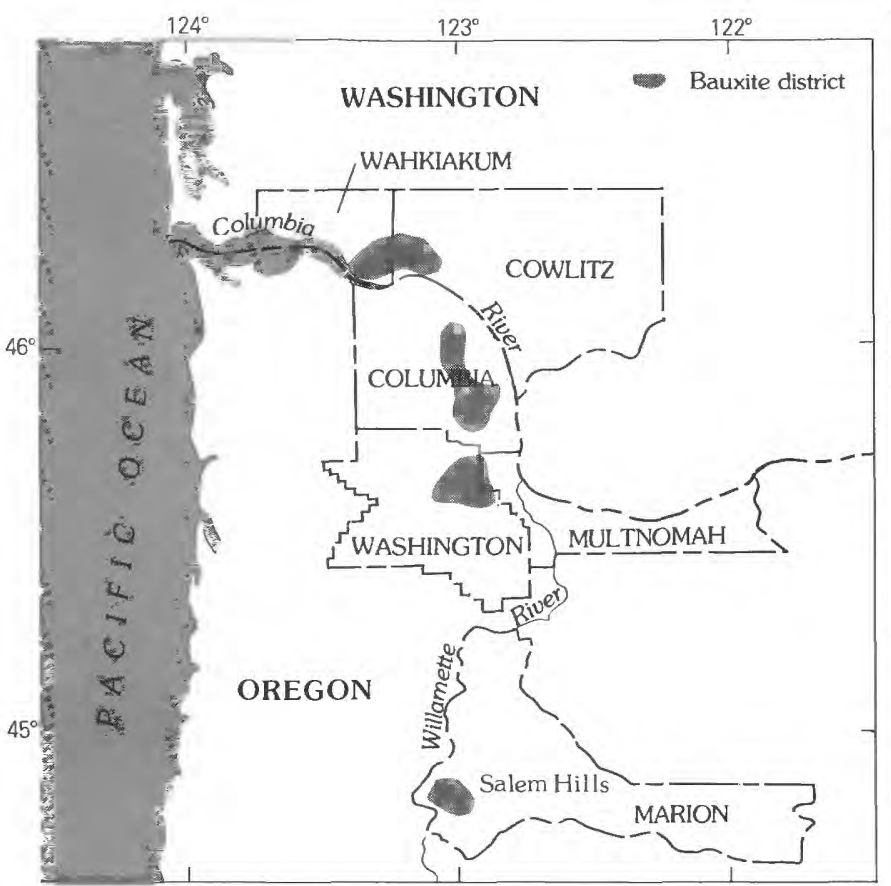

A

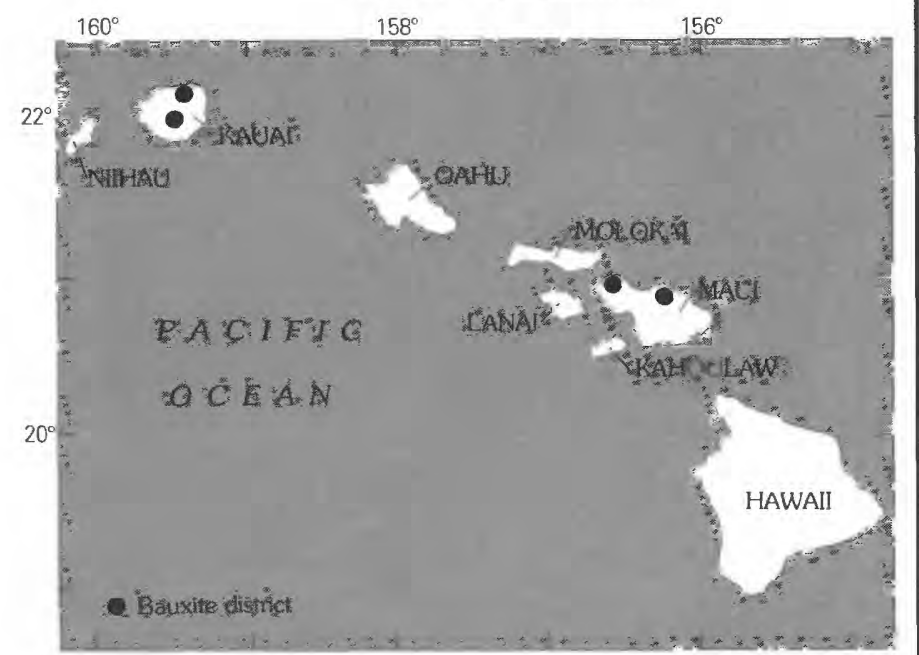

B

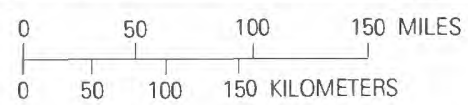

Figure 11.-Locations of ferruginous bauxite resources in the United States: $A$, Oregon and Washington; $B$, Hawaii.

gibbsite in the Hawaiian deposits. Halloysite also occurs in the Washington and Oregon deposits, but according to an old report (V.T. Allen, 1948), kaolinite is more abundant than halloysite. The iron minerals that formed during weathering of the parent rock are mainly goethite and hematite. Magnetitic ilmenite and magnetite are the principal original minerals remaining from the parent rock. Magnetite and ilmenite are ordinarily so abundant in the bauxite that dry fragments can be picked up with a magnet. Most deposits are uncommonly rich in titanium, which occurs mainly in anatase and ilmenite.

In Washington, Oregon, and Hawaii, ordinarily only that part of lateritic bauxitic material containing 10 percent $\mathrm{SiO}_{2}$ or less is called bauxite. Large resources of higher silica laterite and weathered rock are present in all three regions. The bauxite tends to occur in the upper part of thick sections of weathered rock. The upper part of the bauxite is nodular, concretionary, or fragmental, the lower part of the bauxite is saprolitic, and the textures and structures of parent volcanic rock are preserved. In most places, the saprolitic bauxite grades downward into similar weathered rock having higher silica content (10-30 percent). The higher silica saprolite is ordinarily much thicker than the bauxite. Therefore, quantities of high-silica saprolite are much larger than the bauxite resources.

All the ferruginous lateritic bauxite deposits have formed from basalt or andesite lavas and related volcanic rocks. The deposits in Washington and Oregon formed on basalt and possibly related pyroclastic materials of the Columbia River Basalt Group of Miocene age. Silt overlying the bauxite in Oregon is of Pleistocene age (Livingston, 1966, p. 63). Lavas of the Kola Volcanics, on which the bauxite on Kauai, Hawaii, occurs, are of Pleistocene age. Most of the bauxite formed on these rocks in Pleistocene time, and the process is apparently still going on. The deposits on West Maui, Hawaii, formed on andesite and soda trachytes (S.H. Patterson, 1971, p. 56). These volcanic rocks are richer in aluminum than the parent rock of other bauxites in Hawaii, which is the reason the West Maui deposits contain the best grade bauxite in the State.

In addition to the geologic investigations cited in foregoing references, the ferruginous bauxite has been investigated by industry and by the U.S. Bureau of Mines. Four companies are known to have explored deposits in Washington and Oregon during the period 1945-72. Tests of the Pedersen process by the U.S. Bureau of Mines (Blake and others, 1967; Fursman, Blake, and Mauser, 1968) have established that a reasonably good recovery of alumina can be obtained from Oregon bauxite containing as much as 13 percent $\mathrm{SiO}_{2}$. In 1970 Reynolds Metals Company mined a 50,000-ton bulk sample from nine pits, including at least one in each of the four major districts in Oregon and Washington. This bauxite was shipped to Hurricane Creek, Ark., where metal-grade alumina was recovered in Reynolds' Bayer-process plant. Four aluminum companies also evaluated the lateritic bauxite in Hawaii (Abbott, 1958, p. 844). Investigations by Calhoun and 
Hill (1962) have shown that 70.0-78.8 percent of the alumina in this bauxite can be extracted by the Bayer process. Furthermore, recovery of alumina can be increased to 79.5-85.5 percent of the amount present by calcining and caustic desilication.

\section{DIASPORE IN PENNSYLVANIA AND MISSOURI}

Diaspore, a constituent of bauxite in some countries, occurs in the Clearfield district, Pennsylvania, and the north-central Ozark region, Missouri. The diaspore in both States has been mined for many years for use in refractory products, and the deposits in Pennsylvania were investigated as a possible source of alumina during the World War II emergency (Conley and others, 1947). The refractory products produced from diaspore are 50-70 percent alumina, and they are intermediate in temperature resistance between those made from calcined fire clay $\left(<45\right.$ percent $\left.\mathrm{Al}_{2} \mathrm{O}_{3}\right)$ and the better grades of refractory bauxite and fused alumina (8099 percent $\mathrm{Al}_{2} \mathrm{O}_{3}$ ).

The diaspore deposits in the Clearfield district in Pennsylvania are part of a widespread kaolinitic flintclay bed associated with the Mercer coal of Pennsylvanian age (Pennsylvania Geological Survey, 1964). In these deposits diaspore replaces kaolin as small irregular veinlets and nodulelike masses, and it also occurs in fine disseminated form (Foose, 1944, p. 574; Bolger and Weitz, 1952). Some of the higher grade deposits consist of more than 50 percent nodules. Most of the diaspore is concentrated in lenticular bodies scattered irregularly through the lower grade flint clay.

The diaspore deposits in Missouri occur mainly in small deposits scattered through Crawford, Franklin, Gasconade, Maries, Osage, and Phelps Counties in the north-central Ozark region (McQueen, 1943). The deposits are of Early Pennsylvanian age (Keller, Wescott, and Bledsoe, 1954), and they are preserved in shallow karst depressions and sinkholes in Mississippian limestone that are as much as $33 \mathrm{~m}$ deep. The diaspore is commonly concentrated in nodules and oolites, and it also occurs in fine grains disseminated through the clay groundmass. Minor quantities of boehmite are commonly associated with the diaspore; the associated clay is chiefly kaolinite. The diaspore clay is commonly 65 percent $\mathrm{Al}_{2} \mathrm{O}_{3}, 12-15$ percent $\mathrm{SiO}_{2}$, and about 1 percent $\mathrm{Fe}_{2} \mathrm{O}_{3}$.

Though deposits in the Clearfield district, Pennsylvania, will continue to be mined for use in high-alumina refractories, diaspore is not a significant potential source of aluminum for the following reasons. (1) Diaspore deposits in Missouri are virtually exhausted, and those in Pennsylvania contain only a few million tons. (2) Many diaspore deposits occur under considerable overburden, and underground mining costs would be prohibitive. (3) Diaspore is even more stable than boehmite, and recovery of alumina from it would require higher digestive temperatures and major changes in plant design. Because of these factors, diaspore is not included in the estimates of bauxite resources in the United States.

\section{Resources \\ RESERVES}

The principal reserves of metal-grade bauxite in the United States are in the Arkansas region, and small reserves of refractory- and chemical-grade bauxite are present in the Andersonville, Ga., and Eufaula, Ala., districts. Deposits of refractory-, chemical-, and abrasivegrade bauxite, some of which may require beneficiation, also occur in the Arkansas region but are not separated from the metal-grade reserves, because of the absence of adequate information for resource estimates.

Arkansas region.-Several estimates of the bauxite reserves in the Arkansas region have been made. The U.S. Geological Survey (Gordon, Tracey, and Ellis, 1958 ) and the U.S. Bureau of Mines (Malamphy and others, 1948) made estimates based on thorough investigations during World War II. Later the U.S. Bureau of Mines in cooperation with the Arkansas Geological Commission (Stroud and others, 1969, p. 33-43) updated the estimates. This update, which was based on 1963 figures, included estimates of deposits discovered by industry since the war in the estimates for metal-grade, marginal, high-iron, and submarginal bauxite and bauxitic clay (table 16). A more recent estimate of 55 million tons for wet bauxite reserves in Arkansas was prepared for the Minerals Availability System (MAS), a computerized data bank of the U.S. Bureau of Mines. This estimate included measured, indicated and inferred bauxite in deposits $1.6 \mathrm{~m}$ or more thick and having an average $\mathrm{Al}_{2} \mathrm{O}_{3}$ content of $\mathbf{4 5}$ percent or more.

The estimate used for Arkansas bauxite reserves as of 1983 in this report is 35 million tons. The 35 -millionton figure is based on Stroud and others' (1969) estimate for metal-grade, marginal, and high-iron bauxite (table 15) plus bauxite that was reclassified as reserves instead of subeconomic since 1963, minus the total mined since the estimate was made.

Southeastern States.-The bauxite reserves in the Southeastern States, which are in the Andersonville, Ga., and Eufaula, Ala., districts, are estimated to be about 3 million dry tons. Cofer, Wright, and Carey (1976) estimated that the Andersonville district contained 1.2 
TABLE 16.-Bauxite reserves and other identified resources in the Arkansas bauxite region as of January 1, 1963

Modified from Stroud and others (1969, table 12), who considered estimates for all grades to be reserves. Calculations based on published and unpublished data, and personal communications with the Arkansas Geological Commission. Terms are those of Malamphy and others (1948, p. 5), defined as follows:

Metal-grade bauxite. Bauxite that inherently or through blending will yield a product containing more than 32 percent available alumina (determined by subtracting 1.1 times the percentage of $\mathrm{SiO}_{2}$ from the percentage of $\mathrm{Al}_{2} \mathrm{O}_{3}$ ) and less than 10 percent ferrous oxide.

Marginal bauxite. Bauxite that met wartime requirements and that may be used as an ore in an emergency but that otherwise is of doubtful economic value.

High-iron bauxite. Bauxite that is not suitable for use as an aluminum ore under usual treatment methods because of its high iron content but that, if beneficiated by removal of the iron alone, would yield a marketable bauxite concentrate.

Submarginal bauxite. Bauxite containing more than 40 percent gibbsite that is not chemically suitable for use as an ore for reasons other than its iron content.

Bauxitic clay. Material containing between 15 and 40 percent gibbsite and less than 25 percent impurities.

\begin{tabular}{|c|c|}
\hline Classification & $\begin{array}{c}\text { Thousands of } \\
\text { dry tons }\end{array}$ \\
\hline Metal-grade bauxite & 37,000 \\
\hline Marginal bauxite & 12,100 \\
\hline High-iron bauxite & 12,890 \\
\hline Submarginal bauxite & 18,800 \\
\hline Bauxitic clay & 34,680 \\
\hline Total & 115,470 \\
\hline
\end{tabular}

million dry tons of indicated and about 600,000 tons of inferred bauxite reserves by 1976 . This estimate was based on a study of drill core from about 600 exploratory drill holes and observations in many strip mines. The estimates of bauxite reserves in the Eufaula, Ala., district are privileged information, as most of the deposits were found by company drilling programs in the 1960's and 1970's. However, Clarke (1972, p. 89) reported that deposits containing 100,000 tons of bauxite have been found by several companies. According$\mathrm{ly}$, the 1.8 million tons of indicated and inferred bauxite in the Andersonville district and several deposits of 100,000-ton size in the Eufaula district support the estimate of approximately 3 million tons of bauxite reserves in the Southeastern States.

\section{SUBECONOMIC RESOURCES}

The subeconomic bauxite resources in the United States are mainly the ferruginous laterite deposits in Oregon, Washington, and Hawaii and bauxite and bauxitic clay deposits in the Arkansas region and the Southeastern States that are too low in grade or that for other reasons cannot be profitably mined under existing economic and technologic conditions.
Washington, Oregon, and Hawaii.-The resources of demonstrated subeconomic lateritic bauxite in Washington and Oregon are estimated to be $\mathbf{7 0}$ million dry tons. This estimate is the approximate 50-percent probability figure in the U.S. Bureau of Mines MAS file. The estimates of Washington and Oregon bauxite in the MAS file are modified from an unpublished report prepared by John W. Hook in cooperation with the Oregon Department of Geology and Mineral Industries. The weighted composition of the deposits in these estimates is as follows: 36.26 percent $\mathrm{Al}_{2} \mathrm{O}_{3}, 5.90$ percent $\mathrm{SiO}_{2}$, 31.77 percent $\mathrm{Fe}_{2} \mathrm{O}_{3}$, and 5.95 percent $\mathrm{TiO}_{2}$. The grade cutoff applied in arriving at the estimates was not less than 30 percent $\mathrm{Al}_{2} \mathrm{O}_{3}$ and not more than 10 percent $\mathrm{SiO}_{2}$. All of this bauxite is considered to be in the subeconomic category because alumina has been recovered from it.

The low-grade lateritic bauxite deposits in Hawaii were estimated (S.H. Patterson, 1962, p. 2; 1971, table 12, p. 65 and 66 ) in short dry tons as follows: (1) Kauai-100 million, (2) West Maui-9 million, and (3) East Maui-22 million. Since 1961, the end of the field work leading to these estimates, considerable bauxite acreages on Kauai have been withdrawn, for all practical purposes, from possible mining by real estate development. In the Princeville Ranch area, northern Kauai (S.H. Patterson, 1971, pl. 1), hotels, condominiums, and recreational facilities now in existence, under construction, or planned have taken up so much land seaward from Hawaii Highway 56 that virtually no bauxite in this area is available. Considering the withdrawal of these resources and the likelihood that bauxite lands will continue to be lost because of higher value for other uses, the total subeconomic bauxite in Hawaii now should be estimated at only about 100 million dry tons. All of this bauxite is classified in the subeconomic category because of its low grade and the fact that much of it is on lands that will be increasing in value for several uses other than mining.

The total resources of subeconomic ferruginous or lateritic type bauxite includes the $\mathbf{7 0}$ million dry tons in Oregon and Washington and the 100 million dry tons in Hawaii. Total resources of subeconomic lateritic bauxite are therefore about $\mathbf{1 7 0}$ million dry tons.

Arkansas and the Southeastern States.-The subeconomic aluminum resources in the Arkansas region consist mainly of 18.8 million dry tons of bauxite and 34.5 million dry tons of bauxitic clay (table 16). In addition, high-grade bauxite in beds less than $1.6 \mathrm{~m}$ thick and some deeply buried deposits are in this category because they are unprofitable to mine. The total subeconomic bauxite resources in the Arkansas region are estimated to be 50 million- 60 million tons.

Subeconomic bauxite resources in the Andersonville 
district, Georgia, and the Eufaula district, Alabama, consist mainly of bauxitic clay. Information now available on the total subeconomic bauxite resources in these two districts is incomplete, but the total is thought to be 15 million-20 million dry tons.

\section{UNDISCOVERED RESOURCES}

Moderate or large undiscovered bauxite deposits may be present at depth in one region, and small deposits may yet be found in others. The possibilities for moderate to large deposits at depth are mainly in the Mississippi embayment (fig. 8), a deep trough-shaped depression filled with Mesozoic and Cenozoic sediment. Masses of igneous rock are known to be present under considerable thicknesses of sedimentary beds at scattered localities in this large embayment. Some of these may have been exposed in early Eocene time and bauxite may have formed on them as it did on the nepheline syenite in Arkansas during the interval. One such buried mass is suggested by a geophysical anomaly a few kilometers east of the Arkansas bauxite region (Jespersen, 1964). This mass is likely to be the same type of syenite as the parent rock of the Arkansas bauxite, and it is probably covered by sedimentary rocks only a few tens of meters thick.

Small undiscovered bauxite deposits are very likely to be present in the following regions, although the most favorable areas have been prospected by industry and government. (1) The Washington and Oregon region contains several scattered areas that are, in varying degrees of probability, favorable for bauxite but that have not been thoroughly explored. More bauxite than is presently known no doubt exists in this region, but many deposits are likely to be on lands having high value for uses other than mining. (2) The Andersonville, Ga., and Eufaula, Ala., districts and the belt between these districts probably contain undiscovered bauxite. Probably the most favorable area for new discoveries is the part of the Andersonville district explored by widely spaced drill holes that may have missed small deposits (Cofer, Wright, and Carey, 1976). The Eufaula district has been thoroughly explored (Clarke, 1972), but a few small deposits probably remain to be found. Information on the possibilities for bauxite between these two districts is incomplete, and the belt is considered geologically favorable for bauxite. (3) The Valley and Ridge province of Appalachia has a long history of mining of small deposits, and it is very unlikely that all the bauxite in this region has been discovered. As the deposits in the province occur in karst depressions, the numerous sinkholes, small ponds, and swamps are considered the most favorable places for discovery of additional bauxite.
Insofar as the authors are aware, only a few attempts have been made to estimate the undiscovered bauxite resources. One estimate is the approximately 15 million tons of ferruginous bauxite projected at a 25- to 50-percent probability on favorable but unexplored terrain in Washington and Oregon by John W. Hook (U.S. Bureau of Mines, unpub. data, 1975). Another is the hypothetical 1.5 million tons of bauxite and 6 million tons of bauxitic clay thought to be present in the Andersonville district, Georgia (Cofer, Wright, and Carey, 1976, table 2). The Nation's undiscovered resources are probably at least twice that total thought to be present in the Andersonville district, Georgia, and Washington and Oregon, or 40 million-50 million dry tons.

SUMMARY OF BAUXITE RESOURCES IN THE UNITED STATES

Reserves of bauxite in the United States in 1983 were estimated, in millions of tons, as follows: metal grade in the Arkansas region-35; refractory grade in the Andersonville, Ga., and Eufaula, Ala., districts-3. The total is rounded at 38 million tons, the estimate published by the U.S. Bureau of Mines (Baumgardner and McCawley, 1983, table 3).

The Nation's subeconomic and undiscovered bauxite resources, expressed in millions of dry tons (metric and long tons are considered equal within the hmits of accuracy), consist of the following: (1) 50-60 of bauxite and bauxitic clay in Arkansas; (2) 15-20 of bauxitic clay in the Andersonville, Ga., and Eufaula, Ala., districts; (3) 70 of ferruginous bauxite in Washington and Oregon; (4) 100 of ferruginous bauxite in Hawaii; and (5) possibly 40-50 of hypothetical bauxite in Washington and Oregon, Arkansas region, and the Southeastern States. The total subeconomic and undiscovered bauxite resources are 275 million to 300 million tons, rounded.

Total resources of bauxite in the United States consisting of reserves and the subeconomic and undiscovered resources are considered to be 300 million-325 million dry tons.

\section{MEXICO}

Bauxitic materials reportedly occur at several places in Mexico. A bauxite deposit occurring under gypsum layer at a locality midway between the cities of Tampico and San Luis Potosi has been declared a national reserve by the Mexican government (Wilmot, Sullivan, and Trought, 1960, p. 236). High-iron lateritic weathered rocks have been investigated in the States of Veracruz, Puebla, Oaxaca, and Tabasco. Though much gibbsitic and kaolinitic rock containing 30-40 percent $\mathrm{Al}_{2} \mathrm{O}_{3}$ is present, no commercial bauxite had been 
found by 1959 (Salas, 1959, p. 10). The bauxitic clays in the State of Puebla, located 1-6 km south of Xicotepec de Juarez, were investigated further by the Mexico Consejo de Recursos Naturales No Renovables (1972, p. 59-60). They contain 600,000 tons of gibbsitic material having an average alumina content of approximately 27 percent.

\section{CENTRAL AMERICA}

Bauxite is known to occur at several places in Central America, but, at the time this report was written, efforts to produce it had not been successful. The Costa Rican Government has been interested in developing bauxite in that country for many years. One plan considered was joint participation with Alcoa in operating mines and an alumina plant. Alcoa withdrew from the project in 1975 , but since that time other aluminum companies are reported to have expressed interest, though no firm plans have been announced. The other bauxite deposits in Central America that have attracted the attention of the aluminum industry are in Panama. Small bauxite deposits are reported to be present in Honduras, and bauxite probably occurs in other countries as well.

\section{COSTA RICA}

The principal bauxite district in Costa Rica is in the San Isidro region, on the Pan American Highway south of San José (Sandoval, 1969). The deposits are the laterite type that formed in weathered volcanic and sedimentary rocks of Tertiary age and in Pliocene and Pleistocene terrace gravels consisting of transported volcanic and igneous materials. Thicknesses of the deposits range from 1 to $7 \mathrm{~m}$ and average about $2.3 \mathrm{~m}$. Gibbsite is the principal mineral in the deposits, and some contain appreciable quantities of iron oxides and silica. The $\mathrm{Al}_{2} \mathrm{O}_{3}$ content of much of the bauxite in the San Isidro region ranges from 33 to 44 percent, and the reactive silica content ranges from 2.2 to 18.9 percent.

Total bauxite resources in Costa Rica are estimated to be approximately 200 million tons. Several reports, including Sandoval $(1969$, p. 2$)$, indicate that a reserve of 150 million tons of bauxite containing 35 percent $\mathrm{Al}_{2} \mathrm{O}_{3}$ is present in the San Isidro region. Sandoval reported that the region may contain an additional 150 million tons having an $\mathrm{Al}_{2} \mathrm{O}_{3}$ content of 25 percent or more. Subeconomic bauxite is present in two other areas. The Abejonal and Cañon area is thought to contain approximately 40 million tons that is $30-35$ percent $\mathrm{Al}_{2} \mathrm{O}_{3}$, and about the same quantity having an average $\mathrm{Al}_{2} \mathrm{O}_{3}$ content of 30 percent is present in the Guácimo area. Sandoval also observed that the geology of Costa Rica is far from completely known, and several more areas are favorable for valuable bauxite deposits. One of these apparently is the Zona de Paraiso de Cartago, where Dondoli (1970) identified 10 million15 million tons of gibbsitic bauxite. The nine samples of this bauxite analyzed by Alcoa ranged from 39.4 to 51.4 percent $\mathrm{Al}_{2} \mathrm{O}_{3}$, of which 26.5-34.2 percent was extractable by the Bayer process. These samples also contained 13.7-25.4 percent $\mathrm{SiO}_{2}, 2.93-15.8$ percent $\mathrm{Fe}_{2} \mathrm{O}_{3}$, and 1.78-3.45 percent $\mathrm{TiO}_{2}$.

\section{HONDURAS}

During investigations of samples from Honduras, Ljunggren (1958) found that soils in some areas contain abundant alumina in hydrated form and suggested the possibility of finding valuable bauxite deposits. The areas in which the alumina is most abundant are on the southeastern slopes of mountains along the Pacific coast. Apparently these or other parts of Honduras have been examined for bauxite, as Bárdossy (1964, table 2) listed an estimate of 10 million tons for the potential bauxite in Honduras and El Salvador.

\section{PANAMA}

Bauxite occurs in Panama in several areas in a belt scattered along the Pacific Coast. The largest deposits are in the so-called David area in Chiriqui province. Other deposits occur in the province, and small deposits have been found in Veraguas province. The deposits in Chiriqui have been evaluated by both Alcoa and Kaiser aluminum companies. They are estimated to contain 70 million tons of bauxite that is 40 percent $\mathrm{Al}_{2} \mathrm{O}_{3}$ and 6 percent $\mathrm{SiO}_{2}$ (U.S. Army Corps of Engineers, Agency for Resource Inventories, 1967, p. T-9). The deposits in Veraguas province are apparently small; no estimates of their size are available.

\section{SUMMARY OF BAUXITE RESOURCES IN GENTRAL AMERICA}

The estimates of bauxite in countries in Central America in this report are, in million of tons: Costa Rica-approximately 200, Panama-70, and Honduras-possibly 10. Bauxite not included in these estimates has been found in places in Costa Rica and Panama, and small deposits will certainly be found in other countries. The reasons for this conclusion are that 
the geologic investigations of many areas in Central America are inadequate, and several areas are favorable for bauxite. The 150 million tons of bauxite in the San Isidro region of Costa Rica are considered to be reserves. An equal amount of subeconomic and undiscovered bauxite is estimated to be present in all of Central America. The total reserves and subeconomic and undiscovered bauxite are therefore estimated to be 300 million tons.

\section{CARIBBEAN ISLANDS}

Bauxite was discovered in Jamaica in 1942, when an agronomist analyzed soil to find ways to improve its fertility. Attention then focused on the possibility that bauxite might be found on the other Caribbean Islands, and bauxite was recognized in Haiti and the Dominican Republic during World War II. The long delay in the discovery of these deposits was due chiefly to the fact that they are earthy and soil-like and very different from the aluminum ore that had been used before World War II.

The bauxite in Jamaica, the Dominican Republic, and Haiti occurs as earthy material on the karst surface of limestone. Most deposits are extremely fine grained porous bauxite that is soft to moderately hard and dark red, reddish brown, or mottled yellow, depending on the amount and form of iron oxide present. It is sticky when wet and friable when dry and will stand in steep mine faces for considerable periods of time. Most of it is massive, but pisolitic material is present in the upper parts of some deposits. The deposits in Jamaica overlie the White Limestone Formation of middle Eocene to early Miocene age. According to Robinson (1971, fig. 3), some of the bauxite in Trelawny and St. Ann Parishes could have formed in early Miocene time, the principal interval of formation of high-grade bauxite was late Miocene, and bauxite terra rossa and lateritic soils were still forming in Pleistocene time. The limestone below the bauxite in the Dominican Republic and Haiti is approximately the same age as the White Limestone in Jamaica.

The origin of the bauxite in the Caribbean Islands continues to be the subject of much discussion and differing opinions among geologists. The principal disagreement is over the source of the aluminous parent material of the bauxite. According to one school of thought (Schmedeman, 1948, p. 79; Hartman, 1955, p. 746; Hill, 1955, p. 687-688; Clarke, 1966; Sinclair, 1967; Hose, 1963, p. 66-68), the bauxite formed by the alteration of residual material from a considerable thickness of the exceptionally pure limestone on which the deposits occur. Other geologists (Chubb, 1963;
Goldich and Bergquist, 1948, p. 109; Zans, Lemoine, and Roch, 1961; Burns, 1961; Lee, 1965; Roch, 1966; Kelly, 1961) have suggested that aluminous parent materials were transported to positions above the limestone. Most of these authors postulate that the andesitic tuffaceous rocks such as are exposed in the central part of Jamaica were the type of aluminous rocks transported. Hill and Davis (1971, p. 23) suggested that the bauxite formed both as residual material from limestone and as transported aluminous sediments. Comer $(1974,1984)$ has presented evidence that not all of the White Limestone Formation is as pure as previously thought; some of it contains thin-bedded and disseminated altered volcanic ash. He believed that this ash, which may have been introduced from volcanoes at some distance from Jamaica, was the principal source of the aluminum in the bauxite.

\section{DOMINICAN REPUBLIC}

History and Production

Bauxite was discovered in red soil in the Dominican Republic in July 1943 by geologists of the Reynolds Mining Corporation, and shortly thereafter the Aluminum Company of America located similar deposits. In 1944 the deposits were investigated by the U.S. Geological Survey, working in cooperation with officials of the Dominican Republic Government (Goldich and Bergquist, 1947). Alcoa began bauxite mining in 1959. Annual production was a little more than 1 million tons during the early 1970's (table 6). It dropped to 754,000 tons in 1975 during the worldwide reduction in aluminum demands, was well below 1 million tons in the 1976-81 period, and only 141,000 tons was produced in the recession year of 1982 . No bauxite was mined in 1983 , and in 1984 Alcoa announced that it would mine no more bauxite in the Dominican Republic (Metal Bulletin, 1984). The deposits that were mined are in the Aceitillar district (fig. 12), located about $30 \mathrm{~km}$ northeast of Pedernales, and the Las Mercedes district $14 \mathrm{~km}$ northeast of this city.

\section{Bauxite Districts and Deposits}

The principal bauxite districts in the Dominican Republic are on the slopes of the Sierra de Baoruco, Barahona province. The deposits in the Aceitillar district accumulated in valleys in middle and upper Eocene limestone (Goldich and Bergquist, 1947, p. 53). Those in the Las Mercedes district overlie middle and upper Oligocene limestone at altitudes of about $350 \mathrm{~m}$ 


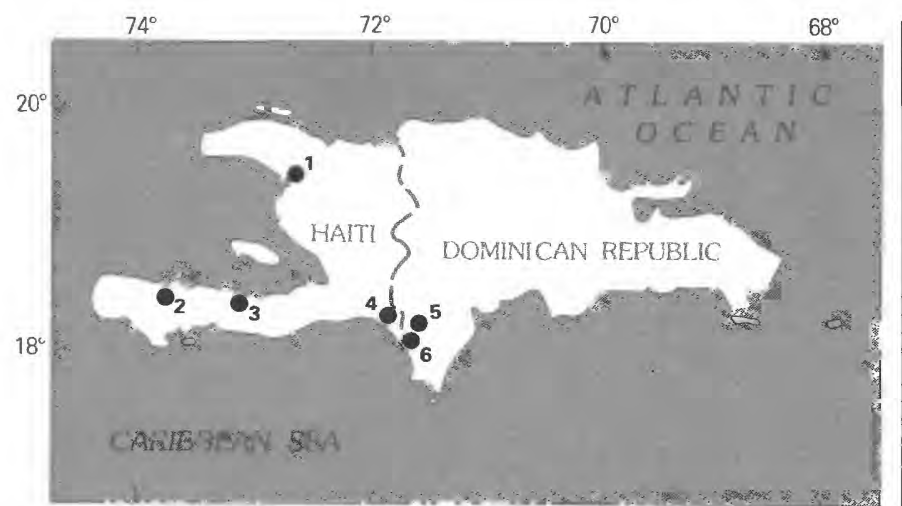

\begin{tabular}{lcccc}
0 & \multicolumn{2}{c}{50} & 100 & 150 MILES \\
0 & 50 & 100 & 150 & KILOMETERS
\end{tabular}

EXPLANATION

$$
\begin{aligned}
& \text { BAITI } \\
& \text { 1. Sauxite district } \\
& \text { 2. Beaumont } \\
& \text { 3. Rochelois plateau } \\
& \text { 4. Savane Zombi } \\
& \text { DOMINICAN REPUBLIC } \\
& \text { 5. Aceitillar } \\
& \text { 6. Las Mercedes }
\end{aligned}
$$

FIgURE 12.-Locations of bauxite districts in Haiti and the Dominican Republic.

(Engineering and Mining Journal, 1977). Bauxite has also been found in the Canote area at an altitude of $1,525 \mathrm{~m}$ and in the Masico-Abejo area at an altitude of 1,190 m (Caribbean Geological Congress, 1980, p. 34). The bauxite in these two districts also rests on Tertiary limestone.

The bauxite occurs in elongate and funnel-shaped pockets that range in size from small occurrences to deposits extending over more than $2 \mathrm{~km}^{2}$. Most are 6-15 m thick (Engineering and Mining Journal, 1977, p. 140-141), but one is more than $80 \mathrm{~m}$ thick.

Both trihydrate and mixed types of bauxite are present in the deposits. Deposits in the Aceitillar district are 60-75 percent gibbsite and contain only minor quantities of boehmite (Goldich and Bergquist, 1947, p. 69). Most of the Las Mercedes deposits contain 20 percent boehmite or a little more. Kaolinite is present in both districts, but a few deposits contain as much as 5 percent of this mineral. Hematite and goethite are the principal iron minerals, and quartz, zircon, magnetite, or ilmenite are present in minor amounts.

\section{Resources}

The reserves of bauxite in the Dominican Republic were listed by the International Bauxite Association (1976b, table 1) as 26 million tons measured and 45 million tons total. The average grade of this bauxite was given as 50 percent total $\mathrm{Al}_{2} \mathrm{O}_{3}$ and 5 percent $\mathrm{SiO}_{2}$. In a later article by this association (International Bauxite Association, 1977b, p. 49), it was noted that the total bauxite mined is $\mathbf{1 3 . 6}$ million tons and the reserves remaining are 32.4 million tons. The composition of the typical bauxite in these reserves is 50 percent total $\mathrm{Al}_{2} \mathrm{O}_{3}, 45$ percent available $\mathrm{Al}_{2} \mathrm{O}_{3}, 2.5$ percent total $\mathrm{SiO}_{2}, 20$ percent $\mathrm{Fe}_{2} \mathrm{O}_{3}$, and 25 percent LOI (loss on ignition). Subeconomic bauxite and bauxitic clay are known to be present in the Dominican Republic, but the extent of the deposits has not been determined. Highsilica bauxite is associated with the deposits mined, and bauxitic clay was found along a trail in the region west of the deposits mined (Goldich and Bergquist, 1947, p. 72). Though some undiscovered bauxite may be present in the Dominican Republic, few areas are favorable for finding large deposits. Probably at least 10 million tons of subeconomic and undiscovered bauxite is present in the Dominican Republic, and the total resources are about 40 million tons. According to the U.S. Bureau of Mines (Baumgardner and McCawley, 1983, table 3), the remaining bauxite reserves in the Dominican Republic are 30 million tons. These reserves presumably include the deposits discovered in Pedernales Province (Mining Engineering, 1971b, p. 12).

\section{HAITI}

\section{History and Production}

Bauxite was discovered in Haiti in 1943 (Schmedeman, 1948, p. 79), and Reynolds Haitian Mines opened its first mine in 1956. During the first 12 years of mining, annual production was in the 250,000 - to 450,000 -ton range. After this period, production increased to 743,000 tons in 1973 but declined after that year (table 6). Reynolds Metals Company closed its Miragoâne bauxite mine in late 1982 (Hyde, 1984, p. 1113). The reason given was that the high silica content of the remaining bauxite and the depressed aluminum market made further mining unprofitable. The deposits mined were on the Rochelois plateau at an altitude of approximately $600 \mathrm{~m}$. The mines were about $10 \mathrm{~km}$ southwest of the port of Miragoâne.

\section{Bauxite Districts and Deposits}

The largest bauxite deposits in Haiti are on the Rochelois plateau on the the southern peninsula 
southwest of Miragoâne; other deposits occur near (1) Beaumont, in the Massif de la Hotte; (2) Savane Zombi, in the Massif de la Selle; and (3) Savane Terre Rouge, on the plateau northwest of Gonaives (Goldich and Bergquist, 1948, p. 63, 108-109). The bauxitic material is finely divided reddish-brown, yellowish-brown, and buff lateritic soil. Gibbsite, boehmite, hematite, and goethite are the principal minerals. Clay minerals, chiefly kaolinite, and compounds of titanium, manganese, and phosphorus are minor constituents; quartz, zircon, and magnetite are accessory minerals. Gibbsite and boehmite together compose about 60 percent of the deposits, but their proportions vary considerably. Some parts of the deposits are 25 percent gibbsite and 35 percent boehmite, and others are as much as 45 percent gibbsite and only 13 percent boehmite (Goldich and Bergquist, 1948, p. 82). Recent mineralogical studies (Bárdossy and others, 1977b, table 1) have confirmed the presence of as much as 27 percent boehmite in the deposits on the Rochelois plateau. Hematite was found to be approximately five times as abundant as goethite in these deposits; the titanium is mainly in the form of anatase, but minor quantites of rutile are also present. One of the samples studied contained a little chlorite, and the phosphate mineral identified was crandallite.

\section{Resources}

The reserves of bauxite in Haiti were listed by the International Bauxite Association (1966, table 1) as 6.9 million tons measured and 14 million tons total. The average grade of these deposits is 50 percent total $\mathrm{Al}_{2} \mathrm{O}_{3}$ and less than 7 percent total $\mathrm{SiO}_{2}$. According to Goldich and Bergquist (1948, p. 83-85, table 3), the average available alumina content in the better grade of bauxite on the Rochelois plateau is 44.8 percent. This bauxite contains $2-5$ percent $\mathrm{SiO}_{2}$ and $20-23$ percent $\mathrm{Fe}_{2} \mathrm{O}_{3}$. The deposits discovered in the Savane Zombi district are reported (Organization of American States, 1972 , p. 416) to range in $\mathrm{Al}_{2} \mathrm{O}_{3}$ content from 45.32 to 46.98 percent and in $\mathrm{SiO}_{2}$ content from 6.35 to 9.55 percent.

Subeconomic high-silica bauxite is known to be associated with the reserves (Goldich and Bergquist, 1948) and elsewhere. The remaining bauxite reserves in Haiti are estimated by the U.S. Bureau of Mines (Baumgardner and McCawley, 1983, table 3) to be 10 million tons. The total resources-reserves and subeconomic and undiscovered bauxite-may be as much as $\mathbf{5 0}$ million tons (Cheilletz, Le Mailloux, and Samama, 1973).

\section{JAMAICA}

\section{History and Production}

Bauxite mining began in Jamaica in 1952, and by 1958 this country was the leading world producer, a position held until Australia took the lead in 1971. The free moisture content of bauxite when mined ranges from 19 to 25 percent; it is reduced to $8-14$ percent in oil-fired rotary dryers for export. Total bauxite produced in Jamaica from the first mining through 1982 was 261 million tons. Annual production from 1961 through 1983 is listed in table 6.

\section{Bauxite Districts and Deposits}

Bauxite is mined in Jamaica in the Parishes of St. Ann, Clarendon, Manchester, and St. Elizabeth (fig. 13), which contain the largest deposits, and bauxite also occurs in the Parishes of St. Catherine, St. James, and Trelawny (Lyew-Ayee and Stewart, 1982, fig. 1). Lowgrade bauxites of little present value also occur in the John Crow Mountains in the eastern part of Jamaica (Hughes, 1973), and small deposits are known to be present in the westernmost Parishes.

Most bauxite deposits in Jamaica are overlain by soil that is rarely as much as $1 \mathrm{~m}$ thick; however, in a few places in Manchester and St. Elizabeth Parishes, detrital material has been deposited above the bauxite concealing it (Porter and Anderson, 1982). The detrital material, which consists mainly of limestone gravel and finer particles, ranges in thickness from a feather edge to about $30 \mathrm{~m}$. Removal of the detrital overburden has led to the discovery of as much as 500,000 tons of additional bauxite. In a few places calcite from the overburden material has mixed with the bauxite, causing $\mathrm{CaO}$ content of as much as 7 percent.

The bauxite deposits are irregular in shape and of various sizes; they rest on the karst surface of the White Limestone Formation of middle Eocene to early Miocene age. In some of the irregular sinkhole fillings, narrow pipes of bauxite extend down into limestone 7 or $8 \mathrm{~m}$, and pinnacles of limestone extend upward into bauxite. In places bauxite extends over the limestone ridges between sinkholes. Deposits range in size from about $15 \mathrm{~m}$ in diameter to bowl-shaped masses more than $10 \mathrm{~km}$ across, and one trough-shaped deposit is nearly continuous for $30 \mathrm{~km}$. Thicknesses range from less than $1 \mathrm{~m}$ to more than $30 \mathrm{~m}$, and the average thickness of deposits mined is about $7 \mathrm{~m}$. Tonnages of individual bauxite bodies range from a few thousand to tens of millions. The overburden ordinarily is only 


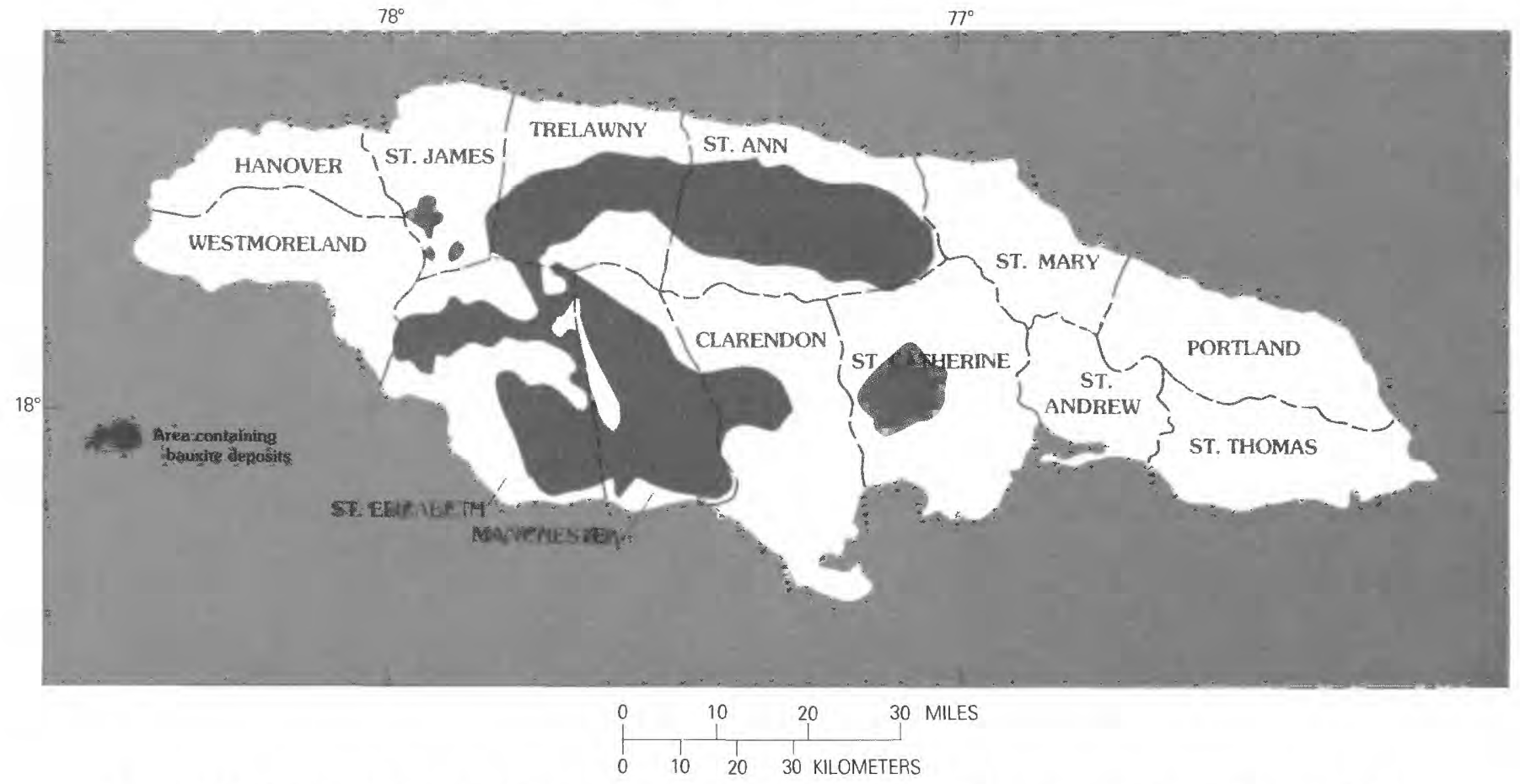

FIGURE 13.-Locations of principal bauxite regions in Jamaica (modified from Lyew-Ayee and Stewart, 1982, fig. 1).

a thin soil that is stockpiled and used in reclamation of mined-out lands.

The bauxite is the Jamaica or mixed (trihydrate and monohydrate) type containing considerable quantities of iron minerals and a few other impurities. Gibbsite is the principal bauxite mineral present, and it is chiefly in grains of less than $1 \mu \mathrm{m}$ size (Hill, 1955, p. 680). Nordstrandite, a polymorph of gibbsite, has been found recently in several Jamaican bauxite deposits in quantities ranging from minor to abundant (Davis and Hill, 1974). Boehmite occurs in most deposits, and in a few places this mineral constitutes as much as 20 percent of the bauxite. The bauxite mined commonly contains 7-10 percent of this mineral (Strahl, 1971, p. 66). The high iron content of Jamaica bauxite is chiefly due to the abundance of very fine grained hematite and goethite, but some of the iron may be in noncrystalline form. In many deposits, the goethite contains aluminum in isomorphous substitution for iron.

Kaolinite and halloysite, the principal clay minerals, occur in only minor amounts in the bauxite that is mined, but they are abundant in the low-grade high-silica bauxite. Other mineral impurities in Jamaican bauxite include quartz, the titanium minerals rutile and anatase, manganese-bearing minerals, phosphate minerals, calcite, and numerous minor accessory minerals. The amounts of the mineral impurities vary, but the total is rarely more than 5 percent of the bauxite. In a few places, calcite that was introduced after the bauxite formed is so abundant it makes the bauxite unsuitable for processing; such deposits are bypassed in mining. Most Jamaican bauxite is deep red due the presence of hematite; however, deposits enriched in goethite are yellow (Douglas, Hill, and Lyew-Ayee, 1984). Grubbs and others $(1980$, table 1) gave a summary of the mineralogy of red and yellow bauxites in the Mocho Mountains and Harmons Valley areas (listed in the following table).

Summary of the mineralogy of Jamaican red and yellow bauxites [In percent. From Grubbs and others (1980, table 1)]

\begin{tabular}{|c|c|c|}
\hline & Red bauxite & Yellow bauxite \\
\hline Gibbsite & $69-75$ & $64-69$ \\
\hline Boehmite & $1-4$ & $3-5$ \\
\hline Kaolinite .. & $1-3$ & $1-3$ \\
\hline Hematite . . & $10-14$ & $1-5$ \\
\hline Goethite & $5-8$ & $14-24$ \\
\hline$\left(\mathrm{Al}_{2} \mathrm{O}_{3}\right.$ in goethite $)$ & $(11 \pm 3)$ & $(17 \pm 3)$ \\
\hline Anatase $\ldots \ldots \ldots \ldots \ldots \ldots \ldots$ & $2-3$ & $2-3$ \\
\hline Apatite $\ldots \ldots \ldots \ldots \ldots \ldots$ & $<2$ & $<<1$ \\
\hline $\begin{array}{l}\text { Secondary phosphates } \\
\text { (wavellite, crandallite, variscite) }\end{array}$ & $<<1$ & $<4$ \\
\hline
\end{tabular}

The high-grade Jamaica bauxite contains approximately 50 percent $\mathrm{Al}_{2} \mathrm{O}_{3}$, nearly 20 percent $\mathrm{Fe}_{2} \mathrm{O}_{3}$, and very little $\mathrm{SiO}_{2}$ (table 17), and the low-grade bauxite contains less alumina and more reactive $\mathrm{SiO}_{2}$. Because alumina is extractable from gibbsite at low temperatures 
$\left(150^{\circ} \mathrm{C}\right)$ and higher temperatures are required to recover it from boehmite (Sabiston, 1975, p. 46), Bayer plants are modified to process Jamaica bauxite. Bauxite in the Claremont area, St. Ann Parish, Jamaica, contains an average of only 0.8 percent $\mathrm{SiO}_{2}$ (R.E. Anderson, 1982). The Claremont bauxite contains $1.5-12$ percent boehmite; $\mathrm{Fe}_{2} \mathrm{O}_{3}$ is mostly in the range $17-20$ percent, and nearly all the iron is in goethite. Bauxite of little present value in St. Catherine Parish contains as much as 14 percent $\mathrm{SiO}_{2}$ (Bracewell, 1962, p. 115), and Lewis (1967, table 1) listed analyses of bauxitic clay in St. Ann Parish containing 12-23 percent $\mathrm{SiO}_{2}$ and only 13-23 percent available $\mathrm{Al}_{2} \mathrm{O}_{3}$. About 75 percent of the $\mathrm{SiO}_{2}$ in most of the bauxite is in the form of kaolinite and halloysite and is therefore reactive in low-temperature Bayer process (Meikle, 1973). In addition to the major oxides, most Jamaica bauxite contains 1.7-2.8 percent $\mathrm{TiO}_{2}$, approximately 0.5 percent $\mathrm{P}_{2} \mathrm{O}_{5}$, and about 0.3 percent $\mathrm{MnO}$ (R.E. Anderson, 1971). Some of the deposits contain more than 3 percent $\mathrm{P}_{2} \mathrm{O}_{5}$, which causes problems of phosphorus contamination of alumina. The contamination is prevented by the addition of 1.3 tons of $\mathrm{CaO}$ for each ton of $\mathrm{P}_{2} \mathrm{O}_{5}$ in the bauxite (Strahl, 1971, p. 67). The percentage of gallium in Jamaica bauxite has been found to range from 0.0039 to $\mathbf{0 . 0 0 8 2}$, and the average is approximately 0.007 (Blackwood and others, 1982, p. 82).

\section{Resources}

Estimates of the bauxite resources in Jamaica have increased markedly in the last 25 years and are now very large. In 1957 the Chief Minister (Manley, 1957) announced that the reserves were 500 million-600 million tons and the amount of noncommercial-grade bauxite was of the same order of magnitude as the reserves. According to the Jamaica Geological Survey Department (Hughes, 1973, p. 14), the reserves were believed to be in excess of 1 billion tons, and large tonnages of subeconomic bauxite were also known to be present. A recent estimate by the Jamaica Bauxite Institute lists the reserves as a little more than 2 billion dry tons (Lyew-Ayee, 1984, p. 280). All the reserves contain more than 40 percent $\mathrm{Al}_{2} \mathrm{O}_{3}$ and less than 10 percent $\mathrm{SiO}_{2}$. In addition to the reserves, some bauxite of this grade is not included in the estimate because it is located under towns, residential areas, highway rightsof-way, and so forth, where it is unavailable for mining. Also bauxite deposits in red soil in the western and eastern parts of Jamaica, which are outside in the principal producing region and have not been thoroughly investigated, are not included in the estimates. The quantity of bauxite in these nonreserve categories is
TABLE 17.-Chemical composition of bauxite mined in Jamaica and exported in 1952

[All values in percent. From Bracewell, 1962, p. 115. 1, Average analysis of the 100,271 tons produced by Alumina Jamaica Limited in 1952. 2, Average analysis of the ore mined by Reynolds Jamaica Mines Limited in 1952. 3, Analysis of the first shipment of ore made by the Kaiser Bauxite Company in 1953. The free moisture content of No. 3 is given as 13.1 percent, the total available $\mathrm{Al}_{2} \mathrm{O}_{3}$ as 48.1 percent, and the trihydrate available as 36.3 percent]

\begin{tabular}{|c|c|c|}
\hline 1 & 2 & 3 \\
\hline .50 .61 & 49.08 & 50.53 \\
\hline $\mathrm{SiO}_{2}$ & .69 & 1.64 \\
\hline$\ldots 18.91$ & 20.47 & 19.75 \\
\hline$\ldots \quad 2.59$ & 2.51 & 2.67 \\
\hline Combined water .. & 27.25 & 24.63 \\
\hline
\end{tabular}

probably at least 100 million-300 million tons and may be greater. The total bauxite resources (reserves plus subeconomic, unavailable and undiscovered deposits) in Jamaica are estimated to be 2 billion-2.5 billion tons.

\section{OTHER CARIBBEAN OCCURRENCES}

Bahama and Grand Cayman Islands.-Low-grade lateritic bauxite is reported (Ahmad and Jones, 1969) to be present on Eleuthera and New Providence Islands in the Bahamas and on Grand Cayman Island. The deposits on all three islands contain considerable quantities of boehmite and gibbsite. No information on the size of deposits is available, but considering the small size of the islands it is unlikely that any of the deposits is large enough to be mined profitably.

Cuba.-A reconnaissance for bauxite deposits in Cuba was made by the U.S. Geological Survey during World War II (M.N. Bramlette, written commun., 1943). Several areas of laterite clay developed on limestone were examined. Deposits containing 26-37 percent $\mathrm{Al}_{2} \mathrm{O}_{3}$ were located north of Guantanamo and in Camaguay Province. However, no bauxite having a grade comparable to the bauxite in Jamaica was found and no detailed investigations were made.

Investigations by Cuban and Soviet geologists (Buguelskiy and Formell Cortina, 1974) and authors cited by Lyew-Ayee (1984) revealed bauxite at the following localities: (1) laterite-type bauxite formed from gabbro in the central and eastern parts of Cuba, (2) karst-type bauxite in Camaguay and Guantanamo Provinces, (3) bauxite on carbonaceous chalky limestone in Pinar del Rio Province in the western part of the country, and (4) transported bauxite associated with limestone highlands in western Cuba. One sample of laterite bauxite on gabbro was 49 percent $\mathrm{Al}_{2} \mathrm{O}_{3}$. In one area in Guantanamo, karst bauxite occurs on limestone of early Miocene age, and in another area the 
bauxite is on limestone of middle Miocene age. The deposits on lower Miocene limestone are $35 \pm 7.2$ percent $\mathrm{Al}_{2} \mathrm{O}_{3}$ and $26.3 \pm 7.7$ percent $\mathrm{SiO}_{2}$. The deposits on middle Miocene limestone are $28 \pm 4.7$ percent $\mathrm{Al}_{2} \mathrm{O}_{3}$ and $24 \pm 4.7$ percent $\mathrm{SiO}_{2}$.

The bauxite minerals in the deposits associated with carbonaceous limestones are diaspore and mixtures of diaspore and boehmite; hematite is the principal ironbearing mineral. The transported deposits consist of bauxite boulders in an unconsolidated clay matrix. The zone containing the boulders extends for $15 \mathrm{~km}$ and is 100-400 $\mathrm{m}$ wide and 10-15 $\mathrm{m}$ thick. The bauxite boulders make up 30-60 percent of the deposits. The bauxite boulders are reported to be $55-58$ percent $\mathrm{Al}_{2} \mathrm{O}_{3}, 2-5$ percent $\mathrm{SiO}_{2}$, and $22-25$ percent $\mathrm{Fe}_{2} \mathrm{O}_{3}$.

Puerto Rico.-Aluminous laterite, saprolite, and soil occur on remnants of a high-level peneplain in eastcentral Puerto Rico (Briggs, 1960), and bauxitic clay occurs in sinkholes in limestone in the north-central part of the island (Hildebrand, 1960). The clays in the sinkholes consist of mixtures of boehmite, quartz, anatase, kaolinite, and halloysite. Eight samples analyzed (Hildebrand, 1960, p. 371) contained 23.2-40.7 percent $\mathrm{Al}_{2} \mathrm{O}_{3}, 18.7-36.9$ percent $\mathrm{SiO}_{2}, 10.8-18.3$ percent $\mathrm{Fe}_{2} \mathrm{O}_{3}, 1.0-1.8$ percent $\mathrm{TiO}_{2}$, and $0.66-2.5$ percent $\mathrm{P}_{2} \mathrm{O}_{5}$. None of this material seems to be sufficiently high in $\mathrm{Al}_{2} \mathrm{O}_{3}$ to have value as bauxite.

\section{SUMMARY OF BAUXITE RESOURCES IN THE CARIBBEAN REGION}

The total bauxite reserves in the Caribbean region are estimated to be 2 billion tons (rounded), and the resources (reserves and subeconomic and undiscovered resources) are thought to be in the 2-billion- to 3-billionton range. The reserves, in millions of tons, are as follows: Jamaica-2,000, Dominican Republic-45, and Haiti-20. The subeconomic and undiscovered bauxite is mainly in Jamaica, but some in these categories, no doubt, is present in Haiti, the Dominican Republic, and possibly Puerto Rico.

\section{SOUTH AMERICA}

The principal productive bauxite deposits in South America are in Brazil, Guyana, and Suriname; large deposits have been discovered in Venezuela; deposits of moderate size occur in Colombia and French Guiana; and minor deposits occur in Chile and Bolivia. The deposits having the longest history of major production are in lowland areas in the coastal-plain region of Guyana and Suriname. Major mining in the Amazon basin of Brazil has recently begun, and other new bauxite developments there and in Venezuela are planned. Large laterite-type bauxite deposits, which may be mined in the future, occur on plateaus in inland regions of Suriname and Guyana and in scattered areas, some of which are near the coast, in French Guiana and Colombia.

\section{ARGENTINA}

Argentina has no high-grade bauxite deposits, but the existence of low-grade bauxite and aluminous laterite in Misiones Province in the northern part of Argentina has been known for a long time. Small tonnages of this material have been mined for use in water purification (Bracewell, 1962, p. 189). A pilot test for extracting alumina from this material by the Alto Paran Mining Co. was reported in the Mining Journal (1971a, p. 78).

\section{BRAZIL}

History and Production

Bauxite has been produced in Brazil since the mid1930's, and most mining has been in the Poços de Caldas district, Minas Gerais. During the period 1961-78 (table 6), annual production increased from 111 thousand tons to 1.2 million tons. Virtually all of the increased production through 1978 was needed to fulfill the demands of the expanding domestic aluminum industry. With the opening of the Trombetas district in 1979 (Mining Magazine, 1983), Brazil entered the international bauxite market. Production increased to 5.8 million tons in 1981, and further major increases are forecast.

The aluminum industry in Brazil has expanded greatly in recent years. In southern Brazil, three companies are now operating integrated complexes (mining bauxite and producing alumina and aluminum), and a few others are mining bauxite. Alcan Aluminio do Brasil S.A., owned by Alcan Aluminum Ltd. of Canada, has bauxite reserves in several districts in Minas Gerais and produces alumina and aluminum at Saramenha, Minas Gerais, and aluminum at Aratu, Bahia. Companhia Brasileira de Aluminio, S. A., which is Brazilian owned, mines and washes bauxite in the Poços de Caldas district, Minas Gerais, and operates an alumina and aluminum plant at Sorocaba, São Paulo. Alcominas (Cia. Miniera de Aluminio, S. A.), owned jointly by Alcoa, Hanna Mining Co., and Brazilian interests, operates an integrated complex in the Poços de Caldas district. In addition to the aforementioned complexes, major complexes are either active or planned in the Amazon region. 
The Trombetas district operated by Mineração Rio do Norte, S. A. (Brazilian Government, Alcan, and other interests) ranks with the world's leading bauxite districts. Bauxite from this district is exported and will also supply Alcoa's alumina plant at São Luis until this company's own deposits in the Trombetas district (International Bauxite Association, 1981) are mined. Also, thorough feasibility studies in preparation for bauxite mining in the Paragominas region have been completed (Sechiari and Sangster, 1979).

Several Brazilian and foreign companies and Brazilian government agencies were active in bauxite exploration in Minas Gerais and nearby States in the 1950's and early 1960 's, and, about 1968 or a little earlier, exploration on a large scale shifted to the lower Amazon region. Though occurrences of bauxitic material along the Amazon have been known for a long time (Abreu, 1962), the enormous bauxite resources of this region were not discovered until a reconnaissance program was initiated by Alcan International (1975), Ltd. under the direction of E.W. Greig, vice president. The major discovery of large high-grade deposits was in the Trombetas region in 1976. This bauxite was found by an Alcan crew led by I.M. Shvily, chief geologist. The deposits in northern Brazil are now thought to be so large that, when adequately explored, this country may rank with Australia and Guinea as one of the leading countries in bauxite resources.

\section{Bauxite Districts and Regions}

AMAZON BASIN AND OTHER PARTS OF NORTHERN BRAZIL

The very large deposits of bauxite in the Amazon basin (fig. 14) are mainly along the Trombetas, Jari, and other tributaries in the States of Pará and Amazonas and the territory of Amapá. Very large deposits also have been found in the Paragominas region along the boundary between Pará and Maranhão. Smaller phosphatic bauxite deposits occur at Chapada Pirocaus and Trauíra Island, Maranhão.

The bauxite deposits in the lower Amazon basin occur on isolated terraces, most of which are at altitudes of $100-200 \mathrm{~m}$. The bauxite is of the laterite type, and it formed by the weathering of horizontal beds of clays and sandy clays of continental origin. The bauxite is predominately gibbsite. The gibbsite occurs mainly as pisolites and concretions, but it also occurs in massive, compact, and, rarely, friable forms. Minable deposits contain 50 percent $\mathrm{Al}_{2} \mathrm{O}_{3}$ and only about 5 percent silica after the ore is washed.

Many of the bauxite deposits in the Amazon basin occur in two zones (Wolf, 1972). The upper zone consists of yellow plastic clay, 0-8 $\mathrm{m}$ thick; a layer of pisolitic gibbsitic bauxite that is rich in iron oxide, $0-1.5 \mathrm{~m}$ thick; and hard blocky ferruginous and siliceous concretions in clay or ferruginous laterite, 0-1.5 m thick. The lower leached zone consists of a layer of hard pink or red gibbsitic concretions and blocky masses in clay having variable contents of iron oxide, $0-4 \mathrm{~m}$ thick; nodular blocky gibbsite intermixed with kaolin and variegated clay, 0-1 m thick; and an underlying unit of pink and white speckled clay.

Almeirim.-The Almeirim district is located between the lower Pará and Jari Rivers in the State of Pará. Like other deposits in the Amazon basin, the bauxite is overlain by a clay stratum having an average thickness of $8 \mathrm{~m}$ (Assad and Machado, 1976). The bauxite varies from 2 to $6 \mathrm{~m}$ in thickness. According to the Brazil Departamento Nacional da Produção Mineral (DNPM) $(1982$, p. 122), the reserves of bauxite in the Almeirim district in millions of tons are as follows: measured71.9, indicated-23.6, and inferred-0.37. According to Assad and Machado (1976), 15 million tons of the reserves are refractory-grade bauxite having the following composition: 58 percent total $\mathrm{Al}_{2} \mathrm{O}_{3}, 7$ percent $\mathrm{SiO}_{2}$, and 2 percent $\mathrm{Fe}_{2} \mathrm{O}_{3}$. The metal-grade bauxite is 45-53 percent available $\mathrm{Al}_{2} \mathrm{O}_{3}$ and 2-6 percent $\mathrm{SiO}_{2}$.

Carajas.-Bauxite has been discovered in the Serra dos Carajas, which is located about $550 \mathrm{~km}$ south of Belém. The deposits are only about $2 \mathrm{knn}$ from the site of a future terminal on the railroad extending $890 \mathrm{kun}$ from Carajas to the port of São Luis now under construction (Ridley and Kaba, 1983).

The bauxite in the Carajas district occurs in weathered basalt in the vicinity of the $\mathrm{N} 5$ Serra Norte iron deposits (Ridley and Kaba, 1983, p. 53, 57). The bauxite extends over about $65 \mathrm{~km}^{2}$. The deposits consist of three layers. The upper layer, which is overlain by only a thin soil, is earthy ferruginous bauxite containing some ferruginous nodules and pisolites. The second layer is hard laterite that is locally pisolitic. The lowermost layer consists of plastic red clay that is apparently an alteration product of basalt. By 1983, 120 sample pits had been dug in the district, and the amount of bauxite present was estimated to be 48 million tons. This bauxite was found to be 35 percent $\mathrm{Al}_{2} \mathrm{O}_{3}, 1-7$ percent $\mathrm{SiO}_{2}, 25$ percent $\mathrm{Fe}_{2} \mathrm{O}_{3}$, and 4 percent $\mathrm{TiO}_{2}$. According to another report, the total bauxite in the Carajas district is estimated to be $\mathbf{1 2 0}$ million tons (Schiller, 1977, p. 247).

Faro region.-The settlement of Faro is located on the east bank of Lago do Faro on the Nhamunda River, Pará. According to a map by Greig (1977, fig. 2), bauxite deposits are located north of Faro and at several places on the west side of Lago do Faro, which are in Amazonas. Presumably the bauxite in the Faro region 

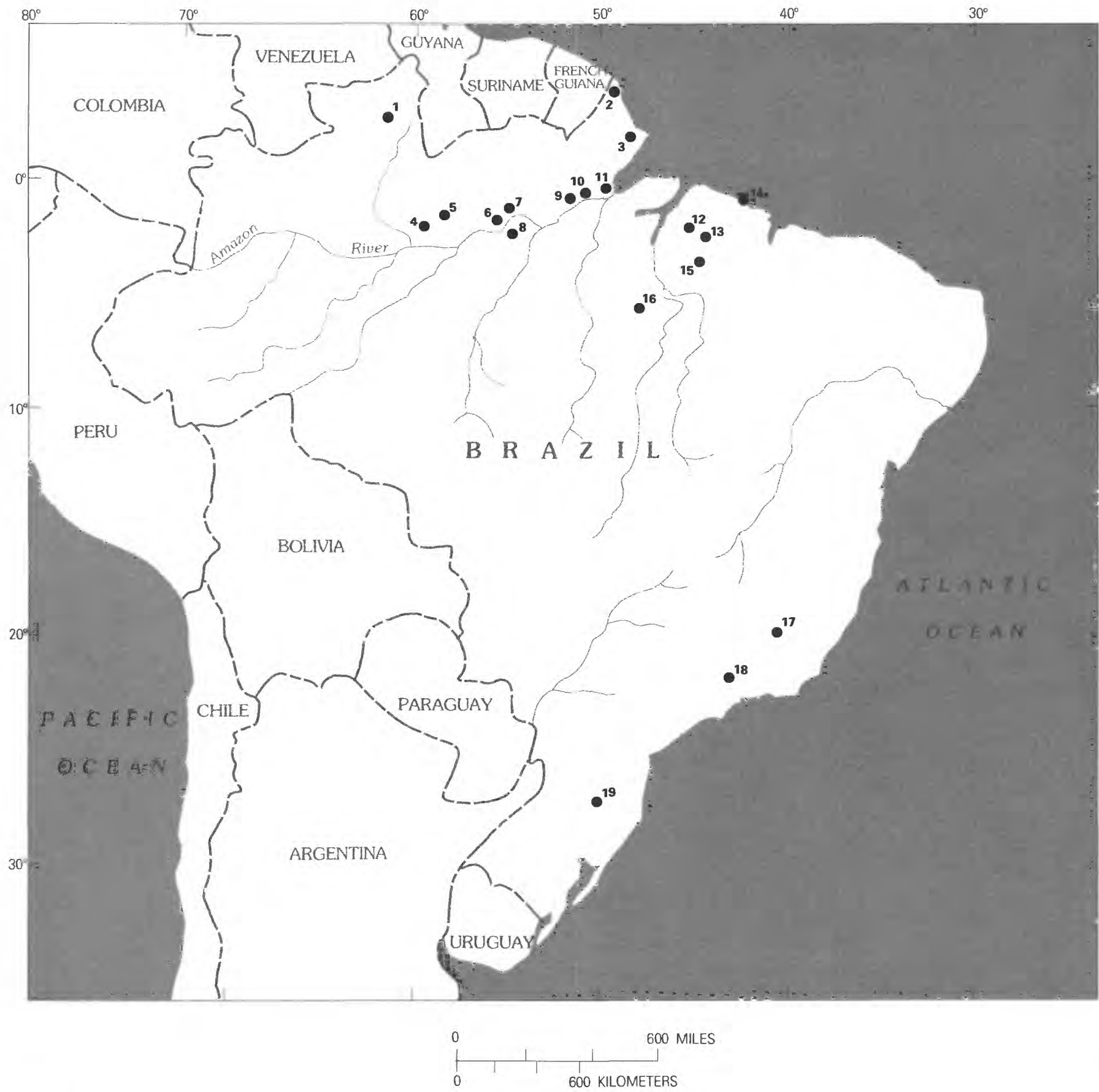

\section{EXPLANATION}

Bauxite district
1. Boa Vista, Rio Branco
2. Oiapoque, Amapá
3. Amapá
4. Uatumã, Amazonas
5. Jatapu, Amazonas
6. Faro, Pará

7. Trombêtas, Pará

8. Parintins-Juruti, Pará

9. Almeirim, Pará

10. Jari, Amapá

11. Mazagao, Amapá

12. São Domingos do Capim, Pará

13. Irituia, Pará
14. Ilha Trauira, Maranhão

15. Paragominas, Maranhão

16. Carajás, Pará

17. Ouro Prêto-Nova Lima-Mariana, Minas Gerais

18. Poços de Caldas, Minas Gerais

19. De Lajes, Santa Catarina

FIgURE 14.-Locations of bauxite districts in Brazil 
is similar to that in the Trombetas district. According to the Brazil Departamento Nacional da Produção Mineral $(1982$, p. 122), bauxite reserves in the Faro region are 283.2 million tons. The average $\mathrm{Al}_{2} \mathrm{O}_{3}$ content of this bauxite is 49.17 percent.

Paragominas region.-The Paragominas region is named for the town of Paragominas, which is on the Brasília-Belém highway approximately $160 \mathrm{~km}$ south of Belém. The bauxite deposits extend north, south, and southwest of Paragominas into the headwater regions of the Capim and Gurupi Rivers, which are east of the Amazon basin.

The bauxite in the Paragominas region commonly occurs in an upper concretionary zone and a lower leached zone (Wolf, 1972). The concretionary zone from the surface downward consists of yellow plastic clay, 0-22 $\mathrm{m}$ thick; a layer containing abundant aluminumrich spherical concretions that are less than $2 \mathrm{~cm}$ in diameter, 0-2 $\mathrm{m}$ thick; and ferruginous blocky laterite in clay, 0-4 m thick. The leached zone consists of pink, red, and white hard gibbsitic bauxite containing columnar structures as much as $10 \mathrm{~cm}$ long, $0-4 \mathrm{~m}$ thick; a layer of pink, red, and white gibbsitic clay containing columnar structures in its upper part, 0-4 m thick; and weathered red silty or sandy clay, 0-1 m thick. According to Kotschoubey and Truckenbrodt (1981), bauxite deposits in the Paragominas district were formed by complex processes marked by mechanical reworking of $\mathrm{Al}$ and $\mathrm{Fe}$. Five stages of development are recognized: initial lateritization, formation of the hard cap rich in $\mathrm{Al}$ and $\mathrm{Fe}$, the first phase of gibbsitization of the hard cap, reworking of the laterite and formation of pisolites, and finally the second phase of gibbsitization of the upper part of the laterite. The bauxite is reported (Assad, 1973, p. 26) to be 53 percent $\mathrm{Al}_{2} \mathrm{O}_{3}, 5$ percent $\mathrm{SiO}_{2}, 12$ percent $\mathrm{Fe}_{2} \mathrm{O}_{3}$, and 0.8 percent $\mathrm{TiO}_{2}$. Gibbsite is the principal bauxite mineral, and the deposits contain little or no boehmite (Grubb, 1979, p. 740, fig. 3). The deposits contain only $9 \mathrm{ppm}$ gallium, much less than in most bauxite (Kronberg and others, 1979).

Evaluations of bauxite in the Paragominas region have been concentrated in three districts. The Brazilian Government Company, Companhia Vale do Rio Doce (CVRD), through its subsidiary Rio Doce Geologia e Mineração S.A. (Docegeo), investigated deposits in the Jabuti district, north-northeast of Paragominas, and the Futuro district, northeast of this town. Reserves in the Jabuti district are estimated to be 200 million tons, and the grade is 47.4 percent $\mathrm{Al}_{2} \mathrm{O}_{3}$ and 5.3 percent $\mathrm{SiO}_{2}$ (Mineração Metalurgia, 1975). This same reference lists the reserves in the Futuro district as $\mathbf{1 5 0}$ million tons and the grade as 52.8 percent $\mathrm{Al}_{2} \mathrm{O}_{3}$ and 6.7 percent $\mathrm{SiO}_{2}$. Mineração Vera Cruz, Ltda., a subsidiary of Rio Tinto Zinc, evaluated deposits in the Miltonia area west of Paragominas and within $32 \mathrm{~km}$ of the Capim River (Sechiari and Sangster, 1979). In this evaluation 274 million tons of crude bauxite was blocked out. The recoverable washed bauxite from these reserves was calculated to be 165 million tons. The washed bauxite would have the following average composition: 56.18 percent total $\mathrm{Al}_{2} \mathrm{O}_{3}, 50.72$ percent available $\mathrm{Al}_{2} \mathrm{O}_{3}, 5.02$ percent $\mathrm{SiO}_{2}, 8.17$ percent $\mathrm{Fe}_{2} \mathrm{O}_{3}, 1.5$ percent $\mathrm{TiO}_{2}$, and 9.43 percent moisture.

Trombetas.-This district is located on the Trombetas River about $120 \mathrm{~km}$ upstream from its junction with the Amazon at Oriximina (Engineering and Mining Journal, 1975), State of Pará. The bauxite occurs on flattopped plateaus that are 70-120 m above the surrounding lowlands. A section downward through a typical deposit is as follows: (1) clayey overburden, approximately $6 \mathrm{~m}$ thick; (2) nodular bauxite, $1 \mathrm{~m}$ thick; (3) ironrich bauxite, $1 \mathrm{~m}$ thick; (4) massive bauxite of variable hardness; (5) mottled clay. Gibbsite is the principal mineral in the deposits. The average composition of the Trombetas deposits, in percent (Greig, 1977, table 3) is as follows:

\section{Average composition of bauxite from Trombetas, Para, Brazil, in percent}

[LOI, loss on ignition. Available $\mathrm{Al}_{2} \mathrm{O}_{3}$, gibbsite alumina extractable by lowtemperature digestion. From Greig (1977, table 3)]

\begin{tabular}{|c|c|}
\hline Nodular bauxite & Massive bauxite \\
\hline$\ldots \ldots \ldots 27.8$ & 28.6 \\
\hline $\mathrm{SiO}_{2} \ldots \ldots \ldots \ldots \ldots \ldots \ldots$ & 4.8 \\
\hline $\mathrm{Fe}_{2} \mathrm{O}_{3} \ldots \ldots \ldots \ldots \ldots \ldots \ldots \ldots$ & 9.3 \\
\hline $\mathrm{TiO}_{2} \ldots \ldots \ldots \ldots \ldots \ldots \ldots \ldots$ & 1.3 \\
\hline $\mathrm{Al}_{2} \mathrm{O}_{3} \ldots \ldots \ldots \ldots \ldots \ldots \ldots \ldots$ & 55.9 \\
\hline Reactive $\mathrm{SiO}_{2} \ldots \ldots \ldots \ldots \ldots, 6.8$ & 4.6 \\
\hline Available $\mathrm{Al}_{2} \mathrm{O}_{3} \ldots \ldots \ldots \ldots \ldots 4.2$ & 50.0 \\
\hline
\end{tabular}

The reserves of bauxite in the Trombetas district are now estimated to be 492 million tons of the massive variety and 100 million tons of the nodular type (Greig, 1977, p. 17). The nodular bauxite must be washed to remove part of the silica, which occurs in the form of kaolinite, but the massive type does not require beneficiation. According to the initial plans for development, the massive type is to be shipped during the first year of production and the nodular type is to be stockpiled. At a later date, the washed nodular bauxite is to be blended with the massive type and shipped for use in Bayer processing plants.

Other bauxite deposits in northern Brazil.-Bauxite is known to be present at several places in northern Brazil in addition to the districts discussed on preceding pages. Deposits similar to those in the Trombetas district occur in the Uatumã and Jatapu districts northeast of Manaus, Amazonas (fig. 14), and the Parintins-Juruti 
district on the south side of the Amazon west of Santarém (Greig, 1977). Bauxite deposits associated with sedimentary rocks occur in the Oiapoque and Mazagão districts, Amapá, and deposits on the Precambrian rocks are present at Boa Vista in northern Amazonas and Rio Branco and Tartarugal Hills, Amapá (L.J. Moraes, 1959; Suszczynski, 1973; Greig, 1977; Aleva, 1984).

According to the DNPM $(1982$, p. 22), the bauxite reserves in the minor districts in northern Brazil, in millions of tons, are as follows: Orem, Pará-2.4 measured and 9 indicated; Irituia, Pará-57.4 measured and 61.6 indicated; São Domingos do Capim, Pará-89.3 measured, 13 indicated, and 31 inferred; Mazagão, Amapá-41 measured, 13 indicated, and 31.1 inferred; and Nhamunda, Amazonas-33 measured. The bauxite reserves in the Parintins-Juruti district are estimated to be 170 million tons (Schiller, 1977, p. 247).

Phosphatic bauxite and aluminous laterite deposits are located on Trauíra Island and on the Chapada (mesa) Pirocaus on the northwest coast of the State of Maranhão (fig. 14). The deposits are formed on Precambrian phyllites. The phosphate is guano containing 20-30 percent $\mathrm{P}_{2} \mathrm{O}_{5}$, overlying the bauxite. Drilling in the Trauíra deposits shows that phosphate contents decrease with increasing depth. The bauxitic rock is reported to contain 30 percent $\mathrm{Al}_{2} \mathrm{O}_{3}$ (Abreu, 1962). Although they are low in aluminum content, these deposits may be of value because of the possibility of recovering phosphate as a coproduct (Feigl, Braile, and Ignacio Miranda, 1946). Preliminary development work suggests that the phosphatic bauxite deposits on Trauíra Island contain 10 million tons (Jobim, 1941).

\section{SOUTHERN BRAZIL}

Bauxite deposits occur in several districts in southern Brazil (fig. 14). The principal deposits are in the Poços de Caldas region, which is mainly in southern Minas Gerais but extends into adjoining parts of São Paulo and the Ouro Prêto-Nova Lima-Mariana region of Minas Gerais. The minor deposits in southern Brazil include the bauxite in the Municipios de Nepomuceno, Descoberto, and Diamantina in Minas Gerais; Municipio de Mimoso do Sul in Espírito Santo; Municipios de São Paulo, São Bernardo do Canıpo, Aguas da Prata, and Mogi das Cruzes in São Paulo State; the area of the Itatiaia massif of alkaline rocks in Rio de Janeiro State; the Municipios de Correntina and Barra do Mendes in the State of Bahia (Abreu, 1962); and the Municipio de Lajes, Santa Catarina.

Ouro Prêto.-Although it is difficult to identify the rock on which bauxite has formed because of the intense weathering in the area, the bauxite at Ouro Prêto appears to have weathered from a hematitic-sericitic phyllite located at the top of the Minas group of Precambrian age (Abreu, 1962, p. 552-553). The bauxite is pink to red; the color results from the amount and state of oxidation of the iron inherited from the parent rock. The lighter colored bauxite tends to have the higher content of silica. The ore occurs in compact masses and in disseminated concretions in laterized rock.

Poços de Caldas. - The bauxite deposits on the Poços de Caldas plateau are underlain by gneiss and granite of Precambrian age intruded by Upper Cretaceous alkaline rocks. The alkaline rocks include gneissictextured syenite, eudialyte syenite, nepheline syenite, nepheline-cancrinite syenite, phonolite, and phonolite porphyry. According to Webber (1959a), high-quality bauxite commonly has formed on nepheline syenite and on the high-level alluvial deposits that were transported from nepheline syenite and phonolite porphyry. The bauxite formed on the gneiss usually contains silica as free quartz.

The bauxite occurs at elevations ranging from $1,220 \mathrm{~m}$ at the foot of the highlands to $1,678 \mathrm{~m}$ on the tops of ridges. Some of the deposits are on slopes having maximum inclination of $27^{\circ}$. Deposits are particularly abundant on alkaline intrusives in the northern part of the plateau. The bauxite occurs in four principal forms: (1) surficial nodule layers less than $1 \mathrm{~m}$ thick formed from the weathering of homogeneous bauxite deposits and the removal of interstitial clay; (2) light-yellow, porous, homogeneous bauxite composed almost entirely of gibbsite; (3) nodular gibbsite or kaolinite in a clay matrix; and (4) irregular masses of homogeneous bauxite in a clay matrix. This last form is apparently the result of incomplete bauxitization of the kaolinite clay. The principal bauxite mineral is gibbsite, and the clay, where present, is mainly kaolimite.

Santa Catarina.-Laterite-type bauxite and clayey bauxite in Municipio de Lajes, Santa Catarina, in southern Brazil have been thoroughly investigated by Casimiro and d'Avila (1975). The best grade deposits are in the Farinha Seca area. These deposits are altered from phonolite, and gibbsite is the principal mineral in them. Deposits elsewhere in de Lajes have formed on nepheline syenite and diabase. The Farinha Seca area has 4.5 million tons of proved bauxite resources containing 51.3 percent $\mathrm{Al}_{2} \mathrm{O}_{3}, 5.3$ percent reactive silica, and 7.4 percent $\mathrm{Fe}_{2} \mathrm{O}_{3}$. About 40.3 million tons of lower grade clayey bauxite is present in this district. The total bauxite including low-grade material in Municipio de Lajes is approximately $\mathbf{7 5}$ million tons (Casimiro and d'Avila, 1975, table 21).

Other areas favorable for bauxite in southern Brazil.-Suszcynski (1978) announced the discovery of 
bauxite at several localities in an extensive belt along the eastern boundary of the Brazilian shield. The belt thought to be favorable for finding large bauxite deposits is $560 \mathrm{~km}$ long and ranges from 20 to $60 \mathrm{~km}$ in width. This belt lies between the small bauxite deposits in Rio de Janeiro, northeastern São Paulo, and Espírito Santo, which have been known for a long time, and the deposits now mined farther inland in Minas Gerais. The bauxite in this belt developed on aluminumrich volcanogenic schist-gneiss rocks of Precambrian age.

Deposits containing 60 million tons of bauxite have been discovered recently in the Cataguases district, Minas Gerais (L.H. Baumgardner, written commun., 1984).

\section{Resources}

The estimates of bauxite reserves in Brazil have increased markedly in recent years. According to a 1973 estimate published by the Brazil Departamento Nacional da Produção Mineral (DNPM) (1973), the total measured, indicated, and inferred bauxite reserves in this country were only a little more than 440 million tons, and the reserves in the Trombetas district alone are now known to be much greater than this estimate. A 1977 estimate by the DNPM (1978) listed the reserves in millions of tons as follows: measured-1,929, indicated-140, inferred-38; the total of these figures is 2.1 billion. A report on the minerals in the State of Pará by the DNPM (1975b) contains an estimate of 2 billion tons for the bauxite in the Paragominas region and one of 3.3 billion tons for the total bauxite in the Amazon region.

The bauxite reserves in southern Brazil are much smaller than those in the north. According to Moraes $(1978$, p. 63$)$ the total bauxite reserves in southern Brazil are 65 million tons. The DNPM $(1978$, p. 109) listed estimates for measured, indicated, and inferred bauxite reserves in Minas Gerais as having a total of 83 million tons and totals for Rio de Janeiro and São Paulo of about 2 million tons each. This same report lists about 1 million tons for bauxite reserves in Espírito Santo. An estimate of 5 million tons of bauxite reserves in Santa Catarina is listed in some reports.

Schiller (1977, p. 247) listed estimates for reserves in Amazon districts as having a total of a little more than 3 billion tons. Wolf (1972) estimated that the Amazon reserves may possibly be as much as 4 billion tons. According to Moraes (1978), the total bauxite reserves in Brazil are 3.6 billion tons, and 98 percent of them are in the northern part of the country. Assad and Machado (1976), Grubb (1979, p. 735) Sugden (1984), and DNPM
(1982, p. 122) all list an estimate of 2.5 billion tons for the bauxite reserves in the Amazon basin.

In addition to the reserves there are large subeconomic and undiscovered bauxite resources in Brazil. Subeconomic bauxite is almost certainly present in all the known districts in the Amazon basin. Undiscovered bauxite most likely exists in the valleys of the Amazon and major tributaries headward from the known districts. One very large region that has not been explored for bauxite is the southern half of the Guyana shield. This shield of weathered Precambrian rock extends from the syncline along the Amazon River northward to the coastal-plain region of Venezuela, Guyana, Suriname, and French Guiana, as pointed out by Aleva (1984, p. 316). The southern half of the shield, which is in Brazil, most likely has as much bauxite as the northern half, where large bauxite deposits have been found in Venezuela, Guyana, and Suriname. The presence of bauxite in the remote Boa Vista region district (Greig, 1977, fig. 1) is proof that bauxite does exist on the Guyana shield in Brazil. Large laterite-type bauxite deposits may also remain undiscovered in southern Brazil if Suszczynski's (1978) conclusion that aluminous weathered rocks are present throughout a very extensive belt is correct.

The bauxite reserves in Brazil were estimated by the U.S. Bureau of Mines (Baumgardner and McCawley, 1983 , table 3) to be 2.25 billion tons. Subeconomic and undiscovered bauxite resources in Brazil are almost certainly much larger than 2.7 billion tons. The 2.7-billionton figure was calculated by subtracting and rounding the reserve estimated from the total 5 billion tons of measured, indicated, and inferred bauxite (DNPM, 1982, p. 122).

\section{COLOMBIA}

Bauxitic laterites have been recognized in Colombia for a long time (Bracewell, 1962, p. 191). The principal deposits are in the Department of Cauca (Cathcart, 1971; Rosas G., 1973, 1978); other deposits are located in the Serrania de la Macarena on the eastern flank of the Andes, Department of Meta (Dario Velasquez, 1973, p. 165, fig. 2). The deposits in Cauca are mined on a small scale for local use, presumably in refractory products. They have also been investigated by aluminum companies, but no plans for large-scale mining have been made. The remote location of the Serranía de la Macarena deposits detracts from their value, and insofar as the authors are aware, little interest has developed in them.

The bauxitic laterite in the Department of Cauca extends over a large area located between the city of 
Popayán and the northern departmental boundary, a distance of about $80 \mathrm{~km}$ (Cathcart, 1971, p. 29-43). Small scattered deposits of the laterite also are present in southern Valle del Cauca, the Department adjoining Cauca on the north. The bauxitic material in this region formed by the weathering of water-laid tuffaceous beds in the Popayán Formation of Pliocene and Pleistocene age. Thicknesses of the laterite range from $1 \mathrm{~m}$ to as much as $5 \mathrm{~m}$. The bauxite consists mainly of irregular impure aggregates of gibbsitic material as much as $5 \mathrm{~cm}$ in the longest dimension and tubular structures as much as $4 \mathrm{~cm}$ long. Both the aggregates and the tubular structures form on the surfaces of the weathered tuff as it dries. Apparently, the aluminous material brought to the surface with drying is either in aqueous solution or in very finely divided form.

According to Rosas G. (1973), 80 million tons of bauxitic clay are present in Cauca, and one-fourth of this material is in the form of gibbsitic aggregates that are considerably higher grade than the clay. According to analyses completed by the Instituto Nacional de Investigaciones Geológico-Mineras, the bauxitic clay is 35.70-43.87 percent $\mathrm{Al}_{2} \mathrm{O}_{3}, 20.07-32.34$ percent $\mathrm{SiO}_{2}$, 10.16-13.03 percent $\mathrm{Fe}_{2} \mathrm{O}_{3}, 0.74-1.11$ percent $\mathrm{TiO}_{2}$, and 16.67-23.41 percent LOI. A later report by Rosas G. (1978) contains an estimate of 400 million tons for bauxite in Cauca that is 38 percent $\mathrm{Al}_{2} \mathrm{O}_{3}$. The report indicates that 100 million tons of washed bauxite could be recovered from this resource; its partial composition would be 59.02 percent $\mathrm{Al}_{2} \mathrm{O}_{3}, 3.02$ percent $\mathrm{SiO}_{2}$, 4.43 percent $\mathrm{Fe}_{2} \mathrm{O}_{3}$, and 1.19 percent $\mathrm{TiO}_{2}$.

\section{FRENCH GUIANA}

The existence of laterite in French Guiana has been known since the middle of the last century. Regions favorable for bauxite have been investigated by the Bureau Minier Guyanais (Annales des Mines, 1955) and by several aluminum companies. One of the plans advanced to develop the bauxite was by Compagnie Alcoa de Guyane (a partnership of Alcoa and Pechiney of France) to mine bauxite and ship it to the Suralco plant in Suriname. This plan was dropped in 1974, and options on the deposit were allowed to lapse.

The principal bauxite deposits in French Guiana occur on the Mahury plateau (fig. 15), which is near the coast about $10 \mathrm{~km}$ southeast of Cayenne, and in the nearly flat-topped Kaw and Roura Mountains. These two low mountain ranges are southeast of Cayenne, and most deposits in them are no more than $30 \mathrm{~km}$ from the coast. The deposits on the Mahury plateau are at altitudes of about $150 \mathrm{~m}$, those in the Roura Mountains are 200-250 $\mathrm{m}$ above sea level, and the deposits in the Kaw Mountains are as much as $100 \mathrm{~m}$ higher. Other deposits have
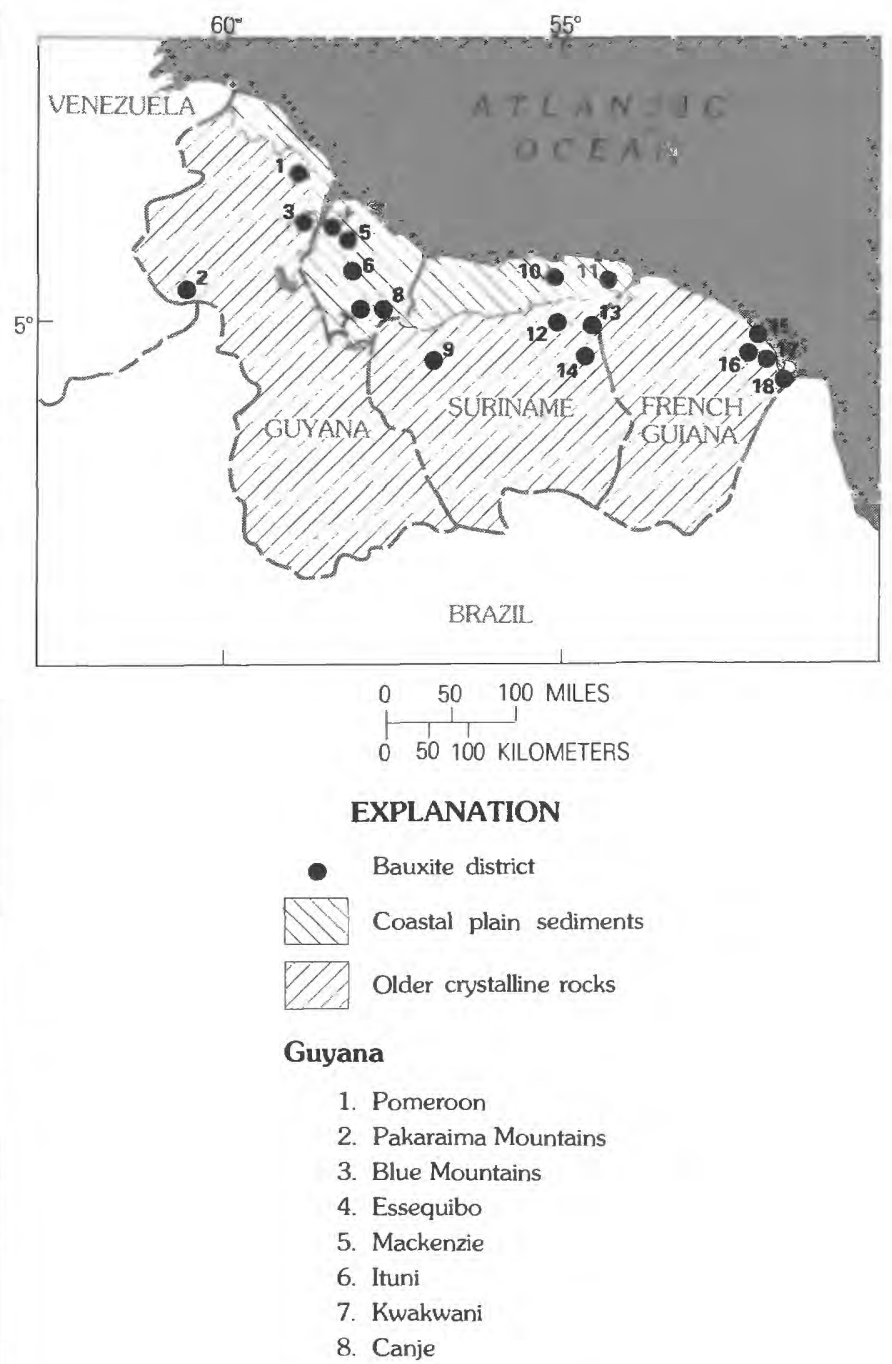

Suriname

9. Bakhuis Mountains

10. Onverdacht-Paranam

11. Moengo

12. Brownsberg Mountains

13. Nassau Mountains

14. Lely Mountains

French Guiana
15. Mahury Plateau
16. Roura Mountains
17. Kaw Mountains
18. Mts. de l'Observatoire

FIGURE 15.-Locations of bauxite districts in Guyana, Suriname, and French Guiana.

been found in the Monts de l'Observatoire (Choubert, 1962), which are east of the Kaw Mountains. Bauxitic laterite crusts on uplands in remote interior parts of French Guiana are also shown on geologic maps prepared by the Service de la Carte Géologique de la France. 
Some of the laterite deposits are as much as $30 \mathrm{~m}$ thick, but the average thickness is about $6 \mathrm{~m}$ (Annales des Mines, 1955, p. 12). The deposits in the Kaw Mountains have weathered from schists and greenstones and are separated from fresh rock by a thick zone of deeply weathered rocks rich in clay minerals. Finely crystalline gibbsite is the principal bauxite mineral, but small amounts of boehmite occur locally (Annales des Mines, 1955 , p. 7), and noncrystalline aluminous materials are probably also present. Only small amounts of quartz occur in the bauxite, and most of the silica present is in clay minerals. Iron is chiefly in the form of goethite and limonite, but X-ray analysis of one sample, presumably from the Kaw Mountains, showed that the bauxite was chiefly gibbsite and hematite (Keyser, 1959, p. 980, fig. 4). Minor amounts of rutile, brookite, anatase, ilmenite, zircon, and tourmaline have also been identified in the bauxite.

A considerable number of samples, representative of the $\mathbf{1 5 0}$ million tons of laterite in the Kaw Mountains, were analyzed by the Bureau Minier Guyanais (Annales des Mines, 1955, p. 10-12). Results of this work outlined reserves of 42 million tons of bauxite having a chemical composition of 41.5 percent $\mathrm{Al}_{2} \mathrm{O}_{3}, 1.7$ percent $\mathrm{SiO}_{2}, 30$ percent $\mathrm{Fe}_{2} \mathrm{O}_{3}$, 4 percent $\mathrm{TiO}_{2}, 0.8$ percent other oxides, and 22 percent LOI. Tbtal resources are thought to be 170 million tons (Shaffer, 1975, table 5), and probably more laterite-type deposits will be found in remote parts of the country.

\section{GUYANA}

\section{History and Production}

Deposits later found to be bauxite were first noted by government geologists in 1869 and 1873 . However, the identification of bauxite and the recognition of its potential value was by Sir John Harrison, the pioneer in research on tropical weathering, in the period 1897-1910 (J.B. Harrison, 1934). Bauxite properties, one of which was assigned to the Demerara Bauxite Company, were acquired in 1916. The first shipment of 2,037 tons of bauxite was in 1917, and, from that year to the end of 1960, a total of about 39 million tons of bauxite (table 18) had been produced and exported (Bracewell, 1962 , p. 104). Guyana has long been the world leader in the production of calcined refractory-grade bauxite and ranked second behind Suriname in total bauxite produced for the period 1938-55. The Demerara Bauxite Company, Ltd. (Demba), a subsidiary of Aluminum of Canada, was the chief producer until its mines and plants were taken over by the government-owned Guyana Bauxite Company (Guybau) on July 15, 1971 (Guyana Geological Surveys and Mines Department, 1972 , p. 2). The company known as Reynolds Guyana Mines, $L t d$. became active in Guyana in 1952, and this company has been the second largest producer. The operations of Reynolds Guyana Mines were nationalized by Guyana on January 1, 1975 (Blumenreich, 1975, p. 92).

Guybau processes bauxite in a drying and calcining plant and operates an alumina plant at MackenzieLinden on the Demerara River. The drying plant, formerly owned by Reynolds Guyana Mines, Ltd., is at Everton on the east bank of the Berbice River south of New Amsterdam. This plant is now operated by the Berbice Mining Enterprise. Total production increased from 2.4 million tons in 1961 to a maximum of 4.4 million tons in 1970 (table 6). Production declined after the peak year to $1,430,000$ tons in the recession year of 1982 . The decline resulted from periodic labor difficulties, problems in mining, Guybau's efforts to increase the output of refractory-grade bauxite (which apparently restricted the mining of metal-grade bauxite), and the world-wide economic recession of 1982 .

The bauxite mined in Guyana is high-grade trihydrate type. It is principally gibbsite, but small amounts of boehmite are present in most deposits. According to analyses listed by Pollard and Barron (1955, p. 39), bauxite mined in the Mackenzie and Ituni districts ranged in composition as follows: $59.03-60.45$ percent $\mathrm{Al}_{2} \mathrm{O}_{3}$,

TABLE 18.-Specifications of refractory and chemical grades of bauxite produced in Guyana

[All values except bulk specific gravity in percent; min, minimum; max, maximum. Dash leaders (---), no data. From Lachmansingh and Nooten (1977)]

\begin{tabular}{|c|c|c|c|c|c|c|}
\hline & \multirow{2}{*}{\multicolumn{2}{|c|}{$\begin{array}{c}\text { Guyana Bauxite Co. } \\
\text { RASC }^{1}\end{array}$}} & \multicolumn{4}{|c|}{ Berbice Mining Enterprise } \\
\hline & & & \multicolumn{2}{|c|}{ Refractory calcined } & \multicolumn{2}{|c|}{ Chemical } \\
\hline & Typical & Guaranteed & Typical & Guaranteed & Typical & Guaranteed \\
\hline $\mathrm{Al}_{2} \mathrm{O}_{3}$ & 88.00 & $86.50 \mathrm{~min}$ & 89.00 & $86.50 \mathrm{~min}$ & 60.00 & $59.00 \mathrm{~min}$ \\
\hline $\mathrm{SiO}_{2}$ & 6.50 & $7.50 \mathrm{max}$ & 5.25 & $7.50 \mathrm{max}$ & 4.50 & $6.00 \max$ \\
\hline $\mathrm{Fe}_{2} \mathrm{O}_{3}$ & 2.00 & $2.50 \max$ & 2.00 & $2.50 \max$ & 1.00 & $1.25 \max$ \\
\hline $\mathrm{TiO}_{2}{ }^{3}$. & 3.25 & -- & 3.50 & --- & 2.70 & $3.20 \max$ \\
\hline Loss on ignition & .25 & $.50 \max$ & .25 & $.50 \mathrm{max}$ & 30.50 & --- \\
\hline 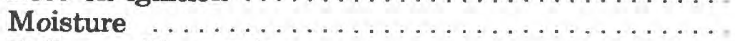 & -- & -- & -- & -- & 3.00 & $5.00 \max$ \\
\hline Bulk specific gravity $\ldots \ldots \ldots \ldots \ldots \ldots \ldots \ldots \ldots$ & . 3.15 & --- & 3.05 & --- & -- & --- \\
\hline
\end{tabular}

\footnotetext{
${ }^{1}$ Trade name for "super-calcined" refractory bauxite.
} 
4.78-7.07 percent $\mathrm{SiO}_{2}, 1.17-2.85$ percent $\mathrm{Fe}_{2} \mathrm{O}_{3}$, 1.90-2.53 percent $\mathrm{TiO}_{2}$, and 29.61-30.40 percent LOI. The uncommonly low iron and low silica contents of the bauxite fulfill rigid specifications for refractory bauxite (table 18).

\section{Bauxite Districts and Deposits}

The principal bauxite districts in Guyana are scattered through a belt in the inland part of the coastal plain (fig. 15), and low-grade deposits are present in laterite cappings of inland plateaus. The most productive districts are Mackenzie, located near Linden along the Demerara River about $105 \mathrm{~km}$ from its mouth, Ituni on the west side of the Berbice River, and Kwakwani on the east side of that river. Other deposits occur in the Pomeroon region in the western coastal lowlands, along the Essequibo River south of Georgetown, and in the Canje district in the eastern part of the country. Aluminous laterite deposits on much older crystalline rocks of the Guyanan shield occur in several places in Guyana. Some laterites, such as those in the Blue Mountains, are in uplands at intermediate altitudes and are surrounded by coastal plain sediments. However, the very large deposits are on higher plateaus in the Pakaraima Mountains and other inland areas.

The association of bauxite and laterite deposits in Guyana and elsewhere in northern South America with old planation levels has been recognized for a long time (Meulen, 1948), and prominent seaward-sloping levels were identified by Kersen (1956, p. 255-317) and Bleackley (1961, p. 224-226; 1964, p. 95-97, fig. 14). Prominent peneplains in the Pakaraima Mountains are at altitudes of $400-500 \mathrm{~m}$ and $700-800 \mathrm{~m}$. The lower surface slopes seaward to an altitude of about $300 \mathrm{~m}$ in the Blue Mountains. Still lower planation levels extend seaward and are represented by unconformities in coastal plain sediments. Laterite on inland plateaus clearly has formed on the old planation surfaces, and bauxite is thought to have formed during periods of nondeposition represented by the unconformities in the coastal-plain sediments.

The bauxite deposits in the coastal plain of Guyana are in the sedimentary beds of the Corentyne Series (Bleackley, 1964, p. 20, 148). Locally, the deposits rest on weathered crystalline rock, but at most places sand and clay containing some sandstone and conglomerate are present below the bauxite. The bauxite is overlain by the Berbice or White Sand Formation consisting of sand, silty clay, and silt that was probably deposited in brackish water. By a thorough study of pollen, Van der Hammenn and Wymstra (1964, p. 223, fig. 26) determined that the beds below the bauxite are of Late
Cretaceous (Maestrichtian) to early Eocene age and that the lower parts of those above the bauxite are of early Oligocene age. Therefore, the interval of bauxite formation was from early Eocene to early Oligocene.

Bauxite deposits in Guyana and elsewhere in northern South America formed in more than one way (Krook, 1969). Most deposits in the region are underlain by clay consisting chiefly of kaolinite, but halloysite is also present. Several authorities agree that the kaolin layers are the immediate parent material of the bauxite, and Kersen $(1956$, p. 326) has presented mineralogical evidence supporting this theory, including electron micrographs of leached kaolin crystals and photomicrographs of kaolinite partly altered to gibbsite. Some of the kaolin deposits have been transported, and others have formed in place. Bauxite associated with transported kaolin probably formed by a two-stage process as suggested by Moses and Michell (1963) and Vletter (1963). The first stage included deep weathering of metaniorphic and igneous rocks inland and the transportation to and deposition of the kaolinitic weathering products on the coastal lowlands. The second stage was the desilication of the kaolinitic materials and the formation of bauxite. Aleva (1965) recognized the relationships of the bauxite and underlying kaolin clay but believed that the two were distinct sedimentary units and that the bauxite formed from a porous arkosic or silty parent material. Bauxite that formed in place from residual clay on granite occurs at the Montgomery mine in the Mackenzie district, Guyana (Kersen, 1956, p. 301-305), and a deposit in the southern part of the Ituni group in Guyana is underlain by a thin brown clay retaining relict texture of the underlying gabbro (Pollard and Barron, 1955, p. 13). Most bauxite deposits on plateaus evidently formed in place, inasmuch as they grade downward into hard rock through saprolite and incompletely weathered zones. Gibbsite also formed below accumulations of decaying organic matter in swamps during Holocene geologic time (Kersen, 1956, p. 367-368). The parent material of this gibbsite is an illite clay in parts of the Coropina Formation that are thought to be of Pleistocene age. Halloysite occurs as an intermediate stage in the formation of gibbsite.

The high-grade bauxite in the coastal plain occurs in irregularly shaped beds and lenticular deposits that range in size from about 100,000 tons to as much as 1 million tons (Lachmansingh and Nooten, 1977). Most deposits are dome shaped, and they range in maximum thickness from a few meters to as much as $20 \mathrm{~m}$. Most deposits are underlain by kaolinitic clay that locally is residual on crystalline rock. Beds above the bauxite consist of sand, clay, and lignitic clay occurring in the following sequence from surface downward: (1) white 
sand or sandy clay ranging from a few meters to more than $50 \mathrm{~m}$ in thickness; (2) hard clay 2-20 $\mathrm{m}$ thick; and (3) a layer of lignitic cemented sand ranging from a few centimeters to $10 \mathrm{~m}$ in thickness. The uppermost part of the bauxite, called "capping," is commonly a mixture of bauxite pebbles and clay. This capping ordinarily is 20-25 percent reactive silica, and it is discarded with the overburden in mining.

The mineralogy of deposits at the Montgomery, Nieu Haarden, Maria Elizabeth, and Warababaru mines was investigated by Brindley and Sutton (1957), who used $\mathrm{X}$-ray methods to analyze samples taken at $0.6-\mathrm{m}$ vertical intervals. Gibbsite is the principal mineral in all deposits, and some samples contain as much as 95 percent of this mineral. Boehmite is present at all localities; the vertical distribution of this mineral is irregular. Most deposits contain only 1-3 percent boehmite. The highest concentration of boehmite is at the Maria Elizabeth mine, where layers containing 5 percent are common and one sample contained 15 percent. Anatase is uniformly distributed in amounts of 1-2 percent in nearly all the bauxite. Goethite occurs in all deposits but rarely makes up more than 5 percent of the deposit, except at Warababaru, where 5-15 percent is present in some layers. Hematite occurs in the bauxite at the Nieu Haarden and Warababaru mines, and one layer contains 10 percent of this mineral.

Large deposits of aluminous laterite and ferruginous bauxite have been discovered in remote parts of the Pakaraima Mountains (Bateson, 1961; Bleackley, 1964, p. 95-135). The most extensive deposits are on plateaus at altitudes of $670-760 \mathrm{~m}$; other deposits are at 370$460 \mathrm{~m}$ and at about $915 \mathrm{~m}$. The aluminous laterites have been investigated in three areas. Deposits in the Kopinang River basin are reported to be $3.5 \mathrm{~m}$ thick and to cover $1160 \mathrm{~km}^{2}$; the average partial composition of samples from 35 pits is 40.4 percent $\mathrm{Al}_{2} \mathrm{O}_{3}, 6.1$ percent $\mathrm{SiO}_{2}, 27.6$ percent $\mathrm{Fe}_{2} \mathrm{O}_{3}$, and 2.1 percent $\mathrm{TiO}_{2}$. Deposits in the Sukabi River basin cover $965 \mathrm{~km}^{2}$, and the average partial composition of samples from the upper $5 \mathrm{~m}$ in three test pits is 34.4 percent $\mathrm{Al}_{2} \mathrm{O}_{3}, 16.5$ percent $\mathrm{SiO}_{2}, 25.8$ percent $\mathrm{Fe}_{2} \mathrm{O}_{3}$, and 1.9 percent $\mathrm{TiO}_{2}$. Deposits in the Kamarang-Kukui areas in the basin of the upper Mazaruni River cover $1545 \mathrm{~km}^{2}$, and the average partial composition of samples from the upper $4.3 \mathrm{~m}$ in 16 test pits is 33.3 percent $\mathrm{Al}_{2} \mathrm{O}_{3}, 20.3$ percent $\mathrm{SiO}_{2}$, and 19.7 percent $\mathrm{Fe}_{2} \mathrm{O}_{3}$.

Aluminous laterite deposits cap the surface of the Blue Mountains in several places (Bleackley, 1964, p. 85-87). These mountains and a smaller highland nearby, called the Oko Mountains, are about $8 \mathrm{~km}$ west of the Essequibo River. The surface of these highlands slopes about 2 or $3 \mathrm{~m}$ per kilometer from an altitude of $350 \mathrm{~m}$ in the south to $120 \mathrm{~m}$ above sea level in the north. Aluminous laterite covers an area of $12-18 \mathrm{~km}^{2}$, and the amount present is approximately 50 million tons. This area was prospected by Harvey Aluminum Inc., and several patches of laterite containing an average of 50 percent $\mathrm{Al}_{2} \mathrm{O}_{3}$ were located.

Aluminous laterites in the Hariwa area, $10 \mathrm{~km}$ north of Ituni, and the Kamakabara area, $16 \mathrm{~km}$ south of Ituni, were investigated by the Guyana Geological Surveys and Mines Department (1972, p. 31-32). Much of this laterite is as much as 45 percent $\mathrm{Al}_{2} \mathrm{O}_{3}$. Most of it is low in $\mathrm{SiO}_{2}$, and some is low in $\mathrm{Fe}_{2} \mathrm{O}_{3}$. In preliminary investigations only about one-half million tons of aluminous laterite were identified, but total tonnages in these and other areas may be large.

\section{Resources}

Estimates of resources of bauxite in Guyana range widely. According to the Société Aluminum Pechiney (1975, table 1), the total bauxite reserves were estimated to be 300 million tons, of which two-thirds was considered certain and probable and one-third potential. Shaffer (1975, table 5) listed 290 million tons of reserves and additional potential resources of bauxite for this country. According to data supplied to the International Bauxite Association (1976b, table 1) by Guyana, the reserves are as follows: measured -500 million tons and total-1 billion tons. The grade of the bauxite is listed as 50-63 percent $\mathrm{Al}_{2} \mathrm{O}_{3}$ and 1-5 percent $\mathrm{SiO}_{2}$. $\mathrm{A}$ more recent report on Guyana published by the International Bauxite Association (1978a, p. 40) gave the measured reserves of high-quality ore (50-63 percent $\mathrm{Al}_{2} \mathrm{O}_{3}, 1-10$ percent $\mathrm{SiO}_{2}$ ) as 520 million tons and the lower grade reserves (30-55 percent $\left.\mathrm{Al}_{2} \mathrm{O}_{3}\right)$ as 170 million tons. This article further stated that possible reserves of both grades are 1,160 million tons. The measured reserves are all in the coastal-plain region, and they include deposits found during an exploration program carried on in 1971-76. The major deposits discovered are in the Ituni and Mackenzie districts. The total 1,160-million-ton figure includes probable and possible reserves in the Essequibo, Kwakwani, and Canje districts, but no lowgrade laterite bauxite in inland areas is included in these estimates. The U.S. Bureau of Mines estimate for bauxite reserves in Guyana is $\mathbf{7 0 0}$ million tons (Baumgardner and McCawley, 1983, table 3).

Subeconomic and undiscovered bauxite resources in inland laterite deposits are very large. In writing about the total resources, Singh $(1972$, p. 625), former Director of the Guyana Geological Surveys and Mines Department, made the following comments.

In Guyana there are two types of aluminous rocks from which alumina and aluminum could be produced. There are the high-grade bauxites 
of the coastal area, or the lowland bauxites which have been mined since the beginning of this century and upon which our present bauxitealumina industry is based. The other type of aluminous material is aluminous laterite, generally regarded as the upland type, which occurs in enormous quantities in Guyana. The total reserves of laterites so far computed are over 25,000 million tons. Of these reserves over 7,000 million tons seem to be of potential commercial value, being similar in chemical composition to materials from which alumina is extracted on a commercial scale in other parts of the world. The bettergrade aluminous laterites occur in association with lower-grade ferruginous laterites in large bodies ${ }^{* * *}$.

In this report, the bauxite reserves in Guyana are considered to be 700 million tons, the rounded total of the high-grade and lower grade bauxite reported in the article published by the International Bauxite Association (1978a). The subeconomic bauxite resources in this country are assumed to be 300 million tons, and the total resources (reserves plus subeconomic deposits) are estimated to be 1 billion tons. The extremely large resources in the inland laterite deposits discussed in the foregoing paragraph are lumped with the total unevaluated and undiscovered bauxite in South America.

\section{PARAGUAY}

Laterite is widespread in southeastern Paraguay (Putzer, 1962, p. 124; Eckel, 1959, p. 79), and bauxite is reported to have been found at San Juan Nepomuceno, Alto, Piribebuy, and Paraguarí. Some of the areas favorable for bauxite are underlain by weathered nepheline syenite, shonkinite, and other alkalic rocks similar to those on which the bauxite in the Poços de Caldas region of Brazil have formed. Other areas in which the bauxite is reported are shown on a geologic map (Eckel, 1959, pl. 1) as basalt, and probably bauxite has also formed on this type of rock. Insofar as the authors are aware, none of the bauxite in Paraguay has been evaluated and no estimates of the resources present have been published.

\section{SURINAME}

\section{History and Production}

Bauxite deposits were known in Suriname by the turn of the century; it was first shipped by the Aluminum Company of America (Alcoa) in 1922, and a second company, NV Billiton Maatschappij Suriname, began mming in 1941. When both companies were active, Suriname led the world in bauxite production for the period 1947-1956. From the time of the first shipments through 1960 more than 50 million tons of bauxite had been exported. From 1960 to 1978 annual bauxite production has ranged from 3.3 to 7.8 million tons (table 6). Production has declined since the peak year and reached a low of 3 million tons in the recession year of 1982. The bauxite consumed in Suriname is used for alumma and aluminum in a fully integrated industry inaugurated in 1965 when the Suriname Aluminum Company opened plants at Paranam to make both alumima and aluminum. Much of the electric power for this operation is from a dam and generating station on the Suriname River at Afobaka (Brokopondo Falls). Suriname is now a major exporter of bauxite, alumina, and alumimum. Part of the bauxite exported has been marketed for abrasive, chemical, and refractory uses.

In addition to the activation of an integrated aluminum industry, several developments related to bauxite have taken place in Suriname in recent years. Grassalco, the Suriname Government corporation, and Reynolds Suriname Mines, Ltd., in a 50-50 joint venture evaluated bauxite reserves in the Bakhuis Mountains (Michell, 1974, p. 103). Because of problems concerning the adequacy of reserves found during this project, Reynolds Metals Co. termmated its activities in Suriname with the agreement that the Suriname Government pay Reynolds $\$ 3.5$ million for its bauxite concessions and exploration equipment (Michell, 1975, p. 72). Grassalco also has signed agreements to participate with Billiton Suriname NV in evaluating other bauxite resources in Suriname and possibly processing bauxite into alumina and alummum. The Suriname Government, following the lead of Jamaica, moved to substantially increase revenues and government participation in bauxite and alumina production (Michell, 1975, p. 72). Suralco and the Suriname Government signed a letter of intent in November 1974 to increase the production levy on bauxite to $\$ 11.02$ a ton, retroactive to January 1,1974 . This rate is more than four times the previous one.

The principal bauxite mines in Suriname are near Paranam and Onverdacht (fig. 15) on the Suriname River and near Moengo in the eastern part of the coastal plain. Suralco operated mines west of Paranam and southeast of Moengo. The Billiton Company Suriname, a subsidiary of the Royal Dutch Shell Company since 1973 , has mimes near Onverdacht. Mining is by openpit methods; overburden removal is complicated by excessive water resulting from poor drainage in low swampy terrain. As recently as 25 years ago, the maximum overburden removed was about $20 \mathrm{~m}$ thick; now as much as $30 \mathrm{~m}$ of overburden is removed; and in the future even greater thicknesses will be stripped (Van Lissa, 1975). Cost of removing overburden was a major factor leading to agreements between Suralco and Billiton Companies whereby the alumima plant at Paranam would be jointly owned (U.S. Embassy, Paramaribo, Suriname, State Department Airgram, 3/22/84). 
A further agreement was reached that bauxite would be mined by Billiton, whose deposits can be mined more cheaply than those controlled by Suralco. The joint ventures were approved by the Government of Suriname, which wants a greater share of the income from the use of the country's natural resources and may participate in joint ventures in the future.

The bauxite produced in the Onverdacht district is very high grade trihydrate type containing very little boehmite and silica. The chemical composition of representative shipments (table 19) listed by Aleva (1975) indicates the quality. However, not all of the bauxite produced is as high grade; Suriname Geologisch Mijnbouwkundige Dienst (1953, p. 21) listed 55.0-59.2 percent $\mathrm{Al}_{2} \mathrm{O}_{3}$ and $3.8-10.0$ percent $\mathrm{Fe}_{2} \mathrm{O}_{3}$ among the ranges of principal components. This same reference gave the composition of calcined bauxite as 85.386.0 percent $\mathrm{Al}_{2} \mathrm{O}_{3}, 3.5-4.2$ percent $\mathrm{SiO}_{2}, 5.8-7.0$ percent $\mathrm{Fe}_{2} \mathrm{O}_{3}$, and 2.9-3.5 percent $\mathrm{TiO}_{2}$.

\section{Bauxite Districts and Deposits}

In Suriname, bauxite deposits occur in sedimentary beds in the coastal plain and as laterite-type cappings of inland plateaus. The deposits mined are in the Onverdacht, Paranam, and Moengo districts, which are in the eastern one-third of the coastal plain (fig. 15). The laterite-type bauxite deposits in inland regions are mainly in the Bakhuis Mountains, but other deposits occur in the Nassau, Browns, and Lely Mountains (fig. 15) (Bosma, Ho Len Fat, and Welter, 1973).

Most of the bauxite in the coastal lowlands overlies kaolin deposits and arkosic sand of the Berbice or Onverdacht Formation and is overlain by the White Sand or Coeswyne Formation (Montagne, 1964; Aleva, 1965). Beds below the bauxite are reported to contain pollen of early Eocene age, and pollen in the beds above the deposits is Oligocene to Miocene in age. A major break in the sedimentary record during which weathering and bauxite formation took place is thought to have occurred in late Eocene to early Oligocene time (Aleva, $1981 \mathrm{a}, \mathrm{b})$. The bauxite ranges from hard tough types requiring blasting for mining to plastic clay; concretionary, massive, cellular, banded, and breccialike forms are present.

Investigations by Aleva and others (1969) have established that the buried bauxite in the coastal plain occurs as preserved flat-topped cappings of older sediments. Deep erosion in late Eocene and early Oligocene time removed the coastal-plain sediments except in the bauxite-capped areas. In late Oligocene time, renewed sedimentation resulted in the filling of areas between the present bauxite, and later, in Pliocene and Pleistocene
TABLE 19.-Chemical composition of bauxite produced at Onverdacht, Suriname

[All values in weight percent. From Aleva (1975); analyses are representative of shipments of 5,000 tons or inore]

\begin{tabular}{|c|c|c|c|c|c|}
\hline & $\mathrm{Al}_{2} \mathrm{O}_{3}$ & $\mathrm{SiO}_{2}$ & $\mathrm{Fe}_{2} \mathrm{O}_{3}$ & $\mathrm{TiO}_{2}$ & $\mathrm{H}_{2} \mathrm{O}$ \\
\hline \multirow[t]{4}{*}{ Metal grade } & 60.0 & 3.4 & 2.7 & 2.5 & 31.4 \\
\hline & 59.1 & 3.8 & 3.4 & 2.7 & 31.0 \\
\hline & 58.5 & 4.3 & 4.0 & 2.4 & 30.8 \\
\hline & 58.6 & 3.9 & 4.4 & 2.4 & 30.7 \\
\hline \multirow[t]{3}{*}{ Chemical grade } & 60.8 & 3.6 & 1.2 & 2.8 & 31.6 \\
\hline & 60.1 & 4.6 & 1.4 & 2.6 & 31.3 \\
\hline & 59.3 & 6.1 & 1.2 & 2.5 & 30.9 \\
\hline
\end{tabular}

time, sediment completely covered the bauxite. Valeton $(1973 a, b, c)$ noted evidence for bedding in bauxite near Onverdacht and Moengo and stated that heavy minerals in the bauxite are similar to those in the underlying sediments. She concluded that the parent material of the bauxite in the two districts came from crystalline rocks in different source areas because of differences in heavy-mineral suites. Kaolinite has been diagenetically altered to gibbsite in the upper parts of prebauxite sediment. The depositional environmental of the prebauxite sediment was probably a series of marine fans along the coast. Plant-root remains in the uppermost parts of the sediment suggest temporary emergence and probably the existence of mangrove swamps, but the presence of burrows in many places may indicate deposition in shallow marine water. Though Valeton is less than clear on this subject, she apparently believed that postdepositional alteration of kaolin and other aluminumbearing minerals was the most logical explanation for the origin of the bauxite.

The deposits mined differ in size; some are small, some large. The Moengo Hill deposit, now mined out, was $5 \mathrm{~km}$ long and $1 \mathrm{~km}$ wide and yielded 10 million tons of bauxite. Most deposits are cappings 3-7 $\mathrm{m}$ thick on low, flat-topped hills and are overlain by only a thin veneer of soil and sedimentary rock. Most deposits rest on transported kaolin that overlies weathered schist and other Precambrian rocks, but a few rest on coarse sand.

Bauxite in the deposits mined has several different lithologies. They are as follows:

(1) Dense, homogeneous, pink to yellowish-white bauxite, some of which is fine grained and some of which consists of gibbsite crystals as much as $4 \mathrm{~mm}$ in size. In this type, small vugs filled with white clay are common.

(2) Laminated bauxite consisting of alternating layers of gibbsite and kaolin or of dense and porous forms of gibbsite. 
(3) Porous bauxite containing vugs of various sizes and shapes, some of which retain the outlines of leached quartz grains.

(4) Very thin walled cellular bauxite consisting chiefly of crystalline gibbsite.

(5) Bauxitic clay containing concretions, as much as $1.5 \mathrm{~cm}$ in diameter, consisting chiefly of dense fine-grained bauxite resembling kaolin.

The largest laterite-type deposits in Suriname are in an area in the Bakhuis Mountains formerly known as the Adampada-Kabalebo region (Janssen, 1966; Aleva, 1971; Aleva and Hilversum, 1984). The bauxite in part of this region formed from rocks of intermediate composition including dolerite, gabbro, and charnockite (Pollock, 1981, p. 279). In other parts of the region, the bauxite formed from granulite interlayered with quartzite, calc-silicate rock and amphibolite, and a volcanic complex with intrusions of gabbro and ultramafic rock (Aleva and Hilversum, 1984, p. 330). The bauxite varies greatly in mineralogical and chemical composition. The patchy and irregular extent of deposits probably is caused by variations in the parent rock. The bauxite ranges in thickness from 2 to $8 \mathrm{~m}$. Most deposits are richest in iron in their uppermost meter or two where local concentration of iron oxide are as much as 40 percent. Most of this highly ferruginous material is hard and brittle, and it is mainly in concretions and botryoidal masses lacking relict textures and structures of the parent rock. Iron contents generally decrease with depth, and the bauxite below the iron-rich layer has the consistency of compacted earth. Earthy bauxite grades downward into siliceous saprolite from which it is difficult to distinguish. Pollock (1981, p. 282-283) described one section of Bakhuis bauxite as follows: (1) topsoil with an organic layer, (2) fragmented cavernous hardcap with clayey material having nearly vertical banding, mostly dark brown, (3) pale-yellow clay with reddish-brown layers, (4) kaolinitic pebbles in a brownish-yellow clay matrix, (5) dark-brown clay matrix with kaolimitic pebbles, and (6) fresh crystalline rock. Pollock's report states that "the mineral composition of the bauxite is roughly as follows: gibbsite $63 \%$, kaolinite $5 \%$, quartz $1 \%$, hematite $8 \%$, goethite $18 \%$ and $2 \%$ anatase."

Iron has been leached from the upper parts of bauxite deposits where the deposits are almost continuously in contact with surface runoff water (Aleva and Hilversum, 1984, p. 338, table 5). Some of the leached bauxite contains 2 percent $\mathrm{Fe}_{2} \mathrm{O}_{3}$ and about 63 percent $\mathrm{Al}_{2} \mathrm{O}_{3}$ and is the best grade bauxite in the district.

In addition to the Bakhuis Mountains, other uplands in Suriname capped by laterite-type bauxite include the Nassau, Lely, and Brownsberg Mountains (Aleva and Hilversum, 1984, fig. 1). Bauxite deposits on all three uplands are much smaller than the deposits in the Bakhuis Mountains.

\section{Resources}

The bauxite resources in Suriname are in the highgrade deposits in the coastal plain region (Moengo, Onverdacht, and Paranam districts) and the iron-rich laterite deposits in mountainous inland districts. Suriname submitted to the International Bauxite Association (1976b, table 1) estimates of 270.8 million tons for measured bauxite reserves and 490 million tons for total reserves. According to Rene Cambridge (oral commun., March 1977), these estimates include 75 million tons for deposits in the Bakhuis Mountains, and the remainder is for high-grade deposits in the coastal plain. Since 1975 approximately 30 million tons of bauxite have been mined from coastal plain deposits, leaving a total of about 385 million tons of bauxite in the coastal belt.

In an early assessment of the bauxite in the Bakhuis Mountains, it was inferred that the deposits extended over $800 \mathrm{~km}$ (Aleva and Hilversum, 1984, p. 327). As much as 5 billion tons of bauxite would be present if deposits were continuous and if the estimated thickness and density of 1.75 were correct. This large estimate was probably the basis for the estimate of 1.1 billion tons announced by a Suriname politician (American Metal Market, 1969) and the 1-billion-ton estimate for potential bauxite in the Bakhuis Mountains given by Dahlkamp and Kirchner (1968, p. 68). In more detailed investigations, it was found that the laterite-type bauxite in the Bakhuis Mountains was far more irregularly distributed than previously thought (Aleva and Hilversum, 1984, p. 328-329), and reserve estimates were reduced markedly.

After completing 3,000 drill holes in the AdampadaKabalebo region in 1971-73, Reynolds Suriname Mines Ltd. reported 40 million tons of proven, probable, and possible bauxite reserves (Roever, 1975, p. 99). Approximately 18 million tons of these reserves in one area contain 46-47 percent extractable alumina and 1.5-3 percent silica. These deposits are 6-8 $\mathrm{m}$ thick and are under overburden that is $1-1.5 \mathrm{~m}$ thick.

The bauxite reserves in the Bakhuis Mountains were estimated by Dahlkamp and Kirchner (1968, table 2) as follows: 104 million tons containing 52.7 percent total $\mathrm{Al}_{2} \mathrm{O}_{3}$ and 2.0 percent $\mathrm{SiO}_{2}, 94$ million tons containing 44.0 percent $\mathrm{Al}_{2} \mathrm{O}_{3}$ and 3.9 percent $\mathrm{SiO}_{2}$, and the total of both grades was 198 million tons. After Billiton Maatschappij Suriname completed a feasibility study for Grassalco, the Suriname government aluminum company, in 1979, Aleva and Hilversum $(1984$, p. 329, 
table 2) also estimated the reserves to be 198 million tons. This bauxite has an average thickness of $4.6 \mathrm{~m}$. It contains an average of 48.6 percent $\mathrm{Al}_{2} \mathrm{O}_{3}$ and the recovery by the low-temperature process is 42.8 percent; the reactive $\mathrm{SiO}_{2}$ is 2.5 percent. A little more than half of the bauxite (104 million tons) is considered higher grade bauxite. This higher grade bauxite has an average thickness of $3.9 \mathrm{~m}$. It contains 52.7 percent $\mathrm{Al}_{2} \mathrm{O}_{3}$, 2.0 percent $\mathrm{SiO}_{2}$, and 14.8 percent $\mathrm{Fe}_{2} \mathrm{O}_{3}$. The $\mathrm{Al}_{2} \mathrm{O}_{3}$ available when the low-temperature process is used is 50.0 percent, and the reactive $\mathrm{SiO}_{2}$ is 1.8 percent.

Doeve $(1957$, p. 25$)$ calculated that reserves of bauxite in the Nassau Mountains total 14 million tons, the composition of which is 53.5-55.5 percent $\mathrm{Al}_{2} \mathrm{O}_{3}, 3-$ 3.5 percent $\mathrm{SiO}_{2}$, 8.5-10.5 percent $\mathrm{Fe}_{2} \mathrm{O}_{3}, 4-6$ percent $\mathrm{TiO}_{2}$, and 27-29 percent LOI. In addition, 6 million tons that contains 47.5-49.5 percent $\mathrm{Al}_{2} \mathrm{O}_{3}$ and 17.5-19.5 percent $\mathrm{Fe}_{2} \mathrm{O}_{3}$ is present. Additional reserves of bauxite were found in the Nassau Mountains by company exploration during 1975 and 1976 (Rene Cambridge, oral commun., March 1977).

More than 1,000 exploratory drill holes have been put down since 1952 in the western two-thirds of that part of the coastal plain favorable for bauxite, but little more than bauxite shows have been found (Van Lissa, 1975, enclosure 45). However, many of these holes are widely spaced; large, inaccessible, swampy areas have not been explored; and many holes were not drilled to depths at which bauxite is now known to occur in the eastern part of the country. Therefore, undiscovered bauxite may be present in the western part of the coastal plain.

The total reserves of bauxite in Suriname are estimated to be 575 million tons (Baumgardner and McCawley, 1983, table 3), and the total resources are about $\mathbf{8 0 0}$ million tons. The figure for total resources is the estimate of the Suriname Geological and Mining Service (Rene Cambridge, oral commun., 1977). This estimate includes reserves plus deposits containing as much as 8 percent $\mathrm{SiO}_{2}$, instead of 6 percent as used in earlier estimates, and low-grade bauxite in remote parts of the Bakhuis Mountains. The total bauxite resources in Suriname are most likely considerably larger than 800 million tons, inasmuch as upland areas on the Guyana shield in remote southern parts of the country have not been fully explored for bauxite.

\section{VENEZUELA}

Venezuela has been an aluminum producer since 1967. The government initiated the construction of the Interalumina plant at Ciudad Guayana in 1969 (Rodriguez, 1982, p. 108). This plant when completed will have an annual capacity of 1.6 million tons of alumina. A small tonnage of bauxite and kaolin is produced in the Upata district for use in refractories. The alumina plant will be supplied by imported bauxite. However, plans for mining the Los Pijiguaos bauxite and completing the integration of the Venezuelan aluminum industry were in an advanced stage when this report was written.

The Venezuelan government and private interests have put forth major efforts to find domestic bauxite resources. In the early prospecting, small subeconomic bauxite deposits similar to the deposits in the coastal plain in Guyana were found in the Orinoco Delta region, and laterite-type deposits were discovered in remote inland areas of Venezuela. Large laterite-type bauxite deposits were discovered in the Los Pijiguaos uplands (fig. 16) in the western part of the State of Bolivar in 1974 by the Venezuelan Direccion de Geología, Ministerio de Minas e Hidrocarburos (Rodriguez, 1982). The Los Pijiguaos bauxite was explored by the Corporación Venezolana de Guayana (De Ratmiroff, 1979). Feasibility studies of mining and transporting bauxite from these deposits were underway in 1978 and 1979; other studies have been made more recently. The earlier investigations in other districts were by the Venezuelan Dirección de Geología del Ministerio de Minas e Hidrocarburos (Candiales, 1961; Lavie, 1974; Perfetti, Márquez, and Candiales, 1951) and by the University of Oriente Núcleo de Bolívar (Baptista Gómes, 1973; Amelinck and Herrero N., 1971-72). In this earlier work bauxite deposits were discovered in the following districts (fig. 16): (1) along the Toro, Aroy, and Acure Rivers, Delta Amacuro Territory; (2) La Mesa Copeyal, El Chorro and other mesas in the vicinity of Upata; (3) the Nuria plateau; (4) the Serranía de los Guaicas; and (5) highland areas in the Gran Sabana region near the Brazilian border. The last four districts are in the State of Bolivar.

Los Pijiguaos district.-The Los Pijiguaos bauxite district is in the western part of the State of Bolivar midway between the towns of Caicara and Puerto Ayacucho on the Orinoco River. The district is in the Los Pijiguao Mountains about $35 \mathrm{~km}$ east of the Orinoco River. The deposits occur on uplifted dissected plateaus. They formed from the Parguaza granite, which is a large batholith intrusion in volcanic rocks.

As described by Menendez and Sarmentero (1984, p. 401-402), the weathered profile on the Parguaza granite consists of the following zones. (1) A bauxite zone, which is overlain only by a very thin soil, made up of a bauxite crust of spongy textured cemented pisolites overlying a thicker layer of quartz-bearing earthy, pink to reddish-brown bauxite. The combined crust and earthy bauxite has an average thickness of about $8 \mathrm{~m}$. This bauxite zone is $60-90$ percent gibbsite, 5-10 percent hematite, and $<5$ percent goethite and 

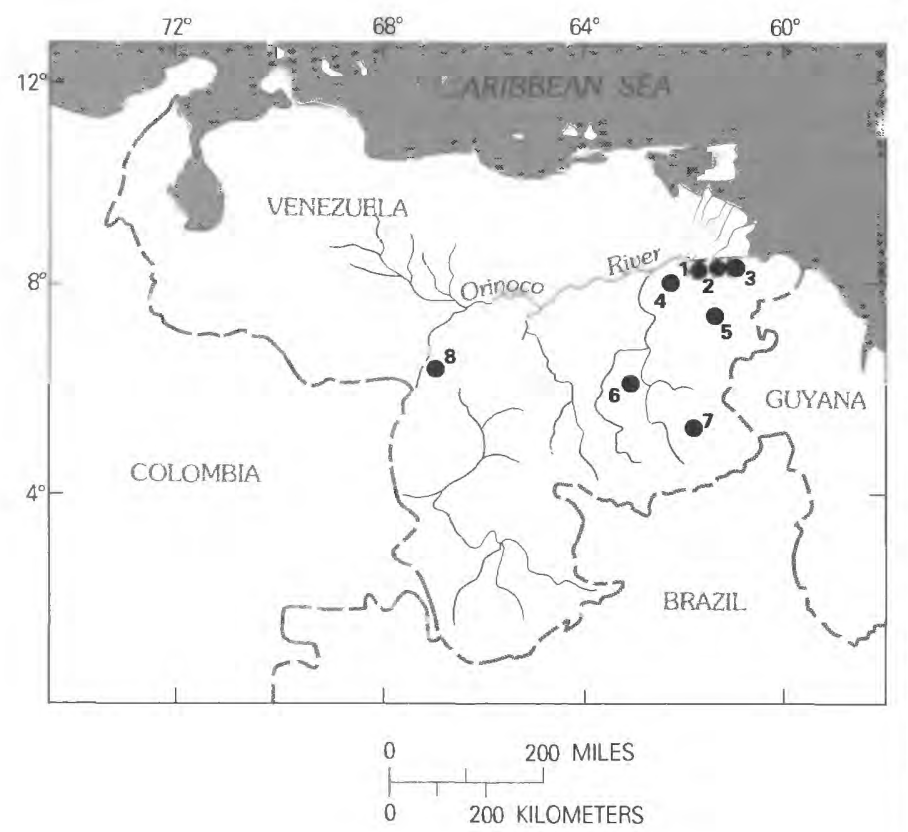

EXPLANATION

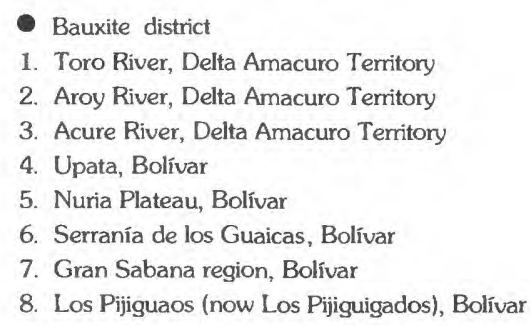

FIGURE 16.-Locations of bauxite and aluminous laterite districts in Venezuela.

contains traces of boehmite and kaolinite. (2) The second zone is a mottled earthy aggregate of kaolinite, quartz, and mica having granite pseudotextures in the lower part. (3) The third zone is a concretionary bauxite layer consisting of brownish-red spongy and cellular textured material. This concretionary zone was intersected by only one drill hole. (4) The fourth zone is a pallid layer having a composition similar to the mottled zone. (5) The fifth zone is saprolite in which the granite texture is preserved. (6) The lowermost zone is granite, the parent rock of the bauxite. Granite was penetrated in one drill hole at a depth of $49 \mathrm{~m}$.

Other districts.-The minor bauxite resources in Venezuela, like those in the Los Pijiguaos district, formed from igneous and metamorphic rocks in the Guyana shield, except the small deposits in the Orinoco Delta region, which, like the bauxite in the coastal plain of Guyana, are in sedimentary beds. Most bauxite deposits in Venezuela, except the small deposits in the Orinoco Delta region, are the laterite type on plateaus, and they have formed from several types of rocks.
Deposits in the Upata and Nuria districts are at an altitude of about $600 \mathrm{~m}$. In these two districts the bauxite has formed on gneiss, amphibolite, granitic rocks, and diabase. At some localities the bauxite is pisolitic, and at others it is compact, massive, cellular, and fine grained. At least some of the deposits in the Upata region evidently formed in place, inasmuch as lenses of bauxite overlie kaolin and kaolinized gneiss, and original textures of the parent rock are indicated by preserved sericite (Candiales, 1961, p. 1672).

Laterite from the Serranía de los Guaicas district, which is located $230 \mathrm{~km}$ south of Ciudad Bolivar in the State of Bolivar, was analyzed by Schoin and Labrecque (1983) and found to be 37.39 percent $\mathrm{Al}_{2} \mathrm{O}_{3}, 1.16$ percent $\mathrm{SiO}_{2}, 3.15$ percent $\mathrm{TiO}_{2}$, and 35.77 percent $\mathrm{Fe}_{2} \mathrm{O}_{3}$. The parent of the deposits is diabase (Sinkovec, 1965). According to Šinkovec, the lateritic bauxite is composed of gibbsite, kaolinite, halloysite, quartz, a material referred to as "amorphous limonite," goethite, hematite, ilmenite, and leucoxene. Gibbsite occurs in cryptocrystalline and crystalline forms. Cryptocrystalline gibbsite occurs with goethite and "amorphous limonite" in colloform masses. Crystalline gibbsite is colorless replacements of plagioclase, and it occurs in lamellar, tabular, and square-shaped forms in fibrous aggregates.

\section{Resources}

During early exploration the Los Pijiguaos bauxite deposits have been evaluated by bomb digest testing of more than 1,500 samples from 139 drill holes and 20 test pits (De Ratmiroff, 1979). The bauxite present was calculated to be 300 million tons containing more than 50 percent $\mathrm{Al}_{2} \mathrm{O}_{3}$ and less than 8 percent $\mathrm{SiO}_{2}$, and a total of 500 million tons, including the better grade, is more than 48 percent $\mathrm{Al}_{2} \mathrm{O}_{3}$ and less than 10 percent $\mathrm{SiO}_{2}$. The $\mathrm{Al}_{2} \mathrm{O}_{3}$ is in trihydrate form, most of the silica is in free quartz, and reactive $\mathrm{SiO}_{2}$ is low. The deposits included in these estimates extend over $30 \mathrm{~km}^{2}$.

After more thorough evaluation, Rodriguez (1982, p. 112) and Menendez and Sarmentero (1984, p. 404) listed the proven reserves in 9 blocks in the Los Pijiguaos district as $\mathbf{1 7 6 . 9}$ million tons. These reserves are 49.5 percent $\mathrm{Al}_{2} \mathrm{O}_{3}, 9.3$ percent $\mathrm{SiO}_{2}$ (7.6 percent quartz), and 12.6 percent $\mathrm{Fe}_{2} \mathrm{O}_{3}$. The average thickness is $7.6 \mathrm{~m}$. In addition to the proven reserves, some 60 million tons in adjacent areas can be regarded as probable reserves. The total bauxite in the region may be very large inasmuch as Rodriguez $(1982$, p. 112) described the extent of bauxite-bearing rock as follows: "According to work carried out in the large northern bauxite of the Parguaza batholith by the Geological Survey of Venezuela, possible reserves are expected to 
be of the order of several billion metric tonnes in view of the extensive area covered by the parent rock of the Los Pijiguaos bauxite." Menendez and Sarmentero $(1984$, p. 404) pointed out that the surface of plateau remnants on which bauxite occurs extends over a total of $350 \mathrm{~km}^{2}$, suggesting the Pijiguao Mountains contain 5.8 billion tons of possible bauxite reserves.

In addition to the deposits in the Los Pijiguaos district, bauxite resource estimates are available for the following districts. (1) The remote Urekan area in the Gran Sabana region is thought to contain 220 million tons (Amelinck and Herrero N., 1971-72). This estimate is based on the extent of the lateritic bauxite along the Cuquenan River for a distance of $50 \mathrm{~km}$ and some drilling and analytical work. The samples analyzed range in composition as follows: $50.9-63.6$ percent $\mathrm{Al}_{2} \mathrm{O}_{3}$, 0.7-2.2 percent $\mathrm{SiO}_{2}, 5.6-14.2$ percent $\mathrm{Fe}_{2} \mathrm{O}_{3}, 0.7-$ 1.5 percent $\mathrm{TiO}_{2}$, and $28.5-35.2$ percent LOI. (2) The quantity of bauxite in the Nuria Plateau district was, according to one estimate quoted by Lavie $(1974$, p. 551), 27.5 million tons proven and 38.7 million tons probable. Lavie's own estimate was 41 million tons. The bauxite included in this estimate has the following composition: 45.8 percent $\mathrm{Al}_{2} \mathrm{O}_{3}, 7.5$ percent $\mathrm{SiO}_{2}$, and 22.9 percent $\mathrm{Fe}_{2} \mathrm{O}_{3}$. (3) The Upata district contains about 4 million tons of bauxite (Candiales, 1961, p. 1973). According to Rodriguez (1982, p. 109), the bauxite mined in the Upata district and used with kaolin for refractories is 60.12 percent $\mathrm{Al}_{2} \mathrm{O}_{3}, 11.78$ percent $\mathrm{Fe}_{2} \mathrm{O}_{3}$, and 0.94 percent $\mathrm{SiO}_{2}$. (4) The Los Guaicas district contains hundreds of millions of tons of aluminous deposits (Baptista Gomes, 1973 , p. 59), but they are only about 35 percent $\mathrm{Al}_{2} \mathrm{O}_{3}$ and 37 percent $\mathrm{Fe}_{2} \mathrm{O}_{3}$.

More conservative reserve estimates have been made by the Venezuela Dirección de Geología, Ministerio de Energia y Minas (Rodriquez, 1982, table 1) in millions of tons, as follows: Nuria district-8, Los Guaicas district-60, Camoiran district-54, Santa Elena district-49, and Upata district-2.

The bauxite reserves in Venezuela are estimated by the U.S. Bureau of Mines (Baumgardner and McCawley, 1983 , table 3) to be 235 million tons. The total resources are mainly the large possible bauxite deposits in the Los Pijiguaos district and the several minor districts that are probably 6 billion- 8 billion tons.

\section{OTHER SOUTH AMERICAN COUNTRIES}

Discovery of bauxite in the province of Sud Yungas and near Suri, La Paz, Bolivia, has been reported (Mining World, 1955). No information is available on the size and grade of these deposits.

Four bauxite deposits have been identified in Chile (Metals Sourcebook, 1975a; Romero, 1971). The deposits are in the Bio-Bio and Llanquihue regions in the southern part of the country. They are reported to contain 7.2 million tons of bauxite that could be mined by open-pit methods. Small bauxite deposits apparently having little value also occur in the Province of Aconcagua about $40 \mathrm{~km}$ north-northwest of Santiago. These deposits are the laterite type formed on Upper Cretaceous sedimentary rocks and overlain by volcanic rocks of early Tertiary age. Gibbsite is the major bauxite mineral, boehmite is also present, and parts of the deposits are mainly kaolinite.

\section{SUMMARY OF BAUXITE RESOURCES IN SOUTH AMERICA}

The total bauxite reserves in South America are estimated to be approximately 3.8 billion tons (rounded), and the resources (reserves and subeconomic and undiscovered resources) on the continent are probably in the 19- to 25-billion-ton range. The principal reserves, in millions of tons, are in Brazil-2,250, Guyana-700, Suriname-575, and Venezuela-235. The very large subeconomic and probable undiscovered deposits that are estimated to be 15 billion-21 billion tons include the 7 billion tons of lateritic bauxite in inland areas of Guyana, similar areas in Suriname and Venezuela, and large areas in the Amazon basin and elsewhere in Brazil. Smaller subeconomic bauxite deposits are known to be present in Colombia and French Guiana, and the total bauxite in the latter country is probably considerably greater than the authors have been able to find listed in published reports.

\section{EUROPE}

The principal bauxite deposits in Europe are in France, Greece, Hungary, Yugoslavia (fig. 17), and the U.S.S.R.; smaller deposits occur in Austria, Italy, Romania, the United Kingdom, and other countries. Most of the European bauxites consist mainly of boehmite, but a few are mixed boehmite and gibbsite, and a very few are mainly gibbsite. Some deposits in Greece and northern Hungary are chiefly diaspore.

\section{AUSTRIA}

Minor quantities of bauxite were produced from one mine in Unterlaussa, Austria, during the 20-year period 1944-64. Most of the output was consumed by the Austrian iron, cement, and abrasives industries; a small proportion was shipped to an alumina plant in Bavaria (Bracewell, 1962, p. 137). 

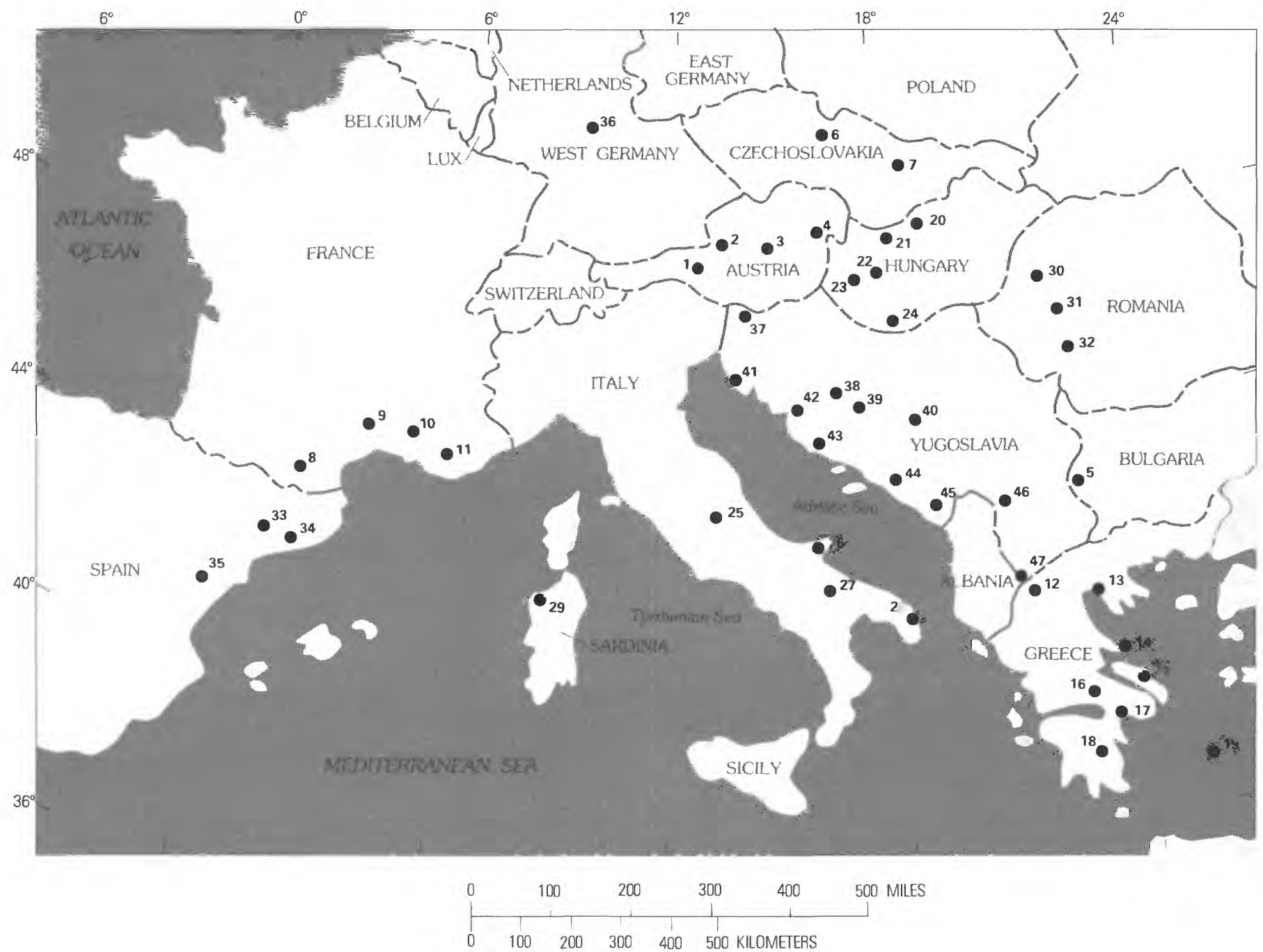

\section{EXPLANATION}

Bauxite distric $\nmid$ 11. Var

\section{Austria}

1. Brandenberg

2. Untersberg

3. Unterlaussa

4. Dreistetten

\section{Bulgaria}

5. Trŭn

\section{Czechoslovakia}

6. Rychnov

7. Mojtín

\section{France}
8. Ariège
9. Hérault
10. Bouches-du-Rhône

\section{Greece}
12. Vroderon (Flórina)
13. Thessaloníki
14. Skōpelos
15. Évvoia
16. Elikón-Parnassós- Gióna-Oíti Mountains
17. Elvsis-Megara-Mandra
18. Pelopónnisos
19. Amorgós

\section{Hungary}
20. Vác, Nézsa, Nayszály
21. Gánt
22. Iszkaszentgyörgy

\begin{abstract}
23. Nyirád, Halimba, Kislöd, Bakonyszentlászló-Fenyöfö

24. Nagyharsány
\end{abstract}

Italy

25. Casamaina-Puzzili

26. San Giovanni Rotondo

27. Spinazzola-Ampliamento-Cavone

28. Palmariggi-Poggiardo-Otranto

29. Sassari, Sardinia

\section{Romania}

30. Pădurea Craiului

31. Cîmpeni-Sohodol

32. Hateg basin

Spain

33. Lerida
34. Coastal area of Catalonia 35. Teruel and Ebro

\section{West Germany}

36. Vogelsberg

\section{Yugoslavia}

37. Podlipa Borounica
38. Bosanska Krupa
39. Jace
40. Vlasenica
41. Rovinj
42. Gospić
43. Drniš
44. Mostar
45. Nikšić
46. Priština
47. Kruševo

FIGURE 17.-Locations of bauxite districts in Europe exclusive of the U.S.S.R. and the United Kingdom. 
Small bauxite deposits occur in Austria in the following four districts (Ruttner, 1970): (1) Brandenberg, north of Rattenberg in Tirol, (2) on the northern slopes of the Untersberg near Salzberg, (3) Unterlaussa in southern upper Austria, and (4) Dreistetten, west of Wiener Neustadt. In the Brandenberg and Unterlaussa districts, the bauxite is in the lower part of a Cretaceous shale unit overlying pre-Cretaceous limestone. Austria apparently has no more than a few million tons of bauxite, and, because mining is inactive, these deposits are considered to be subeconomic resources in this report.

Resources of bauxite in Austria are too small to be worthy of much consideration in world estimates. However, in previous estimates, S.H. Patterson (1967, p. 61) listed a reserve of 1 million tons, and Bárdossy (1964, table 2) gave figures of 0.7 million tons for proven and 2 million tons for indicated bauxite in Austria.

\section{CZECHOSLOVAKIA}

The small known bauxite deposits in Czechoslovakia occur at Rychnov in Bohemia (Konta, 1954, p. 58-60) near the village of Mojtin, between Zilina and Trencin, in central Czechoslovakia (Orlov, 1938). The bauxite at Rychnov overlies amphibolite schists and probably formed from both the schist and transported material. Three types of bauxite present are (1) dense mixtures of kaolin and boehmite containing minor amounts of gibbsite, (2) pisolitic bauxite that is chiefly boehmite, and (3) porous pisolitic diaspore. The Mojtin bauxite occurs as irregular scattered deposits in limestones of Triassic age and is overlain by Eocene conglomerates. Some of the bauxite probably formed in place as a chemical sediment or as the product of lateritization of clayey material that filled karst depressions. That part of the bauxite composed chiefly of boehmite may have been tranported (Orlov, 1939).

\section{FRANCE}

\section{History and Production}

France was the leading producer of bauxite during the early years of the aluminum industry and again during the period 1923-39. Annual bauxite production was 2 million-3.4 million tons during the period 1961-75 (table 6). Production peaked in 1972; it has declined since then because of the increasing costs of underground mining and growing imports of bauxite from Guinea, Australia, and other countries.

Bauxite is mined at several places in southern France. The mines are located in the vicinity of Villeveyrac and east of Bedarieux and elsewhere in Hérault Province (Boudrot, 1975) and near Peygros, Mazaugues, and Maron in the Brignoles region, Var Province (Vidal, 1963); and a mine has been opened near Les Baux, Bouches-du-Rhône Province (Brucy, 1973).

Most bauxite mining in France is by underground methods, but a few deposits are strip mined. Commonly the parts of deposits near the surface are stripped, the bauxite is removed, and then the underground mines are opened. In recent years, requirements for the protection of the environment have greatly increased mining costs (Brucy, 1973).

\section{Bauxite Districts and Deposits}

The principal bauxite deposits in France are in a belt in the southern part of the country, extending from near the Spanish border to within $75 \mathrm{~km}$ of the Italian border (fig. 17). The deposits and related rocks have been mapped by the Bureau de Recherches Géologiques et Minières as part of broader geologic investigations, as for example the map of the region east of Brignoles by Mennessier (1969). The bauxite districts are also shown on small-scale maps by Caillère and Pobeguin (1965, fig. 1), Nicolas (1970, fig. 2), and Combes (1970a, fig. 67). Much has been written about the geology of French bauxite deposits (see bibliographies in reports by Combes, 1970a, and Nicolas, 1970); one of the best summaries is a report by Combes and others (1974), who classify the bauxite deposits in southern France into primary and secondary types.

Secondary bauxites occur in sedimentary and displaced deposits. The sedimentary deposits consist of bauxite that formed elsewhere and was transported to and deposited at its present location. The typical sedimentary deposit is red in the lower part and grades upward through a rose- or pink-mottled zone into white bauxite (Lapparent, 1930). A few deposits are green, and some are gray where they contain minor quantities of organic matter. Most deposits are pisolitic or oolitic, some are massive, and a few are layered and brecciated. Sedimentary bauxites vary appreciably; some are uniform and high grade, but others are interbedded with clayey and ferruginous sediments. Displaced deposits have collapsed due to solution of underlying carbonate beds. They consist of mixtures of blocks of bauxite enclosed in argillite and heterogeneous brecciated material. Such deposits cannot be mined profitably underground, and some must be hand-cobbed.

The primary bauxite deposits, which occur only in the Ariege region, were formed on the north side of an elongate trench. Most of the coastal region along this trench was flat-lying lowlands characterized by littoral 
swainps and lagoons, but seacliffs were present along part of the shoreline. The bauxite formed by leaching of several types of clayey sediments transported from the central massif to the north. Some of these sediments were deposited in swainps and, therefore, occur mainly in the form of lenticular bodies. Typical deposits consist of pisolitic bauxite that is underlain by bauxitic clayey argillite. The lowermost argillite rests on linestone having karst irregularities of only about $1 \mathrm{~m}$. The upper parts of the deposits are commonly silicified and depleted in iron. In many places, a layer of lignitic clay is present between the bauxite and the overlying limestone. Most deposits are lenticular; some extend for several hundred meters, and maximum thicknesses are about $10 \mathrm{~m}$.

The bauxite deposits in France are concentrated in a zone of tectonic disturbance. In Ariège the zone consists of the North Pyrenean structural trench (Combes, 1970a). Farther east the disturbance is characterized by numerous faults and folds, which cause some of the bauxite beds to be essentially flat lying and others to be nearly vertical. Several deposits extend to depths of more than $600 \mathrm{~m}$, which is about the maximum for profitable mining, and at a few places bauxite is known to be present at much greater depths.

According to Combes and others (1974), deposits in the Villeveyrac region, Hérault, and in several districts in Var are above Upper Jurassic limestone and are overlain by Upper Cretaceous (Senonian) lacustrine limestone. Bauxite in Ariège occurs in several zones in Lower Cretaceous (Barremian and Aptian) beds (Combes, 1970a, p. 316). The rocks below the bauxite are Upper Jurassic and Lower Cretaceous carbonate beds.

The typical French bauxite deposit is principally boehmite (Caillère and Pobeguin, 1965), but some deposits in Ariège and a few other places contain appreciable quantities of diaspore, and some in Bouchesdu-Rhône and elsewhere contain a little gibbsite. Most of the silica in the bauxite is in kaolinite, and this mineral is the principal impurity of much of the subeconomic bauxite. Hematite is the most common iron mineral, and goethite occurs in a few deposits. Iron also occurs in the atomic structure of boehmite and diaspore (Caillère and Pobeguin, 1962). Calcite is a major impurity in some deposits.

The French bauxite currently mined contains $50-$ 55 percent $\mathrm{Al}_{2} \mathrm{O}_{3}$ and $5-10$ percent $\mathrm{SiO}_{2}$ (Société Aluminium Pechiney, 1975, p. 544). This bauxite, therefore, is more siliceous than much of the high-grade laterite type in tropical regions. Mercier and Noble $(1974$, p. 782$)$ listed the composition of typical French bauxite processed in alumina plants as 53.0 percent $\mathrm{Al}_{2} \mathrm{O}_{3}, 21.4$ percent $\mathrm{Fe}_{2} \mathrm{O}_{3}, 7-8$ percent total $\mathrm{SiO}_{2}$,
1.5-1.7 percent $\mathrm{CaO}, 2.6$ percent $\mathrm{TiO}_{2}, 0.3$ percent organic matter, and 13.3 percent LOI.

\section{Resources}

Bauxite resources in France consist of relatively small reserves and large subeconomic and undiscovered resources. The reserves that can be mined profitably by open-pit or underground methods were estimated by Weisse (1968, table 2) to be 50 million-70 million tons and by the Sociéte Aluminium Pechiney (1975, table 1) to be 40 million tons. The subeconomic resources consist of deposits near the surface that are too low in grade to be mined profitably, and others, including high grade deposits, that are too deep for profitable mining. Many of the deep deposits are subeconomic because they are below the water table where flooding problems are very costly to control. The total bauxite resources in France were estimated to be 240 million tons by Shaffer (1975, table 5). French geologists have told the authors that there is at least twice this ainount of subeconomic bauxite in France. This observation is similar to that of Bárdossy (1977, table 1), who listed estimates of 330 million tons for the bauxite in Provence and 200 million tons for the deposits in Languedoc. The estimate of the U.S. Bureau of Mines for the bauxite reserves in France is 30 million tons (Baumgardner and McCawley, 1983, table 3 ), and the total resources are approximately 500 million tons.

\section{GREECE}

\section{History and Production}

Bauxite has been exported from Greece for many years, and production has increased since 1965 (table 6) to keep pace with increased domestic requirements and growing exports. In recent years, most exports have been shipped to the European Economic Community and the U.S.S.R.

Eight companies mine bauxite at several localities in Greece (Industrial Minerals, 1973, p. 41). Most of the deposits mined are in the Elevsis-Mégara-Mándra and Elikón-Parnassós-Gióna-Oíti regions (fig. 17) and other districts in Stereá Ellás (Central Greece), including Dhístomon-Arákhova, Eliaon near Amfissa, Levádhia, and Voiotía.

Bauxite from the Parnassós-Giona district has been investigated for use as refractory bauxite (Mposkos, Tsalikis, and Vgenopoulos, 1978). It was found that coarse-grained refractory bauxite could be made by mixing this material with phosphate rock and calcining it at $1500^{\circ} \mathrm{C}$. 


\section{Bauxite Districts and Deposits}

Karst-type bauxite of several different ages is widely distributed in Greece. Most deposits in Stereá Ellás, which are the largest and most productive in Greece, are associated with limestone of Mesozoic age (Papastamatiou, 1964). Deposits of Mesozoic age also occur in eastern Evvoia, on the island of Amorgós (Papastamatiou, 1964), and in Thessaloníki (Tataris, 1971). Deposits on the island of Skopelos consist chiefly of clay and diaspore, and they are thought to be slightly metamorphosed. Deposits of Eocene age have been discovered in western Greece and in at least three localities in Peloponnisós. Deposits along the contact of Cretaceous and Quaternary formations have been found in the Vroderon (Florina) district.

Bauxite deposits in the Elevsis-Mégara-Mándra district are between Upper Triassic and Upper Cretaceous limestones (Papastamatiou and Maksimović, 1970). The bauxite is $8-10 \mathrm{~m}$ thick, chocolate brown, and pisolitic in texture. The principal bauxite mineral is boehmite, and diaspore is present in quantities ranging from 3 to 12 percent. Hematite is the principal impurity; minor minerals include kaolinite, goethite, and rutile; and several other minerals including chromite have been identified. The bauxite is $48-49$ percent $\mathrm{Al}_{2} \mathrm{O}_{3}$ and 33-38 percent $\mathrm{Fe}_{2} \mathrm{O}_{3}$. In addition to chromium, the deposits contain trace amounts of nickel and uranium. A red clay layer between the bauxite and the underlying limestone contains as much as 0.93 percent nickel (Papastamatiou and Maksimović, 1970), and parts of a green clay zone a few millimeters thick contain more than 20 percent $\mathrm{NiO}$ (Weisse, 1967). Because of the chromium and nickel contents in the bauxite and other evidence, sediment transported from lateritized ultramafic rocks is believed to have been the parent material of the bauxite.

The major productive bauxite districts in Stereá Ellás, other than the Elevsis-Mégara-Mándra district, are in the Elikon-Parnassós-Giona-Oiti Mountains (Aronis, 1953; Papastamatiou, 1965). Bauxite in these mountains occurs in three stratigraphic positions. The lower two, which are separated by a linestone formation, are in Upper Jurassic rocks. The upper one is in Upper Cretaceous strata. The bauxite and associated beds have been folded and faulted in several places. According to Bárdossy and Mack (1967), the most valuable bauxite deposits are in the middle and upper stratigraphic positions. The deposits in the middle position are chiefly boehmite, and the main impurities are hematite and kaolinite. The upper deposits are chiefly diaspore; small quantities of corundum are also present. The principal iron minerals in these deposits are goethite and hematite, and most of the silica present is in kaolinite. Nia $(1968,1971)$ has shown that the distribution of boehmite and diaspore is quite variable, and parts of the upper deposits are chiefly boehmite. The average composition of 30 samples of bauxite from the southern Parnassós-Elikon area (Aronis, 1955) is 57.61 percent $\mathrm{Al}_{2} \mathrm{O}_{3}, 3.05$ percent $\mathrm{SiO}_{2}, 22.80$ percent $\mathrm{Fe}_{2} \mathrm{O}_{3}, 2.75$ percent $\mathrm{TiO}_{2}$, and 12.17 percent LOI. This average composition is remarkably similar to that of the boehmite-diaspore mixed bauxite processed at the alumina plant near Dhisthomon. The bauxite processed has the following composition: 57.0 percent $\mathrm{Al}_{2} \mathrm{O}_{3}$, 22-23 percent $\mathrm{Fe}_{2} \mathrm{O}_{3}, 3$ percent $\mathrm{SiO}_{2}, 2.7$ percent $\mathrm{TiO}_{2}$, 1.0 percent $\mathrm{CaO}, 0.05$ percent organic matter, and 13.0 percent LOI (Mercier and Noble, 1974, p. 784).

Deposits of gibbsitic bauxite have been discovered in the Vroderon (Flórina) district in the western part of northern Greece (Vgenopoulos and Kanellos, 1978). The bauxite formed by the weathering of Pliocene aluminous sediment that was deposited in a graben basin (Papastavrou and Mitsaki-Hafner, 1983). The deposits occur mainly along the contact between Tertiary and Quaternary liniestones. The bauxite is light gray, yellow, and red. Gibbsite is the principal bauxite mineral, and boehmite is present in most deposits. Kaolinite occurs throughout the deposits and is abundant locally. The $\mathrm{Al}_{2} \mathrm{O}_{3}$ contents of 24 samples for which analyses were published (Vgenopoulos and Kanellos, 1978, table 1) were mostly in the 40- to 45-percent range, and two-thirds of the samples were more than 15 percent $\mathrm{SiO}_{2}$. The light-gray bauxite has been found to convert to mullite when heated to about $1500^{\circ} \mathrm{C}$ and is reported to be suitable for use in refractory products.

Vgenopoulos and Kanellos (1978, p. 934) stated that more than 200 exploration holes have been drilled in the Vroderon (Florina) district and that "huge" bauxite reserves are present. According to Dacko (1979), the preliminary estimate of the bauxite present is 100 million tons, and 25 million tons is considered proven.

According to Coumoulos (1984, table 2), of 56 percent $\mathrm{Al}_{2} \mathrm{O}_{3}$ in Parnasse bauxite 17.2 percent is in boehmite, 35.0 percent is in diaspore, and 3.8 percent is in kaolinite. The bauxite is 4.6 percent $\mathrm{SiO}_{2}$, which, except for a trace amount of quartz, is all in kaolinite. The bauxite is 21 percent $\mathrm{Fe}_{2} \mathrm{O}_{3}, 18.5$ percent in hematite and 2.5 percent in goethite.

\section{Resources}

Estimates of the amount of bauxite in Greece have increased considerably in the last few years, because of expanded exploration programs and mining of bauxite. Mack (1964, p. 233) estimated that the total measured, 
indicated, and inferred bauxite, located mainly in Steréa Ellás but including other deposits on the islands of Amorgos, Evvoia, and Skopelos, was 390 million tons. More recent estimates of the bauxite in Greece (Industrial Minerals, 1973, p. 41; Shaffer, 1975, table 5) listed 500 million tons, and Bárdossy (1977, appendix 1) listed estimates for reserves in 11 districts having a total of 484 million tons. The Sociéte Aluminium Pechiney (1975, table 1) estimated 100 million certain and probable and 500 million potential or a total of 600 million tons for Greece. A news item in Industrial Minerals (1976), noted that one Greek bauxite mining company has $\mathbf{5 8 0}$ million tons of bauxite. Stamper and Kurtz (1978, table 5) gave an estimate of more than 750 million tons for the bauxite reserves in Greece. Coumoulos' (1984, p. 758) estimate of bauxite reserves in Greece was 1 billion tons, and he considered 150 million tons to be in the measured category. In this report the bauxite reserves in Greece are assumed to be 600 million tons as estimated by the U.S. Bureau of Mines (Baumgardner and McCawley, 1983, table 3), and the total resources are 1 billion tons.

\section{HUNGARY}

\section{History and Production}

Bauxite mining began in Hungary during the First World War but was suspended from 1918 to 1922 (Bracewell, 1962, p. 149). Significant mining was not attained until 1927. Annual bauxite production was about one-half million tons in 1938, and output was doubled to supply the German aluminum industry during World War II. In the 1970's Hungary's annual production was nearly 3 million tons (table 6). Both bauxite and alumina are exported; most shipments are to the U.S.S.R. and Austria, but other European countries receive shipments. In addition to being a major producer of both metallurgical alumina and bauxite, Hungary produces considerable alumina and bauxite for nonmetal uses. Alumina is used for artificial corundum, firebrick, and glass (Huvos, 1974, p. 373), and aluminum sulfate is made, presumably from bauxite, for both domestic use and export.

The principal bauxite mines in Hungary are in the Bakony and Vértes Mountains, which are in the Transdanube region southwest of Budapest. The most productive districts in recent years are Gánt, Nyirád, Halimba, Kislőd, and Iszkaszentgyörgy (Bárdossy, 1971). Most of the mining in the Gant district has been by open-pit methods, but underground mining has been necessary in most of the other districts. Because deposits near the surface are depleted, efforts are being made to mine deeper deposits. The deeper mining creates several problems, one of which is mine dewatering. Because the bauxite is associated with carbonate rock, excessive ground-water flow is common. Hungarians have put forth considerable effort in increasing mining efficiency and in solving water problems, as is indicated by papers presented at symposia and meetings [for example, those by Kis (1971), Schmieder and Pohl (1970), and Vizy (1970)].

\section{Bauxite Districts and Deposits}

The principal bauxite deposits in Hungary are north of Lake Balaton; smaller deposits occur in the Nézsa and Naszály districts northeast of Vac and in the Nagyharsany district in the southern part of the country (Bárdossy, 1971). The major deposits north of Lake Balaton include those in the Gant, Iszkaszentgyörgy, Nyirád, Halimba, Kislőd, and Bakonyszentlászló and Fenyöfö districts. The largest deposits in Hungary are in the Halimba district (Erdélyi, 1965).

The bauxite deposits of Hungary are the karst type; they vary considerably in size and shape (Bárdossy, 1971; Barnabás, 1970). Most are lenticular pocket deposits whose size is controlled by the karst depression in which they occur. In some districts, the deposits are in grabens arranged in checkerboard fashion. Most deposits in Gánt, Iszkaszentgyörgy, and Halimba are 5-10 $\mathrm{m}$ thick, but some deposits in local deep depressions in the underlying karst surface are as much as $40 \mathrm{~m}$ thick. Of 102 lenticular deposits in the Nyirád district, 40 extend over areas of 0.1-1.0 hectares, 53 cover between 1.1 and 5.0 hectares, and 9 cover between 5 and 10 hectares.

The period of bauxite formation began in the Early Cretaceous and lasted through early Eocene time (Karoly and others, 1970). Most known deposits are in one of two stratigraphic zones. The deposits in the lower zone, such as those in the Nagyharsány district, overlie Upper Triassic to Upper Jurassic limestone. These deposits are thought to have formed in Early Cretaceous (Hauterivian and Barremian) time, as some are overlain by slightly younger Lower Cretaceous beds and some by Upper Cretaceous units. The deposits in the second zone, including those in the Nyirád, Kislöd, and Gánt districts as well as the districts northeast of Vác, are overlain by lignitic clay and limestone of Eocene age. They are thought to be of Paleocene age.

Hungarian geologists have advanced several different theories of origin for the deposits in this country. As with the explanation of the origin of karst bauxite elsewhere, there are conflicting opinions as to whether the deposits formed mainly from residual materials 
from carbonate rock or from materials from other rocks introduced into carbonate depressions. Bárdossy and Pantó (1973) found that distinctive trace minerals in bauxite deposits in the Gant district are the same as those in granites in mountains $15 \mathrm{~km}$ southeast of the district, which indicates that some of the parent materials of the bauxite came from these granites. Some deposits seem clearly to have been reworked; some of the redeposition probably occurred shortly after the bauxite formed and before it was covered by younger sediments; some redeposition also may have occurred in Miocene, Pliocene, or Quaternary time after the overlying rocks had been eroded. Some deposits have been disturbed by collapse resulting from the solution of underlying carbonate rocks long after the bauxite formed.

Hungarian bauxites are mineralogically complex and variable, and though most deposits are mainly the monohydrate type, the proportions of monohydrate and trihydrate bauxite vary considerably. In studies of the Iszkaszentgyörgy bauxite, Komlossy (1970) found that boehmite is present in all and is the dominant mineral in all but two deposits in which gibbsite is the most abundant mineral. Boehmite commonly forms $60-85$ percent of the Nyirád, Halimba, Gánt, and Nagyharsány deposits and as much as 50 percent of many other deposits (Bárdossy, 1959 , p. 4-21). Gibbsite contents range from 1 to 35 percent in the Gánt deposits and are rarely as much as 20 percent in other deposits. Most of the gibbsite occurs as submicroscopic crystals in the groundmass of the bauxite, but it also occurs as secondary nodules and crusts. Diaspore is abundant in parts of the Nézsa bauxite and forms as much as 10 percent of the Nagyharsány bauxite. Most of the iron in Hungarian bauxite is in goethite and hematite; other iron-bearing minerals, including magnetite, ilmenite, ankerite, chamosite, and nontronite, occur in minor amounts. The silica in the bauxite is chiefly in kaolin minerals, but minor amounts of quartz and traces of many detrital silicate minerals are present. The kaolin minerals are chiefly well-crystallized kaolinite, but disordered kaolinite is abundant locally, and dickite has been identified at a few places. Titanium minerals in the bauxite are chiefly rutile, anatase, and brookite.

The chemical composition of Hungarian bauxite varies considerably (Bárdossy, 1958a,b). Most deposits contain 50-60 percent $\mathrm{Al}_{2} \mathrm{O}_{3}$, but some contain as much as 76.8 percent $\mathrm{Al}_{2} \mathrm{O}_{3}$, and others are very low grade. In most deposits, $\mathrm{SiO}_{2}$ amounts to 1-5 percent. Some deposits contain almost no $\mathrm{Fe}_{2} \mathrm{O}_{3}$, and others consist of as much as 50 percent $\mathrm{Fe}_{2} \mathrm{O}_{3}$.

\section{Resources}

Several estimates of the bauxite resources in Hungary have been made. Bárdossy (1964, table 2) listed an estimate of 150 million tons for the indicated bauxite reserves in this country; Weisse (1968, table 2) estimated the total at 100 million-150 million tons. Shaffer (1975, table 5) listed 150 million tons for the total estimated reserves and potential resources. The Société Aluminum Pechiney (1975, table 1) estimate was 200 million tons certain and probable, 100 million tons potential bauxite, and 300 million tons total bauxite reserves in Hungary. In his thorough text on karst bauxites, Bárdossy (1977, table 1) listed revised estimates for several Hungarian bauxite districts, having a total of 371 million tons. In this report the reserves of bauxite in Hungary are considered to be 300 million tons, and the subeconomic and undiscovered bauxite resources are probably at least in the 50-million- to 100 -million-ton range.

\section{ITALY}

History and Production

Although Italy has many scattered bauxite deposits and a long history of mining, production has decreased steadily since 1961 (table 6), and all of the metal-grade bauxite is imported. The Gargano mine, the last major metal-grade bauxite producer in Italy, closed because of the exhaustion of economically minable high-grade ore in 1974 (Quattroclocchi, 1975, p. 492). In that year, Italy imported 1.9 million tons of bauxite from Australia, Guinea, and Yugoslavia (U.S. Bureau of Mines, 1976).

In 1977 approximately 35,000 tons of bauxite was mined (U.S. Embassy, Rome, Italy, State Department Airgram A-160, September 7, 1978, p. 6). This bauxite was used in cement and other noninetal products. All of the production since 1978 has been for nonunetallurgical uses.

\section{Bauxite Districts and Deposits}

Bauxite deposits are widely scattered through the central and southern parts (fig. 17) of the Italian mainland (Castaldo and Stampanoni, 1975, p. 132-136 and map). Most deposits are small, and few are favorably located for open-pit mining, which is the reason for the low production. The principal producing districts in past years are as follows: (1) San Giovanni Rotondo, (2) SpinazzolaAmpliamento-Cavone, (3) Casamaina-Puzzili, and (4) Palmariggi-Poggiardo-Otranto.

The bauxite deposits of central Italy are of the karst type. They occur in tabular lenses and thick fillings of narrow steep-walled karst depressions that are subconical in cross section. Most deposits in the Casamaina-Puzzili district are 50-300 $\mathrm{m}$ in lateral extent, but one deposit 
at Campo Felice has an almost continuous outcrop for more than 1,000 m (Bárdossy and others, 1977a). Deposits mined in the Spinazzola district were as much as $40 \mathrm{~m}$ thick. Most of the bauxite is associated with an unconformity between carbonate rocks of Early and Late Cretaceous age (Crescenti, 1970; d'Argenio, 1970). Deposits in the Palmariggi-Poggiardo-Otranto district in southern Italy are thought to be of Tertiary age (Crescenti and Vighi, 1964).

The mineral composition of Italian bauxite is typical of European deposits. Bárdossy and others (1977a) found that boehmite is the main bauxite mineral. Gibbsite occurs in very minor amounts, and diaspore is rare. Quartz is rare in the bauxite, and virtually all of the silica present is in clay minerals. Hematite occurs in all the red bauxite, in amounts ranging from 14 to 24 percent. Aluminous goethite is widespread, but it is not as abundant as hematite. According to Bárdossy and others $(1977 \mathrm{a}$, p. 27) the substitution of aluminum for iron in goethite ranges from 4 to 32 percent.

The 6 million tons of bauxite mined in the San Giovanni Rotondo district contained 54-60 percent $\mathrm{Al}_{2} \mathrm{O}_{3}$ and only 1.5-4.0 percent $\mathrm{SiO}_{2}$ (Castaldo and Stampanoni, 1975, p. 135). A small reserve of bauxite at D'Orsello, which is south of Casamaina, is 52.4 percent $\mathrm{Al}_{2} \mathrm{O}_{3}$, 8.5 percent $\mathrm{SiO}_{2}, 25.5$ percent $\mathrm{Fe}_{2} \mathrm{O}_{3}$, and 2.5 percent $\mathrm{TiO}_{2}$ (Weisse, 1973).

Bauxite deposits occur at several localities on Sardinia. They have been prospected in the Sassari district north of Alghero and in the Olmedo district (Stamper, Sullivan, and Trought, 1961, p. 248). Most deposits occur between limestones of Cretaceous age (Pecorini, 1956). Both pisolitic and massive types of bauxite are present in the area north of Alghero. The composition of three samples of this bauxite (Moretti, 1955, p. 464) is 53.06-65.94 percent $\mathrm{Al}_{2} \mathrm{O}_{3}, 6.64-13.14$ percent $\mathrm{SiO}_{2}$, 3.04-23.51 percent $\mathrm{Fe}_{2} \mathrm{O}_{3}, 2.97-3.35$ percent $\mathrm{TiO}_{2}$, and 13.23-15.15 percent $\mathrm{H}_{2} \mathrm{O}$.

In 1979 a mining company became active in the Nurra region in northwestern Sardinia (Ceccarini, Oggiano, and Salvadori, 1984). The bauxite occurs between the Lower and Upper Cretaceous rocks, which consist of limestone and dolomite. A typical section of the bauxite from the base upward consists of bauxitic clay, 40-50 cm thick; clayey bauxite containing oolite-like structures, 70-80 cm thick; compact bauxite with oolite and pisolite textures containing 0.8-5 percent $\mathrm{SiO}_{2}$, $100-200 \mathrm{~cm}$ thick; and pseudoconglomeratic bauxite containing 7-16 percent $\mathrm{SiO}_{2}, 0-50 \mathrm{~cm}$ thick. According to Cecarini, Oggiano, and Salvadori (1984, fig. 5), the bauxite ranges from 48 to 73 percent $\mathrm{Al}_{2} \mathrm{O}_{3}$. It is principally boehmite with minor kaolinite; iron occurs as hematite and goethite; titanium is principally in the form of anatase; and quartz is virtually absent. Bauxite resources in the Nurra district are estimated to be 50 million-70 million tons (International Bauxite Association, 1982).

\section{Resources}

According to Bárdossy and others (1977a, p. 5, 11), the bauxite resources in Italy are estimated to be approximately $\mathbf{4 5}$ million tons. The tonnage is distributed as follows: Apulia (now Puglia), which includes the San Giovanni Rotondo, Spinazzola-Ampliamento-Cavone, and Palmariggi-Poggiardo-Otranto districts-20 million; Casamaina-Puzzili and scattered smaller districts to the south and southwest-25 million. The bauxite reserves in Italy are 5 million tons, according to the estimate by the U.S. Bureau of Mines (Baumgardner and McCawley, 1983, table 3). The total resources of bauxite in this country including the recently discovered deposits in Sardinia are probably about 50 million tons.

\section{ROMANIA}

History and Production

Romania has made significant progress in expanding its bauxite mining production in the 1970's (table 6). About one-half of the country's bauxite supply is now produced domestically.

\section{Bauxite Districts and Deposits}

The principal bauxite districts in Romania are Pădurea Craiului (Apuseni Mountains), Hateg basin (South Carpathians) and Cîmpeni-Sohodol (Apuseni Mountains), Bihor. The bauxite in all three districts is of the karst or Mediterranean type. Deposits in the Pădurea Craiului district occur above Upper Jurassic beds and are overlain by freshwater chalks (Papiu, Minzatu, and Iosof, 1970b, p. 241). Those in the CimpeniSohodol district are in formations of Late Cretaceous (Santonian) age (Papiu and others, 1975). The deposits in the Hateg basin are of Early Cretaceous (late Aptian) age. They rest on older Mesozoic limestones and are overlain by clayey detrital deposits of Late Cretaceous (Cenomanian) age (Papiu and others, 1971). According to Papiu and others (1970), the bauxite in Pàdurea Craiului district, which is one of the principal centers of bauxite mining in Romania, is 54-62 percent diaspore, 15-17 percent kaolinite, 11-29 percent hematite, and 2.2-3.5 percent rutile and anatase, but 
deposits in part of this district may contain considerable boehmite (Papiu, Minzatu, and Iosof, 1970a). Bauxite deposits in the Hateg basin and Cimpeni-Sohodol districts are mainly boehmite (Papiu and others, 1975, 1971). Most of the bauxite is high in iron content (table 20); hematite is the principal iron mineral, but goethite, leptochlorite, siderite, and pyrite are also present in most deposits. Kaolinite is the major silicabearing mineral, and apparently some deposits contain so much of it that they have little value. Most of the $\mathrm{TiO}_{2}$ in the bauxite is in anatase, but rutile is also present. The average alumina content of the deposits in the three major districts is about 50 percent (table 20).

TABLE 20.-Chemical composition of Romanian bauxite from three districts

[Modified from Papiu and Udrescu (1973, tables 3 and 4). Major-oxide contents given in percent; minor elements given in parts per million]

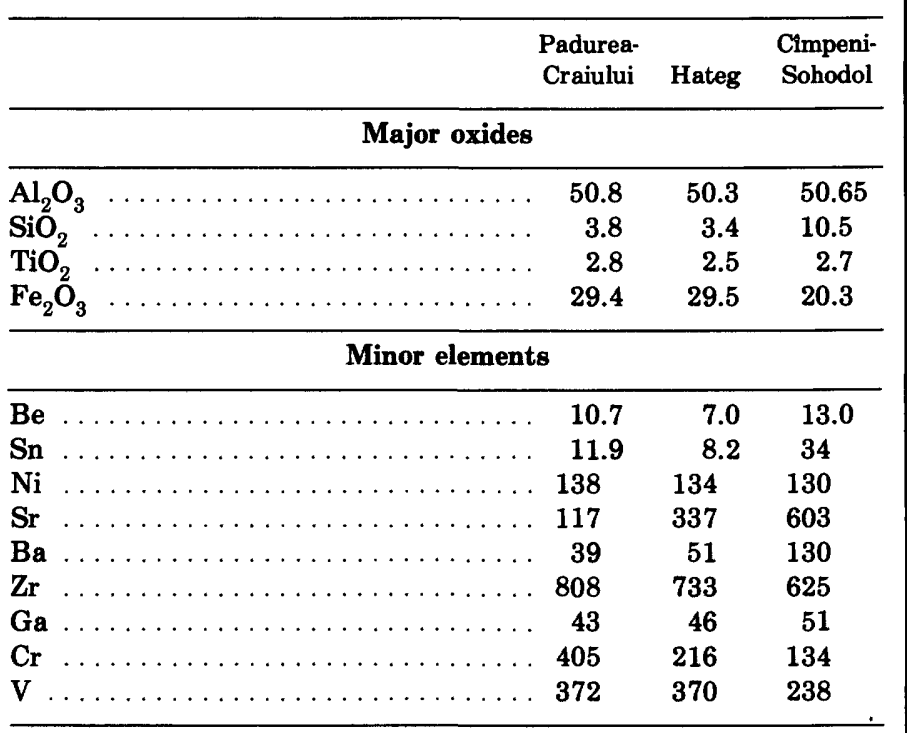

Resources

The total reserves of bauxite in Romania are assumed to be $\mathbf{5 0}$ million tons, which is the total of the certain and probable categories published by the Société Aluminium Pechiney (1975, table 1). Additional subeconomic deposits must be present, but the authors have found no estimates for such deposits.

\section{SPAIN}

\section{History and Production}

The small tonnages of bauxite produced in Spain are used in nonmetallic products; however, efforts have been made to find domestic deposits that will make the nation less dependent on imports for aluminum raw materials (Corrick, 1974, p. 743). The annual production in recent years has been approximately 15,000 tons, and the bauxite is used in refractories and aluminous cement. Most of the mining is in the Sierra de Montroig and Alós de Balaguer areas near Lerida and the Cañada de Verich, Valderrobres, and La Ginebrosa areas near Teruel.

\section{Bauxite Districts and Deposits}

The principal bauxite deposits in Spain are located in the northeastern part of the country, and small deposits are present in the southeastern and northwestern regions. The deposits in the northeastern region (Closas Miralles, 1954; Cabellero, Menendez Del Valle, and Martin Vivaldi, 1974) are located as follows: (1) northeast of Lerida, (2) in the coastal area of Catalonia between Barcelona and Tarragona, and (3) in the Ebro area northeast of Teruel. The small deposits are located between Albacete and Murcia in the southeastern region and near León in northwestern Spain.

The clayey bauxite deposits in northeastern Spain are of the karst or Mediterranean type. Most deposits are discontinuous stratiform bodies occurring above irregular surfaces on Jurassic limestone and overlain by beds of Cretaceous age. Combes (1970a) found that the Spanish bauxites are quite similar to those in southern France. He concluded that the deposits formed in Early Cretaceous (Barremian to Albian) time from clayey sediments deposited in narrow marine lagoons and lakes. Galan, Lopez Aguayo, and de Aza (1977) believed that these bauxitic clays formed by lateritic weathering of clayey sediments that accumulated in karst depressions developed on carbonate rock. Galan (written commun., 1979) thought that most of the bauxitic clays formed during Cretaceous time in low, flat terrain near a shoreline. He recognized three intervals of bauxite formationtwo in the Cretaceous Period, during the BarremianAptian transition, and one in Paleocene time. Deposits of the three ages are rarely present at the same locality.

The small deposits at Portilla de Luna near León were described by Font-Altaba and Closas Miralles (1960) as being of Devonian age and were therefore thought to be the oldest deposits in Europe. However, recent investigations have established that this so-called bauxite consists of minor weathering products of shales that formed in a much younger period (Bárdossy and Fontboté, 1977).

According to Cabellero, Menendez del Valle, and Martin Vivaldi (1974), the principal bauxite mineral in Spanish deposits is boehmite; however, Galan, Lopez 
Aguayo, and de Aza (1977) found deposits northeast of Teruel to be rich in gibbsite. Virtually all the bauxite contains considerable quantities of kaolinite. Other minerals present include hematite, goethite, and anatase. $\mathrm{Al}_{2} \mathrm{O}_{3}$ contents of the bauxite range from 30 to 60 percent.

\section{Resources}

Bauxite resources in Spain have been inadequately investigated, and only a few resource estimates have been made. According to a metallogenic map prepared by the Spanish National Program of Mining (Spain Instituto Geologíco y Minero, 1972), the total probable bauxite reserves in Spain are 62.27 million tons. Most of the probable reserves are in the districts near Tarragona and Teruel. Only a very few million tons, mainly in the Sierra de Montroig and Alós de Balaguer areas, Lerida, have been proved. An estimate of 100 million tons (Shaffer, 1975, table 5) and one of 150 million tons (Corrick, 1974, p. 743) for the total bauxite resources in Spain have also been made. Considering the present limitations on the knowledge of bauxite resources in Spain, the authors have listed the total at 100 million-150 million tons (table 11). All these resources are classed in the subeconomic category, except for 5 million tons considered to be reserves by the U.S. Bureau of Mines (Baumgardner and McCawley, 1983, table 3).

\section{UNITED KINGDOM}

\section{History and Production}

Low-grade bauxite in Northern Ireland has been mined intermittently over a long period. This bauxite was first mined in 1873 for use in refractory brick, alum, and quick-setting cement (Bracewell, 1962, p. 84). In 1894 the British Aluminium Company began to use this bauxite for the manufacture of alumina. The total bauxite mined from 1882 to 1915 was 292,626 tons. During World War I, the output increased to a maximum of 14,724 tons in 1917. Mining decreased after that war and ceased in 1934. Mining was again active between 1941 and 1945 when about 300,000 tons was produced to help supply World War II needs. Since 1945, Ghana has been the principal source of bauxite used in the United Kingdom. Diaspore clays from the Ayrshire district, Scotland, have been used in the manufacture of alum and refractories (Bracewell and Healing, 1963).

\section{Bauxite Districts and Deposits}

Northern Ireland.-Bauxite deposits occur in the County of Antrim and in the Coleraine area in adjoining parts of the County of Londonderry. The deposits are in a region of basaltic rocks and are associated with lateritic iron ores of late Miocene or early Pliocene age. Several similarities between the bauxites in Ireland and those in Oregon were noted by V.T. Allen (1960, p. 231). The chief difference between the two is that Oregon deposits are near the surface whereas Irish deposits, formed during "interbasaltic intervals," are overlain by younger basalt accumulations. The rocks of two "interbasaltic intervals" occur in the northern part of the region; the rocks of only one are present in the southern part (E.M. Patterson, 1955). The deposits associated with the bauxite include lignite, pisolitic iron ore, clays, basaltic lithomarge (saprolite formed from basalt), and weathered rhyolitic debris. Most of the bauxite deposits that were mined were $0.6-1.7 \mathrm{~m}$ thick. Three types of aluminous laterites or bauxites are present (Eyles and others, 1952 , p. 5): (1) highly ferruginous red bauxite formed from basalt and commonly containing 20-30 percent $\mathrm{Fe}_{2} \mathrm{O}_{3}$ and 5-10 percent $\mathrm{SiO}_{2}$; (2) siliceous gray bauxite formed mostly from rhyolitic debris and commonly containing $5-10$ percent $\mathrm{Fe}_{2} \mathrm{O}_{3}$ and $20-40$ percent $\mathrm{SiO}_{2}$; and (3) bauxites of mixed origin, which have formed from both basalt and rhyolitic material and are intermediate in composition between the first two types.

Gibbsite is the most common bauxite mineral present (Eyles and others, 1952, p. 39). Boehmite is common in parts of deposits near basalt dikes, and corundum was identified in one sample collected $15 \mathrm{~cm}$ from a dike. Hematite is the principal iron-oxide mineral in all three types of bauxite; minor amounts of goethite, magnetite, maghemite, and ilmenite are also present (Eyles and others, 1952 , p. 39-42), and spherulites of a mineral having the optical properties of siderite were recognized by V.T. Allen (1960, p. 230). Titanium-bearing minerals in the bauxite and weathered basalt include anatase, brookite, rutile, and ilmenite. The most common clay minerals are kaolinite and halloysite, and a clay mineral that is probably of the chlorite type is also present (Eyles and others, 1952, p. 38, 50-51). The composition of 19 samples of bauxite from the Skerry, Lyles Hill, and Ballynabanish mines (Eyles and others, 1952, p. 63, 66) is 28.70-53.09 percent $\mathrm{Al}_{2} \mathrm{O}_{3}, 1.58-12.12$ percent $\mathrm{SiO}_{2}$, 17.85-32.30 percent $\mathrm{Fe}_{2} \mathrm{O}_{3}, 2.31-5.20$ percent $\mathrm{TiO}_{2}$, and 13.54-27.70 percent LOI.

Scotland.-The Ayrshire high-alumina clay occurs along the west coast of Scotland in a belt extending about $19 \mathrm{~km}$ from Saltcoats eastward to Kilwinning and at other places as far south as Stranraer. In most places, the clay rests on mafic lava flows and is overlain by the lowest coal bed of the Coal Measures. The clay is in a discontinuous and lenticular bed, and deposits range from a few centimeters to nearly $10 \mathrm{~m}$ in thickness and from about $10 \mathrm{~m}$ to several hundred meters in lateral 
extent. Boehmite and diaspore occurring in pisolites and oolites were found in samples of the clay from one locality (Lapparent, 1936), but the clay now mined at other localities contains neither of these minerals. Some of the clay taken from the early mines was reported to be as much as 60 percent $\mathrm{Al}_{2} \mathrm{O}_{3}$ (Wilson, 1922, p. 9).

\section{Resources}

According to one estimate (Daniels and Derbyshire, 1959), the amount of bauxite in Northern Ireland containing about 10 percent $\mathrm{SiO}_{2}$ and 45 percent $\mathrm{Al}_{2} \mathrm{O}_{3}$ is approximately 2.5 million-3 million tons. This bauxite should be considered as resources because it is in thin deposits that must be mined by underground methods and cannot compete with imported bauxite in peacetime. No estimates of the amount of the high-alumina clay in Scotland are available.

\section{U.S.S.R., INCLUDING SOVIET ASIA}

\section{History and Production}

Bauxite for use in making aluminum was first mined in the U.S.S.R. in 1931, and in recent years bauxite production has been 4 million-4.6 million tons annually (table 6). The Northern Urals region has long been the leader in bauxite mining in the Soviet Union (U.S. Bureau of Mines, Mineral Yearbooks; Sutulov, 1973, p. 146-152). Kazakhstan is second in bauxite production, and bauxite is also mined in the West Urals, the Tikhvin district, near Savinska on the Onega River, and elsewhere. Most of the mining in the Urals region is by underground methods, but open-pit methods are used in Kazakhstan, the Onega district, and elsewhere. According to Stankovich (1978), about 40 percent of the aluminum produced in the U.S.S.R. is made from imported bauxite and alumina. Many of the bauxite deposits mined in the U.S.S.R are high-silica varieties, and because of the high silica content a combined Bayersinter process is used in several alumina plants (Prokopov and Malts, 1974). Notwithstanding efforts to increase mine production in several districts, the U.S.S.R. finds it necessary to import substantial quantities of both alumina and high-grade bauxite (Levine, 1983, table 7).

The U.S.S.R. leads the world in the use of nonbauxite ores for aluminum. The nonbauxite materials used for aluminum are nepheline syenite and alunite. Nepheline syenite is mined in the Kirovsk district on the Kola Peninsula and the Kiya-Shaltyr' (Belogorsk) area on the border of Krasnoyarskiy Kray and Kemerovskaya
Oblast'. The alunite is mined in the Zaglik district near Yervan, which is located in Azerbaijan, a few kilometers north of the Turkish border between the Black and Caspian Seas.

\section{Bauxite Districts and Deposits}

Bauxite occurs at many places in the U.S.S.R. As shown on the bauxite map of the U.S.S.R. and described in the accompanying text (Sidorenko, 1973), the principal districts are in the following regions: Altai-Sayan, Urals, Timan, Tikhvin-Onega, Voronezh, Central Asia, Turgay, Central Kazakhstan, Yenisey, and Ukrame (fig. 18). According to Sidorenko (1973) and Bushinskiy $(1975$, p. 349-364), bauxite in the U.S.S.R. formed in several different geologic time intervals and occurs in rocks of the following ages: (1) Proterozoic and Early Cambrian, (2) Ordovician(?), (3) Devonian, (4) Carboniferous, (5) Triassic and Jurassic, and (6) Cretaceous and Paleocene. Most of the large deposits mined are of Devonian, Early ${ }^{4}$ Carboniferous, or Cretaceous and Paleocene age. The highest quality bauxite in U.S.S.R. is of the karst type filling shallow depressions in carbonate rock. The bauxite deposits in Ordovician rocks were discovered recently, but whether deposits of the grade and size required for mining exist is yet to be determined.

Since a symposium on the mineralogy and genesis of bauxite (Strakhov and Bushinskiy, 1958), in which 26 papers were presented, most Soviet geologists accept the theory that bauxite formed by the deposition of alumina from weathering zones in sedimentary basins. U.S.S.R. bauxite deposits are assigned to two types (Bushinskiy, 1967), the platform type and the geosynclinal type. Deposits of the platform type are associated with carbonate and aluminum-silicate rocks. The geosynclinal type occurs along the margins of intrageosynclinal arches, the cores of which contain igneous rocks or shales. Both types ordinarily occur in karst depressions.

To aid in alleviating the shortage of aluminum raw materials, many geologists continue to search for ores for the expanding Soviet aluminum industry. The bauxite map of the U.S.S.R. (Sidorenko, 1973), which includes the work of many authors and compilers, summarizes the geology of Soviet bauxite and is intended to aid in the search for more deposits. G.I. Bushinskiy's volume (1975) contributes materially to the knowledge of bauxite in the Soviet Union as well as of deposits elsewhere in the world. The bauxite

\footnotetext{
"The terms "Early Carboniferous," "Lower Carboniferous," and "Middle
} Carboniferous," used in this section, are Soviet nomenclature. 

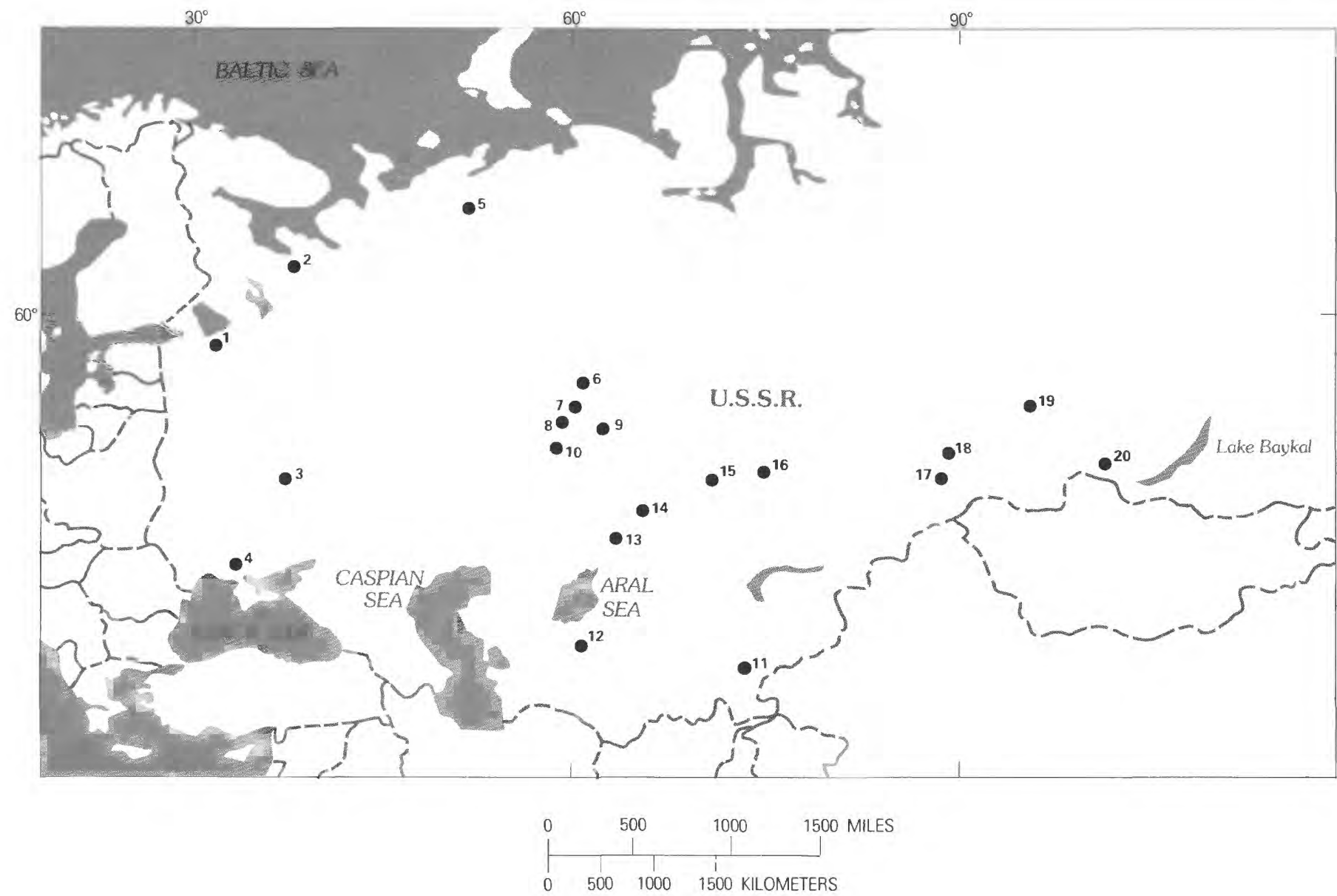

EXPLANATION

- Bauxite district
1. Tikhvin
2. Onega
3. Voronezh
4. Ingulets-Dneprousk, Ukraine
5. Timan
6. Cheremukhovo, Urals
7. Karpinsk, Urals
8. Krasnaya Shapochka, Urals
9. Kamensk-Ural'skiy, Urals
10. Novaya Pristan', Urals

Novaya Pristan', Urals
11. Fergana, Central Asia
12. Kyzylkum, Central Asia
13. Turgay
14. Amangel'dy, Kazakhstan
15. Tselinograd, Kazakhstan
16. Ekibastuzsk, Kazakhstan
17. Kuznets. Altai-Sayan
18. Salair Range, Altai-Sayan
19. Yenisey
20. East Sayan, Altai-Sayan

FIGURE 18.-Locations of bauxite districts in the U.S.S.R.

literature is replete with hundreds of scientific papers that have been published by the Soviets since the last review of world aluminum resources (S.H. Patterson, 1967). Most of these publications deal only with minor new discoveries or with additions to the knowledge about previously known deposits. In addition to investigations of bauxite, Soviet geologists have continued studies of other sources of aluminum.

Altai-Sayan.-The Altai-Sayan bauxite region is in an area of folded rocks on the southern rim of the Siberian platform (Sidorenko, 1973, p. 12-14). Bauxite in this region is mainly in the East Sayan Mountains and Kuznets districts. Scattered deposits have been found in the Salair Range elsewhere. Some of the deposits in the Salair Range are associated with limestone formations of Late Silurian to Middle Devonian age. The East Sayan deposits are in carbonate sedimentary rocks of the Late Proterozoic Bokson Series. The average 
thickness of the ore layers, which include bauxite and a variegated argillaceous schist overlying it, is $4.5 \mathrm{~m}$, but these layers are 20-30 $\mathrm{m}$ thick in places. Diaspore and boehmite are the bauxite minerals. The bauxite is low grade, according to Sidorenko $(1973$, p. 13); it contains only 37 percent $\mathrm{Al}_{2} \mathrm{O}_{3}$ and 23 percent $\mathrm{SiO}_{2}$. Deposits have been traced for tens of kilometers, and reserves are described as being substantial. The Kuznets district is a large area where several scattered bauxite deposits have been found, and it is considered favorable for the discovery of more deposits (Sidorenko, 1973, p. 14). Apparently the best deposit found to date is the Lespromkhoz bauxite in the Tel'bes River valley. This bauxite consists of diaspore, corundum, chloritoid, spinel, and other minerals and is $30-50$ percent $\mathrm{Al}_{2} \mathrm{O}_{3}$.

Central Asia.-Many scattered bauxite occurrences have been found in the mountainous region of Central Asia (Sidorenko, 1973, p. 32-33). The deposits extend a considerable distance from the Fergana region on the east to central Kyzylkum on the west. The bauxite is in the upper part of a group of carbonate units of Devonian and Early and Middle Carboniferous age. Deposits in the Fergana region are as much as $\mathbf{1 5} \mathrm{m}$ thick, and some extend $120 \mathrm{~m}$ laterally (Abdullayev, 1968). The bauxite is chiefly the monohydrate type. A few deposits are mainly diaspore, others are mixtures of diaspore and boehmite, and some are mainly boehmite. Kaolinite is the principal mineral impurity in many deposits. The deposits range considerably in composition, as indicated by the following analyses (Sidorenko, 1973, p. 33): 20-50 percent $\mathrm{Al}_{2} \mathrm{O}_{3}, 10-30$ percent $\mathrm{SiO}_{2}$, and $10-60$ percent $\mathrm{Fe}_{2} \mathrm{O}_{3}$ and $\mathrm{FeO}$. Bauxites of Triassic and Jurassic age are known in at least three districts in Central Asia (Sidorenko, 1973, p. 37-39). They apparently have formed from several different types of sedimentary and volcanic rocks, and the deposits vary considerably in composition. Occurrences of bauxite of Early Cretaceous and Cretaceous to Paleocene age have also been found in Central Asia (Sidorenko, 1973, p. 49-50). Most of this bauxite is low grade. No deposits of significant economic value have been found to date, but Soviet geologists consider this area favorable for bauxite discoveries.

Central Kazakhstan.-The principal bauxite deposits occur in the following three districts: Amangel'dy, Tselinograd, and Ekibastuzsk. Small deposits are also known to occur at several scattered localities. The Amangel'dy district contains the largest reserves and is apparently the most active bauxite-producing area in Kazakhstan. The bauxite occurs in sandy and shaly sedimentary rocks overlying much older carbonate beds, and the bauxite deposits are restricted to karst basins and valleys developed on the carbonate units. Soviet geologists disagree as to the time of bauxite formation (Sidorenko, 1973); some think it was Paleocene and early Eocene, others Late Cretaceous, and one believes Early Cretaceous. The bauxite is all gibbsitic, and deposits consist of layers of clayey and stony bauxite and refractory kaolinitic clay. Thicknesses of deposits range from 10 to $70 \mathrm{~m}$, and the areal extent of deposits ranges from a few square meters to as much as $2 \mathrm{~km}^{2}$. The average partial composition of the bauxite is 12 percent $\mathrm{SiO}_{2}, 47$ percent $\mathrm{Al}_{2} \mathrm{O}_{3}$, and 12.5 percent $\mathrm{Fe}_{2} \mathrm{O}_{3}$. Bauxite occurs in many scattered deposits in the Tselinograd and Ekibastuzsk districts (Sidorenko, 1973). The deposits are in a weathered crust, commonly tens of meters thick, developed mainly on carbonate rocks but also locally on intrusive rocks. Palynological data indicate that the deposits are of Late Cretaceous and possibly Paleocene age. Gibbsite is the principal bauxite mineral in all deposits. Large deposits of kaolinitic clays are associated with the bauxite, particularly the deposits on intrusive rocks.

Timan.-Bauxite deposits of Devonian and Early Carboniferous age occur in the Timan region (Sidorenko, 1973 , p. 21-23, 28-30). The Devonian deposits are on the northwest limb of a horst-anticline. The parent material is thought to have been Proterozoic schists and younger volcanic materials. Thicknesses of bauxite range from 1 to $25 \mathrm{~m}$. Most of the bauxite is dense, but some is spongy and fragmental (presumably brecciated). The bauxite minerals are diaspore and boehmite, and the major impurities include goethite and chamosite. Gibbsite, which is ordinarily rare in Paleozoic deposits, also occurs in some deposits (Demina, Gulyayev, and Kolokol'tsev, 1970). The best parts of the deposits contain 4-8 percent $\mathrm{SiO}_{2}$ and $48-53$ percent $\mathrm{Al}_{2} \mathrm{O}_{3}$, and the average partial composition of deposits in this region is 44-46 percent $\mathrm{Al}_{2} \mathrm{O}_{3}, 8-10$ percent $\mathrm{SiO}_{2}$, and 27-30 percent $\mathrm{Fe}_{2} \mathrm{O}_{3}$. The Lower Carboniferous deposits are mainly in the southern part of the Timan region. Most of these deposits are of lower grade than the Devonian bauxite, and they have not been fully explored.

Tikhvin-Onega province.-This province is on the northwest side of the Moscow basin, where the rocks overlap onto the eastern flank of the Baltic Shield. Most of the bauxite deposits are associated with watertransported sandy and shaly rocks containing brown coal and kaolinitic beds (Sidorenko, 1973, p. 25). These deposits and associated beds are of Early Carboniferous age. Soviet geologists have concluded that a tropical climate existed in this region at the time the bauxite formed (Grayzer and others, 1976). The bauxite minerals apparently formed by tropical weathering and were deposited in a swampy or lagoonal environment. The Tikhvin district is near Boksitogorsk, east of Leningrad. The bauxite deposits are associated with aluminous 
clays that occur along an erosional unconformity between rocks of Devonian and Early Carboniferous age. Most of this bauxite consists of pebbles or pellets enclosed by fine-grained interstitial material. The coarse particles are chiefly boehmite, but they also contain diaspore and corundum (Gladkovsky and Ushatinsky, 1964 , p. 154). The interstitial material is chiefly kaolinitic clay, but some secondary gibbsite is also present. The principal oxides in the bauxite (Sidorenko, 1973, p. 26) range within the following limits: 10.5-16.9 percent $\mathrm{SiO}_{2}, 37.7-50.3$ percent $\mathrm{Al}_{2} \mathrm{O}_{3}, 4.5-21.1$ percent $\mathrm{Fe}_{2} \mathrm{O}_{3}, 1.6-6.3$ percent $\mathrm{TiO}_{2}$, and 0.7-9.0 percent $\mathrm{CaO}$. According to an old estimate, the Tikhvin district contains 8.3 million tons of bauxite, including some bauxitic clays. However, considerable mining has been done since that estimate was made, and the results of recent exploration in the district are not available. The bauxite deposits in the Onega district are located mainly in the Onega River valley north of Tikhvin. Most deposits in the region are similar to those in the Tikhvin district, but bauxite in an ancient weathering zone on diabase and diabase porphyry is also present. This bauxite is thought to have been formed by tropical weathering in Late Devonian time (Trubina, 1958a). The better grades of bauxite in the northern part of the Onega district contain 52-54 percent $\mathrm{Al}_{2} \mathrm{O}_{3}, 16-19$ percent $\mathrm{SiO}_{2}$, and as much as 29 percent $\mathrm{Fe}_{2} \mathrm{O}_{3}$ (Sidorenko, 1973, p. 26).

Soviet geologists have found shows of bauxite in a few places between the Tikhvin and Onega districts. They regard this area as favorable for finding more deposits (Sidorenko, 1973; Grayzer and others, 1976).

Turgay.-Bauxite deposits in Albian-CenomanianTuronian (Lower and Upper Cretaceous) beds overlying the Paleozoic basement are present at several places in the broad Turgay basin (Kim, 1970). The deposits are in isolated bodies containing from a few hundred thousand to millions of tons of bauxite (Sidorenko, 1973, p. 40-43). Deposits of bauxite along the western limb of the Turgay depression are of the karst type and represent a continuation of the bauxite belt of the Central Urals (Kuzemkina, 1960). Pisolites in this bauxite range in size from 2 to $22 \mathrm{~mm}$. Unaltered pisolites, investigated by X-ray methods, contain hematite, magnetite, corundum, siderite, pyrite, gibbsite, titanium minerals, and quartz. The corundum occurs in the central parts of the pisolites, and the outer parts are chiefly gibbsite. Kuzemkina believed that the corundum formed in place, because it occurs only in pisolites and no corundum is present in the cementing materials enclosing the pisolites or in the nonpisolitic bauxite. Bauxite deposits in the Turgay region vary appreciably in composition, but the following range is typical of many deposits: 412 percent $\mathrm{SiO}_{2}, 40-55$ percent $\mathrm{Al}_{2} \mathrm{O}_{3}, 7-30$ percent $\mathrm{Fe}_{2} \mathrm{O}_{3}$.
Ukraine.-Bauxite occurs at several places on the Ukrainian Shield in southern Ukraine (Sidorenko, 1973; Bass, 1958). The largest deposits are in the InguletsDneprovsk district in the eastern part of the shield area. Some of the bauxite is residual in weathered parts of Proterozoic amphibolite and schist. Other deposits have been transported and are associated with clay-rich sedimentary beds of middle Eocene age. Textures of the bauxite range from relict features of the parent rock to brecciated, pisolitic, and clayey materials. The bauxite minerals are mainly gibbsite and small quantities of boehmite. All the bauxite is reported to contain abundant iron in the form of hematite and goethite, and kaolinite, quartz, and ilmenite minerals are abundant in some deposits. The average composition of the bauxite is 8 percent $\mathrm{SiO}_{2}, 38$ percent $\mathrm{Al}_{2} \mathrm{O}_{3}$, and 29 percent $\mathrm{Fe}_{2} \mathrm{O}_{3}$. According to one report (Wilmot, Sullivan, and Trought, 1958, p. 236), deposits in the vicinity of the village of Shestunia near Dneprovsk contain about 20 million tons of bauxite.

Urals.-Bauxite occurs in many districts scattered through the Urals region, which extends more than $1,000 \mathrm{~km}$ from Ivdel' on the north to near Orsk in the southern part of the mountain chain (Sidorenko, 1973, p. 17-20). Deposits of Devonian, Carboniferous, Triassic and Jurassic, and Cretaceous and Paleocene ages are present. The best grade deposits are of Devonian age. The principal districts include Karpinsk, KamenskUral'skiy, Krasnaya Shapoclıka (Red Cap), Cheremukhovo, and others in the East Urals and Novaya Pristan' in the West Urals. Four bauxite zones have been found in Devonian carbonate rocks in the East Urals. The lower, which is of Middle Devonian age, is the principal one mined in Krasnaya Shapoclıka, Cheremukhovo, and other districts. This bauxite is of the monohydrate type and occurs in reddish-brown, dense, earthy rock that is $60-80$ percent fine-grained diaspore. Boehmite is ordinarily only a minor constituent, but this mineral, together with pyrite and siderite, is abundant in the upper part of some deposits. Hematite is present in substantial amounts in most of the deposits, and other minerals present include kaolinite and leptochlorite. According to Sidorenko (1973, p. 19), the bauxite mined has the following ranges of composition: $3.2-6.5$ percent $\mathrm{SiO}_{2}, 46.4-59.4$ percent $\mathrm{Al}_{2} \mathrm{O}_{3}, 16.1-24.2$ percent $\mathrm{Fe}_{2} \mathrm{O}_{3}$, and 2.8-3.0 percent $\mathrm{TiO}_{2}$. In the West Urals, two bauxite zones are present, but only one, which is of Late Devonian age, contains significant minable deposits. Most of this bauxite is reddish brown and stony, but some is brecciated, and the lower parts of deposits are commonly pisolitic. The Novaya Pristan' deposits are the most valuable ones in this region. Soviet geologists (Kolesnikov, Nevzorova, and Shishakov, 1972) recognize the following types of bauxite in this group: (1) red karst 
bauxite of continental origin, (2) gray bauxite thought to have been deposited in a marine environment, and (3) mottled bauxite formed by leaching of the gray bauxite material. At places the upper parts of deposits are interlayered with marl containing plant inipressions and a few thin coal lenses. The bauxite is of diasporeboehmite composition and according to Sidorenko $(1973$, p. 20) has the average composition of 9.3 percent $\mathrm{SiO}_{2}, 48.8$ percent $\mathrm{Al}_{2} \mathrm{O}_{3}, 21.3$ percent $\mathrm{Fe}_{2} \mathrm{O}_{3}$, and 4.6 percent $\mathrm{CaO}$. It is therefore somewhat lower in grade than the bauxite in the East Urals.

Voronezh.-The Voronezh bauxite deposits are in the Belograd iron-ore region. The bauxite is of Carboniferous age, and it is covered by younger strata 400-700 m thick (Sidorenko, 1973, p. 27-29). The bauxite formed on phyllite and schist consisting mainly of quartz, sericite, biotite, and chlorite (Nikitina and Zvyagin, 1973). These authors believed the micaceous minerals altered to kaolinite by leaching and hydrolysis, and kaolinite was further weathered to form gibbsite. Gibbsite was presumably changed to monohydrate minerals by diagenesis after burial. The bauxite is 8-12 percent $\mathrm{SiO}_{2}, 30-52$ percent $\mathrm{Al}_{2} \mathrm{O}_{3}$, and as much as 30 percent $\mathrm{Fe}_{2} \mathrm{O}_{3}$. Considerable quantities of bauxite at depths of $500 \mathrm{~m}$ or more are thought to be present.

Yenisey.-Low-grade bauxite deposits have been found in karst depressions in a few places in the Yenisey region. Most geologists believe this bauxite is of Paleocene and Eocene age, but its formation may have begun in the Cretaceous. The bauxite is gibbsitic and is mixed with variegated kaolinitic clays and ironbearing minerals. Most bauxite bodies are lenticular, and maximum thicknesses range from a few meters to $40 \mathrm{~m}$. The partial chemical composition of the bauxite in the Yenisey range is 6-9.5 percent $\mathrm{SiO}_{2}, 37-39$ percent $\mathrm{Al}_{2} \mathrm{O}_{3}, 26-34$ percent $\mathrm{Fe}_{2} \mathrm{O}_{3}$, and 4-4.5 percent $\mathrm{TiO}_{2}$.

\section{Resources}

Estimates of the total bauxite resources in the U.S.S.R. are not available; however, the many occurrences in rocks of several different geologic ages as shown on a recent map of bauxite resources (Sidorenko, 1973) make it clear that the total resources are very large. Many of these resources are of low grade, and most of them apparently occur in large quantities only at considerable depths, and they are therefore of little value. One of the few published estimates of bauxite resources in the U.S.S.R. was by Bárdossy $(1977$, table 1), who listed the following figures, in millions of tons, for karst bauxite in the three principal producing regions: Turgay-Hateg-270, North Urals-220, and
Central Kazakhstan-190. The total in these three regions is 680 million tons. In the appendix of this same report, Bárdossy listed the estimates for these three regions and estimates for eight more regions where apparently no bauxite is mined. The total of the estiniates for all 11 regions is 994 million tons. Strishkov (1976, p. 483) estimated that the bauxite reserves in the U.S.S.R. suitable for Bayer plant processing are approximately 250 million tons, of which about 65 million tons is considered proved. The authors of this report are arbitrarily considering the bauxite reserves in the U.S.S.R. to be approximately 300 million tons, and the total resources (reserves and subeconomic and undiscovered bauxite) are thought to be 600 million-700 million tons.

\section{WEST GERMANY}

Small bauxite deposits in red soil occur at several localities on the slopes of the Vogelsberg Mountains in Hessen. Small tonnages of bauxite have been produced from these deposits intermittently since the turn of the century for use in chemicals and abrasives. Production was 3,900 tons in 1965 and dropped to 800 tons in 1975 (Metallgesellschaft AG., 1976, p. 12). West Germany relies on imported bauxite to supply its alumina industry.

The Vogelsberg bauxite was thought to have formed by the weathering of basaltic lavas and tuffs in Pliocene tine (Harrassowitz, 1922). Schellmann (1966) confirmed that the weathering-in-place explanation was correct when he found and described exposures showing that the bauxite and associated red soil grade downward into kaolinized basalt. Schellman also noted that the deposits are similar to other laterite-type bauxites on basalt, except that quartz was deposited during weathering in the Vogelsberg area. Gibbsite is the principal bauxite mineral. The bauxite nodules, which presumably are representative of the grade beneficiated and used, have the following composition: 52.9-53.6 percent $\mathrm{Al}_{2} \mathrm{O}_{3}, 3.02-3.44$ percent $\mathrm{SiO}_{2}, 9.67-10.3$ percent $\mathrm{Fe}_{2} \mathrm{O}_{3}, 2.19-3.54$ percent $\mathrm{TiO}_{2}$, and 27.5-27.8 percent $\mathrm{H}_{2} \mathrm{O}$. According to the U.S. Bureau of Mines estimate (Baumgardner and McCawley, 1983, table 3), the bauxite reserves in West Germany are 2 million tons.

\section{YUGOSLAVIA}

\section{History and Production}

Bauxite has been mined in Yugoslavia since before 1920; however, annual production did not surpass 1 
million tons until 1960. According to the International Bauxite Association (1978b), bauxite is mined in the following districts and regions (fig. 17): Vlasenica, Mostar, and Jace in Bosnia-Hercegovina; Rovinj, Istria; Drniš, Dalmatian coast of Croatia; Nikšic, Montenegro; Podlipa-Borovnica, Slovenia; Pristina, Kosovo; and Kruševo, Macedonia. The production in 1978 was approximately 2.5 million tons (table 6), and it increased to 3.7 million tons in 1982 . Virtually all of this output was used in domestic alumina plants. The increases are part of a major change in the trend in Yugoslavia's aluminum industry. In 1972 only 17.5 percent of the bauxite mined was consumed domestically, and the rest was exported. In 1976, exports were reduced to 51.4 percent of production.

The composition of bauxite in Yugoslavia varies considerably. According to the Sociéte Aluminium Pechiney (1975, p. 544), most Yugoslav metal-grade bauxite is 53-55 percent $\mathrm{Al}_{2} \mathrm{O}_{3}$ and 5-6 percent $\mathrm{SiO}_{2}$. However, the domestic boehmite bauxite processed at the alumina plants built by Aluminium Pechiney at Titograd and Mostar has the following composition: 56-58 percent total $\mathrm{Al}_{2} \mathrm{O}_{3}, 20-22$ percent $\mathrm{Fe}_{2} \mathrm{O}_{3}, 3-5$ percent $\mathrm{SiO}_{2}$, 0.5-1.0 percent $\mathrm{CaO}, 0.1$ percent organic matter, and 13.0 percent LOI (Mercier and Noble, 1974, p. 784).

Bauxite in the vicinity of Niksic includes extensive deposits of white bauxite that is used in refractory products and in quick-setting cement (Dragovic, 1965, p. 33). This bauxite consists mainly of boehmite and variable quantities of admixed kaolinite. One grade of refractory bauxite produced contains a minimum of 45 percent $\mathrm{Al}_{2} \mathrm{O}_{3}$ and a maximum of 5 percent $\mathrm{Fe}_{2} \mathrm{O}_{3}$. Bauxite used in quick-setting cement contains a minimum of 50 percent $\mathrm{Al}_{2} \mathrm{O}_{3}$ and maximums of 12 percent $\mathrm{SiO}_{2}$ and 25 percent $\mathrm{Fe}_{2} \mathrm{O}_{3}$. Abrasive-grade bauxite is produced in one mine near Bosanska Krupa mainly for shipment to the U.S.S.R. (Sondermayer, 1974, p. 887).

\section{Bauxite Districts and Deposits}

Bauxite occurs at more than 200 localities (Grubić, 1970 , fig. 1) and in rocks of several different ages in Yugoslavia, and numerous reports have been written on the subject (see bibliographies by Sakac and Marusic, 1974, 1978). Probably the best summary discussions of bauxite in this country are by Grubic $(1970,1975)$, and much of the information given here is from his reports. Bauxite is known to occur in or be associated with rocks of the following ages: Triassic; Jurassic; Cretaceous; between Late Cretaceous and Tertiary; Paleogene; middle Eocene; and Oligocene. Most deposits are in the Dinaric Alps, but others occur farther southeast and in coastal areas. The typical deposits are residual accumulations of the karst or Mediterranean type, and some deposits in Cretaceous beds and at several different stratigraphic positions of Tertiary age have been transported from older deposits. Most of the transported deposits are low grade and therefore are not mined. All but a few deposits are in rocks that have been folded and faulted. Deposits in downfolded rocks are known to occur $700 \mathrm{~m}$ below the surface, and bauxite has been mined at depths of $400 \mathrm{~m}$.

The mineralogy of Yugoslav bauxites varies with age (Grubić, 1975, p. 172; Weisse, 1948). Triassic bauxites are mostly boehmite and hematite but contain variable quantities of diaspore, and a few deposits are mainly diaspore. Jurassic and Cretaceous red bauxites, generally consisting of boehmite and diaspore, are rare. Kaolinite is abundant in the so-called white bauxites of this age. Boehmite is the most abundant bauxite mineral in deposits of Paleogene age, but gibbsite is ordinarily also present. Lutetian (middle Eocene) deposits contain abundant gibbsite and goethite, but some are rich in boehmite. Oligocene bauxites in Slovenia consist mainly of clay-sized minerals and, surprisingly, contain as much as 36 percent diaspore. Some bauxites are uncommonly rich in chlorite, and a few contain as much as 50 percent of this mineral. The abundance of chlorite and monohydrate bauxite minerals in younger bauxites may be due to metamorphism.

Bauxite at Rovinj, in Istria, occurs in cone-shaped bodies in karst depressions on Late Cretaceous (Cenomanian and Turonian) limestone (Šinkovec, 1973). In some places the deposits are overlain by carbonate rocks of Paleocene and Eocene age; in others this rock has been eroded and the deposits are covered only by terra rossa. Boehmite is the principal mineral in most deposits, and gibbsite occurs in a few. Hematite, kaolinite, and anatase are the major impurities. The average composition of the bauxite is 54.28 percent $\mathrm{Al}_{2} \mathrm{O}_{3}, 21.88$ percent $\mathrm{Fe}_{2} \mathrm{O}_{3}, 5.93$ percent $\mathrm{SiO}_{2}, 3.18$ percent $\mathrm{TiO}_{2}$, and 14.00 percent LOI.

According to Grubic (1975, p. 62-65), the extensive bauxite deposits in the Vlasenica district are above Triassic limestone and are overlain by marl of middle Cretaceous age. These deposits are mainly the monohydrate type, as indicated by the low LOI in analyses of samples from 15 deposits (Grubic, 1975, table 15) having the following ranges of composition: 29.4-56.2 percent $\mathrm{Al}_{2} \mathrm{O}_{3}, 1.3-19.6$ percent $\mathrm{SiO}_{2}$, 15.49-40.32 percent $\mathrm{Fe}_{2} \mathrm{O}_{3}, 2.1-4.70$ percent $\mathrm{TiO}_{2}$, and 9.4-12.3 percent LOI.

Bauxites of Triassic, Jurassic, and Cretaceous age occur interbedded with carbonate rocks in the Niksic district (Dragovic, 1965). The bauxite has many colors, and much of it is shades of red, brown, gray, or white. 
The white and lighter colored bauxite tends to be concentrated in the upper parts of deposits. Grades of bauxite range from high-quality monohydrate types to very high silica material containing much kaolinite. The imprints of leaves and carbonized plant material found in the white bauxite suggest the deposits formed in an acid environment capable of forming aluminum silicates and reducing trivalent iron (Luković, 1966). The grades of white, high-silica bauxite produced for use in refractory products and quick-setting cement are given in the section on history and production. Most of the bauxite mined for aluminum contains more than 50 percent $\mathrm{Al}_{2} \mathrm{O}_{3}$ and is low in $\mathrm{SiO}_{2}$.

The bauxite deposits in the Jace district occur between two formations of Late Cretaceous (Maestrichtian) age. According to Grubic (1975, p. 72-76, 170), some of the deposits have been transported and redeposited. Four analyses of bauxite from this district (Grubic, 1975, table 18) show the following ranges in composition: $51.7-59.0$ percent $\mathrm{Al}_{2} \mathrm{O}_{3}$, 1.6-9.7 percent $\mathrm{SiO}_{2}$, 21.3-23.7 percent $\mathrm{Fe}_{2} \mathrm{O}_{3}, 1.6-3.3$ percent $\mathrm{TiO}_{2}$, and 11.8-15.0 percent LOI. The LOI in these analyses indicates that the bauxite is mainly boehmite.

Bauxite in uppermost Cretaceous or lower Paleocene rocks occurs in Istria, on the islands of Cres, Rab, Pag, and Hvar, in Dalmatia (Obrovac, Drniš, and Sinj), and in the Mostar basin, Hercegovina (Grubic, 1975, p. 170). Four samples from the Mostar basin (Grubic, 1975, table 22) range in composition from 40 to 58 percent $\mathrm{Al}_{2} \mathrm{O}_{3}$ and from 3 to 20 percent $\mathrm{SiO}_{2}$.

The authors were successful in finding only a few odds and ends of information on the geology of bauxite mined in the Pristina and Krusevo districts (International Bauxite Association, 1978b) during their search of the literature. These districts are apparently southeast of the Dinaric Alps, and, as noted by Grubic $(1975$, p. 170), few results of research on such deposits have been published. The one analysis of Krusevo bauxite found (Edlin and Tenyakov, 1975, table 1) records 47.90 percent $\mathrm{Al}_{2} \mathrm{O}_{3}, 4.20$ percent $\mathrm{SiO}_{2}$, and 20.80 percent $\mathrm{Fe}_{2} \mathrm{O}_{3}$.

Bauxite occurs in several places in Slovenia. The total bauxite in most districts is in the 1-million- to 3-million-

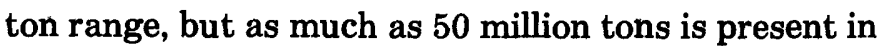
the Podlipa-Borovnica area (Bárdossy, 1977, appendix 1). The four analyses of Podlipa bauxite listed by Buser and Lukács (1970) gave the following ranges of composition: 40.00-57.06 percent $\mathrm{Al}_{2} \mathrm{O}_{3}, 13.70-20.74$ percent $\mathrm{Fe}_{2} \mathrm{O}_{3}, 8.69-21.41$ percent $\mathrm{SiO}_{2}, 1.15-1.55$ percent $\mathrm{TiO}_{2}$, and 11.75-75.58 percent LOI. This bauxite was 50-60 percent boehmite, 1.5 percent diaspore, and 10-20 percent kaolinite.

\section{Resources}

According to the Societé Aluminium Pechiney (1975, table 1), the bauxite reserves in Yugoslavia located mainly in the Drnis, Gospic, Mostar, Vlasenica, and Niksic districts are 170 million tons. Large deposits having high iron and silica contents, which are subeconomic under foreseeable economic conditions, are present in these and several other districts (Grubic, 1975, p. 171). Total bauxite resources were listed at 300 million tons by Shaffer (1975, table 5). Yugoslavia submitted an estimate of 200 million tons of measured reserves and 400 million tons of total reserves for a compilation of total reserves in member countries of the International Bauxite Association (1976b, table 1). The 400-million-ton estimate included bauxite containing as little as 45 percent $\mathrm{Al}_{2} \mathrm{O}_{3}$ and as much as 10 percent $\mathrm{SiO}_{2}$. In his summary of karst bauxite resources, Bárdossy (1977, table 1) listed 290 million tons in Dalmatia and 210 million tons in Montenegro for Yugoslavia, and therefore his total for the country was 500 million tons. In appendix 1 of the same report, he listed estimates for 29 bauxite districts, including many having only small resources, in millions of tons by provinces, as follows: Slovenia-63, Istria-41, Dalmatia, Bosnia, Hercegovina-295, Montenegro-210, Vlasenica-70. The total of these estimates, which must apply to reserves and subeconomic resources as used in this report, is 679 million tons. However, meaningful information on the quantity of subeconomic bauxite resources containing excess quantites of silica and iron is unavailable. Grubic $(1975$, p. 171) stated that enormous quantities of bauxite in the Lika, Bosanska Krupa, and other districts must be considered uneconomic reserves because of their high silica and iron contents. Yugoslav geologists have told the authors that several hundred million tons of this low-grade bauxite is present. In this report the bauxite reserves in Yugoslavia are considered to be $\mathbf{3 5 0}$ million tons as estimated by the U.S. Bureau of Mines (Baumgardner and McCawley, 1983, table 3). The total resources including reserves, subeconomic resources, and undiscovered bauxite are estimated to be 700 million-900 million tons.

\section{OTHER EUROPEAN COUNTRIES}

Small bauxite deposits occur in Albania, and presumably they are similar to those in Montenegro, Yugoslavia, to the northwest. An estimate of 1 million tons for the inferred bauxite in Albania was listed by Bárdossy (1964, table 2). 
Small deposits of bauxite occur in Bulgaria near Trün, which is $61 \mathrm{~km}$ west of Sofia. The deposits are reported to be of low grade (McCroskey, 1944, p. 16), but they were worked prior to World War II (Bracewell, 1962, p. 138).

Bauxite deposits that are high in silica and presumably small occur between rocks of Triassic and Jurassic age in Switzerland (Badoux and Weisse, 1959).

Deposits of mixed gibbsite-boehmite karst-type bauxite containing about 1 million tons are reported to occur at Andorinha, Portugal (Bárdossy, 1977, appendixes 1 and 3).

\section{SUMMARY OF BAUXITE RESOURCES IN EUROPE}

The total bauxite reserves in Europe are estimated to be 1.5 billion tons (rounded), and the resources (reserves and subeconomic and undiscovered resources) are thought to be in the 2.5-billion- to 4-billion-ton range. The principal reserves, in millions of tons, are distributed in the following countries: Greece-600, Yugoslavia-350, Hungary -300 , and the U.S.S.R.300. The reserves in France are about 30 million tons, and those in Romania are estimated to be 50 million tons. The rounded reserve estimate is similar to the one by Zámbó (1978, table 1), who listed the reserves of bauxite suitable for processing by Bayer technology, in millions of tons, as follows: Western Europe (France, Greece, Italy, Spain)-368 proved and 317 estimated; European Socialist countries (Hungary, Romania, the U.S.S.R., Yugoslavia) -510 proved and 360 estimated. According to these estimates, the total proved and estimated bauxite in Europe is 1,600 million tons. The subeconomic bauxite is mainly in low-grade deposits and deposits of all grades occurring at depths too great for profitable mining in the countries containing the reserves. Undiscovered bauxite deposits no doubt exist in Europe. However, the discovery of large highgrade deposits that are favorably situated for mining is unlikely because most of Europe has been thoroughly prospected. The total subeconomic and undiscovered bauxite in Europe is arbitrarily estimated to be 1 billion-2.5 billion tons.

\section{AFRICA}

The known bauxite resources in Africa are larger than those on any of the other continents. The principal reserves are in laterite deposits in Guinea, Ghana, and Sierra Leone, the three countries in Africa currently producing bauxite. Cameroon is also considered to have reserves because of the efforts to produce domestic raw material to supply the aluminum smelter at Edea. Small bauxite reserves are present in Mozambique where bauxite is mined for nonmetallurgical uses. The principal subeconomic resources are in the three major producing countries and in Cameroon, Malawi, Madagascar, Mah, Zaire, and Guinea-Bissau. Small subeconomic bauxite resources have been found in Chad, Ivory Coast, Upper Volta (now Burkina Faso), South Africa, and Zimbabwe, and bauxite may occur in Angola. Much of tropical Africa is favorable for the discovery of additional laterite-type bauxite, and no doubt more will be found in remote regions of Zaire, Cameroon, Guinea, Guinea-Bissau, Mah, and other countries.

\section{ANGOLA}

A contract for the exploration of bauxite in Angola, between the Government of Portugal and N.V. Billiton Maatschappij of The Hague, Netherlands, was announced in 1957 (U.S. Bureau of Mines, 1957). One report (Mining World, 1960) noted that a Portuguese aluminum company has investigated bauxite deposits in the Dondo district where an aluminum plant having a capacity of 50,000 short tons a year has been considered. No information is available on the size and grade of the deposits; however, a figure of 10 million tons for possible bauxite in Angola is listed by Martens (1971, table 8).

\section{CAMEROON}

\section{History}

An aluminum smelter has been operating at Edea since 1957, and the Cameroonian government and aluminum industry have been interested in extracting alumina from the large domestic bauxite deposits to supply this plant. The principal effort was by the Sociéte d'Etudes des Bauxites du Cameroon (SEBACAM), a group financed mainly by the Government and Pechiney-Ugine-Kuhlmann of France and with minor participation by Vereinigte Aluminium Werke of West Germany and Kaiser Aluminum of the United States; SEBACAM was formed in 1970 to encourage the production of alumina (U.S. Embassy, Yaounde, Cameroon, State Department Airgram A29, July 26, 1976, 3 p., 1 encl.). This group evaluated the large bauxite deposits in the central part of the country and the possibilities for mining and processing. Though considerable interest in development exists, problems in transportation, lack of power, and infrastructure 
financing make it unlikely that production will begin for several years. One of the difficulties is that the Trans-Cameroon railroad now extending into the general region of the large bauxite deposits lacks heavyload-bearing capacity, and a heavy-gauge railroad more than $600 \mathrm{kin}$ long probably would have to be built.

\section{Bauxite Districts and Deposits}

The major bauxite deposits in Cameroon are located in the Minim-Martap and the NgaoundalNgaoundourou districts in the Adamaoua region and the Fongo-Tongo district (Laplaine, 1969, p. 47-56). The two districts in the Adamaoua region that contain Cameroon's very large deposits are in the central part of the country (fig. 19) approximately $500 \mathrm{kun}$ from the port of Douala. The Fongo-Tongo district is located $12 \mathrm{~km}$ northwest of Dschang.

Minim-Martap and Ngaoundal-Ngaoundourou districts.-The bauxite in these districts occurs as laterite cappings of flat-topped remnants of a plateau. The deposits are at altitudes of $1200-1300 \mathrm{~m}$ and are 100-200 $\mathrm{m}$ above the local streams. The parent rock of the bauxite is mostly basalt and trachyte of Cretaceous and Tertiary age. The laterite cappings range from 3 to $15 \mathrm{~m}$ in thickness. Most deposits and particularly those in the central parts of the larger upland areas are brown and reddish brown and consist mainly of gibbsite, goethite, kaolinite, and anatase (Belinga, 1968, 1969, 1970, 1972; Nicolas and Belinga, 1969). Deposits near the edges of the laterite cappings apparently have been leached more than those in the central parts, because they contain considerably less $\mathrm{SiO}_{2}$ in the form of kaolinite. Large blocky masses of displaced laterite crust blanket the slopes of the uplands. These bauxite masses are brecciated and commonly contain boehmitic oolites and pisolites.

Four prospecting programs have been completed in the Minim-Martap and Ngaoundal districts (Gsell, 1984). The first one was in 1958-61 by the Direction des Mines et de la Géologie du Cameroun and by the Bureau de Recherches Géologiques et Minières (BRGM). During this period 276 pits were hand dug to depths of more than $17 \mathrm{~m}$ in the Minim-Martap district. The next two programs, 1969-70 and 1970-71, were conducted by SEBACAM in the Minim-Martap district. This work consisted of drilling 810 holes on 11 plateau remnants. It was designed to delineate sufficient tonnage of bauxite for mining. The last exploration program, 1971-72, was the drilling of 116 holes (total $12,196 \mathrm{~m}$ ) and the analysis of samples from $11,692 \mathrm{~m}$ of drill core. A 300-ton test batch of bauxite collected from bulldozed trenches $12 \mathrm{~m}$ deep was sent to the alumina plant at
Gardanne, France. It was found that alumina could be extracted from this bauxite by the low-temperature Bayer process. The prospecting programs on 11 plateau remnants in the Minim-Martap district proved the reserves of 560 million tons. One square kilometer in this district contains 18 million tons of bauxite (dry basis) that is 48.6 percent total $\mathrm{Al}_{2} \mathrm{O}_{3}, 43$ percent extractable $\mathrm{Al}_{2} \mathrm{O}_{3}$, and 1.8 percent reactive $\mathrm{SiO}_{2}$. The exploration in the $\mathrm{Ngaoundal}$ district proved reserves of 120 million tons of bauxite. One square kilometer in this district contains 30 million tons of bauxite (dry basis) that is 46.3 percent total $\mathrm{Al}_{2} \mathrm{O}_{3}, 39.2$ percent extractable $\mathrm{Al}_{2} \mathrm{O}_{3}$, and 1.8 percent reactive $\mathrm{SiO}_{2}$.

In addition to the 11 areas in the Minim-Martap district that were thoroughly explored, bauxite is known to be present on 15 plateau remnants having a total area of $24 \mathrm{~km}^{2}$. With the addition of this bauxite to the proven reserves, the available bauxite in the Minim-Martap and Ngaoundal districts is considered to be 1 billion tons.

Fongo-Tongo district.-Most of the bauxite in the Fongo-Tongo district occurs in upland areas, but part of it is in talus and transported material on the slopes. The largest deposits formed on basalt in the Bambouto massif (Laplaine, 1969, p. 48), and smaller deposits have developed on trachyte (Hieronymus, 1971). Gibbsite is the principal bauxite mineral, and kaolinite and hematite are the major impurities.

\section{Resources}

The Bureau de Recherches Géologiques et Minières and the Cameroon Direction des Mines have estimated that 1.1 billion tons are present in the Minim-Martap and Ngaoundal-Ngaoundourou districts (Laplaine, 1969, p. 54). According to other estimates (Michell, 1972, p. 35; Belinga, 1973, p. 209), the total bauxite in this region is 1.5 billion tons. The larger estimate includes blocks of bauxite talus on slopes on the edges of plateaus that were not included in the smaller estimate. Gsell's (1984, p. 565) estimate for the available bauxite reserves in these two districts was 1 billion tons.

The bauxite in the Fongo-Tongo district found in one prospecting program is estimated to be 46 million tons, from which 34 million tons could be recovered by washing and screening (Laplaine, 1969, p. 50). The grade of the washed bauxite would be 47 percent $\mathrm{Al}_{2} \mathrm{O}_{3}$ and 3.6 percent $\mathrm{SiO}_{2}$. The Bambouto area in this district contains an additional 4 million tons of bauxite that is 46 percent $\mathrm{Al}_{2} \mathrm{O}_{3}$ and 4.3 percent $\mathrm{SiO}_{2}$.

The U.S. Bureau of Mines (Luke Baumgardner, written commun., 1984) estimate for bauxite reserves in Cameroon is 680 million tons. The total bauxite 

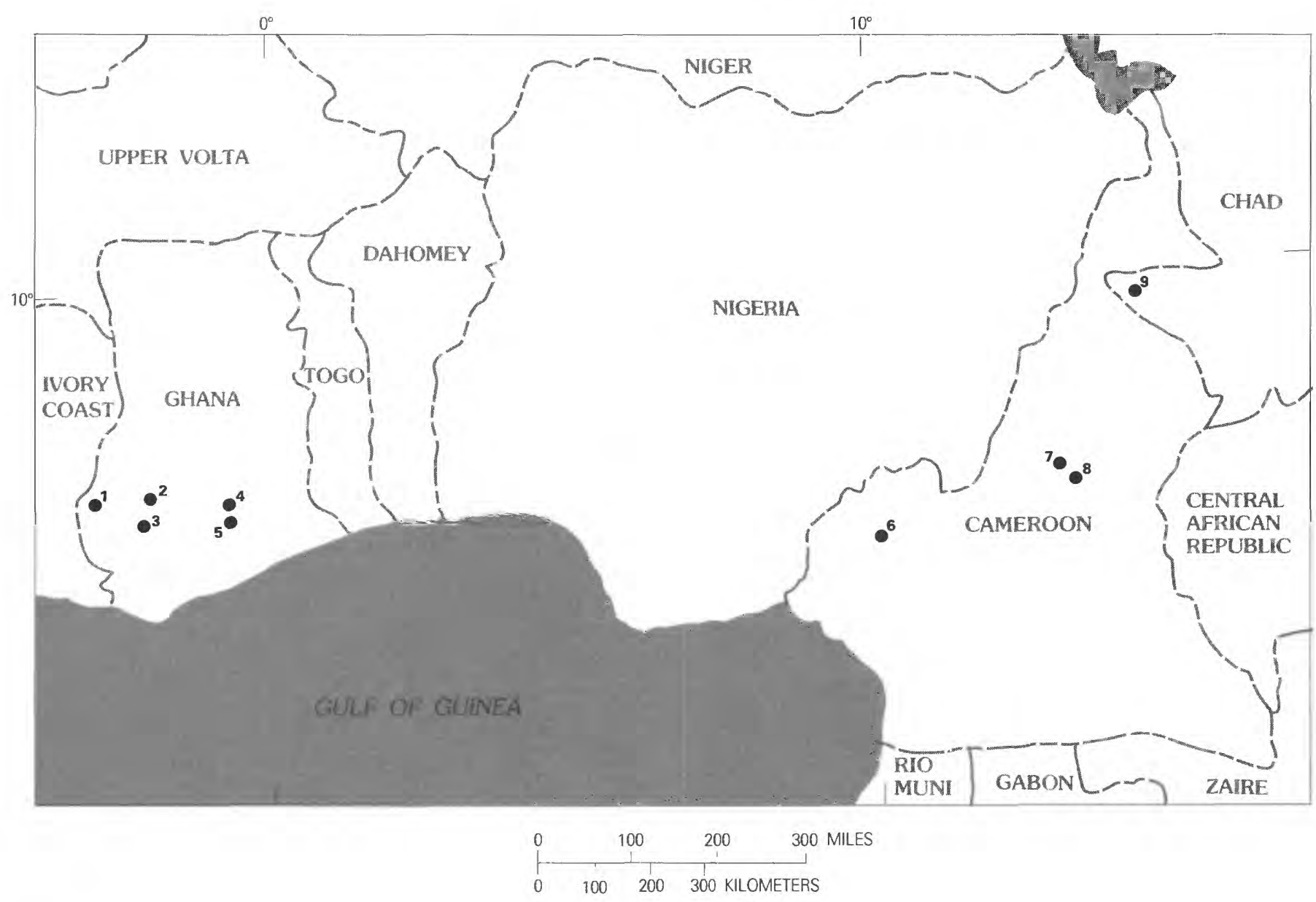

\footnotetext{
- Bauxite district

Ghana

1. Asafo
2. Nyinahin
3. Affoh-Sefwi Bekwai (Awaso)
4. Mount Ejuanema
5. Kibi-Atewa Range
}

\section{EXPLANATION}

\section{Cameroon}

6. Fongo-Tongo

7. Minim-Martap

8. Ngaoundal-Ngaoundourou
Chad

9. Pala

FIGURE 19.-Locations of bauxite districts in Ghana, Cameroon, and Chad.

resources in this country are probably at least 1.5 billion tons.

\section{CHAD}

Laterite-type bauxite occurs on small plateaus in the vicinities of Koro and Pala (Wacrenier, 1961). The deposits are on weathered kaolinitic clays and sand of Tertiary age. Gibbsite is the bauxite mineral present, and the deposits are about 50 percent $\mathrm{Al}_{2} \mathrm{O}_{3}$. The resources of this grade bauxite have been estimated to be about 8 million tons. Total bauxite resources are presumably as much as 30 million tons (Bárdossy, 1964, table 2).

\section{GHANA}

\section{History and Production}

Bauxite was discovered in Ghana in 1914 by Sir Albert Kitson, former Director of the Gold Coast Geological Survey (Cooper, 1936, p. 6), and mining began in 1940. Production rose to 168,000 tons in 1943 . The average annual rate was about 141,000 tons during 
the 1950's. The peak annual production was 363,000 tons in 1974 (table 6), and during all of the 1960's and 1970 's the annual production was greater than 200,000 tons. Production fell to about 180,000 tons in 1980 and to little more than 64,000 tons in 1982 . Most of the mining has been in the Kanaiyerebo (Awaso) deposits in the Affoh-Sefwi Bekwai district, which originally contained 10.2 million tons of bauxite (Bracewell, 1962, p. 91). By the late 1960's, reserves in these deposits were depleted, and the Ichiniso deposits, which are also near Awaso, were opened (Doughman, 1971, p. 328). The bauxite was mined and exported to the United Kingdom by British Aluminium Company, Ltd. In 1973, the Government of Ghana acquired a 55-percent equity in the operations, and a jointly owned company, Ghana Bauxite Company, was formed.

The Government of Ghana has long been interested in developing other domestic bauxite deposits and in constructing an alumina plant to supply the smelter at Tema, and several groups have considered schemes. Perhaps the most thorough study was made by Bascol, a consortium of Kaiser Aluminum and Chemical Corp., which has a major interest in Volta Aluminum Company Ltd., and five Japanese companies. Bascol investigated the feasibility of an alumina plant supplied with bauxite from the Kibi deposits.

\section{Bauxite Districts and Deposits}

Bauxite in Ghana is scattered across a belt $250 \mathrm{~km}$ long and $80 \mathrm{~km}$ wide, located $130-160 \mathrm{~km}$ north of the coast (fig. 19). The major groups of deposits are in the following areas: (1) Nyinahin, Ashanti Region, (2) Affoh-Sefwi Bekwai (includes Awaso), Western Region, (3) Asafo near Asempaneye, Western Region, (4) Mount Ejuanema near Nkawkaw, Eastern Region, and (5) Kibi-Atewa Range area, Eastern Region (Kesse, 1974, 1984). The principal bauxite deposits in Ghana occur on flat-topped remnants of highly dissected plateaus, and they formed on several types of rocks. The deposits in the Ashanti and Western Regions rest on steeply dipping, folded and sheared phyllites, lavas, ashes, and tuffs of probable Precambrian age. These rocks locally contain grits, conglomerates, and granitic intrusions that weather to bauxite rich in silica or iron. The Ejuanema deposits and others in the Eastern Region formed on flat-bedded shales of Carboniferous age.

Nyinahin.-The bauxite deposits in the Nyinahin district, about $60 \mathrm{~km}$ west of Kumasi, are scattered through a belt $30 \mathrm{~km}$ long. The bauxite occurs on flat-topped, steep-sided hills at altitudes of $450-730 \mathrm{~m}$. Kesse (1974, p. 11-43) described the deposits as being 12-21 $\mathrm{m}$ thick and overlain by only a thin clayey overburden. The bauxite is soft in the lower part and hard in the upper part, and most of it is pisolitic. The best grade bauxite is in low-iron deposits located in shallow basins in upland areas. These deposits are associated with peaty material, and iron has been removed by organic complexing. Gibbsite is the principal bauxite mineral present, but considerable quantities of boehmite occur in some deposits. Some of the gibbsite occurs as small crystals lining pore spaces and interstices between pisolites, but most of it is cryptocrystalline. Iron-free aggregates are nearly colorless, and iron-rich ones are dark red and brown. Impurities that have been identified in the bauxite include kaolinite, zircon, brookite, ilmenite, and rutile. Lava and phyllite are the principal rocks from which the bauxite has weathered.

When Kesse's (1974) report was written, the total measured and indicated bauxite on eight concessions in the Nyinahin district was 277 million tons. This total did not include deposits in large areas in the district that are known to contain bauxite but have not been investigated sufficiently to determine the quantities present. However, the total measured, indicated, and inferred bauxite in the district is estimated to be 350 million tons (Kesse, 1984, p. 574). The measured and indicated bauxite in the eight concessions is summarized as follows:

Measured and indicated bauxite resources in eight concessions, Nyinahin district, Ghana

[From Kesse (1974, p. 42); Do, ditto]

\begin{tabular}{|c|c|c|c|c|}
\hline \multirow[t]{2}{*}{ Concession } & \multicolumn{2}{|c|}{$\begin{array}{c}\text { Reserves } \\
\text { (thousands of metric tons) }\end{array}$} & \multicolumn{2}{|c|}{$\begin{array}{c}\text { Grade } \\
\text { (percent) }\end{array}$} \\
\hline & Measured & Indicated & $\mathrm{Al}_{2} \mathrm{O}_{3}$ & $\mathrm{SiO}_{2}$ \\
\hline \multicolumn{5}{|l|}{$\begin{array}{l}\text { Nyinahin } 1 \text { and } 2 \\
\text { and south part }\end{array}$} \\
\hline of Aya ........... & 101,403 & 0 & 44.4 & 2.5 \\
\hline Do $\ldots \ldots \ldots$ & 0 & 33,376 & 47.1 & 2.3 \\
\hline \multirow[t]{5}{*}{5 others .. } & 0 & 52,121 & 49.3 & 2.5 \\
\hline & 0 & 17,069 & 51.0 & 4.4 \\
\hline & 0 & 19,812 & 49.4 & 2.8 \\
\hline & 0 & 32,004 & 48.9 & 3.1 \\
\hline & 0 & 22,047 & 50.2 & 3.9 \\
\hline
\end{tabular}

Affoh-Sefwi Bekwai (Awaso) district.-This bauxite district is located a short distance north of the town of Sefwi Bekwai and about $90 \mathrm{~km}$ northwest of Dunkwa. The deposits cap a group of hills at altitudes of 450$550 \mathrm{~m}$. The ore has been mainly the trihydrate type, but about 9 percent of the total $\mathrm{Al}_{2} \mathrm{O}_{3}$ in it was in the monohydrate form (Davies, Lloyd, and Macfie, 1974, p. 76). A typical analysis of this bauxite is as follows: 51.64 percent $\mathrm{Al}_{2} \mathrm{O}_{3}, 1.28$ percent $\mathrm{SiO}_{2}, 17.43$ percent $\mathrm{Fe}_{2} \mathrm{O}_{3}, 1.87$ percent $\mathrm{TiO}_{2}$, and 27.78 percent LOI. Bracewell $(1962$, p. 91) reported that sufficient monohydrate 
was present to warrant recycling at high temperatures and pressures after the alumina in trihydrate form had been removed.

The mineralogy of the bauxite mimed at Awaso was also investigated by Trashliev and Stefanov (1974). These Soviet geologists found the bauxite to be chiefly gibbsite, which occurs in both crystalline and cryptocrystalline forms. Only a minor amount of boehmite was recognized, and it occurred mainly in lighter colored bauxite. Analyses of the raw and washed bauxite and waste reported by Trashliev and Stefanov (1974) follow:

Analyses, in percent, of raw and washed bauxite and waste from Awaso, Ghana

[From Trashliev and Stefanov (1974)]

\begin{tabular}{|c|c|c|c|}
\hline & Raw & Washed & Waste \\
\hline $\mathrm{SiO}_{2}$ & 2.60 & 1.02 & 8.65 \\
\hline $\mathrm{TiO}_{2}$ & 1.88 & 1.76 & 2.40 \\
\hline $\mathrm{Al}_{2} \mathrm{O}_{3}$ & 52.54 & 54.86 & 45.55 \\
\hline $\mathrm{Fe}_{2} \mathrm{O}_{3}$ & 15.92 & 13.60 & 20.85 \\
\hline $\mathrm{H}_{2} \mathrm{O}$. & 27.03 & 28.85 & 22.49 \\
\hline Sur & 99.97 & 100.09 & 99.94 \\
\hline
\end{tabular}

The differences between the results of the two investigations may be that Davies, Lloyd, and Macfie (1974) listed an analysis typical of the deposits mimed at Kanaiyerebo, whereas Trashliev and Stefanov (1974) reported on the Ichiniso deposits.

Kesse (1984, p. 574) listed the reserves in the Sefwi Bekwai (Awaso) district as 19 million tons.

Asafo district. - The Asafo bauxite deposits occur in hills east of the Bia River $65 \mathrm{~km}$ northwest of Wiawso, which is about $165 \mathrm{~km}$ by road from Dunkwa. The best deposits apparently are about $8 \mathrm{~km}$ northeast of Asempaneye. Observed thicknesses of the bauxite range from 7.5 to $11.5 \mathrm{~m}$. Cooper (1936, p. 30) estimated the bauxite resources in the Asafo district at 25 million tons. About 80 percent of this bauxite contains 50 percent $\mathrm{Al}_{2} \mathrm{O}_{3}$ and 20 percent $\mathrm{Fe}_{2} \mathrm{O}_{3}$, and more than half of it is even higher grade.

Mount Ejuanema district.-The Mount Ejuanema bauxite deposits are on a flat highland along the escarpment of the faulted and dissected Kwahu plateau. They are at an altitude of about $750 \mathrm{~m}$ and are $525 \mathrm{~m}$ above the railway at Nkawkaw $3 \mathrm{~km}$ away. This town is $180 \mathrm{~km}$ from the port at Accra. The bauxite has weathered from a bed of shale in the upper part of a thick section of sedimentary rocks of probable Carboniferous age. The following section, which is typical of the deposits in general, is a modification of Cooper's section $(1936$, p. 18), which was based on earlier work by Kitson (1925, p. 17-22).
Geologic section of bauxite in the Ejuanema district, Ghana [Froin Cooper (1936, p. 18)]

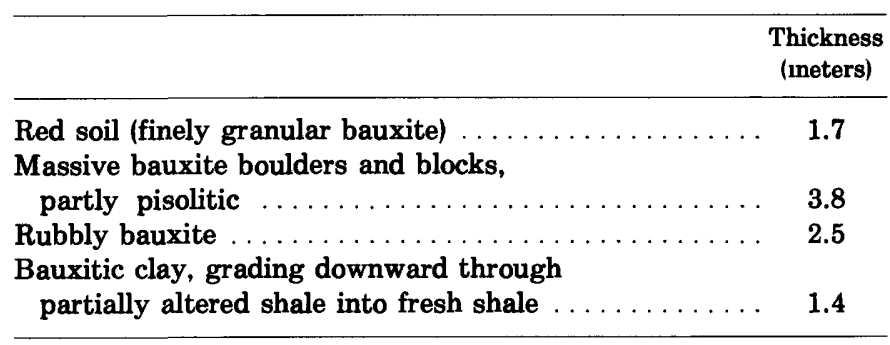

The deposits were estimated by Cooper (1936, p. 19) to contain only about 4 million tons, but they are high grade, and therefore an attempt was made to mime them. Cooper listed the mean of 17 samples analyzed as 60.55 percent $\mathrm{Al}_{2} \mathrm{O}_{3}, 9.75$ percent $\mathrm{Fe}_{2} \mathrm{O}_{3}, 2.21$ percent $\mathrm{TiO}_{2}, 1.42$ percent $\mathrm{SiO}_{2}$, and 25.59 percent $\mathrm{H}_{2} \mathrm{O}$. In the attempt to mine the deposits during World War II a road was built from the district to the Nkawkaw railway station (Bracewell, 1962, p. 89).

Kibi-Atewa Range district.-The Kibi-Atewa Range bauxite deposits occur on flat-topped summits of low mountains (Hunter, 1961). They overlie a complex group of rocks of Precambrian age including phyllite, clay, shale, graywacke, and basic intrusive rocks (Szabó, 1973). The best grade bauxites in this district are residual deposits in the uplands. Low-grade bauxite also is associated with some of the better deposits and occurs on the slopes of plateaus. Local muddy swamps underlain by kaolin occur on the plateaus. The bauxite associated with such deposits is ordinarily low grade.

The bauxite reserves in the Kibi-Atewa Range district are estimated to be 152-180 million tons (Kesse, 1984, p. 574).

\section{Resources}

Several estimates of the bauxite resources in Ghana have been made. Those the authors are aware of include the following: (1) Kibi-Atewa Range-120 million tons of high-grade bauxite (Michell, 1972, p. 34), 182 million tons (International Bauxite Association, 1977e, p. 33), and 300 million tons (International Bauxite Association, 1977c), (2) Nyinahin district-150 million tons (Michell, 1972, p. 34), 350 million tons (Kesse, 1974, p. 42), and 580 million tons (International Bauxite Association, 1977e, p. 33), (3) Awaso-20 million tons (International Bauxite Association, 1977e, p. 34), (4) Ejuanema district-4 million tons (Cooper, 1936, p. 19), and (5) Asafo district-25 million tons (Cooper, 1936, p. 30). In addition, bauxite occurrences are known at several other localities in Ghana (Ghana Geological Survey, 1962, p. 9, 10). 
Estimates for the total bauxite reserves in Ghana include the following: (1) 300 million tons (Sociéte Aluminium Pechiney, 1975, table 1), (2) 570 million tons (International Bauxite Association, 1976b, table 1), (3) 590 million tons (Zámbó, 1978, table 1), (4) 780 million tons (International Bauxite Association, 1977e, p. 33), (5) 520-550 million tons (Kesse, 1984, p. 474), and (6) 450 million tons (Baumgardner and McCawley, 1983, table 3). The total bauxite resources in Ghana are assumed to be 780 million tons, the estimate published by the International Bauxite Association in 1977.

\section{GUINEA}

\section{History and Production}

Guinea has the world's largest bauxite reserves. It produced 10.8 million tons in 1976 (table 6) and became the second ranking bauxite-producing country. Bauxite mine development in Guinea began on the Îles de Los near Conakry in 1938 by the Sociéte Bauxite du Midi, a subsidiary of Alcan, but large-scale mining on the Îles de Los did not begin until 1952.

Currently, all Guinea's bauxite comes from three large mining operations on the mainland. The Fria mine was the first of these to begim production. All of the bauxite from this mine has been used to supply an alumina plant at Kimbo, which began production in 1960. This operation, known as Friguia, is owned by the Government of Guinea (49 percent) and a consortium of foreign aluminum companies (51 percent). The annual capacity of the alumina plant is 700,000 tons, and bauxite production is 1.5 million-2 million tons.

In 1973, the Guinea Bauxite Company (CBG) began bauxite production at a mine in the Sangaredi district of the Boké region. CBG is also owned 49 percent by the Government and 51 percent by a consortium of foreign companies. The bauxite is transported $140 \mathrm{~km}$ by rail to the new port of Kamsar. CBG has facilities at Kamsar for crushing and drying metallurgical-grade bauxite and for calcining abrasive-grade bauxite (Hoppe, 1978). CBG was expected to produce bauxite at its rated capacity of 9 million tons by 1979 .

A third producer, Office des Bauxites de Kindia (OBK), began mining bauxite at Débélé in the Kindia district in 1974. OBK is owned entirely by the Government of Guinea; however, the U.S.S.R. provided financial and technical assistance in the construction and technical assistance in the operation of the project. Bauxite is shipped by rail approximately $100 \mathrm{~km}$ to Conakry for export, largely to the U.S.S.R. Production capacity was rated at 2.5 million tons per year (Wyllie, 1976).
In addition to the active mining operations, several plans for the development of new bauxite deposits were under consideration. The Governments of Guinea, Saudi Arabia, Kuwait, Libya, Egypt, Iraq, and the United Arab Emirates have agreed to a joint venture to build a large bauxite-alumina complex based on the bauxite deposits at Ayé Koyé in the Boké region. Other proposals included the development of deposits in the Dabola and Tougué regions.

\section{Bauxite Districts and Deposits}

The extensive bauxite deposits in Guinea occur mainly in Boké, Fria, Kindia, Tougué, and Dabola regions (fig. 20). The small high-grade deposits in the Îles de Los are no longer mined. All of the deposits on the mainland are of the laterite type. The plateaus on which they occur range in elevations from about $1,200 \mathrm{~m}$ at Tougué, the farthest inland region, to about $300 \mathrm{~m}$ at Boké and Fria. The plateaus typically have open or brushy gently rolling uplands incised by wooded stream valleys. This type of country is known as "bowes" or the singular "bowal."

Fria - The bauxite mined at Fria occurs near the junction of the Badi and Konkouré Rivers. In a brief outhine published by the International Bauxite Association (1979), the bauxite is described as red earthy material containing hard lumps and crusts, and the deposits are 8-12 $\mathrm{m}$ thick. The bauxite overlies and apparently formed on a dolerite sill. Gibbsite is the only bauxite mineral in the deposits (Mercier and Noble, 1974, p. 780). Most of the iron is in goethite, but hematite is common in the upper parts of deposits. Kaolinite is the principal clay mineral present. About one-third of the silica occurs as very fine grained quartz, and most of the remainder is in kaolinite. The bauxite contains about 0.3-0.4 percent organic matter. The typical composition of the Fria bauxite is 48 percent $\mathrm{Al}_{2} \mathrm{O}_{3}, 2.5$ percent $\mathrm{SiO}_{2}, 21$ percent $\mathrm{Fe}_{2} \mathrm{O}_{3}, 2.2$ percent $\mathrm{TiO}_{2}$, and 25 percent LOI.

The estimates of the bauxite reserves in the Fria district have increased considerably since the early exploration programs. The Annales des Mines (1958, p. 690) reported that 150 million tons had been found by drilling and test pitting on 150-m centers over an area of more than 1,240 hectares. Estimates increased in more recent years, and Charbonneaux's $(1974$, p. 566) figure was 500 million tons. This reserve estimate is apparently the official one of the Guinea Government (International Bauxite Association, 1979).

Boké region (Sangaredi and Ayé Koyé districts).Boke is located on the tidal estuary of the Nunez River about $160 \mathrm{~km}$ north of Conakry. The very large bauxite 

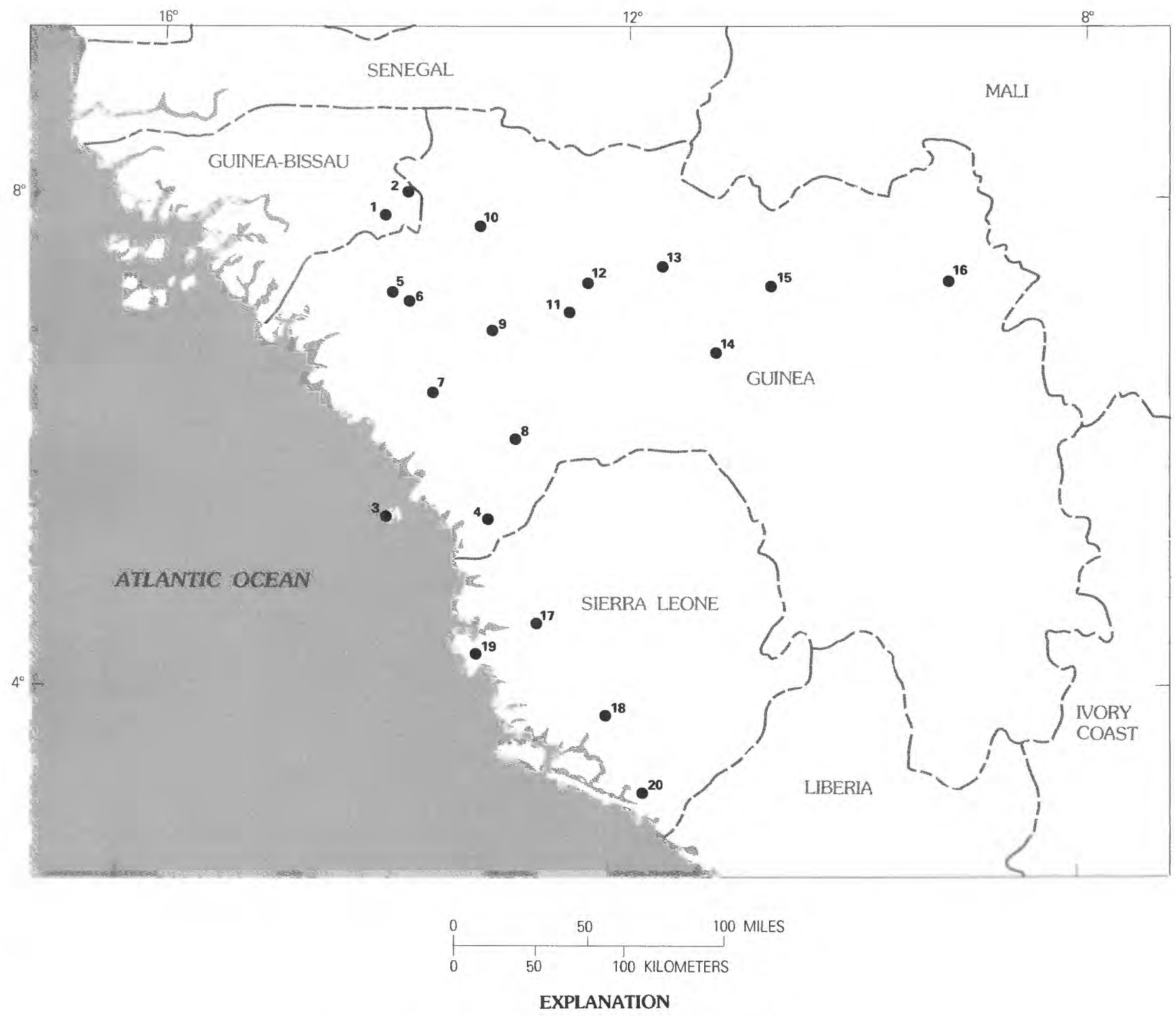

- Bauxite district Guinea-Bissau

1. Grand Boé

2. Trans Féfiné

Republic of Guinea
3. Îles de Los
4. Forécariah
5. Ayé Koyé, Boké
6. Sangaredi, Boké
7. Fria
8. Kindia-Débélé
9. Télimélé

10. Gaoual

11. Pita

12. Labé

13. Tougué

14. Dabola

15. Dinguiraye

16. Siguiri

\section{Sierra Leone}
17. Port Loko
18. Mokanji Hills
19. Sierra Leone Peninsula
20. Krim-Kpaka Chiefdom

FIGURE 20.-Locations of bauxite districts and regions in Guinea-Bissau, Guinea, and Sierra Leone. 
deposits in this region are in the Sangaredi and Ayé Koyé districts in the drainage of the Congon River 50-60 km northeast of Boké.

The bauxite occurs in the capping laterite layer of the bowes. The lower slopes of stream valleys between the bowes are generally covered by soil and forest, but laterite extends down into the valleys locally. Rock outcrops and boulders in the streams are chiefly gabbroic diabase that is believed to be part of a large diabase sill forming the parent rock of the laterite (Harder, 1952, p. 55). The diabase is fine grained and consists chiefly of andesine-labradorite, augite, and minor amounts of biotite and perthitic quartz-orthoclase intergrowths. Nearly horizontal thin-bedded sandstone and micaceous siltstone and shale of probable early Paleozoic age crop out in the Congon River and its deeper tributaries. These rocks presumably are part of the host rocks into which the diabase sill was intruded. Some of the bauxite also formed on sedimentary rocks such as those Balkay and Bárdossy (1967) have observed at Kassongoni near Boké. At Kassongoni the bauxite overlies schist of Silurian age. Deposits in the Sangaredi district are reported to rest on weathered mixtures of schist and sandstone of Devonian or post-Devonian age, and the uppermost fresh rock under the bauxite is cordierite hornfels (Schmidt, 1984, p. 495).

The Sangaredi bauxite is unique because it is the thickest and highest grade deposit in the world. The average thickness of the bauxite is about $15 \mathrm{~m}$, but locally deposits are nearly twice that thick. According to Akayemov (1975), the bauxite occurs in three layers or members. The upper member, which is 8.7-13 m thick, consists of alternating layers and lenses of poorly sorted rounded grains and pebbles of bauxite. The middle member is 8-19.5 m thick and consists of fairly well sorted gravelly bauxite. The lower member is 2.5-13 $\mathrm{m}$ thick and consists of interbedded gravelly and clayey bauxite. The lower member rests with a sharp contact on Silurian siltstone. Gibbsite is the principal mineral in the bauxite, and boehmite is present in minor amounts. The latter tends to increase in abundance with depth; this tendency is the opposite of the trend in typical laterite-type deposits elsewhere.

Two samples of Boké (Sangaredi) bauxite were investigated by an Italian aluminum company (Landi and Casola, 1977). The samples are apparently representative of the bauxite produced in this district and have the following mineralogical composition: 83-86 percent gibbsite, $3.5-5.5$ percent boehmite, approximately 1 percent kaolinite, $0.5-1.0$ percent quartz, a trace of hematite, 5.5-6.5 percent goethite, 1 percent rutile, and 2 percent anatase. The chemical composition of these samples was 59.09-59.62 percent total $\mathrm{Al}_{2} \mathrm{O}_{3}$, of which $3.00-4.50$ was in monohydrate form; $0.74-0.86$ percent
$\mathrm{SiO}_{2}$, of which approximately one half was reactive; 4.93-5.92 percent $\mathrm{Fe}_{2} \mathrm{O}_{3} ; 3.31-3.47$ percent $\mathrm{TiO}_{2}$; and $30.56-30.99$ percent LOI.

The age and origin of the Sangaredi deposit are still somewhat conjectural. Bushinskiy $(1975$, p. 384$)$ stated that the information now available suggests the deposits formed in about Oligocene and Miocene time. Akayemov (1975) concluded that the bauxite had been transported, on the basis of rounded pebbles and grains of gibbsite and boehmitic gibbsite and bedding. $\mathrm{He}$ believes deposition took place in lakes, lagoons, and coastal alluvial deposits. If this interpretation is correct, the deposits are quite different from the typical laterite-type bauxite elsewhere. Winnowing of impurities from gibbsite particles during transportation and rapid deposition of the particles may be the reasons for the high grade and uncommon thickness of the Sangaredi deposits.

Estimates of the bauxite reserves in the Sangaredi district include the following: (1) 150 million tons that is 60 percent $\mathrm{Al}_{2} \mathrm{O}_{3}$ and 1.3 percent $\mathrm{SiO}_{2}$ found during exploratory drilling in 1948-1952 by Bauxites du Midi (Bushinskiy, 1975, p. 383), (2) 300 million tons (Charbonneaux, 1974, p. 568), (3) 420 million tons (Martens, 1971, p. 49), and (4) 120 million tons remaining after mining 80 million tons (Schmidt, 1984, p. 496). Schmidt stated that this reserve was high grade and that an additional 300 million tons of bauxite containing approximately 10 percent less $\mathrm{Al}_{2} \mathrm{O}_{3}$ than the Sangaredi deposits was present in the immediate vicinity. Furthermore, resources of such lower grade bauxite (approximately 50 percent $\mathrm{Al}_{2} \mathrm{O}_{3}$ ) occur in practically unlimited quantities within a radius of $10 \mathrm{~km}$ of Sangaredi.

Bauxite in the Ayé Koye district is similar to the Sangaredi bauxite. In most of the Ayé Koyé district, the bauxite has formed from dolerite, but on one plateau bauxite grades down into weathered rock having sedimentary structures. The bauxite deposits are characterized by three zones. An upper zone, $2 \mathrm{~m}$ thick, is an iron-rich crust overlying massive bauxite about $3 \mathrm{~m}$ thick. The lowermost zone, which is approximately $5 \mathrm{~m}$ thick, consists of gravelly bauxite having lower $\mathrm{Al}_{2} \mathrm{O}_{3}$ and higher $\mathrm{Fe}_{2} \mathrm{O}_{3}$ content than the massive bauxite. The average grade of an estimated nearly 4 billion tons of bauxite in the Aye Koye district is 44-45 percent $\mathrm{Al}_{2} \mathrm{O}_{3}$ and 1.7-2 percent $\mathrm{SiO}_{2}$ (Schmidt, 1984, p. 496). About 1.1 billion tons of this bauxite is about 49.5 percent $\mathrm{Al}_{2} \mathrm{O}_{3}$ and $1.5-1.7$ percent $\mathrm{SiO}_{2}$. Investigations with closely spaced drilling have proved 195 million tons of the higher grade bauxite.

The total estimates of bauxite reserves in the Boke region range broadly, depending on which authority is selected. Estimates of reserves were stated to be several hundred million tons in Annales des Mines (1958, p. 690) 
and Mining Journal (1971b). Other sources listed 1 billion tons that is 55 percent $\mathrm{Al}_{2} \mathrm{O}_{3}$ (Bushinskiy, 1975, p. 383), more than 1 billion tons (Engineering and Mining Journal, 1967, p. 130), and 1.5 billion tons that is 58 percent $\mathrm{Al}_{2} \mathrm{O}_{3}$ (Charbonneaux, 1974, p. 568); two authorities (Hassan and Williams, 1969, p. 55) published an estimate of nearly 4 billion tons. The estimate of the Guinea Government published by the International Bauxite Association $(1979$, p. 38$)$ is 2 billion tons that is 58-62 percent $\mathrm{Al}_{2} \mathrm{O}_{3}$ and 0.8-1 percent $\mathrm{SiO}_{2}$. Schmidt's (1984, p. 496) estimates are 120 million tons of high-grade bauxite plus 300 million tons of moderategrade bauxite within $10 \mathrm{~km}$ of Sangaredi. In addition the Ayé Koyé district contains nearly 4 billion tons of bauxite of which 1.1 billion tons is of moderate grade and 195 million tons have been proved by closely spaced drilling.

Dabola. - The town of Dabola is on the ConakryKankan railroad in central Guinea, about $400 \mathrm{~km}$ from the coast. Bauxite deposits in this region are on bowes between the Niger and Tinkisso Rivers. The deposits on the Oursa bowal near Dabola formed on diabase; elsewhere in this region laterite formed on mica schist (Lacroix, 1913, p. 283). Extensive drilling on the Oursa (Ouroussa) and Sinseri bowes a few kilometers north of Dabola (Moyal, 1956, p. 1062) and on other bowes $32 \mathrm{~km}$ east and about $50 \mathrm{~km}$ west of Dabola has revealed very large deposits of bauxite. The Yugoslav Energoproject, which has plans for mining in this district, is reported to have confirmed 425 million tons of high-grade bauxite in the Dabola district (International Bauxite Association, 1977d, p. 3). Total reserves in the Dabola district have been estimated to be as much as 1.5 billion tons (Michell, 1977, p. 55). The estimate of the Guinea Government for reserves in the Dabola district (International Bauxite Association, 1979, p. 38) is 1 billion tons that is 48-52 percent $\mathrm{Al}_{2} \mathrm{O}_{3}$ and 2-3 percent $\mathrm{SiO}_{2}$.

Îles de Los. - The exhausted bauxite deposits in the Îles de Los consisted of an upper layer 1-3 m thick cemented by ferruginous material and an underlying red concretionary layer 5-10 m thick (Bonifas, 1959, p. 82-91). The concretionary layer, in turn, graded downward into fresh nepheline syenite, from which the bauxite had weathered, through a porous layer only $5-10 \mathrm{~cm}$ thick. Gibbsite was the principal mineral in the deposits, but some hematite and anatase were also present. The washed bauxite from these deposits contained an average of 54 percent $\mathrm{Al}_{2} \mathrm{O}_{3}, 6$ percent $\mathrm{SiO}_{2}, 11$ percent $\mathrm{Fe}_{2} \mathrm{O}_{3}$, and 28 percent $\mathrm{H}_{2} \mathrm{O}$.

Kindia including Débélé. - The Kindia bauxite district centers around the town of that name located $120 \mathrm{~km}$ northeast of the capital and port city of Conakry. The deposits occur on scattered bowes, and bauxite is mined on the largest one, named Débéle (Wyllie, 1976). The
Débélé bauxite ranges in thickness from 3 to $12 \mathrm{~m}$, and most of it is 6-8 $\mathrm{m}$ thick. Gibbsite is the principal bauxite mineral in the Kindia district (Kowalski, 1970). Minable bauxite in the Kindia district extends over areas having a total of 737 hectares (Annales des Mines, 1958). The Débélé deposit contains 41 million tons of bauxite (Wyllie, 1976). Available estimates for the bauxite reserves in the entire district are 85 million tons (Annales des Mines, 1958, p. 690 ) and 100 million tons (Martens, 1971, p. 49). The Débélé bauxite has an average $\mathrm{Al}_{2} \mathrm{O}_{3}$ content of 48 percent, and $\mathrm{SiO}_{2}$ ranges from 1 to a maximum of 3 percent (Wyllie, 1976). The estimate of the Guinea Government for the bauxite reserves in the Kindia district (International Bauxite Association, 1979, p. 38) is 200 million tons that is 48-52 percent $\mathrm{Al}_{2} \mathrm{O}_{3}$ and 2-3 percent $\mathrm{SiO}_{2}$. Schmidt's (1984, p. 498) estimate is that the Kindia district originally contained 100 million tons of bauxite, and, considering present-day production of about 2.5 million tons annually, the district contained about 75 million tons of bauxite in 1984 .

Tougué. - The extensive Tougué district is in central Guinea (fig. 20) about $100 \mathrm{~km}$ north of Dabola. Lateritetype bauxite deposits in this district occur as cappings of several dozen bowes having a total area of about $1,000 \mathrm{~km}^{2}$ (Bushinskiy, 1975, p. 382).

Estimates of bauxite reserves in the Tougue district range widely. Bushinskiy $(1975$, p. 382$)$ noted that reserves of 1,526 million tons are present on six bowes and the predicted reserves are 4 billion tons. Other reserve estimates for the Tougue district include 2 billion tons (Mining Journal, 1971b, p. 185) and 3 billion tons (Michell, 1977, p. 55). The estimate of the Guinea Government for the bauxite reserves in the Tougue region (International Bauxite Association, 1979, p. 38) is 4 billion tons that is $47-52$ percent $\mathrm{Al}_{2} \mathrm{O}_{3}$ and 34 percent $\mathrm{SiO}_{2}$. Schmidt (1984, p. 498-499) stated that investigation in the Tougue region in 1956-58 discovered reserves of more than 1 billion tons of bauxite, and reserves in both the Tougue and Dabola regions have a total of about 2.5 billion tons of which 500 million tons can be considered higher grade.

The parent rock of the bauxite is assumed to be dolerite (Sclimidt, 1984, p. 498); however, sandstone and schist are known to be present in the region. A typical profile of the bauxite consists of a top layer of cemented bauxite blocks several meters thick that is overlain only by a thin soil. The middle layer is similar to the top one except the bauxite blocks are smaller. The lowermost zone is dark-reddish-brown, fine-grained bauxite containing some gravel in the upper part. The average thickness of the bauxite is about $8 \mathrm{~m}$. Bauxite on the Pontiola plateau near the town of Tougue has average contents of 47 percent $\mathrm{Al}_{2} \mathrm{O}_{3}$ and 2 percent $\mathrm{SiO}_{2}$. 
Other districts. - In addition to the bauxite districts summarized in foregoing sections, bauxite is known to occur at several other places. Bauxite reserves were listed in a report on Guinea published by the International Bauxite Association (1979) for the districts listed in the following table:

Bauxite reserves and analyses for five districts in Guinea [From International Bauxite Association (1979). Reserves in millions of tons; analyses in percent]

\begin{tabular}{llrrr}
\hline District & \multicolumn{1}{c}{ Reserves } & $\mathrm{Al}_{2} \mathrm{O}_{3}$ & $\mathrm{SiO}_{\mathbf{2}}$ \\
\hline Pita $\ldots \ldots \ldots \ldots \ldots \ldots \ldots \ldots \ldots \ldots \ldots \ldots$ & $\mathbf{2 0 0}$ & $\mathbf{4 8 - 5 2}$ & $\mathbf{2 - 3}$ \\
Dinguiraye $\ldots \ldots \ldots \ldots \ldots \ldots \ldots \ldots \ldots \ldots$ & $\mathbf{6 0}$ & $\mathbf{4 5 - 4 8}$ & $\mathbf{3 - 4}$ \\
Siguiri $\ldots \ldots \ldots \ldots \ldots \ldots \ldots \ldots \ldots \ldots$ & $\mathbf{3 0}$ & $\mathbf{4 5 - 4 8}$ & $\mathbf{3 - 4}$ \\
Forecariah $\ldots \ldots \ldots \ldots \ldots \ldots \ldots \ldots \ldots \ldots$ & $\mathbf{1 0}$ & $\mathbf{4 4 - 4 7}$ & $\mathbf{4 - 5}$ \\
Gaoual $\ldots \ldots \ldots \ldots \ldots \ldots \ldots \ldots \ldots \ldots$ & $\mathbf{2 0 0}$ & $\mathbf{5 8 - 6 0}$ & $\mathbf{1 - 2}$ \\
\hline
\end{tabular}

In addition to these districts, bauxite is reported to have been investigated in the Labé and Télimélé districts under the direction of the Guinea Mimistry of Mines and Geology (U.S. Embassy, Conakry, Guinea, State Department Airgram A-004, January 13, 1977).

\section{Resources}

In this report the bauxite reserves in Guinea are considered to be 5.6 billion tons as estimated by the U.S. Bureau of Mines (Baumgardner and McCawley, 1983, table 3 ). The total bauxite resources are probably at least in the 8- to 10-billion-ton range. Although the Guinea Government submitted an estimate of 8.2 billion tons for the bauxite reserves in this country to the International Bauxite Association (1979), the estimate is conservative. Schmidt (1984) noted the presence of 4 billion tons in the Ayé Koyé district, 80 million tons of high-grade and 300 million tons of lower grade bauxite in the Sangaredi district plus practically unlimited quantities of bauxite within a $10-\mathrm{kin}$ radius of this district, and 2.5 billion tons of bauxite in the TouguéDabola region. Lotze's (1984, table 4) estimate of the bauxite in Guinea is developed and undeveloped reserves -4.555 billion tons and potential bauxite in developed and undeveloped districts-14.240 billion tons, and the total is 18.795 billion tons. In this report the total bauxite resources in Guinea are assumed to be 8 billion- 10 billion tons.

\section{GUINEA-BISSAU}

In Guinea-Bissau laterite-type bauxite, which is considered to be an extension of the deposits in the Boké region of Guinea, occurs in the Grand Boe and the Trans Féfine regions. The Grand Boe region is between the Corubal River and the Guinea border mainly northeast of the town of Madina. The second region is farther eastnortheast on the far side of the Féfine River.

The bauxite deposits rest on dolerite sills that overlie impure sandstone (Hose, 1960, p. 239). The laterite was described by Weisse $(1954$, p. 176) as consisting of a hard cemented surficial layer 2-3 $\mathrm{m}$ thick overlying a brick-red vesicular layer $10-12 \mathrm{~m}$ thick. These two layers are separated from the underlying weathered dolerite by a clayey concretionary layer and a bleached clay zone having a total thickness of 3-5 m. Gibbsite is the principal mineral in the deposits, but some boehmite is also present, as identified by differential thermal analysis. Mottled bauxite from these deposits contains 53.73-53.82 percent $\mathrm{Al}_{2} \mathrm{O}_{3}, 0.89-1.25$ percent $\mathrm{SiO}_{2}, 14.87-16.40$ percent $\mathrm{Fe}_{2} \mathrm{O}_{3}, 1.68-1.79$ percent $\mathrm{TiO}_{2}$, and 26.24-28.74 percent LOI; a white bauxite contains 63.42 percent $\mathrm{Al}_{2} \mathrm{O}_{3}$ (Weisse, 1954, p. 177).

N.V. Billiton Maatschappij is reported to have explored bauxite deposits in the Grand Boé region of Guinea-Bissau in the late 1950's. According to newspaper accounts, 120 million tons of bauxite were found. Of this amount, 24 million tons, presumably the best grade, contained 47 percent $\mathrm{Al}_{2} \mathrm{O}_{3}$ and 3 percent $\mathrm{SiO}_{2}$. Recent preliminary studies by foreign experts have suggested that as much as 500 million tons of moderate- and low-grade bauxite is present in the Grand Boé and Trans Féfiné regions (U.S. Embassy, Bissau, Guinea-Bissau, State Department Airgram A-01, March 1, 1977). All of the bauxite in Guinea-Bissau is presently considered to be subeconomic because of the economic uncertainties about mining it.

\section{IVORY COAST}

Small laterite-type bauxite deposits have been discovered on isolated plateaus at many localities in Ivory Coast (Zanone, 1971). The districts in which the bauxite has been found include Bongouanou, Toumodi, Divo, Sassandra-Lakota, and Tabou. The deposits are mainly gibbsite, but most contain minor quantities of boehmite. Apparently the best grade and largest deposits are in the Bénéné district, which is approximately $170 \mathrm{~km}$ north of Abidjan. These deposits are estimated to contain 10.7 million tons of bauxite that is 50 percent $\mathrm{Al}_{2} \mathrm{O}_{3}$ (Zanone, 1971, p. 95). As Bénéné is smaller than some of the other districts, the total subeconomic bauxite resources in Ivory Coast is probably at least 3 or 4 times the total in this district.

The only published estimates of bauxite resources in Ivory Coast found by the authors were the 10.7 million 
tons in the Bénéné district (Zanone, 1971) and one for 10 million tons proved, 100 million tons estimated having the total of 110 million tons (Zámbó, 1978, table 1). Inasmuch as the basis for Zámbó's estimate is unknown, the subeconomic bauxite resources in Ivory Coast are assumed to be 10 million tons in this report (table 12).

\section{MADAGASGAR}

Pechiney, the French aluminum company, evaluated bauxite deposits at Manantenina and elsewhere along the southeastern coast of Madagascar. The deposits in the Manantenina region occur on weathered leptynite, gneiss, and cordierite-bearing granite (Balcet, 1966). Deposits farther north are on weathered basalts. Weathering in most areas has progressed to depths of 10-20 m. Most of the bauxite is intermixed with clay. The following average partial composition of the $>1.6-\mathrm{mm}$ fraction of bauxite from four test pits is given in the Balcet article: total $\mathrm{SiO}_{2}-11$ percent, combined $\mathrm{SiO}_{2}-1.7$ percent, total $\mathrm{Al}_{2} \mathrm{O}_{3}-50.1$ percent, reactive $\mathrm{Al}_{2} \mathrm{O}_{3}$ [recoverable by Bayer process]-46 percent, $\mathrm{Fe}_{2} \mathrm{O}_{3}-8.9$ percent. Deposits investigated by Pechiney were estimated to be $\mathbf{7 5}$ million tons (Mining Journal, 1971a, p. 82). Presumably, this estimate applies to the tonnage that can be recovered by washing, as another estimate (Mining Journal, 1970, p. 427) lists the total as 100 million tons.

Bauxite deposits also occur at several places in Madagascar (Besairie, 1960, 1962, 1964) other than in the Manantenina region. Ferruginous bauxite deposits on the Analavory and Marangaka plateaus at altitudes of 1,460 to $1,680 \mathrm{~m}$ are $0.5-6.3 \mathrm{~m}$ thick (Emberger, 1957). The deposits overlie granitic rocks from which they presumably have weathered. Much of the bauxite is in irregular porous and pisolitic ferruginous concretions scattered throughout fine-grained ferruginous rock; however, massive bauxite blocks are also present. The Analavory deposits are estimated to contain 4 million tons that is 54 percent $\mathrm{Al}_{2} \mathrm{O}_{3}$, and the Marangaka deposits contain 40 million tons that is 38 percent $\mathrm{Al}_{2} \mathrm{O}_{3}$ (Besairie, 1960). Very ferruginous bauxite deposits occur at several places on the Tampoketsa plateau (Hottin, 1960). Some of these deposits are on basalt, and others on sedimentary rocks. Much of this bauxite contains only $36-38$ percent $\mathrm{Al}_{2} \mathrm{O}_{3}$, but scattered deposits contain as much as 50 percent $\mathrm{Al}_{2} \mathrm{O}_{3}$. Ankazobe deposits are estimated to contain approximately 800,000 tons, those at Fenoarivo 3.8 million tons, and the Analamaitso deposits as much as 5 million tons of bauxite.

The potential bauxite resources in Madagascar are estimated to be 200 million tons by the Société
Aluminium Pechiney (1975, table 1). All of these resources are considered subeconomic in the absence of plans to mine them.

\section{MALAWI}

Bauxite has been found in several places in Malawi. The largest and best deposits and the only ones in this country that are considered to contain possible commercial bauxite are on the Lichenya plateau in the Mlanje Mountains. These deposits were investigated by the Malawi (formerly Nyasaland) Geological Survey in the 1950's (Cooper, 1957) and again by industry in the 1969-72 period (Manos, 1977). The other localities in which bauxite is known to occur in Malawi include the Chambe, Sombani, and Little Ruo plateaus, the Sombani and Ruo valleys, the flanks of Manene Hill (Dixey, 1925), and the Zomba and Nyika plateaus (Manos, 1977).

The bauxite on the Lichenya plateau is the laterite type formed on syenite cut by granite intrusions and by pegmatite dikes and veins (Cooper, 1957). Gibbsite is the principal aluminous mineral in these deposits (Stephen, 1963), and it occurs in fine grains that are intermixed with kaolin mimerals, quartz, and feldspar, as well as goethite, ilmenite, and several other heavy minerals. Quartz is particularly abundant where the bauxite is derived from pegmatite veins.

The Lichenya deposits were estimated to contain approximately 60 million tons of bauxite (Cooper, 1957, p. 15-16). The average partial composition of 250 analyses is 42.73 percent $\mathrm{Al}_{2} \mathrm{O}_{3}, 13.93$ percent $\mathrm{Fe}_{2} \mathrm{O}_{3}$, and 1.57 percent $\mathrm{TiO}_{2}$; the bauxite contains 15.65 percent quartz and 2.2 percent other silicates. Investigations of these deposits between 1969 and 1972, which include test pitting and drilling, were reported to have proved a reserve of 28.8 million tons. These so-called reserves are reported (Manos, 1977) to contain 43.7 percent $\mathrm{Al}_{2} \mathrm{O}_{3}, 13.3$ percent free quartz, 2.2 percent combined silica, 14.2 percent $\mathrm{Fe}_{2} \mathrm{O}_{3}, 1.8$ percent $\mathrm{TiO}_{2}$, and 24.6 percent LOI. In this report, the Lichenya deposits are considered to be subeconomic resources because of the absence of active plans to develop them.

\section{MALI}

Ferruginous laterites are present in many plateau areas in the western part of Mali, and bauxite deposits occur along the River Niger. One old report (France Bureau d'Etudes Géologiques et Mimères Coloniales, 1933) describes bauxite deposits near Koulouba, Kita, the Bassaro Plateau, M'Pebougou, along the River 
Niger, near Segou, and at Quenkoro. Deposits from M'Pebougou reportedly contain $70-75$ percent $\mathrm{Al}_{2} \mathrm{O}_{3}$, 1-2.6 percent $\mathrm{SiO}_{2}$, and 2.0-2.8 percent $\mathrm{Fe}_{2} \mathrm{O}_{3}$. Some of the laterites along the River Niger are alluvial deposits (Jodot, 1934). The bauxite near Koulouba and Segou is chiefly in pisolites of boehmite, but some gibbsite is also present (Lapparent and Hocart, 1938). Exploration in the 1950's resulted in the discovery of a deposit in the Fantofa plateau area where the bauxite is reported to contain 45 percent $\mathrm{Al}_{2} \mathrm{O}_{3}$ (Wilmot, Sullivan, and Trought, 1960, p. 238).

The total low-grade (39-44 percent $\mathrm{Al}_{2} \mathrm{O}_{3}$ ) bauxitic laterite in parts of Mali near the Guinea border was estimated to be 550 million tons (De Kun, 1965, p. 79). A brief note (U.S. Bureau of Mines, 1973a, p. 1036) indicates that the French Bureau de Recherches Géologiques et Minières and the Société Aluminium Pechiney were studying the deposits in western Mali. The region is thought to contain $\mathbf{8 2 0}$ million tons of bauxite that is 40 percent $\mathrm{Al}_{2} \mathrm{O}_{3}$, and most of it has less than 4 percent $\mathrm{SiO}_{2}$. Total potential bauxite resources in Mali were estimated to be 1 billion tons by the Sociéte Aluminium Pechiney (1975, table 1). According to a report of a study released by the Malian Ministry of Mines (U.S. Embassy, Bamako, Mali State Department, telegram 02286, July 1,1977 ), the total bauxite reserves in this country are estimated to be approximately $\mathbf{8 8 0}$ million tons. All this bauxite is considered to be subeconomic because of its remote location.

\section{MOZAMBIQUE}

The bauxite deposits in the mountainous region along the border of Mozambique and Zimbabwe continue to be mined on a small scale (Soares-Rebelo, 1972). This bauxite is exported and used mainly in making refractory products; South Africa has been the leading purchaser in recent years.

The bauxite occurs at altitudes of nearly $2,000 \mathrm{~m}$ near Penhalonga, Zimbabwe. It is in the form of gibbsite intermixed with aluminous clay. The rock containing the bauxite is weathered to depths of more than $30 \mathrm{~m}$. The average chemical composition of bauxite mined to 1941 was 61 percent $\mathrm{Al}_{2} \mathrm{O}_{3}, 10$ percent $\mathrm{SiO}_{2}$, and 1-2 percent $\mathrm{Fe}_{2} \mathrm{O}_{3}$ (Colin, 1942, p. 329); other analyses published by the Southern Rhodesia Geological Survey (Rhaup, 1937, p. 79) report that nodules of this grade are present. The reserves of bauxite in the Penhalonga deposits are 2.4 million tons, according to an old estimate (Colin, 1942, p. 331). Presumably more deposits have been discovered since that estimate was made.

Bauxite was found in the Maúzo Mountains in central Mozambique by the Moçambique Serviços de Geologia e Minas (Afonsos and Pinto, 1977).

\section{SIERRA LEONE}

Bauxite mining began in Sierra Leone in 1963 when 10,000 tons were shipped by the Sierra Leone Ore and Metal Co., a subsidiary of Suisse Aluminum Industrie AG. The total tonnage mined from the first shipment through 1982 was more than 10 million tons (table 6).

All bauxite mining prior to 1982 was in the Mokanji Hills district in the Moyamba region. In 1982 most of the mining activity was shifted to the Gondama district, which is about $35 \mathrm{~km}$ southeast of Mokanji Hills. After the Gondama mines were opened, the only mining in Mokanji was small lots on special requests (Schmidt, 1984, p. 489). The bauxite in both districts is sufficiently soft that it can be loaded with hydraulic shovels without blasting, although ripping is required for the removal of some hard zones. The bauxite is crushed, washed, screened, and trucked to Nitti, which is on tidal water.

The major bauxite deposits in Sierra Leone have formed from the Precambrian Kasila Series. This series forms a belt parallel to the coast with a strike in a northwesterly direction. Rocks within the series on which most of the bauxite rests are granulites containing feldspar, garnet, pyroxene, and andalusite. The parent rock resembles granite.

The bauxite in the Mokanji Hills occurs in lenticular bodies (50-200 $\mathrm{m}$ wide and 400-1,000 $\mathrm{m}$ long). Deposits occur in parallel channels 5-20 m thick that wedge in and out irregularly (Schmidt, 1984). The extent and orientation of deposits is apparently controlled by drainage conditions. In places good bauxite is terminated on fresh rock, and big bauxite boulders commonly contain unaltered cores of parent rock. The bauxite ranges from light yellow to reddish brown, and color depends on the content of mafic minerals in the parent rock. The lighter colored bauxite is the best grade. Beneficiated bauxite from this district is pure trihydrate ore containing 55-57 percent $\mathrm{Al}_{2} \mathrm{O}_{3}$ and about 4.5 percent $\mathrm{SiO}_{2}$. It is exceptionally low in titanium minerals as it contains less than 0.4 percent $\mathrm{TiO}_{2}$.

The bauxite in the Gondama district is considerably more uniform and less jointed than deposits in the Mokanji Hills. Some blanket-shaped deposits are as much as $400 \mathrm{~m}$ wide and $1,000 \mathrm{~m}$ long. Thicknesses vary from 2 to $18 \mathrm{~m}$, and the average is about $9 \mathrm{~m}$. Some of the bauxite is intermixed with soft kaolin layers, and this clay also occurs in cracks. Beneficiated bauxite from the Gondama deposits is also the pure trihydrate type containing 53-55 percent $\mathrm{Al}_{2} \mathrm{O}_{3}, 2.5-3$ percent $\mathrm{SiO}_{2}$, 10-13 percent $\mathrm{Fe}_{2} \mathrm{O}_{3}$, and 0.7-0.9 percent $\mathrm{TiO}_{2}$.

Although scattered bauxite deposits had been found in the Port Loko district earlier, the potential of this district was not recognized until the 1970's. Bauxite in 
the district has also formed from the feldspathic rocks in the Kasila Series. Bauxite deposits in this district range widely in grade and shape. They occur in numerous isolated lenses. Deposits of value range from 50 to $500 \mathrm{~m}$ in width and from 100 to $500 \mathrm{~m}$ in length. The overburden is soft dark soil containing lateritic gravel that ranges in thickness from 0.5 to $5 \mathrm{~m}$. Bauxite thicknesses range from 2 to $15 \mathrm{~m}$, and the average is $7 \mathrm{~m}$. Due to high contents of kaolin impurities, recovery from washing will be low. The beneficiated bauxite is expected to be about 47 percent $\mathrm{Al}_{2} \mathrm{O}_{3}$, 4 percent $\mathrm{SiO}_{2}, 21.5$ percent $\mathrm{Fe}_{2} \mathrm{O}_{3}$, and 1.9 percent $\mathrm{TiO}_{2}$. The Port Loko district straddles a railroad extending from the Marampa iron ore district to the deep-water harbor $15 \mathrm{~km}$ from the bauxite district. According to Schmidt (1984, p. 493), there is no doubt that the Port Loko bauxite will be mined when economic conditions become favorable, and it is likely to be used in a local alumina plant.

Bauxite deposits in Sierra Leone, mentioned in the Annual Reports of the Sierra Leone Geological Survey Department, other than those in the Mokanji Hills, Gondama, and Port Loko districts, are in the following areas: (1) Gbonge, located about $40 \mathrm{kun}$ southeast of the Mokanji Hills. These deposits are along the strike of the same feldspathic Kasila Series that is the parent rock of the deposits mined in the Mokanji Hills. (2) The Sierra Leone Peninsula, where deposits were prospected by geologists of the British Aluminium Company. (3) The Krim-Kpaka chiefdom, where some of the deposits are on feldspathic gneiss that is weathered to depths of 10-12 m. Others near Lake Mabesi are under about $1.5 \mathrm{~m}$ of loose soil and extend to depths of as much as $8 \mathrm{~m}$. (4) An inland region located along the Guinea border, where a mineral map of Sierra Leone (Sierra Leone Geological Survey Department, 1975) shows high bauxite potential.

Bauxite reserves (beneficiated basis) in Sierra Leone are as follows: Mokanji district-2 million tons, Gondama district-10 million tons and an additional 5 million tons indicated, and Port Loko district-104 million tons (Schmidt, 1984, p. 489-492). The U.S. Bureau of Mines (Baumgardner and McCawley, 1983, table 3) gives an estimate of 140 million tons for the bauxite reserves in Sierra Leone, which is the same estimate used by Shaffer $(1983$, table 5$)$ for the total bauxite in this country.

\section{SOUTH AFRICA}

South Africans have been searching for a suitable domestic raw material for aluminum (McColloch, 1967). Several different types of rock including diaspore, syenite, anorthosite, clay, and scattered occurrences of lateritic bauxite have been investigated (Brabers, 1974). The first discovery of significant bauxite in South Africa was announced (Chamber of Mines Journal, 1976; Industrial Minerals, 1976), and it was suggested that the deposits may be large enough to be a source of alumina for the smelter at Richards Bay. The bauxite occurs in the Nome region in north-central Natal, the Karkloof district in central Natal, and near Weza in southern Natal. The deposits are the laterite type formed by the weathering of dolerite of Jurassic age. Nine samples from the Karkloof district investigated by Bredell (1983, table 1) range from 51.9 to 62.4 percent gibbsite. The potential bauxite resources near the town of Weza were reported to be 15-20 million tons (Industrial Minerals, 1977b). According to Shaffer (1983, table 5), the total bauxite resources in South Africa are estimated to be $\mathbf{7 0}$ million tons.

\section{UPPER VOLTA \\ (now Burkina Faso)}

Bauxite deposits occur on many plateaus in the central and western parts of Upper Volta (Upper Volta Direction de la Géologie et des Mines, 1970). In the Kaya-Kongoussi area, 10 hills with about 1 million-1.5 million tons each of bauxite that is very rich in $\mathrm{Al}_{2} \mathrm{O}_{3}$ have been reported. In the western region, surveys have discovered the occurrence of bauxite near Sabi, Diekui, and Kono (U.S. Bureau of Mines, 1973b, p. 1057). A deposit containing 6 million tons of bauxite is reported $95 \mathrm{~km}$ north of Ouagadougou (U.S. Bureau of Mines, 1972 , p. 998). Total resources of bauxite, all of which are in the subeconomic category, are probably more than 20 million tons.

\section{ZAIRE}

The principal bauxite deposits in Zaire are located in the Sumbi district (Zaire Department des Mines, 1975), and occurrences have been reported in the northern and northeastern part of the country. The Sumbi district, which is referred to as the Mayumbe region in some reports, is located $50-75 \mathrm{~km}$ north-northwest of the falls on the Zaire (formerly Congo) River at Inga. The bauxite occurrences in the other regions include those noted in the Basoko and Niangara areas (Vanderstappen and Cornil, 1955) and on weathered granitic rocks on a remote high plateau bounded by the Ituri, Bima, and Rubi Rivers (Sluys, 1946).

The deposits in the Sumbi district were investigated by the Société de Recherches et d'Exploration des 
Bauxites du Congo (Bracewell, 1962, p. 167) and by Belgian geologists (Stas, 1959; Grosemans, 1959). The bauxite has formed on mafic lavas and consists principally of gibbsite, goethite, and kaolinite. According to Stas (1959), only a small part of it contains more than 40 percent $\mathrm{Al}_{2} \mathrm{O}_{3} ; \mathrm{SiO}_{2}$ is commonly in the 5-10 percent range, and $\mathrm{Fe}_{2} \mathrm{O}_{3}$ is $15-20$ percent. Large porous blocks in some deposits are 0.5 percent $\mathrm{SiO}_{2}, 36.9$ percent $\mathrm{Fe}_{2} \mathrm{O}_{3}$, and 42.6 percent $\mathrm{Al}_{2} \mathrm{O}_{3}$.

The Société Aluminium Pechiney (1975, table 1) gave an estimate of 200 million tons for potential bauxite in Zaire. This estimate is apparently for the resources in the Sumbi district, because the authors have found no reports on detailed studies of bauxite in the remote northern and northeastern parts of Zaire, where large regions are favorable for the discovery of bauxite. All bauxite in Zaire is considered to be subeconomic in this report because of low alumina and high iron contents. However, opinions have been expressed that the Sumbi bauxite might be suitable for treatment by the Pedersen process (Bracewell, 1962, p. 167). Interest in these deposits will no doubt increase if the power potential at Inga Falls is ever developed.

\section{ZIMBABWE}

Alumina-rich clays, gibbsite-rich nodules, and laterite occur in Zimbabwe on the slopes of ridges along the Zimbabwe-Mozambique border and in the area north of Umtali. Deposits north of Penhalonga are unsuitable for refractory brick but can be used for aluminum sulfate. One partial chemical analysis (South African Mining and Engineering Journal, 1941) listed 64.91 percent $\mathrm{Al}_{2} \mathrm{O}_{3}, 5.86$ percent silica, and 1.09 percent iron.

A geochemical profile described by Grubb (1973, fig. 4E) indicates that bauxite at Mountain Home in the Penhalonga district is more than $20 \mathrm{~m}$ thick. Gibbsite is the only bauxite mineral present, and the deposits contain minor quantities of kaolinite. The upper parts of the deposits are rich in hematite and goethite, and quartz and muscovite are abundant at depth. According to an old report (Rhodesian Mining Journal, 1957), 2 million tons of bauxite occur near the Southampton mine about $7 \mathrm{~km}$ north of Umtali. Shaffer (1983, table 5) listed an estimate of 5 million tons for the total bauxite resources in Zimbabwe.

Diaspore is mined on a small scale in the Nuanetsi district and sold as a fluxing material in the ferroalloy industry (Grubb, 1976). The diaspore occurs mainly in cryptocrystalline nodules associated with quartz, kaolinite, and goethite. It overlies the Karoo shale but is near intrusive dolerite and probably formed by metamorphism of the products of lateritic weathering.

\section{OTHER AFRICAN COUNTRIES}

Bauxite deposits in Liberia occur near Zigida in the Western Province (now Lofa County) and in the Careysburg district in the Central Province (now Montserrado County) (Bracewell, 1962, p. 171). According to Bushinskiy $(1975$, p. 381), bauxite and laterite occur below Eocene lavas on the Ahuggar heights in Algeria. Martens (1971, table 8) lists probable bauxite resources of 50 million tons for Sudan, but he gives no details on location or source of information. Extensive laterite deposits in Nigeria were reconnoitered for bauxite by the British Aluminium Company (Bracewell, 1962, p. 94); however, no valuable bauxite was discovered. The occurrence of bauxitic material on the Seychelles Islands has been known for many years (Bauer, 1898), but these deposits reportedly have very little economic value (Fox, 1932, p. xxix). Bauxite has been discovered on Baumann (Agu) Mountain in Togo (Robertson, 1921, p. 40-41), about $95 \mathrm{~km}$ northwest of the port of Lome. This bauxite contains 46-53 percent $\mathrm{Al}_{2} \mathrm{O}_{3}$ and 1830 percent $\mathrm{Fe}_{2} \mathrm{O}_{3}$ (Arnaud, 1945, p. 84). Low-grade lateritic bauxite has been reported in Uganda in the Northern and Eastern Provinces and Buganda (Uganda Geological Department, 1921, p. 54), and diaspore occurs on Kaweri Island in Lake Kyogo (Bisset, 1943, p. 18). Deposits of ceramic-grade diaspore and pyrophyllite containing 51.7 percent $\mathrm{Al}_{2} \mathrm{O}_{3}$ occur in Swaziland (De Kun, 1965, p. 308). Alummous deposits in the Phalaborwa area have been explored, but no large deposits of bauxite have been found (Mining Journal, 1965 , p. 185). Most of these deposits are probably ferruginous laterites and have little value as bauxite. Very large deposits of weathered aluminous phosphatic rocks in Senegal have been called laterite (Bruckner, 1957, p. 248-250); however, this rock is quite different in composition from typical laterites. Large areas favorable for bauxite in the Tanganyika region of Tanzania have only been partly explored. Several small deposits have been reported, and the outlook is favorable for additional discoveries. The best bauxite that has been reported (Teale and Oates, 1946, p. 70-71) is on the Usambra highlands near the town of Amani, which is about $80 \mathrm{~km}$ west of the port of Tanga. At this locality, the bauxite overlies hornblende-pyroxene granulite and garnet-biotite-pyroxene gneiss. One of three samples from Amani that were analyzed (Teale and Oates, 1946, p. 71) contained 57.7 percent $\mathrm{Al}_{2} \mathrm{O}_{3}, 10.53$ percent $\mathrm{SiO}_{2}, 1.15$ percent $\mathrm{Fe}_{2} \mathrm{O}_{3}, 1.66$ percent $\mathrm{TiO}_{2}$, and 26.8 percent $\mathrm{H}_{2} \mathrm{O}$, but the other two samples were high in $\mathrm{SiO}_{2}$ and low in $\mathrm{Al}_{2} \mathrm{O}_{3}$. Small bauxite deposits occur in Luanda, Angola (Peterson and Arbelbide, 1983, table A-4). 
SUMMARY OF BAUXITE RESOURCES IN AFRICA

The total bauxite reserves in Africa are estimated to be about 7 billion tons (rounded), and the continent's resources (reserves plus subeconomic and undiscovered resources) are thought to be in the 15- to 20-billion-ton range. The reserves in the principal bauxite-producing countries are as follows: Guinea-5.6 billion tons, Ghana-450 million tons, and Sierra Leone-140 million tons. At least 2 million tons of reserves and probably considerably more is present in Mozambique, where bauxite is mined for nonmetallurgical uses. Cameroon is considered to have 680 million tons of bauxite reserves, because of the continuing efforts to develop domestic deposits. The principal subeconomic deposits, which are estimated to have a total of 5-7 billion tons, are located in the countries that have large reserves, and in Guinea-Bissau, Malawi, Mali, Madagascar, and Zaire. It is virtually certain that additional bauxite deposits will be discovered in African countries known to have bauxite, and the total subeconomic and undiscovered bauxite is probably in the 8- to 13-billion-ton range.

\section{ASIA (EXCLUDING U.S.S.R.)}

Extensive deposits of bauxite occur in India, the People's Republic of China, and Indonesia (United Nations Economic Commission for Asia and the Far East, 1963); deposits of small or moderate size occur in Turkey, peninsular Malaysia, Pakistan, and Vietnam; and lowgrade laterite is common on some of the islands in the Philippines. In addition, large areas of Southeast Asia lie in the tropics, and many extensive areas favorable for bauxite have not been explored adequately. Accordingly, significant bauxite discoveries may be made in the future in Kampuchea and Laos, as well as in countries in which bauxite is now known to occur. Bauxite is now mined for aluminum in India, Indonesia, Malaysia, Turkey, and the People's Republic of China. Small tonnages of bauxite were mined in Sarawak, Malaysia, until deposits were exhausted in 1965. Some bauxite was produced in Vietnam during World War II; minor quantities of bauxite in Pakistan have been used in making cement and for other nonmetallic uses.

\section{INDIA}

\section{History and Production}

The existence of bauxite at many places in India has long been known (Roy Chowdhury, 1974). Mining for nonmetallurgical uses began about 1910. During the
1940 's, two Indian aluminum companies began to mine bauxite in the Rānchł district, Bihăr, for the recovery of alumina. The yearly bauxite production reached 387,000 tons in 1960 , and by 1970 the output had increased to more than 1.3 million tons (table 6). Bihar, Madhya Pradesh, Maharashtra, and Gujaratt are the leading producing states, and bauxite is mined in four other states. According to the Indian Bureau of Mines (1974, table II-38), 12 companies are mining bauxite. Most of the bauxite mined is used for metallurgical purposes; however, in 1970 the nonmetallurgical uses included 61,609 tons for refractories, 43,630 tons for chemicals, 56,388 tons for cement, 14,143 tons for iron and steel flux, and 14,437 tons for ceramics, abrasives, foundry uses, paints, and other uses (Indian Bureau of Mines, 1974, table II-38). A few thousand tons of diaspore is also produced in India for refractory uses each year.

\section{Bauxite Districts and Deposits}

All but a few bauxite deposits in India are the laterite type. They occur mainly as blanket deposits on extensive high plateaus and as capping on the Hill ranges of peninsular India and on scattered lower inland plateaus and coastal lowlands (Roy Chowdhury and Venkatesh, 1972). Many of the laterite cappings are indurated, and in several districts significant bauxite resources occur as talus of laterite blocks on the slopes on the edges of the plateaus. Most of the higher plateau deposits are at altitudes of approximately $1,000 \mathrm{~m}$; the lower ones are at altitudes of $250-300 \mathrm{~m}$. The major high-level deposits occur mainly in the following regions (fig. 21): (1) the plateau bordering the states of Bihär and Madhya Pradesh, (2) Maikala Range in Madhya Pradesh, (3) Western Ghats, and (4) East Coast bauxite province, Andhra Pradesh and Orissa. The principal low-level deposits are in the Katni area, Madhya Pradesh; the Saurāshtra and Kutch districts, Gujarăt; the Kolaba district, Maharashtra; and coastal areas of Karnataka (Mysore) and Goa.

Gibbsite is the principal mineral in the laterite-type bauxite deposits, but minor quantities of boehmite are present in many deposits (Roy Chowdhury and Venkatesh, 1972, p. 83). Cliachite is apparently also present in some deposits. Kaolinite, hematite, anatase, and rutile are the principal mineral impurities in several deposits, and many other minerals occur in minor quantities.

Contents of silica and iron oxides in Indian bauxites vary considerably. Most of the high-level deposits are low in silica and rich in iron, but there are several exceptions. Typical deposits in southern India are 10-20 

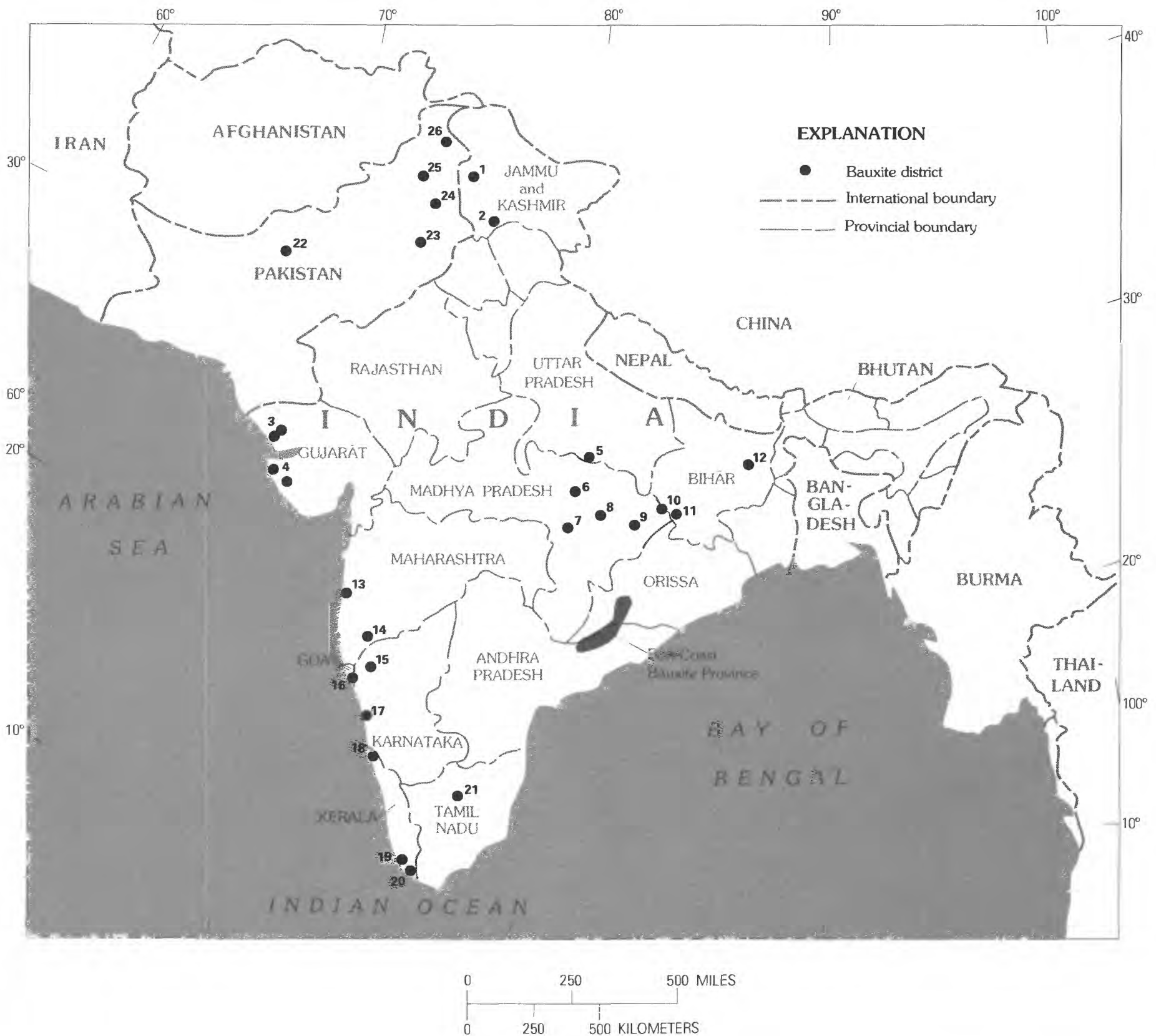

India
1. Pūnch
2. Riāsi
3. Kutch
4. Saurāshtra
5. Banda
6. Jabalpur
7. Mandla and Bälāghăt
8. Raigarh
9. Bilāspur and Shahdol

10. Surguja (Ambikāpur)
11. Rānchì and Palāmau
12. Monghyr
13. Koläba
14. Kolhãpur
15. Belgaum
16. Goa
17. South Kanara
18. Cannanore
19. Alleppey and Quilon

20. Trivandrum

21. Salem

\section{Pakistan}

22. Ziärat

23. Sargodha-Khushāb, Salt Range

24. Kotli Tehsil

25. Campbellpore, Kăla Chitta Range

26. Muzaffaräbad

FIGURE 21.-Locations of bauxite districts in India and Pakistan. 
percent $\mathrm{SiO}_{2}$, whereas most deposits on the Central Indian Plateaus (Deccan upland) and Gujarāt contaim less than 5 percent silica. Deposits formed on the Deccan Trap in Madhya Pradesh, Bihār, and Maharashtra have uncommonly high $\mathrm{TiO}_{2}$ contents of 5-12 percent. Indian bauxite also contaims several other metals in trace amounts (Roy Chowdhury and Venkatesh, 1972, p. 85-86). The possible recovery of vanadium and phosphate during Bayer processing of Indian bauxite has been investigated by the Indian Bureau of Mines (Bhattacharyya, 1971).

Most Indian bauxites have formed by lateritic weathering of the Deccan Trap, and a few have formed from other types of igneous rocks (Roy Chowdhury and Venkatesh, 1972, p. 86). Some deposits in Gujarăt are thought to have been transported from other bauxites, as suggested by the presence of poorly sorted bauxite pebbles and grams. Deposits in Karnataka have formed from sedimentary clays (Radhakrishna, 1965), and those in Uttar Pradesh developed on feldspathic sandstone (Swarup, 1973). Deposits on the Bargru Plateau, Rancht district, Bihar, formed on granite gneiss (Guha, 1967); those in the Kalahandi (Bhawanipatna) district, Orissa, developed on Precambrian garnetiferous quartzsillimanite schist and hypersthene-bearing plutonic rock (Murty, 1963); the parent rock of deposits in the Monghyr area, Rāncht, Bihara, is shale (Hasan, 1966). Small deposits in the Ahmadabad district of Gujarat are in irregular pockets on himestone and are of the Mediterranean or terra rossa type. The bauxite in Jammu and Kashmir is associated with kaolin clay occurring above limestone. This bauxite differs from other deposits in India in consisting mainly of diaspore. The few thousand tons of diaspore mined each year in India for refractory uses is produced primarily in Madhya Pradesh and Uttar Pradesh (Indian Bureau of Mines, 1974, p. 277).

Bihār.-The major bauxite deposits mined in India are in the highlands of the Rancht district (fig. 21) and adjoining parts of the Palamau district, Bihăr State (Roy Chowdhury, 1958, p. 29). Extensive laterite-type bauxite deposits cap plateaus and ridges at altitudes of $950-1,100 \mathrm{~m}$, and accumulations of detrital laterite occur at scattered localities in valleys. Roy Chowdhury $(1958$, p. 36) thought the bauxite formed as a residual weathering product on the Deccan Trap. Guha (1967, p. 101-102) pointed out that the Deccan Trap is nowhere exposed in the district, and he presented several pieces of evidence indicating that granite gneiss is the parent material. Guha also identified gibbsite as the principal bauxite mineral and stated that only minor amounts of boehmite are present. The bauxite occurs in pisolitic, oolitic, brecciated, and fine-grained forms. Small low-grade deposits occur in the Kharagpur Hills,
Monghyr district, Bihār (Anandalwar, 1962). These deposits contam about 1.5 million tons of bauxite. Most of it is only 35-40 percent $\mathrm{Al}_{2} \mathrm{O}_{3}$, but some higher grade bauxite is also present.

The Rancht district has for several years been India's leading producer of metal-grade bauxite. The yearly output has been approximately one-half million tons. Approximately one-half of this tonnage has been in the grade range of 45-50 percent $\mathrm{Al}_{2} \mathrm{O}_{3}$, and one-half has been 50-55 percent $\mathrm{Al}_{2} \mathrm{O}_{3}$ (Indian Bureau of Mines, 1974, table II-35).

The Indian Bureau of Mines estimate for the bauxite reserves in Bihăr (Kumar and others, 1977, supp., p. iii), in millions of tons, is as follows: measured-10.82, indicated-16.56, inferred-48.10, and total-75.48. Das Gupta (1984, table 2) lists the reserves as 45 million tons.

East Coast bauxite province. - The East Coast bauxite province is an extensive belt in northeastern Andhra Pradesh and southern Orissa in which major bauxite discoveries have been made recently (Bharat Aluminium Company, 1977; Ramam, 1977). Bauxite deposits in this province occupy an area of approximately $25,000 \mathrm{~km}^{2}$. The province is $300 \mathrm{~km}$ long; it lies approximately between $17^{\circ} 30^{\prime}$ and $20^{\circ} 00^{\prime} \mathrm{N}$. latitude and $81^{\circ} 30^{\prime}$ and $83^{\circ} 0^{\prime} \mathrm{E}$. longitude.

The deposits occur on plateaus and formed on the Archean khondalite of the Eastern Ghats. Plateau surfaces are 300-500 $\mathrm{m}$ above the surrounding valleys. Surfaces are generally flat and have gentle slopes, and most have a laterite boulder cover with local grassy and marshy patches underlain by clay-rich zones. At most places the laterite profile is $10-15 \mathrm{~m}$ thick, but thicknesses range from 5 to $51 \mathrm{~m}$. The deposits are mostly red, reddish brown, and pink, but cream-colored bauxite occurs locally. The khondalite on which the bauxite formed is a quartz-feldspar-sillimanite-garnet-graphite schist. Evidence that this schist is the parent rock of the bauxite includes relict foliation, pseudomorphic replacement of the minerals in and gradational transition of bedrock into bauxite.

The bauxite is mainly the trihydrate type, but some monohydrate minerals and considerable impurities also occur in the deposits (Bharat Aluminium Company, 1977). In addition to gibbsite, the principal mineral, the trihydrate minerals nordstrandite and bayerite are reported to make up as much as 9 percent of some of the deposits. Boehmite and diaspore make up less than 5 percent of the deposits, and the latter is ordinarily present only in trace amounts. Hematite and goethite are the principal iron minerals, and identifiable quantities of siderite are present. Much of the goethite is the aluminous variety, and trace amounts of aluminum are reported to occur in hematite. Anatase and rutile are 
the principal titanium minerals present. Most of the $\mathrm{SiO}_{2}$ is in kaolinite, but sillimanite is also present. Investigation by the Bharat Aluminium Company has established that bauxite in 19 deposits in the East Coast province extends over areas having a total of $113.7 \mathrm{~km}^{2}$. About 4 percent of this area has been drilled and sampled with closely spaced holes, and an additional 20 percent has been explored by widely spaced holes. The remaining area has been explored by surface studies and sampling along scarps and other outcrops. The total possible bauxite in these deposits is estimated to be 1.2 billion tons (Bharat Aluminium Company, 1977). The composition of the bauxite is as follows: 43.7-56.49 percent $\mathrm{Al}_{2} \mathrm{O}_{3}, 0.55-4.20$ percent $\mathrm{SiO}_{2}, 8.65-38.39$ percent $\mathrm{Fe}_{2} \mathrm{O}_{3}, 2.10-3.55$ percent $\mathrm{TiO}_{2}$, and 24.56-30.55 LOI.

Other estimates of the bauxite reserves and total resources in the East Coast province have been published by the Indian Bureau of Mines. One (Kumar and others, 1977, supp., p. i-ii) lists the total measured, indicated, and inferred reserves, in millions of tons, as 923.28 for Orissa and 398.23 for Andhra Pradesh. The total bauxite resources in the province are, therefore, approximately 1.3 billion tons. Kumar and others (1977, supp., p. vii) also cite an unpublished report by the Geological Survey of India which gives an estimate of more than 1.6 billion tons for the bauxite in Orissa and Andhra Pradesh. The bauxite included in these estimates is less than 5 percent $\mathrm{SiO}_{2}$ and $45-49$ percent $\mathrm{Al}_{2} \mathrm{O}_{3} ; 680$ million tons of this total has $\mathrm{Al}_{2} \mathrm{O}_{3}$ contents in the 46- to 51-percent range. According to the latest available estimates by the Indian Bureau of Mines and the Geological Survey of India, the East Coast province contains 3 billion tons of bauxite resources (Das Gupta, 1984, p. 483; G.V. Rao, 1982, p. 40).

Goa.-Lateritic bauxite at a low level near the coast has been discovered in Goa. Mining began in 1968, and most of the bauxite produced has been shipped to Europe. Reserves were estimated to be 80 million tons (Roy Chowdhury, Venkatesh, and Banerjee, 1970, p. 181). However, the Indian Bureau of Mines (Kumar and others, 1977, supp., p. iii) listed more conservative estimates, in millions of tons, as follows: measured8.23, indicated-9.34, inferred-7.02, and total-24.59.

Gujarāt.-Ferruginous bauxite in laterite plateau cappings occurs in belts along the coast in Saurashtra and Kutch and in small inland districts in Saurasshtra (Roy Chowdhury, 1965, p. 108-123). The laterite in the principal districts along the coast is thought to have formed from pyroclastic material in the Deccan basalts, and some of the bauxite in the small inland districts may have weathered from calcareous sediments (Sahasrabudle, 1964). Kutch has the largest reserves, which are estimated to be 27.7 million tons (Vittal, 1973, p. 2). The Jāmnagar and Bhavnagar districts in Saurāshtra contain about 12 million tons. According to U.D.G. Rao (1975), the reserves of bauxite in Gujarat are 37 million tons. Considerably more bauxite must have been found in Gujarat in the last few years, inasmuch as Das Gupta (1984, table 2) listed reserves as 100 million tons. Another estimate by the Indian Bureau of Mines (Kumar and others, 1977, supp., p. iii) lists the bauxite reserves in Gujarat, in millions of tons, as follows: measured-40.11, indicated-3.97, inferred-1.63, and total-45.71. Part of this bauxite contains reactive silica in the form of kaolinite, and the total metallurgicalgrade bauxite is 20 million tons. The metallurgical-grade bauxite in Kutch contains 4.2 percent $\mathrm{SiO}_{2}, 56.1$ percent $\mathrm{Al}_{2} \mathrm{O}_{3}, 8.9$ percent $\mathrm{Fe}_{2} \mathrm{O}_{3}, 4.7$ percent $\mathrm{TiO}_{2}$, and 1.0 percent $\mathrm{CaO}$. Bauxite has been mined for export in three major districts for several years, and some bauxite from the small inland districts has been used in making portland cement and in purifying kerosene.

Karnataka (Mysore).-The best known bauxite deposits in Karnataka are in the inland Belgaum district, but bauxite also occurs in districts in coastal regions and elsewhere. The Belgaum bauxite is of the laterite type overlying the Deccan Trap; its average thickness is about $5 \mathrm{~m}$ (Roy Chowdhury, 1965, p. 88). Lateritic bauxite in the South Kanara district along the coast is underlain by pebbles (Nagaraja, 1967, p. 5), indicating that the parent material was sedimentary rock. Much of the bauxite in the coastal region is a high-silica variety containing 45-55 percent $\mathrm{Al}_{2} \mathrm{O}_{3}$ (Radllakrishna, 1965 , p. 65-66). Content of iron oxide is variable, and quantities of $\mathrm{TiO}_{2}$ present are rarely more than 2 percent. Bauxite has been mined in the Belgaum district for several years and shipped for use in the ceramic, chemical, and metallurgical industries (Nanjundaiah and Krishnachari, 1971). Total measured, indicated, and inferred reserves of bauxite in Karnataka are reported to be more than 15 million tons (Indian Bureau of Mines, 1974, table II-34), and in more recent estimates, the Bureau (Kumar and others, 1977, supp., p. iv) increased the total in these three categories to 23.6 million tons.

Although the best known bauxite in Karnataka is in the Belgaum district, larger low-grade deposits are present in the Mundalli, Bhatkal, and Bainduru districts (Das Gupta, 1984, p. 476). These three districts have a potential bauxite reserve of $\mathbf{4 0}$ million tons. The bauxite is approximately 48 percent $\mathrm{Al}_{2} \mathrm{O}_{3}, 16$ percent $\mathrm{SiO}_{2}$ (4.5 percent reactive $\mathrm{SiO}_{2}$ ), 11 percent $\mathrm{Fe}_{2} \mathrm{O}_{3}$, and 1.3 percent $\mathrm{TiO}_{2}$.

Jammu and Kashmir.-Deposits of bauxite having very high alumina contents occur in several areas near the town of Riāsi, Jammu Province, and in the Punch area. These deposits are stratigraphically above a rock 
unit known as the "great limestone" and are overlain by a series of coal-bearing rocks of Eocene age (Roy Chowdhury, 1955, p. 214). The bauxite is in areas of dipping strata, and altitudes range from 1,200 to $1,700 \mathrm{~m}$. Thicknesses of the bauxite range from 1 to $7 \mathrm{~m}$. Both massive and pisolitic types are present, and diaspore is reported to be the principal mineral (Caillère and Singh, 1967). In these deposits, the bauxite grades downward into a clay zone above the "great limestone." The best grade deposits are restricted to areas where the coal series has been eroded. Where deposits extend under thick overburden the bauxite is replaced laterally by clay, which suggests that the bauxite formed by weathering at or near the surface after erosion of the coal-bearing rocks.

Deposits in five areas in the Riasi district are estimated to contain 2 million tons of bauxite that is 75-82 percent $\mathrm{Al}_{2} \mathrm{O}_{3}$ and 1-5 percent $\mathrm{SiO}_{2}$ (Roy Chowdhury, 1959, p. 26). These deposits are associated with approximately 10 million tons of bauxite that is 65-75 percent $\mathrm{Al}_{2} \mathrm{O}_{3}$ and 6-15 percent $\mathrm{SiO}_{2}$. Deposits in the Punch area of Kashmir contain 600,000-800,000 tons, most of which contains more silica than the better grade bauxite in the Riāsi district.

According to the Indian Bureau of Mines estimates (Kumar and others, 1977, supp., p. iv), the bauxite reserves in Jammu and Kashmir are 2.78 million tons, and all is in the inferred category. Das Gupta (1984, table 2) listed the reserves as 3 million tons.

Kerala. - In Kerala, bauxite has been found in the Trivandrum, Quilon, Alleppey, and Cannanore districts. According to Kumar and others (1977, p. 95-96), who refer to unpublished work by the Geological Survey of India, some of the deposits are residual on Archean rocks and others are detrital sedimentary units underlying sandstone and clays. According to the Indian Bureau of Mines (Kumar and others, 1977, supp., p. iv), the bauxite reserves in Kerala, in millions of tons, are as follows: measured-0.77, indicated-4.2, inferred-2.72, total-7.7.

Madhya Pradesh. - Bauxite occurs at more than 100 localities in Madhya Pradesh. According to Roy Chowdhury $(1965$, p. 26), the major districts are as follows: (1) the continuation of the plateau region of Bihār into the districts of Surguja (now Ambikapur), Raigarh, and Bilaspur, (2) the plateau region forming the Maikala Range of hills in the districts of Shahdol, Bilasspur, Drug, Mandla and Bālagghăt, and (3) the Kătni area of the Jabalpur district. Bauxite also occurs in three other regions in the state, but insofar as presently known these regions do not contain significant resources.

The most productive mines are in the Katni area of the Jabalpur district and in the Shahdol district. For several years, bauxite was produced for use by the chemical, refractory, and abrasives industries, and, in recent years, metal-grade bauxite has also been produced. Thickness of bauxite mined in the Jabalpur district is as much as $7 \mathrm{~m}$, and the $\mathrm{Al}_{2} \mathrm{O}_{3}$ contents of several deposits in this district range from 55 to 70 percent (Pathak, 1958, p. 35-38). Much of the bauxite in the Shahdol district is 54-60 percent $\mathrm{Al}_{2} \mathrm{O}_{3}$ (Roy Chowdhury, 1965, p. 51-52), and, hke other deposits on the Deccan Trap, it is low in silica, rich in titania, and moderately rich in iron oxides. Gibbsite is the principal bauxite mineral, as is indicated by the high LOI.

The bauxite on the Phutka Pahar plateau, Bilaspur district, has been investigated thoroughly by the Geological Survey of India (Roy Chowdhury, Anandalwar, and Tyagi, 1968). Like other bauxites in Madhya Pradesh, these deposits were found to overlie the Deccan Trap; however, some are separated from the underlying basalt by a layer of tuffaceous clay. The bauxite is light gray to pinkish white. Thicknesses range from 1 to $5 \mathrm{~m}$, and the average thickness is 2$2.5 \mathrm{~m}$. Gibbsite is the principal mineral in the bauxite, but boehmite is common in parts of the deposits. Diaspore is also present locally in minor quantities. The iron is mainly in the form of hematite, but goethite is also present. Chemical composition of the bauxite is 50-60 percent $\mathrm{Al}_{2} \mathrm{O}_{3}, 3-9$ percent $\mathrm{Fe}_{2} \mathrm{O}_{3}$, as much as 2 percent $\mathrm{SiO}_{2}$ and 8 percent $\mathrm{TiO}_{2}$, and LOI is 2327 percent. The specific gravity of the bauxite ranges from 2.49 to 2.56. The area contains 1.96 million tons of proved bauxite that is at least 50 percent $\mathrm{Al}_{2} \mathrm{O}_{3}$ and 3 million tons that is 45 percent $\mathrm{Al}_{2} \mathrm{O}_{3}$.

The Amarkantak area, which is in the Maikala Range, Shahdol and Mandla districts, was investigated as a possible source of bauxite for an Indo-Hungarian aluminum project (Roy Chowdhury, Venkatesh, and Paul, 1968). Also, the Hindustan Aluminum Co. has controlled leases in the area and has mined bauxite on a small scale for several years. The bauxite deposits in the Amarkantak area are similar to plateau deposits elsewhere in Madhya Pradesh. Parts of the deposits contain appreciable quantities of boehmite, and goethite is abundant in others. In detailed studies by the Geological Survey of India (Roy Chowdhury, Venkatesh, and Paul, 1968), 8.5 million tons of bauxite ore was proved, and an additional 4 million tons was inferred to be present. All this bauxite contains more than 45.5 percent $\mathrm{Al}_{2} \mathrm{O}_{3}$, and 1.9 million tons is 57.0 percent $\mathrm{Al}_{2} \mathrm{O}_{3}$.

The total reserves of bauxite in Madhya Pradesh were estimated by the Indian Metallurgical and Engineering Consultants, Ltd., in millions of tons (U.S. Embassy, New Delhi, India, State Department Airgram, Aug. 21, 1976) as follows: measured-59.08, indicated-12.83, inferred-28.58, and total-100.49. The Indian Bureau 
of Mines estimates (Kumar and others, 1977, supp., p. iii), in millions of tons, are as follows: measured56.36 , indicated-13.40, inferred-37.26, and total107.02. According to Das Gupta (1984, p. 466), the Geological Survey of India estimated the measured bauxite reserves in Madhya Pradesh to be 59 million tons and the potential reserves to be 42 million tons.

Maharashtra.-Lateritic bauxite occurs on several plateaus in Maharashtra. The largest resources are in the Kolhapur district, but the smaller deposits in the Kolaba district are attractive because they are located near the coast. Bauxite resources in several other districts are apparently small (Roy Chowdhury, 1965, p. 92-106).

The deposits in the Kolhapur district cap plateaus at altitudes of 700-1,300 $\mathrm{m}$ and overlie the Deccan Trap. The bauxite ranges in thickness from 2.6 to $8 \mathrm{~m}$. It is overlain by ferruginous laterite $0.3-2.6 \mathrm{~m}$ thick and underlain by $4-10 \mathrm{~m}$ of soft porous laterite that is, in turn, underlain by 3-7 $\mathrm{m}$ of soft lithomarge and 13$20 \mathrm{~m}$ of kaolinized basalt. The bauxite is chiefly gibbsite but contains minor quantities of boelımite (Mathad and Altekar, 1960). According to Balasubramaniam and Paropkari (1975), the iron in deposits on the Nagardaswadi plateau in this district is in the form of goethite and maghemite, silica is in the form of kaolinite and halloysite, and leucoxene was the only titanium-bearing mineral identified. The average partial chemical composition of the better grade bauxite is 55.54 percent $\mathrm{Al}_{2} \mathrm{O}_{3}, 1.13$ percent $\mathrm{SiO}_{2}, 7.45$ percent $\mathrm{Fe}_{2} \mathrm{O}_{3}, 7.17$ percent $\mathrm{TiO}_{2}$, and 27.73 percent LOI.

The total reserves of bauxite in Maharashtra were estimated by the Indian Metallurgical and Engineering Consultants, Ltd. (U.S. Embassy, New Delhi, India, State Department Airgram, Aug. 21, 1976), in millions of tons, as follows: measured-52.42, indicated-50.95, inferred-17.58, and total-120.95. These estimates of the bauxite reserves in Maharashtra are similar to those of the Indian Bureau of Mines (Kunnar and others, 1977, supp., p. ii), which are, in millions of tons, as follows: measured-50.69, indicated-32.09, inferred-45.36, and total-128.14. Das Gupta (1984, p. 473-475) listed the following bauxite resource estimates for Maharashtra: Kolhāpur district-72 million tons, Satara and Thana districts-2.6 million tons, and Kolaba and Ratnagiri districts -10 million tons. Das Gupta noted that an area of $20 \mathrm{mi}^{2}\left(50 \mathrm{~km}^{2}\right)$ in the Ratnagiri district is covered with an aluminous laterite having an average thickness of about $10 \mathrm{~m}$. Detailed exploration and successful beneficiation may establish in the future the economic viability of using about 1 billion tons of lateritic bauxite in this area.

Tamil Nadu (Madras). - Most of the bauxite in Tamil $\mathrm{Nadu}$ is in laterite that caps six hills in the Shevaroy
Hills, Salem district (Krisluna Rao, Borreswara Rao, and Sundar, 1974), and small deposits occur in the Nilgiri and Palni Hills nearby. The Shevaroy Hills are $13 \mathrm{~km}$ south of the town of Salem. The flat tops of the hills are at elevations of about $1,800 \mathrm{~m}$. The best grade bauxite is the Shevaroy Hills deposits, which have weathered from leptynite (Krislnan, 1942); the lower grade Nilgiri deposits formed on charnockite (Valeton, 1968).

The bauxite deposits are 7-10 $\mathrm{m}$ thick, and the quantity present is estimated to be 6-7 million tons (Roy Chowdhury, 1955, p. 210). The average $\mathrm{Al}_{2} \mathrm{O}_{3}$ content of the bauxite is 50 percent; silica and titania are low, but most of the bauxite contains more than 8 percent $\mathrm{Fe}_{2} \mathrm{O}_{3}$. The bauxite is chiefly gibbsite; limonite, ilmenite, quartz, and kaolin are the principal impurities. The Indian Bureau of Mines estimates (Kumar and others, 1977, supp., p. iv) list the following reserves, in millions of tons: measured-3.16, indicated-0.95, inferred-2.26, and total-6.37.

Uttar Pradesh. - Bauxite was discovered in 1965 in the Rajuhuan area, Banda district, near the southern border of Uttar Pradesh (Swarup, 1973). This bauxite occurs in blanket-type laterite deposits in residual accumulations on feldspathic sandstone. The deposits are on flat-topped hills at altitudes of about $360 \mathrm{~m}$, which is appreciably lower than the large deposits on the Deccan Trap farther south. The bauxite is of irregular thickness, but some deposits are as much as $30 \mathrm{~m}$ thick. Mineralogical studies by Srivastava and Srivastava (1970) have revealed that gibbsite is the principal bauxite inineral, but minor quantities of boehmite are also present. The bauxite is uncominonly rich in anatase, and $\mathrm{TiO}_{2}$ contents range from 6 to 18 percent (Swarup, 1973, p. 176). The deposits contain 8 million-10 million tons of bauxite, and large areas are favorable for the discovery of more bauxite (Swarup, 1973, p. 169). Deposits in the Banda district are now being mined on a small scale (Indian Bureau of Mines, 1974, table II-35). The Indian Bureau of Mines estimates for the bauxite reserves in Uttar Pradesh (Kumar and others, 1977, supp., p. iv), in millions of tons, are as follows: measured-10.38, indicated-3.70, inferred-1.40, and total-15.48.

\section{Resources}

Several estimates of the reserves of bauxite in India have been made, and the estimates have increased markedly in recent years. According to one estimate published by the United Nations Economic Commission for Asia and the Far East (1962, p. 6), the total bauxite reserves in India were 64 million tons. An estimate ten years later by Roy Chowdhury and Venkatesh (1972, 
p. 87) of the Geological Survey of India listed the total bauxite reserves as 179.8 million tons, the largest reserves being in the states of Madhya Pradesh and Maharashtra. An estimate by the Indian Bureau of Mines (1974, table II-34) completed in 1971 gave bauxite reserves, in millions of tons, as follows: measured145.21, indicated-33.37, and inferred-54.08. Estimates compiled jointly by the Indian Bureau of Mines and the Geological Survey of India in 1971 (Kumar and others, 1977, p. 163) were, in millions of tons, as follows: measured-141.8, indicated-33.4, inferred-51.6, and total-226.8. Revised estimates made 4 years later by the Indian Bureau of Mines and the Geological Survey of India (table 21) list a total of more than 1.7 billion tons. Das Gupta (1984, table II) listed the proven bauxite reserves in India as 255 million tons and the potential reserves as 1,994 million tons with a total of 2,249 million tons. Das Gupta's report also makes the following statement (p. 483): "A potential reserve of 1,500 million tonnes and proved reserve of 114 million tonnes of aluminous laterite which can be treated by the Bayer process has been claimed by Government Survey Departments for both Orissa and Andhra Pradesh***." Estimates for 1,500 million tons for each of two States equals the 3,000-million-ton estimate for the bauxite reserves in the East Coast province (G.V. Rao, 1982, p. 40).

In this report the bauxite reserves in India are assumed to be 1 billion tons, the estimate of the U.S. Bureau of Mines (Baumgardner and McCawley, 1983, table 3). The total resources (reserves and subeconomic and undiscovered bauxite) are estimated to be 3 billion5 billion tons. This estimate includes the 3 billion tons thought to be in the East Coast province, about 1 billion tons of low-grade bauxite in the Ratnagiri district, Maharashtra (Das Gupta, 1984, p. 475), and the resources in all the other bauxite districts in India.

\section{INDONESIA}

\section{History and Production}

Bauxite was discovered in the Riau Archipelago in 1924, and mining began on the island of Bintan in 1935. Most production has been on Bintan, but bauxite has also been mined on other small islands nearby (Sigit and others, 1969, p. 71). Annual production for most years during the period from 1936 to 1960 was between 100,000 and 400,000 tons. Output rose to more than 900,000 tons in 1967 (table 6). In 1969, Kidjang Strait was dredged to accommodate ore ships as large as 30,000 tons, and the loading facilities were expanded (Indonesian Ministry of Mines, 1970, p. 7). Production
TABLE 21.-Bauxite reserves in India, by States [All values in millions of tons. --, no data. Estimates by Indian Bureau of Mines and the Geological Survey of India (Kumar and others, 1977, supp.)]

\begin{tabular}{|c|c|c|c|c|}
\hline State & Measured & Indicated & Inferred & Total \\
\hline Orissa & 15.43 & 353.89 & 553.96 & 923.28 \\
\hline Andhra Pradesh & 16.98 & 56.25 & 325.00 & 398.23 \\
\hline Maharashtra & 50.69 & 32.09 & 45.36 & 128.14 \\
\hline Madhya Pradesh ...... & 56.36 & 13.40 & 37.26 & 107.02 \\
\hline Bihār . . . . . . . . . & 10.82 & 16.56 & 48.10 & 75.48 \\
\hline Gujarāt $\ldots \ldots \ldots \ldots$ & 40.11 & 3.97 & 1.63 & 45.71 \\
\hline Goa $\ldots \ldots \ldots \ldots \ldots$ & 8.23 & 9.34 & 7.02 & 24.59 \\
\hline Karnataka & 1.19 & 8.97 & 13.51 & 23.67 \\
\hline Uttar Pradesh & 10.38 & 3.70 & 1.40 & 15.48 \\
\hline$\ldots \ldots \ldots \ldots \ldots$ & .77 & 4.24 & 2.72 & 7.73 \\
\hline Tamil Nadu .......... & 3.16 & .95 & 2.26 & 6.37 \\
\hline Jammu and Kashmir & -- & - & 2.78 & 2.78 \\
\hline Total & 214.12 & 503.36 & $1,041.00$ & $1,758.48$ \\
\hline
\end{tabular}

during 1969-81 averaged more than 1 million tons per year, but only 700,000 tons were produced during the recession year of 1982 . All production is now under the management of the government enterprise, P.N. Aneka Tambang. Virtually all Indonesian production has been exported; most shipments have been to Japan, but some have gone to Western Europe and North America.

Bauxite mining in Indonesia could increase appreciably if a planned alumina plant that will process Indonesian bauxite is constructed. Although alumina has never been produced in Indonesia, the construction of two large alumina plants, one on Bintan Island (Metals Sourcebook, 1974a) and one in West Kalimantan (Metals Sourcebook, 1975b, p. 1), has been proposed. The construction of an aluminum smelter drawing power from a hydroelectric development on the Asahan River in Sumatra has created an increased demand for alumina in Indonesia.

\section{Bauxite Districts and Deposits}

Until the recent discovery of large bauxite deposits in West Kalimantan, the largest bauxite deposits in Indonesia were thought to be on Bintan Island (fig. 22), which is in the Riau Archipelago approximately $100 \mathrm{~km}$ southwest of Singapore. The bauxite on Bintan is in a laterite layer 2-10 $\mathrm{m}$ thick; the average thickness is approximately $4 \mathrm{~m}$. The bauxite consists of layers of hard lateritic concretions dispersed in a soft mottled clay. The concretions are $2.5-10 \mathrm{~cm}$ in longest dimension. They are chiefly gibbsite and goethite, but minor amounts of silica-bearing minerals are also present. Interstitial clay makes up one- to two-fifths of the total laterite mass (Bemmelen, 1940, p. 112). This clay is 


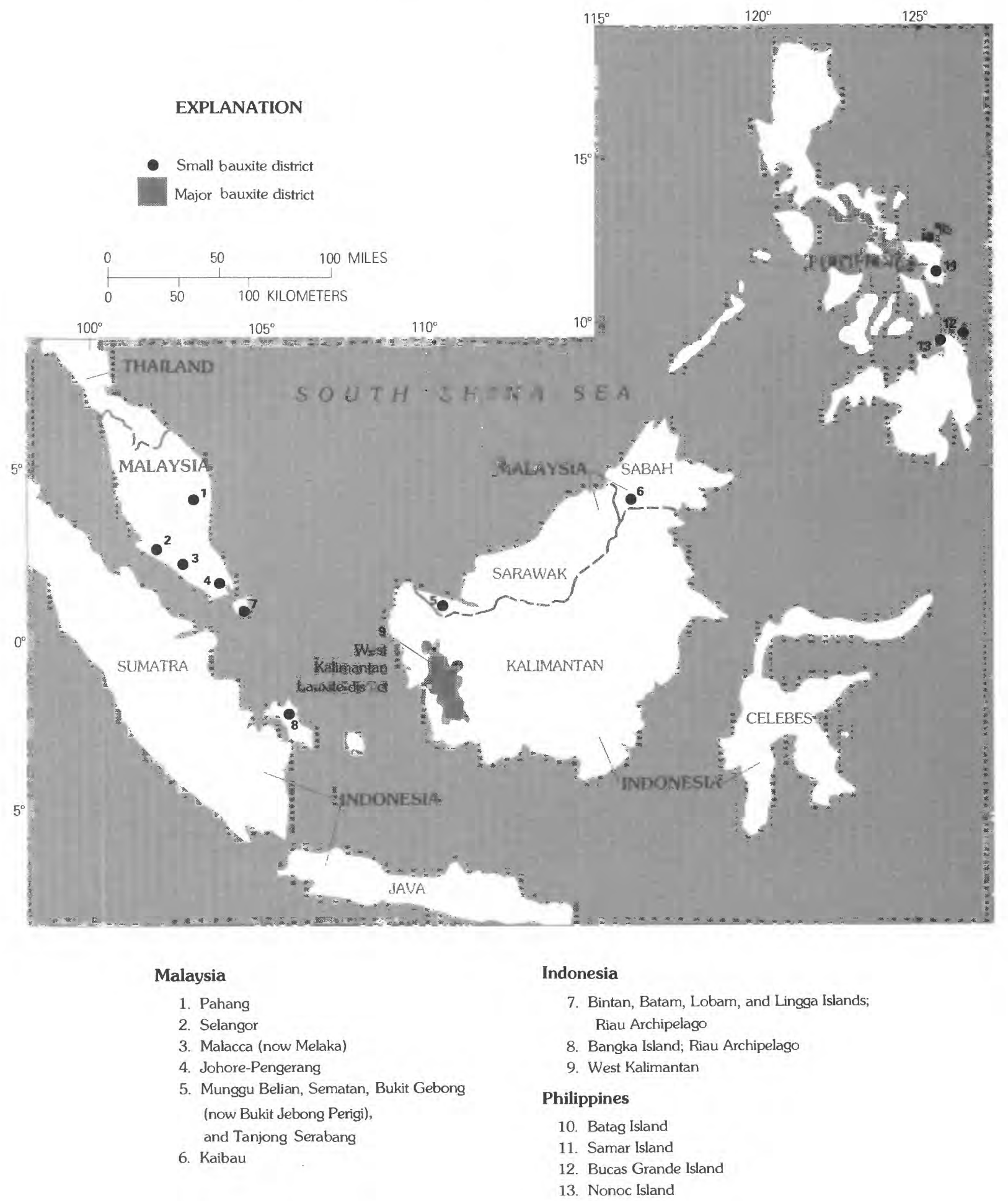

Figure 22.-Locations of bauxite districts in southeastern Asia and the southwestern Pacific region.

higher in silica content than the concretions; therefore, the quality of the bauxite can be improved by washing out the clay. A black, aphanitic hornfels of probable Triassic age is the parent rock of the bauxite. A section of the bauxite and underlying rocks that is presumably typical of the bauxite areas was described by Bemmelen (1941, p. 635). In modified form, the description is as follows: (1) surficial bauxite, $7 \mathrm{~m}$ thick, (2) clay, $45 \mathrm{~m}$ thick, upper part structureless, lower part contains streaks of intensely weathered siliceous rocks, 
lowermost $4 \mathrm{~m}$ contains blocks of unweathered parent rock, and (3) black hornfels parent rock.

Low-grade bauxite deposits located inland from the mining districts on Bintan were investigated by three Japanese aluminum companies during 1967-69 (Iijima, Kimiya, and Yanagimoto, 1973). These deposits have an average thickness of a little more than $2 \mathrm{~m}$ and are overlain only by a thin soil. They contain 5.5 percent $\mathrm{Fe}_{2} \mathrm{O}_{3}$ and have an average $\mathrm{SiO}_{2}$ content of 12.8 percent. More than one-half of the silica is in reactive form. The principal minerals in these deposits are gibbsite, kaolinite, quartz, hematite, goethite, and lepidocrocite. Minor quantities of boehmite were found to be present in the middle part of the deposits.

Several small bauxite deposits on five small islands near Bintan and Batam were intensively prospected in 1962 by the Indonesian Government with technical assistance from the U.S. Agency for International Development. These deposits are very similar in occurrence to those on Bintan. During this work, syenite intrusions, volcanic rocks, and phyllite were found to be favorable for the formation of a good grade of bauxite, but only thin low-grade deposits formed on sandstone and shale. Johnson and Marjono $(1963$, p. 9) found about 1 million tons of bauxite that is 50 percent $\mathrm{Al}_{2} \mathrm{O}_{3}$ and 600,000 tons of lower grade bauxite on Lobam and Ngenang Islands. P.T. Alcoa Minerals of Indonesia also found bauxite on Bangka Island and in the Lingga Archipelagos (Gunawan and Valk, 1972, p. 29).

All the bauxite on the several islands in the Riau Archipelago is high in iron content except the deposits on Lobam Island. Some of these deposits are residual on granitic rocks, and some consist of concretionary material in marine terraces that has been transported and deposited near shore (Johnson and Marjono, 1963, p. 36-37). These authors have estimated reserves of low-iron bauxite to be 228,000 tons measured and 65,000 tons probable. According to Sigit and others (1969, p. 71), these low-iron deposits are 61.5 percent $\mathrm{Al}_{2} \mathrm{O}_{3}, 2.5$ percent $\mathrm{Fe}_{2} \mathrm{O}_{3}, 2.5$ percent $\mathrm{SiO}_{2}, 0.25$ percent $\mathrm{TiO}_{2}$, and 33.0 percent $\mathrm{H}_{2} \mathrm{O}$.

Bauxite deposits in West Kalimantan in a belt $300 \mathrm{~km}$ long and $50-100 \mathrm{~km}$ wide that is parallel to and inland from the west coasthne were investigated by P.T. Alcoa Minerals of Indonesia and Indonesian geologists during 1969-74 (Rodenburg, 1984). These bauxite deposits are the laterite type formed on an uplifted and dissected peneplain. They occur capping low hills of $15-60 \mathrm{~m}$ of local relief. These hills are surrounded by swampy areas. Parent rocks of the bauxite in the northern part of the belt include basalt, andesite, dacite, and quartz monzonite that are cut by lamprophyre, aplite, and pegnnatite dikes. The deposits in the southern part of the belt formed on sandy shales, sandstone, limestone, granite batholiths, gabbro, diorite, and dolerite.
According to Gunawan and Valk $(1972$, p. 31$)$, the typical laterite in West Kalimantan consists of the following sequence of layers from the surface downward: (1) soil and clay overburden generally $0.5-2.0 \mathrm{~m}$ but locally as much as $5 \mathrm{~m}$ thick, (2) aluminous laterite generally $0.5-4.0 \mathrm{~m}$ but locally as much as $9 \mathrm{~m}$ thick, (3) transition zone of saprolite $0.5-2.5 \mathrm{~m}$ thick, and (4) bedrock. The upper part of the laterite consists of gibbsite concretions in clay matrix, and the clay content ranges from 20 to 40 percent. The concretions range in size from a few millimeters to more than $10 \mathrm{~cm}$, and they occur in platy, botryoidal, elongate, cylindrical, and irregular forms. The lower zone consists of irregular laterite boulders and blocks having relict textures of the parent rock.

The West Kalimantan bauxite in place contains 13-29 percent $\mathrm{SiO}_{2}$, but it is amenable to beneficiation (Rodenburg, 1984), because gibbsite is concentrated in coarse nodules and the $\mathrm{SiO}_{2}$ is mainly in kaolimite. Crushing, washing, and sieving concentrates a coarse (plus 12 mesh) fraction, and the kaolinite is removed in the fine fraction.

\section{Resources}

The high-grade bauxite reserves are on the island of Bintan where mining is underway. Bauxite reserves on Bintan were estimated to be 40 million tons (Hassan and Williams, 1969, p. 55); however, they were somewhat less in 1979 because of depletion. Japanese interests have since discovered additional bauxite on Bintan that is lower in grade than the deposits mined. These lower grade reserves are reported to contain 28 million tons by Iijima, Kimiya, and Yanagimoto (1973, p. 56) and 78 million tons by the Metals Sourcebook (1974a).

P.T. Alcoa Minerals of Indonesia found considerable bauxite. Proven bauxite was established by test pits on a 200-m by 200-m grid and analysis of washed samples for available $\mathrm{Al}_{2} \mathrm{O}_{3}$ and reactive $\mathrm{SiO}_{2}$. Proven bauxite in the West Kalimantan bauxite belt was calculated to be 809 million tons (Rodenburg, 1984, p. 613-617). This bauxite has the following average composition: 38.4 percent available $\mathrm{Al}_{2} \mathrm{O}_{3}$ and 3.0 percent reactive $\mathrm{SiO}_{2}$. The total bauxite is inferred to be more than 2 billion tons (washed basis), because only a part of the laterite belt in West Kalimantan has been systematically evaluated on a 200 -m-grid pattern.

The U.S. Bureau of Mines estimate for the bauxite reserves in Indonesia is $\mathbf{7 5 0}$ million tons (Baumgardner and McCawley, 1983, table 3). The total resources of bauxite in this country are more than 2 billion tons and are probably as much as 2.5 billion tons. 


\section{IRAN}

Deposits of high-alumina clays near Tehran have been worked for a long time for use in refractory brick, and bauxitic clay deposits occur at many places (Swiss, 1970). Diaspore clays of Permian age are scattered through an extensive belt in the central part of the country, extending from near Yazd to southeast of Kermann. Boehmite-bearing clays of Cretaceous age have been found in west-central Iran. All the bauxitic clays are apparently low grade and have high $\mathrm{SiO}_{2}$ contents; they are therefore unsuitable for Bayer processing. Bárdossy (1977, appendix 1) estimated that about 70 million tons of karst-type bauxite is present in eight districts in Iran. This bauxite is considered to be subeconomic as an aluminum resource because the maximum quantity in a single district is $\mathbf{1 5}$ million tons.

\section{MALAYSIA}

\section{History and Production}

Bauxite has been produced in Peninsular Malaysia since before World War II and was also produced in Sarawak during the period 1957-65. Bauxite mining began on the peninsula in 1936 when 36 tons were produced (Grubb, 1968, p. 38). During World War II, the Japanese took over mining and produced about 50,000 tons of bauxite containing 55-59 percent $\mathrm{Al}_{2} \mathrm{O}_{3}$; about 40,000 tons of this amount remained in a stockpile at the end of the war. Aluminum Company of Canada (Alcan) prospected for bauxite in the southern part of Peninsular Malaysia before World War II. This company renewed its interests in the postwar period and, after the political unrest of 1948 , had some of the deposits mined under contract by Ramunia Bauxite Limited, a Malaysian company which began producing bauxite in 1952. In 1962, Alcan formed a subsidiary company, Southeast Asia Bauxites Ltd., and became the largest of the two bauxite producers in Malaysia. The annual production peaked at a little more than 1.1 million tons in 1973 (table 6) and has decreased in most of the following 10 years. The low year was 1979 when only 387,000 tons was produced; 589,000 tons was produced in the recession year of 1982 .

All the bauxite produced in Malaysia has been beneficiated by washing to obtain a high-grade ore mainly for export to Japan. In the early history of mining, considerable bauxite was lost in the washing process. Because of the existence of the bauxite-rich tailings, Peninsular Malaysia is one of the few places in the world where washing wastes have been recycled. In the process used, the tailings were blended with low-grade bauxite to avoid clogging screens with excessive finegrained material (Grubb, 1968, p. 76, 98).

\section{Bauxite Districts and Deposits}

Peninsular Malaysia. - The best grade and most productive bauxite deposits in Malaysia are in the Pengerang area in southeastern Johore, approximately $50 \mathrm{~km}$ east of Singapore. Other deposits are known to exist elsewhere in Johore and in Malacca (now Melaka), Selangor, and Pahang. Though several of the deposits outside of the Pengerang area are high grade, insofar as is now known they do not contain large reserves.

According to Grubb (1968, p. 60-83), the valuable bauxite in the Pengerang area, Peninsular Malaysia, occurs in residual and alluvial deposits. The residual deposits have formed on rhyolite, tuff, granite, micropeginatite, diaspore-pyrophyllite-bearing hornfels, and schistose rocks. Bauxite in these deposits occurs in pisolites, concretions, and nodules and in shaly forms. Most residual deposits cap hills that are less than $65 \mathrm{~m}$ in altitude and have slopes not exceeding 30 degrees. Gibbsite is the principal mineral in the deposits; limonite (probably goethite), hematite, and kaolin minerals are the principal impurities. The accessory minerals include anatase and zircon, and the deposits that formed on schistose rocks contain some graphite and vermiculite. The alluvial deposits are scattered through the broad low southern coastal plain. The largest known deposit covers approximately 648 hectares. It ranges in thickness from a few centimeters to nearly $3 \mathrm{~m}$ and contains a minimum of 4 million tons of bauxite (Grubb, 1968, p. 76).

Sarawak.-Bauxite was discovered in Sarawak in 1949 , and by 1959 more than 20 deposits had been found. A local company began mining bauxite in 1957, and within 2 years bauxite became Sarawak's most valuable mineral product (Wolfenden, 1961, p. 972). Mining ceased in 1965 after the production of a little more than 1.5 million tons. The best deposits are at Munggu Belian, Sematan, and at Bukit Gebong (now Bukit Jebong Perigi) about $8 \mathrm{~km}$ southeast of Sematan; ferruginous bauxite deposits occur at Tanjong Serabang. The bauxite at Munggu Belian formed by weathering of andesite. The deposits are on hills less than $35 \mathrm{~m}$ high that are flanked by terrace alluvium and alluvial swamp deposits. The bauxite is chiefly gibbsite and contains minor amounts of quartz, kaolin minerals, and iron and titanium minerals. It occurs as hard pinkbrown and gray nodules $0.5-30 \mathrm{~cm}$ long. The nodules are scattered through a buff or brownish-red clayey saprolite, and part of the bauxite occurs as fillings of 
vesicles preserved from the parent andesite. Microcrystalline gibbsite is commonly a pseudomorphic replacement of plagioclase laths. Mixtures of gibbsite and iron minerals replaced pyroxene, but magnetite and rutile of the parent andesite are unaltered (Wolfenden, 1961, p. 975).

The scattered lateritic bauxite deposits formed from several types of rocks. Gabbro and diorite are the parent materials of deposits at Bukit Gebong. Deposits at Bukit Siol formed from quartz diorite and are high in silica; other deposits formed from plagioclase amphibolite, saussuritized gabbro, and several types of altered intermediate and mafic volcanic rocks.

Reserves of easily accessible washed bauxite were originally about 5.5 million tons (Wolfenden, 1961, p. 972), and unappraised resources of bauxite underlie alluvium at Munggu Belian and probably at several other localities in Sarawak. One grade of washed bauxite recovered from the deposits at Bukit Gebong was 52.10 percent $\mathrm{Al}_{2} \mathrm{O}_{3}, 4.66$ percent $\mathrm{SiO}_{2}, 13.14$ percent $\mathrm{Fe}_{2} \mathrm{O}_{3}, 0.49$ percent $\mathrm{TiO}_{2}$, and 29.61 percent LOI; a second grade was 46.97 percent $\mathrm{Al}_{2} \mathrm{O}_{3}, 7.27$ percent $\mathrm{SiO}_{2}$, 18.02 percent $\mathrm{Fe}_{2} \mathrm{O}_{3}, 0.57$ percent $\mathrm{TiO}_{2}$, and 27.17 percent LOI. According to the Malaysia Geological Survey $(1981$, p. 53), an estimated 1.5 million tons of washed bauxite probably still could be recovered from 265 hectares of bauxite-bearing terrain in the Bukit Gebong district.

Sabah.-Bauxite has been discovered in a number of shallow pits dug in an area about $1.6 \mathrm{~km}$ west of Kaibau (Collenette, 1961, p. 68). This bauxite appears to have been derived from coarse-grained basalt. It is considered to be of medium grade, but the amount present is unknown, and it is unfavorably situated for development.

According to the Malaysia Geological Survey (1981, p. 69), ferruginous bauxite formed on gabbro intrusions is present in several areas in the lower Labuk valley. Also, bauxite deposits extending over an area $1.6 \mathrm{~km}$ by $2.4 \mathrm{~km}$, located south of Telupid, were investigated by pitting. About 2.5 million tons of medium- to highgrade bauxite may be present in the Telupid district.

\section{Resources}

The bauxite reserves in Malaysia are located principally in the Pengerang district, and reserves in this district were estimated in 1979 to be about 8 million tons (Malaysia Geological Survey, 1981, p. 40). Reserves scattered in other districts amount to only a few thousand tons (Grubb, 1968, table 50). The U.S. Bureau of Mines (Baumgardner and McCawley, 1983, table 3) gave an estimate of 15 million tons for the bauxite reserves in Malaysia. Subeconomic bauxite resources in Peninsular
Malaysia, Sarawak, and Sabah have a total that is probably about 5 million tons. Total bauxite resources in Malaysia are considered to be about 20 million tons in this report.

\section{PAKISTAN}

Bauxite, bauxitic clays, and aluminous laterite occur at many places in Pakistan. Bauxite and clays in the Kala Chitta Range are mined for use in refractories (Ashraf, Ahinad, and Faruqi, 1976). Small tonnages have been produced for use in chinaware and as building and road surfacing materials (S.A. Stanin, written commun., 1965), and minor quantities have been used in making cement (United Nations Economic Commission for Asia and the Far East, 1962, p. 11). The Pakistan Government has long been interested in the development of the deposits as a source of alumina. A pilot plant test was made of bauxite from the Sargodha district, which is in the Salt Range (Metals Sourcebook, 1974b). The efforts were increased with construction of a plant having the capacity of 1 ton per day (Industrial Minerals, 1978b). The deposits evaluated are in the Campbellpore (Kăla Chitta Range) and Khushab (Salt Range) districts.

The principal bauxite and clay deposits in Pakistan are in the Kăla Chitta Range (Ashraf, Ahmad, and Faruqi, 1976) and the Salt Range (Ashraf, Chohan, and Faruqi, 1972). The Salt Range deposits occur below an erosional unconformity of post-Permian age and are overlain by Paleocene and Eocene beds. The Kala Chitta deposits are in a formation of Jurassic age. The deposits in both ranges are in strata that are structurally deformed; dips in the Kala Chitta Range are as much as $79^{\circ}$. The bauxite and clay occur in tabular lenses ranging from about $70 \mathrm{~m}$ to more than $300 \mathrm{~m}$ in length, and the average thickness of the deposits is $3 \mathrm{~m}$. The principal bauxite mineral in the Salt Range deposits is boehmite; the Kãla Chitta deposits are mainly diaspore. Kaolinite is abundant in both regions. On the basis of the few analyses published, the Kala Chitta deposits are 36.6-74.0 percent $\mathrm{Al}_{2} \mathrm{O}_{3}$ and 7.6-37.8 percent $\mathrm{SiO}_{2}$. The Salt Range deposits are 36.0-72.8 percent $\mathrm{Al}_{2} \mathrm{O}_{3}$ and 8.6-46.96 percent $\mathrm{SiO}_{2}$. The deposits in both districts are remarkably low in iron oxide; few of the available analyses reveal the presence of as much as 2 percent.

The laterite in the Ziarat district, Quetta Division, occurs between Cretaceous limestone and younger liniestones of Cretaceous and Paleocene age. Most deposits in this district are 1-3 $\mathrm{m}$ thick, but some are more than $15 \mathrm{~m}$ thick. According to Shah (1960, p. 86), boehmite and diaspore are the principal bauxite minerals present. This bauxite has been described as being pisolitic, shaly, marly, sandy, concretionary, and nodular. 
Other bauxite districts include Kotli Tehsil (southeast of Rawalpindi) and Muzaffarabad, Kashmir (S.A. Stanin, written commun., 1965). Surficial aluminous laterite deposits also occur at several localities in southern Pakistan (S.A. Stanin, written commun., 1965), and laterite with Devonian carbonate rocks has been found in northern Pakistan (Stauffer, 1969). This Devonian laterite consists mainly of boehmite, diaspore, and hematite.

Total resources of bauxite, clay, and low-iron laterite in Pakistan have been estimated to be about 500 million tons (Ashraf, Ahmad, and Faruqi, 1976, p. 41). The reserves of bauxite in these resources were estimated to be 20 million tons by the U.S. Bureau of Mines (Baumgardner and McCawley, 1983, table 3). All these reserves are considered to be refractory grade because of the present use and high content of diaspore in many of the deposits. Inasmuch as kaolinitic clay makes up a high proportion of the resources, how much of the 500 million ton estimate should be considered subeconomic bauxite is problematical. An estimate of 100 million-150 million tons for the total bauxite, including reserves, is assumed in this report.

\section{PEOPLE'S REPUBLIC OF CHINA}

History and Production

Aluminum was first made in China by the Japanese in 1938. The active plants in the World War II era were in the Fushun area of Liaoning Province and the Boshan area of Shandong Province. According to a report on the Canadian Minerals and Metals Mission to China (Canadian Mining Journal, 1973, p. 25), the Fushun plant has a capacity of about 100,000 tons of aluminum per year. Although this may be the largest aluminum smelter in China, reports indicate that China may have several plants with annual capacities over 30,000 tons and a large number of very small operations. Because the People's Republic of China does not publish production data, the output of bauxite, alumina, and aluminum can be at best estimated. Estimates by the U.S Bureau of Mines (table 6) show that bauxite production rose from less than 500,000 tons in 1961 to 1.3 million tons in 1976 and is thought to have been about 1.5 million tons in recent years. The bauxite production data (table 6) include 100,000-200,000 tons produced each year for use in refractories. China exports refractory-grade and abrasive-grade bauxite.

\section{Bauxite Districts and Deposits}

Aluminum resources in the People's Republic of China consist of bauxite, aluminous shale, and alunite. Bauxite was discovered by two Japanese geologists, who were investigating refractory clay deposits in the Penchi (now Benxi) basin, Liaoning. This bauxite and most other large deposits discovered later occur in Carboniferous and Permian sedimentary rocks and are the monohydrate type. Small deposits of trihydrate bauxite of Tertiary age are present in one district. Shales, some of which are associated with bauxite and are rich in diaspore or boehmite, or both, were used for aluminum by the Japanese during World War II and still are the principal raw materials of at least one alumina plant. Alunite occurs in very large quantities in the People's Republic of China. This mineral was also used for aluminum by the Japanese during the World War II occupation, and some may still supply small alumma plants.

T. Sakamoto and T. Oobane, who discovered the Carboniferous and Permian bauxite and aluminous shale, found a series of beds that they designated G to A (Sakamoto, 1958; Ikonnikov, 1975, 1984). These designations are still widely used in referring to bauxite in China. Bed G, which has been the principal source of the bauxite mined, occurs at the base of Middle or Upper Carboniferous strata and rests on older Paleozoic limestone. Bed F, which is mainly clay, occurs above bed G; at most places the two beds are separated by a sandy shale about $1 \mathrm{~m}$ thick. Bed $\mathrm{E}$ is also mainly clay, and its stratigraphic position is below Upper Carboniferous limestone. Beds D and C are aluminous shales of Late Carboniferous age. Bed B is clay, but it is sufficiently rich in aluminum locally to be classified as bauxite. Bed $A$, at the base of Upper Permian formations, is mainly clay containing local bauxite deposits. Other beds of clay containing minor quantities of bauxite are present in younger Permian coal measures, but this bauxite is apparently of little economic importance.

According to the information now available, the bauxite in beds $\mathrm{G}$ and $\mathrm{A}$ is the monohydrate type. Diaspore is the principal mineral, and boehmite is the second most common one. Virtually all the deposits either contain or are closely associated with kaolimitic flint clay, which means that many deposits are rich in reactive silica. Many of the bauxite deposits contain gallium and germanium in sufficient quantities for industrial use, and some contain uranium (Ikonnikov, 1975, p. 363).

Many of the deposits in beds A and B are similar to the diaspore deposits in the United States, as was also noted by Schüller (1957). The diaspore of both China and the United States is of late Paleozoic age, and deposits in both countries are closely associated with coal.

Yunnan Province-Very large deposits of bauxite occur near Kunming, and other deposits are present in the Anning and Fumin districts in Yunnan Province (fig. 23). Most deposits mined are in bed G. The bauxite 


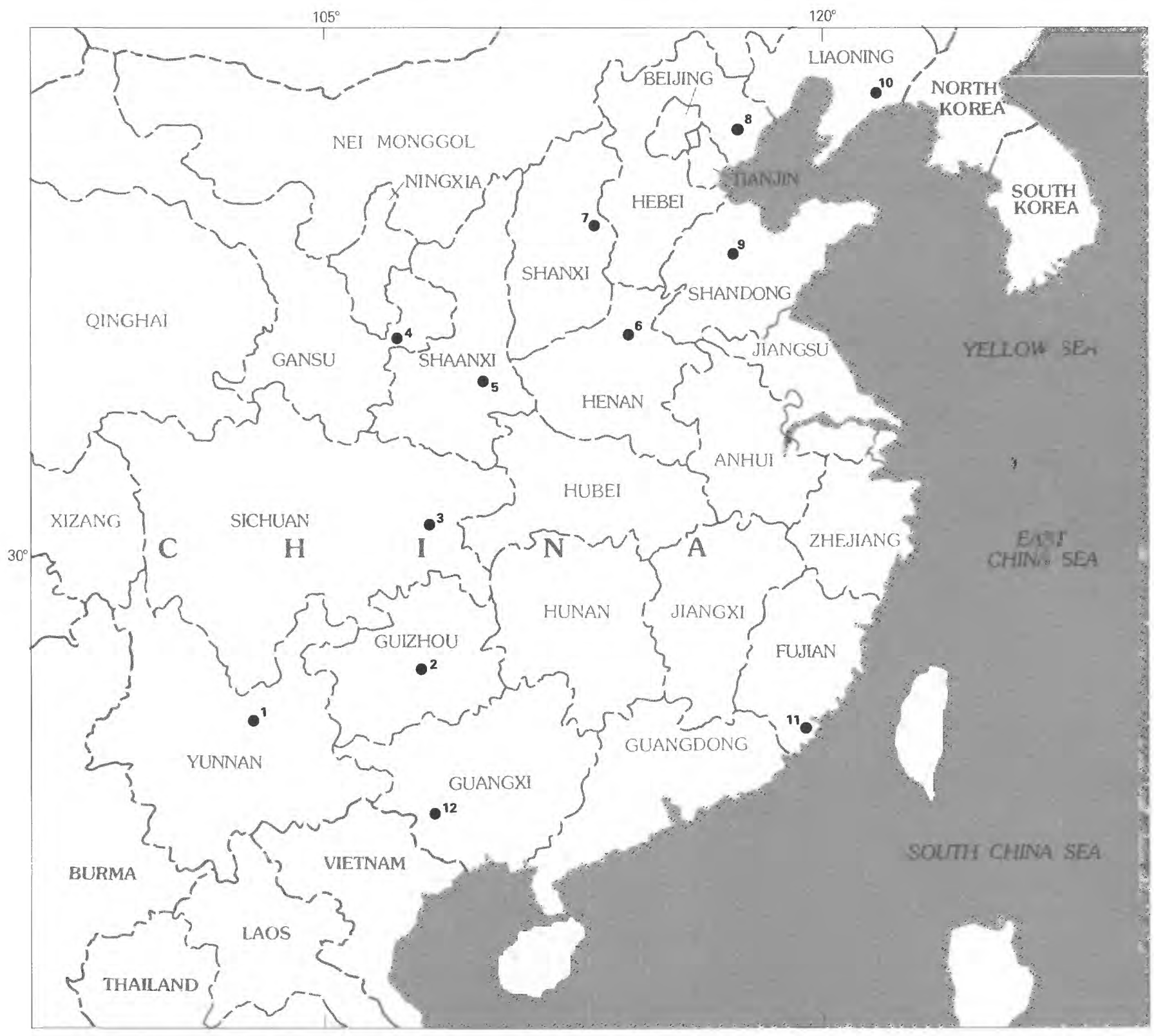

\begin{tabular}{lcccccc}
0 & 100 & 200 & 300 & 400 & 500 \\
\hline 0 & 100 & 200 & 300 & 400 & 500 KILOMETERS
\end{tabular}

\section{EXPLANATION}

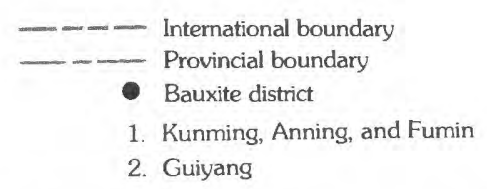

3. Sichuan
4. Gansu Province
5. Xi'an
6. Gongxian
7. Yangquan

8. Kaiping basin

9. Nanding

10. Benxi-Fuxian

2. Guiyang

11. Zhangpu

12. Pingguo

Figure 23.-Locations of principal bauxite districts in the People's Republic of China. 
is reported to be composed of both diaspore and boehmite. Dr. P.F. Kerr of Columbia University identified boehmite in one sample by X-ray methods (Li and Hsieh, 1946 , p. 4); available information on the identification of diaspore is less reliable. The deposits were described as similar to the bauxites in Guizhou Province. Bauxite reserves in the vicinity of Kunming are estimated to be 100 million-150 million tons, and 20 million tons of the resource is considered to be high-grade reserves of bauxite (K.P. Wang, 1959, p. 75). The high-grade ore is 70 percent $\mathrm{Al}_{2} \mathrm{O}_{3}, 6$ percent $\mathrm{SiO}_{2}$, and 11 percent $\mathrm{Fe}_{2} \mathrm{O}_{3}$; the average grade is 52 percent $\mathrm{Al}_{2} \mathrm{O}_{3}, 33$ percent $\mathrm{SiO}_{2}$, and 3 percent $\mathrm{Fe}_{2} \mathrm{O}_{3}$.

Guizhou Province-Very large bauxite deposits occur in the vicinity of Guiyang and in other areas in the central and west-central parts of the Province, and smaller deposits are present elsewhere. The large deposits in the central parts of the Province are in bed G. These deposits are in extensive tabular lenses as much as $8 \mathrm{~m}$ thick. The bauxite is in massive, oolitic, and pisolitic forms. One sample of this bauxite was found by Dr. P.F. Kerr of Columbia University by means of X-ray methods to be chiefly diaspore (Li and Hsieh, 1946, p. 3). The other bauxite deposits, which are mostly smaller, are in the Kaiyang, Wungnan, Chianhsi (now Qianxi), and Dafang districts (Wang Chung-hsing, 1969). These deposits are of Early Permian age, and they presumably are in bed A. They are similar to bed $\mathrm{G}$ deposits, but they occur in thinner and lower grade masses. According to Wang Chung-hsing (1969, tables 1 and 2), the bed $\mathrm{G}$ deposits are $60-80$ percent $\mathrm{Al}_{2} \mathrm{O}_{3}, 2-20$ percent $\mathrm{SiO}_{2}, 2-20$ percent $\mathrm{Fe}_{2} \mathrm{O}_{3}$, and 2-3 percent $\mathrm{TiO}_{2}$, and they contain very minor amounts of $\mathrm{CaO}, \mathrm{CO}_{2}$, and $\mathrm{S}$ and trace amounts of $\mathrm{Ga}, \mathrm{Ge}, \mathrm{Be}$, and $\mathrm{U}$. The Permian bauxite is $50-70$ percent $\mathrm{Al}_{2} \mathrm{O}_{3}$, 2-30 percent $\mathrm{SiO}_{2}, 5-12$ percent $\mathrm{Fe}_{2} \mathrm{O}_{3}$, and 1.5-3 percent $\mathrm{TiO}_{2}$. According to Ikonnikov (1975, table VI-1), Guizhou contains only 100 million tons of bauxite, but K.P. Wang (1959, p. 75) listed the resources of bauxite in the Guiyang district as 200 million-500 million tons and indicated that at least 50 million tons is high grade.

Sichuan Province-Bauxitic clays occur in the southern part of Sichuan Province. The clays are in lenses and pockets in the upper part of a coal series of Permian age, and they are overlain by limestone. Alumina contents of this clay range from 48 to 78 percent ( $\mathrm{Li}$ and Hsieh, 1946 , p. 4). No estimates of the amount of bauxitic clay in this Province are available.

Gansu Province-Bauxite, alunite, and high-alumina shale and clay occur in Gansu Province. The bauxite is in the southern part of the Province. The aluminous shale and clay are mainly in coal fields, and the alunite occurs in weathered deposits. According to Ikonnikov (1975, table VI-1), Gansu Province contains 351 million tons of bauxite.
Shaanxi Province.-Bauxitic deposits have been discovered recently in the vicinity of Xi' an. Detailed information on the geology, location, and size of these deposits is not available, but they probably supply the new alumina plant at Xi'an. The deposits are undoubtedly extensive and probably consist of aluminous shale, some of which is of good grade (K.P. Wang, 1959, p. 75-76).

Henan.-G bed and other bauxite deposits occur in the Kunghsien (now Gongxian) district and elsewhere in Henan (Ikonnikov, 1975, p. 363, 402). The Gongxian bauxite district extends over an area several tens of kilometers long and several kilometers wide. Six layers of bauxite are present in the district, and fossil plants of Late Carboniferous age occur in the third layer from the base. Bauxite bodies, particularly in bed $\mathrm{G}$ deposits and associated clay, occur in extensive layers of uniform thickness. The bauxite is light gray to white; oolitic, pisolitic, and massive types are present. Diaspore is the principal bauxite mineral, and muscovite, chlorite, kaolinite, rutile, and quartz are the main impurities. According to Ikonnikov (1975, p. 402) the pisolitic bauxite is 53-60 percent $\mathrm{Al}_{2} \mathrm{O}_{3}, 16-30$ percent $\mathrm{SiO}_{2}, 1-4$ percent $\mathrm{Fe}_{2} \mathrm{O}_{3}$, and 2.9-3.8 percent $\mathrm{TiO}_{2}$.

Bauxite deposits in the Gun district were investigated by Schüller (1957). These deposits occur above a karst surface on Ordovician limestone and are overlain by black fusulinid-bearing limestones of Late Carboniferous age. Diaspore is the principal mineral, and massive, oolitic, and pisolitic forms are present. According to chemical analyses of five samples (Schüller, 1957, tables 1 and 2), the bauxite is 54.1-68.9 percent $\mathrm{Al}_{2} \mathrm{O}_{3}$, 10.6-12.7 percent $\mathrm{SiO}_{2}, 0.6-3.7$ percent $\mathrm{Fe}_{2} \mathrm{O}_{3}$ and $\mathrm{FeO}$, and 2.9-3.8 percent $\mathrm{TiO}_{2}$, and spectrochemical analyses record that it contains some $\mathrm{Ba}, \mathrm{Cr}, \mathrm{Cu}, \mathrm{Mg}$, $\mathrm{Na}, \mathrm{Ni}, \mathrm{Pb}$, and $\mathrm{V}$.

According to Ikonnikov (1984, p. 548), a Chinese source stated that bauxite in the G bed in the Gongxian district contains proven reserves of 270 million tons "presumably of alumina."

Shanxi Province.-High-alumina shale deposits reportedly occur in the vicinity of Yangchuan (now Yangquan), Shanxi Province (K.P. Wang, 1959, p. 75). The deposits are reported to contain 45-55 percent alumina. The size of the deposits is unknown, but they are probably at least moderately extensive.

Hebei Province.-Bauxitic clays and high-alumina shales occur in several places in the Kaiping basin, Hebei Province. The deposits are estimated to contain 100 million-400 million tons of aluminous rock, and at least 30 million tons is probably high grade (K.P. Wang, 1959, p. 75). The rock is $50-70$ percent $\mathrm{Al}_{2} \mathrm{O}_{3}$, 5-27 percent $\mathrm{SiO}_{2}, 1-15$ percent $\mathrm{Fe}_{2} \mathrm{O}_{3}$, and 1-3 percent $\mathrm{TiO}_{2}$. 
Shandong Province.-The most productive bauxite mines in mainland China are near the Tsingtoa-Tsinan railroad in the general vicinity of Nanding, Shandong Province. Bauxite was mined from these deposits during Japanese occupation (Kleinhans, 1948, p. 4), and the deposits now supply the alumina plant at Nanding. The most productive areas are reported to extend over $800 \mathrm{~km}^{2}$. Chinese newspaper accounts cited by Ikonnikov $(1984$, p. 549) describe the deposits as being the largest in China, and one of the very few largest in the world. The bauxite is described as rich, under shallow overburden, and close to water and land transportation.

The G-bed deposits have been mined most extensively, but several other bauxite beds, including bed A, aluminous shale, and alunite deposits are also present in Shandong. According to Kleinhans (1948, p. 4), the G-bed deposits are irregular in thickness, and the best bauxite occurs near the middle of the thicker parts of the bed. Diaspore is the principal bauxite mineral present, and kaolinite occurs in the upper and lower parts of the deposits. The best grade bauxite is reported to be 60 percent $\mathrm{Al}_{2} \mathrm{O}_{3}, 13$ percent $\mathrm{SiO}_{2}, 10$ percent $\mathrm{Fe}_{2} \mathrm{O}_{3}$, and 2 percent $\mathrm{TiO}_{2}$. Reserves and resources are estimated to be between 100 million and 300 million tons; at least 30 million tons (K.P. Wang, 1959, p. 75) and possibly as much as 68 million tons (C.C. Wang, 1932 , p. 30 ), is high-grade bauxite.

Inner Mongolia. - Small alumina reserves have been reported as occurring on the Ordos grasslands in Inner Mongolia (Nei Monggol). These deposits were found during extensive work by many teams of prospectors. No detailed information on the deposits is available. However, Sakamoto (1958) mentioned that bed G occurs in Inner Mongolia, and the deposits are probably aluminous shales associated with coal-bearing rocks.

Liaoning. - Both bauxite (beds $\mathrm{G}$ and $\mathrm{A}$ ) and aluminous shale occur in Liaoning (Ikonnikov, 1975, p. 378-380). The principal bauxite deposits are in the Benxi-Fuxian region and in the Fuzhou district $30 \mathrm{~km}$ west of Fuxian. Aluminous shale occurs in the Niuxintai district $15 \mathrm{~km}$ northeast of Benxi. The Fuzhou bauxite is 50-72 percent $\mathrm{Al}_{2} \mathrm{O}_{3}, 7-30$ percent $\mathrm{SiO}_{2}, 1.5-2.5$ percent $\mathrm{Fe}_{2} \mathrm{O}_{3}$, and $2.2-3.1$ percent $\mathrm{TiO}_{2}$. The Niuxintai aluminous shale is $45-55.5$ percent $\mathrm{Al}_{2} \mathrm{O}_{3}, 20-30$ percent $\mathrm{SiO}_{2}$, 2-3 percent $\mathrm{Fe}_{2} \mathrm{O}_{3}$, and 2-3.1 percent $\mathrm{TiO}_{2}$. The aluminous shale deposits in the vicinity of Benxi contain 50 million-100 million tons, and possibly 20 million tons is high grade (K.P. Wang, 1959, p. 75). The grade of the rock mined is 53 percent $\mathrm{Al}_{2} \mathrm{O}_{3}$, 20 percent $\mathrm{SiO}_{2}, 10$ percent $\mathrm{Fe}_{2} \mathrm{O}_{3}$, and 3 percent $\mathrm{TiO}_{2}$. Sakamoto (1958) gave an analysis of the shale that is considerably higher in alumina than analyses given by Wang, but no information on the amount of the highgrade material is available. According to Ikonnikov
$(1972$, p. 357), the reserves of bauxite in this province are estimated to be 110 million tons.

Fujian Province. -Small (3- to 4-m-thick) bauxite deposits consisting chiefly of gibbsite occur in the Zhangpu district along the coast southwest of Amoy. The bauxite has formed by weathering of basalt. Some deposits are residual; others evidently have been transported, inasmuch as they contain boulders of bauxite several tens of centimeters in diameter. Ikonnikov $(1975$, p. 365$)$ reported that the average composition of this bauxite is 47.6 percent $\mathrm{Al}_{2} \mathrm{O}_{3}, 22.4$ percent $\mathrm{SiO}_{2}$, and 20.4 percent $\mathrm{Fe}_{2} \mathrm{O}_{3}$. The deposits are small but probably contain more than the 500,000-ton estimate (Kleinhans, 1948, p. 7).

Guangxi.-Several trade journals published notes in 1978 that high-grade bauxite has been discovered recently in the Pingguo district. The deposits are reported to be located along the Yu Jiang River. They are described as being 59.9 percent $\mathrm{Al}_{2} \mathrm{O}_{3}$ and minable by open-pit methods.

\section{Resources}

Estimates of the bauxite resources in the People's Republic of China range widely because of the variety in mineralogy of rocks included, the unavailability of reliable evaluation data, and the language barrier, among other problems. Reserves of high-grade bauxite in Shandong, Liaoning, Guizhou, Hebei, and Yunnan Provinces are approximately 150 million tons (K.P. Wang, 1959, p. 75), the estimate used in this report (table 12). Reserves of lower grade bauxite and aluminous shale have been estimated by the Geological Survey of the People's Republic of China to be as much as 882 million tons (Ikonnikov, 1972, p. VI-1). Total resources of all bauxite and aluminous shale in China have been estimated to be 400 million- 1.3 billion tons by K.P. Wang $(1959$, p. 75$)$ and 550 million- 1,450 million tons (United Nations, Economic Commission for Asia and the Far East, 1962, p. 4). For the purpose of this report total resources of bauxite and aluminous shale in the People's Republic of China are considered to be 0.5 billion-1.5 billion tons. Even the upper limit of this estimate would probably be proven conservative if adequate and thorough evaluations of all the resources in this country were available.

An estimate of 150 million tons of bauxite reserves in the People's Republic of China was published by the U.S. Bureau of Mines (Baumgardner and McCawley, 1983 , table 3). Shaffer's (1983, table 5) estimate of the total bauxite resources in the People's Republic of China is 1 billion tons. Both Lebauer (1983, p. 9-11) and the International Bauxite Association have published 
estimates of 1 billion tons for the refractory-grade bauxite in this country. The refractory-grade bauxite is reported by Lebauer (1983) to be located in Guizhou, Henan, Shanxi, and Sichuan provinces and the Kwangsi-Chung (Guangxi-Zhuang) autonomous region.

\section{PHILIPPINES}

Bauxite was discovered on the Island of Samar in 1970 (Weisse, 1976), and the Philippines Bureau of Mines began investigating it in 1975 (Jacolino, 1977). The deposits are the karst type and occur on limestone of middle and late Miocene age. They are located mainly in the central part of Samar and on the small island of Batag off the northern coast. The bauxite consists of fine-grained (mostly less than $1 \mu \mathrm{m}$ ) particles of brickred, chocolate-brown, and yellowish-brown material. The principal bauxite mineral is gibbsite, considerable boehmite is also present, and nordstrandite has been found in several places (Weisse, 1979, p. 11). Vanadium minerals are identifiable in it, but the varieties were not reported (Jacolino, 1977). According to Weisse (1976, table 1), samples analyzed by Alusuisse had the following composition: 46.5-50.9 percent $\mathrm{Al}_{2} \mathrm{O}_{3}, 1.0-4.5$ percent $\mathrm{SiO}_{2}, 20.9-24.0$ percent $\mathrm{Fe}_{2} \mathrm{O}_{3}, 1.6-2.2$ percent $\mathrm{TiO}_{2}, 0.8-2.6$ percent $\mathrm{P}_{2} \mathrm{O}_{5}, 0.5-1.1$ percent $\mathrm{MnO}_{2}$, and the LOI is 21.4-24.1 percent. A sample analyzed by Comalco (Jacolino, 1977, table 3 ) contained 39.40 percent total $\mathrm{Al}_{2} \mathrm{O}_{3}, 31.10$ percent available $\mathrm{Al}_{2} \mathrm{O}_{3}$, and 28.90 percent trihydrate $\mathrm{Al}_{2} \mathrm{O}_{3}$. This sample also contained 6.50 percent total $\mathrm{SiO}_{2}$, of which 2.00 percent was quartz, and 1.17 percent orgamic carbon.

Bauxite deposits in the Salcedo and Mercedes municipalities in eastern Samar have been investigated by the Philippine Bureau of Mines and Geosciences (Isaac, 1982). The bauxite consists of reddish to yellowish-brown unconsolidated fine-grained material that resembles laterite or soil. The bauxite deposits occur as pockets in sinkholes and as blankets covering Pliocene and Pleistocene limestones. The bauxite is a gibbsite-boehmite variety containing varying amounts of silica and alumina. Much of the bauxite in the Salcedo-Mercedes deposits is 33-45 percent $\mathrm{Al}_{2} \mathrm{O}_{3}$, 1-5 percent $\mathrm{SiO}_{2}$, and 24-27 percent $\mathrm{Fe}_{2} \mathrm{O}_{3}$, and it contains minor quantities of $\mathrm{CaO}$ and $\mathrm{MgO}$.

The Philippine Bureau of Mines evaluated the bauxite on Batag Island but had only reconnoitered the deposits on the main island of Samar when Jacolino's report (1977, p. 14-17) was published. The deposits on Batag contain more than 11 million tons of bauxite, of which 7.7 million tons is considered recoverable. Potential bauxite areas on the main island cover 182,000 hectares, which is much larger than the areas underlain by bauxite on Batag. Therefore the total bauxite in Samar including Batag is no doubt larger than the published estimates.

The Philippine Bureau of Mines has also investigated low-grade aluminous ferruginous laterite on Nonoc Island (Esguerra, 1961) and Bucas Grande Island (Esguerra, 1967). Both islands are parts of the Surigao Mineral Reservation, Mindanao. The Nonoc deposits contain an estimated 100 million tons of low-grade laterite (United Nations Economic Commission for Asia and the Far East, 1963, p. 29), and Esguerra (1967, p. 71) estimated about 200 million tons for similar laterite on Bucas Grande. Only a small part of this laterite contains more than 30 percent $\mathrm{Al}_{2} \mathrm{O}_{3}$.

The total amount of bauxite in the Philippines is probably 200 million-300 million tons. Most of the bauxite is low grade, and the best grade deposits are on Samar. The total bauxite in several districts on this island is reported to be 120 million tons (Wu, 1983, p. 798). Deposits in the central part of the island contain a little more than 35 percent available $\mathrm{Al}_{2} \mathrm{O}_{3}$.

\section{SAUDI ARABIA}

Bauxite was discovered near the village of Zabirah in northern Saudi Arabia in the early 1950's by geologists of the Arabian American Oil Company (Bramkamp and Ramirez, 1963; Bramkamp and others, 1963). The deposits were investigated by the Riofinex Geological Mission, Jiddah, Saudi Arabia, during the period 1979-81 (Black, 1982; Black, Lozej, and Maddah, 1984). Zabirah $\left(27^{\circ} 55^{\prime} \mathrm{N} .43^{\circ} 41^{\prime} \mathrm{E}\right.$.) is $180 \mathrm{~km}$ north of the town of Buraydah. The nearest deep-water port is Dharhran, which is on the Arabian Gulf about $650 \mathrm{~km}$ east-southeast.

The Zabirah bauxite is a Cretaceous paleolaterite that formed on rocks probably Triassic to Middle Jurassic age, was buried by younger sedimentary beds, and later was exposed by erosion resulting from late Tertiary or Quaternary uplift. The bauxite is in the Wasia Formation of Albian (late Early Cretaceous) to Turonian (early Late Cretaceous) age. The Wasia Formation consists mainly of fluviatile sandstone with some siltstone and mudstone.

The Zabirah bauxite occurs in a laterite profile that is known to be preserved over an area of at least $250 \mathrm{~km}$. The deposits are discontinuous lenses, the largest of which extends over a few kilometers. In most places the pisolitic bauxite zone is $2-3 \mathrm{~m}$ thick, and the maximum thickness is about $7 \mathrm{~m}$. The bauxite is generally hard and compact, but weathered parts of deposits near the surface are friable and soft. A kaolin clay zone occurs above the bauxite and another one is present below the bauxite. 
The bauxite minerals in the Zabirah deposits are chiefly boehmite and gibbsite, and only trace amounts of diaspore have been found. The boehmite:gibbsite ratios vary from 1:1 to 4:1, and the average is about 2:1 (Black, Lozej, and Maddah, 1984, p. 627). Most of the boehmite occurs in pisolites, and boehmite tends to be most abundant in the lower parts of the bauxite zone. Gibbsite tends to occur as interstitial material and as rims enclosing boehmite pisolites. Iron in the bauxite is in the form of hematite and goethite, which are present in varying proportions. One distinctive form of goethite is pseudomorphic after pyrite. Kaolinite is the principal silicate mineral in the bauxite; minor amounts of quartz and traces of tourmaline, zircon, kyanite, and staurolite are also present.

The indicated bauxite resources in the Zabirah district are calculated to be 33.7 million tons, and an additional 109.0 million tons of bauxite is inferred to be present (Black, 1982, p. 70). Almost 45 million tons of the indicated and inferred bauxite is in the central part of the district where the average $\mathrm{Al}_{2} \mathrm{O}_{3}$ content is 61.9 percent and the $\mathrm{SiO}_{2}$ is 6.7 percent. Nearly 100 million tons of indicated and inferred bauxite is in the southern part of the district where the average $\mathrm{Al}_{2} \mathrm{O}_{3}$ content is 57.0 percent and the $\mathrm{SiO}_{2}$ is 6.6 percent. The indicated and inferred resources are in deposits having an overburden-to-bauxite ratio of 4.5:1.

In addition to the bauxite, the Zabirah district contains approximately 1 billion tons of high-alumina clay (Black, 1982, p. 72). This kaolinitic clay is in beds having an average thickness of $5 \mathrm{~m}$, containing 45 percent $\mathrm{Al}_{2} \mathrm{O}_{3}$ and 24 percent $\mathrm{SiO}_{2}$. This clay has an average overburden-to-clay ratio of $2.8: 1$.

\section{TAIWAN}

Small (mostly less than 1-m-thick) deposits of bauxite were discovered on the island of Chinmen (Quemoy) in 1948. The deposits are associated with clays overlying weathered basalt. In the early 1950's, 2,000 tons was shipped to the Taiwan Aluminum Corporation in Taiwan for testing. The tests showed that contents of $\mathrm{Al}_{2} \mathrm{O}_{3}$ in the bauxite range from 40 to 50 percent, and both iron oxides and silica are abundant in most of the deposits. Reserves in these deposits were estimated at 150,000 tons (U.S. Bureau of Mines, 1948); however the reserve estimate was probably overly optimistic (S. Rosenblum, oral commun., 1963). The quality of the bauxite is not competitive with that of imports from Malaysia and Indonesia.

Laterite-type bauxite, formed on rocks of the Tatun Volcanic Group, has been found on Taiwan (Taiwan Mining Research and Service Organization, 1977, p. 32).
The deposits are on slopes, lowlands, and coastal terraces. They consist of gibbsite, fine-grained quartz, cristobalite, goethite, and magnetite. The ranges of principal oxides in these deposits are $20-45$ percent $\mathrm{Al}_{2} \mathrm{O}_{3}$, 14-50 percent $\mathrm{SiO}_{2}, 10-16$ percent $\mathrm{Fe}_{2} \mathrm{O}_{3}$, and 1-1.5 percent $\mathrm{TiO}_{2}$. Processes of upgrading this bauxite to produce a suitable material to supply an alumina plant are being investigated. According to one published note on these deposits (Dacko, 1979), they are reported to contain several hundred million tons of lateritic bauxite. In this report the estimate of 200 million tons given by Shaffer (1983, table 5) is assumed to be correct for the subeconomic bauxite in Taiwan.

\section{TURKEY}

\section{History and Production}

The first production of bauxite in Turkey was in 1964 when the Turkish Mineral Research and Exploration Institute mined and shipped 800 tons of high-silica bauxite from the Akseki deposits for use as refractories in metallurgical furnaces near Antalya. The total produced that year was 4,500 tons. Production of bauxite in Turkey remained small until 1970 when the output was more than 50,000 tons. Bauxite mining, mainly in the Seydisehir region, increased rapidly and was more than one-half million tons in the mid-1970's (table 6). The growth in bauxite mining resulted from increasing exports to the U.S.S.R. and the activation of an alumina plant at Seydisehir in 1973. This plant has a capacity of 220,000 tons per year; about one-half of the output supplies an aluminum plant nearby and the remaining alumina is shipped to the U.S.S.R. (Kurtz, 1975, p. 203). The U.S.S.R. assisted in the financing and construction of the aluminum complex.

\section{Bauxite Districts and Deposits}

The principal bauxite deposits in Turkey are in the Seydisehir-Akseki region in the western Taurus Mountains (fig. 24), but small deposits occur in Zonguldak Province and at several other localities (Ankara Maden Tetkik ve Arama Enstitüsü, 1965, 1966; Göksu, 1954). All these deposits are of the Mediterranean or karst type, and the deposits in most districts occur as numerous pockets and lenses (Ozlu, 1978). The country rock in most districts has been folded and faulted, which makes the evaluation and mining of the deposits more difficult. Virtually all the deposits are the monohydrate type.

Zonguldak Province-The bauxite deposits in this Province are located in the Hayatkoy-Kokaksu Mevkii 


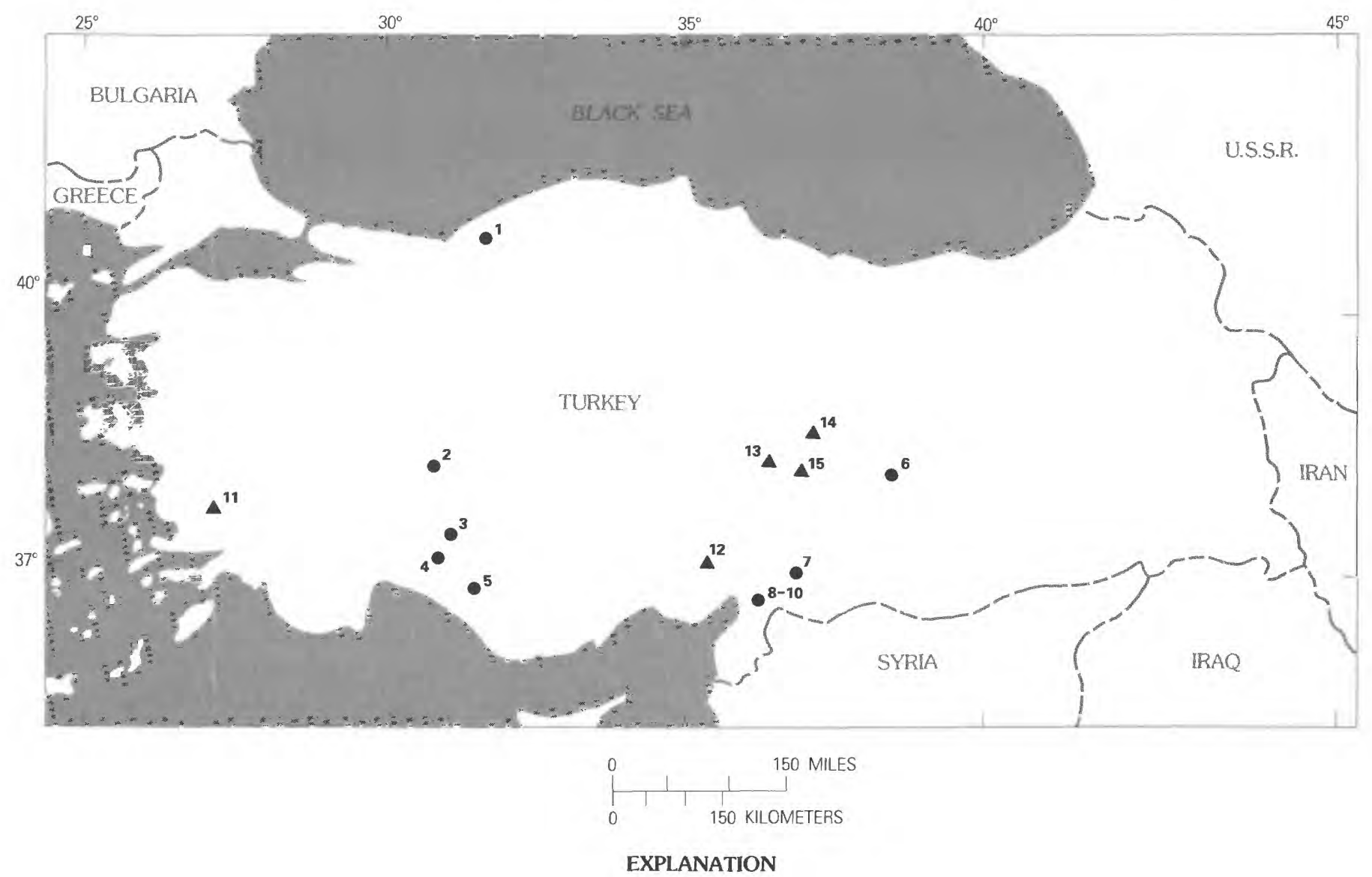

\section{BAUXITE}

- Bauxite district

1. Zonguldak-Kokaksu

2. Konya-Isparta

3. Konya-Seydişehir

4. Antalya-Akseki

5. Antalya-Alanya-Gündoğmuş

6. Malatya-Doğanşehir

7. Gaziantep-Islahiye

8. Hatay-Dörtyol-Payas-Kuzguncuk
9. Hatay-Dörtyol-Payas-Sardam, Kizilkaya

10. Hatay-Dörtyol-Payas-Çağlalik

\section{DIASPORE}

- Diaspore district

11. Muğla-Milas-Yatağan

12. Konya-Ayranci-Bolkardaği

13. Adana-Saimbeyli-Mağra Bölgesi

14. Kayseri-Sariz-Haydanköy

15. K. Maraş-Göksun-Acielma-Körkuyu

FIGURE 24.-Locations of bauxite and diaspore districts in Turkey.

district (Ankara Maden Tetkik ve Arama Enstitüsü, 1965 , p. 15), which is approximately $3 \mathrm{~km}$ south of the city of Zonguldak on the Black Sea. They are at altitudes of about $300 \mathrm{~m}$. The bauxite is in lenses and pockets on a karst surface on Carboniferous limestone and is overlain by middle Cretaceous sandstone. Hard and soft varieties of bauxite are present. The hard type contains abundant diaspore pisolites (Göksu, 1954, p. 195), and the soft type is similar to terra rossa. Göksu (1954, p. 195) listed the average chemical composition of hard bauxite as 55 percent $\mathrm{Al}_{2} \mathrm{O}_{3}, 5$ percent $\mathrm{SiO}_{2}$, 20 percent $\mathrm{Fe}_{2} \mathrm{O}_{3}, 3$ percent $\mathrm{TiO}_{2}$, and 13 percent $\mathrm{LOI}$ and of soft bauxite as 40 percent $\mathrm{Al}_{2} \mathrm{O}_{3}, 30$ percent $\mathrm{SiO}_{2}, 10$ percent $\mathrm{Fe}_{2} \mathrm{O}_{3}, 2.5$ percent $\mathrm{TiO}_{2}$, and 15 percent LOI.

Seydissehir-Akseki region.-More than 100 occurrences of bauxite are known in the Seydişehir-Akseki region, but only a few are large enough to be of value (Ankara Maden Tetkik ve Arama Enstitüsü, 1965; Göksu, 1954; Güldari, 1973). The bauxite occurs as pockets and lenticular deposits within Upper Cretaceous limestone. They are along an unconformity on Turonian limestone beds and are overlain by limestone breccias and conglomerates of Senonian age (Wippern, 
1964). The deposits are associated with terra rossa and are of the karst or Mediterranean type. According to Wippern (1962), the bauxite originated from reworked feldspathic material from igneous rocks. The bauxite is chiefly boehmite (Göksu, 1954, p. 189).

The Mortas bauxite deposit located $15 \mathrm{~km}$ south of Seydișehir consists mainly of boehmite but contains variable quantities of diaspore (Atabey, 1976). The bauxite also contains minor amounts of gibbsite, kaolinite, and montmorillonite. Iron occurs in the form of hematite and goethite. Noncrystalline aluminous materials are also present (Atabey, 1976). The bauxite varies considerably in composition; $\mathrm{Al}_{2} \mathrm{O}_{3}$ ranges from 40 to 60 percent, $\mathrm{SiO}_{2}$ from 5 to 12 percent, and $\mathrm{Fe}_{2} \mathrm{O}_{3}$ from 14 to 20 percent. Most of the bauxite is about 2.5 percent $\mathrm{TiO}_{2}$.

Other districts.-Deposits at Islahhiye are underlain by limestone of Late Jurassic and Early Cretaceous age and are overlain by a limestone series of Late Cretaceous age. Much of the bauxite is pisolitic and dark brown, and all is rich in iron. Of 110 samples analyzed (Göksu, 1954, p. 193), 48 contained more than 50 percent $\mathrm{Al}_{2} \mathrm{O}_{3}$ and 23 contained more than 45 percent $\mathrm{Al}_{2} \mathrm{O}_{3}$. The $\mathrm{Fe}_{2} \mathrm{O}_{3}$ contents in these samples ranged from 15 to 17.41 percent.

Small bauxite deposits having high silica contents occur along the unconformity between Lower and Upper Cretaceous limestones at Kaș (Ankara Maden Tetkik ve Arama Enstitüsü, 1965, p. 21). Small deposits of Eocene age also occur in this area.

Göksu (1954) noted that bauxite has been found at Kan in the east Taurus Mountains, at Sebilkoy near the southern coast, and elsewhere. Probably these deposits are too small to be of much value.

Several bauxite occurrences have been found in the area between Seydisehir-Akseki and the city of Alanya on the coast (Peyronnet, 1971). Some of this bauxite contains considerable diaspore. A sample of one deposit was found to be uncommonly rich in gallium (Peyronnet, 1969).

Diaspore.-The extensive diaspore deposits in Turkey occur mainly near the southwestern coast on the Aegean Sea, but other deposits are scattered throughout the southern part of the country. Most of these deposits are lens-shaped and occur in marble along the boundary between Permian and Triassic rocks (Wippern, 1964; Peyronnet, 1971). The deposits are generally scattered along the flanks of a crystalline massif (Ankara Maden Tetkik ve Arama Enstitüsü, 1965, p. 2). The diaspore is believed to have been formed by metamorphism of bauxite deposits in the late Paleozoic or early Mesozoic.

\section{Resources}

The reserves of bauxite in the Konya-Seydișehir region were estimated by the Ankara Maden Tetkik ve Arama
Enstitüsü (Apaydin and Erscen, 1981, p. 2) to be approximately 42,473 thousand tons. The U.S. Bureau of Mines (Baumgardner and McCawley, 1983, table 3) made a more conservative estimate of 25 million tons. In addition to the reserves in the Konya-Seydisehir region, an estimated 276,490 thousand tons of bauxite is present in nine other districts (table 22). Diaspore resources in five districts, which are presently considered subeconomic, are estimated to be 143,443 thousand tons. The total bauxite and diaspore resources in Turkey are estimated to be about 460 million tons (table 22).

TABLE 22.-Estimates of resources of bauxite and diaspore in Turkey and contents of major oxides

[Modified from Apaydin and Erscen $(1981$, p. 2)]

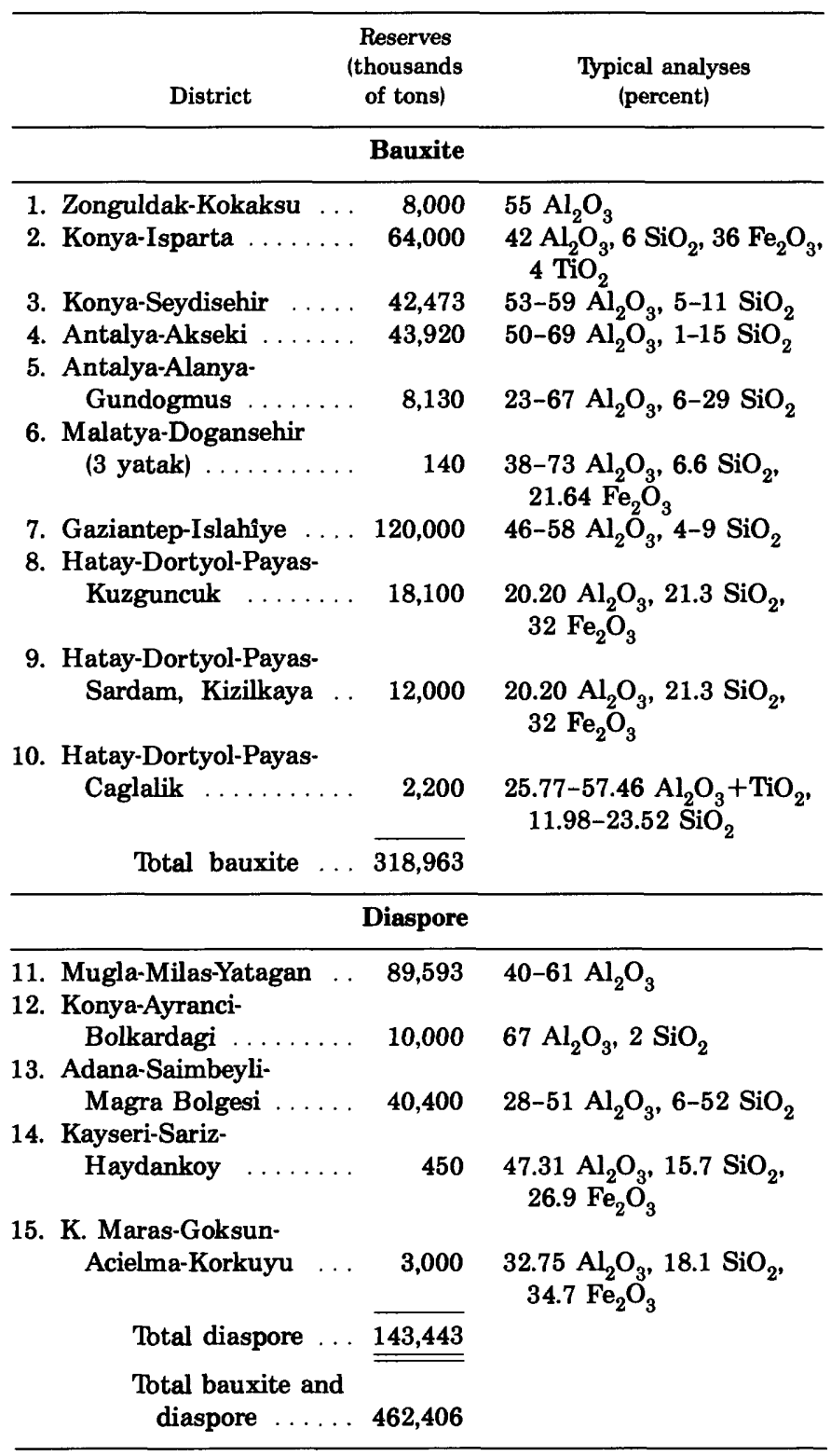




\section{VIETNAM}

Bauxite was discovered in Vietnam by Japanese geologists in 1941 and has been investigated by Soviet and Hungarian geologists more recently. The deposits are located near the border with the People's Republic of China and are now known to occur in nine districts scattered through a belt about $125 \mathrm{~km}$ long (Chebotarev and Buy Fu Miy, 1961; Koinlóssy, 1976). Small tonnages of bauxite were mined at Lang Son near Don Dang and Dai Phat during the Japanese occupation (Harrington, 1948). Presumably this bauxite was for test purposes, because there are no reports of significant production.

The bauxite is the karst type, occurring in deformed Paleozoic rocks. The deposits are of Late Permian age. They are underlain by Carboniferous and Permian rocks and overlain by limestones and marine shales of Late Permian and younger ages. They range considerably in thickness because of irregularities in the subjacent karst surface, but some are as much as $\mathbf{4 0} \mathrm{m}$ thick. Most deposits are steeply inclined, and some are cut and displaced by faults.

Koinlóssy (1976, table 4) investigated 421 samples of bauxite from six of the Vietnam districts and found them to be mainly the monohydrate type. The 220 samples from five districts had diaspore contents of 16.3-46.7 percent, and the average boehmite content ranged from 2.0 to 21.4 percent. The samples from deposits in the one district having low diaspore contents had an average kaolinite content of 34.9 percent. Kaolinite was also present in the samples from the other districts, and chamosite, hematite, and goethite occur in considerable quantities in all districts. Chebotarev and Buy Fu Miy (1961) recorded the following ranges of major oxides in the bauxite: 49-54 percent $\mathrm{Al}_{2} \mathrm{O}_{3}$, 7-10 percent $\mathrm{SiO}_{2}$, and 22-26 percent $\mathrm{Fe}_{2} \mathrm{O}_{3}$.

Laterite-type deposits occur at several places in former South Vietnam. Hebb $(1974$, p. 301, table A) noted that deposits occur at Thua Thien and Quang Nam. Presumably these deposits and others in plateau areas in the lower Mekong basin were investigated in 1961 by the United Nations Economic Commission for Asia and the Far East (1962, p. 18). No reports on the results of this work have been widely circulated, but Fontaine and Workman (1978, p. 588-589) noted that deposits in southern Vietnam are reported to contain 40-50 percent $\mathrm{Al}_{2} \mathrm{O}_{3}$.

According to Bárdossy (1977, appendix 1), districts in the vicinity of Lang Son in the southern part of the bauxite belt near the People's Republic of China contain 70 million tons, and 130 million tons of bauxite is present near Cao Dang in the northern part of the belt. The total resources of 200 million tons have little value as a source of aluminum because of the high diaspore contents. However, the technology of alumina extraction from this bauxite has been investigated by Vietnamese and Soviet specialists (Dik, Eremm, and Chestyakova, 1976).

\section{OTHER ASIAN COUNTRIES}

In Yemen (Aden), a thin zone of bauxitic rock associated with lignite and gypsum occurs in variegated shales between sandstones of Cretaceous age and massive limestone of middle Eocene age (Little, 1925, p. 105, 136-137). The aluminous rock and associated strata crop out in cliff faces north of the port of Makalla (Mukalla). The bauxitic zone is about $1 \mathrm{~m}$ thick and white to pink. At the surface it is brittle to powdery, and the hard parts break with a conchoidal fracture. At one locality the bauxite contained 46 percent $\mathrm{Al}_{2} \mathrm{O}_{3}$; at another, 67 percent $\mathrm{Al}_{2} \mathrm{O}_{3}$ and small quantities of $\mathrm{Fe}_{2} \mathrm{O}_{3}, \mathrm{CaO}, \mathrm{MgO}, \mathrm{K}_{2} \mathrm{O}$, and $\mathrm{SiO}_{2}$.

Occurrences of bauxite in the alluvium-filled Mae Klong and Khwae Noi valleys in Thailand were described by Richardson (1947). These deposits, reported to be 2 $m$ thick, consist of irregularly shaped gray concretions.

Bauxite is known to occur in three places in Kampuchea. Deposits associated with Permian limestone occur in the Battambang and Sisophon areas in northwestern Kampuchea (Gorovoy and Nyrkov, 1974; Dottin, 1972; Fleuriot de Langle, 1973). Deposits at one locality are mixtures of boehmite and chamosite, and those at another are chiefly diaspore and hematite. Some of this bauxite has $\mathrm{Al}_{2} \mathrm{O}_{3}$ contents in the range 50-60 percent (Workman, 1972, p. 62-65). Bárdossy (1977, appendix 1) gave an estimate of 3 million tons for the bauxite in the Sisophon area. Red lateritic bauxite is known to be present in the Haut Chhlong (Khet Mondolkiri) plateau area in the extreme eastern part of Kampuchea (Fontaine and Workman, 1978, p. 587). Three samples of the bauxite from the Haut Chhlong plateau contained 43-50 percent $\mathrm{Al}_{2} \mathrm{O}_{3}, 17-24$ percent $\mathrm{Fe}_{2} \mathrm{O}_{3}, 3$ percent $\mathrm{TiO}_{2}$, and 1-2 percent $\mathrm{SiO}_{2}$.

Small bauxite deposits are reported at Qandahăr in Afghanistan (Bárdossy, 1977, appendix 1). They are the karst type and are of Late Jurassic age. They are thought to contain approximately 5 million tons.

In a reconnaissance survey, Dissanayake and Vitanage (1977) found some evidence of bauxite in Sri Lanka. One laterite soil horizon in the central part of the island was 46.7 percent $\mathrm{Al}_{2} \mathrm{O}_{3}$, and gibbsite was the primcipal bauxite mineral. This soil is 19.6 percent $\mathrm{SiO}_{2}$ that is in the form of quartz and halloysite.

Small bauxite deposits have reportedly been discovered in Israel (Chemical Age, 1956). These deposits are 
in the Ramon area in the Negev region. These may be the deposits Bárdossy (1977, appendix 1) noted in the Maktesh area that contain 5 million tons of bauxite.

Several mining journals (Engineering and Mining Journal, 1976; E/MJ International Directory Mining Activity Digest, 1976; Mining Magazine, 1976) published reports of the discovery of large bauxite deposits in South Korea. These news items were inaccurate reports of the discovery of a large mass of anorthosite by the Korea Research Institute of Geoscience and Mineral Resources (Dr. Byung Koo Hyun, written commun., 1976).

\section{SUMMARY OF BAUXITE RESOURCES IN ASIA}

The total bauxite reserves in Asia are estimated to be approximately 2 billion tons (rounded), and the resources (reserves and subeconomic and undiscovered resources) are thought to be 6 billion-11 billion tons. The principal reserves, in million of tons, are located in the following regions: India-approximately 1,000, Indonesia-750, and the People's Republic of China150. Malaysia, Pakistan, and Turkey each have reserves in the 15-million- to 30-million-ton range. The large identified subeconomic bauxite deposits of little or no foreseeable value are mainly in India, Indonesia, and the People's Republic of China. The principal regions where undiscovered bauxite deposits are likely to be present are India, Indonesia, People's Republic of China, and at scattered places in the tropical belt of Southeast Asia and the Philippines.

\section{OCEANIA}

The principal bauxite resources in Oceania are in Australia, but smaller resources are known in the Solomon Islands, Palau, and Fiji. Very small deposits occur on several other islands, and low-grade ferruginous laterite deposits are known in New Zealand. Little mineral prospecting has been done on several Pacific islands having areas favorable for bauxite formation, and therefore more bauxite deposits of small to medium size ( 5 million-100 million tons) will probably be discovered in the future.

\section{AUSTRALIA}

\section{History and Production}

In less than 30 years, Australia has progressed from an alumina-importing nation to the world's leading producer of bauxite and alumina. In 1971, Australia took over world leadership among the bauxiteproducing countries with an output of 12.7 million tons, and in 1977 the total was twice that amount (table 6). Though bauxite had been produced on a small scale for refractory and chemical products at several places for a long time and is still mined for these uses, the alumina for the first aluminum plant at Bell Bay was imported (Coghill, 1972). Bauxite deposits of sufficient size and grade to support an aluminum industry were discovered in 1955 near Weipa on the Cape York Peninsula (fig. 25), by Harry Evans, the chief geologist of Frome Broken Hill Co. (Raggatt, 1968, p. 85). The bauxite deposits on this peninsula are now known to be among the largest in the world.

Metal-grade bauxite is mined at Gove, Northern Territory; Jarrahdale and Del Park in the Darling Range, Western Australia; and Weipa, Queensland (fig. 25). The major production of bauxite in Australia for nonmetallurgical uses is in the Weipa district, but minor tonnages are also mined in other districts. The Weipa district now has the capacity for calcining 250,000 tons of abrasive-grade bauxite per year. Ingram (1973) gave the following list of other bauxite deposits mined for nonmetallurgical uses. (1) Deposits in the Tambourine Mountain (now Hendersons Knob) district, Queensland, have been used for water purification, making aluminum sulfate, and road metal. (2) More than 175,000 tons of bauxite has been mined in the Moss Vale district, New South Wales, for flux in steel making and as a raw material for cement. (3) Deposits in the Mirboo district, Victoria, are used for aluminous chemicals, and approximately 100,000 tons have been mined.

\section{Bauxite Districts and Deposits}

\section{NEW SOUTH WALES}

The Inverell district contains many separate bauxite deposits (Owen, 1954, p. 29-63). The bauxite is in laterite that is derived from basalt and is overlain by younger basalts of Pliocene age. The deposits range in thickness from 5 to $13 \mathrm{~m}$. The bauxite is pisolitic and earthy in texture and grades downward into clay-rich weathered rocks in which basaltic textures have been preserved. Proved and indicated reserves of bauxite in the Inverell district are 15,606 million tons (Ingram, 1973 , p. 11). The composition of this bauxite is 38.6 percent $\mathrm{Al}_{2} \mathrm{O}_{3}, 3.2$ percent $\mathrm{SiO}_{2}$, and 30.1 percent $\mathrm{Fe}_{2} \mathrm{O}_{3}$.

Bauxite occurs in surficial laterite derived from basalt in several places in the Moss Vale district. Some deposits are as much as $15 \mathrm{~m}$ thick, but most are less than $6 \mathrm{~m}$ thick. The upper part of most deposits is dark-red 


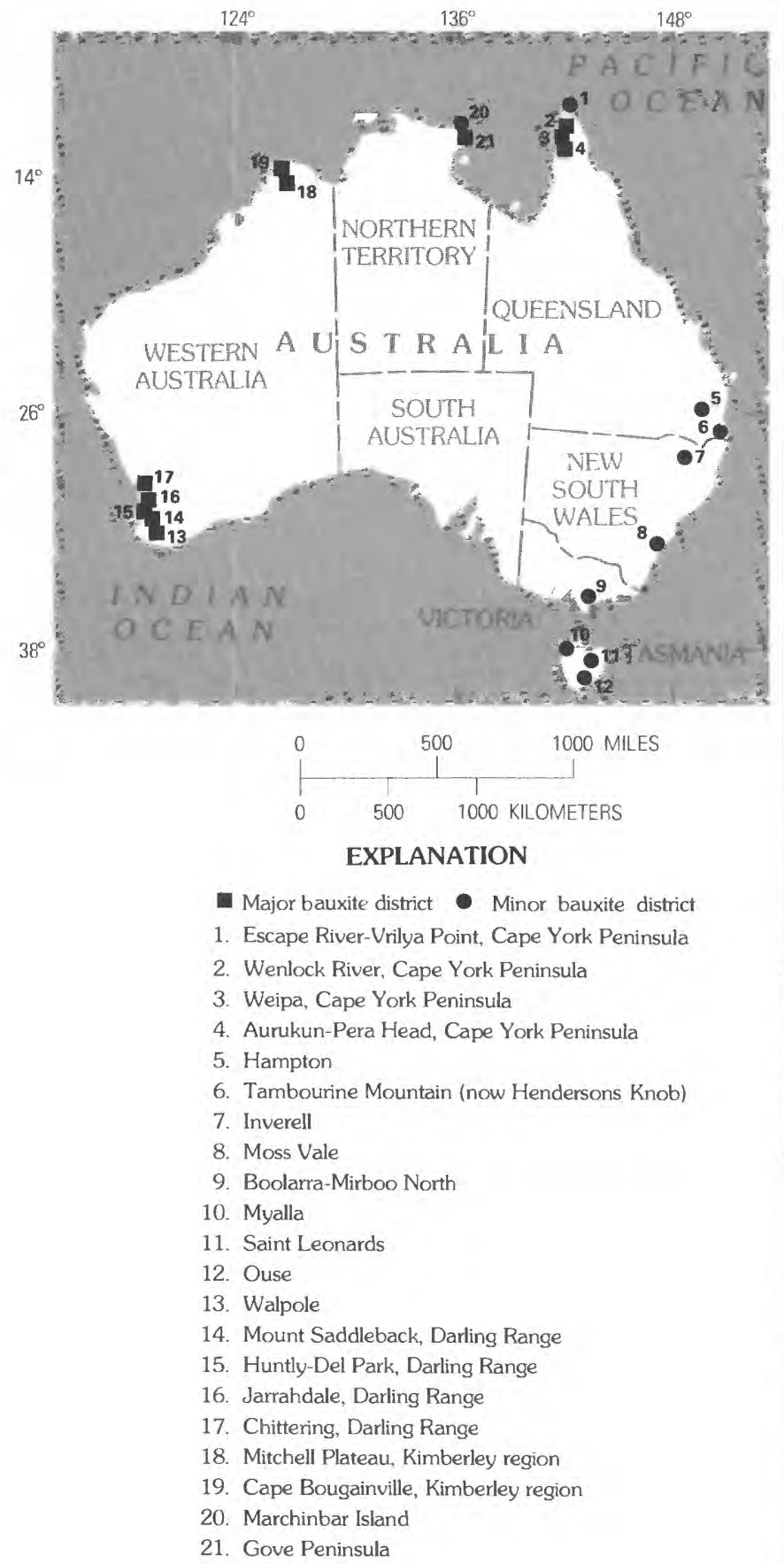

FIGURE 25.-Locations of bauxite districts in Australia.

pisolitic laterite, which is separated from fresh basalt by layers of variegated red and buff kaolinized basalt. Some of the bauxite in the Moss Vale district has been used as a flux in making steel. The Moss Vale district is estimated to contain 4 million tons of proved and indicated bauxite. The better grade of bauxite in these deposits is 39.4 percent $\mathrm{Al}_{2} \mathrm{O}_{3}, 5.4$ percent $\mathrm{SiO}_{2}, 31.1$ percent $\mathrm{Fe}_{2} \mathrm{O}_{3}$, and 5.2 percent $\mathrm{TiO}_{2}$ (Ingram, 1973, p. 11).
Several small deposits of bauxitic laterite occur in the Trundle district $80 \mathrm{~km}$ west of Moss Vale. These deposits are estimated to contain 770,000 tons of bauxite containing about 24 percent free alumina (Ingram, 1973, p. 11).

\section{NORTHERN TERRITORY}

Gove.-The largest deposits in the Northern Territory are at Gove (fig. 25). These deposits, which were among the first large laterite-type bauxites discovered in Australia, were described briefly by Owen $(1954$, p. 169$)$. They underlie remnants of an undulating plateau surface at $30-50 \mathrm{~m}$ above sea level. Thicknesses of minable bauxite are as much as $10 \mathrm{~m}$, but most deposits are 3-4 $\mathrm{m}$ thick. Somm (1975) described a typical section of the bauxite exposed in mines as $2.0 \mathrm{~m}$ of overburden, $3.0 \mathrm{~m}$ of loose pisolitic bauxite, $1.5 \mathrm{~m}$ of cemented pisolitic bauxite, $1.0 \mathrm{~m}$ of tubular bauxite, and $5.0 \mathrm{~m}$ of ferruginous and siliceous (barren) laterite.

According to Grubb (1970), the bauxite on the Gove Peninsula formed on thick beds of nearly horizontal shales, siltstones, and sandstones, which rest on an irregular granitic basement. The sediments were originally thought to be Proterozoic, but they are now considered to be Early Cretaceous in age. The shale units in the sediments are considerably more bauxitized than the beds of other lithologies. A drill hole described by Grubb from the surface downward penetrated the following beds: bauxite, mainly pisolites, 0-7.5 m; mottled clay, 7.5-9 m; purplish clay, apparently weathered from shale, 9-18 m; sands, partly arkosic, 18-175 m. Most of the bauxitization that formed the Gove deposits probably took place in the late Tertiary, but some of the initial weathering probably began in the Mesozoic. The bauxite consists mainly of gibbsite, but some boehmite is present, particularly at shallow depths. Silica contents are low, and this oxide occurs mainly in kaolinite. Iron minerals present are mainly hematite and goethite. The bauxite also contains titanium in rutile, anatase, and ilmenite.

Minable bauxite at Gove extends over areas covering a total of $63 \mathrm{~km}^{2}$. According to Somm (1975, p. 964), proven reserves are 250 million tons. The International Bauxite Association (1976a, p. 37) listed this same figure for measured bauxite and 500 million tons for total reserves in the region. Somm (1975, p. 964) stated that the average grade of the reserves is 51 percent $\mathrm{Al}_{2} \mathrm{O}_{3}$ and 4 percent $\mathrm{SiO}_{2}$. The International Bauxite Association (1977a, p. 37) reported the following analysis for the reserves: 50 percent $\mathrm{Al}_{2} \mathrm{O}_{3}$, 3.4-4.2 percent total $\mathrm{SiO}_{2}, 3.4$ percent reactive $\mathrm{SiO}_{2}$, 17.1 percent $\mathrm{Fe}_{2} \mathrm{O}_{3}, 3.4$ percent $\mathrm{TiO}_{2}$, and 26.4 percent LOI. 
Marchinbar Island.-Eight deposits of bauxite on Marchinbar Island in the Wessel Islands have been described by Owen (1954, p. 150-168). The bauxite is in laterite resting on quartzite, massive sandstone, and shale of Precambrian age. The bauxite probably formed during the Tertiary Period. It is partly covered by a layer of wind-blown sand as much as $0.3 \mathrm{~m}$ thick. Approximately 10 million tons of bauxite containing 47.7-53.3 percent $\mathrm{Al}_{2} \mathrm{O}_{3}, 4.1-8.8$ percent $\mathrm{SiO}_{2}$, and 6.4-17.2 percent $\mathrm{Fe}_{2} \mathrm{O}_{3}$ was found on Marchinbar Island during early investigations (Owen, 1954, p. 15).

Minor deposits of bauxite occur in Melville and Croker Islands and the Coburg Peninsula, Northern Territory (Hughes, 1978). Deposits on Croker Island have been estimated to contain 660,000 tons by one company and 5 million tons by another. As much as 50 million tons may be present on Vashon Head on the Coburg Peninsula. Most of this bauxite contains more than 10 percent reactive silica according to the few analyses that are available.

\section{QUEENSLAND}

Extensive bauxite deposits occur in several districts in the western part of the Cape York Peninsula (fig. 25). Small deposits are located in the Escape River district on the northeastern coast of the peninsula and in the Tambourine Mountain (now Hendersons Knob) and Hampton districts in southeastern Queensland.

Districts in western Cape York Peninsula.-Weipa, the largest and the only presently producing district on the Cape York Peninsula, is in the central part of a belt extending for about $350 \mathrm{~km}$ from Aurukun in the south to Vrilya Point in the north (Raggatt, 1968; MacGeehan, 1972).

The Weipa bauxite deposits are flat-lying to gently dipping blanket deposits having an average thickness of $2.4 \mathrm{~m}$ and less than one meter of overburden (Evans, $1959,1975)$. The bauxite deposits are underlain by a thick sequence of arkosic, sandy, silty, and clayey strata that some geologists date as Cretaceous (Grubb, 1971b) and others as Tertiary (Evans, 1975). The bauxite grades downward through bauxitic kaolin into strata consisting of clay and sand (Murray, 1984) that are the parent material of the bauxite. These strata are 30-60 percent quartz sand, and the remainder is chiefly kaolinite with minor quantities of illite, montmorillonite, and titanium-bearing and other heavy minerals. The heavy minerals in the clay-sand strata are similar to those in the bauxite (Grubb, 1971b), which supports the conclusion that the clay-sand strata are the parent materials of the bauxite. The bauxite formed mainly by leaching by meteoric water under seasonal tropical conditions, and the lateritization process is still going on within the profile (Evans, 1972). The upper 2-3 $\mathrm{m}$ of deposits in the Weipa district consists of loose pisolitic bauxite (Jepsen and Schellmann, 1974). Boehmite makes up as much as 20 percent of this upper zone, but this mineral decreases in abundance with depth and is ordinarily rare below depths of about $3 \mathrm{~m}$ (Schellmann and Jepsen, 1973). Kaolinite is present throughout most of the deposits. This clay and some of the quartz, hematite, goethite, and heavy-mineral contaminants are removed by washing.

Weipa bauxite deposits are overlain only by a soil that is as much as $1 \mathrm{~m}$ thick and is missing in places. The bauxite is as much as $6 \mathrm{~m}$ thick (Loughnan and Sadleir, 1984, p. 441). It consists of loosely bound red pisolites with minor quantities of interstitial material of a deeper red. Pisolites in the upper part of the bauxite are coarse grained, and many of them exceed $20 \mathrm{~mm}$ in diameter. Pisolites in the lower part tend to be much finer grained. The pisolitic bauxite is underlain with sharp contact by a dark-red, iron-enriched concretionary zone that is generally several meters thick. In most places the concretionary zone is massive, but tubular structured bauxite occurs locally. The concretionary zone contains less $\mathrm{Al}_{2} \mathrm{O}_{3}$ than the pisolitic zone, and it is not being mined. The concretionary zone is separated from the underlying Weipa Formation by a partly mottled bleached kaolinitic sand of variable thickness. The average grade of beneficiated bauxite produced in 1977 (see table) was approximately 54.8 percent $\mathrm{Al}_{2} \mathrm{O}_{3}$ and 5.3 percent $\mathrm{SiO}_{2}$. Some higher grade bauxite has been produced; Weipa bauxite shipped to West Germany (Meusel, 1974, p. 92) was 58 percent $\mathrm{Al}_{2} \mathrm{O}_{3}, 4$ percent $\mathrm{SiO}_{2}, 7$ percent $\mathrm{Fe}_{2} \mathrm{O}_{3}, 0.21$ percent organic matter, and 27 percent LOI. One of two samples of Weipa bauxite analyzed in Italy by Landi and Casola (1977, table 1a) was of similar composition. The other sample was 55.61 percent $\mathrm{Al}_{2} \mathrm{O}_{3}$. The percentage of $\mathrm{Al}_{2} \mathrm{O}_{3}$ occurring in the form of boehmite in these samples was 14.0 and 15.0.

Average grades of bauxite from Weipa, Cape York Peninsula, Australia [In percent. From Roberts (1977)]

\begin{tabular}{|c|c|c|c|c|c|c|}
\hline & $\mathrm{Al}_{3} \mathrm{O}_{3}$ & $\mathrm{SiO}_{2}$ & Quartz & $\mathrm{Fe}_{2} \mathrm{O}_{3}$ & Gibbsite & Boehmite \\
\hline $\begin{array}{l}\text { North of } \\
\text { Mission }\end{array}$ & & & & & & \\
\hline $\begin{array}{r}\text { River } \\
\text { Weipa }\end{array}$ & $50-55$ & $1-7$ & $0.5-2$ & $12-20$ & $36-44$ & $8-15$ \\
\hline Peninsula & $56-60$ & $3-10$ & $1-4$ & $5-8$ & $36-45$ & $8-16$ \\
\hline $\begin{array}{l}\text { South of } \\
\text { Embley }\end{array}$ & & & & & & \\
\hline River. & $45-56$ & $6-10$ & $2-4$ & $7-15$ & $30-40$ & $10-15$ \\
\hline
\end{tabular}

Bauxite resources in the Weipa district, which includes Andoom, a part of the district north of the Mission River where mining is underway, and an area south 
of the Embley River, are estimated to be 3,133 million tons (National Miner, 1977, p. 90). Reserves of recoverable (washed) bauxite were estimated to be 2.5 billion tons as of 1975 (Roberts, 1977, p. 3-4). Of this amount, 599 million tons was proven, 794 million tons probable, and the remainder possible bauxite. The three categories of reserves used by Roberts apparently are approximately equivalent to measured, indicated, and inferred.

The bauxite in the Aurukun district described by MacGeehan (1972) is quite similar to the deposits at Weipa. It also is differentiated into an upper, boehmiterich and a lower, gibbsite-rich zone. MacGeehan attributed the differences in mineralogy to youthful and mature stages of formation, and the development of the second stage is thought to have followed a lowering of the water table. According to Evans (1976, table 1), who referred to Aurukun as the Archer River district, the bauxite reserves are 600 million tons. The National Miner $(1977$, p. 90$)$ listed the reserves in this district as 1,016 million tons and the grade as $\mathbf{5 3 . 5}$ percent $\mathrm{Al}_{2} \mathrm{O}_{3}$ and 8.5 percent $\mathrm{SiO}_{2}$.

Other bauxite districts in the western part of the Cape York Peninsula include the following: (1) Pera Head, which is located on the coast between Aurukun and Weipa. The resources in this district are reported to be 73 million tons; they are low in silica and have an average $\mathrm{Al}_{2} \mathrm{O}_{3}$ content of 55.5 percent (National Miner, 1977 , p. 90). (2) South Weipa, south of the principal Weipa leases. Bauxite reserves owned by the AustralPacific Mining Corporation in this district are estimated to be 139 million tons containing 45 percent $\mathrm{Al}_{2} \mathrm{O}_{3}$ (National Miner, 1977, p. 90). Evans (1976, table 1) made a questionable estimate of 92 million tons controlled by Austral-Pacific/Falkirk in this district. (3) Wenlock River, an inland district along the upper reaches of a stream of this name, northeast of Weipa. According to the National Miner $(1977$, p. 90$)$, there are 51 million tons of bauxite in this district. The grade of the deposits is not available, but they are believed to be high in silica. Evans (1976, table 1) listed the Wenlock River reserves owned by "C.R.A./N.B.H.C." as being 45 million tons. (4) North Weipa, which is, as the name indicates, north of the principal Weipa leases. It is near the coast and on the south side of the Wenlock River. According to the National Miner $(1977$, p. 91 ), this district is owned by Alcan of Australia, Ltd. The bauxite reserves are 76 million tons and the grade is unavailable. Evans (1976, table 1) listed the Alcan deposits in the Wenlock River district as 296 million tons containing $>45$ percent $\mathrm{Al}_{2} \mathrm{O}_{3}$ and $<15$ percent total silica. (5) Vrilya Point, in the northwest part of the Cape York Peninsula (National Miner, 1977, p. 89). No estimates of the bauxite resources in this district are available.
Escape River district. - Low-iron bauxite has been discovered in the Escape River district (fig. 25) in northeastern Cape York (A.H. White, 1976). The low-iron deposits are in the low parts of a gently undulating prePliocene lateritic surface. They grade through thin transition zones into high-iron (more than 15 percent $\mathrm{Fe}_{2} \mathrm{O}_{3}$ ) bauxite on the crests of the undulations. The deposits contain only about 5 million tons, and they are therefore probably too small to be mined profitably. However, they are of interest because they are the only low-iron deposits so far found in Australia, and possibly a grade of bauxite suitable for some of the nonmetal uses could be recovered from them. The low-iron bauxite is 44.6 percent $\mathrm{Al}_{2} \mathrm{O}_{3}, 31.3$ percent $\mathrm{SiO}_{2}, 0.65$ percent $\mathrm{Fe}_{2} \mathrm{O}_{3}$, and 2.3 percent $\mathrm{TiO}_{2}$. Gibbsite is virtually the only bauxite mineral present in these deposits, and silica occurs in the form of quartz and clay minerals. A.H. White (1976) concluded that the iron was leached from these deposits by percolating water having a low Eh and moderately low $\mathrm{pH}$. This chemical environment resulted from humic acids formed from organic matter in overlying eolian sand.

Tambourine Mountain (now Hendersons Knob). - The bauxite deposits at Tambourine Mountain are about $56 \mathrm{~km}$ south-southeast of Brisbane. The bauxite is in laterite deposits formed from the weathering of andesitic and basaltic lavas of probable Eocene or Oligocene age. Most of the laterite caps high ridges, but some of it occurs at intermediate altitudes. The bauxite in these deposits has been mined for use in aluminum sulfate. The size and grade of the deposits are incompletely known; however, the deposits are $8 \mathrm{~m}$ thick at one locality, and they are estimated to contain about 1.3 million tons of proved and indicated bauxite (Owen, 1954, p. 15). The bauxite is $37.3-41.0$ percent $\mathrm{Al}_{2} \mathrm{O}_{3}$, 4.0-7.0 percent $\mathrm{SiO}_{2}$, and 22.0-24.0 percent $\mathrm{Fe}_{2} \mathrm{O}_{3}$.

Hampton.-The bauxites at Hampton, northwest of Brisbane, are presumably similar in occurrence to the Tambourine Mountain deposits. Hampton deposits contain about 250,000 tons of indicated bauxite whose partial composition is 1.9 percent $\mathrm{SiO}_{2}, 37.8$ percent $\mathrm{Al}_{2} \mathrm{O}_{3}$, and 32.7 percent $\mathrm{Fe}_{2} \mathrm{O}_{3}$ (Owen, 1954, p. 15).

\section{TASMANIA}

Several small bauxite deposits occur near Ouse, Saint Leonards, and Myalla in Tasmania. Laterite and ferruginous bauxite occur in the Ouse area in a layer of weathered rock derived from dolerite (Matthews, 1975). After the formation of the laterite the rocks were faulted, tilted, eroded, and buried by freshwater sediments and basalt flows. The bauxite is associated with remnants of the former land surface uncovered by erosion. Reserves of bauxite are estimated to be about 
625,000 tons having 38.6-41.0 percent $\mathrm{Al}_{2} \mathrm{O}_{3}, 5.6-6.1$ percent $\mathrm{SiO}_{2}$, and 25.7-30.2 percent $\mathrm{Fe}_{2} \mathrm{O}_{3}$ (Owen, 1954, p. 15). Small deposits of bauxite resting on dolerite occur in the Saint Leonards area near the city of Launceston. The deposits contain about 140,000 tons of proved bauxite having 40.9-41.7 percent $\mathrm{Al}_{2} \mathrm{O}_{3}$, 5.6-7.1 percent $\mathrm{SiO}_{2}$, and 25.7-27.4 percent $\mathrm{Fe}_{2} \mathrm{O}_{3}$. Several small deposits of bauxite derived from basalt occur near Myalla. These deposits are estimated to contain about 190,000 tons of bauxite.

Total bauxite reserves in Tasmania are estimated to be only 975,000 tons (Ingram, 1973, p. 13). The average total alumina content of this bauxite is 41 percent.

\section{VICTORIA}

Most of the bauxite deposits in Victoria are scattered over the part of County Buln Buln that is south of the Gippsland railway. The bauxite is derived from basalt and is probably of early or middle Eocene age. According to Bell (1961), the distribution of the deposits is controlled by a major fault system, and the origin of the bauxite is apparently related to ground-water movement along the vaults.

The bauxite reserves in the Boolarra and Mirboo North townships, Victoria, were listed by Ingram (1973, p. 12), who cited earlier work, as 798,000 tons measured and 118,000 tons indicated. The measured bauxite is 50.7 percent $\mathrm{Al}_{2} \mathrm{O}_{3}, 7.6$ percent $\mathrm{SiO}_{2}, 8.5$ percent $\mathrm{Fe}_{2} \mathrm{O}_{3}$, and 5.5 percent $\mathrm{TiO}_{2}$. A bauxite exploration program by Reynolds Metals Corp. in the region of these districts in 1959 failed to find significant additional reserves (Bell, 1961, p. 51). Bauxite has been mined since 1927 on a small scale in the Mirboo North district for use in aluminous chemicals.

\section{WESTERN AUSTRALIA}

Darling Range.-The bauxite districts in the Darling Range are in a belt $350 \mathrm{~km}$ long and $60 \mathrm{~km}$ wide located $30 \mathrm{~km}$ inland and parallel to the southern part of the west coast (Murray, 1979). The principal districts are the following: (1) Jarrahdale, $48 \mathrm{~km}$ south-southeast of Perth. The bauxite in this district is trucked to a central point, where it is crushed, screened, and then shipped to Alcoa's alumina refinery at Kwinana. (2) The Huntley-Del Park district, about $90 \mathrm{~km}$ south of Perth. The bauxite is trucked to a mobile crusher and transported by a continuous conveyer to the Pinjara alumina plant (Kirk and Murray, 1979). (3) Boddington, near Mount Saddleback, $130 \mathrm{~km}$ south-southeast of Perth (Ingram, 1973, p. 16). Mining began in the Boddington district in 1983. This bauxite is transported to an alumina refinery at Worsley owned by Reynolds Australia
Alumina Ltd. (40 percent), the Shell Co. of Australia (30 percent), Broken Hill Proprietary Co. Ltd. (20 percent), and Kobe Alumina Associates (10 percent) (International Bauxite Association, 1983a, p. 5). Development schemes have been advanced for two other large bauxite districts. (4) Chittering, in the northern part of the Darling Range $40 \mathrm{~km}$ northeast of Perth. (5) The Walpole district, described by Ingram $(1973$, p. 17$)$ as being $100 \mathrm{~km}$ west of Albany and, therefore, in the southern part of the Darling Range.

The bauxite in the Darling Range occurs on a dissected undulating plateau. The deposits are mainly at elevations of $250-340 \mathrm{~m}$, but some deposits occur on isolated ridges as high as $500 \mathrm{~m}$ (Baker, 1975). The bauxite occurs in blanket deposits, and the better grade deposits are on ridge slopes rather than on crests or in valleys. Ore bodies range in size up to about 80 hectares. Most deposits are overlain by an overburden of loose sand 0.3-0.6 $\mathrm{m}$ thick. The upper part of the bauxite consists of a ferruginous hardcap having a maximum thickness of about $1.5 \mathrm{~m}$. The bauxite zone has an average thickness of about $4 \mathrm{~m}$, but in places it is more than $12 \mathrm{~m}$ thick. Lithologies of this zone vary considerably. In some places it is massive, and in others it is fragmental, pisolitic, and, rarely, tubular or layered.

The bauxite deposits in the Darling Range formed on ancient complex rocks, and some difference of opinion exists among geologists as to whether or not the bauxite has had a complex history. According to Owen and Hargreaves (1975), the bauxitic laterite is of two principal types depending on its parent rock. Deposits on granitic rocks have high quartz contents, whereas deposits on intermediate and mafic rocks are virtually free of quartz. Grubb (1971a) suggested that the bauxite, instead of forming on ancient crystalline rocks, developed on a blanket of feldspathic fluviatile Cretaceous sediments for which little evidence remains. Baker $(1972 ; 1975$, p. 984$)$ took issue with this idea and pointed out that, at one isolated locality, the shale from which the bauxite formed could be of Proterozoic age.

The Jarrahdale deposits, which are more or less typical of the Darling Range bauxites, are low grade as compared with other bauxite deposits in Australia and elsewhere. The principal bauxite mineral is gibbsite, but boehmite, diaspore, and corundum are also present in very minor quantities (Grubb, 1971a). The Jarrahdale and other deposits in the Darling Range are uncommonly rich in silica, but nearly all of it is in the form of quartz, which is nonreactive in the Bayer process for extracting alumina. The principal iron minerals are hematite and goethite, and, as in most laterites, hematite tends to be most abundant in the upper parts of deposits. The goethite in these deposits, like the bauxite in the Kimberley region farther north, is thought to 
contain aluminum (Owen and Hargreaves, 1975). The composition of typical bauxite mined in the Darling Range is given by Sibly and Bucket $(1982$, p. 130$)$ as total $\mathrm{Al}_{2} \mathrm{O}_{3} 37$ percent, available $\mathrm{Al}_{2} \mathrm{O}_{3} 30$ percent, total $\mathrm{SiO}_{2} 24$ percent, reactive $\mathrm{SiO}_{2} 1.5$ percent, LOI 20 percent, $\mathrm{Fe}_{2} \mathrm{O}_{3} 18$ percent, and $\mathrm{TiO}_{2} 1$ percent.

The large bauxite resources in the Darling Range are scattered in several districts. The reserve estimates, in millions of tons, are as follows: (1) Gigegannup area south of Chitterling-69 (National Miner, 1977, p. 92); (2) Jarrahdale-80 (National Miner, 1977, p. 91); (3) Huntly-Del Park-1,000 (National Miner, 1977, p. 92); (4) Mount Saddleback-250 (Ingram, 1973, p. 16); and (5) Chittering (Muchea)-100-200 (National Miner, 1977, p. 92; Ingram, 1973, p. 16). Other large bauxite deposits, which are described by Evans (1976, table 1) as "substantial" and are in areas of claims covering $620 \mathrm{~km}^{2}$ (Ingram, 1973, p. 17), are present in the Walpole district in the southern part of the Darling Range. Also, numerous small deposits in the Mount Saddleback district extending over areas as large as 3 hectares and containing as much as 300,000 tons were considered too small to be included in reserve estimates (Owen and Hargreaves, 1975 , p. 991). Total bauxite resources in the Darling Range are more than 1.6 billion tons (rounded).

Kimberley region (Mitchell plateau and Cape Bougainville).-The bauxite deposits in the Kimberley region are on the Mitchell plateau and Cape Bougainville, which border the Admiralty Gulf on the northern coast of Western Australia (Joklik, Jackson, and Zani, 1975; Ingram, 1973; Parker and Sadleir, 1984). Reynolds Pacific Mines Ltd. discovered bauxite on Cape Bougainville in 1958 (Gellatly and Sofoulis, 1969, p. 15). American Metals Climax (Amax) explored the two districts in the late 1960's (Joklik, Jackson, and Zani, 1975). Amax had plans for producing bauxite in this district, but construction was deferred due to a decline in aluminum demand in 1972. Mitchell Plateau Bauxite Co. Pty. Ltd. and Alcoa of Australia took over Amax's interests and re-evaluated the Mitchell bauxite deposit in 1979 and 1980.

The bauxite deposits in the Kimberley region are on a plateau that slopes northward from an altitude of $350 \mathrm{~m}$ in the southern part of the Mitchell plateau to about 60 $\mathrm{m}$ at the northern end of Cape Bougainville. The plateau is supported by Proterozoic volcanic rocks, which are the parent material of most of the bauxite. Locally small deposits of bauxite formed from sedimentary beds that are interlayered with the volcanic rocks.

According to Joklik, Jackson, and Zani (1975, p. 970971), the Mitchell plateau bauxite covers $40 \mathrm{~km}^{2}$ and has an average thickness of $3.2 \mathrm{~m}$. It is 47 percent $\mathrm{Al}_{2} \mathrm{O}_{3}$ and contains an estimated 230 million tons of bauxite.

The bauxite of Cape Bougainville described by Joklik, Jackson, and Zani (1975) is similar to that on the Mitchell plateau. However, the Bougainville deposits contain less aluminum and more iron and are much thicker than the Mitchell plateau deposits. The Cape Bougainville deposits cover $44 \mathrm{~km}^{2}$, have an average thickness of 8.6 $\mathrm{m}$, are 36 percent $\mathrm{Al}_{2} \mathrm{O}_{3}$, and contain an estimated 980 million tons of bauxite.

During the investigation of the Mitchell plateau it was found that the overburden above the bauxite consists of soil and a ferruginous laterite layer (Parker and Sadleir, 1984). The soil consists chiefly of clay and humus material and is $1 \mathrm{~m}$ thick. The ferruginous laterite layer varies in aluminum content and is enriched in hematite and goethite or maghemite. The bauxite layer is of variable thickness; the average thickness is about $3 \mathrm{~m}$. The bauxite is underlain by a lateritic clay zone consisting of nodules embedded in a clay matrix, which is as much as $5 \mathrm{~m}$ thick. Below the lateritic clay zone is a layer consisting of kaolinite containing minor quantities of montmorillonite and iron and titanium oxides.

The mineralogy of the Mitchell plateau bauxite is typical of laterite-type deposits (Parker and Sadleir, 1984; Grubb, 1970). Gibbsite is the most abundant aluminum mineral in the deposits. Amounts present range from more than 60 percent in high-grade deposits to less than 25 percent in low-grade deposits. At most places gibbsite contents increase with depth to a maximum at the centers of deposits. Gibbsite occurs as white massive mineral aggregates of submicroscopic grains. Boehmite occurs in quantities ranging from less than 1 percent to about 10 percent of the bauxite, and the average is about 4 percent. Boehmite tends to be concentrated near the top of deposits. Kaolinite contains the reactive silica in the bauxite; quartz is rarely present. The average clay-mineral content of the bauxite is about 6 percent, and it can be reduced to less than 3 percent by washing and screening out the $<35$ mesh (smaller than $0.725 \mathrm{~mm}$ ) particles (Joklik, Jackson, and Zani, 1975, p. 973). Goethite is the most common iron oxide mineral; most of the bauxite contains between 1 and 3 percent $\mathrm{Al}_{2} \mathrm{O}_{3}$ in this iron mineral. Parts of deposits depleted in iron oxide have potential for refractory-grade calcined bauxite.

\section{Resources}

According to the Australia Bureau of Mineral Resources, Geology and Geophysics (1978, table 8), resources of bauxite, in millions of tons, in this country are as follows: demonstrated-2,703, inferred-1,740, paramarginal-1,598, and submarginal-137; totaling 6,179 . Tbtals from other published resource estimates for the various districts (table 23) range from 6.5 billion 
TABLE 23.-Summary of estimates of bauxite resources in Australia

[Estimates given in thousands of tons. Metric and long tons considered equal within limits of accuracy. ---, no data]

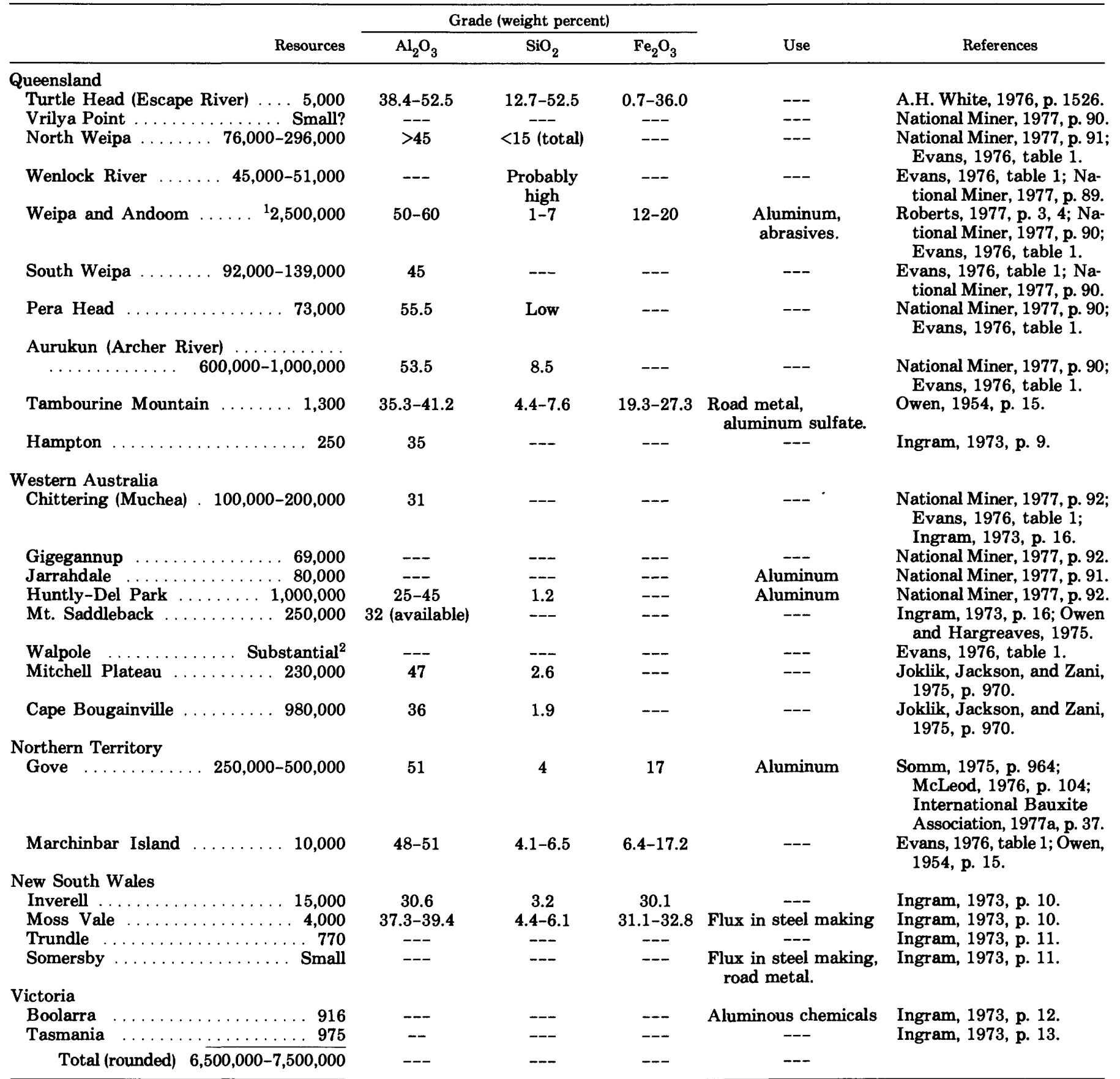

\footnotetext{
${ }^{1} 1975$ estimate, includes 499 million tons of proved bauxite containing 54-56 percent $\mathrm{Al}_{2} \mathrm{O}_{3}$ and 4.5-9.0 percent $\mathrm{SiO}_{2}$, and 794 million tons of reserves classified as probable that are 48-56 percent $\mathrm{Al}_{2} \mathrm{O}_{3}$ and 8-12 percent $\mathrm{SiO}_{2}$; the remainder is considered possible reserves.

${ }^{2}$ Bauxite claims cover about $620 \mathrm{~km}^{2}$ (Ingram, 1973, p. 17).
}

to 7.5 billion tons (rounded). Only a few bits of information support a conclusion that large subeconomic and undiscovered bauxite resources are present in Australia, including the following: (1) The Western Australia Department of Resources Development $(1983$, p. 3) noted that the State has bauxite reserves and resources exceeding 3,500 million tons containing 2742 percent available $\mathrm{Al}_{2} \mathrm{O}_{3}$; (2) Smart $(1977$, p. 18) observed, "Bauxite reserves in the west coast of Cape York Peninsula are considerable, and are probably over 
3000 million tons of economic grade; in addition, there are large reserves of lower-grade ore;" and (3) many deposits in some districts that extend over areas as much as 3 hectares are considered too small to be included in reserve estimates. No estimates are available for the Vrilya Point and Walpole districts.

In this report the bauxite reserves in Australia are considered to be 4,440 million tons (Baumgardner and McCawley, 1983, table 3), which is the rounded sum of the demonstrated and inferred reserves given in the preceding paragraph. Subeconomic and undiscovered bauxite resources are thought to be 1.5 billion-3.5 billion tons. The total bauxite resources in Australia are considered to be 6 billion- 8 billion tons.

\section{FIJI}

The possibilities for commercial bauxite deposits have been investigated on the main islands of Viti Levu and Vanua Levu and on 13 of the Lau islands. Bauxite deposits have been found on most of these islands (Bracewell, 1962, p. 134; Guest, 1959). The aluminous materials occur as (1) irregular gibbsite nodules as much as $15 \mathrm{~cm}$ in diameter scattered throughout surface gravels, (2) brown earthy saprolitic bauxite occurring chiefly as exfoliated shells of weathered basalt, and (3) earthy phosphatic bauxite associated with limestone. The gibbsite nodules contain an average of 57 percent $\mathrm{Al}_{2} \mathrm{O}_{3}, 9$ percent $\mathrm{SiO}_{2}, 4.5$ percent $\mathrm{Fe}_{2} \mathrm{O}_{3}, 0.8$ percent $\mathrm{TiO}_{2}$, and 29 percent LOI; brown earthy bauxite contains 51 percent $\mathrm{Al}_{2} \mathrm{O}_{3}, 3$ percent $\mathrm{SiO}_{2}, 16$ percent $\mathrm{Fe}_{2} \mathrm{O}_{3}, 1.7$ percent $\mathrm{TiO}_{2}$, and 28 percent LOI.

The largest bauxite deposits in Fiji are on Vanua Levu. They are located in the Wainunu region on the eastern flank of the Seatura volcano and in four districts in northwest Vanua Levu (Colley, 1976). A Japanese company began mining preparations at Savu Levu in the Wainunu region during 1969-72 but ceased operation prior to the first shipment of washed bauxite.

The deposits in the northwestern part of Viti Levu occur near the surface of dissected peneplain remnants that slope seaward from an altitude of $170 \mathrm{~m}$ down to $55 \mathrm{~m}$. Other deposits occur north of Vakambuli and elsewhere in the Lautoka-Mba region. The bauxitic layer ranges in thickness from 3 to $6.5 \mathrm{~m}$. Washing would be required to obtain an acceptable grade, and preliminary tests indicate that recovery would range from 20 to 30 percent. The deposits on Viti Levu are estimated to contain 6.5 million tons of bauxite (Houtz and Phillips, 1963, p. 25). According to Colley (1976, table 19), 1.2 million tons containing 35 percent extractable $\mathrm{Al}_{2} \mathrm{O}_{3}$ could be recovered by washing this bauxite.

The total bauxite recoverable by washing Fiji bauxite deposits is listed by Colley $(1976$, table 19) as
14.6 million-17.5 million tons. The recoverable $\mathrm{Al}_{2} \mathrm{O}_{3}$ content of this bauxite ranges from 34 to 53 percent.

\section{NEW ZEALAND}

The low-grade bauxite in New Zealand occurs as gibbsite in red and brown soils on volcanic rocks in North Auckland. Most of these soils contain kaolin minerals in addition to gibbsite, and most are high in iron oxide and titania. This bauxitic soil is very similar to deposits in Hawaii, and apparently the deposits in the two areas formed under similar conditions (Kear, Waterhouse, and Swindale, 1961, p. 5). Potentially valuable bauxitic soils cover $12 \mathrm{~km}^{2}$, and very low grade bauxitic clays cover an additional $77 \mathrm{~km}^{2}$. The soils richest in alumina are in an area of little more than $2.5 \mathrm{~km}^{2}$ near the town of Kerikeri. They were investigated by Swindale (1959) and by Kear, Waterhouse, and Swindale (1961, p. 11), who found that deposits in seven areas are 3-5 m thick and contain approximately 20 million tons of bauxite. The probable average composition of this bauxite is 37.4 percent $\mathrm{Al}_{2} \mathrm{O}_{3}, 5.5$ percent $\mathrm{SiO}_{2}, 25.6$ percent $\mathrm{Fe}_{2} \mathrm{O}_{3}$, 6.4 percent $\mathrm{TiO}_{2}$, and 23.6 percent LOI. The probable extractable alumina content is 30.6 percent.

\section{PALAU}

Bauxite deposits occur south and southeast of the village of Ngardmau and in the northwestern part of Babelthaup Island of Palau. The bauxite occurs in deeply weathered andesitic agglomerates. Deeply weathered rocks support only a dense fern growth, and generally areas are heavily forested only where fresh rock is at or near the surface; therefore, the distribution of fern growth outlines areas worth prospecting. According to Bridge and Goldich (1948, p. 22), the vertical sequence of weathered rocks containing the bauxite is typically as follows: (a) A surface bauxitic gravel bed $10-15 \mathrm{~cm}$ thick; (b) a reddish- or yellowish- brown clay $12-30 \mathrm{~cm}$ thick, containing small bauxite concretions; (c) concretionary dark reddish brown clay 1.2-1.8 m thick at most places, containing concretions and hard beds of bauxite as much as $0.6 \mathrm{~m}$ thick; (d) a mixed zone of reddishbrown clay and variegated kaolinitic clay $0.3-0.6 \mathrm{~m}$ thick, containing a few sheets and layers of ferruginous gibbsite along joints; (e) variegated purple, red, brown, yellow, and gray clay having an estimated maximum thickness of $12.2 \mathrm{~m}$ and retaining ghosts of structures and textures of parent rock; and (f) volcanic agglomerate parent rock.

Gibbsite is the chief bauxite mineral present, and hematite is the chief impurity. Minor amounts of 
boehmite and goethite and appreciable quantities of kaolinite and halloysite are also present in the bauxite. The average chemical composition of unwashed samples from one locality representing a bauxite layer $7.3 \mathrm{~m}$ thick is 35.89 percent $\mathrm{Al}_{2} \mathrm{O}_{3}, 10.33$ percent $\mathrm{SiO}_{2}, 20.75$ percent $\mathrm{Fe}_{2} \mathrm{O}_{3}, 0.7$ percent $\mathrm{TiO}_{2}$, and 32.56 percent LOI (Bridge and Goldich, 1948, p. 26).

A Japanese company produced approximately 370,000 tons of washed bauxite on Babelthaup from 1938 through part of 1944 , when operations were terminated by American bombing. The composition of this washed bauxite was 51 percent $\mathrm{Al}_{2} \mathrm{O}_{3}, 2.5$ percent $\mathrm{SiO}_{2}$, and 16 percent $\mathrm{Fe}_{2} \mathrm{O}_{3}$ (Bridge and Goldich, 1948, p. i).

Japanese geologists have estimated that 2 million3 million tons of washed bauxite can be recovered from deposits in which the concentrate is 30 percent by weight. The resources would be as much as 5 million tons if the washed concentrate requirement is reduced to 20 percent of the bauxite in the ground. Very tentative estimates place the total potential bauxite resources on Babelthaup at 40 million-50 million tons (Bridge and Goldich, 1948, p. 6-8).

\section{SOLOMON ISLANDS}

Bauxite deposits occur on several islands in the Solomon Islands. Those on Santa Cruz and Vanikero were found shortly after World War II (Owen, 1954, p. 234); larger and better grade deposits have been found on Rennell, New Georgia, and Vaghena (Wagina), and small deposits have been found on Rendova (Michell, 1976, p. 29). Several plans to develop these deposits have been considered, but only bulk samples used for pilot plant tests have been mined.

The bauxite on both Vaghena and Rennell is in terrarossa type soils occurring in tropical rain forests and is overlain only by humus a few meters thick (Chapman and Evans, 1979; Matsunaga, Akiyama, and Fujie, 1978). Thickness of deposits varies considerably, because the bauxite occurs in discontinuous pockets. The pockets fill depressions on the uneven karst surface of uplifted Pleistocene coral limestone. The average pocket deposit on Rennell contains only 5,500 tons of bauxite. The deposits on both islands are extremely fine grained trihydrate type; those on Vaghena are 60 percent $\langle 1 \mu \mathrm{m}$ particles. Goethite is the only iron mineral present, and most of it is aluminous. Organic carbon is present in amounts as much as 0.85 percent; the average $\mathrm{P}_{2} \mathrm{O}_{5}$ content of the deposits on Rennell is 1.7 percent.

The origin of the bauxite on Vaghena and Rennell has been discussed by Weisse (1970), Taylor and Hughes
(1975), Matsunaga, Akiyama, and Fujie (1978), and Chapman and Evans (1979). Weisse (1970) believed that, like the large depostis in Jamaica, the bauxite deposits on Vaghena and Rennell are weathering products of limestone. Taylor and Hughes (1975) cited evidence for a theory that the deposits formed by biogenic degradation of andesitic volcanic ash sediments in a shallowwater lagoonal environment. Matsunaga, Akiyama, and Fujie (1978)d and Chapman and Evans (1978) favored the limestone source rock idea but agreed that some of the aluminum in the bauxite may have originally been in volcanic ash.

Deposits on Rennell contain 25 million tons of bauxite of which 80 percent is considered proved (Matsunaga, Aikyama, and Fujie, 1978), and 30 million tons of bauxite is known to be present on Vaghena (Chapman and Evans, 1978). Typical analyses of the deposits follow:

Typical analyses of bauxite on Rennell and Vaghena, Solomon Islands $[-$, no data. Analyses in percent]

\begin{tabular}{|c|c|c|}
\hline & Rennell & Vaghena \\
\hline $\mathrm{Al}_{2} \mathrm{O}_{3}$ & 48.0 & 47.09 \\
\hline $\mathrm{SiO}_{2}{ }^{3}$ & .2 & 3.04 \\
\hline $\mathrm{Fe}_{2} \mathrm{O}_{3}$ & 18.4 & 16.69 \\
\hline $\mathrm{TiO}_{2}{ }^{3}$ & 2.1 & 1.75 \\
\hline $\mathrm{P}_{2} \mathrm{O}_{5}^{2}$ & 1.7 & 3.35 \\
\hline Total carbon & $0.50-0.95$ & - \\
\hline Organic carbon & $0.38-0.85$ & - \\
\hline Loss on ignition & $29.5-30.1$ & 27.0 \\
\hline Weight loss on heating to $100^{\circ} \mathrm{C}$ & $29.5-32.5$ & - \\
\hline
\end{tabular}

According to the U.S. Bureau of Mines (Peterson and Arbelbide, 1983, table 6) the bauxite reserves in the Solomon Islands are 50.3 million tons. Total bauxite resources in these islands are at least 60 million tons.

\section{OTHER ISLANDS}

Small bauxite deposits have been found on Manus in the Admiralty Islands and the Mussau, Woodlark, and Deboyne (now Panaete) Islands (Ingram, 1973, p. 23; Grainger and Grainger, 1974). Though several areas have been prospected in the Papua half of New Guinea, no bauxite has been found. Hose $(1960, p .246)$ reported an analysis of bauxite from Mare Island, New Caledonia, and Weisse (1976) examined deposits on Ouvea and Lifou, which are in the Iles Loyautés.

Several samples of laterite from Samoa contain 33-38 percent $\mathrm{Al}_{2} \mathrm{O}_{3}$ (Seelye, Grange, and Davis, 1938), but no estimates of the amount of this rock on the island have been made. Bauxitic soils overlie limestone on Guam (Carroll and Hathaway, 1963, p. 39-40), but 
deposits on this island are probably too small to be of value (Tracey and others, 1964, p. 74). Small deposits of bauxite also occur on several islands of the Caroline group other than Palau. Bauxite deposits covering 25 hectares on Witipon and small deposits on Moen in the Truk Islands have been described by Stark and Hay (1963, p. 13). Bauxite also occurs on Ponape and Saipan (Bridge, 1948, p. 224) and on Yap and Kusaie (Watanabe, 1939); deposits on Ponape contain about 300,000 tons of low-grade bauxite (Fischer, in U.S. Bureau of Mines, 1953, p. III-45).

About 600,000 tons of bauxite having an average thickness of $2 \mathrm{~m}$ and containing about 50 percent $\mathrm{Al}_{2} \mathrm{O}_{3}$ has been found in the Lepatuan area on Manus Island (Jaques, 1976, p. 10). Other areas on this island are known to contain low-grade bauxite, but none of these deposits are considered to be of economic importance.

\section{SUMMARY OF BAUXITE RESOURCES IN OCEANIA}

The total bauxite reserves in Oceania are estimated to be 4.5 billion tons (rounded), and the total resources (reserves, subeconomic, and undiscovered bauxite) are thought to be in the 7-billion- to 10-billion-ton range. The reserves are located in Australia- 4.5 billion tonsand the Solomon Islands -60 million tons. The subeconomic resources are also located mainly in Australia; small deposits have been found in Fiji, Palau, and New Zealand. It seems virtually certain that undiscovered bauxite deposits exist in Australia and several of the Pacific Islands. The total bauxite in the subeconomic and undiscovered categories is arbitrarily estimated to be 2.5 billion- 5.5 billion tons.

\section{REFERENCES}

Abbot, A. T., 1958, Occurrence of gibbsite on the island of Kauai, Hawaiian Islands: Economic Geology, v. 53, no. 7, p. 842-853.

Abdullayev, A. U., 1968, The Devonian bauxite of Sredna Azii: Lithology and Mineral Resources, 1967, no. 3, p. 331-339. (English translation of Litologiya i Poleznye Iskopayemye, 1967, no. 3 , p. 70-80.)

Abreu, S. F., 1962, Alumínio, in Abreu, S. F., Recursos minerais do Brasil; Volume II, Combustíveis fosseis e minérios metallicos: Rio de Janeiro, Brazil Institut Nacional de Tecnologia, p. 545-561.

Adams, J. A. S., and Richardson, K. A., 1960, Thorium, uranium and zirconium concentrations in bauxite: Economic Geology, v. 55, no. 8, p. $1653-1675$.

Adler, Isidore, 1966, X-ray emission spectrography in geology: Amsterdam, Elsevier, 258 p.

Afonsos, R. S., and Pinto, M. S., 1977, Contribuição para o conhecimento da bauxitização dos macicos alcanos das areas de melange e morrungala: Republica Popular de Moçambique Serviços de Geologia e Minas Boletím 39, 114 p.

Ahınad, N., and Jones, R. L., 1969, Occurrence of alummous lateritic soils (bauxites) in the Bahamas and Cayman Islands: Economic Geology, v. 64, no. 7, p. 804-808.

Akayemov, S. T., 1975, Litologiya i genezis boksitov Sangaredi (Zapadnaya Afrika) [Lithology and genesis of Sangaredi bauxite, western Africa], in Bushinskiy, G. I., ed., Problemy genezisa boksitov [Problems of bauxite genesis]: Moscow, Izdatel'stvo Nauka, p. 235-246.

Aleva, G. J. J., 1965, The buried bauxite deposit of Onverdacht, Surinam, South America: Géologie en Mijnbouw, v. 44, no. 2, p. $45-58$.

[1971], Some notes on the geology of Adampada-Kabalebo area, western Surinam, in Lee, M. A., ed., Proceedings of the eighth Guiana Geological Conference, Georgetown, Guyana, 11-15 August 1969: Georgetown, Guyana Department of Geology and Mines, p. XI-3/14-XI-13/14.

1975 , The bauxite of the Guiana Shield as a source for refractory grade raw materials: Intercain, v. 24, no. 4, p. 259-261. 1981a, Essential differences between the bauxite deposits along the southern and northern edges of the Guiana Shield, South America: Economic Geology, v. 76, p. 1142-1152.

1982b, Bauxitic and other duricrusts on the Guiana Shield, South America, in International Seminar on Lateritisation Processes, [1st], Trivandrum, India, 1979, Proceedings: Rotterdam, Netherlands, A. A. Balkema, p. 261-269.

1984, Lateritization, bauxitization and cyclic landscape development in the Guiana Shield, in Jacob, Leonard, Jr., ed., Bauxite [Bauxite Symposium, Los Angeles, Cahi., 1984, Proceedings]: New York, American Institute of Mining, Metallurgical, and Petroleum Engineers, p. 297-318.

Aleva, G. J. J., and Hilversum, A. H., 1984, Bauxite in West Surinaine: known deposits and potential, in Jacob, Leonard, Jr., ed., Bauxite [Bauxite Symposium, Los Angeles, Calif., 1984, Proceedings]: New York, American Institute of Mining, Metallurgical, and Petroleum Engineers, p. 319-348.

Aleva, G. J. J., and others, 1969, Some sections through the bauxite belt of the Zanderij-Onverdacht-Lelydorp area, Surinain, in Guiana Geological Conference, 7th, Paraunaribo, November 1966, Proceedings: Nederlands Geologisch Mijnbouwkundig Genootschap Verhandelingen, v. 27, p. 85-88, 4 sheets in pocket.

Allen, A. D., 1971, Montague Sound, Western Australia: Austraka Bureau of Mineral Resources, Geology and Geophysics 1:250,000 Geological Series-Explanatory Notes, Sheet SD/51-12, 16 p.

Allen, S. A., 1949, Bauxite investigations, Eufaula district, Barbour and Henry Counties, Alabama: U.S. Bureau of Mines Report of Investigations $4521,85 \mathrm{p}$.

Allen, V. T., 1948, Formation of bauxite from basaltic rocks of Oregon: Economic Geology, v. 43, no. 8, p. 619-626.

1960, Comparison of bauxite deposits of Europe with those in U.S.A.: International Geological Congress, 21st, Copenhagen, 1960, Report, pt. 16, p. 230-236.

Allen, V. T., and Sherman, G. D., 1965, Genesis of Hawaiian bauxite: Economic Geology, v. 60, no. 1, p. 89-99.

Amelinck, L. A., and Herrero N., José, 1971-72, Posibilidades de producir alumina en la Gran Sabana: Geominas, no. 8, p. 32-35.

American Metal Market, 1969, Alcoa bauxite development promoted growth in Surinam: American Metal Market, v. 76, p. 23, 30.

Anandalwar, M. A., 1962, Bauxite deposits in the Khargpur Hills, Monghyr district, Bihar: Indian Minerals, v. 16, no. 1, p. 30-33.

Anderson, E., 1969, Geophysical survey operations of the Demerara Bauxite Company in connection with the search for bauxite in Guyana: Guyana Geological Survey Record, v. 6, p. VI(1-8). 
Anderson, R. E., 1971, Notes on the geology of the bauxite deposits of Jamaica, in Proceedings of bauxite/alumina symposium, [1st, Kingston, Jamaica], 1971: Geological Society of Jamaica Journal, Special Issue, p. 9-16.

1982, "No silica" occurrences and other mineralogical variations in the bauxites of the Claremont area, St. Ann, Jamaica, in Procedings of bauxite symposium V, Kingston, Jamaica, 1982: Geological Society of Jamaica Journal, Special Issue 7, p. 62-68.

Anderson, R. J., 1936, World resources of aluminum ore: Mining Magazine [London], v. 55, no. 6, p. 329-341.

Andrews, W. H., 1984, Uses and specifications of bauxite, in Jacob, Leonard, Jr., ed., Bauxite [Bauxite Symposium, Los Angeles, Calif., 1984, Proceedings]: New York, American Institute of Mining, Metallurgical and Petroleum Engineers, p. 49-66.

Ankara Maden Tetkik ve Arama Enstitüsü, 1965, Emery, diaspore and bauxite deposits of Turkey: Ankara, Maden Tetkik ve Arama Enstitüsü Yayinlarindan Publication 122, 21 p.

1966, Türkiye'nin baslica alüminyum cevherleri: Ankara, Maden Tetkik ve Arama Enstitüsü Yayinlarindan Veröffentlichungen $130,68 \mathrm{p}$.

1977, M.T.A. Enstitüsünce bilmen Türkiye yeralti kaynaklari envanteri [Inventory of subsurface deposits known by M.T.A. Institute]: Ankara, Maden Tetkik ve Arama Enstitüsü Yayinlarindan Veröffentlichungen 168,390 p.

Annales des Mines, 1955, Les gisements de bauxite des montagnes de Kaw en Guyane française: Annales des Mines [Paris], v. 144 no. 10, p. $3-13$.

1958, Bauxite et aluminum, in Rapport de la Commission des Mines et des Métaux Non Ferreux: Annales des Mines [Paris], v. 147 , no. 10 , p. $686-692$.

Apaydin, Nihat, and Erscen, Necdet, 1981, [Known ore and mineral resources of Turkey]: Ankara, Maden Tetkik ve Arama Enstitüsü Yayinlarindan $185,67 \mathrm{p}$.

Arnaud, G., 1945, Les ressources minières de l'Afrique occidentale: [French West Africa] Direction des Mines Bulletin 8, $100 \mathrm{p}$

Aronis, G. A., 1953, [The bauxites of the Eleusis-Mandra area]: Mineral Wealth of Greece, v. 3, p. 171-200. [In Greek; English summary.]

1955, [Reconnaissance study of the bauxitic deposits of the south Parnassus-Hélikon area]: Greece Hypēresia Ereunōn Hypedaphous Geōlogikai Anagnōriseis Ekthesis Report 25, 42 p. [In Greek.]

Ashraf, Mohammad, Ahmad, Mushtaq, and Faruqi, F. A., 1976, Jurassic bauxite and kaolinite deposits of Chhoi area, Kāla Chitta Range, Punjab, Pakistan: Punjab University [Lahore, Pakistan] Geological Bulletin 12, p. 41-54.

Ashraf, Muhammad, Chohan, N. A., and Faruqi, F. A., 1972, Bauxite and clay deposits in the Kattha area, Salt Range, Punjab, West Pakistan: Economic Geology, v. 67, no. 1, p. 103-110.

Assad, Roberto, 1973, Depósitos de bauxita da região Paragominas (PA) [abs.]; in Congresso Brasileiro de Geologia, 27th, Aracaju, Brazil, 1973, Resumo das Comunicaçðes, Sessoes Téchnicas: Sociadade Brasileira de Geologia, Núcleo da Bahia, Boletim 1, p. 24-26.

Assad, Roberto, and Machado, J. E., 1976, Bauxite in the Amazon sedimentary basin [abs.]: International Geological Congress, 25th, Sydney, 1976, Abstracts, v. 1, p. 205.

Atabey, M. E., 1976, Mineralogy, chemistry and origin of the Mortas bauxite deposit, Seydisehir, Konya, Turkey: Comite International pour l'Etude des Bauxites de l'Alumine et de l'Aluminium Travaux, no. 13, p. 77-89. [Also published in Türkiye Jeoloji Kurumu Bulteni, v. 19, no. 1, p. 9-14, 1976, in Turkish with English abstract.]

Australia Bureau of Mineral Resources, Geology and Geophysics, Mineral Economics Section, 1978, Australian mineral resources,
1977: Australian Mineral Industry Quarterly Review, v. 30 , no. 4 , p. 175-182.

1983, Australian identified mineral resources, 1981: Australian Mineral Industry Quarterly, v. 34, no. 4, p. 151-155. Australian Mineral Economics Pty., 1981, Aluminium industry of the world: Sidney, New South Wales, Australia, 2 v.; v. 1, 410 p.; v. $2,349 \mathrm{p}$.

Badoux, Héli, and Weisse, J. G. de, 1959, Les bauxites siliceuses de Dreveneuse (Préalpes valaisannes): Société Vaudoise des Sciences Naturelles Bulletin, v. 67, pt. 4, no. 300, p. 169-177. [Also published in Lausanne Université, Laboratoires de Géologie Bulletin 126, 1959.]

Baker, G. F. U., 1972, Origin of Darling Range bauxites, Western Australia [discussion]: Economic Geology, v. 67, no. 7, p. 981. 1975, Darling Range bauxite deposits, W.A., in Knight, C. L., ed., Metals, v. 1 of Economic geology of Australia and Papua New Guinea: Australasian Institute of Mining and Metallurgy Monograph Series 5, p. 980-986.

Balasubramaniam, K. S., and Paropkari, A. L., 1975, Mineralogy and genesis of bauxites of Nagardaswadi Plateau, Kolhapur district, Maharashtra State (India): Canadian Mineralogist, v. 13, pt. 3, p. 222-226.

Balazs, E. T., 1984, Research and development in developing countries-assistance of UNIDO, in Jacob, Leonard, Jr., ed., Bauxite [Bauxite Symposium, Los Angeles, Calif., 1984, Proceedings]: New York, American Institute of Mining, Metallurgical and Petroleum Engineers, p. 912-918.

Balcet, R., 1966, Notes sur les bauxites de la région de Manantenina (sud-est de Madagascar): Madagascar Semaine Géologique Comptes Rendus, 1965, p. 121.

Balkay, Bálint, and Bárdossy, György, 1967, Lateritesedési részfolyamat-vizsgalatok Guinea latériteken: Földtani Közlöny, v. 97 , no. 1 , p. $91-110$.

Banerjee, P. K., 1975, A reconnaissance survey of the distribution of some trace elements in Indian bauxite: Mineralium Deposita, v. 10 , no. 2 , p. $177-188$.

Banks, F. E., 1979, Bauxite and aluminum-An introduction to the economics of nonfuel minerals: Lexington, Mass., Lexington Books, 189 p.

Baptista Gómes, José, 1973, Evaluacion de las lateritas aluminosas de la Serrania de los Guaicas: Geominas, no. 9, p. 59-63.

Bárdossy, György, 1958a, The geochemistry of Hungarian bauxites; Part I: Acta Geologica (Academiae Scientiarum Hungaricae), v. 5, no. 2, p. 103-155. [German and Russian summaries.]

$1958 \mathrm{~b}$. The geochemistry of Hungarian bauxites; Part II, The variation of the main elements of bauxite: Acta Geologica (Academiae Scientiarum Hungaricae), v. 5, nos. 3-4, p. 255-285. [German and Russian summaries.]

1959, The geochemistry of Hungarian bauxites; Parts III and IV: Acta Geologica (Academiae Scientiarum Hungaricae), v. 6, nos. 1-2, p. 1-53. [German and Russian summaries.]

1964, Die Entwicklung der Bauxitgeologie seit 1950, in International Committee for Studies of Bauxites, Oxides and Hydroxides of Aluminium, [ICSOBA International Symposium, 1st, Zagreb, 1963, Proceedings]: Zagreb, Yugoslavia, Académie Yougoslave des Sciences et des Arts, v. 1, p. 31-50.

ed., 1970, Conference on bauxite geology, Budapest, 1969: [Hungary] Földtani Intézet Evkönyve, v. 54, no. 3, 484 p.

1971, Bauxite deposits of Hungary, in International Committee for Studies of Bauxites, Oxides and Hydroxides of Aluminium, Bauxite-alumina-aluminium [ICSOBA International Symposium, 2d, Budapest, 1969, Proceedings]: Budapest, Hungary Research Institute for Non-Ferrous Metals, v. 2, p. 9-20. 
1973, Bauxite formation and plate tectonics: Acta Geologica (Academiae Scientiarum Hungaricae), v. 17, nos. 1-3, p. 141-154. [1975], The complex methods developed in Hungary for the mimeralogical, petrological and geochemical evaluation of bauxites: Budapest, Femipari Kutato Intézet, p. 27-42. [Reprint with cover title "Mineralogical and technological evaluation of bauxites."]

1977, Karsztbauxitok (bauxittelepek karbonátos közetekben) [Karst bauxites (bauxite deposits on carbonate rocks)]: Budapest, Akadémiai Kiado, 413 p.

1979, Growing significance of bauxites: Episodes, 1979, no. 2, p. 22-25.

1981, Paleoenvironinents of laterites and lateritic bauxitesEffect of global tectonism on bauxite formation, in International Seminar of Lateritisation Processes, 1st, Trivandrum, India, 1979, Proceedings: Rotterdam, Netherlands, A. A. Balkema, p. 287-294.

1982, Karst bauxites; Bauxite deposits of carbonate rocks: Amsterdam, Elsevier, 441 p. [Expanded English version of Bárdossy, 1977.]

Bárdossy, György, Csanády, A., and Csordás, A., 1978, Scanning electron microscope study of bauxites of different ages and origins: Clays and Clay Minerals, v. 26, no. 4, p. 245-262.

Bárdossy, György, and Fontboté, J. M., 1977, Observations on the age and origin of the reported bauxite at Portilla de Luna, Spain: Economic Geology, v. 72, no. 7, p. 1355-1358.

Bárdossy, György, and Mack, Erwin, 1967, Zur Kenntnis der Bauxite des Parnass-Kiona-Gebirges: Mineralium Deposita, v. 2, no. 4, p. 334-348.

Bárdossy, György, and Nicolas, J., 1973, Proposition pour une terminologie des bauxites: Comité International pour l'Etude des Bauxites, des Oxydes et des Hydroxydes d'Aluminium Travaux, no. 9 , p. 99-104.

Bárdossy, György, and others, 1972, Le métamorphisme de contact de la bauxite de Bedarieux et quelques aspects géneraux du métamorphisme des bauxites [Contact metamorphism of the Bedarieux bauxite and some general aspects of bauxite metamorphism]: Société Géologique de France Bulletin, v. 12, no. 5, p. 856-869.

1977a, Bauxites of peninsular Italy-Composition, origin and geotectonic significance: [Gebrüder Borntraeger] Monograph Series on Mineral Deposits, no. 15, 61 p.

$1977 \mathrm{~b}$, Interrelations of bauxite texture, micromorphology, mineral individualism, and heteromorphism: Economic Geology, v. 72 , no. 4 , p. $573-581$.

1980, Automated quantitative phase analysis of bauxites: American Mineralogist, v. 65, nos. 1-2, p. 135-141.

Bárdossy, György, and Pantó, György, 1971, Investigation of bauxites with the help of electron-probe: Tschermaks Mineralogische und Petrographische Mitteilungen, v. 15, no. 3, p. 165-184.

1973, Trace mineral and element investigation in bauxites by electron-probe, in International Committee for Studies of Bauxites, Oxides and Hydroxides of Aluminium, [ICSOBA International Symposium, 3d, Nice, France, 1973, Proceedings]: Paris, Sedal, p. 47-53.

Bárdossy, György, Vassel, K. R., and Arkossy, K., [1975], Quantitative phase analysis and texture of typical Hungarian and Soviet bauxite samples: Budapest, Femipari Kutato Intézet, p. 43-141. [Reprint with cover title "Mineralogical and technological evaluation of bauxites."]

Barnabás, K., 1970, Die vergleichende Untersuchung der charakteristischen Bauxitlagerstätten des Mittelgebirges von Dunantul [Typical bauxite deposits of the Dunantul hill region-A comparative investigation], in Bárdossy, György, ed., Conference on bauxite geology, Budapest, 1969: [Hungary] Földtani Intézet Evkönyve, v. 54, no. 3, p. 69-93.

Bass, J. B., 1958, Boksity yuga Ukrainy $i$ ikh genezis [Bauxites of $S$. Ukraine and their genesis], in Strakhov, N. M., and Bushinskiy, G. I., eds., Boksity, ikh mineralogiya i genezis [Bauxites, their mineralogy and genesis]: Moscow, Akademiya Nauk SSSR, Otdelenie Geologo-Geograficheskikh Nauk, p. 351-354. [Reviewed by Zans, V. A., in Economic Geology, v. 54, no. 5, p. 963, 1959.]

Bateson, J. H., 1961, Preliminary report on the ferruginous bauxites of the Pakaraima Mountains: British Guiana Geological Survey Mineral Resources Pamphlet 10, 29 p.

Bauer, Max, 1898, Beiträge zur Geologie der Seyschellen, insbesonderen zur Kenntnis des Laterits: Neues Jahrbuch für Mineralogie, Geologie und Paläontologie, 1898, v. 2, p. 163-219.

Baumgardner, L. H., and McCawley, F. X., 1983, Aluminum: U.S. Bureau of Mines Mineral Commodity Profiles, 1983, $20 \mathrm{p}$.

Beck, W. A., 1949, Investigation of the Springvale bauxite district, Randolph County, Georgia: U.S. Bureau of Mines Report of Investigations $4555,20 \mathrm{p}$.

Behre, C. H., Jr., 1932, Origin of bauxite deposits: Economic Geology, v. 27 , no. 7 , p. $678-680$.

Belinga, S. E., 1968, Etude pétrographique des bauxites du Ngaoundal et de Minim-Martap dans l'Adamaoua (Cameroun) [Petrographic studies of the bauxites of Ngaoundal and MinimMartap in Adamaoua, Cameroon]: Cameroun Université Fédérale, Faculté des Sciences Annales, no. 1, p. 55-68. [English summary.]

1969. Composition minéralogique des bauxites de l'Adamaoua (Cameroun) [Mineralogic composition of the Adamaoua bauxites, Cameroon]: Cameroun Université Fédérale, Faculté des Sciences Annales, no. 2, p. 59-76.

1970, Découverte de formations bauxitiques dans le massif du Ngaoundourou, dans l'Adamaoua, au Cameroun [Discovery of bauxitic formations in the Ngaoundourou Massif in Adamaoua, Cameroon]: Cameroun Université Fédérale, Faculté des Sciences Annales, no. 4, p. 3-9.

1972, L'altération des roches basaltiques et le processus de bauxitization dans l'Adamaoua (Cameroun) [Alteration of basaltic rocks and the processes of bauxitization in Adamaoua, Cameroon]: Paris Université, Doctoral dissertation, 571 p.

1973, Nature sédimentaire et autochtone des bauxites de l'Adamaoua, au Cameroun [Sedimentary nature and autochthony of the bauxites of Adamaoua, Cameroon], in International Committee for Studies of Bauxites, Oxides and Hydroxides of Aluminium, [ICSOBA International Symposium, 3d, Nice, France, 1973, Proceedings]: Paris, Sedal, p. 209-213.

Bell, Geoffrey, [1961], Notes on the bauxite deposits of the Mirboo North district, South Gippsland: Mining and Geological Journal [Australia], v. 6, no. 4 (1960-61), p. 51-62.

Beminelen, R. W. van, 1940, Bauxiet in Nederlandsch-Indie: Nederlandsch-Indie Dienst van den Mijnbouw, Verslagen en Mededeelingen betreffende Indische Delfstoffen en Hare Toepassingen (Batavia), no. 23, 115 p.

1941, Origm and mining of bauxite in Netherlands-India: Economic Geology, v. 36, no. 6, p. 630-640.

Beneslavsky, S. J., 1959, Chemical and mineralogical composition of bauxites and some problems concerning the genesis of their minerals: Acta Geologica (Academiae Scientiarum Hungaricae), v. 6, nos. 1-2, p. 55-64. [German and Russian suminaries.]

1970, The need to search for all genetic types of bauxites: Soviet Journal of Non-Ferrous Metals, 1970, no. 8, p. 35-39. (English translation of Tsvetnye Metally, 1970, no. 8.)

Besairie, Henri, 1960, Madagascar carte minière: Madagascar Service Géologique. 
1962, Contribution à l'étude des bauxites du Sud-Est de Madagascar: Malagasy Republic Service Géologique Rapport Annuel, 1962, p. 153-163.

1964, Bauxite, in Besairie, Henri, Gites minéraux de Madagascar (premier volume): Malagasy Republic Bureau Géologique Documentation 167a, p. 45-81.

Bharat Aluminium Company, 1977, East Coast bauxite: Faribad, India, Thompson Press, 16 sheets.

Bhattacharyya, B. N., 1971, Studies in the recovery of vanadium from indigenous sources including bauxite sludge: Mines and Minerals [India], v. 7, no. 4 (1970), p. 119-125.

Bielfeldt, Klaus, Lotze, Jürgen, and Winkhaus, Günter, 1978, TonEin Aluminiumrohstoff?: Erzmetall, v. 31, no. 3, p. 105-110. [English summary.]

Biscaye, P. E., 1965, Mineralogy and sedimentation of Recent deepsea clay in the Atlantic Ocean and adjacent seas and oceans: Geological Society of America Bulletin, v. 76, no. 7, p. 803-832.

Bisset, C. B., [1943], Aluminium ore, Kaweri Island, Lake Kyoga, in Annual report of the Geological Survey Department for the year ended 31st December, 1942: Entebbe, Uganda Geological Survey Department, p. 18.

Black, R. H., 1953, Analysis of bauxite exploration samples-An Xray diffraction method: Analytical Chemistry, v. 25, no. 5, p. 743-748.

Black, R. Y., 1982, Az Zabirah bauxite project phase 1 and phase 2 evaluation: Saudi Arabia Minister of Petroleum and Mineral Resources Open-File Report RF-OF-02-6, 80 p.

Black, R. Y., Lozej, G.P., and Maddah, S. S., 1984, Geology and mineralogy of the Zabirah bauxite, northern Saudi Arabia, in Jacob, Leonard, Jr., ed., Bauxite [Bauxite Symposium, Los Angeles, Calif., 1984, Proceedings]: New York, American Institute of Mining, Metallurgical and Petroleum Engineers, p. 619-638.

Blackwood, A., Greenway, R. J., Lancashire, R. J., Magnuske, K. E., Douglas, C. G. C., and Nugent, L. C. A., 1982, Gallium levels of Jamaica bauxites, in Proceedings of bauxite symposium $\mathrm{V}$, Kingston, Jamaica, 1982: Geological Society of Jamaica Journal, Special Issue 7, p. 77-82.

Blake, H. E., and others, 1967, Adaptation of the Pederson process to the ferruginous bauxites of the Pacific Northwest: U.S. Bureau of Mines Report of Investigations 6939, 21 p.

Bleackley, D., 1961, Status of investigations into the bauxite deposits of British Guiana: Inter-Guiana Geological Conference, 5th, Georgetown, British Guiana, 1959, Proceedings, p. 213-227. 1964, Bauxites and laterites of British Guiana: British Guiana Geological Survey Bulletin 34, 156 p.

Blumenreich, Sidney, 1975, Aluminum-From shortage to surplus in '74, reversing the pattern of '73: Engineering and Mining Journal, v. 176 , no. 3 , p. $92-96$.

Bohor, B. F., and Lahodny-Sarc, O., 1971, Scanning electron microscope study of white bauxite and allophane: Comité International pour l'Etude des Bauxites, des Oxydes and des Hydroxydes de l'Aluminium Travaux, no. 7, p. 1-8.

Bolger, R. C., and Weitz, J. H., 1952, Mineralogy and origin of the Mercer fireclay of north-central Pennsylvania, in American Institute of Mining and Metallurgical Engineers, Problems of clay and laterite genesis-Symposium, St. Louis, Mo., 1951: New York, p. 81-93.

Bonifas, Marthe, 1959, Contribution à l'étude géochimique de l'altération latéritique: Alsace-Lorraine Service de la Carte Géologique Mémoire 17, 159 p. [English summary.]

Bosma, W., Ho Len Fat, A. G., and Welter, C. C., 1973, Minerals and mining in Suriname, in Contributions to the geology of Suriname 3: Surinam Geologisch Mijnbouwkundige Dienst Mededeling 22, p. 71-101, map at scale 1:1,000,000.
Boudrot, J., 1975, Mise en valeur des gisements souterrains de bauxite dans l'Hérault, une exploitation difficile-La Rouquette: Industrie Minérale, Mine, no. 5-75, p. 441-445.

Brabers, A. J. M., 1974, Sources of aluminium in the Republic of South Africa: South Africa Geological Survey Bulletin 59, 89 p.

Bracewell, Smith, 1962, Bauxite, alumina and aluminium: [London], Great Britaim Overseas Geological Surveys, Mineral Resources Division, 235 p.

Bracewell, Smith, and Healing, R. A., 1963, The non-metallic uses of bauxite, in Symposium on Industrial Rocks and Minerals, Lahore, Pakistan, 1962: [Ankara, Turkey] Central Treaty Organization, p. 413-417.

Bramkamp, R. A., and Ramirez, L. F., 1963, Geologic map of the Darb Zubaydah quadrangle, Kingdom of Saudi Arabia: U.S. Geological Survey Miscellaneous Geologic Investigations Map I-202-A, scale 1:500,000.

Bramkamp, R. A., Ramirez, L. F., Brown, G. F., and Pocock, A. E., 1963, Geologic map of the Wadi Ar Rimah quadrangle, Kingdom of Saudi Arabia: U.S. Geological Survey Miscellaneous Geologic Investigations Map I-206-A, scale 1:500,000.

Brazil Departamento Nacional da Produção Mineral, 1973, Anuário mineral brasileiro 1973: Brazil Departamento Nacional da Produção Mineral Anuário Mineral Brasileiro, [v. 2], 329 p.

1975a, Anuário mineral brasileiro 1975: Brazil Departamento Nacional da Produção Mineral Anuário Mineral Brasileiro, v. 4, $323 \mathrm{p}$.

1975b, Avaliação regional do setor mineral-Pará: Brazil Departamento Nacional da Produção Mineral Boletim 36, 165 p.

1978, Anuário mineral brasileiro 1978: Brazil Departamento Nacional da Produção Mineral Anuário Mineral Brasileiro, v. 7, $318 \mathrm{p}$.

1982, Anuário mineral brasileiro 1982: Brazil Departamento Nacional da Produção Mineral Anuário Mineral Brasileiro, v. $11,372 \mathrm{p}$.

Bredell, J. H., 1983, Calculation of available alumina in bauxite during reconnaissance exploration: Economic Geology, v. 78, no. 2, p. $319-325$.

Bridge, Josiah, 1948, On the occurrence of bauxite on Truk: Pacific Science, v. 2, no. 3, p. 223-224.

1950, Bauxite deposits of the southeastern United States; in Snyder, F. G., ed., Symposium on mineral resources of the southeastern United States: Knoxville, Tennessee University Press, p. 170-201.

Bridge, Josiah, and Goldich, S. S., 1948, Preliminary report on the bauxite deposits of Babelthaup Island, Palau Group: U.S. Far East Command GHQ Tokyo, Office of Engineer Report, 46 p. [Abstract in Geological Society of America Bulletin, v. 59, no. 12 , pt. 2 , p. 1313,1948 .]

Briggs, R. P., 1960, Laterization in east-central Puerto Rico: Caribbean Geological Conference, 2d, Mayaguez, Puerto Rico, 1959, Transactions, p. 103-119.

Brindley, G. W., 1961, Kaolin, serpentine, and kindred minerals, in Brown, George, ed., The X-ray identification and crystal structures of clay minerals (2d ed.): London, Mineralogical Society, Clay Minerals Group, p. 51-131.

Brindley, G. W., and Sutton, W. H., 1957, An X-ray mineralogical study of some British Guiana bauxite deposits: Economic Geology, v. 52, no. 4, p. 391-399.

Bruckner, W. D., 1957, Laterite and bauxite profiles of West Africa as an index of rhythmical cliniatic variations in the tropical belt: Eclogae Geologicae Helvetiae, v. 50, no. 2, p. 239-256.

Brucy, J., 1973, Environnement et mines-Le problème des Baux: Annales des Mines [Paris], 1973, no. 3, p. 9-14. [English summary on p. 1 of this issue.] 
Buguelskiy, Y. Y., and Formell Cortina, F., 1974, Sobre la existencia de cortezas de intemperismo bauxiticas en Cuba [The existence of bauxite weathering crusts in Cuba]: Academia de Ciencias de Cuba, Instituto de Geología y Paleontologia Publicación Especial, no. 3 , p. $82-91$.

Burns, D. J., 1961, Some chemical aspects of bauxite genesis in Jamaica: Economic Geology, v. 56, no. 7, p. 1297-1303.

Burst, J. F., 1974, Genetic relationship of the Andersonville, Georgia, and Eufaula, Alabama, bauxitic kaolin areas: American Institute of Mining, Metallurgical and Petroleum Engineers Transactions, v. 256 , p. $137-143$.

Buser, Stanko, and Lukács, Egon, 1970, Bauxite in Slowenien [Bauxite in Slovenia], in Bárdossy, György, ed., Conference on bauxite geology, Budapest, 1969: [Hungary] Földtani Intézet Evkönyve, v. 54, no. 3, p. 209-220. [In German.]

Bushinskiy, G. I., 1967, Kak reshalas' problema boksitov v SSSR [The solution to the bauxite problem in the Soviet Union]: Geologiya Rudnykh Mestorozhdeniy, v. 9, no. 6, p. 3-15. [Reviewed by Alexandrov, E. A., Economic Geology, v. 64, no. 6, p. 705, 1969.]

1971, Geologiya boksitov [Geology of bauxite]: Moscow, Izdatel'stvo Nedra, 366 p.

1975, Geologiya boksitov [Geology of bauxite] (2d ed.): Moscow, Izdatel'stvo Nedra, 416 p.

Butcher, Gerry, 1982, Aluminium-The international perspective: London, Financial Times Business Information, $180 \mathrm{p}$.

Butty, D. L., and Chapallaz, C. A., 1984, Bauxite genesis, in Jacob, Leonard, Jr., ed., Bauxite [Bauxite Symposium, Los Angeles, Calif., 1984, Proceedings]: New York, American Institute of Mining, Metallurgical and Petroleum Engineers, p. 111-151.

Cabellero, A., Menendez del Valle, F., and Martin Vivaldi, J. L., 1974, Yacimientos españoles de bauxitas y alunitas [Spanish deposits of bauxite and alunite]: [Spain] Instituto Geologico y Minero Boletín Geologico y Minero, v. 85, no. 1, p. 32-42.

Caillère, Simonne, Hénin, S., and Pobeguin, T., 1962, Présence d'un nouveau type de chlorite dans les "bauxites" de Saint-Paul-deFenouillet (Pyrénées-Orientales): Académie des Sciences [Paris] Comptes Rendus, v. 254, no. 9, p. 1657-1658.

Caillère, Simonne, Maksimović, Z., and Pobeguin, T., 1976, Les éléments en traces dans quelques bauxites karstiques de l'Ariège et du Var: Comité International pour l'Etude des Bauxites, d'Alumine et d'Aluminium Travaux, no. 13, p. 233-252.

Caillère, Simonne, and Pobeguin, T., 1961, Sur les minéraux ferrifères des bauxites: Académie des Sciences [Paris] Comptes Rendus, v. 253 , no. 2 , p. $288-290$.

1962, Boehmite et diaspore ferrifères dans une bauxite de Péreille (Ariège): Académie des Sciences [Paris] Comptes Rendus, v. 254 , no. 1 , p. $137-139$.

1965, Considérations générals sur la composition minéralogique et la genèse des bauxites du midi de la France: Muséum National d'Histoire Naturelle [Paris] Mémoires, ser. C, v. 12 , no. 4,212 p.

Caillère, Simonne, and Singh, Ashok, 1967, Contribution à l'étude des bauxites de la province de Jammu au Kashmir (Cachemire): Académie des Sciences [Paris] Comptes Rendus, ser. D, v. 264, no. 18 , p. $2177-2180$.

Calhoun, W. A., 1950, Titanium and iron minerals from black sands in bauxite: U.S. Bureau of Mines Report of Investigations 4621, $16 \mathrm{p}$.

Calhoun, W. A., and Hill, T. E., Jr., 1962, Metallurgical testing of Hawaiian ferruginous bauxites: U.S. Bureau of Mines Report of Investigations $6003,43 \mathrm{p}$.

Canadian Mining Journal, 1973, CMJ and the Canadian Minerals and Metals Mission to China: Canadian Mining Journal, v. 94, no. 1, p. 19-31.
Candiales, L. J., 1961, Descubrimiento y exploración de bauxita en Venezuela, in Congreso Geológico Venezolano, 3rd, Memoria: Venezuela Dirección de Geología Publicación Especial 3, v. 4, p. $1661-1680$.

Caribbean Geological Conference, 1980, Field guide: Caribbean Geological Conference, 9th, Santo Domingo, Dominican Republic, 1980 , p. 33-38.

Carniglia, S. C., 1977, Specialty aluminas-Production and application: American Institute of Mining, Metallurgical and Petroleum Engineers, Society of Mining Engineers, annual meeting, Atlanta, 1977, release, $39 \mathrm{p}$.

Carroll, Dorothy, and Hathaway, J. C., 1963, Mineralogy of selected soils from Guam: U.S. Geological Survey Professional Paper 403-F, $53 \mathrm{p}$.

Casimiro, E. S., and d'Avila, V. V., 1975, Avaliação das reservas e da qualidade dos depósitos de bauxita do munićpio de Lages, SC: Rio de Janeiro, Brazil Ministerio do Interior, Superintendéncia do Desenvolvimento da Região Sul, 67 p.

Castaldo, G., and Stanipanoni, G., coordinators, 1975, Memoria illustrativa della carta mineraria d'Italia; scala 1.000.000 [I]lustrative memoir of the mining map of Italy; scale 1,000,000]: Italy Servizio Geologico Memorie per Servire alla Descrizione della Carta Geologica d'Italia, v. 14, 213 p.

Cathcart, J. B., 1971, Phosphate investigations in Colombia, 1969-A progress report, with a note on the aluminous laterite deposits of the Department of Cauca: U.S. Geological Survey Open-File Report, 44 p.

Ceccarini, C., Oggiano, G., and Salvadori, I., 1984, Nurra (Sardinia, Italy) bauxite deposit, in Jacob, Leonard, Jr., ed., Bauxite [Bauxite Symposium, Los Angeles, Calif., 1984, Proceedings]: New York, American Institute of Mining, Metallurgical and Petroleum Engineers, p. 525-538.

Chaniber of Mines Journal, 1976, Vast new bauxite discovery: Chamber of Mines Journal [South Africa], v. 18, no. 8, p. 46.

Chapman, J. H., and Evans, H. J., 1979, Wagina Island bauxiteExploration and mining assessment, in Jones, M. J., ed., Proceedings of the 11th Commonwealth Mining and Metallurgical Congress, Hong Kong, 1978: London, Institution of Mining and Metallurgy, p. 441-447.

Charbonneaux, J., 1974, The bauxites of Guinea: Industries et Travaux d'Outre Mer [Paris], June 1974, p. 565-570.

Chebotarev, M. V., and Buy Fu Miy, 1961, Severo-V'etnamskiy boksitonosnyy rayon [The North Vietnam bauxite-bearing region]: Sovetskaya Geologiya, 1961, no. 6, p. 79-88.

Cheilletz, Alain, Le Mailloux, Y., and Samama, J. C., 1973, Inventaire et carte des gites minéraux d'Haiti [Inventory and map of mineral deposits of Haiti]: Sciences de la Terre, v. 18, no. 4, p. 381-407. [English summary.]

Chemical Age, 1956, Israeli chemicals: Chemical Age, v. 76, no. 1953, p. 449.

Choubert, Boris, 1962, Feuille de la Baie de l'Oyapock et de Pointe Behague et notice explicative: Orléans, France, Service de la Carte Géologique, 15 p.

Chowdhury, A. N., Chakraborty, S. C., and Bose, B. B., 1965, Geochemistry of gallium in bauxite from India: Economic Geology, v. 60, no. 5, p. 1052-1058.

Chubb, L. J., 1963, Bauxite genesis in Jamaica: Economic Geology, v. 58 , no. 2 , p. $286-289$.

Clarke, O. M., Jr., 1966, The formation of bauxite on karst topography in Eufaula district, Alabama and Jamaica, West Indies: Economic Geology, v. 61, no. 5, p. 903-916.

1972, Bauxite and kaolin in the Eufaula bauxite district, Alabama: Alabama Geological Survey Bulletin 100, 90 p. 
Closas Miralles, J., 1954, Las bauxitas del N.E. de España: International Geological Congress, 19th, Algiers, 1952, Comptes Rendus, no. 12 , p. 199-223.

Cloud, P. E., Jr., 1966, Bauxite deposits of the Anniston, Fort Payne, and Ashville areas, northeast Alabama: U.S. Geological Survey Bulletin 1199-0, 35 p.

1967, Geology and bauxite deposits of the Rock Run and Goshen Valley areas, northeast Alabama: U.S. Geological Survey Bulletin 1199-N, $74 \mathrm{p}$.

Cofer, H. E., Jr., Wright, N. A., and Carey, M. A., 1976, Preliminary report on the kaolin and bauxite deposits of the Andersonville district, Georgia: U.S. Geological Survey Open-File Report 76-682, 23 p.

Coghill, Ian, 1972, Australia's mineral wealth: Melbourne, Sorrett Publishing Company, 208 p.

Colin, L. L., 1942, Bauxite in the Moçambique Territory: South African Mining and Engineering Journal, v. 53, pt. 2, no. 2602, p. 329-332.

Collenette, P., 1961, North Borneo mineral resources; in Fitch, F. H., British territories in Borneo: Borneo, British Territory, Geological Survey Department, Annual Report, p. 68.

Colley, Howard, 1976, Mineral deposits of Fiji (metallic deposits): Suva, Fiji Mineral Resources Division, p. 97-103.

Combes, P.-J., 1970a, Recherches sur la genèse des bauxites dans le Nord-Est de l'Espagne, le Languedoc et l'Ariège (France) [Studies of the genesis of bauxites in northeast Spain and in Languedoc and Ariège, France]: Montpellier Université, Centre d'Etudes et de Recherches Géologiques et Hydrogéologiques Mémoires, v. 3-4 (1969), $342 \mathrm{p}$.

$1970 \mathrm{~b}$, Observations et interpretations nouvelles sur les bauxites du Nord-Est de l'Espagne (stratigraphie, paléogéographie, genèse) [Recent observations and interpretations of bauxites from northestern Spain (Stratigraphy, paleogeography, genesis)], in Bárdossy, György, ed., Conference on bauxite geology, Budapest, 1969: [Hungary] Földtani Intézet Evkönyve, v. 54, no. 3 , p. 265-279.

Combes, P.-J., and others, 1974, Low-grade bauxites and clay deposits in southern France-Different deposit types and mining conditions: Comité International pour l'Etude des Bauxites, des Oxydes et des Hydroxydes d'Aluminium Travaux, no. 12, p. 11-23.

Comer, J. B., 1974, Genesis of Jamaican bauxite: Economic Geology, v. 69 , no. 8 , p. $1251-1264$.

1984, Geological and geochemical constraints on the origin of bauxite in Jamaica, in Jacob, Leonard, Jr., ed., Bauxite [Bauxite Symposium, Los Angeles, Calif., 1984, Proceedings]: New York, American Institute of Mining, Metallurgical and Petroleum Engineers, p. 152-164.

Conant, L. C., 1965, Bauxite and kaolin deposits of Mississippi, exclusive of the Tippah-Benton district: U.S. Geological Survey Bulletin 1199-B, 70 p.

Conley, J. E., and others, 1947, Production of metallurgical alumina from Pennsylvania nodular diaspore clays: U.S. Bureau of Mines Bulletin 465, $193 \mathrm{p}$.

Cooper, W. G. G., 1936, The bauxite deposits of the Gold Coast: Gold Coast Geological Survey Bulletin 7, 34 p.

1957. The geology and mineral resources of Nyasaland (rev. ed.): Nyasaland Geological Survey Bulletin 6, 43 p.

Corcoran, R. E., and Libbey, F. W., 1956, Ferruginous bauxite deposits in the Salem Hills, Marion County, Oregon: Oregon Department of Geology and Mineral Industries Bulletin 46, $53 \mathrm{p}$.

Cornish, J. K., [1978], The bauxite/alumina/aluminiun industry in 1977 and forecasts for 1978: IBA Quarterly Review, v. 3, no. 3, p. $30-44$.

Corrick, J. D., 1974, The mineral industry of Spain: U.S. Bureau of Mines Minerals Yearbook, 1972, v. 3, p. 731-751.
Coumoulos, G. D., 1984, Processing diasporic bauxites-The Greek case, in Jacob, Leonard, Jr., ed., Bauxite [Bauxite Symposium, Los Angeles, Calif., 1984, Proceedings]: New York, American Institute of Mining, Metallurgical and Petroleum Engineers, p. 747-774.

Crescenti, Uberto, 1970, Stratigraphic position of the bauxites in the central-southern Italy, in Bárdossy, György, ed., Conference on bauxite geology, Budapest, 1969: [Hungary] Földtani Intézet Evkönyve, v. 54, no. 3, p. 235-239.

Crescenti, Uberto, and Vighi, Luciano, 1964, Caratteristiche, genesi e stratigrafia dei depositi bauxitiei cretacici del Gargano e delle Murge; cenni sulle argille con pisoliti bauxitiche del Salento (Puglie) [Characteristics, genesis and stratigraphy of the Cretaceous bauxite deposits of Gargano and Murge; clay with bauxitic pisolites from Salento (Puglie)]: Societa Geologica Italiana Bollettino, v. 83, p. 285-350.

Crittenden, S. J., 1983, Sintered bauxite proppants for deep oil and gas well simulation: American Institute of Mining, Metallurgical and Petroleum Engineers, Society of Mining Engineers Preprint 83-132, $4 \mathrm{p}$.

Crockett, R. N., compiler, 1978, Bauxite, alumina and aluminium: [Great Britain] Institute of Geological Sciences, Mineral Resources Consultative Committee, Mineral Dossier, no. 20, 53 p.

Cundiff, W. H., 1974, Influence of bauxite composition on alumina plant technology: Comité International pour l'Etude des Bauxites, des Oxydes et des Hydroxydes d'Aluminium Travaux, no. 12, p. $67-73$.

Dacko, Andrew, 1979, Bauxite and alumina: Mining Engineering, v. 31 , no. 5 , p. $557-558$

Dahlkamp, F. J., and Kirchner, Gerhard, 1968, Die Bauxitlagerstätte im Adampada-Kabalebo-Gebiet in Suriname: Berg- und Hüttenmännische Monatschefte, v. 113, no. 2, p. 62-68.

Daniels, G. A., and Derbyshire, S. F., 1959, Bauxite deposits of the world; Paper 2 in Aluminum in Australia, Symposium: Brisbane, Australian Institute of Mining and Metallurgy, Metals and Chemical Institute, $48 \mathrm{p}$.

d'Argenio, Bruno, 1970, Central and southern Italy Cretaceous bauxites (stratigraphy and paleogeography), in Bárdossy, György, ed., Conference on bauxite geology, Budapest, 1969: [Hungary] Földtani Intézet Evkönyve, v. 54, no. 3, p. 221-233.

Dario Velasquez, José, 1973, The economics of bauxite-aluminaaluminum in western Colombia: Colorado School of Mines Quarterly, v. 68 , no. 4 , p. $163-189$.

Das Gupta, S. K., 1984, Bauxite and aluminium ore resources in India, in Jacob, Leonard, Jr., ed., Bauxite [Bauxite Symposium, Los Angeles, Calif., 1984, Proceedings]: New York, American Institute of Mining, Metallurgical and Petroleum Engineers, p. 451-485.

Davies, V. E., Lloyd, J. E., and Macfie, D., 1974, History of bauxite processing in British aluminium: Comité International pour l'Etude des Bauxites, des Oxydes et des Hydroxydes d'Aluminium Travaux, no. 12 , p. 75-80.

Davis, C. E., 1973, The mineralogy of Jamaican bauxites, in Proceedings of bauxite symposium II, [Kingston, Jamaica], 1973: Geological Society of Jamaica Journal, Special Issue [2], p. 6-20.

Davis, C. E., and Hill, V. G., 1974, Occurrence of nordstrandite and its possible significance in Jamaica bauxites: Comité International pour l'Etude des Bauxites, d'Alumine et d'Aluminium Travaux, no. 11, p. $61-70$

De Kun, Nicolas, 1965, The mineral resources of Africa: Amsterdam, Elsevier, 740 p

Demina, V. N., Gulyayev, G. P., and Kolokol'tsev, V. G., 1970, O paleozoyskikh gibbsitovykh boksitakh Timana [Paleozoic gibbsite bauxites from Timan]: Geologiya Rudnykh Mestorozhdeniy, v. 12 , no. 2 , p. 65-72. 
Dennen, W. H., and Norton, H. A., 1977, Geology and geochemistry of bauxite deposits in the lower Amazon Basin: Economic Geology, v. 72, no. 1 , p. 82-89.

De Ratmiroff, Gregor, 1979, Discovery and development of de Los Pijiguaos bauxite deposit, Venezuela: American Institute of Mining, Metallurgical and Petroleum Engineers, Society of Mining Engineers Preprint 79-87, 10 p.

Dik, Pham Dang, Eremin, N. I., and Chestyakova, A. A., 1976, Study of the basic technological properties of bauxite from the Democratic Republic of Vietnam: The Soviet Journal of NonFerrous Metals, v. 4, no. 6, p. 229-232. [English translation of Tsvetnye Metally, 1976, no. 6, p. 31-36.]

Dissanayake, C. B., and Vitanage, P. W., 1977, Exploration for bauxite in Sri Lanka, preliminary investigations: Geological Society of India Journal, v. 18 , no. 7 , p. 338-343.

Dixey, F., 1925, Bauxite deposits in Nyasaland: Mining Magazine [London], v. 33, p. 201-205.

Doeve, G., 1957, De Bauxietexploratie op het Nassaugebergte (1951-1953) [Exploration for bauxite in Nassaugebergte, Surinam, 1951-1953]: Surinam Geologisch Mijnbouwkundige Dienst Jaarboek, 1955, p. 25-64.

Doeve, G., and Groeneveld Meijer, W. O. J., 1963, Bauxite deposits of British Guiana and Surinam in relation to underlying unconsolidated sediments suggesting two-step origin: Economic Geology, v. 58, no. 7, p. 1160-1162.

Dondoli B., Cesar, 1970, Localización de un horizonte lateritico bauxitico en la zona de Paráiso de Cartago: Costa Rica, Dirección de Geología, Minas y Petróleo, Informes Técnicos y Notas Geológicas, no. 36, 12 p.

Dottin, O., 1972, Carte géologique de reconnaissance à 1/200 000[Notice explicative sur la feuille] Siemreap: [Khmer Republic] Service National des Mines, de la Géologie et du Pétrole, 16 p.

Doughman, A. J., 1971, The mineral industry of Ghana: U.S. Bureau of Mines Minerals Yearbook, 1969, v. 4, p. 325-329.

Douglas, C. G. C., Hill, V. G., and Lyew-Ayee, P. A., 1984, Mineralogy and process characteristics of Jamaica bauxites, in Jacob, Leonard, Jr., ed., Bauxite [Bauxite Symposium, Los Angeles, Calif., 1984, Proceedings]: New York, American Institute of Mining, Metallurgical and Petroleum Engineers, p. 349-369.

Dragović, D., 1965, Some characteristics of the deposits of white bauxites in Crna Gora: Comité International pour l'Etude des Bauxites, des Oxydes et des Hydroxydes d'Aluminium Travaux, no. 1, p. 21-35.

Dreyer, R. M., 1977, Principles of evaluation of lateritic ores: Mining Engineering, v. 30, no. 8, p. 1201-1202.

Dudich, E., Jr., 1973, Beiträge zum geochemischen Vergleich der Spurenelementgehalte der Karstbauxite von Ungarn, Rumanien, Bulgarien und Jugoslawien [Geochemical distribution of trace elements in the karst bauxite of Hungary, Romania, Bulgaria, and Yugoslavia], in Carpatho-Balkan Geological Association Congress, 9th, Budapest, 1969, Proceedings, v. 4: Budapest, Akadémiai Kiado, p. 47-55.

Dugain, F., and Tatar, J., 1970, Rapid and quantitative determination of $\mathrm{Al}_{2} \mathrm{O}_{3}$ and $\mathrm{SiO}_{2}$ content in bauxites by neutron activation analysis, in Bárdossy, György, ed., Conference on bauxite geology, Budapest, 1969: [Hungary] Földtani Intézet Evkönyve, v. 54, no. 3, p. 375-386.

Dunlap, J. C., and others, 1965, Bauxite deposits of Tennessee: U.S. Geological Survey Bulletin 1199-L, 37 p.

Eckel, E. B., 1959, Geology and mineral resources of Paraguay-A reconnaissance, with sections on Igneous and metamorphic rocks, by Charles Milton and E. B. Eckel, and Soils, by P. T. Sulsona: U.S. Geological Survey Professional Paper 327, 110 p.

Edlin, M. G., and Tenyakov, V. A., 1975, [Natural distribution of boron in bauxite and its genetic inportance], in Novye dannye po geologii boksitov: Vsesoyuznyy Nauchno-Issledovatel'skiy Institut Mineral'nogo Seriya, 1975, no. 2, p. 29-42. [In Russian.]

Emberger, A., 1957, Recherches de bauxites dans l'Ankaizina: Madagascar Service Géologique Rapport Annuel, 1957, p. 49-64.

E/MJ International Directory Mining Activity Digest, 1976, Korea rep. (S): E/MJ International Directory Mining Activity Digest, v. 2 , no. 12 , p. 6 .

Engineering and Mining Journal, 1967, Alcoa invests in Halco; To buy bauxite from Guinea: Engineering and Mining Journal, v. 168 , no. 3 , p. 126,130 .

1975, Trombetas-Major bauxite reserves in search of a future: Engineering and Mining Journal, v. 176, no. 11, p. 153-157. 1976, South Korea [bauxite deposits]: Engineering and Mining Journal, v. 177, no. 5, p. 17.

1977, The Caribbean-New faces in a mixed mining scene: Engineering and Mining Journal, v. 178, no. 11, p. 55-198.

1985, From bauxite to gold at Worsley Partners: Engineering and Mining Journal, v. 186, no. 4, p. 29.

Erdélyi, M., 1965, Geological studies in the Halimba basin: Acta Geologica (Academiae Scientiarum Hungaricae), v. 9, nos. 3-4, p. 339-362. [Russian summary.]

Erhart, Henri, 1973, Itinéraires géochimiques et cycle géologique de l'aluminum-Genèse des minerais d'alumine; latéritisation, bauxitisation, aluminification: Paris, Doin, 253 p.

Esguerra, F. B., 1961, Progress report on the aluminous laterite investigation, Nonoc Island, Surigao Mineral Reservation: Philippines Bureau of Mines Report of Investigation 33, $8 \mathrm{p}$.

1967, Genesis of ferruginous bauxite deposits in Bucas Grande Island, Surigao Mineral Reservation, Mindanao: Philippine Geologist, v. 21, no. 3, p. 71-98.

Evans, H. J., 1959, The geology and exploration of the Cape York peninsula bauxite deposits in northern Queensland: Chemical Engineering and Mining Review [Melbourne], v. 51, no. 11, p. 48-57. [Also published in Queensland Government Mining Journal, 1959, v. 60, no. 697, p. 679-688; summary in Mining Journal [London], 1959, v. 253, nos. 6469-6470, p. 141-143, 164.] [1972?], Weipa bauxite deposit, Queensland, Australia [abs.]: Pacific Science Congress, 12th, Canberra, Australia, 1971, Record of Proceedings, v. 1, p. 432.

1975, Weipa bauxite deposit, Q., in Knight, C. L., ed., Metals, v. 1 of Economic geology of Australia and Papua New Guinea: Australasian Institute of Mining and Metallurgy Monograph Series 5, p. 959-964.

1976, Australian bauxite deposits-Discovery and development, in Halbouty, M. T., Maher, J. C., and Lian, H. M., eds., Circum-Pacific energy and mineral resources: American Association of Petroleum Geologists Memoir 25, p. 405-409.

Everts, J. A., 1984, Calcined bauxite, in Jacob, Leonard, Jr., ed., Bauxite [Bauxite Symposium, Los Angeles, Calif., 1984, Proceedings]: New York, American Institute of Mining, Metallurgical and Petroleum Engineers, p. 84-97.

Eyles, V. A., 1958, A phosphatic band underlying bauxite deposits in Jamaica: Nature, v. 182 , no. 4646, p. 1367-1368.

Eyles, V. A., and others, 1952, The composition and origin of the Antrinı laterites and bauxites: Northern Ireland Geological Survey Memoir, $90 \mathrm{p}$.

Feigl, Fritz, Braile, Nicolau, and Ignacio Miranda, Luiz, 1946, A solubilização da bauxita fosforosa do Maranhão, Brasil: Congresso Panamericano de Engenharia de Minas e Geologia, 2d, Rio de Janeiro, 1946, v. 2, p. 141-162.

Fleischer, Michael, and others, 1952, Geochemical association of niobium (columbium) and titanium and its geological and economic significance: U.S. Geological Survey Circular 225, 13 p. 
Fleuriot de Langle, P., 1973, Carte géologique de reconnaissance à 1/200 000-Mondulkiri: [Khmer Republic] Service National des Mines, de la Géologie et du Pétrole.

Flock, W. M., 1966, Mineralogy and petrology of the Andersonville, Georgia bauxite district: University Park, Pennsylvania State University, Doctoral dissertation, $228 \mathrm{p}$.

Fontame, H., and Workman, D. R., 1978, Review of the geology and mineral resources of Kampuchea, Laos and Vietnam: Regional Conference on Geology and Mineral Resources of Southeast Asia, 3d, Bangkok, Thailand, 1978, Proceedings, p. 539-606.

Font-Altaba, M., and Closas Miralles, J., 1960, A bauxite deposit in the Paleozoic of Leon, Spaim: Economic Geology, v. 55, no. 6, p. 1285-1290.

Foose, R. M., 1944, High-alumina clays of Pennsylvania: Economic Geology, v. 39 , no. 8, p. 557-577.

Fox, C. S., 1932, Bauxite and aluminous laterite (2d ed.): London, C. Lockwood and Son, $312 \mathrm{p}$.

[France] Bureau d'Etudes Géologiques et Minières Coloniales, 1933, Les bauxites du Soudan: Chronique des Mines Coloniales, v. 2, no. 11, p. 103,105 .

Frederickson, L. D., Jr., 1954, Characterization of hydrated aluminas by infrared spectroscopy-Application to study of bauxite ores: Analytical Chemistry, v. 26, no. 12, p. 1883-1885.

Fursman, O. C., Blake, H. E., Jr., and Mauser, J. E., 1968, Recovery of alumina and iron from Pacific Northwest bauxites by the Pedersen process: U.S. Bureau of Mines Report of Investigations 7079, 22 p.

Fursman, O. C., and others, 1970, Utilization of red mud residues from alumina production: U.S. Bureau of Mines Report of Investigations $7454,32 \mathrm{p}$.

Galan, E., Lopez Aguayo, F., and deAza, S., 1977, Bauxitic clays of NE Teruel (Spain), in Konta, Jiru, ed., Conference on clay mineralogy and petrology, 7th, Karlovy Vary, Czechoslavakia, 1976, [Proceedings]: Prague, Univerzita Karlova, p. 487-497.

Gardner, L. R., 1970, A chemical model for the origin of gibbsite from kaolinite: American Mineralogist, v. 55, nos. 7-8, p. 1380-1389.

Gedeon, T. G., 1956, Bayerite in Hungarian bauxite: Acta Geologica (Academiae Scientiarum Hungaricae), v. 4, no. 1, p. 95-105.

Gellatly, D. C., and Sofoulis, J., compilers, 1969, Drysdale and Londonderry, W.A.: Australia Bureau of Mineral Resources, Geology and Geophysics 1:250,000 Geologic Series-Explanatory Notes, Sheet SD/52-5 and 52-9, $19 \mathrm{p}$.

Geological Society of Jamaica, 1971, Proceedings of bauxite/alumina symposium, [1st, Kingston, Jamaica], 1971: Geological Society of Jamaica Journal, Special Issue, $94 \mathrm{p}$.

1973, Proceedings of bauxite symposium II, [Kingston, Jamaica], 1973: Geological Society of Jamaica Journal, Special Issue [2], $40 \mathrm{p}$.

1975, Proceedings of bauxite symposium III, Kingston, Jamaica, 1975: Geological Society of Jamaica Journal, Special Issue [3], $59 \mathrm{p}$.

1980, Proceedings of bauxite/alumina symposium IV, Kingston, Jamaica, 1980: Geological Society of Jamaica Journal, Special Issue $5,370 \mathrm{p}$.

1982, Proceedings of bauxite symposium V, Kingston, Jamaica, 1982: Geological Society of Jamaica Journal, Special Issue $7,328 \mathrm{p}$.

Ghana Geological Survey, 1962, References in the reports of the Director of Geological Surveys to occurrences of economic minerals in Ghana with notes on their industrial applications and a map showing mineral deposits: Ghana Geological Survey Bulletin 28,63 p.

Ginsberg, Hans, 1962, Aluminium: Stuttgart, Ferdinand Enke Verlag, $135 \mathrm{p}$.

Ginsberg, Hans, and Wefers, Karl, 1971, Aluminium und Magnesium (2d ed.): Stuttgart, Ferdinand Enke Verlag, 218 p.
Gladkovsky, A. K., and Ushatinsky, I. N., 1964, Genesis and alteration of aluminous minerals in bauxite, in International Committee for Studies of Bauxites, Oxides and Hydroxides of Aluminium, [ICSOBA International Symposium, 1st, Zagreb, 1963, Proceedings]: Zagreb, Yugoslavia, Académie Yougoslave des Sciences et des Arts, v. 1, p. 153-170.

Göksu, Ekrem, 1954, Uber die Geologie und Genese der BauxitVorkommen in der Turkei: International Geological Congress, 19th, Algiers, 1952, Comptes Rendus, no. 12, p. 183-197.

Goldich, S. S., and Bergquist, H. R., 1947, Aluminous lateritic soil of the Sierra de Bahoruco area, Dominican Republic, West Indies: U.S. Geological Survey Bulletin 953-C, p. 53-84.

1948, Aluminous lateritic soil of the Republic of Haiti, West Indies: U.S. Geological Survey Bulletin 954-C, p. 63-111.

Gorbachev, B. F., 1973, Genesis of corundum in noninetamorphosed bauxites (thermodynamic analysis): Lithology and Mineral Resources, v. 7, no. 3, p. 370-374. [English translation of Litologiya i Poleznye Iskopayemye, 1972, no. 3, p. 136-141.]

Gordon, Mackenzie, Jr., Tracey, J. I., Jr., and Ellis, M. W., 1958, Geology of the Arkansas bauxite region: U.S. Geological Survey Professional Paper 299, 268 p.

Goretskiy, Yu. K., 1958, Zakonomernosti v razmeshcheniy boksitovykh mestorozhdeniy i usloviya ikh obpazoveniy [Principles of distribution of bauxite deposits and the conditions of their formation], in Strakhov, N. M., and Bushinskiy, G. I., eds., Boksity, ikh mineralogiya i genezis [Bauxites, their mineralogy and genesis]: Moscow, Akademiya Nauk SSSR, Otdelenie Geologo-Geograficheskikh Nauk, p. 93-119. [Reviewed by Zans, V. A., Economic Geology, v. 54, no. 5, p. 960, 1959.]

Gorovoy, A. F., and Nyrkov, A. A., 1974, Nekotoryye dannyye o geosinklinal'nykh boksitakh Kambodzhi [Some data on geosynclinal bauxites in Cambodia]: Mineralogiya Osadochnykh Obrazovaniy, v. 1, p. 128-131.

Gramger, D. J., and Graimger, R. L., 1974, Explanatory notes on the 1:2 500000 mineral deposits map of Papua New Guinea: Australia Bureau of Mineral Resources, Geology and Geophysics Bulletin $148,171 \mathrm{p}$.

Grayzer, M. I., and others, 1976, Long-term assessment of the bauxite potential of the Russian Platform: International Geology Review, v. 18, no. 2, p. 209-213. [English translation of Sovetskaya Geologiya, 1974, no. 4, p. 63-69.]

Greig, E. W., 1977, Trombetas and other Amazon bauxites, Brazil: American Institute of Mining, Metallurgical and Petroleum Engineers, Society of Mining Engineers Transactions, v. 264, p. 1719-1726.

Grosemans, P., 1959, La bauxite dans le Bas-Congo: Académie Royale des Sciences Coloniales [Brussels] Bulletin, new ser., v. 2, p. 457-469.

Grubb, P. L. C., 1968, Geology and bauxite deposits of the Pengerang area, southeast Johore: West Malaysia Geological Survey District Memoir 14, $125 \mathrm{p}$.

1970, Mineralogy, geochemistry, and genesis of the bauxite deposits on the Gove and Mitchell plateaux, northern Australia: Mineralium Deposita, v. 5, no. 3, p. 248-272.

1971a, Mineralogical anomalies in the Darling Ranges bauxites at Jarrahdale, Western Australia: Economic Geology, v. 66, no. 7 , p. $1005-1016$.

$1971 b$, Genesis of the Weipa bauxite deposits, N.E. Australia: Mineralium Deposita, v. 6, no. 4, p. 265-274.

1973, High-level and low-level bauxitization-A criterion for classification: Mineral Science and Engineering [Johannesburg, South Africa], v. 5, no. 3, p. 219-231.

1976, Project 68; Bauxite in Rhodesia: University of Rhodesia, Institute of Mining Research Report 19, p. 44-45. 
1979, Genesis of bauxite deposits in the lower Amazon Basin and Guianas coastal plain: Economic Geology, v. 74, no. 4, p. 735-750.

Grubbs, D. K., 1982, The iron and phosphate mineralogy of the bauxite in Harmons Valley and the Mocho Mountains, Jamaica, in Proceedings of bauxite symposium V, Kingston, Jamaica, 1982: Geological Society of Jamaica Journal, Special Issue 7, p. 54-61.

Grubbs, D. K., Libby, S. C., Rodenburg, J. K., and Wefers, K. A., 1980, The geology, mineralogy and clarification properties of red and yellow Jamaican bauxites, in Proceedings of bauxite/alumina symposium IV, Kingston, Jamaica, 1980: Geological Society of Jamaica Journal, Special Issue 5, p. 176-186.

Grubbs, D. K., Rodenburg, J. K., and Wefers, K. A., 1982, Origin of aluminous goethite in Suriname bauxite, in Bell, G. M., ed., Light metals, 1981 [Proceedings of Technical Sessions at the 110th AIME Annual Meeting, Chicago, Feb. 22-26, 1981]: New York, American Institute of Mining, Metallurgical and Petroleum Engineers, p. 3-14.

Grubic, Aleksandar, 1970, Les bauxites de Yougoslavie [Yugoslavian bauxites], in Bárdossy, György, ed., Conference on bauxite geology, Budapest, 1969: [Hungary] Földtani Intézet Evkönyve, v. 54 , no. 3 , p. $195-207$.

1975, Geologija jugoslovenskih boksita [Geology of Yugoslavian bauxites]: Srpska Akademija Nauka i Umetnosti [Belgrad] Posebna Izdanja, no. 483 (Odeljenje Prirodno-Matematichkih Nauka, no. 44), 181 p. [English summary.]

Gsell, Alain, 1984, Cameroon bauxites from the Minim Martap deposit, in Jacob, Leonard, Jr., ed., Bauxite [Bauxite Symposium, Los Angeles, Calif., 1984, Proceedings]: New York, American Institute of Mining, Metallurgical and Petroleum Engineers, p. 556-571.

Guest, N. J., 1959, Bauxite in Fiji: Fiji Geological Survey Department Long Report 55, $12 \mathrm{p}$.

Guha, P. K., 1967, Bauxite deposits of Bargru plateau (Lohardaga) and their origin: Geological, Mining and Metallurgical Society of India Quarterly Journal, v. 39, no. 2, p. 99-102.

Güldari, Nuri, 1973, Seydisehir and Akseki bauxite deposits and their relation to paleokarst phenomena in Taurus Mountains, in Congress of Earth Sciences on the Occasion of the 50th Anniversary of Turkish Republic, December 1973: Ankara, Turkey Mineral Research and Exploration Institute, p. 392-408.

Gunawan, R., and Valk, C. B. C, 1972, Notes on the geology of the aluminous laterites of West Kalimantan, Indonesia: Indonesia National Institute of Geology and Mining Bulletin, v. 4, no. 1, p. 29-36.

Gutkin, Ye. S., 1971, Gallium, scandium, niobium, and tantalum in bauxites of the northern Ural basin: Lithology and Mineral Resources, 1970, no. 3, p. 277-284. [English translation of Litologiya i Polezyne Iskopayemye, 1970, no. 3, p. 27-36.]

Guyana Geological Surveys and Mines Department, 1972, Report on the Geological Survey Department for the year 1971: Guyana Geological Surveys and Mines Department Report, 1971, 40 p.

Hall, R. B., 1978, World nonbauxite aluminum resources-Alunite: U.S. Geological Survey Professional Paper 1076-A, 35 p.

Harben, Peter, 1978, Abrasives-Taking the rough with the smooth: Industrial Minerals, no. 134, p. 49-73.

Harden, G., and Bateson, J. H., 1963, A geochemical approach to the problem of bauxite genesis in British Guiana: Economic Geology, v. 58 , no. 8 , p. $1301-1308$.

Harder, E. C., 1933, Origin of bauxite deposits [discussion]: Econounic Geology, v. 28, no. 4, p. 395-398.

1952, Examples of bauxite deposits illustrating variations in origin, in American Institute of Mining and Metallurgical Engineers, Problems of clay and laterite genesis-Symposium, St. Louis, Mo., 1951: New York, p. 35-64.
Harder, E. C., and Greig, E. W., 1960, Bauxite, in Gillson, J. L., and others, eds., Industrial minerals and rocks-Nonmetallics other than fuels (3d ed.): New York, American Institute of Mining, Metallurgical and Petroleum Engineers, p. 65-85.

Harrassowitz, Herman, 1922, Die Entstehung der oberhessischen Bauxite und ihre geologische Bedeutung [Genesis of upper Hessian bauxite and its geologic importance]: Deutsche Geologische Gesellschaft Zeitschrift, v. 73, nos. 8-10, p. 179-192.

Harrington, J. F., 1948, Sources of bauxite in Asia: U.S. Bureau of Mines Mineral Trade Notes, v. 26, no. 6, Special Supplement 27, $17 \mathrm{p}$.

Harrison, J. B., 1934, The katamorphism of igneous rocks under humid tropical conditions: Harpenden, England, Imperial Bureau of Soil Science, Rothamsted Experimental Station, 79 p.

Hartman, J. A., 1955, Origin of heavy minerals in Jamaican bauxite: Econounic Geology, v. 50, no. 7, p. 738-747.

1959, The titanium mineralogy of certain bauxites and their parent materials: Economic Geology, v. 54, no. 8, p. $1380-1405$.

Hasan, Zia-ul, 1966, On the occurrence and geochemistry of bauxite deposits of Monghyr area (India): Economic Geology, v. 61, no. 4, p. 715-730.

Hassan, E. A., Jr., and Williams, G. K., 1969, Bauxite: Mining Engineering, v. 21, no. 1, p. 54-56.

Hathaway, J. C., and Schlanger, S. O., 1965, Nordstrandite $\left(\mathrm{Al}_{2} \mathrm{O}_{3} \cdot \mathrm{H}_{2} \mathrm{O}\right)$ from Guam: American Mineralogist, v. 50, nos. 7-8, p. $1029-1037$.

Hebb, D. H., 1974, The mineral potential of Viet-Nam: Mining Magazine, v. 131, no. 4, p. 297-303.

Henderson, F. B., III, Penfield, G. T., and Grubbs, D. K., 1984, Bauxite exploration by satellite, in Jacob, Leonard, Jr., ed., Bauxite [Bauxite Symposium, Los Angeles, Calif., 1984, Proceedings]: New York, American Institute of Mining, Metallurgical and Petroleum Engineers, p. 200-242.

Hendricks, S. B., Goldich, S. S., and Nelson, R. A., 1946, A portable differential thermal analysis unit for bauxite exploration: Economic Geology, v. 41, no. 1, p. 64-76.

Hewett, D. F., Cornwall, H. R., and Erd, R. C., 1968, Hypogene veins of gibbsite, pyrolusite, and lithiophorite in Nye County, Nevada: Economic Geology, v. 63, no. 4, p. 360-371.

Hieronymus, Bernard, 1971, Note préliminaire sur l'altération des trachytes de la zone bauxitique de Fongo-Tongo, Memoua, Cameroun [Preliminary note on the weathering of trachyte of the bauxitic zone of Fongo-Tongo, Memoua, Cameroon]: Cameroun Université Fédérale, Faculté des Sciences Annales, no. 6, p. 39-52. [English summary.]

Hildebrand, F. A., 1960, Occurrences of bauxitic clay in the karst area of north-central Puerto Rico: U.S. Geological Survey Professional Paper 400-B, p. B368-B371.

Hill, V. G., 1955, The mineralogy and genesis of the bauxite deposits of Jamaica, B.W.I.: American Mineralogist, v. 40, nos. 7-8, p. 676-688.

1980, The rational development of bauxite resources; in Proceedings of bauxite/alumina symposium IV, Kingston, Jamaica, 1980: Geological Society of Jamaica Journal, Special Issue 5, p. 3-19.

Hill, V. G., and Davis, C. E., 1971, Progress report on compositional correlation and structural relationships in Jamaica bauxite deposits, in Proceedings of bauxite/alumina symposium, [1st, Kingston, Jamaica], 1971: Geological Society of Jamaica Journal, Special Issue, p. 17-24.

Hill, V. G., and Ostojic, Slavko, 1981, The bauxite supply potential for the aluminum industry: IBA Quarterly Review, v. 7, no. 2, p. 20-30. 
1982, The bauxite deposits of Jamaica: a distinctive karstic type, in Lyew-Ayee, Anne, ed., Proceedings of bauxite symposium V, Kingston, Jamaica, 1982: Geological Society of Jamaica Journal, Special Issue 7, p. 8-18.

1984, The characteristics and classification of bauxites, in Jacob, Leonard, Jr., ed., Bauxite [Bauxite Symposium, Los Angeles, Calif., 1984, Procedings]: New York, American Institute of Mining, Metallurgical and Petroleum Engineers, p. 31-48.

Hinds, S. A., Ralph, Brian, and Pollard, Berkley, 1983, South American refractory-grade bauxite-A guaranteed supply of high $\mathrm{Al}_{2} \mathrm{O}_{3}$ refractory grog well into the 21 st century: Ceramic Science Proceedings, v. 4, nos. 1-2, p. 15-27.

Hoppe, Richard, 1978, Sangaredi pit in Guinea carves up a rich deposit of solid bauxite, in Hoppe, Richard, ed., E/MJ operating handbook of mineral surface mining and exploration (2d ed.): New York, McGraw-Hill, p. 336-338.

Hose, H. R., 1960, The genesis of bauxites; the ores of aluminium: International Geological Congress, 21st, Copenhagen, 1960, Report, pt. 16, p. 237-247.

1961, The origin of bauxites in British Guiana and Jamaica: Inter-Guiana Geological Congress, 5th, Georgetown, British Guiana, 1959, Proceedings, p. 185-198.

1963, Jamaica type bauxites developed on limestones: Economic Geology, v. 58, no. 1, p. 62-69.

Hosking, J. R., and Tubey, L. W., 1973, Experimental production of calcined bauxites for use as road aggregate: Great Britain Transport and Road Research Laboratory Report LR 588, 15 p.

Hottin, G., 1960, Recherches de bauxite sur les Tampoketsa [Studies of bauxites in Tampoketsa]: Malagasy Republic Service Géologique Rapport Annuel, 1960, p. 97-110.

Houtz, R. E., and Phillips, K. A., 1963, Interim report on the economic geology of Fiji: Fiji Geological Survey Department Economic Report 1,36 p.

Hudson, L. K., 1965, Gallium as a by-product of alumina manufacture: Journal of Metals, v. 17, no. 9, p. 948-951.

Hughes, I. G., compiler, 1973, The mineral resources of Jamaica: Jamaica Geological Survey Department Bulletin 8, 89 p.

Hughes, R. J., 1978, The geology and mineral occurrences of Bathurst Island, Melville Island, and Cobourg Peninsula, Northern Territory: Australia Bureau of Mineral Resources, Geology and Geophysics Bulletin 177, 71 p.

Hunter, J. M., 1961, Morphology of a bauxite summit in Ghana: Geographical Journal [London], v. 127, pt. 4, p. 469-476.

Huvos, J. B., 1974, The mineral industry of Hungary: U.S. Bureau of Mines Minerals Yearbook, 1972, v. 3, p. 367-377.

Hyde, D. M., 1984, The mineral industry of the islands of the Caribbean: U.S. Bureau of Mines Minerals Yearbook, 1982, v. 3, p. 1105-1125.

Iannicelli, Joseph, 1984, Beneficiation of bauxite to refractory grade quality by high intensity magnetic separation, in Jacob, Leonard, Jr., ed., Bauxite [Bauxite Symposium, Los Angeles, Calif., 1984, Proceedings]: New York, American Institute of Mining, Metallurgical and Petroleum Engineers, p. 681-698.

ICSOBA see International Committee for Studies of Bauxites, Oxides and Hydroxides of Aluminium and International Congress for the Study of Bauxites, Alumina and Aluminum.

Iijima, A., Kimiya, K., and Yanagimoto, H., 1973, Relationship between mineral composition and grain-size distribution in the low-grade bauxite deposit on Bintan Island, in International Committee for Studies of Bauxites, Oxides and Hydroxides of Aluminium, [ICSOBA International Symposium, 3d, Nice, France, 1973, Proceedings]: Paris, Sedal, p. 55-62.

Ikonnikov, A. B., 1975, Mineral resources of China: Geological Society of America Microform Publication 2, 6 microfiche containing 555 p.
1984, Notes on the geology of bauxite deposits in China, in Jacob, Leonard, Jr., ed., Bauxite [Bauxite Symposium, Los Angeles, Calif., 1984, Proceedings]: New York, American Institute of Mining, Metallurgy and Petroleum Engineers, p. 539-555.

Il'in, S. F., 1977, Elementy-primesi v boksitakh Tikhvinskikh mestorozhdeniy [Elements-admixture of bauxites of Tikhvinskiy]: Akademiya Nauk SSSR Izvestiya, Seriya Geologicheskaya, 1977, no. 2 , p. 133-141.

Indian Bureau of Mines, 1974, Indian minerals yearbook 1970: New Delhi, 520 p.

Indonesian Ministry of Mines, 1970, Review of the role played by the mining sector in the economic development of Indonesia in the First United Nations Development Decade (1960-1970) and considerations of a long term program for the 1970's: Indonesia National Institute of Geology and Mining Bulletin, v. 3, no. 2, p. 1-21.

Industrial Minerals, 1972, CE minerals-Georgian bauxite and kaolin calcined for refractory grog: Industrial Minerals, no. 56, p. 17-22. 1973, Greece mineral by mineral: Industrial Minerals, no. 75 , p. $27-45$.

1974, Bauxite and alumina offer more than aluminium: Industrial Minerals, no. 85, p. 9-23.

1976, Company news and mineral notes: Industrial Minerals, no. 110, p. 41.

1977a, A complete range of Chinese high-alumina refractory raw materials: Industrial Minerals, no. 120, p. 40.

$1977 \mathrm{~b}$, Company news and mineral notes: Industrial Minerals, no. 123 , p. 69 .

1978a, The world aluminium industry, 1976: Industrial Minerals, no. 129 , p. 58.

1978b, Pakistan pilot plant for alumina extraction: Industrial Minerals, no. 135, p. 10.

1978c, Alumino-silicate raw materials from China [advertisement]: Industrial Minerals, no. 134, p. 60.

Ingram, J. A., compiler, 1973, Bauxite deposits (2d ed.): Australia Bureau of Mineral Resources, Geology and Geophysics Mineral Resources Report 1, 26 p.

International Bauxite Association, [1976a], Guinea: IBA Quarterly Review, v. 1 , no. 4 , p. 3 .

[1976b], Statistical section; Table 1, Bauxite reserves in IBA member countries: IBA Quarterly Review, v. 1, no. 2 (title page says v. 2), p. 15. [In English and French.]

[1977a], Australia: IBA Quarterly Review, v. 2, no. 2, p. $33-40$.

[1977b], Dominican Republic: IBA Quarterly Review, v. 2, no. 3 , p. 47-49.

[1977c], Ghana; Kibi bauxite project still on: IBA Quarterly Review, v. 2 , no. 2 , p. 7 .

[1977d], Guinea; Massive developments underway: IBA Quarterly Review, v. 2, no. 2, p. 7-8.

[1977e], The Republic of Ghana: IBA Quarterly Review, v. 3, no. 1 , p. $32-34$.

[1978a], The Co-operative Republic of Guyana: IBA Quarterly Review, v. 3 , no. 4, p. 37-41.

[1978b], Yugoslavia moves to greater domestic utilization of its bauxite: IBA Quarterly Review, v. 3, no. 2, p. 13-14. [1979], The Peoples Revolutionary Republic of Guinea: IBA Quarterly Review, v. 4, nos. 2-3, p. 35-40.

[1981], Alcoa gets the green light for Trombetas bauxite purchase: IBA Quarterly Review, v. 7, no. 2, p. 11.

[1982], Sardinian bauxite find: IBA Quarterly Review, v. 8, no. 1 , p. 11 . p. 4-5. [1983a], Australia: IBA Quarterly Review, v. 9, no. 2, 
[1983b], China, export volume to US up: IBA Quarterly Review, v. 8, no. 3, p. 9.

International Committee for Studies of Bauxites, Oxides and Hydroxides of Aluminium, 1964-65, [ICSOBA International Symposium, 1st, Zagreb, 1963, Proceedings]: Zagreb, Yugoslavia, Acadéınie Yougoslave des Sciences et des Arts, 3 v. (v. 1, 2, 1964; v. 3, 1965.) [In French, English, German, or Russian.]

1971, Bauxite-alumina-aluminum [ICSOBA International Symposium, 2d, Budapest, 1969, Proceedings]: Budapest, Hungary Research Institute for Non-Ferrous Metals, 4 v.

1973, I.C.S.O.B.A. Congrès International [ICSOBA International Symposium, 3d, Nice, France, 1973, Proceedings]: Paris, Sedal [Société d'Edition d'Aluminium], 732 p. [In English, French, German, or Russian.]

International Congress for the Study of Bauxites, Alumina and Aluminium, 1978, [ICSOBA International Symposium, 4th, Athens, 1978, Proceedings]: Athens, Greece, National Technical University of Athens, 3 v. [In English, French, or German.]

International Seminar on Lateritisation Processes, 1981, Lateritisation processes [1st, Trivandrum, India, 1979, Proceedings]: Rotterdam, Netherlands, A. A. Balkema, 450 p.

1983, Lateritisation processes [2d, São Paulo, Brazil, 1982, Proceedings]: University of São Paulo, Instituto Astronounica e Geofisico.

Isaac, A. E., Jr., 1982, The bauxite deposits of Salcedo and Mercedes, eastern Samar, Philippine Islands, in Proceedings of bauxite symposium V, Kingston, Jamaica, 1982: Geological Society of Jamaica Journal, Special Issue 7, p. 100-107.

Jackson, R. L., 1971, Description of the ferrugimous bauxite ore profile in Columbia County, Oregon: Ore Bin, v. 33 , no. 12 , p. 223-229.

Jacob, Leonard, Jr., ed., 1984, Bauxite [Bauxite Symposium, Los Angeles, Calif., 1984, Proceedings]: New York, American Institute of Mining, Metallurgical and Petroleum Engineers, $918 \mathrm{p}$.

Jacolino, R. B., 1977, Bauxite deposits of Samar: Philippines Bureau of Mines Report of Investigation 89, $39 \mathrm{p}$.

Janekovic, A., and Ivekovic, H., 1973, Determination of anatase and rutile in bauxite by means of X-ray diffraction and orgamic solvent, in International Committee for Studies of Bauxites, Oxides and Hydroxides of Aluminium, [ICSOBA International Symposium, 3d, Nice, France, 1973, Proceedings]: Paris, Sedal, p. 331-338.

Janssen, J. J., 1966, Bauxite in the Adampada-Kabalebo area, Surinam, in Conferencia Geologica das Guianas [Inter-Guiana Geological Conference], 6th, Anais: Brazil Divisão de Geologia e Mineralogia Avulso, no. 41, p. 189-193.

Jaques, A. L., 1976, Explanatory notes on the Admiralty Islands: Papua New Guinea Geological Survey Report 76/15, 31 p.

Jepsen, Klaus, and Schellmann, Werner, 1974, Uber den Stoffbestand und die Bildungsbedingungen der Bauxitlagerstätte Weipa/ Australien [The composition and genesis conditions of the Weipa bauxite deposits, Australia]: Geologisches Jahrbuch, Reihe D, no. 7, p. 19-106. [English, French, and Russian summaries.]

Jespersen, Anna, 1964, Aeromagnetic prospecting for bauxite deposits in the Mississippi embayment, Arkansas and Missouri: U.S. Geological Survey Geophysical Investigations Map GP-370, scale $1: 125,000$.

Jobim, José, [1941], The inineral wealth of Brazil: Rio de Janeiro, Livraria José Olympio, 169 p.

Jodot, Paul, 1934, Etude de quelques roches latéritiques de la vallée du Niger (Soudan occidental français): Société Géologique de France Bulletin, ser. 5, v. 3, nos. 7-8, p. 619-658.

Johnson, R. F., and Marjono, 1963, Geology and bauxite deposits of the Central Riau Islands, Indonesia: Indonesia Direktorat Geologi, Publikasi Teknik, Seri Geologi Ekonoıni, no. 6, 54 p.
Joklik, G. F., Jackson, W. D., and Zani, J. A., 1975, Kimberley bauxite deposits, W.A., in Knight, C. L., ed., Metals, v. 1 of Econounic geology of Austraha and Papua New Guinea: Australasian Institute of Mining and Metallurgy Monograph Series 5, p. $968-980$.

Jónás, Klára, and Solymár, Károly, 1970, Preparation, X-ray, derivatographic and infrared study of aluminium-substituted goethites: Acta Chimica (Academiae Scientiarum Hungaricae), v. 66 , no. 4 , p. $383-394$.

Jones, G. P., 1972, Origin, diagenesis and structure of bauxite deposits in southeast Alabama, in Forum on Geology of Industrial Minerals, 7th, Proceedings: Florida Bureau of Geology Special Publication 17, p. 23-28.

Jurkovic, Ivan, and Sakaç, Krešimir, 1964, Stratigraphical, paragenetical and genetical characteristic of bauxites in Yugoslavia, in International Committee for Studies of Bauxites, Oxides and Hydroxides of Aluminium, [ICSOBA International Symposium, 1st, Zagreb, 1963, Proceedings]: Zagreb, Yugoslavia, Académie Yougoslave des Sciences et des Arts, v. 1, p. 253-263.

Károly, György, and others, 1970, Stratigraphic horizons of the footwall and hanging-wall formations of bauxite deposits in Hungary, in Bárdossy, György, ed., Conference on bauxite geology, Budapest, 1969: [Hungary] Földtani Intézet Evkönyve, v. 54, no. 3, p. 95-107.

Kauter, Kurt, 1969, Bauxitvorräte kapitahstischer Länder [Bauxite occurrences in capitahistic countries]: Zeitschrift für Angewandte Geologie, v. 15, no. 11, p. 602-604.

Kear, David, Waterhouse, B. C., and Swindale, L. D., [1961], Bauxite deposits in Northland: New Zealand Department of Scientific and Industrial Research Information Series $32,58 \mathrm{p}$.

Keller, W. D., 1964, The origin of high-alumina clay minerals-A review, in Bradley, W. F., ed., Clays and clay minerals; National Conference on Clays and Clay Minerals, 12th, Atlanta, Ga., 1963, Proceedings: New York, Macmillan Company, p. 129-151.

Keller, W. D., Wescott, J. F., and Bledsoe, A. O., 1954, The origim of Missouri fire clays, in Swineford, Ada, and Plummer, N. V., eds., Clays and clay minerals; National Conference on Clays and Clay Minerals, 2d, Columbia, Mo., 1953, Proceedings: National Research Council Publication 327, p. 7-46.

Kelly, W. C., 1961, Some data bearing on the origin of Jamaican bauxite: American Journal of Science, v. 259, p. 288-294.

Kersen, J. F. van, 1956, Bauxite deposits in Suriname and Demerara (British Guiana): Leidse Geologische Mededelingen, v. 21, pt. 1, p. 247-375. [Dutch summary.]

Kesse, G. O., 1974, Bauxite deposits of Ghana: Ghana Geological Survey Report 75/2, 62 p.

1984, The geology of the bauxite deposits of Ghana, in Jacob, Leonard, Jr., ed., Bauxite [Bauxite Symposium, Los Angeles, Cahif., 1984, Proceedings]: New York, American Institute of Mining, Metallurgical and Petroleum Engineers, p. 572-601.

Keyser, W. L. de, 1959, Note concernant la composition et le traitement des bauxites du Bas-Congo: Académie Royale des Sciences Coloniales [Brussels] Bulletin, new ser., v. 5, no. 4, p. 975-991.

Khorosheva, D. P., 1969, Bayerite, boehunite, diaspore, and corundum in the bauxites of the iniddle Dnieper region: Lithology and Mineral Resources, 1969, no. 2, p. 171-178. [English translation of Litologiya i Poleznye Iskopayemye, 1969, no. 2, p. 41-50.]

Kim, Yu. I., 1971, The Turgai bauxite-bearing karst province: International Geology Review, v. 13, no. 6, p. 981-989. [English translation of Sovetskaya Geologiya, 1970, no. 8, p. 13-24.]

Kirke, E. A., and Murray, A. M., 1979, Bauxite-Mining and processing, in Prider, R. T., ed., Mining in Western Austraha: Nedlands, W. A., University of Western Austraha Press, p. 219-228. 
Kis, I., 1971, Protection against karst water in the Bakony bauxite mines, in International Committee for Studies of Bauxites, Oxides and Hydroxides of Aluminium, Bauxite-alumina-aluminium [ICSOBA International Symposium, 2d, Budapest, 1969, Proceedings]: Budapest, Hungary Research Institute for Non-Ferrous Metals, v. 2, p. 219-226.

Kitson, A. E., 1925, Outlines of the mineral and water-power resources of the Gold Coast, British West Africa, with hints on prospecting: Gold Coast Geological Survey Bulletin 1, 56 p.

Kleinhans, R. E., 1948, The light-metals industries in China: U.S. Bureau of Mines Mineral Trade Notes, v. 26, no. 2, special supplement 23, $18 \mathrm{p}$.

Knechtel, M. M., 1963, Bauxitization of terra rossa in the southern Appalachian region: U.S. Geological Survey Professional Paper 475-C, p. C151-C155.

Kolesnikov, N. A., Nevzorova, A. I., and Shishakov, V. B., 1972, Lithological-geochemical characteristics and composition of bauxites in ore deposits from Novaya Pristan' group, southern Ural: International Geology Review, v. 14, no. 2, p. 150-159. [English translation of Geologiya Rudnykh Mestorozhdeniy, v. 11, no. 6, p. $62-73,1969$.]

Komlóssy, György, 1970, The Iszkaszentgyörgy bauxite (SE Bakony Mts, Hungary)-Problems of genesis and mineral formation, in Bárdossy, György, ed., Conference on bauxite geology, Budapest, 1969: [Hungary] Földtani Intézet Evkönyve, v. 54, no. 3, p. $347-358$.

1976, Minéralogie, géochimie et génétique des bauxites du Vietnam du Nord: Acta Geologica (Academiae Scientiarum Hungaricae), v. 20, nos. 3-4, p. 199-244. [Russian sumunary.]

Konta, Jiř́, 1954, Príspvek k petrografii a genesi rychnovského bauxitu [Contribution to the petrography and genesis of the bauxite of Rychnov]: Acta Universitatis Carolinae (Karlova Universita, Prague) Geologica, no. 9, p. 37-62. [In Czech; Russian and English summaries.]

1973, Remarks to the proposition on bauxite terminology: Comité International pour l'Etude des Bauxites, des Oxydes et des Hydroxydes d'Aluminium Travaux, no. 9, p. 109-110.

Kotschoubey, Basile, and Truckenbrodt, Werner, 1981, Evolução poligenetica das bauxitas do distrito de Parágominas, Acailandia (Estados do Pará e Maranhão) [Polygenetic evolution of the bauxites of Parágominas, Acailandia]: Revista Brasileiro de Geociencias, v. 11 , no. 3, p. 193-202.

Kowalski, W. M., 1970, Boksytyzacja mikrodiorytu z Tabouna (Republika Gwinea) [Bauxitization of the microdiorite in the Tabouna region, Republic of Guinea]: Polskie Towarzystwo Geologiczne Rocznik, v. 40, no. 2, p. 341-365. [In Polish; French summary.]

Krishna Rao, G., Borreswara Rao, C., and Sundar, Y. S., 1974, Mineralogical studies on the bauxites from Shevaroy Hills, Tamilnadu State: Geological Society of India Journal, v. 15, no. 1, p. 58-64.

Krishnan, M. S., 1942, Bauxite in the Shevaroy Hills, Salem district, Madras Presidency: India Geological Survey Record, v. 77 (Professional Paper 8), 16 p.

Kronberg, B. I., and others, 1979, Minor element geochemistry of the Paragominas bauxite, Brazil: Economic Geology, v. 74, no. 8, p. 1869-1875.

Krook, L., 1969, The origin of bauxite in the coastal plain of Surinam and Guyana, in Contributions to the geology of Surinam [1]: Surinam Geologisch Mijnbouwkundige Dienst Mededeling 20, p. $173-180$.

Kumar, G. S., and others, 1977, Monograph on bauxite: Indian Bureau of Mines Mineral Facts and Problems, no. 5, 465 p.; Supplement, 8 p.

Kurtz, H. F., 1975, Bauxite: U.S. Bureau of Mines Minerals Yearbook, 173 , v. 1 , p. $189-204$.
1975, Bauxite: U.S. Bureau of Mines Minerals Yearbook, 1973 , p. 203.

Kuzemkina, E. N., 1960, Sostav i osobennosti stroeniya bobovin mezozoiskikh boksitov Kustanaiskoi oblasti [Composition and structural features of pisolites from Mesozoic bauxites of the Kustanai region]: Geologiya Rudnykh Mestorozhdeniy, v. 2, no. 3, p. 96-107. [Reviewed by Alexandrov, E. A., Economic Geology, v. 57, no. 2, p. 283, 1962.]

Lachniansingh, S. V., and Nooten, G. A., 1977, The occurrence and production of speciality grades of bauxite in Guyana: American Institute of Mining, Metallurgical and Petroleum Engineers, Society of Mining Engineers Preprint 77-H-31, 14 p.

Lacroix, A., 1913, Les latérites de la Guinée et les produits d'altération qui leur sont associés: Muséum National d'Histoire Naturelle [Paris] Nouvelles Archives, ser. 5, p. 255-358.

Lajomie, J. P., and Bonifas, M., 1962, Les dolérites du Konkouré et leur altération latéritique (Guinée, Afrique occidentale): [France] Bureau de Recherches Géologiques et Mimières Bulletin 1961, no. 2, p. 1-34.

Landi, M. F., and Casola, Alfredo, 1977, Joint digestion of Boke and Weipa bauxites, with particular reference to silica separationResults and observations, in Light metals 1977, v. 2: American Institute of Mining, Metallurgical and Petroleum Engineers, Metallurgical Society, annual meeting, 106th, Proceedings, p. 79-102.

Lang, W. B., and others, 1965, Bauxite and kaolin deposits of the Irwin ton district, Georgia: U.S. Geological Survey Bulletin 1199-J, 26 p.

Laplaine, Louis, 1969, Indices minéraux et ressources minérales du Cameroun [Mineralogic indices and mineral resources of Cameroon]: Cameroun Direction des Mines et de la Géologie Bulletin 5, p. 9-182.

Lapparent, Jacques de, 1930, Les bauxites de la France méridionale: [France] Service de la Carte Géologique Mémoires, 186 p.

1936, Boehmite and diaspore in the bauxitic clays of Ayrshire: Great Britain Geological Survey Summary of Progress for 1934, pt. 2, p. 1-7.

Lapparent, Jacques de, and Hocart, Raymond, 1938, Sur la nature minéralogique des hydroxydes d'aluminium dans les bauxites de l'Afrique occidentale française [Mineralogic nature of the hydroxides of aluminum in the bauxites of French West Africa]: Academie des Sciences [Paris] Comptes Rendus, v. 207, no. 3, p. 202-203.

Lavie, H. J., 1974, Evaluación sistematica de las lateritas aluminosas en la altiplanicie de Nuria [Systematic evaluation of the aluminous laterites in the Nuria plateau]: Venezuela Dirección de Geologia Boletín de Geología Publicación Especial, v. 6, p. 550-554.

Lebauer, L. R., 1983, Chinese refractory-grade bauxite and other refractory raw materials from China: Ceramic Engineering Science, v. 4, nos. 1-2, p. 9-14.

Lee, J. W., 1965, Zans' theory on origin of bauxite deposits supported by Pepper area: Jamaica Scientific and Research Council Bulletin, v. 5 , p. $45-48$.

Lefond, S. J., 1973, Brazilian mining-Relaxed gov't attitudes pave way for exploiting critical reserves: Mining Engineering, v. 25, no. 11, p. $31-45$.

Lelong, F., and others, 1976, Pedogenesis, chemical weathering and processes of formation of some supergene ore deposits, in Wolf, K. H., ed., Supergene and surficial ore deposits-Textures and fabrics, v. 3 of Handbook of strata-bound and stratiform ore deposits: New York, Elsevier, p. 93-173.

Lever, G., 1983, Some aspects of the chemistry of bauxite organic matter on the Bayer process: the sodium oxalate-hunate interaction, in [ICSOBA International Symposium, 5th, Zagreb, 1983, Proceedings]: Comité International pour l'Etude des Bauxites, des Oxydes et des Hydroxydes de l'Aluminium Travaux, no. 18, p. 335-344. 
Lewiecki, W. T., 1949, Investigation of the Hermitage bauxite district, Bartow and Floyd Counties, Georgia: U.S. Bureau of Mines Report of Investigations 4577, $10 \mathrm{p}$.

Lewis, M. E., 1967, Variations in the bauxite deposits of the Monteague basin, St. Ann, Jamaica: Geological Society of Jamaica Journal, v. 9, p. 17-23.

$\mathrm{Li}, \mathrm{C} . \mathrm{Y}$., and Hsieh, C. Y., 1946, Potential sources of aluminum in southwestern China: American Institute of Mining and Metallurgical Engineers Technical Publication 1938, 6 p.

Libbey, F. W., Lowry, W. D., and Mason, R. S., 1945, Ferruginous bauxite deposits in northwestern Oregon: Oregon Department of Geology and Mineral Industries Bulletin 29, $97 \mathrm{p}$.

Lipkowitz, Irving, 1953, World bauxite reserves described by Lipkowitz: Engineering and Mining Journal, v. 154, no. 11, p. 127.

Little, O. H., 1925, The geography and geology of Makalla (South Arabia): Cairo, Egypt Geological Survey, 250 p.

Liu, Yin-jiun, 1965, [Some geochemical characteristics of gallium coexisting in certain bauxite in China]: [Geological Review], v. 23, no. 1 , p. 42-49. [In Chinese.]

Livingston, V. E., Jr., 1966, Geology and mineral resources of the Kelso-Cathlamet area, Cowlitz and Wahkiakum Counties, Washington: Washington Division of Mines and Geology Bulletin $54,110 \mathrm{p}$.

Ljunggren, Pontus, 1958, A inineralogical examination of some soil samples from southern and central Honduras: Lund Universitet [Sweden], Mineralogisk- och Paleontologisk-Geologiska Institutionerna Skrifter, no. 48, p. 125-131.

Logomerac, V. G., 1969, The distribution of rare earths and other minor elements in Surinam bauxite and laterite and in the red mud obtained from them, in Guiana Geological Congress, 7th, Parámaribo, 1966, Proceedings: Nederlands Geologisch Mijnbouwkundig Genootschap Verhandelingen, v. 27, p. 155-162. 1974, The agglomeration and complex utilization of red mud: Comité International pour l'Etude des Bauxites, des Oxydes et des Hydroxydes d'Aluminium Travaux, no. 12, p. 163-171.

Lotze, Jürgen, 1978, Economic evaluation of world bauxite resources, in International Committee for Studies of Bauxites, Alumina, and Aluıninium, [ICSOBA International Symposium, 4th, Athens, 1978, Proceedings]: Athens, Greece, National Technical University of Athens, v. 2, p. 494-506.

1984, Possible impacts of fiscal policy on utilization of bauxite resources, in Jacob, Leonard, Jr., ed., Bauxite [Bauxite Symposium, Los Angeles, Calif., 1984, Proceedings]: New York, American Institute of Mining, Metallurgical and Petroleum Engineers, p. 882-899.

Loughnan, F. C., and Bayliss, Peter, 1961, The mineralogy of the bauxite deposits near Weipa, Queensland: American Mineralogist, v. 46 , p. 209-217.

Loughnan, F. C., and Sadleir, S. B., 1984, Geology of established bauxite-producing areas in Australia, in Jacob, Leonard, Jr., Bauxite [Bauxite Symposium, Los Angeles, Calif., 1984, Proceedings]: New York, American Institute of Mining, Metallurgical and Petroleum Engineers, p. 436-450.

Lukovic, S. M., 1966, On the mineralogy, petrology and genesis of kaolin-bauxites with special reference to the white bauxites of Montenegro (Crna Gora): Coinité International pour l'Etude des Bauxites, des Oxydes et des Hydroxydes d'Aluminium Travaux, no. 2, p. 7-15.

Lyew-Ayee, P. A., 1984, Bauxites in the Caribbean, in Jacob, Leonard, Jr., ed., Bauxite [Bauxite Symposium, Los, Angeles, Calif., 1984, Proceedings]: New York, American Institute of Mining, Metallurgical and Petroleum Engineers, p. 262-296.

Lyew-Ayee, P. A., and Stewart, Raymund, 1982, Stratigraphic and compositional correlations between bauxites and their limestone hosts in Jamaica, in Proceedings of bauxite symposium V, Kingston, Jamaica, 1982: Geological Society of Jamaica Journal, Special Issue 7, p. 19-37.

MacGeehan, P. J., 1972, Vertical zonation within the Aurukun bauxite deposit, north Queensland, Australia: International Geological Congress, 24th, Montreal, 1972, Sec. 4, Proceedings, p. 424-434.

Mack, Erwin, 1964, Berechnung und Schatzung der Bauxit-vorräte im Parnass-Kiona-Gebirge: Berg- und Hüttenmännische Monatshefte, v. 109 , no 6 , p. 218-233.

Mackenzie, R. C., ed., 1957, The differential thermal investigation of clays: London, Mineralogical Society, Clay Minerals Group, $456 \mathrm{p}$.

Maksimović, Z., 1968, Distribution of trace elements in bauxite deposits of Herzegovina, Yugoslavia: Comité International pour l'Etude des Bauxites, des Oxydes et des Hydroxydes d'Aluminium Travaux, no. 5, p. 63-70.

Maksimović, Z., and Papastamatiou, J., 1973, Distribution d'oligoéléments dans les gisements de bauxite de la Grèce centrale [Distribution of trace elements in bauxite deposits of central Greece], in International Committee for Studies of Bauxites, Oxides and Hydroxides of Aluminium, [ICSOBA International Symposium, 3d, Nice, France, 1973, Proceedings]: Paris, Sedal, p. $33-46$.

Malamphy, M. C., and others, 1948, Investigation of Arkansas bauxite, Volume 1: U.S. Bureau of Mines Report of Investigations 4251, $63 \mathrm{p}$.

Malaysia Geological Survey, 1981, Annual report 1979: Kuching, Malaysia, $347 \mathrm{p}$.

Manley, N. W., 1957, Negotiations with the companies: Jamaica Office of Chief Minister and Minister of Development Ministry Paper $2,[5] \mathrm{p}$.

Manos, Anthony, 1977, Industrial minerals of Malawi: Industrial Minerals, no. 123, p. 57, 58, 61-63.

Maric, Luka, 1967-68, Nordstrandit i gibsit (hidrargilit) u terra rossi karsta Dinarida: Geoloski Vjesnik, v. 21, p. 281-291. [French summary.]

Martens, Robert, 1971, Bauxite-Ihre Lagerstätten und Nutzung in Afrika: Deutsches Institut für Afrika-Forschung Hamburg, Afrika Spectrum, Berbau in Afrika, 2/70, p. 39-56.

Mathad, G. G., and Altekar, V. A., 1960, Determination of alumina minerals in Kolhapur bauxite and its suitability for Bayer's process: Science and Culture, v. 25, p. 695-697.

Matsunaga, T., Akiyama, S., and Fujie, T., 1978, Rennell Island bauxite-Exploration and mining assessment: Institution of Mining and Metallurgy, Commonwealth Mining and Metallurgical Congress, 11th, London, Preprint of Papers 17, 5 p.

Matthews, W. L., 1975, Bauxite in Tasmania, in Knight, C. L., ed., Metals, v. 1 of Econoinic geology of Australia and Papua New Guinea: Australasian Institute of Mining and Metallurgy Monograph Series 5, p. 992-993.

McColloch, H. W., 1967, A review of the investigations into the possibility of producing alumina and aluminium from South African ores: South Africa National Institute for Metallurgy Research Report 143, $57 \mathrm{p}$.

McCroskey, B. B., 1944, Mineral resources of Bulgaria: U.S. Bureau of Mines Foreign Minerals Survey 8, v. 1, no. 9, 22 p.

McIntosh, F. K., 1949, Investigation of Hamilton County bauxite district, Tennessee: U.S. Bureau of Mines Report of Investigations 4550, $31 \mathrm{p}$.

McLeod, P., 1976, An outline of the Australian aluminium industry: Metals Australia, v. 6, no. 5, p. 103-106.

McQueen, H. S., 1943, Geology of the fire clay districts of east central Missouri: Missouri Geological Survey and Water Resources [Reports], ser. 2, v. 28, 250 p. 
Meikle, R. A., 1973, The effect of silica reactions in the Bayer process, in Proceedings of bauxite symposium II, [Kingston, Jainaica], 1973: Geological Society of Jamaica Journal, Special Issue [2], p. 30-35.

Menendez, Alfredo, and Sarmentero, Alberto, 1984, Geology of the Los Pijiguaos bauxite deposits, Venezuela, in Jacob, Leonard, Jr., ed., Bauxite [Bauxite Symposium, Los Angeles, Calif., 1984, Proceedings]: New York, American Institute of Mining, Metallurgical and Petroleum Engineers, p. 387-407.

Mennessier, G., 1969, Draguiguan: Orléans, France Bureau de Recherches Géologiques et Minières, Carte Géologique, scale 1:50,000.

Mercier, Henri, and Noble, Maurice, 1974, Optimization of the alkaline treatment of different bauxite varieties, in Forberg, Helge, ed., Light metals, 1974; v. 3, Alumina and bauxite and carbon: American Institute of Mining, Metallurgical and Petroleum Engineers, Metallurgical Society, annual meeting, 103d, Dallas, Texas, 1974, Proceedings, p. 777-786.

Metal Bulletin, 1977, Alcoa calcined bauxite: Metal Bulletin, no. 6214, p. 9.

1984, Light metals: Metal Bulletin, no. 6891, p. 13.

Metallgesellschaft AG., 1976, Metal statistics 1965-1975 (63d e.): Frankfort am Main, 362 p.

Metals Sourcebook, 1974a, Aluminum: Metals Sourcebook, v. 2, no. 10, p. 4 .

1974b, Pakistan: Metals Sourcebook, v. 2, no. 16, p. 2. 1975a, Chile: Metals Sourcebook, v. 3, no. 15, p. 1 .

1975b, Indonesia: Metals Sourcebook, v. 3, no. 2, p. 1.

Meulen, J. ter, 1948, Enkele waarnemingen bij de kaolien van Paranam [Some observations on the kaolin of Paranam]: Geologie en Mijnbouw, new ser., v. 10, no. 6, p. 121-129. [English summary.]

Meusel, W., 1974, Special observations at the processing of tropical bauxite in European aluınina plants as a result of the higher organic substances content in such bauxite grades: Coinite International pour l'Etude des Bauxites, des Oxydes et des Hydroxydes d'Aluminium Travaux, no. 12, p. 91-99.

Mexico Consejo de Recursos Naturales No Renovables, 1972, Informe de actividades correspondiente al periodo 1965-1970: Mexico Consejo de Recursos Naturales No Renovables, 111 p.

Michell, W. D., 1972, Bauxite: Mining Engineering, v. 24, no. 1, p. $34-35$.

1974, Bauxite: Mining Engineering, v. 26, no. 2, p. 103-104.

1975, Bauxite and alumina: Mining Engineering, v. 27, no. 2 , p. 71-72.

1976, Bauxite and alumina: Mining Engineering, v. 28, no. 3 , p. 27-29.

1977, Bauxite and alumina: Mining Engineering, v. 29, no. 3 , p. 54-55.

Mikhailou, B. M., 1971, Comparison between the laterites from some areas of West Africa and the Soviet Union: Comite International pour l'Etude des Bauxites, des Oxydes et des Hydroxydes d'Aluminium Travaux, no. 7, p. 142-159.

Miller, Jan, and Irgens, Aake, 1974, Alumina production by the Pederson process-History and future, in Forberg, Helge, ed., Light metals, 1974; v. 3, Alumina and bauxite and carbon: American Institute of Mining, Metallurgical and Petroleum Engineers, Metallurgical Society, annual meeting, 103d, Dallas, Texas, 1974, Proceedings, p. 789-799.

Mineração Metalurgia, 1975, As jazidas de bauxita descobertas pela Docegeo em Paragominas: Mineração Metalurgia, v. 39, no. 362, p. 25-27.

Mining Engineering, 1971a, Alcoa jungle lab in Brazil for aluminum exploration: Mining Engineering, v. 23, no. 11, p. 6 . 1971b, Mineral industry developments around the world:

Mining Engineering, v. 23, no. 12, p. 12.

Mining Journal, 1965, Mining annual review, 1965: London, 384 p. 1970, Madagascar bauxite: Mining Journal, v. 274, no. 7029 , p. 427

1971a, Aluminium, in Mining Journal, Mining annual review, 1971: London, p. 75-82.

1971b, Gumea bauxite agreement: Mining Journal, v. 276, no. 7073 , p. 185 .

1974, Aluminium, in Mining Journal, Mining annual review, 1974: London, p. 60-67.

Mining Magazine, 1974, Weipa bauxite: Mining Magazine, v. 130, no. 1 , p. 12-21.

1976, South Korean find: Mining Magazine, v. 134, no. 6, p. 545 .

1983, Trombetas bauxite: Mining Magazine, v. 148, no. 1, p. 18-25.

Mining World, 1955, Bolivia: Mining World, v. 17, no. 9, p. 79. 1960, Angola: Mining World, v. 22, no. 12, p. 68.

Miskei, M., Toth, B., and Bogardi, E., 1978, Vanadium- und Galliumgewinnung aus ungarischem Bauxit: Coinité International pour l'Etude des Bauxites, d'Alumine et d'Aluminium Travaux, no. 14, p. 41-48.

Montagne, D. G., 1964, New facts on the geology of the "young" unconsolidated sediments of northern Surinam: Geologie en Mijnbouw, v. 43, no. 12 , p. 499-515.

Moraes, A. E. de, 1978, Brazil: Aluminium, v. 54, no. 1, p. 63-65.

Moraes, L. J., 1959, Bauxite et autres richesses minières du Territoire Fédéral d'Amapa (Brésil), in Conference Géologique des Guyanes [Guiana Geological Conference], 4th, Cayenne, French Guiana, 1957, Communications: [France] Service de la Carte Géologique, Departement de la Guyane, Mémoires pour Servir à l'Explication Géologique Détaillée de la France, p. 93-97.

Moretti, Attilio, 1955, Segnalazione di alcuni giacimenti bauxitiferi nella Nurra di Alghero (Sardegna): Italy Servizio Geologico Bollettino, v. 77 , nos. $4-5$, p. $461-466$

Moses, J. H., and Michell, W. D., 1963, Bauxite deposits of British Guiana and Surinam in relation to underlying unconsolidated sediments suggesting two-step origin: Econounic Geology, v. 58, no. 2, p. 250-262.

Moyal, Maurice, 1956, Aluininum developments in French Africa: South African Mining and Engineering Journal, v. 67, no. 3332, p. 1057-1062.

Mposkos, E., Tsalikis, D., and Vgenopoulos, A., 1978, The use of Greek bauxites as raw material for the refractory industry, in International Congress for the Study of Bauxite, Alumina, and Aluminum, [ICSOBA International Symposium, 4th, Athens, 1978, Proceedings]: Athens, Greece, National Technical University of Athens, v. 2, p. $890-904$.

Murray, A. M., 1979, Mineral deposits of Western Australia-Bauxite, in Prider, R. T., ed., Mining in Western Australia: Nedlands, W.A., University of Western Australia Press, p. 101-111.

Murray, H. H., 1984, Geology, mineralogy, and geochemistry of kaolin at Weipa, Queensland, Australia [abs.]: Clay Minerals Society, 21st annual meeting, Baton Rouge, La, 1984, Program with Abstracts, p. 87.

Murray, H. H., and Walker, S., 1979, Magnetic separation-A process to beneficiate bauxite: Comité International pour l'Etude des Bauxites, des Oxydes et des Hydroxydes d'Aluminium Travaux, na 15, p. $143-150$.

Murty, Y. G. K., 1963, Bauxite deposits of Kalahandi district, Orissa: Indian Minerals, v. 17, no 3, p. 269-280.

Nagaraja, G. H., 1967, Bauxite deposits of Baindu, South Canara District, Mysore State: Mysore Department of Mines and Geology Geological Studies, no 3, 16 p. 
Nalivkin, D. V., 1960, The geology of the U.S.S.R.-A short outline: London, Pergamon Press, 170 p.

Nanjundaiah, G., and Krishnachari, 1971, The mining lease blocks of $\mathrm{M} / \mathrm{s}$ Dalachand Bahadur Singh for bauxite in Belgaum Taluk, Belgaum dist.: Mysore Department of Mines and Geology Geological Studies, no. 32, 7 p.

National Miner, 1977, Bauxite, in The Australian mimes handbook, 1976-77: Perth, Australia, National Miner and Derry, Michener and Booth, p. 87-92.

Newsome, J. W., and others, 1960, Alumina properties (2d rev.): Alcoa Research Laboratory Technical Paper 10, 88 p.

Nia, Rahim, 1968, Zur Bedeutung der methodischen Probennahme für genetische Untersuchungen von Bauxit-Lagerstätten am Beispiel der Oberkreide-Bauxite der Parnass-Kiona-Zone, Griechenlands: Mineralium Deposita, v. 3, no. 4, p. 368-374. [English sumınary.] 1971, Genesis of boehmite and diaspore in Greek Upper Cretaceous bauxites of the Parnassos-Kiona zone, in International Committee for Studies of Bauxites, Oxides and Hydroxides of Aluminium, Bauxite-alumina-aluminium [ICSOBA International Symposium, 2d, Budapest, 1969, Proceedings]: Budapest, Hungary Research Institute for Non-Ferrous Metals, v. 2, p. 69-98.

Nichols, Edward, 1888, An aluminum-ore: American Institute of Mining and Metallurgical Engineers Transactions, v. 16, p. 905-906.

Nicolas, Jean, 1970, Problème de la genèse des bauxites à mur karstique de France (Preuves pétrographiques, paléontologiques et géochimiques de la nature sédimentaire des formations bauxitiques de Provence) [Genesis of bauxites with a karstic footwal] in France (Petrographic, paleontologic and geochemical evidence of the sedimentary nature of bauxitic formations in Provence)]; in Bárdossy, György, ed., Conference on bauxite geology, Budapest, 1969: [Hungary] Földtani Intézet Evkönyve, v. 54, no. 3, p. 135-164.

Nicolas, Jean, and Belinga, S. E., 1969, Contribution à l'étude de l'origine et de l'evolution des bauxites de l'Adamaoua (Cameroun) [Origin and development of the bauxites of Adamaoua, Cameroon]: Académie des Sciences [Paris] Comptes Rendus, ser. D, v. 268, no. 8 , p. $1157-1160$.

Nieberlein, V. A., and others, 1954, Progress report on development of columbium in Arkansas for 1953: U.S. Bureau of Mines Report of Investigations 5064, $23 \mathrm{p}$.

Nikitina, A. P., and Zvyagin, B. B., 1973, Origin and crystal structure features of clay minerals from the lateritic bauxites in the European part of the U.S.S.R.: International Clay Conference, Madrid, 1972, Proceedings, p. 227-233.

Norrish, K., and Taylor, R. M., 1961, The isomorphous replacement of iron by aluminium in soil goethites: Journal of Soil Science [London], v. 12 , no. 2 , p. 294-306.

Norton, S. A., 1973, Laterite and bauxite formation: Economic Geology, v. 68, no. 3, p. 353-361.

Novikov, V. M., and others, 1975 , O ryadakh prevrashcheniya mineralov $\mathrm{v}$ boksitovykh korakh vyvetrivaniya yuzlınogo Urala [Transformation of minerals in the bauxite weathering crusts of the southern Urals], in Bushinskiy, G. I., ed., Problemy genezisa boksitov [Problems of bauxite genesis]: Moscow, Izdatel'stvo Nauka, p. 257-266.

Organization of American States, 1972, Haiti mission d'assistance technique intégrée: Washington, D.C., Organization of American States Office of Regional Development, $656 \mathrm{p}$.

Orlov, Alexandr, 1938, Prvni vyskyt bauxitu v Ceskoslovensku [Note on the bauxite deposits in Czechoslovakia]: Ceskoslovenska Akademie Věd Rozpravy, v. 47, no. 13, 22 p. [In Czech; French suminary. Also published in Ceskoslovenska Akademie Věd Bulletin International, v. 38, p. 58-62, 1937.]
1939, "Primarni" a "sekundarni" facie bauxitu na mojtin skem lozisku ["Primary" and "secondary" bauxite facies in the Mojtin deposit]: [Czechoslovakia] Ustredni Ustav Geologicky Vestnik, v. 14, nos. 1-2, p. 18-25. [In Czech; German summary.]

Ostap, S., 1984, Effect of bauxite mimeralogy on its processing characteristics, in Jacob, Leonard, Jr., ed., Bauxite [Bauxite Symposium, Los Angeles, Cahif., 1984, Proceedings]: New York, American Institute of Mining, Metallurgical and Petroleum Engineers, p. 651-671.

Ostojic, Slavko, 1980, Aluminium from non-bauxite resources: IBA Quarterly Review, v. 6, no. 2, p. 28-42.

Ottlik, P., and Szabadvary, L., 1971, Geophysics in bauxite prospecting [with discussion], in International Committee for Studies of Bauxites, Oxides and Hydroxides of Aluminium, Bauxite-aluminaaluminium [ICSOBA International Symposium, 2d, Budapest, 1969, Proceedings]: Budapest, Hungary Research Institute for Non-Ferrous Metals, v. 2, p. 157-168.

Overstreet, E. F., 1964, Geology of the southeastern bauxite deposits: U.S. Geological Survey Bulletin 1199-A, 19 p.

Owen, H. B., 1954, Bauxite in Australia: Australia Bureau of Mineral Resources, Geology and Geophysics Bulletin 24, 234 p.

Owen, H. B., and Hargreaves, M. R., 1975, Mount Saddleback bauxite area, W.A., in Knight, C. L., ed., Metals, v. 1 of Economic geology of Australia and Papua New Guinea: Australasian Institute of Mining and Metallurgy Monograph Series 5, p. 987-991.

Ozlu, Necmettin, 1978, Etude géologique, mméralogique et géochimique des bauxites de la région d'Akseki-Seydisehir (Taurus occidental-Turquie): Paris, Pierre et Marie Curie Université, Doctoral dissertation, $455 \mathrm{p}$.

Palache, Charles, Berman, Harry, and Frondel, Clifford, 1944, Elements, sulphides, sulfosalts, oxides, v. 1 of The system of mineralogy of James Dwight Dana and Edward Salisbury Dana (7th ed.): New York, Jolın Wiley \& Sons, 834 p.

Papastamatiou, Jean, 1964, Les gisements de bauxite en Grèce, in International Committee for Studies of Bauxites, Oxides and Hydroxides of Aluminium, [ICSOBA International Symposium, 1st, Zagreb, 1963, Proceedings]: Zagreb, Yugoslavia, Académie Yougoslave des Sciences et des Arts, v. 1, p. 285-293.

1965, Quelques observations sur la genèse des bauxites en Grèce: Comité International pour l'Etude des Bauxites, des $\mathbf{O x}$ ydes et des Hydroxydes d'Aluminium Travaux, no. 1, p. 3-8.

Papastamatiou, Jean, and Maksimovic, Zoran, 1970, Contribution to the study of genesis of Greek bauxites-Chemical and mineralogical composition of Mandra II bauxite deposit, in Bárdossy, György, ed., Conference on bauxite geology, Budapest, 1969: [Hungary] Földtani Intézet Evkönyve, v. 54, no. 3, p. 391-402.

Papastavrou, S., and Mitsaki-Hafner, V., 1983, Geology of Vroderon laterite deposit in northern Greece, in [ICSOBA International Symposium, 5th, Zagreb, 1983, Proceedings]: Comité International pour l'Etude des Bauxites, des Oxydes et des Hydroxydes de l'Aluminium Travaux, no. 18, p. 85-95.

Papiu, V. C., Minzatu, Silvia, and Iosof, Vasile, 1970a, Asupra caracterelor petrologice ale bauxitelor din Muntii Bihorului (regiunea vain Galbina) [A petrology of the bauxites from the Galbina Valley, Bihor Mountains]: [Romania] Comitetul Geologic Dari de Seama ale Sedintelor, v. 56, no. 1, p. 209-217. [English, French suminaries.]

1970b, Genetische Typen der Karstbauxiten in den rumanischen Kreideformationen [Genetic types of karst bauxite in the Romanian Cretaceous], in Bárdossy, György, ed., Conference on bauxite geology, Budapest, 1969: [Hungary] Földtani Intézet Evkönyve, v. 54, no. 3, p. 241-263. 
Papiu, V. C., and others, 1970, Caracterele chimico-mineralogice ale bauxitelor din masivul Padurea Craiului [Chemical and mineralogic composition of the bauxites in the Crai Forest massif]: [Romania] Comitetul de Stat al Geologiei Anuarul, v. 38, p. 111-179.

1971, Alcatuirea chimico-mineralogice a formatiunii bauxitifere din bazinul Hategului [Chemical and mineralogical composition of the bauxite-bearing formation of the Hateg basin]: [Romania] Comitetul Geologic Dari de Seama ale Sedintelor, v. 57, no. 2, p. 77-122. [English, French suminaries.]

1975, Alcatuirea chimico-mineralogica a bauxitelor din regiunea Sohodol-Cimpeni (jud. Bihor) [Chemical and mineralogic composition of the bauxites of the Sohodol-Cimpeni region, Bihor]: [Romania] Comitetul Geologic Dari de Seama ale Sedintelor, v. 61, p. 37-69.

Papiu, V. C., and Udrescu, Constanta, 1973, Eléments mineurs des bauxites de Roumanie [Minor elements in the bauxites of Romania]: Comite International pour l'Etude des Bauxites, des Oxydes et des Hydroxydes d'Aluminium Travaux, no. 9, p. 127-141.

Parekh, B. K., and Goldberger, W. M., 1976, An assessment of technology for possible utilization of Bayer process muds: U.S. Environmental Protection Agency Series EPA-600/2-76-301, $142 \mathrm{p}$.

Parker, C. J., Hathaway, J. C., and Blackmon, P. D., 1956, Some curves from a portable differential thermal analysis unit: U.S. Geological Survey Bulletin 1021-G, p. 237-251.

Parker, T. W. H., and Sadleir, S. B., 1984, Recent investigations of the Mitchell plateau bauxite deposits, Western Australia, in Jacob, Leonard, Jr., ed., Bauxite [Bauxite Symposium, Los Angeles, Calif., 1984, Proceedings]: New York, American Institute of Mining, Metallurgical and Petroleum Engmeers, p. 500-524.

Pathak, S. D., 1958, The bauxite deposits of Madhya Pradesh: Mineral Wealth of Madhya Pradesh, v. 1 , no. 2 , p. $30-47$; no. 4, p. 92-103.

Patterson, E. M., 1955, The Tertiary lava succession in the northern part of the Antrim Plateau: Royal Irish Academy Proceedings, sec. $B$, v. 57 , no. 7 , p. 79-121.

Patterson, S. H., 1962, Investigation of ferruginous bauxite deposits of Kauai and a reconnaissance of bauxite deposits on Maui: U.S. Geological Survey Open-File Report, 339 p.

1963, Estimates of world bauxite reserves and potential resources: U.S. Geological Survey Professional Paper 475-B, p. B158-B159.

1967, Bauxite reserves and potential aluminum resources of the world: U.S. Geological Survey Bulletin 1228, $176 \mathrm{p}$.

1971, Investigations of ferrugimous bauxite and other mineral resources on Kauai and a reconnaissance of ferruginous bauxite deposits on Maui, Hawan̈: U.S. Geological Survey Professional Paper 656, $74 \mathrm{p}$.

Pavolic, S., and Nikolic, D., 1973, Formation des laterites sur les quartzites aux environs de Baney (Guinée) [Formation of laterites on the quartzites in the Baney area, Guinea], in International Committee for Studies of Bauxites, Oxides and Hydroxides of Aluminium, [ICSOBA International Symposium, 3d, Nice, France, 1973, Proceedings]: Paris, Sedal, p. 233-236.

Pecorini, Giuseppe, 1956, La facies bauxitica nel Cretaceous della Nurra (Sardegna)-Nota preliminare: Accademia Nazionale dei Lincei [Rome], Rendiconti della Classe di Scienze Fisiche, Matematiche e Naturali, ser. 8, v. 20, pt. 2, p. 232-239.

Pendleton, R. L., 1941, Laterite and its structural uses in Thailand and Cambodia: Geographical Review, v. 31, p. 177-202.

Pennsylvania Geological Survey, 1964, Map of the Mercer clay and adjacent units in Clearfield, Centre, and Clinton Counties, Pennsylvania: Pennsylvania Geological Survey Series 4, Map 12.
Perfetti, J. N., Marquez, G., and Candiales, J. L., 1951, Yacimiento de bauxita del "Cerro el Chorro," immediaciones de Upata, Estado Bolivar [The "Cerro el Chorro" bauxite deposit, Upata, Bolivar]: Venezuela Dirección de Geología Boletín de Geología, v. 1, no. 3, p. 289-294.

Petersen, Ulrich, 1971, Laterite and bauxite formation: Economic Geology, v. 66, no. 7, p. 1070-1071.

Peterson, G. R., and Arbelbide, S. J., 1982, Aluminum availabilityMarket economy countries, a minerals availabihty program appraisal: U.S. Bureau of Mines Information Circular 8971.

Petkof, Benjamin, 1982, Gallium: U.S. Bureau of Mines Minerals Yearbook, 1982, Preprint, 3 p.

Peyronnet, Philippe de, 1969, Origine des bauxites d'Alanya (Turquie méridionale) [Origin of the Alanya bauxites, southern Turkey]: Académie des Sciences [Paris] Comptes Rendus, ser. D, v. 268, no. 7, p. 1001-1003.

1971, Esquisse géologique de la région d'Alanya (Taurus méridional); origine des bauxites métamorphiques [Geologic sketch of the Alanya region, southern Turkey; origin of metamorphic bauxites]: Ankara, Maden Tetkik ve Arama Enstitüsü [Turkey Mineral Research and Exploration Institute] Bulletin, Foreign Edition, no. 76, p. 90-116.

Pickering, R. J., 1962, Some leaching experiments on three quartz-free sihcate rocks and their contribution to an understanding of lateritization: Economic Geology, v. 57, no. 8, p. 1185-1206.

Pollack, H. R., 1981, Bauxites and laterites of the Bakhuis Mountain zone, western Suriname, a general description with emphasis on geomorphology and chemistry, in International seminar in lateritization processes, [1st], Trivandrum, India, 1979, Proceedings: Rotterdam, A. A. Balkema, p. 270-286.

Pollard, E. R., and Barron, C. N., 1955, The bauxite resources of British Guiana and their development (a revision of a compilation by $D$. W. Bishopp): British Guiana Geological Survey Bulletin 26, 123 p.

Porter, A. R. D., and Anderson, R. E., 1982, Some occurrences of bauxite overlain by overburden in Jamaica, with special reference to orebody Mel \#1, Manchester, in Proceedings of bauxite symposium V, Kingston, Jamaica, 1982: Geological Society of Jamaica Journal, Special Issue 7, p. 38-51.

Porter, A. R. D., and Jooste, R. F., 1982, An occurrence of nordstrandite in orebody A-19, St. Ann, Jamaica, in Proceedings of bauxite symposium V, Kingston, Jamaica, 1982: Geological Society of Jamaica Journal, Special Issue 7, p. 69-76.

Prokopov, I. V., and Malts, N. S., 1974, Industrial realization and perspectives of further development for low grade bauxite processing: Comité International pour l'Etude des Bauxites, des Oxydes et des Hydroxydes d'Aluminium Travaux, no. 12, p. 237-244.

Putzer, Hannfrit, 1962, Geologie von Paraguay: Beiträge zur Regionalen Geologie der Erde, v. 2, 180 p.

Quattroclocchi, Tullio, 1975, Italy, in Mining Journal, Mining annual review, 1975: London, p. 491-493.

Radhakrishna, B. P., 1965, The occurrence of bauxite along the west coast of Mysore state, south India: Geological Society of India Journal, v. 6, p. 62-66.

Raggatt, H. G., 1968, Mountains of ore: Melbourne, Lansdowne Press, $406 \mathrm{p}$.

Ramam, P. K., 1977, The east coast bauxite deposits of India: Comite International pour l'Etude des Bauxites, d'Alumine et d'Aluminium Travaux, no. 15, p. 81-90.

Rao, G. V., 1982, Bauxite resources of India and its future in the world arena: Comité International pour l'Etude des Bauxites, d'Alumine et d'Aluminium Travaux, no. 17, p. 39-51.

Rao, U. D. G., 1975, A review of the bauxite resources for the Gujarat alumina project: Gujarat Directorate of Geology and Mining Mineral Wealth, v. 11, no. 1, p. 1-6. 
Remizov, V. I., 1966, Elektronnomikroskopicheskoye izucheniye morfologii mineralov boksitov [An electron-microscope study of the morphology of bauxite minerals]: Mineralogicheskiy Sbornik, no. 20, pt. 1, p. 22-26. [English summary.]

Reynolds, R. C., Jr., 1971, Clay mineral formation in an alpine environment: Clays and Clay Minerals, v. 19, no. 6, p. 361-374. [French, German, and Russian summaries.]

Rhaup, A. E., 1937, The geology of the Umtali gold belt: Southern Rhodesia Geological Survey Bulletin 32, $186 \mathrm{p}$.

Rhodesian Mining Journal, 1957, Bauxite: Rhodesian Mining Journal, v. 29 , no. 366, p. 357 .

Richardson, J. A., 1947, Bauxite formed in situ in alluvium, and lateritization of alluvium and linestone in the Mae Khlaung and Khwae Noi valleys, Siam: Institution of Mining and Metallurgy Bulletin 490, p. 13-17.

Ridley, R. S. and Kaba, A. F., 1983, Brazil battles the jungle to mine Carajas minerals: World Mining, v. 36, no. 1, p. 50-57.

Roberts, A. L., 1971, Mining of bauxite in Jamaica, in Proceedings of bauxite/alumina symposium, [1st, Kingston, Jamaica], 1971: Geological Society of Jamaica Journal, Special Issue, p. 41-51.

Roberts, R. H., 1977, Bauxite mining-Weipa 1967-1977: American Institute of Mining, Metallurgical and Petroleum Engineers, Society of Minimg Engineers Preprint 77-H-328, $40 \mathrm{p}$.

Robertson, Thomas, 1921, Report on the geology of western Togoland: London, England, published for the Government of the Gold Coast by the Crown agents for the Colonies, $52 \mathrm{p}$.

Robinson, E., 1971, Observations on the geology of Jamaican bauxite, in Proceedings of bauxite/alumina symposium, [1st, Kingston, Jamaica], 1971: Geological Society of Jamaica Journal, Special Issue, p. 3-10.

Roch, Edouard, 1966, A comparison of some European bauxites with those of the Caribbean: Geological Society of Jamaica Journal, v. 8, p. 1-23.

Rodenburg, J. K., 1984, Geology, genesis and bauxite reserves of West Kalimantan, Indonesia, in Jacob, Leonard, Jr., ed., Bauxite [Bauxite Symposium, Los Angeles, Calif., 1984, Procedings]: New York, American Institute of Mining, Metallurgical and Petroleum Engineers, p. 603-618.

Rodriguez, S. E., 1982, Towards a fully integrated aluminium industry in Venezuela, in Proceedings of bauxite symposium V, Kingston, Jamaica, 1982: Geological Society of Jamaica Journal, Special Issue 7, p. 108-115.

Roever, E. W. F. de, 1975, Geology of the central part of the Bakhuis Mountains (W Suriname), in Contributions to the geology of Suriname 4: Surinam Geologisch Mijnbouwkundige Dienst Mededeling 23, p. 65-101.

Romero, Aristides, [1971?], Sobre el origen de los yacimientos de bauxita y caolin de Montenegro Provincia de Aconcagua, Republica de Chile: Simposio Nacional de Geologia Economica, 1st, San Juan, Argentina, 1971, v. 2, p. 351-365.

Rooksby, H. P., 1961, Oxides and hydroxides of aluminum and iron, in Brown, George, ed., The X-ray identification and crystal structures of clay minerals (2d ed.): London, Mineralogical Society, Clay Minerals Group, p. 354-392.

Rosas G., Humberto, 1973, Bauxite in the Morales-Cajibio area, Cauca, Colombia, in International Committee for Studies of Bauxites, Oxides and Hydroxides of Aluminium, [ICSOBA International Symposium, 3d, Nice, France, 1973, Proceedings]: Paris, Sedal, p. 237-244.

1978, Alumínio y bauxita, in Carmona, R. A., ed., Recursos minerales de Colombia [Mineral resources of Colombia]: Colombia Instituto Nacional de Investigaciones Geológico-Mineras, Publicaciónes Geológicas Especiales, no. 1, p. 1-5.
Rose, H. J., Adler, Isidore, and Flanagan, F. J., 1963, X-ray fluorescence analysis of the light elements in rocks and minerals: Applied Spectroscopy, v. 17 , no. 4 , p. $81-85$.

Roskill Information Services, 1979, The economics of aluminium (1st ed.): London, Roskill Information Services, 268 p.; appendix, 204 p.

Ross, C. S., and Kerr, P. F., 1934, Halloysite and allophane: U.S. Geological Survey Professional Paper 185-G, p. 135-148.

Roy Chowdhury, M. K., 1955, Bauxite deposits of India and their utilisation: Indian Minerals, v. 9, no. 3, p. 195-221.

1958, Bauxite in Bihar, Madhya Pradesh, Vindhya Pradesh, Madhya Bharat and Bhopal: India Geological Survey Memoir, v. $85,271 \mathrm{p}$.

1959, The aluminium industry in India: Indian Minerals, v. 13 , no. 1 , p. $17-28$.

1965, Bauxite in India-An assessment of reserves: India Geological Survey Bulletins, ser. A, no. 25, 127 p. 1974, Map of India showing bauxite deposits with grade and reserves: Ganges Printing Company, scale 1:700,000.

Roy Chowdhury, M. K., and Anandalwar, M. A., 1964, Loss-on-ignition as a guide in prospecting for bauxite: Indian Minerals, v. 18, no. 1, p. 49-54.

Roy Chowdhury, M. K., Anandalwar, M. A., and Tyagi, R. C., 1968, Bauxite deposits of Phutka Pahar, Bilaspur district, Madhya Pradesh: India Geological Survey Bulletins, ser. A, no. 21, 140 p.

Roy Chowdhury, M. K., and Venkatesh, V., 1972, Bauxite: India Geological Survey Records, v. 102, pt. 2, p. 79-91.

Roy Chowdhury, M. K., Venkatesh, V., and Banerjee, P. K., 1970, Genetic problems of Indian laterite and bauxite, in Bárdossy, György, ed., Conference on bauxite geology, Budapest, 1969: [Hungary] Földtani Intézet Evkönyve, v. 54, no. 3, p. 179-193.

Roy Chowdhury, M. K., Venkatesh, V., and Paul, D. K., 1968, Report on the detailed investigation of some bauxite deposits of the Amarkantak area, Madhya Pradesh: India Geological Survey Bulletins, ser. A, no. 28, 209 p.

Ruttner, A. W., 1970, Die Bauxit-Vorkommen der Oberkreide in den Ostalpen und deren paläogeographische Bedeutung, in Bárdossy, György, ed., Conference on bauxite geology, Budapest, 1969: [Hungary] Földtani Intézet Evkönyve, v. 54, no. 3, p. 131-134.

Sabiston, G. H., 1975, Mineralogical applications in characterizing new raw materials and intermediate products of the aluminium industry, in Proceedings of bauxite symposium III, Kingston, Jamaica, 1975: Geological Society of Jamaica Journal, Special Issue [3], p. 44-56.

Sahasrabudhe, Y. S., 1964, The origin of the bauxite deposits of Gujarat, India, in Subramaniam, A. P., and Balakrishna, eds., Advancing frontiers in geology and geophysics-A volume in honour of M. S. Krislınan: Hyderabad, Indian Geophysical Union, p. $460-480$.

Sakač, K., and Marušić, R., 1974, Bibliography of publications on Yugoslave bauxites: Comité International pour l'Etude des Bauxites, d'Alumine et d'Aluminium Travaux, no. 11, p. 101-145.

1978 , Bibliography of publications on Yugoslav bauxitesAppendix 1: Comité International pour l'Etude des Bauxites, d'Alumine et d'Aluminium Travaux, no. 14, p. 75-85.

Sakamoto, Takao, 1958, Aluminous shale-Geology and mineral resources of Far East, Manchuria: U.S. Army Corps of Engineers. [In Japanese.] (English translation of Tokyo Geographic Society, v. 6, pt. 8, 1951.)

Salas, G. P., 1959, Los depositos de bauxita en Haiti y Jamaica y posibilidades de que exista bauxita en Mexico: Mexico Universidad Nacional Autónoma, Instituto de Geología Boletín 59, p. 9-42.

Sandoval M., Felipe, 1969, Mining potential in Costa Rica: Costa Rica Dirección de Geología, Minas y Petróleo Informes Técnicos y Notas Geológicas, no. 32, 9 p. 
Sapozhnikov, D. G., ed., 1968, Eksperinıental'nye issledovaniya po razlozheniyu mineralov organicheskimi kislotami [Experiniental studies on the decomposition of minerals by organic acids]: Moscow, Izdatel'stvo Nauka, 177 p. [Also published as Canada Geological Survey Transactions, no. 548, 228 p.]

Sargic, V., and Logomerac, V., 1974, Leaching and extraction in the complex processing of red mud: Comite International pour l'Etude des Bauxites, d'Alumine et d'Aluminium Travaux, no. 11, p. 71-78.

Schellmann, Werner, 1966, Die Bildung von Roterde und Bauxitknollen in Vogelsberg [The genesis of red earth and bauxite in Vogelsberg]: Neues Jahrbuch für Mineralogie Monatshefte, no. 11, p. $321-341$.

1974, Kriterien für die Bildung, Prospektion und Bewertung lateritischer Silikatbauxite [Criteria for the genesis of, exploration for and evaluation of lateritic silicate bauxite]: Geologisches Jahrbuch, Reihe D, no. 7, p. 3-17. [English, French, and Russian suminaries.]

1975, Formation of and prospecting for tropical bauxite above silicate rocks: Mining Magazine, v. 133, no. 1, p. 33-39.

Schellmann, Werner, and Jepsen, Klaus, 1973, Die Bauxitbildung in der Lagerstätte Weipa/Australien als ein Beispiel der lateritischen Verwitterung [Bauxite formation in the Australian Weipa deposits during laterite weathering], in International Cominittee for Studies of Bauxites, Oxides and Hydroxides of Aluminium, [ICSOBA International Symposium, 3d, Nice, France, 1973, Proceedings]: Paris, Sedal, p. 253-261.

Schiller, E. A., 1977, Mineral exploration and mining in Brasil-1977: Mining Magazine, v. 137, no. 3, p. 245-253.

Schmedeman, O. C., 1948, Caribbean aluminum ores: Engineering and Mining Journal, v. 149 , no. 6, p. 78-82.

Schmidt, Felix, 1984, Geology of recent/potential bauxite producing areas in Sierra Leone and in the Peoples' Revolutionary Republic of Guinea (West Africa), in Jacob, Leonard, Jr., ed., Bauxite [Bauxite Symposium, Los Angeles, Calif., 1984, Proceedings]: New York, American Institute of Mining, Metallurgical and Petroleum Engineers, p. 486-499.

Schmieder, A., and Pohl, K., 1970, Results of hydrogeologic investigation of coal and bauxite mining in Hungary: International Mining Congress, 6th, Proceedings, p. 707-723.

Schneider, Hartmut, Seifert-Kraus, Ulrike, and Majdic, Aleksander, 1982, Microchemistry of refractory-grade bauxites: American Ceramic Society Bulletin, v. 61, no. 7, p. 741-745.

Schorin, Hasso, and Labreque, J. J., 1983, A laterite standard reference material-Venezuelan laterite, VL-1: Geostandards Newsletter, v. 7, no. 1, p. 233-242. [French suminary.]

Schüller, Arno, 1957, Mineralogie und Petrographie neuartiger Bauxite aus dem Gun-district, Honan province (China) [Mineralogy and petrography of the bauxite deposits from the Gun district, Hunan, China]: Geologie Zeitschrift für das Gesamtgebiet der Geologie und Mineralogie sowie des Angewandten Geophysik, v. 6, no. 4, p. 379-399.

Sechiari, P. G., and Sangster, K. J., 1979, Bauxite project at Paragominas, Brazil: American Institute of Mining, Metallurgical and Petroleum Engineers, Society of Mining Engineers Preprint, no. 79-71, $15 \mathrm{p}$.

Seelye, F. T., Grange, L. I., and Davis, L. H., 1938, The laterites of western Samoa: Soil Science, v. 46, no. 1, p. 23-31.

Shabad, Theodore, 1976, Soviet experinient in aluminum fails: New York Tinies, Sunday, May 8, section 3, p. 5.

Shaffer, J. W., 1975, Bauxitic raw materials, in Lefond, S. J., ed., Industrial minerals and rocks (nonmetallics other than fuels) (4th ed.): New York, American Institute of Mining, Metallurgical and Petroleum Engineers, p. 443-462.
1983, Bauxitic raw materials, in Lefond, S. J., ed., Industrial minerals and rocks (5th ed.): New York, American Institute of Mining, Metallurgical and Petroleum Engineers, p. 503-527.

Shal, S. H. A., 1960, Laterite deposits of Ziarat, Sibi and Loralai districts, West Pakistan: Pan Indian Ocean Science Congress, 4th, Karachi, Proceedings, Sec. C, p. 85-114.

Sibly, J. M., and Bucket, L. N., 1982, Alcoa of Australia LimitedWestern Australia alumina refining operations, in Light metals, 1981: New York, American Institute of Mining, Metallurgical and Petroleum Engineers, Metallurgical Society, p. 129-137.

Sidorenko, A. V., ed., 1973, Karta boksitonosnosti SSSR [Map of bauxite deposits in the USSR]: Moscow, Vsesoyuznyy NauchnoIssledovatel'skiy Geologicheskiy Institut, 4 sheets, scale 1:5,000,000.

Sierra Leone Geological Survey Department, 1975, Mineral map of Sierra Leone: Freetown, scale 1:1,000,000.

Sigit, Soetarjo, and others, 1969, Minerals and mining in Indonesia: Indonesia Ministry of Mines, $123 \mathrm{p}$.

Sinıandjuntak, H. R., 1982, Bauxite deposits occurrences in Indonesia: [Bandung], Indonesia Ministry of Mines and Energy, $15 \mathrm{p}$.

Sinclair, I. G. L., 1967, Bauxite genesis in Jamaica-New evidence from trace element distribution: Economic Geology, v. 62, no. 7, p. $482-486$.

Singh, Sobharam, 1972, Geological developments in Guyana-The policy and plans for the future: Venezuela Dirección de Geologia Publicación Especial 6, p. 623-628.

Sinkovec, Boris, 1965, Laterites of the Serrania de los Guaicas area (Venezuela) and their mother rocks: Geoloski Vjesnik, v. 18, no. 2, p. 215-243.

1973, The origin of early Paleogene bauxites of Istria, Yougoslavia, in International Committee for Studies of Bauxites, Aluminium Oxides and Hydroxides, [ICSOBA International Symposium, 3d, Nice, France, 1973, Proceedings]: Paris, Sedal, p. $151-164$

Sluys, M., 1946, Un gisement de latérite bauxitique pisolitique sur le substratum granitique (region de Niapu, Congo belge) [A pisolitic bauxitic laterite deposit in the granite substratum of the Niapu region, Belgian Congo]: Societé Géologique de Belgique Annales, v. 69 (Bulletin 5-8), p. B218-B220.

Smart, J., compiler, 1977, Aurukun, Queensland: Australia Bureau of Mineral Resources, Geology and Geophysics 1:250,000 Geological Series-Explanatory Notes, Sheet SD/54-7, 23 p.

Soares-Rebelo, D. J., 1972, The mining of bauxite in MozambiqueAn economic survey: South African Journal of Science, v. 68, no. 3 , p. 66-70

Société Aluminium Pechiney, 1975, La bauxite en Europe: Industrie Minérale, v. 57, no. 7, p. 543-549.

Solymár, Karoly, 1970, Alumogoethit in den ungarischen Bauxiten (Die Bestimmung und Bedeutung des ins Goethitgitter eingebauten Aluminium-Gehaltes in den ungarischen Bauxiten) [Aluminogoethite in Hungarian bauxite (Determination and significance of aluminum content in the goethite lattice of Hungarian bauxites)], in Bárdossy, György, ed., Conference on bauxite geology, Budapest, 1969: [Hungary] Földtani Intézet Evkönyve, v. 54, no. 3, p. 359-373.

Solymár, Karoly, Bárdossy, György, and Jónás, Klara, [1975], Chromium-containing boehmite and aluminium-containing chromium mineral in a bauxite sample from Severoonezhsk: Budapest, Femipari Kutato Intézet, p. 155-160. [Reprint with cover title "Mineralogical and technological evaluation of bauxites."]

Solymár, Karoly, and Jónas, Klara, 1974, Characterization of the digestibility of bauxites by means of infrared spectrophotometry: Comité International pour l'Etude des Bauxites, des Oxydes et des Hydroxydes d'Aluminium Travaux, no. 12, p. 33-36. 
Solymár, Karoly, Zambb, Janos, and Siklosi, Peter, 1984, Technological evaluation of monohydrate bauxites, in Jacob, Leonard, Jr., ed., Bauxite [Bauxite Symposium, Los Angeles, Calif., 1984, Proceedings]: New York, American Institute of Mining, Metallurgical and Petroleum Engineers, p. 727-746.

Somm, A. F., 1975, Gove bauxite deposits, N.T., in Knight, C. L., ed., Metals, v. 1 of Economic geology of Australia and Papua New Guinea: Australasian Institute of Mining and Metallurgy Monograph Series 5, p. 964-968.

Sondermayer, R. V., 1974, The mineral industry of Yugoslavia: U.S. Bureau of Mines Minerals Yearbook, 1972, v. 3, p. 877-892.

Souare, M., 1981, The IBA is not a cartel: IBA Quarterly Review, v. 6 , no. 3 , p. $31-41$.

South African Mining and Engineering Journal, 1941, Penhalonga bauxite deposit: South African Mining and Engineering Journal, v. 52 , pt. 1 , p. $739,741-742$.

Spain Instituto Geológico y Minero, 1972, Mapa previsor de mineralizaciones de aluminio, in the series Mapa metallogenetico de España e. 1:1,500,000: 29 p.

Sparwald, V., 1978, The source of impurities in primary aluminium: Aluminium, v. 54 , no. 10 , p. 1-3.

Srivastava, Prem, and Srivastava, N. K., 1971, X-ray study of bauxite deposits in Rajahuan Forest, Banda District, Uttar Pradesh: Mines and Minerals [India], v. 7, no. 4 (1970), p. 139-146.

Stamper, J. W., 1970 Aluminum, in Mineral facts and problems, 1970: U.S. Bureau of Mines Bulletin 650, p. 437-462.

Stamper, J. W., and Kurtz, H. F., 1978, Aluminum: U.S. Bureau of Mines Mineral Commodity Profile MCP-14, 29 p.

Stamper, J. W., Sullivan, A. C., and Trought, M. E., 1961, Bauxite: U.S. Bureau of Mines Minerals Yearbook, 1960, v. 1, p. 235-251.

Stankovich, I. D., 1978, The aluminium industry in the Soviet Union: London, Metal Bulletin, $61 \mathrm{p}$.

Stark, J. T., and Hay, R. L., 1963, Geology and petrography of volcanic rocks of the Truk Islands, East Caroline Islands: U.S. Geological Survey Professional Paper 409, 41 p.

Stas, M., 1959, Contribution à l'étude géologique et minéralogique des bauxites du Nord-Est du Mayumbe: Académie Royale des Sciences Coloniales [Brussels] Bulletin, new ser., v. 5, no. 2, p. 470-493.

Stauffer, K. W., 1969, Devonian laterite in Chitral State, West Pakistan: Economic Geology, v. 64, no. 4, p. 452-454.

Stephen, I., 1963, Bauxitic weathering at Mount Zomba, Nyasaland: Clay Minerals Bulletin, v. 5, no. 29, p. 203-208.

Strahl, E. O., 1971, The mineralogy of Jamaican bauxite and its effect on Bayer process technology, in Proceedings of bauxite/alumina symposium [1st, Kingston, Jamaica], 1971: Geological Society of Jamaica Journal, Special Issue, p. 62-69.

1977, An automated X-ray spectrometric and diffraction analytical system as an efficient tool for bauxite exploration: American Institute of Mining, Metallurgical and Petroleum Engineers, Society of Mining Engineers Preprint 77-H-399, 22 p.

1982, Modern analytical methods in bauxite survey programs, in Proceedings of bauxite symposium V, Kingston, Jamaica, 1982: Geological Society of Jamaica Journal, Special Issue 7, p. 188-203.

Strakhov, N. M., and Bushinskiy, G. I., eds., 1958, Boksity, ikh mineralogiya i genezis [Bauxites, their mineralogy and genesis]: Moscow, Akademiya Nauk SSSR, Otdelenie GeologoGeograficheskikh Nauk, 487 p. [Reviewed by Zans, V. A., Economic Geology, v. 54, no. 5, p. 957-965, 1959.]

Strishkov, V. V., 1976, Soviet Union, in Mining Journal, Mining annual review, 1976: London, p. 475-492.

Stroud, R. B., and others, 1969, Mineral resources and industries of Arkansas: U.S. Bureau of Mines Bulletin 645, $418 \mathrm{p}$.
Sugden, David, 1984, The laterite-bauxite deposits of the Trombetas and Paragominas regions of the Amazon Basin, in Jacob, Leonard, Jr., ed., Bauxite [Bauxite Symposium, Los Angeles, Calif., 1984, Proceedings]: New York, American Institute of Mining, Metallurgical and Petroleum Engineers, p. 370-386.

Surinam Geologisch Mijnbouwkundige Dienst, 1953, Mijnwezen, bauxiet: Surinam Geologisch Mijnbouwkundige Dienst Jaarboek, 1952, p. 19-24.

Suszczynski, E. F., 1973, Mapa metalogenetico do Brasil: Brazil Ministerio das Minas e Energia, Departamento Nacional da Produção Mineral, scale 1:5,000,000.

1978 , New bauxite ore deposits in the oriental portion of the Brazilian shield, in International Committee for Studies on Bauxites, Alumina and Aluminium, [ICSOBA International Symposium, 4th, Athens, 1978, Procedings]: Athens, Greece, National Technical University of Athens, v. 2, p. 837-840.

Sutulov, Alexander, 1973, Mineral resources and the economy of the USSR: New York, McGraw-Hill, 192 p.

Swarup, Prem, 1973, Mineralogy and origin of the Rajahuan bauxite deposits, Uttar Pradesh, India: Geological Society of India Journal, v. 14 , no. 2 , p. $169-177$.

Swindale, L. D., 1959, Bauxite in the red-brown soils of New Zealand New Zealand Soil Bureau Publication 191 (Paper 184), 6 p.

Swindale, L. D., and Fan, Pow-Foong, 1967, Transformation of gibbsite to chlorite in ocean bottom sediments: Science, v. 157 , no. 3790 , p. 799-800.

Swiss, M., 1970, Iran discovers her mineral wealth: Mining and Minerals Engineering, v. 6, no. 1, p. 18-24.

Szabá, E., 1973, On the bauxite deposits of Ghana: Comite International pour l'Etude des Bauxites, des Oxydes et des Hydroxydes d'Aluminium Travaux, no. 9, p. 55-56.

Taiwan Mining Research and Service Organization, 1977, Mineral resources development in Taiwan, Republic of China: Taiwan Mining Research and Service Organization MRSO Report 165, 37 p.

Tanner, A. B., and others, 1972, A probe for neutron activation analysis in a drill hole using $252_{\mathrm{cr}}$ and a $\mathrm{Ge}(\mathrm{Li})$ detector cooled by a melting cryogen: Nuclear Instruments and Methods 100, no. 1, p. 1-7.

Thataris, A., 1971, Oi voxitai tou dit Pilioi (N.A. Thessalia) [The bauxites of Pelion Mountain, southeastern Thessaly]: Geological Society of Greece Bulletin, v. 8, no. 1, p. 10-24. [In Greek; English summary.]

Taylor, G. R., and Hughes, G. W., 1975, Biogenesis of the Rennell bauxite: Economic Geology, v. 70, no. 3, p. 542-546.

Teale, E. O., and Oates, F., 1946, The mineral resources of Tanganyika territory (3d ed.): Tanganyika Geological Division Bulletin 16, 172 p.

Teas, E. B., and Katte, J. J., 1980, The effect of impurities on process efficiency and methods for impurity control and removal; in Proceedings of bauxitelalumina symposium IV, Kingston, Jamaica, 1980: Geological Society of Jamaica Journal, Special Issue 5, p. 100-129.

Tenyakov, V. A., and others, 1974, Halogens in bauxite: American Geological Institute Doklady, Earth Science Sections, v. 219, p. 213-215. (English translation of Akademiya Nauk SSSR Doklady, v. 219 , no. 4 , p. $977-979$.)

Tertian, R., 1966, Etude d'un échantillon de bauxite blanche recueilli à Vonji Do (Montenegro): Comité International pour l'Etude des Bauxites, des Oxydes et des Hydroxydes d'Aluminium Travaux, no. 3, p. 31-40.

Tertian, R., Fagot, C., and Jamey, M., 1964, Analyse quantitative précise des bauxites par la spectrométrie de fluorescence X [Precise quantitative analysis of bauxites by X-ray fluorescence spectrometry]; in International Committee for Studies of Bauxites, Oxides and Hydroxides of Aluminium, [ICSOBA International Symposium, 1st, Zagreb, 1963, Proceedings]: Zagreb, Yugoslavia, Académie Yougoslave des Sciences et des Arts, v. 2, p. 7-23. 
Thoenen, J. R., and Burchard, E. F., 1941, Bauxite resources of the United States: U.S. Bureau of Mines Report of Investigations 3598, $42 \mathrm{p}$.

Thoenen, J. R., Malamphy, M. C., and Vallely, J. L., 1945, Geophysical survey of Arkansas bauxite region, Pulaski, Saline, Lonoke, White, Grant, Hot Spring, and Clark Counties: U.S. Bureau of Mines Report of Investigations 3791, $49 \mathrm{p}$.

Tourtelot, H. A., 1964, Bauxite deposits of the Tippah-Benton district, Mississippi: U.S. Geological Survey Bulletin 1199-C, 31 p.

Tracey, J. I., Jr., and others, 1964, General geology of Guam: U.S. Geological Survey Professional Paper 403-A, 104 p.

Trashliev, S., and Stefanov, D., 1974, Notes on the mineral composition of the Awaso bauxites from south-west Ghana: Bulgarian Geological Institute Bulletin, Series Metallic and Non-metallic Mineral Deposits, v. 22, p. 223-231.

Trubina, K. N., 1958a, Drevnyaya lateritnaya kora uyvetrivaniya $v$ rayone Severo-Onezhskikh mestorozhdeniy boksitov [Ancient lateritic weathering mantle in the area of the north Onega bauxite deposits], in Strakhov, N. M., and Bushinskiy, G. I., eds., Boksity, ikh mineralogiya $i$ genezis [Bauxites, their mineralogy and genesis]: Moscow, Akademiya Nauk SSSR, Otdelenie GeologoGeograficheskikh Nauk, p. 319-334. [Reviewed by Zans, V. A., Economic Geology, v. 54, no. 5, p. 963, 1959.]

Trubina, K. N., 1958b, Boksitonosnye otlozheniya podmoskovnogo basseyna [Bauxite-bearing deposits of the sub-Moscow basin], in Strakhov, N. M., and Bushinskiy, G. I., eds., Boksity, ikh mineralogiya i genezis [Bauxites, their mineralogy and genesis]: Moscow, Akademiya Nauk SSSR, Otdelenie GeologoGeograficheskikh Nauk, p. 335-346. [Reviewed by Zans, V. A., Economic Geology, v. 54, no. 5, p. 963, 1959.]

Tucan, Fran, 1934, Prilog mineralnome i kemijskome poznavanju lickih boksita [Mineralogic and chemical properties of the bauxite of Lika, Yugoslavia]: Jugoslavenske Akademije Znanosti i Umjetnosti Rad, v. 249, p. 46-79.

Uganda Geological Department, 1921, Annual report of the Geological Department for the year ending 31st March, 1920: Entebbe, Uganda, 88 p.

United Nations Economic and Social Council, Expert Group on Definitions and Terminology for Mineral Resources, 1979, The international classification of mineral resources: New York, N.Y., United Nations Economic and Social Council, Committee on Natural Resources, 28 p.

United Nations Economic Commission for Asia and the Far East, 1962, Bauxite ore resources and aluminum industry of Asia and the Far East: United Nations Economic Commission for Asia and the Far East, Mineral Resources Development Series 17, 51 p.

1963, Mineral distribution map of Asia and the Far East: New York, 53 p., 4 sheets.

Upper Volta Direction de la Géologie et des Mines, 1970, Principaux gisements et indices dans leur cadre géologique: scale 1:1,000,000.

U.S. Army Corps of Engineers, Agency for Resource Inventories, 1967, Panama inventorio fiscos, Centroamerica y Panama-National inventory of physical resources, Central America and Panama: Washington, D.C., v. 1, 30 maps.

U.S. Bureau of Mines, 1948, Bauxite: U.S. Bureau of Mines Mineral Trade Notes, v. 27 , no. 5 , p. 6.

1953, Materials survey, bauxite: U.S. Bureau of Mines [MS 3], [309] p

1957, Aluminum: U.S. Bureau of Mines Mineral Trade Notes, v. 45 , no. 1 , p. 3 .

1970, Pakistan: U.S. Bureau of Mines Mineral Trade Notes, v. 67 , no. 11 , p. 52 .

1972, The mineral industry of other areas of Africa-Upper Volta: U.S. Bureau of Mines Minerals Yearbook, 1970, v. 3, p. $997-998$. 1973a, The mineral industry of other African areas-Mali: U.S. Bureau of Mines Minerals Yearbook, 1971, v. 3, p. $1035-1036$.

$1973 \mathrm{~b}$, The mineral industry of other African areas-Upper Volta: U.S. Bureau of Mines Minerals Yearbook, 1971, v. 3, p. 1056-1057.

1975, Bauxite: U.S. Bureau of Mines Mineral Data Summaries, 1975, p. 14-15.

1976, Bauxite: U.S. Bureau of Mines Mineral Data Summaries, 1976 , p. 16-17.

1977, Bauxite: U.S. Bureau of Mines Mineral Data Summaries, 1977, p. 16-17.

1978, Bauxite: U.S. Bureau of Mines Mineral Commodity Summaries, 1978, p. 16-17.

1979, Gallium: U.S. Bureau of Mines Mineral Commodity Summaries, 1979, p. 54-55.

1982, Bauxite: U.S. Bureau of Mines Mineral Commodity Summaries, 1982, p. 16-17.

1984, Bauxite: U.S. Bureau of Mines Mineral Commodity Summaries, 1984, p. 17-18.

1985, Gallium: U.S. Bureau of Mines Mineral Commodity Summaries, 1985.

U.S. Bureau of Mines and U.S. Geological Survey, 1976, Principles of the mineral resource classification system of the U.S. Bureau of Mines and the U.S. Geological Survey: U.S. Geological Survey Bulletin 1450-A, 5 p.

1980 , Principles of a resource/reserve classification for minerals: U.S. Geological Survey Circular 831, 5 p.

U.S. Surplus Property Board, 1945, Estimated world bauxite reserves by countries and zones-Table 18: Washington, D.C., U.S. Surplus Property Board Report to Congress, p. 125-126.

Valeton, Ida, 1968, Zur Petrographie der Bauxitlagerstätten auf der "charnockite-suite" im Salemdistrikt und in den Nilgiri-Hills, Sudindien [The petrography of bauxite deposits of the charnockite rocks in the Salem district and Nilgiri Hills, southern India]: Mineralium Deposita, v. 3, no. 1, p. 34-47.

1972, Bauxites: New York, Elsevier, 226 p.

1973a, Diagenèse et epigenèse de la bauxite d'Onverdacht/Surinam, in International Committee for Studies of Bauxites, Oxides and Hydroxides of Aluminium, [ICSOBA International Symposium, 3d, Nice, France, 1973, Proceedings]: Paris, Sedal, p. 245-251.

1973b, Laterite als Leithorizonte zur Rekonstruktion tektonischer Vorgange auf den Festlandern-Beispiel, Guianaschild [Laterite as an indicator for paleotectonic reconstruction of continents; example of the Guiana Shield]: Geologische Rundschau, v. 62, no. 1, p. 153-161. [English, French, and Russian suminaries.]

1973c, Pre-bauxite red sediments and sedimentary relicts in Surinam bauxites: Geologie en Mijnbouw, v. 52, no. 6, p. 317-332.

Van der Hammenn, T., and Wymstra, T. A., 1964, A palynological study on the Tertiary and Upper Cretaceous of British Guiana: Leidse Geologische Mededelingen, v. 30, p. 183-241.

Vanderstappen, R., and Cornil, J., 1955, Note sur les "bauxites" du Congo septentrional [The bauxites of northern Congo]: Académie Royale des Sciences Coloniales [Brussels] Bulletin, new ser., v. 1, no. 4, p. 690-709.

Van Essen, M. J., and others, 1971, A simple gibbsite analyzer for rapid field determination of the available alumina content in bauxites: Mineralium Deposita, v. 6, no. 1, p. 41-48.

Van Lissa, R. V., 1975, Review of bauxite exploration in the coastal plain of Suriname, in Contributions to the geology of Suriname 4: Suriname Geologisch Mijnbouwkundige Dienst Mededeling 23, p. 250-254. 
Van Nordstrand, R. A., Hettinger, W. P., Jr., and Keith, C. D., 1956, A new alumina trihydrate: Nature, v. 177, no. 4511, p. 713-714.

Vgenopoulos, A. G., and Kanellos, G. K., 1978, Preliminary study of the bauxite occurrences of Vroderon (Florina), northern Greece, in International Committee for Studies of Bauxites, Alumina and Aluminium, [ICSOBA International Symposium, 4th, Athens, 1978, Proceedings]: Athens, Greece, National Technical University of Athens, v. 4, p. 919-935.

Vidal, V., 1963, La bauxite française: Revue de l'Industrie Minérale, v. 45 , no. 3 , p. $165-190$.

Vittal, N., 1973, Mineral wealth of Gujarat: Mineral Wealth [India], v. 9 , no. 3 , p. 1-4.

Vizy, Bela, 1970, Hydrogeology of the Hungarian bauxite occurrences and protection of bauxite mines against water inrushes, in Bárdossy, György, ed., Conference on bauxite geology, Budapest, 1969: [Hungary] Földtani Intézet Evkönyve, v. 54, no. 3, p. 449-469.

Vletter, D. R. de, 1963, Genesis of bauxite deposits in Surinam and British Guiana: Economic Geology, v. 58, no. 6, p. 1002-1007.

Wacrenier, P., 1961, Mission de recherche de bauxite au Logone et au Mayo-Kebbi (Tchad): Institut Equatoriale de Recherches et d'Etude Géologique et Minière Bulletin 14, p. 37-41.

Wada, K., and others, 1972, Imogolite and allophane formed in saprolite of basalt on Maui, Hawaii: Clays and Clay Minerals, v. 20 , no. 6 , p. 375-380. [French, German, and Russian summaries.]

Wall, J. R. D., and others, 1962, Nordstrandite in soil from West Sarawak, Borneo: Nature, v. 196, no. 4851, p. 264-265.

Wang, C. C., 1932, The bauxite deposits of Poshan and Tzechuan districts, Shantung: China Geological Survey Geological Bulletin 18 , p. 23-37.

Wang Chung-hsing, 1969, Genetic conditions of bauxite deposits, central Kweichow: International Geology Review, v. 11, no. 6, p. 677-682. [English translation of Acta Geologica Sinica, v. 45, no. 3, p. 291-297, 1965.]

Wang, K. P., 1959, Vast expansion of aluminum-alumina is planned by Chinese Communists: Engineering and Mining Journal, v. 160, no. 7 , p. 75-77.

Wargalla, G., and Brandt, W., 1982, Processing of diaspore bauxites, in Bell, G. M., ed., Light metals, 1981: New York, American Institute of Mining, Metallurgical and Petroleum Engineers, Metallurgical Society, p. 83-100.

Warren, W. C., Bridge, Josiah, and Overstreet, E. F., 1965, Bauxite deposits of Virginia: U.S. Geological Survey Bulletin 1199-K, 17 p.

Warren, W. C., and Clark, L. D., 1965, Bauxite deposits of the Eufaula district, Alabama: U.S. Geological Survey Bulletin 1199-E, 31 p.

Watanabe, Toshio, 1939, [Bauxite in the South Seas]: Saiko Yakin Geppo [Mining Metallogenic Monthly], v. 14, no. 4, p. 93-96. [In Japanese.]

Webber, B. N., 1959a, Bauxitization in the Poços de Caldas district, Brazil: Mining Engineering, v. 11, no. 8, p. 805-809.

1959b, Bauxitização no Distrito de Poços de Caldas, Minas Gerais, Brasil [Bauxitization in the Poços de Caldas district, Brazil]: Geologic Society of Brazil Bulletin, v. 8, no. 1, p. 17-30.

Wefers, Karl, and Bell, G. M., 1972, Oxides and hydroxides of aluminum: Aluminum Company of America, Alcoa Research Laboratories Technical Paper 19, $51 \mathrm{p}$.

Weisse, J. G. de, 1948, Les bauxites de l'Europe centrale (province dinarique et Hongrie): Société Vaudoise des Sciences Naturelles Mémoire 58 (v. 9, no. 1), 162 p. [Also published as Lausanne Université, Laboratoire de Géologie, Géographie Physique, Minéralogie et Paléontologie, Bulletin 87, 162 p., 1948.]
1954, Note sur quelques types de laterite de la Guinee portugaise: International Geologic Congress, 19th, Algiers, 1952, Comptes Rendus, v. 21, p. 171-179.

1964, Bauxite latéritique et bauxite karstique [Lateritic and karstic bauxite]; in International Committee for Studies of Bauxites, Oxides and Hydroxides of Aluminium, [ICSOBA International Symposium, 1st, Zagreb, 1963, Proceedings]: Zagreb, Yugoslavia, Académie Yougoslave des Sciences et des Arts, v. 1, p. 7-29.

1967, Sur la presence de nickel dans un gisement de bauxite près de Megare [The presence of nickel in the bauxite deposits of Megare]: Mineralium Deposita, v. 2, no. 4, p. 349-356.

1968, Geographische Lage und wirtschaftliche Aspekte der bedeutendsten Bauxitlagerstätten der Erde: Aluminium, v. 44, p. 579-582.

1970, Bauxite sur un atoll de Pacifique; l'ile de Rennell dans l'archipel des Salomon [Bauxite on a Pacific atoll; Rennell, Solomon Islands]: Mineralium Deposita, v. 5, p. 181-183.

1972, Die Entwicklung der Versorgung Europas mit Bauxit: Erzmetall, v. 25, no. 11, p. 535-539.

1973, Quelques considérations sur les bauxites des Abruzzes et sur la présence de cuivre dans un gisement [Some considerations on the bauxites of Abruzzes and on the presence of copper in a deposit], in International Committee for Studies of Bauxite, Oxides and Hydroxides of Aluminium, [ICSOBA International Symposium, 3d, Nice, France, 1973, Proceedings]: Paris, Sedal, p. 63-71.

1976, Bauxites karstiques sur calcaires recents [Karstic bauxites on Recent limestones]: Comité International pour l'Etude des Bauxites, d'Alumine et d'Aluminium Travaux, no. 13, p. 51-62. [English summary.]

1979, Bauxite genesis and limestone alteration: Comité International pour l'Etude des Bauxites, d'Alumine, et d'Aluminium Travaux, no. 15, p. 7-14.

Weisse, J. G. de, and Louvan, R., 1956, How French bauxite is mined: Mining World, v. 18 , no. 13 , p. 51-53, 76.

Weisse, J. G. de, Mannweiler, U., and Rybach, L., 1978, Rapid laboratory analysis by neutron activation-Experience in bauxite exploration: Journal of Geochemical Exploration, v. 9, no. 1, p. 93-102.

Western Australia Department of Resources Development, 1983, Minerals and mineral development 1982/1983: Perth, Western Australia Department of Resources Development, 102 p.

White, A. H., 1976, Genesis of low iron bauxite, northeastern Cape York, Queensland, Australia: Economic Geology, v. 71, no. 8, p. 1526-1532.

White, J. L., 1974, Evaluation of bauxites by infrared techniques: Comité International pour l'Etude des Bauxites, des Oxydes et des Hydroxydes d'Aluminium Travaux, no. 12, p. 25-31.

White, W. S., 1965, Bauxite deposits of the Warm Springs district, Meriwether County, Georgia: U.S. Geological Survey Bulletin 1199-I, 15 p.

White, W. S., and Denson, N. M., 1966, Bauxite deposits of northwest Georgia, with a section on the Summerville area by J. C. Dunlap and E. R. Overstreet: U.S. Geological Survey Bulletin 1199-M, $42 \mathrm{p}$.

Williams, I. R., and Sofoulis, J., compilers, 1971, Prince Regent and Camden Sound, W.A.: Australia Bureau of Mineral Resources, Geology and Geophysics 1:250,000 Geological SeriesExplanatory Notes, Sheets SD/51-15 and 51-16, 16 p.

Willmott, W. F., and Powell, B. S., compilers, 1977, Torres StraitBoigu-Daru, Queensland: Australia Bureau of Mineral Resources, Geology and Geophysics 1:250,000 Geological SeriesExplanatory Notes, Sheets SG/54-11/12, SC/54-7, SC/54-8, 24 p. 
Wilmot, R. C., Sullivan, A. C., and Trought, M. E., 1958, Bauxite: U.S. Bureau of Mines Minerals Yearbook, 1957, v. 1, p. 237-256. 1959, Bauxite: U.S. Bureau of Mines Minerals Yearbook, 1958 , v. 1, p. 209-227.

1960, Bauxite: U.S. Bureau of Mines Minerals Yearbook, 1959 , v. 1, p. $223-240$.

Wilson, G. V., 1922, The Ayrshire bauxite clay: Scotland Geological Survey Memoir, 28 p.

Wippern, Jobst, 1962, Die Bauxite des Taurus und ihre tektonische Stellung: Ankara, Maden Tetkik ve Arama Enstitüsü [Turkey Mineral Resource and Exploration Institute] Bulletin, Foreign Edition, no. 58, p. $47-70$.

1964, Die Aluminium-Rohstoffe in der Turkei: Ankara, Maden Tetkik ve Arama Enstitüsú [Turkey Mineral Resource and Exploration Institute] Bulletin, Foreign Edition, no. 62, p. 83-90.

Wittmer, D., 1982, A review of potential domestic raw materials as substitutes for refractory grade bauxite, in Light metals, 1981: New York, American Institute of Mining, Metallurgical and Petroleum Engineers, Metallurgical Society, p. 23-35.

Wolf, F. de A. M., 1972, Bauxite na Amazonia: Congresso Brasileira Geologia, 26th, Belem, Resumo das Comunicações, v. 1, p. 36-38.

Wolfenden, E. B., 1961, Bauxite in Sarawak: Economic Geology, v. 56, no. 5 , p. $972-981$.

1965, Geochemical behaviour of trace elements during bauxite formation in Sarawak, Malaysia: Geochimica et Cosmochimica Acta, v. 29, no. 9, p. 1051-1062.

Workman, D. R., 1972, Mineral resources of the lower Mekong basin and adjacent areas of Khmer Republic, Laos, Thailand and Republic of Viet Nam: United Nations Economic Commission for Asia and the Far East, Mineral Resources Development Series, no. $39,148 \mathrm{p}$.

World Mining, 1975, 8th World Mining Conference: World Mining, v. 28 , no. 1, p. $32-39$.

Wu, J. C., 1983, The mineral industry of the Philippines: U.S. Bureau of Mines Minerals Yearbook, 1981, v. 3, p. 789-803.

Wyllie, R. J. M., 1976, OBK, Guinea's national bauxite company, operates 2,500,000 ton mine and railroad: World Mining, v. 29, no. 4 , p. 72-75

Zaire Département des Mines, 1975, Retombe minière de la République du Zaire [Mineral map of Zaire]: scale 1:2,000,000.

Zámbó, Janos, 1978, Bauxite and alumina production-Historical retrospection, review of the present situation and prognosis: New York, United Nations Industrial Development Organization, ID 78-5095, $34 \mathrm{p}$.

Zanone, Livio, 1971, La bauxite en Côte d'Ivoire-Bauxitisation et paléocuirasses: Ivory Coast Direction des Mines et Géologie Bulletin 4, $184 \mathrm{p}$.

Zans, V. A., 1961, Classification and genetic types of bauxite deposits: Inter-Guiana Geological Conference, 5th, Georgetown, British Guiana, 1959, Proceedings, p. 205-211.

Zans, V. A., Lemoine, R. C., and Rock, Edouard, 1961, Genèse des bauxites caraibes [Genesis of Caribbean bauxites]: Académie des Sciences [Paris] Comptes Rendus, v. 252, p. 3302, 3304.

Zapp, A. D., 1965, Bauxite deposits of the Andersonville district, Georgia: U.S. Geological Survey Bulletin 1199-G, 37 p. 